\title{
Microlepidoptera of the
}

\section{Philippine Islands}

\section{Introduction}

Between the continents of Asia and Australia lies a region well known to every biologist since the classical collecting expedition of Alfred Russel Wallace in the 1860s. It has become famous for its rich and variegated fauna, its complicated geological history, and the interesting aspects of its zoogeography.

This region consists roughly of three parts. One is a partly submerged promontory of Asia, the so-called Sunda shelf upon which the Greater Sunda Islands are situated. The second part, a similar bridgehead of the Australian continent, the also partly submerged Sahul shelf, bears New Guinea and dependencies. The third part forms the so-called Wallacea and is situated between the other two.

The well-known theory of Penck (1894) suggests that during the glacial periods of the Pleistocene so much water was extracted from the oceans, due to the forming of an icecap over the Northern Hemisphere, that the seas were about 100 fathoms more shallow than they are today. At that time, the above-mentioned and now submerged plateaus must have formed the land bridges so important for the animal distribution.

Wallacea does not rest upon a submarine plateau and consists of separate islands or island groups that may have retained their archipelagic character for a very long time. The northern part of this region is comprised of the Philippine Islands, with which we are here concerned; the southern, of Celebes and certain Lesser Sunda Islands.

The zoogeographic history of the fauna of the region seems to be thus: in early Tertiary (the Oligocene or Eocene) the northern island, Luzon, was connected through Formosa with the Asiatic continent. Evidence of this connection is suggested by some relicts in the mountains of Luzon, (e.g., Pinus with the Cross Bill and certain continental Asiatic butterflies such as Pieris, Pyrameis, and Argynnis).

Other land bridges, which developed later in the Pliocene and Pleistocene, have left more distinct traces. A broad connection 
existed between North Borneo and the Palawan group of islands as far as Mindoro, which, however, must have been separated earlier than the two preceding. At the same time, along the east side of the archipelago, there must have been another north-south connection, which was disrupted intermittently throughout these periods. Over these land bridges an exchange of northern and southern elements occurred. In addition, it appears certain that there must have been a bridge to Minahassa, the northern peninsula of Celebes, since many elements of the fauna point in this direction. I have proof of both bridges: characteristic species of the Greater Sunda Islands from Palawan and Mindanao. Finally, the marked infusion of the Philippine fauna with Papuan elements suggests the existence of a land bridge between the southern Philippines and New Guinea by way of the North Moluccan Islands.

The study of zoogeography of the Philippine Islands in respect to some other classes, orders, and groups of animals is well advanced; for instance, mammals, birds, land mollusks, amphibians and reptiles, fresh-water fishes, Pachyrrhynchidae among the Coleoptera and, finally, butterflies have served for zoogeographical surveys. It is noteworthy that, in general, the results of analysis of these groups are in reasonable accordance with each other, so that it is possible to subdivide the Philippine Islands into a number of biological provinces.

In general, these provinces reflect the zoogeographic history. The more important ones are: (1) Luzon and dependencies in the north; (2) a central area, partly situated on a shallow plateau, defined in the west by Panay, Masbate, Negros and Cebu, and in the east by Samar, Leyte and Bohol; (3) a southern region with Mindanao and Sula Islands, showing correlations with southern areas such as Celebes and Java, but also having northern elements from the first province, descending along the high mountain ridge and encompassing the entire east coast of the Archipelago ; (4) Palawan and dependencies, with pronounced Bornean features; and (5) Mindoro, more or less independent of the preceding.

In his classic work, "Die Schmetterlinge der Philippinischen Inseln," Semper (1896-1902) presented a division of the fauna of Macrolepidoptera into eight provinces. His survey was based on over 1500 species of butterflies and moths, but the Microlepidoptera were almost entirely excluded.

Our knowledge of the fauna of Philippine Microlepidoptera, alas, forms quite a contrast with that of the "Macro's." My estimation is that the species enumerated in the present survey amount to not more, and probably less, than 20 percent of the existing fauna of these insects. Any speculations on the zoogeography of the group 
should, therefore, be made with utmost caution; however, this applies to the absence of certain elements. The presence of other elements, of course, renders absolute and, therefore, important zoogeographic information.

The available material of Microlepidoptera, however scanty, has a pronounced Malayan character, with distinctly marked elements from Borneo, Celebes, and, also, Java. Unfortunately, the faunas of the former two islands are comparatively little known.

The Papuan element is not numerous, but undoubtedly present. Perhaps the most marked and important in this respect is the characteristic genus Peridaedala Meyrick (Olethreutinae), with three species in New Guinea and not less than six in the Philippines; two records of the genus from the Great Sunda Islands have recently become available.

Little can be said as yet of the microlepidopterous elements of the early northern invasion in Luzon. Of the three species which occur in both Formosa and the Philippines, one indeed is from Luzon, but the second is from Panay and the third from Mindanao.

The most characteristic feature of the fauna without doubt is its high percentage of endemisms, especially of the species. Of the total of 291 species, 203 are endemic, 88 apodemic. Of the 138 genera, however, only 18 are endemic, 120 apodemic. These endemisms are not always striking, although some marked exceptions occur. Most characteristic are numerous vicarious species, differing from their allies in neighboring regions by minor external structure and by genitalia. Some of these forms have escaped the attention of former authors and were erroneously identified with their closest relatives from other regions.

This interesting feature shows the considerable independence of the Philippine fauna and that the isolation of the region must have been of sufficient duration to create the numerous vicarious species, but that it was not long enough for the development of so many genera.

Although the Philippine Islands represent a region that is smaller than the neighboring "Sunda Land" (the Sunda shelf) or the Papuan region, its flora, fauna, and geology are certainly not less complex. One is, therefore, entitled to expect the existence of as rich a fauna of Microlepidoptera as in the other two regions; the more so because of the great variety of plant provinces in the Philippines, the diversity of altitude of the habitats and the existence of extensive forests, especially the lowland dipterocarpous forest.

It was, therefore, a recurrent disappointment to discover how limited is our knowledge of the Philippine Microlepidoptera. When studying the faunas of the Malay Archipelago and the Papuan region 
and trying to establish distribution of certain taxa throughout tropical Asia, one is continually confronted with this lack of data from the Philippine region. This, in turn, appeared to be in agreement with paucity of material of Philippine Microlepidoptera in European museums. It is most unfortunate that all natural history collections in Manila were destroyed during World War II.

These circumstances led the author to a systematic search for Philippine material in museums. In 1954, a trip to several museums in the eastern United States was made, and it was in the U.S. National Museum, Smithsonian Institution, Washington, D.C., that the first extensive collection of the Microlepidoptera of the Philippines was superficially investigated. This collection formed a part of the rich material brought together by the well-known collector of Philippine insects, Charles Fuller Baker, who was Dean of the College of Agriculture at the University of the Philippines. Only a portion of this material had been sent to Edward Meyrick for identification some forty years ago. Since that time, however, the revolutionary introduction of the use of genital characters for the taxonomy of Microlepidoptera has been made, requiring a revision of previous work.

The presence of this important collection in the Smithsonian Museum and my 1954 visit formed the incentive for a study project that was made by Dr. J.F. Gates Clarke, then Chairman, Department of Entomology, Smithsonian Institution, as senior investigator, and the author, as junior investigator. This project, accepted by the Smithsonian Institution, and made possible by a grant of the National Science Foundation, came into effect in 1961 and resulted in the present survey.

The author stayed at the Smithsonian U.S. National Museum (USNM) in 1961-1962 as a research associate for the purpose of a preliminary study of the collection. Dissections of genitalia were made and descriptions or redescriptions of genera and species were construed. This investigation was continued at the Leiden Museum (LM) from 1962 through 1964, where study of the literature was resumed, Snellen's and Meyrick's types were compared with the material, and drawings of genitalia and photographs of the wings were made. The project also included two visits to the British Museum (Natural History) of London, in 1963 and 1964, for study and comparison of Walker's, Walsingham's, and Meyrick's types.

The present survey of microlepidopterous fauna of the Philippines forms but a general outline, as it is based upon too-scanty material. In total 138 genera, 291 species, 5 subspecies and 1 forma are recorded, of which 19 genera, 146 species, 5 subspecies, and 1 forma are described as new. 
The following is a survey of numbers of genera and species divided over the various families.

\author{
Phaloniidae \\ Tortricidae \\ Carposinidae \\ Copromorphidae \\ Xyloryctidae \\ Timyridae \\ Gelechiidae \\ Orneodidae \\ Cosmopterygidae \\ Oecophoridae \\ Glyphipterygidae \\ Heliodinidae \\ Aegeriidae \\ Yponomeutidae \\ Ethmiidae \\ Plutellidae \\ Lithocolletidae \\ Lyonetiidae \\ Tineidae \\ Adelidae
}

Totals

\begin{tabular}{crrrr}
\multicolumn{2}{c}{ endemic } & & \multicolumn{3}{c}{ apodemic } \\
\cline { 1 - 2 } \cline { 5 - 6 } genera & species & & genera & species \\
- & - & & 1 & 1 \\
6 & 46 & & 37 & 31 \\
- & 7 & & 3 & - \\
- & 3 & & 1 & - \\
- & 13 & & 4 & - \\
- & 25 & & 7 & 1 \\
2 & 5 & & 8 & 7 \\
- & - & & 1 & 2 \\
1 & 2 & & 4 & 4 \\
2 & 20 & & 6 & - \\
- & 17 & & 7 & 13 \\
- & 9 & & 3 \\
- & 15 & & 10 & 3 \\
1 & 11 & 4 & 4 \\
1 & 5 & & 1 & 3 \\
2 & 3 & & 1 & 1 \\
- & - & 2 & 2 \\
- & 1 & 2 & 3 \\
3 & 16 & 12 & 10 \\
- & 5 & 1 & - \\
\cline { 5 - 6 } 18 & 203 & 120 & 88
\end{tabular}

The purpose of this paper is to present a basis for further study of this fauna, by recording all earlier described species, with as complete as possible synonymies and lists of references, and, where possible, with photographs of the wings and sometimes illustrations of the genitalia of the two sexes. Where deemed useful, these species have been fully redescribed. The same has been done with the already described genera only when any substantial remarks, emendations, or additions to those earlier descriptions were necessary; where needed, the heads and wing venation have been illustrated. The new genera and species have been described and figured in the usual way, with figures of head and venation for the former, and of wings and $\sigma^{x}$ o genitalia for the latter. Known food plants in- and outside the Philippine area have been recorded.

The material used originated from the following sources. The primary source was the above-mentioned collection of the U.S. National Museum, Smithsonian Institution, Washington, D.C., brought together by Charles Fuller Baker around 1912, almost exclusively from the island of Luzon, chiefly on Mt. Makiling (Maquiling) and in Los Baños, collected at light. Also in this collection there is some reared material, mostly sugar-cane pests of minor 
importance, originating from various places on the island of Panay and stray specimens from other localities.

The otherwise outstanding and extensive collection of the British Museum contained but few specimens of Microlepidoptera from the Philippines. An exception, however, was the collections of unnamed material originating from Lord Rothschild's bequest. They were transferred recently from the Tring Museum to London, where I first saw them in 1963. This material appeared to contain several hundred specimens of Philippine Microlepidoptera collected in 1912-1914 by A. E. Wileman for Lord Rothschild. This interesting material was borrowed and studied in Leiden along with the other collections.

During a stay in the Philippines in 1945, Dr. J. G. Franclemont, of the Department of Entomology, Cornell University, Ithaca, N.Y., collected several interesting species at light on Luzon. A small collection was received from the P. Bernice Bishop Museum, Honolulu; another was selected by the author from the collection of the Carnegie Museum (CMP) when staying in Pittsburgh, Pa. Finally, a collection of moderate extent but of great importance, brought together by the Chicago Natural History Museum Philippine Zoological Expedition, 1946-47, was received from that museum and could be worked.

The additions mentioned above were received after the start of the original work. However welcome, they unavoidably caused considerable delay to the termination of this project.

\section{Acknowledgments}

My sincere gratitude is due to the authorities of the Smithsonian Institution for accepting the study project and for rendering all the necessary facilities for my work as research associate at the U.S. National Museum, Washington, D.C., to the National Science Foundation for the financing of the project, and to Professor Dr. L. D. Brongersma, Director, Rijksmuseum van Natuurlijke Historie, Leiden, Netherlands, for his granting permission and leave of absence for my participation in the project in Washington, D.C., and for rendering all possible facilities for my work on the project in the Leiden Museum.

My special and most cordial thanks I owe to my friend, Dr. J. F. Gates Clarke, senior scientist, Department of Entomology, U.S. National Museum (USNM) for the initiation of the project, his great and continuing interest through all its phases, and his constant help and advice. The same applies to all the staff members of that museum and of the Smithsonian Institution who were concerned with the project. 
Furthermore, to colleagues from the various museums I am grateful for the sending of study material or for assisting me in many ways: to Dr. J.G. Franclemont, Department of Entomology, Cornell University, Ithaca, N.Y., (CUI); Mr. J.D. Bradley, then with the British Museum (Natural History), London, England (BM); Mr. P.E.S. Whalley and Mr. W.G. Tremewan, of the same museum; Dr. P.E.L. Viette, Muséum National d'Histoire Naturelle, Paris, France (MNHN); Dr. John Smart, University Museum, Oxford, England, (OM); Mr. Harry K. Clench of the Carnegie Museum, Pittsburgh, Pa. (CMP) ; Dr. Rupert L. Wenzel of Chicago Natural History Museum, Chicago, Ill. (CNHM) ; Dr. J.L. Gressitt, Bernice P. Bishop Museum, Honolulu, Hawaii (BMH); Dr. Heinz Schröder, Museum Senckenberg, Frankfurt-am-Main, Germany (SMF); Dr. G. Friese, Deutsches Entomologisches Institut, Berlin, Germany (DEI), and Dr. B. Petersen, Universitetets Zoologiske Museum, Copenhagen, Denmark.

Most drawings have been made, under my supervision, by $\mathrm{Mr}$. A.C.M. van Dijk; a few more, by each of the following artists: Miss R. van Crevel, Miss M. Roovers, Messrs. W. Bergmans, W. van Laar, J.G.A.M. Saraber, Th. K.H. Holt, and by the author. The photographs have been made by Mr. H.F. Roman, photographer of the Leiden Museum (LM), together with the author, and by the author himself.

\section{Phaloniidae}

\section{Aethes Billberg, 1820}

\section{Aethes sphenophora (Diakonoff, 1941)}

Figure 481

Phalonia sphaenophora Diakonoff, 1941, Treubia, vol 18, p. 397, pl. 17, figs. 1-2 ( $\sigma^{\top} \uparrow$, Java).

Phalonia sphenophora.-Diakonoff, 1948, Treubia, vol. 19, p. 483 (emend.).

Distribution: East Java.

Material examined: Luzon, Los Baños (Baker), $2 \sigma^{\top}$, genit. slide 5079 (USNM).

This is the only species of the genus known so far from the Malayan region. Aethes is not found in the Pacific region.

\section{Tortricidae}

\section{Tortricinae}

Key to the Philippine Genera of Tortricinae

1. Head smooth; brightly colored, day-flying species . . . . . . . Zacorisca Head with appressed scales 
2. Forewing with veins 7 and 8 stalked . . . . . . . . . . . . . . . 3

Forewing with veins 7 and 8 separate. . . . . . . . . . . . . . . . 7

3. Forewing with vein 3 from well before angle of cell . . . . . . . . . . 4

Forewing with vein 3 from angle . . . . . . . . . . . . . . . . . . 5

4. Hindwing with veins 3 and 4 separate, 3 sometimes from before angle.

Hindwing with veins 3 and 4 stalked from angle. . . . . . Neocalyptis

Adoxophyes
Neocalyptis

5. Palpi ascending, closely appressed to face, with appressed scales, terminal segment short. . . . . . . . . . . . . . . . . . . . Homona

Palpi obliquely ascending or porrected . . . . . . . . . . . . . . . 6

6. Antenna in male with ciliations over 1; uncus broad.

Archidemis, new genus

Antenna in male with ciliations under 1; uncus narrow . . . . . . Capua

7. Forewing with vein 7 to costa . . . . . . . . . . . . . . Acleris

Forewing with vein 7 to termen . . . . . . . . . . . . . . . . . 8

8. Male with a complicated valva; female with a corethrogyne. . . Isotenes

Male without a complicated valva; female without a corethrogyne . . . 9

9. Male antenna with a notch near base . . . . . . . . . . . . Ulodemis

Male antenna without notch . . . . . . . . . . . . . . . . 10

10. Valva with a round tumescence in center . . . . . . . . . . Isodemis

Valva without such tumescence . . . . . . . . . . . . . . . . . . 11

11. Forewing with veins 2 and 3 stalked . . . . . . . . . . . Spatalistis

Forewing with veins 2 and 3 separate . . . . . . . . . . . . . . . 12

12. Greenish with several transverse crimson streaks . . . . Polemograptis

Not so colored . . . . . . . . . . . . . . . . . . . . . . . . . 13

13. Hindwing with both veins 3 and 4 and 6 and 7 connate . . . . . . . 14

Not both these pairs of veins connate . . . . . . . . . . . . . . . 15

14. Forewing with termen rounded; palpus moderate, obtuse, terminal segment very short; gnathos strong, elongate, complicated.

Snodgrassia, new genus

Forewing with termen concave; palpus rather long, sinuate, terminal segment moderate, obtusely pointed . . . . . . . . Ebodina, new genus

15. Forewing with costa sinuate, apex distinct; terminal segment of palpus normal, obtusely pointed; male genitalia of normal Tortricine type, uncus single . . . . . . . . . . . . . . . . . . . . . . . . . . Archips

Forewing wtih costa rounded, apex strongly rounded and indefinite; terminal segment of palpus moderate, clavate and obtuse; male genitalia peculiar, uncus bifid

Phricanthes

\section{Zacorisca Meyrick, 1910}

\section{Key to the Philippine Species of Zacorisca}

1. Forewing entirely orange

Z. heliaula

Forewing orange and blue

2. Forewing orange with a blue terminal fourth, an orange spot before apex.

Z. electrina

Forewing orange with an entirely blue apical sixth . . . . . . Z. pulchella

\section{Zacorisca pulchella (Schultze, 1910)}

Hyperperissa pulchella Schultze, 1910, Philippine Journ. Sci., sect. D, vol. 5, p. 165 , pl. 1, fig. 8 ( $q$, Luzon, Panai). 
Imma pulchella.-Meyrick, 1913, in Aurivillius, Lepidopterorum Catalogus, pars 13, p. 27; 1914, in Wytsman, Genera Insectorum, fasc. 164, p. 10.

Zacorisca pulchella.-Diakonoff, 1949, Treubia, vol. 20, p. 39; 1952, Verh. Ned. Akad. Wet., Nat., ser. 2, vol. 49, no. 1, p. 48.

Distribution: Philippine Is., Luzon, Panai.

Apparently the type of this species has been lost in Manila during the Pacific War.

\section{Zacorisca electrina (Meyrick, 1912)}

FIgURE 483

Megalodoris electrina Meyrick, 1912, Exotic Microlepidoptera, vol. 1, p. 5 ( Mindanao); 1912, in Aurivillius, Lepidopterorum Catalogus, pars 10, p. 15; 1913 in Wytsman, Genera Insectorum, fasc. 149, p. 21.

Zacorisca electrina.-Diakonoff, 1952, Verh. Ned. Akad. Wet., Nat., ser. 2, vol. 49, no. 1, p. 41.-Clarke, 1955, Catalogue . . Microlepidoptera . . Meyrick, vol. 1, p. 124 ; 1958, op. cit., vol. 3 , p. 263, pl. 131, figs. 4-4c.

Distribution: Philippine Is., Mindanao.

\section{Zacorisca heliaula (Meyrick, 1910)}

FIgURE 485

Atteria heliaula Meyrick, 1910, Trans. Roy. Ent. Soc. London, p. 433 ( $\sigma^{\top}$, Mindoro).-Clarke, 1955, Catalogue ... Microlepidoptera . . . Meyrick, vol. 1, p. 154 .

Megalodoris heliaula.-Meyrick, 1912, Exotic Microlepidoptera, vol. 1, p. 5; 1912, in Aurivillius, Lepidopterorum Catalogus, pars 10, p. 15; 1913, in Wytsman, Genera Insectorum, fasc. 149, p. 21, pl. 3, fig. 32.

Zacorisca heliaula.-Diakonoff, 1952, Verh. Ned. Akad. Wet., Nat., ser. 2, vol. 49, no. 1, p. 40.-Clarke, Catalogue ... Microlepidoptera . . Meyrick, vol. 3, p. 263, pl. 131, figs. 3-3b.

Distribution: Philippine Is., Mindoro.

Material examined: "Philippine Ids., Acc. C.M. 9061," "Mindanao, Davao Prov.," “20.IX.1930," 1 o, neallotype, similar to the male type specimen, except for the black area of the hindwing being less extended, limited by the course of vein $1 \mathrm{~b}$ (CNHM).

\section{Isotenes Meyrick, 1938}

\section{Isotenes inae Diakonoff, 1948}

Figures 489-490

Harmologa miserana Fletcher, 1920 (part), not Walker 1863, Mem. Dept. Agric. India, Ent. ser., vol. 6, p. 41 (Assam).

Isotenes miserana.-Diakonoff, 1941, Treubia, vol. 18, p. 390; op. cit., p. 402, 1941 (Java).

Isotenes inae Diakonoff, 1948, Treubia, vol. 19, p. 493, figs. 3, 18-21 (redescr., genit. $\sigma^{7} q$, Java, Sumatra, Assam).

Distribution: Java, Sumatra, Assam. 
Food plants: Thea (tea plant, leaves), Pinus merkusii (inflorescence).

Material examined: Luzon, Mountain Province, Baguio, 7.V.1945, 1 ㅇ, genit. slide 5093 (J.G. Franclemont) (CUI). Mindanao, Davao, La Lun Mts., Calian, 5500 ft., 29-31.XII.1930 (Clagg), 1 ơ , genit. slide 5696 (CNHM).

\section{Adoxophyes Meyrick, 1881}

Adoxophyes Meyrick, 1881, Proc. Linn. Soc. New South Wales, vol. 6, p. 429; 1883, Trans. New Zealand Inst., vol. 15, p. 39; 1910, Proc. Linn. Soc. New South Wales, vol. 35, p. 205; 1912, in Aurivillius, Lepidopterorum Catalogus, fasc. 10, p. 13; 1913, in Wytsman, Genera Insectorum, fasc. 149, p. 18; 1929, in de Joannis, Ann. Soc. Ent. France, vol. 98, p. 710.-Walsingham, 1900, Ann. Mag. Nat. Hist., ser. 7, vol. 5, p. 481.-Fernald, 1908, Genera of the Tortricidae and their types, p. 42, 60.-Fletcher, 1929, Mem. Dept. Agric. India, Ent. ser., vol. 11, p. 6.-Diakonoff, 1939, Zool. Meded., vol. 21, p. 126, 159, figs. 4I (head), 4F (neuration), 7F-G (genit. $\sigma^{\top}$ ), 4B (genit. $९$ ); 1952, Verh. Ned. Akad. Wet., Nat., ser. 2, vol. 49, no. 1, p. 155; 1960, op. cit., vol. 53, p. 12; 1961, Ann. Soc. Ent. France, vol. 130, p. 50.-Obraztsov, 1954, Tijdschr. Entom., vol. 97, p. 198, figs. 126-130, 139.

Type species: Adoxophyes heteroidana Meyrick, 1881 (Australia).

The taxonomy of the present genus is confused, while the discrimination of its species is difficult. This is chiefly due to the dubious indentity of certain old species, inadequately described by Walker, Pagenstecher, and others, and also to the similarity of both the external and internal structures of the numerous species.

It was a satisfaction to find and study many types of Adoxophyes in the British Museum (Natural History). Walker's types were all present, as also the types of Pagenstecher's classical paper on the Lepidoptera of the Bismarck Archipelago; these latter types came to the British Museum with Lord Rothschild's collection.

Unfortunately, the elaborate revision of the Australian Adoxophyes on which J.F.B. Common has been working for several years is not yet available. That is the reason why I abstained, thus far, from publishing a survey of the Malayan and Papuan Adoxophyes species. During a short visit to the Leiden Museum several years ago, Mr. Common showed me his figures and notes on Australian and Papuan Adoxophyes; we compared them with my data on the Malayan species.

The male genitalia of the present genus are of two principal types, those with normal and those with enlarged valvae. The females, on the other hand, differ in the shape of the signum: either a dagger or a denticulate patch. The genus needs a thorough revision.

The species of the first category differ only by minor characters of the male genitalia, such as the shape of the gnathos and of the aedeagus, and especially the shape and size of a rigid spike situated 
somewhat lateral and subapical in the wall of the aedeagus; however, in a few species this structure is entirely absent.

\section{Key to the Philippine Species of Adoxophyes}

1. Forewing with transverse fascia furcate below . . . . . . . . . . . . 2

Forewing with transverse fascia not furcate. . . . . . . . . . . . . . 3

2. Hindwing light pink .

A. fasciculana

Hindwing pale ochreous fuscous $\left(\sigma^{7}\right)$ or tawny fuscous $(q)$. . A. privatana

3. Males . . . . . . . . . . . . . . . . . . . . . 4

Females . . . . . . . . . . . . . . . . . . . . . 5

4. Transverse fascia narrow, straight, slightly undulate; apical patch fasciate.

A. perstricta

Transverse fascia moderate, dilated on dorsum, outwards-convex; apical patch wedge-shaped .

A. aurata, new species

5. Markings more reduced, usually obliterate on dorsum; apical patch reduced.

A. aurata, new species

Markings more developed, not obliterate on dorsum; apical patch more developed

A. perstricta

\section{Adoxophyes fasciculana (Walker, 1866)}

\section{Figure 482}

Tortrix fasciculana Walker, 1866, List Lepidopterous Insects British Mus., pt. 35, p. 1785.

Adoxophyes fasciculana.-Meyrick, 1910, Proc. Linn. Soc. New South Wales, vol. 35, p. 209; 1912, in Aurivillius, Lepidopterorum Catalogus, pars 10, p. 14 (asciculama, err. typogr.) ; 1913, in Wytsman, Genera Insectorum, fasc. 149, p. 18 (syn.: cyrtosema Meyrick, luzonica Sauber).-Diakonoff, 1941, Treubia, vol. 18, p. 34; 1952, Verh. Ned. Akad. Wet., Nat., ser. 2, vol. 49, no. 1 , p. 155 .

Tortrix luzonica Sauber, 1902, in Semper, Schmetterlinge Philippinischen, Inseln vol. 2, p. 703, pl. 5, figs. 9-10 (larva).

Distribution: New Guinea, St. Aignan Is., Moluccas, Philippine Is., Solomon Is., Fiji, Tonga.

No Philippine material was available to me.

\section{Adoxophyes aurata, new species}

FigưRes 1-6, 487-488

Male, 14-15 mm. Head light ochreous yellow, crown suffused with tawny. Palpus moderate, porrected; light ochreous yellow, terminal segment light tawny. Thorax pale ochreous yellow with a golden gloss, shoulder suffused with bright ochreous yellow. Abdomen glossy pale ochreous yellow.

Forewing broad, truncate, dilated, broadest at $3 / 4$. Costa with a fold from beyond base almost to $1 / 3$, gradually arched from base to apex, apex obtuse, termen vertical above, little rounded below. Whitish yellow, with a golden gloss; markings tawny lilac, edged with dark brown or entirely dark brown. Costal edge clearly suffused 
with bright yellow ochreous; with six dark brown dots, second and third of these finely continued across costal fold by oblique brownish lines; basal patch indicated only by an almost straight and subhorizontal streak from beyond base to just before middle of wing, clavate posteriorly; transverse fascia beginning with a narrow horizontal line edging costal fold below, from well before base of wing (this line often obliterate), abruptly dilated beyond this fold, not reaching its lower edge, neither vein 12; this fascia moderately oblique, rather curved (outwards-convex) as far as lower angle of cell, hardly oblique thence; it is gradually dilated from its middle towards both ends, lower end almost twice as broad as upper, sometimes extended along dorsum almost to tornus; costal patch subfasciate, wedge-shaped, slightly curved, with acute point to tornus, its top extending on costa from beyond the sixth dot to well before apex; anterior edge of this patch usually moderately concave, sometimes slightly convex, posterior edge sometimes slightly excavate above middle; a minute, dark brown marginal line around apex, interrupted on veins. Sometimes wing between markings sprinkled with dark brown. Cilia light golden yellow.

Hindwing semitransparent, pale yellow with a pinkish-golden gloss in certain lights, except along costa and along certain veins; dorsum as far as vein 1c suffused with pale grey. Cilia light golden yellow.

Male genitalia: Tegumen higher than broad, uncus long, curved, slightly narrowed at base, less narrowed above middle, top roundedclavate. Socius small, free and pending, rounded, almost as long as broad. Gnathos with broad arms forming a quadrangle with elongate angles, lower angles rounded and produced, finely denticulate; hook strongly sclerotized, top clavate and rounded. Valva moderate, elongate-oval, sacculus rather narrow throughout, its edge forming a narrow, sclerotized fold, extending from beyond middle of sacculus to its indefinite top: disc of valva with a moderate fold above sacculus and a smaller transverse fold at base; cucullus double. Transtilla moderate, thorny; pulvinus small. Aedeagus rather simply shaped, little curved, slightly dilated basad, without a thorn. (Slides studied: nos. 5000, 5002, 5504, 5024; figured, 5504, 5024.)

Female, 17-19 mm. Head and thorax slightly darker than in the male, thorax somewhat suffused and mixed with tawny, except on tegulae. Abdomen brighter yellow.

Forewing broad, truncate, costa strongly arched anteriorly, straight posteriorly, apex obtusely rectangular, termen hardly concave, vertical. Pale yellow, with numerous deeper ochreous-yellow small transverse strigulae, arranged in oblique series. Markings fuscous 
lilac, edged with dark brown, sometimes wing more or less strewn with brown or fulvous dots. Basal patch indicated by a suffused dot or transverse streak in middle of wing, before its base, often absent, seldom extended; transverse fascia more oblique than in male, from $1 / 3$ of costa to $2 / 3$ of dorsum, with wedge-shaped spots on both costa and dorsum, connected by a narrow, rather suffused straight streak; a few dark brown transverse strigulae and irroration along posterior fourth of dorsum; costal patch broken in two parts, viz., on $3 / 4$ of costa, two transverse dark brown strigulae extended by lilac suffusion, and in tornus, a pointed, triangular mark edged by similar strigulae, sometimes the two parts interconnected by dark brown strigulae; two short strigulae between patch and apex. Cilia glossy yellow.

Hindwing light yellow with a golden gloss, costa paler. Cilia golden yellow.

Female genitalia: Sterigma inverted-triangular, with narrow welldefined double edges. Ostium bursae in its center, with indefinite rims. Colliculum, a moderate, S-shaped sclerite with dilated lower half. Ductus bursae long, straight and narrow; corpus bursae small, subspheroidal. Signum $\mathrm{H}$-shaped, interior arm longer and hooklike. (Collum of spermatophore tortuous). (Slides studied: nos. 2877; 9970 J.F.G.C.; 5001, 5003, 5005, 5026 ; figured: 5005).

Material examined: Luzon, Mt. Makiling, Los Baños (Baker), holotype, $\sigma^{\top}$, genit. slide 5025; allotype \%, genit. slide 5505; others are paratypes; total $24 \sigma^{7}, 22$ \% (USNM). Luzon, Manila, 16.I.1913 (A.E. Wileman), 1 व (BM).

A female specimen of an Adoxophyes from Java, together with two specimens out of the present series from Los Baños, have been described by Meyrick as $A$. perstricta. The Javanese and the Philippine examples, however, are not conspecific. Since the above-mentioned female specimen has been selected lectotype of perstricta (by Clarke, 1958), the Philippine species is now separated and described above.

Although the densly brown-irrorated females of aurata have some resemblance to perstricta o- they differ by the yellow tinge of ground color and cilia, and by the genitalia; the males differ more from $A$. perstricta and approach the tripselia Lower type of markings.

Some of the males in the present series were labelled Adoxophyes epizeucta Meyrick. This Australian species, however, is distinct by a conspicuous dark patch of grey scales below the middle of costa of the pale colored hindwings. It seems very probable that $A$. melichroa Lower is a synonym of epizeucta.

Characteristic is the small subapical spike of the aedeagus in $A$. aurata. 


\section{Adoxophyes perstricta Meyrick, 1928}

Figures 32, 486

Adoxophyes perstricta Meyrick, 1928, Exotic Microlepidoptera, vol. 3, p. 453 (Java, Philippines).-Diakonoff, 1941, Treubia, vol. 18, p. 34, 379, 407; 1947, Tijdschr. Ent., vol. 88, p. $340 ; 1952$, Verh. Ned. Akad. Wet., Nat., ser. 2, vol. 49, no. 1, p. $156 ; 1952$, Verh. Naturf. Ges Basel, vol. 63, p. 144.-Clarke, 1955, Catalogue . . Microlepidoptera . . Meyrick, vol. 1, p. 242; 1958, op. cit., vol. 3, p. 23 (euryomis, a synonym).

Distribution: Java, New Guinea, New Britain; Philippine Is.

Material examined: Luzon, Manila, 9.I.1912 (A.E. Wileman), 1 ㅇ (Rothschild bequest, BM).

The female is very similar to that of aurata. The male, however, has a distinctly longer and more robust subapical spike of the aedeagus.

\section{Adoxophyes privatana (Walker, 1863)}

FigURE 484

Dichelia privatana Walker, 1863, Cat. Lepidopterous Insects British Mus., pt. 28, p. 320 (India).-Swinhoe, 1889, in Cotes and Swinhoe, Cat. Moths India, p. 697, no. 4752.-Swinhoe, 1891, Trans. Roy. Ent. Soc. London (1890), p. 294.

Adoxophyes privatana.-Walsingham, 1900, Ann. Mag. Nat. Hist., ser. 7, vol. 5, p. 481 (syn. cyrtosema Meyrick).-Meyrick, 1910, Proc. Linn. Soc. New South Wales, vol. 35, p. 209; 1912, in Aurivillius, Lepidopterorum Catalogus, pars 10, p. 14.-1913, in Wytsman, Genera Insectorum, fasc. 149, p. 18 (syn. euryomis Meyrick).-1914, Ent. Mitt., Suppl., vol. 3, p. 47.-1934, Iris, vol. 48, p. 29; 1930, in de Joannis, Ann. Soc. Ent. France, vol. 99, p. 710; 1935, in Caradja and Meyrick, Materialien ... Microlepidopteren-Fauna, p. 49.-Fletcher, 1920, Mem. Dept. Agric. India, Ent. ser., vol. 6, p. 35.Diakonoff, 1939, Zool. Meded., vol. 21, p. 162; 1939, Rec. Indian Mus., vol. 16 , p. 231 ; 1941, Treubia, vol. 18, p. 213, 378, 404; 1947, Tijdschr. Ent., vol. 88 , p. $340 ; 1948$, Bull. Mus. Hist. Nat., vol. 20, p. 343 ; 1952, Verh. Naturf. Ges. Basel, vol. 63, p. 143.-Clarke, 1955, Catalogue . . Microlepidoptera ... Meyrick, vol. 1, pp. 20, 23.

Adoxophyes euryomis Meyrick, 1902, in Gardiner, Fauna Maldives . . ., vol. 1, no. 7, p. 126 ( $\sigma^{\top}$ \% , Minikoi, Hululu; ? India).-Clarke, 1955, Catalogue . . . Microlepidoptera ... Meyrick, vol. 1, pp. 20, 23.

Distribution: India, Maldive Is., Burma, Assam, Ceylon, Sumatra, Borneo, Java, Celebes, Ambon, Buru, Batian, Tenimber, Ternate, Talaud, New Guinea, Fiji, Tonga, Tonkin, Formosa, China, Japan, Korea.

Material examined: Luzon, Mt. Makiling, 1 o ; Los Baños, 2.VIII.1920, 1 우 (S.M. Cendana); 1 ㄲ, 2 우 (USNM).

It is now clear that $A$. cyrtosema Meyrick, 1886, from Tonga, Fiji Islands, and south China is a distinct species and not a synonym of privatana, as Walsingham (1900) thought (cf. Clarke 1958, vol. 3, p. 20, pl. 10, figs. 1-1b; Diakonoff, 1958, vol. 8, p. 118).

As for A. euryomis Meyrick, I am grateful to Dr. John Smart of 
the Zoology Department, University Museum, Oxford, for sending to me the entire series of this form. Every specimen originally cited by Meyrick was there: 16 specimens from the island of Minikoi and 7 from Hululu, among which a specimen with a label written in Meyrick's hand "Adoxophyes euryomis Meyr., type." Another specimen from Hululu bears the name label only (OM).

The study of the genitalia of these two males (type, slide 5690 and paratype, 5691) and comparison with material of $A$. privatana from Java (slides 5692 and 5693) revealed that they are conspecific. The aedeagus does not have a subapical spike, but possesses minute thorns scattered over more than median third of the ventral surface. The only difference which I am able to find is that in "euryomis" this field is less extended apicad, while the thorns are slightly larger than in the Javanese examples of privatana: a difference too slight to justify even a subspecific distinction.

\section{Neocalyptis Diakonoff, 1941}

Neocalyptis Diakonoff, 1941, Treubia, vol. 18, p. 407, fig. 2; 1952, Verh. Ned. Akad. Wet., Nat., ser. 2, vol. 49, no. 1, p. 33; 1953, op. cit., vol. 49, no. 3 , pp. 6 , 21; 1955, op. cit., vol. 50, no. 3, p. 173.

Type species: Neocalyptis telutanda Diakonoff, 1941 (Java).

\section{Neocalyptis nematodes (Meyrick, 1928), new combination}

Figures 7, 9-12, 491

Capua nematodes Meyrick, 1928, Exotic Microlepidoptera, vol. 3, p. 452 ( Los Baños).-Clarke, 1955, Catalogue . . . Microlepidoptera . . . Meyrick, vol. 1, p. 214 ; 1958, op. cit., vol. 3, p. 72, pl. 36, figs. 4-4c.

Neocalyptis insularis Diakonoff, 1948, Treubia, vol. 19, p. 498, figs. 43, 44, 47 [new synonym].

Distribution: Philippine Is., Luzon; Sebesi Is. (off Java); Java.

Material examined: Luzon, Los Baños (Baker), $4 \sigma^{7}, 9$ \% genit. slides 5008 ㅇ, $5011 \sigma^{7}$.

This additional material (USNM) of the little known species is most welcome. All specimens apparently belong to the type series but not having been cited in the original description they range only as topotypes. The veins 3 and 4 in the hindwing are separate (almost connate), a feature with which the description of this genus should be extended. The male genitalia are very close to those of the type species, Neocalyptis telutanda Diakonoff, from Java.

\section{Neocalyptis nematodes insularis Diakonok, 1948, new status}

Another species, described by me from Sebesi Island and Javaafter three specimens in bad condition-appears so close to nematodes (figs. 8, 13) that I prefer to sink insularis as a subspecies. The differences with the nominate form are only slight: in the male less strong 
and less regular teeth along the top of the labis; in the female, absence of a slight sclerite in the upper part of the ductus bursae and slight differences of the sclerotization of the rim of the ostium bursae.

\section{Homona Walker, 1863}

\section{Key to the Philippine Species of Homona}

1. Males . . . . . . . . . . . . . . . . . . 2

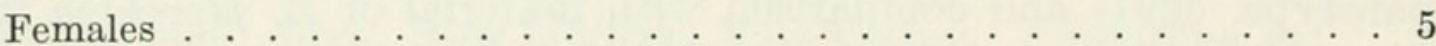

2. Costal fold absent; a large fulvous species $(28 \mathrm{~mm})$. . . . . H. aestivana

Costal fold present . . . . . . . . . . . . . 3

3. Aedeagus with two long, subapical prongs; hindwing pale ochre.

H. bicornis, new species

Aedeagus either with teeth short, or these teeth not only apical; hindwing sometimes light fuscous ... . . . . . . . . . . . 4

4. Aedeagus with two short apical teeth; hindwing fuscous.

H. bakeri, new species

Aedeagus with a subbasal and an apical cusp; hindwing pale ochre.

H. phanaea

5. Very large, $38 \mathrm{~mm}$; forewing broad, not narrowed, with strongly sinuate costa and termen, apex produced; hindwing bright orange yellow.

H. aestivana

Smaller, 24-30 mm; forewing with costa less sinuate or straight, apex not produced; hindwing pale or light ochre . . . . . . . . . . . 6

6. Forewing hardly narrowed posteriorly, ovate truncate; cestum tortuous, not coiled . . . . . . . . . . . . . . H. bakeri, new species

Forewing distinctly narrowed posteriorly, oblong; cestum coiled, not tor-

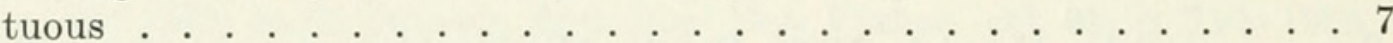

7. Lamella postvaginalis, an oblong, longitudinal plate, continued as colliculum.

H. bicornis, new species

Lamella postvaginalis, a transverse plate, forming with colliculum a $\mathrm{T}$-shaped structure . . . . . . . . . . . . H. phanaea

\section{Homona aestivana (Walker, 1866)}

Figures 303, 492

Ericia aestivana Walker, 1866, List Lepidopterous Insects British Mus., pt. 35, p. 1803 ( $\sigma^{7}$, New Guinea).

Homona aestivana.-Meyrick, 1910, Proc. Linn. Soc. New South Wales, vol. 35 , p. $212 ; 1912$, in Aurivillius, Lepidopterorum Catalogus, pars 10, p. 14 1913, in Wytsman, Genera Insectorum, fasc. 149, p. 19; 1938, Trans. Roy. Ent. Soc. London, vol. 87, p. 505.-Durrant, 1915, in Ogilvie-Grant, Rep. British Ornithologists' Union and Wollaston Exped., . . . Dutch New Guinea, 19101913, vol. 2, pt. 15 , p. 153.-Diakonoff, 1941, Treubia, vol. 18, p. 37 ; 1952, Proc. Ned. Akad. Wet., ser C, vol. 55, p. 404; 1953, Verh. Ned. Akad. Wet., Nat., ser. 2, vol. 49, no. 3, p. 19.

Ericia posticana Walker, 1866, List Lepidopterous Insects British Mus., pt. 35, p. 1803 ( $\sigma^{7}$, Sula Is.).

Distribution: New Guinea, Waigeu Is., Misool Is., Sula Is.; Philippine Is. 
The occurrence of this Papuan species in the Philippine Islands, although recorded by Meyrick (1910), is not yet proven. The specimen represented on figure 492 is from Northwestern central New Guinea, Snow Range, Araucaria Camp, 800 m, 17.III.1939 (L. J. Toxopeus, 3rd Archbold Expedition, LM), male, genit. slide 4946.

The male genitalia may be described as follows: Tegumen moderately rounded. Uncus clavate, rather broad, rounded. Valva large and broad, cucullus weak and plicate, with some dilatations at base. Sacculus strong and slender, over 1, projecting in a slender long point. Vinculum strong. Transtilla bandlike, moderately curved. Aedeagus long, gradually curved at base, top very obliquely truncate above, with a small tooth below. Anellus long. Cornuti, two slender blades.

\section{Homona phanaea Meyrick, 1910}

Figures 35-36, 493-494

Homona phanaea Meyrick, 1910, Proc. Linn. Soc. New South Wales, vol. 35, p. 215; 1912, in Aurivillius, Lepidopterorum Catalogus, pars 10, p. 15; 1913, in Wytsman, Genera Insectorum, fasc. 149, p. 19.-Diakonoff, 1953, Verh. Ned. Akad. Wet., Nat., ser. 2, vol. 49, no. 3, p. 18.-Clarke, 1955, Catalogue . . Microlepidoptera . . Meyrick, vol 1, p. 245.

Distribution: Solomon Is.; New Guinea, St. Aignan Is.; Kei Is.; Philippine Is. (?).

Although the occurrence in the Philippine Islands is recorded by Meyrick, it is not yet proven.

Male genitalia are of the type of Homona coffearia (Nietner). Uncus dilated towards top which is emarginate. Socius moderate, its apical third free. Gnathos with a very strong hook. Sacculus characteristic, sclerotized, with a strong subbasal tooth, also the top of sacculus acutely cuspidate, the whole finely aciculate. Aedeagus strongly curved and narrowed apically, top with a short median and a longer ventral tooth. Cornuti, about four long spines.

Female genitalia: Caudal edge of genital segment with a sclerite on each side, deeply corrugated, with a median longitudinal gully and a parallel prominence above and beneath this, finely aciculate throughout. Ostium bursae proper with lateral prominences below, joined to a moderate, pointed and sclerotized colliculum.

Material examined: "Rendova, Solomon Is., ASM, .05" (in Meyrick's hand), "Homona phanaea Meyr., E. Meyrick det., in Meyrick Coll.," $1 \sigma^{7}$, genit. slide 5769, 19, genit. slide 5770. These are the original syntypes $(\mathrm{BM})$. 


\section{Homona bicornis, new species}

Figures 33, 39-40, 495-496

Male, 15-17 mm. Head and thorax pale tawny ochreous, thorax slightly mixed with brownish or evenly greyish suffused. Palpus pale tawny ochreous. Antenna finely brown-ringed posteriorly. Abdomen whitish ochreous.

Forewing elongate, subtruncate, with a very strong costal fold, almost covering more than the half of wing breadth, costa gently sinuate, apex rectangular, termen gently sinuate, prominent below. Pale ochreous, suffused with somewhat opalescent lilac white, glossy in certain lights. Markings light tawny slightly mixed with pale lilac and with dark brown. Costal fold sometimes tawny, with a few brownish transverse lines; basal patch indicated by dark brown ill-defined suffusion extending from beyond base to about $1 / 4$ of wing, sometimes absent or limited; transverse fascia formed by a moderate transversely semioval lilac grey spot on $2 / 5$ of costa, edged with blackish brown, and by a more oblique rather narrow yellowishochreous fascia from below preceding, running to $2 / 3$ of dorsum, its lower part vertical, its anterior edge well defined throughout, and sometimes pale edged, posterior edge ill defined and obscured by greyish suffusion extending to tornus; costal patch elongate and rather narrow, extending along posterior third of costa to apex, lower edge notched before its middle. A series of short vertical dark brown lines before apex, termen, and in tornus. Cilia glossy pale ochreous.

Hindwing rather dark greyish fuscous, sometimes costal half golden ochreous, sometimes wing more or less semipellucent.

Male genitalia resembling those of Homona wetan Diakonoff. Uncus with an invert-triangular, truncate top. Socius parietal (in wetan free). Gnathos with a much longer hook. Transtilla rather similar, a flat band with inbent margin. Valva subtriangular, higher than long, much shorter than in Homona coffearia. Sacculus $1 / 2$, top strongly dilated and rounded, upper edge irregularly serrate, ending in a short vertical thorn. Aedeagus very characteristic, broad and pistolshaped, top truncate, an oblique median oval thickening on the right side, dorsolaterally, ends produced in two long horns, directed forward, upper straight, lower longer, top slightly pointing downward, or straight. Cornuti, a sheaf of sinuate blades, with a slender and slightly bent, pointed top. Caulis long and curved.

Female 20-25 mm. Head, palpus, and thorax pale ochreous mixed with tawny. Abdomen pale orange. Forewing elongate-truncate, somewhat variable as to the shape, broader or narrower, with apex more or less produced. Pale tawny ochreous scattered with fine transverse dark brown strigulae. Basal patch indicated by some 
dark brown reticulation with an oblique rather straight edge from $1 / 6$ of costa to middle of dorsum; towards dorsum this patch suffused with brown; transverse fascia oblique, from before middle of costa to $3 / 4$ of dorsum, upper half slightly narrowed towards upper edge of cell, thence dilated, with posterior edge rounded and prominent; this fascia sharply edged with dark brown and more or less filled out with grey, anterior half of dilated portion also mixed with dark brown; costal patch narrow, almost fasciate, anterior edge well defined, continued as a regularly curved line across wing and along lower third of tornus; posterior edge of costal patch indefinite, not reaching apex; a narrow dark brown line along apex and termen, a pair of similar shorter transverse lines before apex. Cilia glossy pale ochreous tawny.

Hindwing pale ochreous orange, becoming deeper colored towards apex, pale towards dorsum, apex slightly suffused and strigulated with brown. Cilia whitish ochreous with a brighter ochreous base, around apex cilia mixed with lilac.

Female genitalia similar to those of Homona wetan, but sterigma more erected dorsoventrally (in mount! In $H$. wetan somewhat compressed in that direction). Colliculum is an irregular sclerite, as in wetan, but longer, curved to the left. The sternite possesses an oval thickening on each side of sterigma, with a refracting edge and a strongly granulate surface. Ductus bursae is very long, but cestum is moderate, extending along the lower third only, with a single loop. Signum rather straight, without a capitulum, with a strong basal plate.

Material examined: Luzon, Los Baños, holotype, $\sigma^{x}$, (Baker), genit. slide 5041; allotype \%: the same locality, 11.XII.1922, (D. Valladolid), "Acc. Ec. No. 518, Coll. of Agr. Univ., P. I., gen. no. 5048," paratypes: Los Baños (Baker), genit. slides 5031, 5033, 5051, 5055-5057, 5060, 5066-5072, 5073-5075, 14 \%; Los Baños, alt. 50 m, 7.II.1934-7.XII.1934 (F. Flores), 1 o', genit. slide "A.B. July 22, 1935"; 1 ๙ , genit. slide “A.B. July 23, 1935”; 1 ๙ , genit. slide 5050; Los Baños, 20.I.1935 (F. Reyes), 1 \&, genit. slide 5034; 19.XI.1934 (J.V. Castillo), genit. slide "A.B July 19, 1935”; Manila, Bur. of Plant Industry, 8.XI.1935 (F.L. Butac, R.B. Gines), 4 ㅇ, genit. slide Jan. 24, 1936 (bis) S.B. slide 5064-5065, 5076. Luzon, Mt. Makiling (Baker), $3 \sigma^{7}$, genit. slides 5017, 5042, 5043; 3 \%, genit. slides 5053, 5058, 5063. In total $21 \sigma^{7}, 24$ ㅇ; $4 \sigma^{7}, 4$ ㅇ from Los Baños, Manila and Colombia, Luzon Is., and one from Cadiz, Occidental Negros Is., are without abdomen and are incorporated tentatively (USNM). Luzon, Agoa, La Union, 14.IV.1945, 1 \%, genit. slide 5090; Mt. Apo, 70, 9.II.1945, 1 \%, genit. slide 5091 (J.G. Franclemont) (CUI). North Luzon, 5-6000 ft. (Whitehead), 1 \% (BM). 
Apparently nearest to $H$. wetan Diakonoff and also to $H$. intermedia Diakonoff both from Java.

\section{Homona bakeri, new species}

Figures 30-31, 37-38, 497-498

Male, 18.5-22 mm. Head pale ochreous; palpus brighter ochreous, frontally touched with fuscous. Thorax pale ochreous slightly touched with grey. Abdomen pale ochreous.

Forewing elongate, truncate, costa sinuate, with a large semicircular or semioval fold, sometimes exceeding middle of wing breadth, apex obtuse-rectangular, termen gently sinuate above, rounded beneath. Pale ochreous, sparsely strewn with grey-purple scales, markings light tawny mixed with purplish brown. Costal fold pale tawny, darker than ground color, with some five very narrow dark transverse marks, edge of fold roughly ciliated and mixed with dark purplish; transverse fascia indicated by a rhomboidal, lilac-grey spot on costa before middle, finely edged with blackish purple, and by a fasciate, very oblique streak from upper edge of cell below costal spot, to dorsum before tornus, tawny olive, on dorsum suffused with grey or purplish, this suffusion sometimes extending along dorsum basad; costal patch narrow, fasciate-semioval, from beyond middle of costa to before apex, tawny olive, strewn with blackish-purple dots and small lines along costal edge; a small vertical purple line before apex and upper part of termen, preceded by some brownish suffusion. Cilia glossy pale ochreous, slightly mixed with lilac grey opposite apex.

Hindwing yellowish ochreous, sometimes suffused on dorsal half with brownish, cilia pale ochreous.

Male genitalia resembling those of Homona intermedia Diakonoff. Tegumen and uncus very similar. Socius semiparietal (as in intermedia), transtilla also similar. Valva higher than broad, shorter and more triangular than in that species. Sacculus differently shaped, strongly sclerotized, upper edge with a large triangular dilatation in middle, lower edge with a free, curved submedian thorn, and an oblique apical shorter one. Aedeagus sclerotized, entirely different from that in intermedia: it is rather straight in lateral aspect, but with top curved to the left in dorsal aspect, with a bifid apex (seen laterally). Cornuti, a few narrow spines.

Female, 24-30 mm. Head and thorax pale ochreous tawny, touched with grey. Abdomen orange ochreous.

Forewing elongate truncate, broadest at $1 / 3$, costa strongly arched anteriorly, sinuate posteriorly, apex produced and somewhat falcate, termen strongly sinuate above, obliquely rounded beneath. Pale ochreous with a lilac gloss, with numerous fine transverse ferruginous strigulae, curved and tending to form transverse lines. Basal patch 
indefinite, with two curved transverse lines, first beyond base, vertical, second well beyond first, strongly curved posteriorly below middle of disc; transverse fascia ill defined, indicated by faint brownish suffusion and interrupted undulating narrow edges, running from about middle of costa to middle of dorsum; costal patch represented by a fuscous-greyish streak from beyond middle of costa to before apex, from its posterior extremity an oblique sinuate line running across wing to end of vein 4; a ferruginous marginal line in apex and along upper half of termen; a short strigula before apex. Cilia concolorous, slightly touched with grey.

Hindwing ochreous yellowish, extreme apex purplish. Cilia glossy pale ochreous tawny touched with grey.

Female genitalia resemble those of Homona nubiferana (Walker). Sterigma large, strongly convex, formed by a semioval, corrugated plate on each side, in the middle forming with ostium and colliculum a long tube, open frontally (ventrally) for the half of its length; colliculum with a thick and refracting wall, sclerotized on the inside. Ductus bursae moderate. Ostium long and characteristic, regularly tortuous along its entire length. Signum, a long, hollow thorn without a capitulum, basal plate strongly convex.

Material examined: Luzon, Mt. Makiling (Baker), $1 \sigma^{x}$, holotype, genit. slide 5045; 1 ㅇ, allotype, genit. slide 5016, "on Anona muricata"; $2 \sigma^{\top}$, paratypes, genit. slides 5032 and 5044. Los Baños, $50 \mathrm{~m}$, 10.II.1935 (R. Laher), "Acc. Ec. 1046, Coll. of Agr. Univ., P.I.," 1 o, paratype, genit. slide 5047; same locality, 24.I.1933 (T. S. Komkris), “Acc. no. F92, Coll. of Agric. Univ., P.I.," 1 o, paratype, genit. slide 5035, $5040 \sigma^{7}$, Luzon, Bangui, I.1918, 1 ㅇ, paratype, genit. slide 5059; $3 \sigma^{7}, 4$ ㅇ (USNM). Luzon, Manila, 4 and 13.XII.1913, $2 \sigma^{\Upsilon}$, paratypes, genit. slide 4855. Benguet Prov., Palali, 2000 ft., 25.III.1912; Klondyke, 800 ft., 18 and 20.III.1912, 9.V.1912, 30.V.1914 (A.E. Wileman), 5 o, 2 ㅇ, paratypes (BM).

Nearest to Homona intermedia Diakonoff, from Java, the female of which is not known. A variable but rather worn lot, especially the females. The allotype has the dorsum rubbed in both forewings. The female paratype no. 5059 (with right hindwing missing) has the following markings: a spot of grey suffusion on dorsum before middle; basal patch of costa moderately suffused with grey; transverse fascia not undulating, entire, slightly infuscated; edge of fascia continuous, narrow, running from about $2 / 5$ of costa to $3 / 4$ of dorsum, straight, below vein 2 abruptly turned posterad, so as to form a rounded prominence above dorsum; costal patch emitting slender transverse line from both extremities.

The species is dedicated to the late Professor Charles Fuller Baker, former Dean of the College of Agriculture of the University of 
the Philippines and for years outstanding collector of Philippine insects.

\section{Cариа Ḧ̈̈ner, 1826}

\section{Key to the Philippine Species of Capua}

1. Forewing pale ochreous with a small dark submedian and a paler subapical spot.

C. retractana invalidana

Not thus.

2. Forewing with three parallel oblique transverse lines.

C. thelmae, new species

Not so marked

C. fabrilis

\section{Capua retractana invalidana (Walker, 1863)}

Figures 55, 499

Tortrix retractana Walker, 1863, List Lepidopterous Insects British Mus., pt. 28, p. 322 .

Epagoge retractana.-Diakonoff, 1939, Zool. Meded., vol. 21, p. 165; 1939, Rec. Indian Mus., vol. 41, p. 231 (India) ; 1941, Treubia, vol. 18, p. 379 (Java).

Tortrix invalidana Walker, 1863, List Lepidopterous Insects British Mus., pt. 28 , p. 327.

Epagoge invalidana.-Meyrick, 1908, Journ. Bombay Nat. Hist. Soc., vol. 18, p. 617.-Diakonoff, 1939, Zool. Meded., vol. 21, p. 165.

Epagoge retractana invalidana.-Diakonoff, 1941, Treubia, vol. 18, p. 410; 1947, Tijdschr. Ent., vol. 88, p. 341.

Capua retractana.-Walsingham, in Moore, 1887, Lepidoptera Ceylon, vol. 3, p. 492, pl. 208, fig. 11.-Meyrick, 1910, in Aurivillius, Lepidopterorum Catalogus, pars 10, p. 9; 1913, in Wytsman, Genera Insectorum, fasc. 149, p. 14 .

Dichelia retractana.-Cotes and Swinhoe, 1887, Cat. Moths India, pt. 2, p. 697, no. 4753.-Meyrick, 1934, Iris, vol. 48, p. 29.

Distribution: India, Ceylon.

Foodplants: Chrysanthemum, Acacia arabica, Gossypium, Barleria prionitis, Elephanthopus scaber, Lantana.

Material examined: Luzon, Mountain Province, Baguio, 7.V.1945

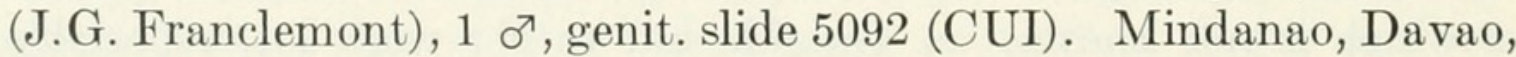
Genitalan, $8 \mathrm{~km} \mathrm{NW}$ of Mt. Apo, $690 \mathrm{~m}$, 17.VIII.1958, jungle clearing, light trap (H.E. Milliron), 1 o, genit. slide 5310 (BMH).

\section{Capua fabrilis Meyrick, 1912}

\section{Figure 501}

Capua fabrilis Meyrick, 1912, Exotic Microlepidoptera, vol. 1, p. 1 ( + , Luzon); 1912, in Aurivillius, Lepidopterorum Catalogus, pars 10, p. 8; 1913, in Wytsman, Genera Insectorum, fasc. 149, p. 13.-Clarke, 1955, Catalogue . . . Microlepidoptera ... Meyrick, vol. 1, p. 139; 1958, op. cit., vol. 3, p. 68, pl. 34 , figs. $3-3 b$.

Distribution: Philippine Is., Luzon. 
It is not certain that the generic position of the species is correct because the males are unknown. The female genitalia, though, agree rather closely with those of the type species, Capua favillaceana Hübner.

\section{Capua thelmae, new species}

Figure 23, 500

Male, $14.5 \mathrm{~mm}$. Head light tawny. Antenna tawny ringed with ferruginous (palpi missing). Thorax dark fuscous, anteriorly suffused with ferruginous, tips of tegulae pale ochreous. Abdomen pale ocherous tawny, tergites posteriorly suffused with grey.

Forewing elongate-truncate, costa strongly curved at base, almost straight posteriorly, apex little rounded, slightly prominent, termen gently sinuate, little oblique. Glossy pale ochreous, dorsum with a faint pinkish tinge. Markings fuscous brown. Basal patch suffused with fulvous, narrowly extended, edge well defined, narrowly dark fuscous brown, from $1 / 6$ of costa to beyond $2 / 5$ of dorsum; transverse fascia rather narrow, from $2 / 5$ of costa to dorsum beyond middle, its anterior edge parallel to that of basal patch; upper half of fascia wedge-shaped, lower half with the entire edge dark and linear, posterior edge ill defined, strongly curved outwards but incomplete above, to dorsum well before tornus, anterior half of the lower part of fascia darker and rather well defined; costal patch represented by a narrow, slightly sinuate dark brown streak from $2 / 3$ of costa, slightly dilated triangularly at origin, to termen just above tornus, anterior edge concave above extremity; a small transverse spot on costa before apex, preceded by a vertical transverse strigula; ill-defined transverse strigulation from dorsum, tending to raise across wing and to part in two light spaces between markings. Cilia pale ochreous mixed with brownish.

Hindwing pale ochreous, scattered with not many rounded spots of pale fuscous suffusion, tending to form transverse curved series; dorsum infuscated. Cilia pale ochreous.

Male genitalia: Uncus strongly clavate. Socius parietal, a broad patch. Gnathos long, pending and slender, hook rather short, oval. Valva elongate, moderately constricted beyond base, costa indicated; sacculus strong, bluntly prominent beyond middle below, cucullus rather obtusely pointed. Aedeagus sclerotized, moderate, top turned to the right, with a tooth on upper side before orifice.

Material examined: Mindanao, Bukidnon, Mt. Katanglad, $1480 \mathrm{~m}$, 27-31.X.1959 (L. Quate and C. Yashimoto), $1 \sigma^{7}$, holotype, genit. slide 5315 (USNM). Mindanao, Davao Prov., east slope of Mt. McKinley, 7000 ft., 16.VIII.1946 (CNHM Philippine Exped. 194647, H. Hoogstraal), $1 \sigma^{\top}$, paratype, genit. slide 5734. 
A characteristically colored species suggesting a Choanograptis Meyrick by coloring and markings. The genus Capua Hübner is meant in its revised concept (by Obraztsov, 1954).

This species is dedicated to Mrs. Thelma M. Clarke.

\section{Archips Hübner, 1826}

\section{Key to the Philippine Species of Archips}

1. Males . . . . . . . . . . . . . . . . . . . . . 2

Females . . . . . . . . . . . . . . . . . . . . . . . . 4

2. Forewing fulvous pink, with a well-defined dark, clavate and oblique spot before middle of costa, followed by two rounded-triangular costal dots; no trace of subapical markings . . . . . . A. dicaeus, new species

Forewing with a pink tinge; the clavate costal spot suffused, mostly interrupted or incomplete; subapical markings developed . . . . . . . . . 3

3. The end of clavate mark incomplete, crescentic; hindwing dark fuscous, opaque . . . . . . . . . . . . . . . . . . . . . A. difficilis

The end of clavate mark elongate oval, mark interrupted below costa; hindwing pale fuscous, almost semipellucent . . . . . . . . A. salaconis

4. Hindwing deep orange, dorsum fuscous; forewing with costa and termen strongly sinuate, apex falcate. . . . . . . . A. aperta, new species

Not thus . . . . . . . . . . . . . . . . . . . . . . . . . . . 5

5. Hingwing pale fuscous, without yellow; forewing with costa abruptly excavate beyond middle . . . . . . . . . . . . . . . . . . . A. salaconis

Hindwing partly yellow; forewing with costa moderately sinuate . . . . 6

6. Hindwing (presumably) pale orange yellow, with transverse dark strigulae; forewing with dark markings well defined . . . A. dicaeus, new species

Hindwing fuscous with orange-yellow suffused apex; forewing with markings suffused . . . . . . . . . . . . . . . . . . . . A. difficilis

\section{Archips salaconis (Meyrick, 1912)}

Figures 14-15, 27, 101, 502-504

Cacoecia salaconis Meyrick, 1912, Exotic Microlepidoptera, vol. 1, p. 15 (Philippine Is., †); 1912, in Aurivillius, Lepidopterorum Catalogus, pars 10, p. 22; 1913, in Wytsman, Genera Insectorum, fasc. 149, p. 25.-Clarke, 1955, Catalogue . . Microlepidoptera... Meyrick, vol. 1, p. 275. Archips salaconis.-Clarke, 1958, Catalogue . . Microlepidoptera . . Meyrick vol. 3 , p. 47 , pl. 23 , figs. $3-3$ c.

Cacoecia xanthochroma Wileman and Stringer, 1929, The Entomologist, vol. 62, p. 65 ( ๙゙, Luzon, Mindanao) [new synonym].

Distribution: Philippine Is., Luzon, Mindanao.

Material examined: Luzon, Los Baños, $50 \mathrm{~m}$, 9.I.1935 (M.R. Tibay), 1 \%; same locality, Sept. 1924 (E. Quisumbing), 1 \%; same locality, 17.IX.1928 (A.V. Guanzon), 1 \%; same locality, 12 ๆ (Baker). Luzon, Mt. Makiling, $46 \sigma^{\Upsilon 7}, 3$ ๆ, genit. slides $5506 \sigma^{7}, 5783$ ๆ (Baker).

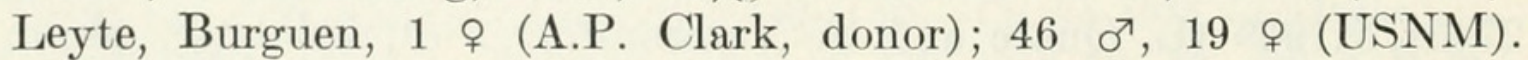
Luzon, Benguet Prov.: Klondyke, $800 \mathrm{ft}$; 20.XII.1911, $2 \sigma^{x}$, 15.III 1912, 1 б ; 1.IV.1912, 2 ठ 12.I and 23.II.1914, 2 ơ; Benguet, Palali, 2000 ft., 27.XII.1912, 
$4 \sigma^{7}$. Mindanao, Lanao, plains, Kolambugan, 30.V, 9 and 13.VI. 1914, $2 \sigma^{7}, 2$ ㅇ, (A.E. Wileman); $11 \sigma^{7}, 2$ 甲 (BM). Mindanao, VIIVIII.1917 (Clagg), $1 \sigma^{\Upsilon}, 1$ \% (CMP). An interesting, large species; the females are characteristic by strongly sinuate costa of the forewings.

The male has been described under the name Cacoecia xanthochroma Wileman and Stringer. I studied the following paratypes of that species: $1 \sigma^{7}$, Mindanao, prov. Lanao, Kolambugan, sea level, 30.V.1914, and 1 \%, Luzon, prov. Benguet, Klondyke, $800 \mathrm{ft.}$, 11.III.1912 (A.E. Wileman).

The male may be redescribed as follows.

Forewing elongate, truncate, moderately dilated, costa without a costal fold, moderately curved anteriorly, slightly curved posteriorly, apex subrectangular, obtusely pointed, termen gently sinuate above, moderately convex beneath, little oblique. Whitish ochreous, on costal half sometimes variably suffused with dark leaden grey. Markings purple or brown. Anterior third of costa more or less suffused with brown and with a few small, transverse marks. Basal patch indicated by a crescentic fasciate patch, from beyond base of dorsum, slightly inwards-oblique, to $1 / 4$ of disc, end turned upwards and obtusely pointed; and by a small round dot halfway between costal edge and above-mentioned mark, slightly before its point, transverse fascia indicated by a wedge-shaped spot on $1 / 3$ of costa, an invert-pyriform spot below and beyond it, extending with a narrowed point to lower angle of cell, and a faint grey quadrate suffusion on $3 / 4$ of dorsum with its concave anterior edge continued by a line rising almost to middle of the anterior edge of pyriform spot; costal patch indicated by a purple streak along costa from before its middle to before apex, and by a sinuate line from posterior edge of that streak to $3 / 4$ of termen; a dot in the extreme angle, continued as a terminal line to middle of termen; posterior third of wing more or less transversely strigulated with purple. Often the markings are reduced, but they are seldom as complete as described above.

Hindwings variably suffused with grey, dorsum paler.

Females 25-31 mm. The markings are rather constant but limited to the slender costal half of the transverse fascia, the narrowly fasciate costal patch and a less distinct sinuate preterminal line from apex. The ground color may vary stronger: from whitish ochreous to greyish ochreous, variably suffused with lilac grey.

Male genitalia, Tegumen moderate, rather slender, almost twice as high as broad. Gnathos, a slender hook, reaching 3/4 distance towards transtilla. Socius parietal, several spread bristles. Uncus rather short, top rounded. Transtilla very slender, strongly nar- 
rowed in middle. Vinculum large, broadly rounded. Valva very large, costa and cucullus portion membranous, making wide and undulating folds (only partially expanded in mount); sacculus part moderately broad, rigid, ending in a triangular lobe. Sacculus proper narrow, dilated posterad, top sclerotized, subobtuse. Aedeagus with a truncate top and a peculiar subapical denticulate and curved thorn. Cornuti, a sheaf of some three very long spines.

Female genitalia: Ostium and colliculum together forming a long simple funnel, with a moderately sclerotized, slightly wrinkled wall; a slight, paler constriction indicating the connection of ostium with colliculum; lower extremity of this funnel obliterate in front. Ductus bursae rather long, with two coils, with a very thin cestrum. Corpus bursae inverted. Signum, an obliquely striped rather long dagger.

The species is nearest to Archips spilotoma (Meyrick), new combination, from Celebes.

\section{Archips dicaeus, new species}

Figures 43, 505-506

Male, $21 \mathrm{~mm}$. Head light brown, posterior edge of eye pale ochreous. Antenna ochreous. Palpus pale ochreous, irrorated with fulvous, except at base. Thorax pale ochreous lilac, posterior half mixed with dark brown. Abdomen light yellow, strongly mixed with dark brown, hairy.

Forewing without a costal fold, broadly suboval, dilated to middle, scarcely dilated beyond middle; costa moderately curved throughout, gently prominent before middle, apex subrectangular, moderately pointed, termen gently rounded, little oblique. Pale ochreous on basal third, thence becoming pale fulvous lilac; an irregular lilac suffusion on posterior fourth of dorsum, rising halfway across wing. Markings deep purple with a green gloss in certain lights, edged with pale ochreous. Edge of costa suffused with pale orange, its anterior third with three small dots; basal patch indicated by a somewhat irregular, strongly outwards-oblique wedge-shaped mark with point on dorsum beyond base, rising to middle of wing, top obliquely truncate; transverse fascia incomplete, tolerably straight, from $2 / 5$ of costa to $3 / 4$ of dorsum; upper half of this fascia forming a conspicuous inverted-clavate mark, with a triangularly dilated base on costa and a rounded top reaching middle of disc; this mark preceded by illdefined lilac suffusion; some four marks between this and dorsum indicating lower half of fascia; first of these purple, rounded, moderate, last ferruginous, oval; other, minute, turning fulvous, edged with ochreous orange; a few purple scales below $1 / 3$ of costa and below middle of fold; three purple triangular spots on posterior half of costa, quickly becoming larger and less distant posteriorly; ultimate one of 
these spots small, preapical; a series of vertical, ferruginous strigulae resting on terminal edge, along termen from apex to tornus. Cilia tawny, becoming pale ochreous, along lower third of termen, greyish in tornus.

Hindwing deep brown bronze, base and dorsum as far as vein la pale fuscous; costa whitish ochreous. Cilia bronze fuscous, a coppery subbasal fascia, base narrowly whitish.

Male genitalia resembling those of Archips encausta (Meyrick), new combination, from Ceylon (fig. 44) closely. Tegumen high. Uncus with a triangular base and a rather broad hook which is not dilated (in encausta distinctly dilated). Socius small, parietal. Gnathos slender, hook short, by far not reaching transtilla (in encausta gnathos arms decidedly much stronger and broader, hook long, in mount exceeding transtilla). Valva higher than long, subquadrate; sacculus sclerotized, its dorsal edge basally especially strong; harpe shaped as a large elongate-oval plate, covering the central part of the disc of valva, ending dorsally in a sharp, rising thorn (in encausta harpe less elongate but more rounded-oval, with a sharper thorn); a membranous elevated ridge separating upper membranous third of the disc of valva. Transtilla, a rather narrow transverse band, broadly emarginate in middle (in encausta broader, upper rim shortly triangularly excised). Pulvinus well developed. Aedeagus little bent, basal third broader, a transverse pair of short thorns below orifice (in encausta basal fourth broader, apical thorns very short).

Female, $28 \mathrm{~mm}$. Head and palpus pale tawny ochreous, face pale tawny. Thorax pale fulvous lilac. (Abdomen and hindwings missing).

Forewing elongate-truncate, costa strongly sinuate throughout, apex falcate and produced, termen deeply excavate above, prominent and obliquely rounded beneath. Pale ochreous, evenly suffused throughout with light fulvous lilac except a round field in tornus and edges to markings. Markings dark purple. Costal edge narrowly orange; several very fine bluish or purplish transverse lines on costa between markings. A round dot above middle of disc, before $1 / 6$; transverse fascia indicated by a lilac, suffused, very oblique patch on $1 / 3$ of costa, finely edged with purple, an oval more oblique purple spot between this and cell, and a few irregular purple spots and scales below this, hardly reaching middle of wing; a triangular spot on middle of costa and three small marks beyond this, becoming smaller posteriorly; falcate apex of wing centered with an elongate spot; cilia ferruginous brown, ochreous along lower third of termen.

Material examined: Luzon, Mt. Makiling (Baker), $2 \sigma^{7}$, holotype, genit. slide 5027, and paratype; 1 ㅇ, allotype (USNM).

This conspicuous species is closely related with Archips encausta Meyrick, from Ceylon, but differs by distinctly less dilated forewings 
in the two sexes, by more limited markings and by the darker hindwings of the male. The male genitalia of dicaeus and encausta are rather similar.

\section{Archips difficilis (Meyrick, 1928)}

Figures 16-19, 507-508

Cacoecia difficilis Meyrick, 1928, Exotic Microlepidoptera, vol. 3, p. 456 ( o' Borneo).-Clarke, 1955, Catalogue . . . Microlepidoptera . . . Meyrick, vol. 1, p. 116.

Homona difficilis.-Diakonoff, 1948, Treubia, vol. 19, p. 509 (Java).

Archips difficilis.-Clarke, 1958, Catalogue . . . Microlepidoptera . . . Meyrick, vol. 3, p. 39, pl. 19, figs. 3-3b (lectotype selected, figured).

Distribution: Borneo, Java, Philippine Is.

Material examined: Luzon, Benguet, Palali, 2000 ft., 28.XII.1912, $10^{7}$, genit. slide 5539. Mindanao, Lanao, plains, Kolambugan, 30.V.1914, 1 ㅇ, genit. slide 5543 (A. E. Wileman) (BM). Genitalia compared with a $\sigma^{7}$ specimen from Java, genit. slide 5540 (LM).

Male genitalia: Tegumen and uncus rather small, the latter with a slightly elevated, rounded top. Valva large, simple, cucullus almost semicircular, lower edge flattened; sacculus over 1/2, moderately sclerotized, with a simple, narrowly triangular rising top. Transtilla simple and narrow. Pulvinus large, semicircular. Aedeagus little bent, lower edge of orifice with a moderate thorn. Cornuti, a couple of slightly sinuate blades.

Female genitalia: Genital sternite forming a sclerotized oblongtruncate plate. Sterigma forming an inverted-triangular, pocketlike sclerite, lamella postvaginalis being much broader than lamella antevaginalis. Colliculum represented by some indefinite small sclerites. Ductus bursae simple, coiled once. Signum large and strong, dagger-shaped, wall around its base distinctly sclerotized.

\section{Archips aperta, new species}

Figures 26, 41-42, 48, 511

Female, $26 \mathrm{~mm}$. Head and thorax deep ferruginous with a purple hue. Palpus orange strongly mixed with ferruginous, except at bases of basal and median segments. Antenna deep ferruginous purple. Abdomen ferruginous, venter yellow orange.

Forewing subtruncate, costa strongly sinuate, apex long, produced, rounded-subfalcate, termen strongly sinuate, vertical, rounded prominently below. Purple ferruginous, glossy, markings limited, narrow deep ferruginous-brown, dull strigulae. Basal fourth suffused with darker ferruginous purple, edge indefinite; transverse fascia indicated by a narrow oblique strigula from the large costal promi- 
nence at $1 / 3$ of wing, running to upper edge of cell; continued in cell by an ill defined roundish spot, below cell, by a cloudy purple transverse suffused patch; costal patch represented by a narrow marginal elongate-suboval streak from before $1 / 2$ to well below apex; less than apical fourth of wing suffused with deep ferruginous purple with anthracite gloss and with some four almost continuous, little outwardsoblique parallel lines, first and second to anterior edge of apical suffusion, third to termen above tornus, last to middle of termen; ultimate of these lines dilated below costa so as to form a quadrate spot before apex; apex with a dark ferruginous spot. Cilia deep ferruginous purple with anthracite gloss, opposite tornus cilia pale ochreous.

Hindwing rather thinly scaled; orange bronze, becoming deep orange towards apex, dorsal portion as far as cell and vein 2 suffused with bronze fuscous, with darker veins. Cilia bronze purplish with a narrow white basal line, towards tornus gradually turning fuscous.

Female genitalia: Sterigma little modified, ostium, a simple broad funnel, little sclerotized. Ductus bursae very long, coiled. Cestum narrow, along less than lower half of ductus, in two coils. Signum with a slender capitulum and a slender long dagger.

Material examined: Luzon, Mountain Province, Baguio, 7.V.1945 (J. G. Franclemont), 1 ㅇ, holotype, genit. slide 5089 (CUI); same locality $5000 \mathrm{ft}$. (Clagg), 1 \%, paratype (BM). Mindanao, Davao Prov., Mt. Mayo (Mati), 4000-5000 ft., 26-30.I.1931 (Clagg), 1 o, paratype, genit. slide 5705 (CMP). "Philippines, Luzon, Baguio, 8.VI.1928" (W. Parsons), 1 \%, paratype (Genova M).

Nearest to Archips machlopis (Meyrick) from Java, having in common the peculiar shape of the forewings; but differing by the color of the hindwing which is deeper orange without the pale costa and, especially, with normal costal cilia, not modified so as to form a thick dark brushlike patch as in machlopis. The ostium bursae is also quite different in machlopis, while the signum differs to a lesser degree I expect the unknown male to be of the machlopis appearance.

\section{Isodemis Diakonoff, 1952}

Isodemis Diakonoff, 1952, Verh. Naturf. Ges. Basel, vol. 63, p. 147, figs. 10, $12,14,15$.

Type species: Batodes serpentinana Walker, 1863 (Borneo).

\section{Isodemis serpentinana (Walker, 1863)}

Figures 513-514

Batodes serpentinana Walker, 1863, List Lepidopterous Insects British Mus., pt. 28 , p. 317 ( $\sigma^{\top}$, Borneo). 
Cacoecia serpentinana.-Meyrick, 1912, in Aurivillius, Lepidopterorum Catologus pars 10, p. 18; 1913, in Wytsman, Genera Insectorum, fasc. 149, p. 24, pl. 3, fig. 33.-Diakonoff, 1941, Treubia, vol. 18, p. 387.

Tortrix serpentinana.-Meyrick, 1921, Zool. Meded., vol. 6, p. 149.

Syndemis serpentinana.-Diakonoff, 1941, Treubia, vol. 18, pp. 41, 421; 1948, op. cit., vol. 19 , p. 511, figs. 30,37 .

Isodemis serpentinana.-Diakonoff, 1952, Verh. Naturf. Ges. Basel, vol. 63, p. 147, figs. $10,12,14,15$.

Distribution: India, Ceylon, Borneo, Sumatra, Java, Sumba, New Guinea.

Material examined: Luzon, Mt. Makiling (Baker), 1 , genit. slide 9525 (J.F.G.C.)(USNM).

\section{Archidemis, new genus}

Head with appressed scales. Ocellus posterior. Proboscis short. Antenna 2/3, long-ciliate in male, ciliations over 1 , minutely ciliated in female. Palpus porrected, rather long, median segment triangularly dilated by roughish scales towards apex above, terminal segment moderate, exposed, slightly drooping (thorax denuded). Forewing elongate-truncate, apex gently produced. Vein 2 from middle of cell, 3 from angle, 4 distant, nearer to 5,7 and 8 stalked, 7 to termen, 11 from befo:e middle, cell very narrow, sinuate, not dilated.

Hindwing without cubital pecten; vein 2 from $2 / 3,3$ and 4 connate from angle, 5 closely approximated, 6 and 7 stalked.

Male genitalia of Pandemis type, but with broadly triangular uncus and smaller socii. Female genitalia of Pandemis type.

Type species: Archidemis anastea, new species.

The genus belongs to a type apparently ancestral to Pandemis Hübner. It differs from that genus and also from Panaphelix Walsingham and Parapandemis Obraztsov, by the neuration of fore- and hindwings, and from Ulodemis Meyrick, by the not-notched base of male antenna. The species has the facies of an Ulodemis, while the male genitalia are very close to those of the European Pandemis ribeana Hübner.

\section{Archidemis anaste a, new species}

Figures 20-22, 24-25, 28-29, 509-510

Male, $25 \mathrm{~mm}$. Head, palpus and thorax bright tawny fulvous, frons, scape of antenna in front and median third of palpus ferruginous. Antenna without notch, ochreous tawny, ciliations 1. Abdomen golden ochreous.

Forewing oblong, subtruncate, hardly dilated beyond middle, costa without fold, curved anteriorly, almost straight along posterior half, apex pointed-rectangular, termen gently sinuate, little oblique. Rather bright ochreous yellowish, strewn with numerous ferruginous 
dots of diverse size, more or less forming oblique transverse rows: suffused throughout with light tawny. Markings hardly indicated by deeper tawny-fulvous suffusion. A faint streak along posterior third of costa to before apex, indicating costal patch; transverse fascia very faint, moderately dilated, from $1 / 3$ of costa to well beyond middle of dorsum; a shadow along base of dorsum; irregular ferruginous dots strewn denser and rather regularly on basal half of wing; a more distinct curved series of larger dots edging costal patch from below and running somewhere towards lower third of termen, so forming the border between a paler central part of disc and the slightly darker apical area. Cilia (damaged) light ochreous tawny.

Hindwing pale golden ochreous, glossy, whitish and semipellucent in cell.

Male genitalia: Tegumen rather broad, subspherical. Uncus porrect, ratherlong, broad at base, gradually narrowed towards rounded top. Socius minute, parietal. Gnathos strongly sclerotized, arms and hook moderate. Vinculum circular. Valva moderate, simple, short stretch of base of costa sclerotized, cucullus over $1 / 2$, gradually rounded, sacculus over $1 / 2$, narrow and simple, sclerotized. Pulvinus not developed. Transtilla moderate, gradually narrowed towards middle. Labis, a sclerotized moderate fold. Aedeagus pistol-like, curved. Cornutus, one straight spine and scars of five more.

Material examined: Mindanao, Davao Prov., east slope of Mt. McKinley, 7000 ft., 22.IX.1946 (CNHM Philippine Zool. Exped. 194647, H. Hoogstraal), $1 \sigma^{7}$, holotype, genit. slide 5732.

Female, $31 \mathrm{~mm}$. Head, palpus and thorax rather bright fulvous tawny; palpus slender and long, sinuate and subascending, moderately dilated and expanded towards apex along its posterior half, terminal segment short, subtriangular, drooping. Antenna with scape fulvous tawny, flagellum fulvous whitish. Abdomen glossy whitish ochreous.

Forewing broad, elongate-truncate, costa strongly curved along anterior $2 / 3$, straight posteriorly, apex subrectangular, termen sinuate, vertical above, broadly rounded and prominent beneath. Lilac fulvous, partially suffused with bright tawny ochreous, with purplish lilac gloss in certain lights. Holotype devoid of any markings, paratype with a subquadrate pale pinkish-ochreous spot on middle of dorsum, edged on both sides with purplish extending in both directions along dorsum; a few purplish-brown dots in disc posteriorly tending to form some three strongly curved series beyond cell from costa to dorsum; a faint deeper tawny spot on costa before middle, being the upper part of transverse fascia, moderate, interrupted by cell, followed by a paler ochreous-tawny spot, representing space between the fascia and apical patch, which, however, is indefinite. Cilia deep fulvous tawny, becoming paler towards tornus. 
Hindwing glossy whitish ochreous, faintly tinged brighter ochreous towards apex and costa, in apex with a faint pinkish tinge. Cilia whitish ochreous, opposite apex touched with pinkish.

Female genitalia: Sterigma not modified. Colliculum large, sclerotized, broadly funnel-shaped, lateral parts dilated. Cestum, a small concave sclerite with serrulate edge. Ductus bursae very long. Bursa pear-shaped, signum of the usual Archipine shape.

Material examined: Luzon, Benguet, Pauai, Haights Place, 7000 ft., 25.VI.1912, (A.E. Wileman) 1 o, allotype, genit. slide 5542, 1 \%, paratype (BM).

\section{Snodgrassia, new genus}

Head with appressed scales, face obtusely prominent above. Antenna ciliate in male, ciliations under 1. Ocellus posterior. Proboscis developed. Palpus angularly bent at first articulation, abruptly ascending close to face; moderately long, top not quite reaching base of antenna; rather smooth, only lower edge with a few projecting short scales; median segment curved, clavate and rounded, terminal segment very short, subobtuse, almost concealed.

Forewing suboval, slightly dilated, without a costal fold in male. Cell rather narrow; 12 veins, all separate; vein 2 bent at a right angle beyond its base, 3 distant from 4,4 and 5 almost connate, 7 to termen, 8 to apex which is rounded and ill defined, 11 from beyond 2/5 of cell; veins prominent on lower surface.

Hindwing without a cubital pecten, 2 from $3 / 5,3$ and 4 connate from angle, 5 closely approximated at base, 6 and 7 separate, almost connate.

Male genitalia: Tegumen strong, triangular, pedunculi with short ventral projections below middle. Uncus very strong, curved, gradually attenuated towards apex which is slender and slightly produced. Socii absent. Gnathos very strong, arms slightly curved, both extremities dilated, hook formed by a strong, pending plate, a rising, clavate hook proper originates from center of plate. Transtilla represented by two moderate oval processes without thorns. Valva moderate, rather broad, cucullus dilated and almost circular; sacculus moderate, sclerotized throughout, pulvinus large, supported by a sclerotized and curved ridge.

Female genitalia: Unknown.

Type species: Cacoecia stenochorda Meyrick, 1928.

The genus is chiefly characterized by the male genitalia, with a dilated and rounded valva and a peculiar gnathos. The latter rather resembles the gnathos in certain Adoxophyes species, but the neuration is quite different. Superficially Snodgrassia stenochorda resembles 
rather a Schoenotenes Meyrick by the oval shape of the forewing, the markings and the raised veins on the underside of both wings.

This genus is dedicated to the famous insect morphologist, the late Dr. R.E. Snodgrass.

\section{Snodgrassia stenochorda (Meyrick, 1928), new combination}

Figures 34, 45-46, 512

Cacoecia stenochorda Meyrick, 1928, Exotic Microlepidoptera, vol. 3, p. 456 ( $\sigma^{7}$, Luzon).-Clarke, 1955, Catalogue . . Microlepidoptera . . Meyrick, vol. 1, p. 294.

Archips stenochorda.-Clarke, 1958, Catalogue . . Microlepidoptera . . Meyrick, vol. 3 , p. 48 , pl. 24 , figs. $4-4$ b (figs. type, genit. $\sigma^{7}$ ).

Distribution: Philippine Is., Luzon.

Material examined: Luzon, Mt. Makiling (Baker), $60 \sigma^{\top}$, genit. slides 5010, 5029 (USNM). This is the original series from which the type specimen comes. Other specimens were not cited in Meyrick's description and therefore range only as topotypes.

\section{Polemograptis Meyrick, 1910}

\section{Polemograptis stauroma, new species}

Figures 56,515

Female, $14 \mathrm{~mm}$. Head and thorax somewhat dull greyish green, sides of forehead pale ochreous, lower half of face yellowish white. Palpus olive, median segment infuscated towards apex, a black spot at apex above, terminal segment olive ochreous. Antenna grey, above pale greenish grey. Abdomen dark grey, venter white, touched with yellow.

Forewing elongate-truncate, broadest at $1 / 3$, costa rather curved along anterior $2 / 3$, gently sinuate posteriorly, apex almost rectangular, termen hardly concave, rounded beneath, vertical. Rather dull light bluish green, partially and slightly suffused with light emerald green. A narrow pale ochreous-pinkish stria along costa from base to apex, its lower edge irregularly serrate; this streak with some five ferruginous-black dots along its anterior fourth, and with two triangular larger dots, at $2 / 5$ and $3 / 5$, alternating with several small ferruginous points and transverse strigulae towards apex; some transverse strigulae rising from dorsum, first six bright red, seventh ferruginous; first streak broader and short, almost along base of dorsum, not exceeding base of fold; following four tolerably parallel to one another, slightly outwards-oblique, somewhat irregularly bent basad above upper edge of cell, second and third truncate at vein 12 , fourth and fifth attenuated above and running into the two triangular costal dots; sixth and seventh striae twice as narrow, slightly zigzagged, less 
oblique, sixth limited by vein 8 ; seventh strigula from tornus, little curved to vein 7 , thence very oblique to $3 / 4$ of costa, furcating just below costa; ocellus region suffused with whitish green, apex beyond last strigula suffused with deeper greyish blue green. Cilia pale ochreous, strongly infuscated except at base.

Hindwing rather thinly scaled, dark grey, turning black towards apex. Cilia concolorous with a narrow pale base.

Female genitalia: Lobus analis slender and narrow, ninth segment sclerotized, erected, conical. Sterigma, a transversely oval plate with deeply emarginate upper edge and rounded upper angles. Ostium situated on the bottom of excavation, shallow and cup-shaped; lamella postvaginalis, a moderate lognitudinal sclerite with two rows of bristles. Ductus bursae moderate, corpus bursae rounded. Signum absent.

Material examined: Oriental Negros, Canlaon, 915 m, 20.XII.1959, 1 ㅇ, holotype, genit. slide 5319 (USNM). Characterized by the green ground color and the seven stripes.

\section{Ebodina, new genus}

Head with appressed scales, with a transverse projecting ridge over face, face prominent in middle. Antenna short-ciliate in male. Proboscis rather weak. Ocellus posterior. Palpus in male rather long, subporrect, strongly sinuate, with closely appressed scales; terminal segment over $1 / 3$, moderately pointed. Thorax smooth. Abdomen normal.

Forewing without costal fold, broad, truncate. Twelve veins, all separate; 2 from middle, 3, 4, and 5 separate and equidistant, 7 separate, to termen, 11 from $1 / 3$. Cell narrowed on both ends. Hindwing $3 / 4$, without cubital pecten. Vein 2 from beyond $2 / 3,3$ and 4 very short-stalked from angle, 5 closely approximated, 6 and 7 connate.

Male genitalia: Tegumen broad and rather low, arms broad. Uncus with a broadly triangular base and a slender, short and curved point. Socius long, slender, pending. Gnathos with very broad arms, lower angles extended laterad as sharp points and with a horizontal ridge; hook of gnathos short. Vinculum, rather long, a triangular broad band. Transtilla, a narrow complete band, bent laterally so as to form blunt prominences and with a triangular median prominence. Valva elongate, simple, dilated in middle; sacculus well defined but narrow, to beyond middle; lower portion of the disc of valva from beyond base with long and dense fine hairs; cucullus with bristly hairs directed basad. Anellus erected, with a triangular excision on top and slightly thickened sides and base. Aedeagus very long and extremely slender, gently bent in middle and gradually dilated toward base. 
Female genitalia: Unknown.

Type species: Ebodina simplex, new species $\left(\sigma^{\top}\right)$.

A somewhat surprising insect, with a facies very similar to that of an Eboda (e.g., E. variabilis Diakonoff, from Java), but with the genitalia very much approaching those of Drachmobola Meyrick, except for the complicated gnathos in Ebodina. The venation, however, is very simple and so different from the complicated and modified situation in Drachmobola that I am unable to incorporate simplex in that, nor in any other known genus of the present group.

\section{Ebodina simplex new species}

Figures 50-53, 516

Male, $15 \mathrm{~mm}$. Head and thorax rather light slate grey, tips of scales whitish. Palpus whitish, median segment slightly sprinkled with grey along basal half, light grey along apical half, with a transverse oblique white stripe above middle, apical edge of segment white; terminal segment grey mixed with white, tip yellow. Chest white. Abdomen lilac grey, venter bright yellow.

Forewing oval-truncate, costa rather angularly bent close to base, gradually and slightly curved posteriorly, with some four short prominent tufts, apex obtusely angular, termen slightly concave and outwards-oblique above, strongly prominent and rounded beneath. Slate grey tinged lilac, beyond cell mixed with ochreous. Whitish between veins. Costal edge broadly orange, interrupted by some seven unequal and unequally spaced broad bars of ground color, alternating with minute grey strigulae; the bars correspond with prominent marginal tufts. Markings formed by olive irroration (tips of scales white), with broad grey-white edges. Basal patch not reaching $1 / 4$ of wing, obliterate at base and on costal third, its edge vertical, gradually and deeply undulate (three teeth, two excavations); this edge followed by faint deep grey suffusion; an irregular obliquely oval spot below $1 / 3$ of costa, containing two purple-black dots, an irregularly clavate vertical fascia from below $2 / 3$ of costa to $3 / 4$ of dorsum, upper half twice as wide as lower, and rounded, lower half slightly oblique, almost interrupted by fold and strewn all over with purple-black dots; a subterminal narrow whitish fascia, abruptly dilated below apex, containing a series of black dots. Cilia (damaged) lilac grey.

Hindwing irrorated dark fuscous, cilia concolorous with a pale basal line.

Male genitalia: As described for the genus.

Material examined: Luzon, Mt. Makiling (Baker), $1 \sigma^{7}$, holotype, genit. slide 5036 (USNM). 
The species resembles Eboda variabilis Diakonoff from Java so closely that I was almost certain it was that species until I studied the genitalia.

\section{Spatalistis Meyrick, 1907 \\ Spatalistis numismata, new species}

Figures 57, 517

Female, $15 \mathrm{~mm}$. Head and palpus yellow, slightly mixed with orange. Thorax yellow, marbled with orange. Abdomen ferruginous purple, anal tuft orange yellow.

Forewing broad, subtruncate, costa curved, apex rather pointed and prominent, termen sinuate, little oblique. Base of wing, costa, apex, and termen bright yellow, costa transversely strigulated with orange; remainder of wing occupied by a large suboval blotch, extending above as far as the course of vein 12 , reaching about $2 / 3$ distance between cell and apex, broadly rounded there and steeply ascending to tornus; with a triangular projection to $1 / 3$ of costal edge and two or three more slender and shorter connections with costal margin at $2 / 3$; this blotch light fulvous lilac between veins which are strongly raised, brightly ferruginous; numerous round deep greyleaden metallic spots scattered over blotch, with some bluish shine in certain lights. Cilia yellow, dark grey in tornus.

Hindwing thinly scaled, pale lilac grey, with a strong violet irridescence in certain lights; extreme apex whitish yellow. Cilia whitish around apex and along upper half of termen, pale purplish grey along lower half of termen and along dorsum.

Female genitalia: Lobus analis subreniform, upper part rather large and oval. Sterigma, a moderate band, lateral lower angles not produced, but rounded-rectangular. Ostium bursae large. Ductus bursae very short; corpus bursae appearing irregularly polygonal because of extended, angulate, and partly cuspidate signum.

Material examined: Mindanao, Bukidnon, Mt. Katanglad, $1480 \mathrm{~m}$, 27-31.X.1958 (H.E. Milliron), 1 \%, holotype, genit. slide 5312 (BMH).

\section{Phricanthes Meyrick, 1881}

Phricanthes Meyrick, 1881, Proc. Linn. Soc. New South Wales, vol. 6, p. 636.Fernald, 1908, Genera of the Tortricidae and their types, p. 174.-Fletcher, 1929, Mem. Dept. Agric. India, Ent. ser., vol. 11, p. 174.-Diakonoff, 1941, Treubia, vol. 18, p. 390.-Common, 1965, Australian Journ. Zool., vol. 13, p. 633 (Protypanthes, a syn.).-Diakonoff, 1966, Zool. Verh. Leiden, no. 85, p. 85. [type species: Phricanthes asperana Meyrick, 1881.]

Protypanthes Meyrick, 1933, Exotic Microlepidoptera, vol. 4, p. 424.-Diakonoff, 1939, Zool. Meded. Leiden, vol. 21, p. 192, figs. 19E-G; 1948, Treubia, vol. 19, p. 517.-Clarke, 1958, Catalogue . . Microlepidoptera . . Meyrick, vol. 3, p. 192, pl. 96, figs. 1-1e.-Common, 1965, Australian Journ. Zool., 
vol. 13, p. 633 (syn. of Phricanthes).-Diakonoff, 1966, Zool. Verh. Leiden no. 85, p. 85. [type species: Protypanthes hybristis Meyrick, 1933.]

The male genitalia, especially the bifid uncus, suggest a high degree of specialization and would assign the genus in the vicinity of such highly modified forms as Eboda; Meyrick placed it in the "Peronea" group. The evidence of the female genitalia, however, is rather surprising and somewhat contradictory. The signum of $P$. biocellana actually is decidedly Archipine (although modified). The genus belongs in the Australian Scolioplecta group of the Tortricini. There is a striking similarity of the characteristic bifid uncus with that in some Oecophorid forms (Hypertrophinae), but this resemblance must be incidental.

\section{Phricanthes biocellana (Walker, 1863), new combination}

Figures 49, 54, 519

Carpocapsa biocellana Walker, 1863, List Lepidopterous Insects British Mus., pt. 28, p. 411 ( $\sigma^{\pi}$, Borneo).

Distribution: Borneo.

A small series of four specimens in good condition enabled me not only to redescribe this rare and hardly known species, but also to ascertain its proper place in the system. This species appears to be not an Olethreutine at all, but to belong to the genus Phricanthes of the Tortricinae.

The characteristically colored and marked species with the distinct facies of the present genus may be redescribed as follows:

Male, $20 \mathrm{~mm}$. Head shining bright metallic olive, lower edge of face dull pale yellow suffused across middle with grey, collar mixed with dull white. Antenna dark fuscous, scape dark fuscous with a fine white longitudinal line above, white beneath. Palpus rather long, porrected and strongly flattened laterally, gently sinuate, lower edge short-ciliate; white, with three oblique transverse pairs of jet-black dots, towards apex above palpus suffused with grey, terminal segment short, exposed, slender and obtuse, greyish, whitetipped. Thorax fuscous mixed with sordid white (tips of scales fuscous), breast pure white. Legs white, suffused with yellowish and irrorated and banded with dark fuscous above. Abdomen fuscous grey, venter paler.

Forewing elongate truncate, costa little curved at base, straight posteriorly, apex and tornus equally and strongly rounded, termen short, convex, little oblique. Whitish, densely covered with short thick blackish-fuscous strigulae, transverse and vertical, towards termen becoming slightly curved and outwards-oblique, forming together a more or less continuous reticulate pattern which partially is obscured by dark fuscous suffusion. Anterior half of costa with 
numerous small dark transverse strigulae, posterior half with three or four marginal streaks alternating with minute transverse marks and slightly edged below with yellow; this color becoming deeper, tawny orange posteriorly and forming a well-defined streak below posterior part of costa and just before apex, halfway to vein 7; a faint dark suffusion on base of dorsum; a well-defined roundish patch of dark fuscous irroration on middle of dorsum, reaching to upper edge of cell, slightly extended basad along its lower edge; a more or less defined wedge-shaped patch of dark fuscous irroration before termen, from below costa almost to tornus, interrupted in its middle by yellow suffusion along veins; a circular jet-black spot above middle and against posterior edge of last mentioned patch, containing an oval pale blue metallic dot towards its lower edge; edge of termen narrowly fuscous, interrupted between veins, preceded by light yellow, before these a thick slightly raised shining silvery-leaden streak parallel to and before edge of wing, from end of vein 9 to that of vein 4 . Cilia pale yellow, a leaden-grey band from apex to $3 / 4$ of termen, cilia beyond this band irrorated and slightly mixed with dark leaden grey.

Hindwing rather dark brownish fuscous with some yellowish tinge, cilia brownish fuscous with pale yellow base and a darker subbasal band, beyond this band and between ends of veins 6 to 3 , cilia pale yellow, narrowly barred with fuscous opposite these veins.

Male genitalia: Tegumen triangular, strongly down-curved. Uncus rather rounded and thickened, long-haired in middle, bifid, halves beak-shaped (broader than in hybristis). Socii absent. Gnathos strong but arms rather narrow, wide; hood represented by a curved, denticulate horizontal rod. Vinculum large, elongate (shorter than in hybristis). Transtilla membranous, ill defined, inverted trapezoidal. Diaphragma forming a thickened transverse ridge, trapezoidal, with a granulate structure. Valva long and narrow, simple, concave lengthwise; costa slightly modified and a little thickened, $3 / 4$, sacculus moderate, under $1 / 2$; cucullus radially wrinkled with two long thorns on lower edge. Aedeagus moderate and rather slender, gradually dilated basad and with a rounded base, top obliquely truncate. Cornuti, a sheaf of not numerous long and slender spines, undulate at their bases, and a fasciate patch of dense fine spines.

Female, neallotype, $20 \mathrm{~mm}$. Fore- and hindwings slightly narrower than in male. Shining scaling on forehead less extended. Fuscous suffusion of forewing more extended, transverse strigulae beyond cell darker, continuous. Otherwise in all respects, also in the length of palpi, similar to the male.

Female genitalia: Lobi anales slender and elongate. Sterigma inverted trapeziodal, laterally ill defined; lamella postvaginalis, a simple 
transverse band; lamella antevaginalis, a stronger similar band, containing the ostium which is circular, with ventral wall broader than dorsal. Colliculum not connected with ostium, tubular, dilated above middle, gradually narrowed downward, end rounded. Ductus bursae rather wide and moderately long. Corpus bursae pear-shaped. Signum very large, with a sickle-shaped hook and an oval concave basal plate with a broad filament, rising halfway up the ductus bursae and apparently homologous with cestum.

Material examined: Luzon, Los Baños (Baker), 2 ơ , 2 \&, genit. slides $50180^{7}$ and 5038ㅇ (USNM).

\section{Phricanthes flexilineana (Walker, 1863)}

\section{Figure 518}

Sciaphila flexilineana Walker, 1863, List Lepidopterous Insects British Mus., pt. 28 , p. 345 ( $\sigma^{\top}$, Ceylon).

Peronea flexilineana.-Meyrick, 1910, Proc. Linn. Soc. New South Wales, vol. 35, p. 292; 1917, Trans. Roy. Ent. Soc. London, p. 14 (British Guiana).-Fletcher, 1932, Imp. Counc. Agric. Res., Sci. Mon., no. 2, p. 17, pl. 10, figs. 1-3.

Phricanthes flexilineana.-Diakonoff, 1941, Treubia, vol. 18, p. 394; op. cit., p. 437; 1960, Verh. Ned. Akad. Wet., Nat., ser. 2, vol. 53, no. 2, p. 187 (Madagascar).-Common, 1965, Australian Journ. Zool., vol. 13, pp. 637, 640. Phricanthes macroura Lower, 1908, Trans. Roy. Soc. South Australia, vol. 32, p. 322 (Australia).

Distribution: Ceylon, India, Burma, Java, Philippine Is., New Guinea, Queensland, Madagascar, and British Guiana.

Food plants: Dillenia indica.

Material examined: Luzon, Mt. Makiling (Baker), 1 \% (USNM).

\section{Olethreutinae}

\section{Key to the Philippine Genera of Olethreutinae}

1. Hindwing with vein 5 curved towards base and approximated to 4 . . . 2 Hindwing with vein 5 straight and almost parallel with 4 . . . . . . . 23

2. Hindwing with veins 3 and 4 separate or connate . . . . . . . . . . 3

Hindwing with veins 3 and 4 stalked or coincident . . . . . . . . . 16

3. Forewing marked with numerous, more or less undulate horizontal lines; ocellus differently colored . . . . . . . . . . . . . . . . . . . . 4

Forewing not so marked . . . . . . . . . . . . . . . . . 5

4. Palpus clavate, obtuse, terminal segment very short, but exposed; valva narrow, furcate at top . . . . . . . . Argyroptocha, new genus

Palpus triangular, obtusely pointed, terminal segment concealed; valva broad, sacculus and cucullus deeply separated. Tetramoera, new genus

5. Greenish colored species, with a well defined rounded subterminal patch; males with hairy posterior tibia and often with pencils of hairs along sides of abdomen. . . . . . . . . . . . . . . . . . . Eudemis

Not greenish, without pencils of hairs along sides of abdomen . . . . 6 
6. Males with strongly asymmetrical valvae . . . . . . . Gatesclarkeana Right and left valva similar, though hairing may be asymmetrical . . 7

7. Uncus and gnathos united into a large rounded pad, with two pairs of pending processes upon it, and with a narrow annular connection with anellus; sterigma bilobed . . . . . . . . . . . . . . Sycacantha

Uncus not united with gnathos or absent . . . . . . . . . . . . 8

8. Uncus well developed, clavate or pointed . . . . . . . . . . . . . . . . 9

Uncus absent or represented by a pencil of hairs . . . . . . . . . . . . 14

9. Tegumen with uncus long, gradually narrowed; valva simple, elongate-oval, moderately curved, with a rounded top.

Hedya (subgenera Hedya and Platypeplus)

Tegumen long, if gradually narrowed, then valva not simple . . . . 10

10. Uncus pointed, gnathos very strong, porrected, with two diverging apical horns .

Gnathmocerodes, new genus

Uncus clavate . . . . . . . . . . . . . . . 11

11. Valva narrow, cucullus with a projection of ventral side . . . . . . . . 12

Valva broad, cucullus without a ventral projection . . . . . . . . . 13

12. Projection of valva subapical or postmedian . . . . . . . . . Statherotis

Projection of valva submedian . . . . . . . . . . O Olethreutes

13. Uncus with a fringe of spines . . . . . . . . . . . . . . Bactra

Uncus without such fringe. . . . . . . . . . . . . Phaecadophora

14. Uncus represented by a pencil of hairs . . . . . . . . . Cryptaspasma

Uncus entirely absent . . . . . . . . . . . . . . . . . . . . . . . 15

15. Valva triangular, narrowed towards rounded top . Bubonoxena, new genus

Valva elongate, dilated towards bilobate top. . Loboschiza, new genus

16. Palpus in male modified, enlarged, triangular, terminal segment apparently absent, a slender black pencil of hairs from forehead . Eucoenogenes

Palpus in male not thus modified . . . . . . . . . . . . . . . . . 17

17. Greenish, in male basal segment of antenna thickened and notched.

Peridaedala

Not greenish, male antenna normal . . . . . . . . . . . . . . . . . 18

18. Corpus bursae in female modified, with a characteristic sclerotised upper edge.

Erinaea

Corpus bursae not so modified . . . . . . . . . . . . . . . . . . . 19

19. Male genitalia of olethreutine type, uncus developed; valva with large spines along edge of sacculus . . . . Hedya (subgenus Cellifera, new subgenus)

Male genitalia of eucosmine type, uncus absent . . . . . . . . . . . 20

20. Valva with a digitoid process from dise below base of costa.

Costosa, new genus

Valva without such process. . . . . . . . . . . . . 21

21. Gnathos distinct, or reduced to lateral rods or to a membranous transverse structure . . . . . . . . . . . . . . . . 22

Gnathos entirely absent. . . . . . . . . . . . Cryptophlebia

22. Gnathos reduced to lateral rods, cucullus moderate, its stalk not narrow, forewing with veins 4 and 5 separate, never connate . . . . . Eucosma Gnathos membranous, cucullus large, broadly semioval, its stalk narrow; forewing with veins 4 and 5 connate or closely approximated. Petrova

23. Socii present, distinct lobes . . . . . . . . . . . . . . . . . . . . 24

Socii entirely absent . . . . . . . . . . . . . . . . . 25

24. Sacculus broadly triangular, cucullus narrowed at base to a stalk.

Sacculus moderate, cucullus not so narrowed at base . . . Strepsicrates 
25. Hindwing in male with vein 8 running into vein 7 near base . . Pammene Hindwing in male with vein 8 separate . . . . . . . . Laspeyresia

\section{Gatesclarkeana Diakonoff, 1966}

Figures 58-64

Gatesclarkeana Diakonoff, 1966, Zool. Verh. Leiden, no. 85, p. 48, figs 28, 30, 32.

Head with roughly appressed scales, in female forming a crest on vertex. Ocellus posterior. Proboscis rather weak and short, especially in male. Palpus moderate, porrected, with rather closely appressed scales, slightly rougher in female, median segment rather curved in male, sinuate in female, roughish along upper edge towards apex, terminal segment moderate. Antenna short-ciliate in male, ciliations under $1 / 2$, pubescent in female. Thorax smooth. Posterior tibia in male sometimes (type species) densely but smoothly scaled above and externally, below with a dense, fanlike brush of long hair scales, along rostral edge of brush hairs curved caudad. (When the hindlegs are in rest, these brushes cover the venter almost completely). Sometimes hindtibiae in male normal. Abdomen sometimes (type species) with the third to fifth sternites modified, dilated, with numerous small folds; apparently especially the third sternite can be strongly expanded, with posteriorly, a dense fringe of scent hairs or scales, especially along a median excision of posterior edge; fourth sternite somewhat less extended and without hairs, fifth with an additional bladder-like trapezoidal appendix with a densely haired top. Sometimes abdomen almost normal, these sternites only slightly enlarged. In type species these sternites covered with extremely large, oval, shining whitish scales.

Forewing with vein 2 from beyond 2/3, 3 from angle, 4 closely approximated, 7 separate, to termen, 8 and 9 closely approximated at base, 11 from before middle.

Hindwing with a cubital pecten, 2 from beyond middle, 3 and 4 connate from angle, 5 closely approximated, 6 and 7 closely approximated towards base.

Male genitalia asymmetrical. Tegumen high, triangular, its legs (pedunculi) rather slender. Uncus clavate, slightly bilobed, membranous and hairy, socius-like. Socii large, pending. Gnathos not distinct. Left valva elongate, cucullus with a narrow base; sacculus, a separate, subquadrate lobe; harpe, a large rounded and flattened pad, covered throughout with strong thorns; right processus dorsalis large and prominent. Right valva much enlarged, right sacculus many times larger than left, semioval; right cucullus long, pointed, with a sheaf of very long bristles at the base extending beyond the 
top of sacculus and laying along its edge; dentate portion of harpe smaller, but its base much more extended across disc of valva and forming a strongly sclerotized dorsal lobe. Juxta elongate and asymmetrical. Caulis very long and slender. Anellus, a broad ring. Aedeagus narrow, attenuated towards top. Signum, a sclerotized and dentate ridge.

Female genitalia: Sterigma indefinite. Colliculum, a large sclerite, dilated downward, twice as broad along upper half as along lower; inside this sclerite, a band, slightly tortuous and rather narrow, protruding beyond the lower edge of the former. Ductus bursae short. Cornuti, a large, elevated, and scobinate knob.

Type species: Platypeplus erotias Meyrick, 1905 (figs. 58-59, 63-64).

Apparently a modification of the Olethreutes stock, judging from the tegumen part of the genitalia. The attachment of the valvae, however, is somewhat Laspeyresiine, which must be due only to the abnormal development of this part.

\section{Gatesclarkeana asynthetes, new species}

Figures 60-62, 521-522

Male, $16 \mathrm{~mm}$. Head dark purplish brown marbled with pale ochreous, scape of antenna anteriorly with a pale ochreous tuft, a dark brown tufted ridge across middle of face, below this, face pale ochreous. Palpus dark purplish brown, base pale ochreous, a series of ill-defined, pale ochreous transverse streaks running across median segment, last one apical. Thorax purplish brown, with a faint median transverse fascia. Abdomen dark grey, normal. Posterior tibia densely clothed with rather short, glossy whitish hairs, without brushes.

Forewing elongate-subtruncate, rather broad, costa gently curved throughout, apex subrectangular, termen distinctly sinuate, little oblique. Ground color showing as a pattern of numerous rounded leaden-grey spots with a lilac gloss. Markings olive brown marbled with dark brown, partly with narrow whitish-ochreous edges. Basal patch to $1 / 3$, edge prominent and truncate in middle, slightly concave above and beneath; anterior part of this patch filled out with leaden grey and violet rounded dots of ground color, separated by fine blackish network; costal edge with several blackish and whitish-ochreous marks and narrowly suffused with bright lilac pink; transverse fascia almost direct, hardly outwards-oblique, narrow and blackish above (on costa beyond middle), with three finger-shaped horizontal appendages in disc; lower of these along dorsum, median edged with pale ochre above; apex of wing occupied by a dark patch mixed with leaden grey and marbled with dark brown; it is distinctly separated 
by a pale fascia from $3 / 4$ of costa to lower half of termen; this fascia narrow above, abruptly extended along lower half, olive, narrowly edged on both sides with whitish ochreous, along lower half centered with leaden grey. Cilia fuscous brown with a leaden gloss, a dull brown basal line.

Hindwing rather dark fuscous bronze, paler at base, cilia concolorous, with a pale basal and a dark subbasal line.

Female, $19 \mathrm{~mm}$. Forewing broader, angle more obtuse, termen less sinuate and less oblique. Ground color paler, lilac grey, more extended, markings more limited, more conspicuous, dark brown. Costa less distinctly suffused with pink. Transverse fascia almost separated in three parts, an oblique costal streak, a horizontal median streak and a dorsal rectangular blotch; space between basal patch and transverse fascia parted by an interrupted dark brown narrow striga; pale transverse fascia separating apical patch, sometmes ill defined.

Hindwing fuscous bronze, deeper colored than in male. Otherwise similar to male.

Male genitalia as described for the genus, differing chiefly by the not modified abdominal sternites. Shallow dorsal organs are present in tergite II. Minor differences of the genitalia proper are the shape of the tegumen which is higher, with a triangular median process in asynthetes; uncus is much smaller and clavate; socius longer, its top reaching above the shoulder of tegumen. The shape of the valvae and their appendages is but slightly different.

Female genitalia show clear-cut differences from those of $G$. erotias. In that species the colliculum is twice as narrow and the signum is reduced to its basal plate only which is concave and finely scobinate, slightly resembling the signum in certain Bactra species.

Material examined: Luzon, Mt. Makiling (Baker), 19, allotype, genit. slide 5035. Occidental Negros, Cadiz, LL 295 (Bayabas), 1 옹 Victorias, genit. slide 5039, 10.XII-15.IV, 1928-1929 (Bayabas), "LL 298 and LL 464, on P 201," $1 \sigma^{7}$, holotype, Cadiz, 9.VIII.1929, genit. slide 5083; paratypes: genit. slides 19 June 1930, $\sigma^{7}$; 20 June 1930, $\sigma^{x}$, Aug. Busck; $5014 \sigma^{x} .4 \sigma^{x}$, 5 ㅇ. On Mallotus (USNM), Palawan, $1.6 \mathrm{~km}$ of Tarumpitao Point, 28.V.1958 (H. E. Milliron) 1으, paratype, genit. slide $5316(\mathrm{BMH})$. Mindanao, Lanao, plains, Kolambugan, 28.V.1914 (A. E. Wileman), 1o, paratype, genit. slide $5532(\mathrm{BM})$.

Externally rather similar to G. erotias, differing by whitish-ochreous edges to some markings. In the male of that species there is only one round white dot in center of disc, corresponding with the posterior end of the upper pale edge of the median portion of the transverse fascia; in erotias there is also no distinct apical patch, the terminal fourth of wing being rather unicolorous and paler, traversed by 
several oblique zigzag dark lines; not only costa, but also termen is suffused with pink. Posterior tibiae in erotias bear a brush of long light grey hairs along the internal side, as was described with the genus above. The females are very similar in the two species, but in erotias the basal patch has a concave excision of the upper edge, while the lower part of that edge is strongly rounded.

Material of Gatesclarkeana erotias (Meyrick) compared: Java, Sindanglaja, $1100 \mathrm{~m}$, genit. slide $2574 \mathrm{o}^{7}$ (C. Franssen); $4549 \mathrm{o}^{\text {T }}$ (P. van der Goot) (LM).

\section{Hedya Hübner, 1825}

Hedya Hübner, 1825, Verzeichniss bekannter Schmettlinge, p. 380.-Hannemann, 1961, Tierwelt Deutschlands, vol. 48, p. 182.

Hedia.-Zeller, 1877, Horae Soc. ent. rossicae, vol. 13, p. 160 (emend.)-Heinrich, 1926, U.S. Nat. Mus. Bull. 132, p. 161.

Type species: Phalaena Tinea salicella Linnaeus, 1758 (Europa).

This generic name has been reestablished by Heinrich (1926, in Zeller's emendated spelling) and is now accepted as Hedya by Obraztsov (in. litt.) and Hannemann (1961) for several Palaearctic and Nearctic species. Whether all these species are congeneric, seems to be open to doubt, e.g., with regard to the Palaearctic Penthina atropunctana Zetterstedt, and Nearctic Olethreutes separatana Kearfott and Penthina cyanana Murtfeldt.

On the other hand, a characteristic group of tropical species, hitherto indicated by generic name Platypeplus Walsingham, 1887, and having rather uniform male genitalia, undoubtedly belongs here; however, there are some minor differences which, to my present knowledge, are constant. Therefore, I propose a division of the entire group into three subgenera which may be separated as follows:

1. Gnathos, a variably shaped, broad transverse band, strongly dilated in the middle downwards and upwards, sometimes even becoming higher than broad, lower edge simple; $\mathrm{Spc}_{2}$ present, sometimes small, shifted distad (salicella), sometimes large, proximal and marginal, hindwing with veins 3 and 4 separate or connate . . . . Subgenus Hedya Hübner, new status

Gnathos, a rather narrow, transverse band of a constant shape, with upper edge straight and simple, lower edge forming two semioval finely denticulate tumescences. $\mathrm{Spc}_{2}$ sometimes present . . . . . . . . . . . . . . 2

2. Outer edge of the base of cucullus without modified large spines; females with two small equal signa; hindwing with veins 3 and 4 usually connate.

Subgenus Platypeplus

Outer edge of the base of cucullus with a row of very large, spindle-shaped spines; females with a single large, curved and blunt signum; hindwing with veins 3 and 4 stalked . . . . . . . . Cellifera, new subgenus

\section{Subgenus Hedya Hübner, 1825, new status}

Hedya Hübner, 1825, Verzeichniss bekannter Schmettlinge, p. 380.

Hedia.-Zeller, 1877, Horae Soc. ent. rossicae, vol. 13, p. 160 (emend.). 
Hedya (Hedya) atrifraga, new species

Figures 67, 524

Male, $14.5 \mathrm{~mm}$. Head fuscous. Palpus sordid pale ochreous, with an oblique supramedian and an apical dark fuscous band, terminal segment dark fuscous. Antenna fuscous tawny, ciliations under 1, white. Thorax dark fuscous grey, tegulae mixed with pale and dark purple grey. Abdomen grey, venter and anal tuft pale grey.

Forewing elongate-subtruncate, little dilated, costa curved along anterior half, straight along posterior, apex moderately rounded, termen almost straight, little oblique, rounded beneath. Light slatey grey, with a strong lilac opalescence in certain lights, below costa posteriorly suffused with light tawny orange. Markings orange brown and dark fuscous, posteriorly edged and mixed with pale tawny. Costa with some seven pairs of white marks, separated by blackish. Basal fourth of costa blackish, containing an oblique spot of ground color beyond base; below this fourth of costa upper portion of disc indistinctly suffused with dark fuscous, towards dorsum becoming an ill-defined dotting; edge of this basal patch ill defined, probably rounded; a blackish moderate transverse fascia, from middle of costa to dorsum before middle, strongly angulate outwards on upper edge of cell, thence straight and inwards-oblique; a dark oblique blotch from below costa well before apex, terminating in middle of termen, and emitting from its middle a branch to dorsum before tornus; apex beyond this mark slatey white, with a dark brown marginal line and a somewhat inwards-oblique subapical line. Cilia (rubbed) fuscous grey.

Hindwing and cilia rather dark grey.

Male genitalia: Uncus moderately broad, with a $V$-shaped, bristled surface ventrally (in front). Gnathos semimembranous, rather folded transversely, with two converging small folds along the upper edge and slightly prominent ends of two larger folds laterally. Valva moderately slender, cucullus not dilated throughout, gently curved, with large but rather scattered bristles, slightly more condensed along lower edge; $\mathrm{Spc}_{1}$ very dense, rounded, moderate, $\mathrm{Spc}_{2}$ moderate, much smaller than $\mathrm{Spc}_{1}$, closer to this than to base.

Material examined: Mindanao, Zamboanga del Sur, $11 \mathrm{~km} \mathrm{NW}$ of Milbuk, 390 m, 5.VIII.1958 (H.E. Milliron), $1 \sigma^{\text {' }}$, holotype, genit. slide $5309(\mathrm{BMH})$. The single specimen is rather damaged, but the genitalia are sufficiently characteristic. An interesting form, being the first tropical member of the subgenus Hedya which comes to my notice. 


\section{Subgenus Platypeplus Walsingham, 1887, new status}

Platypeplus Walsingham, 1887, in Moore, Lepidoptera Ceylon, vol. 3, p. 495. Platypeplum.-Walsingham, 1899, Indian Mus. Notes, vol. 4, p. 105 (emend.).

Type species: Eccopsis aprobola Meyrick, 1886 (Tonga).

\section{Key to the Philippine Species of Subgenus Platypeplus}

1. Forewing with a conspicuous black central spot . . . . . H. (P.) mormopa Forewing without such spot . . . . . . . . . H. (P.) aprobola

\section{Hedya (Platypeplus) aprobola (Meyrick, 1886), new combination}

\section{Figure 523}

Eccopsis aprobola Meyrick, 1886, Trans. Roy. Ent. Soc. London, p. 275 (ه Tonga).-Clarke, 1955, Catalogue . . . Microlepioloptera . . Meyrick, vol. 1 , p. 51.

Platypeplus aprobola.-Walsingham, 1887, in Moore, Lepidoptera Ceylon, vol. 3, p. 495, pl. 208, fig. 2.-Clarke, 1958, Catalogue . . Microlepidoptera . . . Meyrick, vol. 3, p. 572, pl. 285, figs. 1, 1a (type $\sigma^{\nwarrow}$, genit. illustr.).

Argyroploce aprobola.-Meyrick, 1910, Rec. Indian Mus., vol. 5, p. 218; 1911, Proc. Linn. Soc. New South Wales, vol. 36, p. 275; 1911, Trans. Linn. Soc. London, Zool. ser. 2, vol. 14, p. 269; 1914, Ent. Mitt., Suppl., vol. 3, p. 49.Fletcher, 1917, Rep. Proc. Second Ent. Meeting Pusa, p. 219, 230, 267; 1920, Mem. Dept. Agric. India, Ent. ser., vol. 6, pp. 57, 200.-Meyrick, 1929, in de Joannis, Ann. Soc. Ent. France, vol. 98, p. 719.-Fletcher, 1932, Imp. Counc. Agric. Res., Sci. Mon., no. 2, p. 27, pl. 18, figs. 1-3.-Kalshoven, 1950, Plagen Cultuurgew. Indonesia, vol. 1, p. 394.-Diakonoff, 1953, Verh. Ned. Akad. Wet., Nat., ser. 2, vol. 49, no. 3, p. 106.

Distribution: India, Ceylon, Seychelles, Amirante Is., Chagos Is., Java, Tonkin, Formosa, New Guinea, Queensland, Tonga, Tahiti, Society Is. and Austral Is. Probably a mixture of several local species or subspecies.

Foodplants: Numerous species of trees and shrubs.

Material examined: Mindanao, Davao Prov., east slope of Mt. McKinley, 4500 ft., 30.VIII.1946 (CNHM Philippine Exped. 1946-47, H. Hoogstraal), 1 ơ , genit. slide 5735.

\section{Hedya (Platypeplus) mormopa (Meyrick, 1906), new combination}

Figure 520

Platypeplus mormopa Meyrick, 1906, Journ. Bombay Nat. Hist. Soc., vol. 17, p. 136 ( $\sigma^{7}$, Ceylon).-Clarke, 1955, Catalogue . . Microlepidoptera . . . Meyrick, vol. 1, p. 211.

Argyroploce mormopa.-Meyrick, 1926, Sarawak Mus. Journ., vol. 3, p. 152.Fletcher, 1932, Imp. Counc. Agric. Res., Sci. Mon., no. 2, p. 31.

Olethreutes mormopa.-Clarke, 1958, Catalogue ... Microlepidoptera . . . Meyrick, vol. 3, p. 531, pl. 264, figs. 2-2a (lectotype design., genit., wing figured).

Distribution: Ceylon, India, Borneo, Tonkin. 
Foodplant: Jambora vulgaris.

Material examined: Luzon, Mt. Makiling (Baker), 1 \%, genit. slide 5049 (USNM). The genitalia of the male have already been well illustrated by Clarke (1958).

\section{Cellifera, new subgenus}

Similar to the subgenus Platypeplus Walsingham, but with distinct male genitalia, having a series of strong spikes along the basal part of the outer edge of the sacculus, instead of a $\mathrm{Spc}_{3}$, but without $\mathrm{Spc}_{2}$; the female genitalia equally distinct, with a broad, cratershaped aciculate ostium bursae, and with only one large, hook-shaped, blunt signum.

Type species: Polychrosis cellifera Meyrick, 1912 (Ceylon).

\section{Hedya (Cellifera) cellifera (Meyrick, 1912), new combination}

Figures $73,95,525$

Polychrosis cellifera Meyrick, 1912, Journ. Bombay Nat. Hist. Soc., vol. 21, p. 869.-Fletcher, 1920, Mem. Dept. Agric. India, Ent. ser., vol. 6, p. 53.-1932, Imp. Counc. Agric. Res., Sci. Mon., no. 2, p. 25, pt. 16, figs. 1-4.-Clarke, 1955, Catalogue . . Microlepidoptera . . Meyrick, vol. 1, p. 78.

Olethreutes cellifera.-Clarke, 1958, Catalogue . . Microlepidoptera . . Meyrick, vol. 3, p. 495, pt. 246, figs. 1-1b, 2-2b (syn., codonectis Meyrick, lectotype selected).

Argyroploce codonectis Meyrick, 1927, Exotic Microlepidoptera, vol. 3, p. 339; 1931, op. cit., vol. 4, p. 129.-Fletcher, 1932, Imp. Counc. Agric. Res., Sci. Mon., no. 2, p. 28.-Clarke, 1955, Catalogue . . Microlepidoptera . . Meyrick, vol. 1 , p. 95 .

Distribution: Ceylon, India, Malaya, Java.

Food plants: Eugenia malaccensis, E. aquea (Malaya), E. jambolana (India).

Material examined: Luzon, Los Baños, 12.IX-14.X.1920 (A.M. Soriano), $3 \sigma^{7}, 10$ ㅇ, bred from leaves of Eugenia jambolana, genit. slides "8 July, 1927, 4, ME”, ه , $4580 \sigma^{\top}, 5037$ \% , and $5376 \sigma^{\nwarrow}$ (USNM). Male genitalia as described with the subgenus.

\section{Eudemis Hübner, 1826}

Eudemis Hübner, 1826, Verzeichniss bekannter Schmettlinge, p. 382 (type species, Tortrix porphyrana Hübner, 1796-1799).

Acanthothyspoda Lower, 1908, Trans, Roy Soc. South Australia, vol. 32, p. 319 (type species, A. elaeodes Lower, 1908, Australia).-Meyrick, 1911, Proc. Linn. Soc. New South Wales, vol. 36, pp. 263, 281 (syn. of Argyroploce Hübner).-Fletcher, 1929, Mem. Dept. Agric. India Ent. ser., vol. 11, p. 2 (syn. of Argyroploce Hübner).-Diakonoff, 1966, Verh. Mus. Leiden, no. 85, p. 56 , figs. $25,27,71$.

Choganhia Razowski, 1960, Polskie Pismo Ent., vol. 30, p. 387, figs. b, 13 (type species, Argyroploce sphaerocopa Meyrick, 1929, Tonkin). 
The characteristic genus, recognized and resurrected by Obraztsov (personal communication) and by Hannemann (1961), contains in the Palaearctic and Palaeotropic regions several very similar species, hitherto mostly attributed to "Eudemis" purpurissatana Kennel, which species, however, is not even congeneric, as ascertained by Falkovitch recently. It belongs to Eudemopsis Falkovitch, 1962.

The genus Eudemis represents a large complex of species which I propose to divide into two subgenera. The subgenus Eudemis Hübner, new status, comprises chiefly Palaearctic species, of which the males have no additional coremata and posses a simple valva. The subgenus Acanthothyspoda Lower, new status, contains tropical species, usually greenish-colored, males with abundantly haired posterior tibiae, with lateral pairs of hair pencils, being additional coremata on most abdominal segments, with a more complicated valva, and often with socii spiny at the top. The peculiar external characters are restricted to the males and should, consequently, be regarded as secondary sexual characters only. They are absent in true Eudemis but not well developed in some tropical Acanthothyspoda. The specialized (plesiomorph) Eudemis species and apomorph Acanthothyspoda species appear to approach each other closely, linked by intermediate forms. Therefore, there is, in my opinion, no reason for generic separation of the two groups. The females of both are similar.

In Clarke's monograph (1958, vol. 3) not less than 11 species, recorded under Olethreutes, are illustrated (see pp. 49, 51, 52). Photographs of the females of two species have been reproduced by Clarke.

The genus may be redescribed as follows:

Species of moderate size, usually with a big round terminal spot in the forewing, tropical species more or less green-tinged. Head with loosely appressed scales, roughish on crown. Proboscis developed. Ocellus posterior. Antenna in male thickened, fasciculateciliated, ciliations $1 / 2$. Palpus moderately long, porrected, median segment strongly dilated, triangular, terminal segment moderate, exposed, slightly drooping, obtuse. Thorax with a slight double posterior crest. Posterior tibia in male sometimes extremely dilated and expanded by pencils, whorls or brushes of dense hairs of diverse shape. Abdomen in male often normally haired and scaled, but sometimes with a pair of long hair-pencils at the sides of each segment; these pencils are implanted on segments $2-3$, sometimes on more segments, on distinct projecting papillae, or on raised oval fields.

Forewing elongate-subtruncate, moderately broad, termen usually slightly rounded, little oblique. Vein 2 from beyond $2 / 3,3$ from angle, close to or rather distant from 4, 5 distant, 6 slightly diverging from 5 towards base, 7 separate, to termen, 7 to 9 equidistant at base, seldom 7 and 8 almost connate, 11 from before middle of cell, 
upper parting vein developed, from just beyond 10 or from about $2 / 3$ between 11 and 10 to between 6 and 7 ; lower parting vein also developed, sinuate, from towards base to below base of 4 .

Hindwing with a cubital pecten; with tornus sometimes slightly modified, covered with modified scales, sometimes causing anomal venation. Consequently, this venation is subject to considerable variation in the male. Vein 2 from $1 / 2-2 / 3,3$ from before angle, 4 remote from angle, or 3 and 4 connate from angle, 5 approximated at base, 6 and 7 closely approximated toward base.

\section{Subgenus Eudemis Hübner, 1826, new status}

Type species: Tortrix porphyrana Hübner.

Male genitalia: Tegumen elongate, not conspicuously narrowed towards top. Valva usually slender, curved (seldom dilated and rounded), sacculus indefinite; $\mathrm{Spc}_{1}, \mathrm{Spc}_{2}$, and sometimes $\mathrm{Spc}_{3}$ may all be present. Gnathos pending, arms long, strongly bristled or spined at the top.

Female genitalia with a short, funnel-shaped sterigma, and a short, cylindrical colliculum. Signa, two flattened horns.

The following species should be transferred to the present genus. Argyroploce archimedias Meyrick, 1912 (China); Clarke, 1958, vol. 3, p. 540 , pl. 269 , figs. $4-4$ a.

Eucosma mniochlora Meyrick, 1916 (India, China); Clarke, 1958, vol. 3, p. 528, pl. 263, figs. 4-4a.

Argyroploce pompholycias Meyrick, 1935 (China); Clarke, 1958. vol. 3, p. 539, pl. 268, figs. 2-2a.

\section{Key to the Philippine Species of Subgenus Eudemis}

1. Forewing with the dorsal spot reaching above middle of wing, its top pointing to costa before anterior edge of transverse fascia . . . . E. archimedias Forewing with the dorsal spot reaching to middle of wing, its top directed exactly to anterior edge of transverse fascia on costa . . . . E. oxygona

Eudemis (Eudemis) archimedias (Meyrick, 1912), new combination

Figure 526

Argyroploce archimedias Meyrick, 1912, Exotic Microlepidoptera, vol. 1, p. 63 ( ( China).-Clarke, 1955, Catalogue . . Microlepidoptera . . Meyrick, vol. 1, p. 52 .

Olethreutes purpurissatana Clarke, 1958 (not Kennel, 1901), Catalogue . . . Microlepidoptera . . . Meyrick, vol. 3, p. 540, pl. 269, figs. 4-4a (archimedias Meyrick, syn.).-Falkovitch, 1962, Rev. Ent. USSR, vol. 41, p. 191 (archimedias Meyrick, a distinct species).

It may be stipulated that "Penthina" purpurissatana Kennel, 1901 does not belong to the present group of species, in spite of the very 
similar coloring and markings (the outer edge of transverse band is gently excised above middle, the preterminal patch is quite circular, the subbasal dorsal spot is narrowly wedge-shaped in the type specimen of purpurissatana), and that "Argyroploce" archimedias Meyrick is not a synonym.

The identity of Kennel's species has recently been ascertained by Falkovitch, who transferred it into the new genus Eudemopsis. The present author was able to check this identification due to the kindness of Dr. Hannemann of the Berlin Museum, who sent me Kennel's type specimen for closer study.

\section{Eudemis (Eudemis) oxygona, new species}

Figures 65, 111-112, 527

Female, $16 \mathrm{~mm}$. Head and thorax rather pale vinaceous tawny, with a pale violet shine in certain lights (palpi missing). Abdomen fuscous, anal tuft tawny.

Forewing moderately broad, oblong, costa and termen gently curved, apex moderately rounded. Pale ochreous grey, partially suffused with elegant pale pink, except along dorsum, with deeper pinkish-purple tinge in certain lights. Subbasal spot deep vinaceous brown, well defined, erected-subtriangular, occupying about second sixth of dorsum, top reaching obliquely outwards to middle of wing breadth; transverse fascia complete, from before middle of costa to dorsum before tornus, anterior edge well defined and finely margined with white outwardly, moderately convex, with a slight prominence of its median third; posterior edge suffused; this fascia deep vinaceous brown along upper third, forming a broad blotch across wing slightly dilated downward, its posterior edge suffused with greenish brown; lower third of fascia less than twice as narrow, pale greenish brown; posterior half of costa with four brownish-olive well-defined transverse marks, finely edged with blackish and separated by whitish pairs of lines; anterior mark minute, posterior continued by an oblique purplish-crimson line; apex with transverse oval vinaceous-crimson spot, continued along termen as a rather broad streak of the same color, abruptly limited above tornus, these markings edged anteriorly by black points; deep brown, turning gradually paler below posteriorly, preterminal spot large, almost circular, with a very short stalk connected with middle of termen; this spot somewhat irregularly edged with white above except on top. Cilia deep purplish brown, pale ochreous along tornus.

Hindwing deep fuscous black with moderate bronze gloss. Cilia fuscous with a pale basal line, a dark fuscous subbasal band, and whitish tips. 
Female genitalia: Similar to those of E. archimedias Meyrick, but differing by the colliculum sclerite being shorter and less sclerotized and by the excision of the lamella antevaginalis being distinctly triangular; there are no horizontal folds flanking this lamella.

Material examined: Luzon, Los Baños, 2.VII.1932 (A.P. Evangelista), 1ㅇ, holotype, genit. slide 5157 (USNM). Although no material of males is available, the female genitalia are sufficiently distinct from those of archimedias Meyrick (from India and China) to justify description of the present species. It differs superficially from archimedias but slightly, viz., by somewhat larger size and more robust build, by paler and more contrasting ground color and by a more slender subbasal dorsal spot.

\section{Subgenus Acanthothyspoda Lower, 1908, new status}

Acanthothyspoda Lower, 1908, Trans. Roy. Soc. South Australia, vol. 32, p. 319 (type species, A. elaeodes Lower, 1908, Australia).-Meyrick, 1911, Proc. Linn. Soc. New South Wales, vol. 36, pp. 263, 281 (syn. of Argyroploce Hübner).-Fletcher, 1929, Mem. Dept. Agric. India, Ent. ser., vol. 11, p. 2 (syn. of Argyroploce Hübner).

Choganhia Razowski, 1960, Polskie Pismo Ent., vol. 30, p. 387, fig. b, 13 (type species: Argyroploce sphaerocopa Meyrick, 1929, Tonkin).

Male genitalia: Tegumen usually narrowed towards top, more or less erected-triangular. Valva complicated, ventral side of cucullus being more or less prominent triangularly and crowned with a hook; sacculus well defined, usually with a strong $\mathrm{Spc}_{1}$ at top; $\mathrm{Spc}_{2}$ and $\mathrm{Spc}_{3}$ mostly absent. Gnathos as in preceding but stronger, arms more robust, top spiny.

Female genitalia with sterigma less developed, an aciculate short funnel, colliculum longer. Signum one, or two, rounded small patches of thickened wall structure. Figure published (Clarke, 1958, vol. 3, p. 535, pl. 266, figs. 4-4c) of E. phyllochlora (Meyrick).

The following species belong here. Judging from the degree of development of the sacculus they may be arranged in the following natural sequence, from plesiomorph down to apomorph species.

Argyroploce semiculta Meyrick, 1909, (Ceylon)=heteraspis Meyrick, 1936; Clarke, 1958, vol. 3, p. 547, pl. 272, figs. 4-4c.

Argyroploce herbifera Meyrick, 1909 (Assam); Clarke, 1958, vol. 3, p. 516, pl. 257, figs. $4-4$ a.

Argyroploce callichlora Meyrick, 1909 (Assam); Clarke, 1958, vol. 3, p. 549 , pl. 244 , figs. $4-4$ b.

Argyroploce autoberylla Meyrick, 1914 (Java); Clarke, 1958, vol. 3, p. 487, pl. 242, figs. 3-3a.

Argyroploce aeolochlora Meyrick, 1916 (Assam); Clarke, 1958, vol. 3, p. 480 , pl. 239 , figs. $4-4$ a. 
Acanthothyspoda elaeodes Lower, 1908 (Australia), Trans. Roy. Soc. South Australia, vol. 32, p. 319.

Argyroploce phyllochlora Meyrick, 1905 (Ceylon); Clarke, 1958, vol. 3, p. 535, pl. 266, figs. 2-2b, 3-3a, 4-4c.

=ptilosema Meyrick, 1916 .

Argyroploce temenopis Meyrick, 1936 (Formosa); Clarke, 1958, vol. 3, p. 535 , pl. 266 , figs. $4-4 \mathrm{c}$, in my opinion not a synonym of phyllochlora.

Argyroploce camarotis Meyrick, 1936, (India); Clarke, 1958, vol. 3, p. 549 , pl. 244, figs. $3-3$ a.

Argyroploce stygiaula Meyrick, 1933 (Java); Clarke, 1958, vol. 3, p. 552 , pl. 275 , figs. $1-1$ a.

Argyroploce prasinias Meyrick, 1916 (India, China); Clarke, 1958, vol. 3 , p. 540 , pl. 269 , figs. 2-2b.

Eudemis (Acanthothyspoda) chortodes, new species.

Eudemis (Acanthothyspoda) homalopa, new species.

Argyroploce sphaerocopa Meyrick, 1929 (Indo-China).

Argyroploce margaritopa Diakonoff, 1953 (New Guinea).

\section{Key to the Philippine Species of Subgenus Acanthothyspoda}

1. Forewing green, transverse fascia blackish, rhomboidal $\left(\sigma^{7}\right)$.

Forewing greenish, transverse fascia obliterate (ㅇ).

E. (A.) chortodes, new species

E. (A.) homalopa, new species

Eudemis (Acanthothyspoda) chortodes, new species

FiguRes $77-78,528$

Male, $14 \mathrm{~mm}$. Head light olive green. Palpus light olive green, basal segment whitish, median segment with a whitish base and two suffused blackish dots in a transverse series above middle. Antenna pale ochreous. Thorax ochreous yellow, apex mixed with green, patagium bright green. Abdomen with white venter, dorsum dark grey, sides with five pairs of slate grey scale brushes. Legs grey with a strong silvery gloss, posterior tibia strongly extended and dilated triangularly with a thick brush of appressed scales, glossy grey, blackish on the inside, with a white lateral streak, posterior spur, apex of tuft and inner side of posterior tarsus pure white.

Forewing truncate-oval, rather broad, costa considerably curved throughout, apex obtuse, termen straight, long, little oblique. Light glossy greyish green, around edges suffused with rather bright green, except along termen and in tornus. Markings dark green and fuscous black. Basal patch indefinite, basal third of wing with three 
equidistant, curved, very irregular, blackish streaks, partially interrupted, acutely angulate in fold, becoming brown in middle of disc, obliterate towards dorsum; dark markings on costa alternating with pairs of minute short black lines; transverse fascia oblique, from middle of costa, moderately broad to upper edge of cell, thence dilated into a transverse oval, resting on dorsum, its inner edge with a deep oblique excision below, its outer edge with a small blunt tooth below middle; this fascia darker green, in middle of disc suffused with black, posterior half of costa with five brownish-green wedge-shaped marks, first of these narrow, last small, preapical; a big, rounded preterminal spot, occupying the lower $3 / 4$ of wing breadth, connected by an oblique green striga with the narrow costal mark, by a downcurved posterior branch with the middle of termen; lower extremity of this patch elongate, resting in tornus; upper half of patch blackish, lower green; a small irregular horizontal tooth originating from anterior edge of patch above its middle, but not reaching transverse fascia, at its base cut by a white line; terminal edge with a blackish line interrupted between veins, preceded by white. Cilia (imperfect) pale green, along termen with a white line and a few white bars.

Hindwing with vein 2 posteriorly curved upwards and approximated to 3 ; dark fuscous bronze with slight prismatic reflections; a small stiff crest of scales along posterior portion of vein 3 on the upper side, continued so as to cross vein 2 , anterior part of crest formed by very fine modified hair-scales; tornus covered with modified short and very thick glossy greenish-white scales. Cilia concolorous, around tornus cilia absent.

Male genitalia: Tegumen erect triangular, with rather narrow legs. Uncus small, semioval. Gnathos arms slender, curved and pending, tops porrect, clavate and bristly. Tuba analis distinct, long and narrowed, sclerotized except at base which is narrowed and supported by two curved bands (subscaphium). Valva curved and very narrow; sacculus triangular, top with a small cluster of short spines; harpe, a longitudinal tumescence, clothed with hairs; cucullus part abruptly dilated, bilobed, upper lobe rounded, covered with recumbent hairs, especially dense along lower edge; lower lobe dilated and clavate, covered with strong bristly spines, becoming short curved hooks along edge. Transtilla slender, curved. Caulis long, dilated. Aedeagus long, slender, strongly bent and sclerotized.

Material examined: Luzon, Baguio, $1800 \mathrm{~m}$, 2.VII.1945 (J. G. Franclemont), $1 \sigma^{x}$, holotype, genit. slide 5096 (CUI). Easily recognizable by the characteristic genitalia. A novel member of the fascinating group of pretty, greenish species. 


\section{Eudemis (Acanthothyspoda) homalopa, new species}

Figures $117-118,529$

Female, $14 \mathrm{~mm}$. Head and palpus dusty light greyish green, median segment of palpus with a subapical, somewhat oblique blackish streak. Antenna fuscous, scape greenish. Thorax light dusty greyish green, tegulae becoming greyish white towards tips. Abdomen dark fuscous brown.

Forewing oblong, costa gently curved anteriorly, little curved posteriorly, apex tolerably pointed, termen straight, little oblique. Pale fuscous, strewn with darker fuscous, along costa, in apex and along dorsal half as far as fold marbled and suffused with light olive green and fuscous greenish; dorsum also mixed with dark fuscous; a large, round, light fuscous pretornal patch with darker suffused upper and posterior edges; an oblique straight pale greyish transverse band from costa, following pretornal patch and separating apex. Cilia (imperfect) greenish fuscous with a whitish basal line.

Hindwing semipellucent towards base and thinly scaled throughout, especially on dorsum; blackish towards apex, appearing dark grey elsewhere. Cilia blackish with a pale base.

Female genitalia: Seventh sternite densely scaled, its edge forming a quadrate prominence in middle, opposite lamella antevaginalis which is smaller; this lamella strongly sclerotized, obliquely cup-shaped, right side being much shallower than left, which is rounded below; upper edge of lamella antevaginalis concave, finely aciculate. Sclerotized rib or band of colliculum very long, originating from the left side of ostium (lamella antevaginalis) and crossing to the right side, gradually attenuated, extremity pointed. Signum one, a moderate, straight, and scobinate tooth.

Material examined: Mindanao, Davao Prov., 1 \%, holotype, slide 5717 (CMP). A single, somewhat rubbed specimen, distinct by the genitalia, the rib or band of the colliculum being much longer than in any other species known to me.

\section{Statherotis Meyrick, 1909}

Statherotis Meyrick, 1909, Journ. Bombay Nat. Hist. Soc., vol. 19, p. 591.-Clarke, 1958, Catalogue . . Microlepidoptera . . Meyrick, vol. 3, p. 592, pl. 295, figs. 1-1e (neurat. genit. $\left.\sigma^{7}\right)$.

Type species: Statherotis decorata Meyrick, 1909 (Ceylon).

This genus, which was incorporated by Meyrick in his compound genus "Argyroploce" but recently correctly separated by Clarke (1958), may be redescribed as follows, under slight extention of its original concept.

Head with appressed scales. Ocellus posterior. Proboscis developed. Antenna ciliated to fasciculate-ciliated in male, ciliations 
of diverse length. Thorax with or without a posterior crest. Posterior tibiae normally scaled.

Forewing without a fold, veins 8 and 9 stalked, approximated or separate, upper parting vein usually present, from before base of 10 to beyond that of 8 . Usually a field of modified scent scales in male on the underside, along and beyond the posterior part of lower edge of cell. On the upper side usually a pale semioval costal patch.

Hindwing with 2 from beyond middle, 3-5 approximated, 3 from angle, 6 and 7 closely approximated towards base, usually an extended circular patch of scent scales in center of disc on the upper side.

Male genitalia with uncus developed, single and rather slender or paired, lobes sometimes moderate and densely hairy. Socius usually developed, pending or porrect, seldom parietal. Gnathos well developed, sclerotized, sometimes rigid and porrect, with a broad hook part. Valva characteristic, slender and narrow, sacculus ending with a triangular prominent point with one or more spines, a marginal series of strong bristles below point, an isolated and elevated $\mathrm{Spc}_{2}$ sometimes present.

Beside the type species, I attribute the following species to the present genus, judging from the characters of the male genitalia. Argyroploce olenarcha Meyrick, 1931, Exotic Microlepidoptera, vol. 4, p. 136 (Formosa).

Argyroploce ancosema Meyrick, 1932, op. cit., vol. 4, p. 310 (Fiji). Tortrix(?) discana Felder and Rogenhofer, 1875, Reise Fregatte Novara, vol. 2, pl. 137, fig. 41.

Dichelia amoebaea Lower, 1896, Trans. Roy. Soc. South Australia, vol. 20, p. 161.

Argyroploce leucaspis Meyrick, 1902, in Gardiner, Fauna Maldives ..., vol. 1 , no. 7 , p. 126 .

Two more species have already been attributed to Statherotis by Clarke (1958, vol. 3, p. 595, pl. 296), viz.,

Proschistis agitata Meyrick, 1909, Journ. Bombay Nat. Hist. Soc. vol. 19, p. 589 (Ceylon), and Argyroploce aspitias Meyrick, 1909, ibid., p. 599 (India).

Finally, two more species, assigned by Meyrick to Statherotis, should be removed from this genus, as already correctly stated by Clarke:

"Statherotis" catharota Meyrick, 1928, Exotic Microlepidoptera, vol. 3, p. 443 (Andamans), and

"Statherotis" relapsa Meyrick, 1928, ibid., vol. 3, p. 444 (Ceylon).

\section{Key to the Philippine Species of Statherotis}

1. Forewing with a pale subtriangular costal spot . . . . . . . S. leucaspis Forewing with a whitish streak along larger part of costa . . . S. olenarcha 
Statherotis discana (Felder and Rogenhofer, 1875), new combination

Figures 79, 530

Tortrix(?) discana Felder and Rogenhofer, 1875, Reise Fregatte Novara, vol. 2, pl. 137, fig. 41.

Argyroploce discana.-Meyrick, 1911, Proc. Linn. Soc. New South Wales, vol. 36, p. 280; 1929, in de Joannis, Ann. Soc. Ent. France, vol. 98, p. 720.-Fletcher, 1932, Imp. Counc. Agric. Res., Sci. Mon., no. 2, p. 28.-Kalshoven, 1950, Plagen Cultuurgew. Indonesia, vol. 1, p. 394 (Nephelium food plant).Bradley, 1957, Nat. Hist. Renell Is., vol. 2, no. 19, p. 94.

Distribution: Tropical Asia.

Material examined: Mindanao, Zamboanga del Sur, $11 \mathrm{~km} \mathrm{NW}$ of Milbuk, 390 m, 5.VIII.1958 (H.E. Milliron), 1 ð', genit. slide 5311.

Male genitalia: Uncus short, halves flattened and oval, on a curved stalk, strongly long-haired along lower edge. Socius, an elongate tumescence, parietal. Gnathos strong, correct, angular, with a distinct slender hook. Valva moderately narrow, cucullus somewhat dilated, ventral projection triangular, moderate, at $3 / 4$ of valva, with a single row of bristles and a pair of apical bristles. $\mathrm{Spc}_{1}$, an obliquely transverse strong comblike series of bristles, not reaching costa; $\mathrm{Spc}_{2}$ rounded-oval.

\section{Statherotis olenarcha (Meyrick, 1931), new combination}

\section{Figures 74, 532}

Argyroploce olenarcha Meyrick, 1930, Exotic Microlepidoptera, vol. 4, p. 136.-

Clarke, 1955, Catalogue . . . Microlepidoptera . . Meyrick, vol. 1, p. 224. Olethreutes olenarcha.-Clarke, 1958, Catalogue . . Microlepidoptera . . . Meyrick, vol. 3, p. 532, pl. 265, fig. 1 (type $q$ figured).

Distribution: Formosa.

Material examined: Mindanao, Bukidnon, Mt. Katanglad, 1480 m, 27-31.X.1959 (L.M. Quata), 1 ơ , neallotype, hereby designated, genit. slide 5317 (BMH).

Male genitalia: Uncus with slender, little dilated, slightly clavate halves, moderately bristled below. Socius rather large, spatulate, subporrect. Gnathos well developed, rather broad. Valva very slender, cucullus projection at about $2 / 3$ of valva, with several rows of strong bristles, $\mathrm{Spc}_{1}$, a rounded, dense patch of bristles, extended distally, bristles quickly becoming shorter and more scattered; $\mathrm{Spc}_{2}$ absent.

\section{Phaecadophora Walsingham, 1900}

Phaecadophora Walsingham, 1900, Ann. Mag. Nat. Hist., ser. 7, vol. 6, p. 130 (type species: Phaecadophora fimbriata Walsingham, 1900, Japan, Assam).Fletcher, 1929, Mem. Dept. Agric., India, Ent. ser., vol. 11, p. 170 (syn. of 
Argyroploce).-Clarke, 1958, Catalogue . . Microlepidoptera . . Meyrick, vol. 3 , p. 571 .

Temnolopha Lower, 1901, Trans. Roy. Soc. South Australia, vol. 25, p. 72 (type species: Temnolopha mosaica Lower, 1901, Queensland).-Clarke, 1958, Catalogue ... Microlepidoptera .. Meyrick, vol. 3, p. 599 [new synonym].

Argyroploce (in part) Meyrick, 1911 (not Hübner, 1826), Proc. Linn. Soc. New South Wales, vol. 36, p. 263 (Temnolopha syn.).-Fletcher, 1929, Mem. Dept. Agric. India, Ent. ser., vol. 11, pp. 22, 218 (Temnolopha syn.).

It may be stipulated that Argyroploce aeolotechna Meyrick, 1935 (misprinted as eaolotechna) is a synonym of fimbriata Walsingham.

There is no doubt as to the species Temnolopha mosaica Lower being congeneric with the type species of Phaecadophora Walsingham. Temnolopha, therefore, falls as a junior synonym of that genus. But I am not yet certain whether the three other species placed by Walsingham in Phaecadophora really belong there. These species are $P$. acutana Walsingham (Japan), $P$. divisa Walsingham (Assam), and $P$. ochracea Walsingham (Korea).

\section{Phaecadophora mosaica (Lower 1901), new combination}

\section{Figure 531}

Temnolopha mosaica Lower, 1901, Trans. Roy. Soc. South Australia, vol. 25, p. 72 ( $\sigma^{7} \uparrow$, Queensland).-Clarke, 1958, Catalogue ... Microlepidoptera . . . Meyrick, vol. 3, p. 599, pl. 298, figs. 1-1a (clydonias syn., lectotype selected, genit. $\sigma^{\top 7}$ fig.).

Argyroploce mosaica.-Meyrick, 1911, Proc. Linn. Soc. New South Wales, vol. 36, p. 273.

Cydia clydonias Meyrick, 1907, Journ. Bombay Nat. Hist. Soc., vol. 17, p. 734; 1909, op cit. vol. 19, p. 437.-Clarke, 1955, Catalogue . . Microlepidoptera ... Meyrick, vol. 1, p. 94.

Distribution: East Australia, India, Ceylon, Siam, Cambodia, Java.

Material examined: Luzon, Mt. Makiling (Baker), 1 \&, genit. slide 5013 (USNM).

The male genitalia of this species have been illustrated by Clarke (1958). The genitalia of the opposite sex may be described thus.

Female genitalia: The 6 th and 7 th sternites slightly sclerotized and emarginate in the middle. Ostium and colliculum together forming a long, spindle-shaped tube with several partial longitudinal folds, one opening in the middle of the tube; top of tube apparently forming the genital opening, flanked by two small and elongate sclerites. Ductus bursae short, with a tubular cestum, which is distinct but only slightly sclerotized. Signum single, a flattened blade with a rounded top and finely denticulate base. 


\section{Sycacantha Diakonoff, 1959, new status}

Sycacantha Diakonoff, 1959, Arkiv Zool., vol. 12, p. 181, pl. 5, fig. 17 (subgenus of Phaecasiophora Grote); 1966, Zool. Verh., no. 85, pp. 7, 17, 58 (distinct genus).

Type species: Argyroploce hilarograpta Meyrick, 1933= Sycacantha auriflora Diakonoff, 1959, Java.

This form has been originally described by me as a subgenus of Phaecasiophora Grote. Now I am satisfied that it represents a distinct genus. It contains several Indo-Malayan species, which superficially are very similar but show sufficient genital differences in the two sexes.

The entire complex of these closely allied species has been hitherto confused with "Argyroploce" albitibiana=Grapholitha (Sisona) albitibiana Snellen, 1902. The superficial resemblance of this species with Sycacantha misled even Snellen himself; only the holotype of albitibiana belongs to the genus Sisona, but the two $\sigma^{x}$ and one o paratypes belong to a Sycacantha subspecies, described below.

The genus Sycacantha may be redescribed as follows.

Head with rather short, appressed scales, forming a small ridge across forehead. Palpus rather long, slender, ascending, closely appressed to face, with short scales, smooth above, slightly roughish beneath, apical segment very short. Antenna pubescent in male and female. Ocellus posterior. Proboscis developed. Hindtibia and tarsus sometimes strongly extended by dense and long hair-scales, modified and arranged in patches of different color (white, black, etc.), sometimes hindtibiae normal. Abdomen with a long lateral pencil of hairs at extreme base (usually not apparent without removing the abdomen).

Forewing similar to that in Olethreutes Hübner: vein 2 from 2/3, 3 from angle, 4 separate, 5 parallel, 7 separate, to termen, 9 from $1 / 3$ distance between 8 and 10, 11 from slightly before middle.

Hindwing with cubital pecten, 2 from beyond $2 / 3,3$ and 4 very close but separate, from angle, 5 approximated at base, 6 and 7 closely approximated toward base.

Male genitalia: Valva usually long and slender with a dilated base, bulbous at the end of sacculus; cucullus with diversely shaped series of rigid spines, which sometimes are bifid at the top; sometimes cucullus bristles divided into two groups, internal, along the usual area, and external bristles, which are shorter and scalelike, and situated just below the lower edge of the cucullus; top of cucullus usually clavate. Top of tegumen (partly uncus?) complicated, forming a dilated flap of diverse shape, socii small and slender, pending, crowned with long bristles, sometimes there are two more or less 
similar pairs of socii. Caulis usually long. Anellus peculiar, a loose slender ring, encircling base of aedeagus and joined to its lower edge, but also attached at the top to a transverse sclerite between and below socii (gnathos?).

Female genitalia: Ovipositor of a shape characteristic for the Phaecasiophora group of genera. Lobus analis narrowed above and below, with a gently scalloped edge. Lamella antevaginalis large, transverse, lamella postvaginalis, a small median sclerite. Colliculum tubular and dark. Ductus bursae rather long, corpus bursae asymmetrically pear-shaped and elongate. Signa one or two spikes or hooks.

The genus is related with Phaecasiophora group but not with Sisona Snellen. In that genus the hindwing in the male is short, with a projecting lobe at the dorsal angle. The male genitalia of Sisona albitibiana are quite different and closer to the Hedya type. I hope to publish a figure elsewhere.

Excepting the type species and that described below, the third species belonging to this genus is the following:

Argyroploce escharota Meyrick, 1910, Trans. Roy. Ent. Soc. London, p. 436 ( $0^{7}$, South Celebes).-Clarke, 1955, Catalogue . . Microlepidoptera . . . Meyrick, vol. 1, p. 133; 1958, op. cit., vol. 3, p. 508, pl. 253, figs. 1-1a (Olethreutes).

\section{Key to the Philippine Species of Sycacantha}

1. Forewing with ground color whitish ochreous; a conspicuous blackish dot in middle of disc at $2 / 3$. . . . . . . S. potamographa, new species

Forewing with ground color pinkish ochreous; no such spot in middle of disc at $2 / 3$. . . . . . . . . . S. inodes perspicua, new subspecies

\section{Sycacantha inodes (Meyrick, 1911)}

FigURe 70

Argyroploce inodes Meyrick, 1911, Proc. Linn. Soc. New South Wales, vol. 36, p. 269 ( $q$ ).-Clarke, 1955, Catalogue . . . Microlepidoptera . . Meyrick, vol. 1, p. 171.-Diakonoff, 1966, Zool. Verh., no. 85, pp. 7, 10, 19.

Distribution: New Guinea, Woodlark Island.

Male, 17-19 mm. Head pale ochreous, forehead between antennae with a vinaceous-brown suffused spot, tufts on vertex vinaceous brown with paler base, upper part of face with an ochreous flat tuft, a pair of purplish spots partly under this tuft at the sides, lower part of face whitish. Thorax pale ochreous sometimes with a faint vinaceous tinge, marbled with brown. Posterior tibia white, sometimes suffused along dorsal edge with pale ochreous grey, dilated and slightly thickened by long glossy white hairs, outer spurs dark grey. 
Forewing rather broad, strongly dilated to $2 / 3$, costa straight anteriorly, angulate at $2 / 3$, posteriorly gently curved, apex obtuserectangular, termen almost straight and vertical. Whitish ochreous, marbled with pale vinaceous, with tawny, and, slightly, with fuscous. Costa more clearly vinaceous-tinged, markings dark brown; a moderate inverted-triangular spot at $1 / 6$ of costa, preceded by two, followed by one, small round dots, these dark markings alternating with minute short strigulae; a larger triangular patch on costa before middle; one very small and three large, well defined, obliquely triangular spots along costa beyond preceding patch, separated from each other by pairs of slender whitish strigulae: a broad, but faint pale leaden-grey streak, running below these spots, then curving downwards to termen above middle; basal patch indicated by a large triangle of loose dark fuscous-grey irroration, from middle of base of wing, extending along dorsum to $1 / 3$, not reaching above vein 12 , top pointing at median costal spot; outer edge of patch rather well defined, almost vertical, somewhat irregularly excised below middle, upper angle obtuse; triangular spot on dorsum just before tornus, sometimes well defined, fuscous grey to dark brown, with slightly serrate edges; transverse fascia dissolved into irregular marbling, below costal patch forming three ill-defined finger-like projections of posterior edge; some suffusion just before closing vein and a black dot on each upper and lower angle of cell, which are more or less connected with this suffusion; a pale bar along closing vein; very irregular dark brown subapical streak, from below first large costal dot, limiting leaden streak from below, outer edge gradually curved, lower diversely serrate; posterior end of this mark to middle of termen; a curved projection above this, turning basad along vein 6 and dilated into a spot; a row of triangular dots along middle of dorsum; a blackish oval apical spot. Cilia dark brown, with tawny basal half, cilia in tornus tawny.

Hindwing dark fuscous grey, with a bronze gloss. Cilia dull grey; base slightly extended so as to form a slight lobe, base of dorsal edge thickened, naked, colored light brown. Cilia on posterior half of dorsum, whitish.

Male genitalia: Uncus large, subquadrate, top prominent, finely denticulate; socii, two pairs, inner longer, with numerous bristles on top, outer with a few long bristles only. Cucullus bristles in two groups (as described for the genus), outer formed of slender stiff scalelike bristles, inner very dense, of forked flat spines. One very large spike at the base of cucullus; sacculus with a large, extended patch of short, obtuse bristles. Cornuti, a sheaf of very long spines, sinuate beyond base. 
Female, 17-20 mm. Deeper brownish-tinged throughout. Thorax denser marbled with dark brown. Abdomen darker brown. Hindtibia normally scaled, grey.

Forewing narrower and longer, more oval, costa being less distinctly bent at $2 / 3$ than in male. Costal and apical markings tolerably similar. Basal patch basically similar, but usually much paler or hardly defined at all; the same is the case with the pretornal dorsal spot, but to a lesser degree. (In darker specimens there is some leaden-black fine marbling in paler interspaces between dark markings). Hindwing as in male, dorsum normal.

Female genitalia: Eighth segment distinctly sclerotized throughout; sternite broadly semicircular with a deep excavation. Ostium bursae cup-shaped, rather broad, sclerotized. Colliculum moderate, narrowed, about as long as ostium proper. Ductus bursae rather long. Corpus bursae elongate.

Material examined: West Java: Buitenzorg, 1894, $1 \sigma^{7}$, genit. slide 4552 ; Batavia, "G. albitibiana m.," 1 \%, genit. slide 4551 ; Buitenzorg, 1894, $1 \sigma^{7}$. (These three specimens from Snellen collection bear the labels "Grapholitha albitibiana det. Snell." and are recorded as paratypes of Sisona albitibiana Snellen which species is quite distinct as is explained below.) Central Java: teak forest near Semarang, 40 m, 7.VIII.1931, 24.IX.1931, 8.I.1932, bread from leaves of "Kalak" (family Anonaceae); Seneng, 19.X.1931; Telawa, 8-20. VIII.1933 and 8-10.I.1935; Gedangan, 13.I.1931, 24.X.1931, and 30.X.1931, genit. slide 4554 o (all by L.G.E. Kalshoven). Rembang Residency, and Semarang, 13.1V. and 3.V.1931 (F.A.T. Verbeek). $20 \sigma^{\pi}, 9$ \% (LM).

Belongs to a group of closely allied species which have been confused for a long time with Sisona albitibiana Snellen, because of somewhat similar markings and white-haired tibiae.

\section{Sycacantha inodes perspicua, new subspecies}

Figures 71, 533

Male, $18.5 \mathrm{~mm}$. Forewing distinctly longer and narrower. Larger, more distinctly tinged throughout with pale vinaceous. Pretornal dorsal spot dark brown, strongly contrasting.

Hindwing with the base of dorsal edge thickened, devoid of hairs, pinkish-tinged.

Male genitalia: Identical to those of the nominate form.

Material examined: Luzon, Mt. Makiling (Baker), $1 \sigma^{7}$, holotype, genit. slide 4550. Although very similar to the material from Java, this single specimen is sufficiently different to justify subspecific separation. 


\section{Sycacantha potamographa, new species}

Figures 72, 534

Male, $21 \mathrm{~mm}$. Head and thorax dark fuscous, densely marbled and spotted with pale ochreous, lower half of face white (palpi missing). Antenna fuscous, scape dark fuscous, with a broad pale ochreous apical ring. Abdomen dark fuscous, venter pale ochreous.

Forewing broad, rather dilated, costa gently curved anteriorly, distinctly curved posteriorly, slightly prominent at $2 / 3$, apex obtusely rectangular, termen straight, vertical, curved below. Pale ochreous, marbled and dusted with blackish fuscous and with lilac. Markings limited, tawny olive, broadly edged with blackish. Basal patch indicated by a basal and a marginal, rather well-defined fasciae; basal fascia with a strong median projection, marginal before $1 / 4$, traversed by two short streaks with truncate ends, one above cell, another in fold; on costa this fascia extended by a short blackish marginal streak; transverse fascia interrupted, blackish, with a rather large subquadrate or semioval spot on middle of costa and a smaller conspicuous black, obliquely oval spot beyond cell, with two digitoid smaller spots between these posteriorly; costa beyond basal patch with eight pairs of white marks, three anterior little oblique, eighth vertical; fourth to eighth pairs connected below with a broad, almost horizontal leaden fascia, curved downward before apex, streaked with whitish and with pale ochreous olive; costa posteriorly between white marks and apex, black; an ill-defined very irregular fascia of little obscured ground color running straight from above $1 / 3$ of dorsum to well below $2 / 3$ of costa, thence wider, but parted by a blackish, very irregular line; this line flanked by similar paler, lilac-leaden lines, to termen above tornus; an irregular, dark fuscous mark beyond upper half of preceding fascia, edging the leaden streak below, on some veins traversed by tawny-olive longitudinal streaks, jutting out anterad, viz., along veins 5, 7 to 9 ; upper edge of termen with a narrow, blackish streak; dorsum with five black, marginal streaks, separated by paler, above these strongly clouded with dark grey and fuscous.

Hindwing dark fuscous, with pale base and a darker subbasal shade, cilia along dorsum pale ochreous.

Male genitalia similar to those of Sycacantha escharota (Meyrick), but with the top of tegumen and uncus represented by a strongly separated, transversely elongated body, with uncus forming an apical prominence on top of this. Socius moderate, clavate, pending, top bristly; gnathos, a transverse horizontal band. Valva similar to that in S. escharota.

Material examined: Mindanao, Zamboanga del Sur, $24 \mathrm{~km}$ NW of Milbuk near Lebak, 210-240 m, 8.VIII.1958, light trap (H.E. 
Milliron), $1 \sigma^{7}$, paratype, genit. slide 5320 (BMH). East Borneo, Balikpapan, $50 \mathrm{~m}$, 18.X.1950, Mentawir River (A.M.R. Wegner), $1 \sigma^{7}$, holotype, genit. slide 4575 (LM).

Rather distinct from S. escharota by the absence of well-defined dark terminal and dorsal patches; characteristic by the presence of a postmedian discal black spot.

\section{Sisona Snellen, 1901, new status}

\section{Sisona albitibiana Snellen, 1902}

Grapholitha (Sisona) albitibiana Snellen, 1902, Tijdschr. Ent., vol. 44, p. 69, pl. 5, fig. 2, 2a, b, c (o + ), Java (part: $o^{7} 18 \mathrm{~mm}$, not $o^{7} 15.5$ and $16.5 \mathrm{~mm}$, not + ).

To prevent further confusion, a lectotype of this species is selected herewith. It is the unique male specimen, the type of the original colored figure, labelled as follows. "W. Java, Depok, 1886, o" (in Piepers' hand?), "G. (Sisona) Albitibiana m." (in Snellen's hand), "Museum Leiden. Grapholitha albitibiana. Det. Snell.” slide 2629. My lectotype label.

Three more syntypes of the original series belong to Sycacantha inodes perspicua, new subspecies, described above.

\section{Bactra Stephens, 1834}

\section{Key to the Philippine Species of Bactra}

1. Males

Females . . . . . . . . . . . . . . . . 5

2. Valva short and rounded, cucullus with large marginal spines (subgenus Nannobactra) . . . . . . . . . . . . . . . . . . . B. phaulopa

Valva not thus (subgenus Chiloides) . . . . . . . . . . . . . . . . . 3

3. Sacculus rounded, corona formed by long equal spines . . . . B. coronata Sacculus not thus . . . . . . . . . . . . . . . . . . . . . . . . 4

4. Sacculus with a conical lower (rostral) extremity, ending in a cluster of curved spines . . . . . . . . . . . . . . . . . . . . B. orbiculi minax Sacculus with an oblique transverse series of spines . . . . . B. venosana

5. Sterigma weak, aciculate (subgenus Nannobactra) . . . . . . B. phaulopa Sterigma developed, more or less sclerotized (subgenus Chiloides) . . . . 6

6. Sterigma, two oval plates joined medially . . . . . . . . . . B. coronata Sterigma more or less $\mathrm{Y}$-shaped . . . . . . . . . . . . . . B. venosana

\section{Subgenus Chiloides Butler, 1881}

\section{Bactra (Chiloides) coronata Diakonoff, 1950}

Figure 535

Bactra coronata Diakonoff, 1950, Bull. British Mus. Nat. Hist., Ent. ser., vol. 1, p. 286, pl. 5, fig. 17 ( $\sigma^{7}$, Java).

Bactra (Chiloides) coronata.-Diakonoff, 1956, Zool. Verh., no. 29, p. 33, figs. 34-36 ( $\sigma^{\top}$ \%, Java, Borneo, Philippine Is.); 1964, Zool. Verh., no. 70, p. 37. 
Distribution: Java, East Borneo, Philippine Is.

Material examined: Luzon, Los Baños (Baker), 1 ㅇ, genit. slide 5142 (USNM).

\section{Bactra (Chiloides) venosana (Zeller, 1847)}

Figure 536

Phoxopteris venosana Zeller, 1847, Isis, p. 738.

Aphelia venosana.-Herrich-Schäffer, 1849, Systematische Bearbeitung . . ., vol. 4, p. 244.

Bactra venosana.-Rebel, 1901, in Staudinger and Rebel, Cat. Lepidopteren palaearktischen Faun. pt. 2, p. 113.-Kennel, 1910, in Spuler, Schmetterlinge Europas, vol. 2, p. 273; 1910, Palaearktischen Tortriciden, p. 472, pl. 18, fig. 73.

Bactra (Chiloides) venosana.-Diakonoff, 1956, Zool, Verh. 29, p. 33, figs. 31-33; 1959, Bijdr. Dierk., fasc. 29, p. 184; 1963, Ann. Naturhist. Mus. Wien, vol. 66 , p. 474 ; 1964 , Zool. Verh., no. 70 , p. 33 .

Bactra truculenta Meyrick, 1909, Journ. Bombay Nat. Hist. Soc. vol. 19, p. 586; 1922, Exotic Microlepidoptera, vol. 2, p. 521; 1934, in Caradja, Iris, vol. 48, p. 33; 1935, in Caradja and Meyrick, Materialien Microlepidopteren-Fauna, p. 57.-Fletcher and Gosh, 1920, Rep. Proc. 3rd Ent. Meeting Pusa, p. 363, 367, 394.-Fletcher, 1921, Mem. Dept. Agric. India, Ent. ser., vol. 6, p. 53.-Swezey, 1927, Proc. Hawaiian Ent. Soc., vol. 6, p. 349.Diakonoff, 1950, Bull. British Mus. Nat. Hist., Ent. ser., vol. 1, p. 289, pl. 5, fig. 16, pl. 7, fig. 30 ; 1956, Zool. Verh., no. 29, p. 27 figs. 28-30, p. 33, figs. 31-33; 1959, Bijdr. Dierk., fasc. 29, p. 184, pl. 1, fig. 4.-Clarke, 1955, Catalogue . . Microlepidoptera . . Meyrick, vol. 1, p. 319; 1958, op. cit., vol. 3, p. 315, pl. 156, figs. 4-4a.-Bradley, 1961, Bull. British Mus., Ent., vol. 10, p. 122 .

Bactra (Chiloides) truculenta.-Diakonoff, 1956, Zool. Verh., no. 29, p. 27, figs. 28-30; 1959, Bijdr. Dierk., fasc. 29, p. 184.

Bactra scythropa Meyrick, 1911, Proc. Linn. Soc. New South Wales, vol. 36, p. 284.

Bactra geraropa Meyrick, 1931, Exotic Microlepidoptera, vol. 4, p. 147.-Clarke, 1955, Catalogue ... Microlepidoptera ... Meyrick, vol. 1, p. 146; 1958, op. cit., vol. 3 , p. 308 , pl. 153 , figs. $4-4$ b.

Distribution: India, Ceylon, Andaman Is., South China, Formosa, Timor, Hawaii, Australia, Fiji. Known to me also from Borneo, Kissar Is., Philippine Is., Caroline Is., North Africa, Asia Minor, South Europe.

Food plants: Cyperus rotundus.

Material examined: Luzon, Mt. Makiling, 1 \%, genit. slide 5061 (USNM).

After a study of extensive material from all over the region indicated above, I am finally satisfied that Bactra venosana and Bactra truculenta are the same species. Previouslyit seemed that the first species was from the temperate and subtropical regions, while the second was tropical. The surmised differences in anatomy, however, proved to be only illusory. 
The species (under the name $B$. truculenta) is recorded to be of peculiar economic importance as it is a useful pest of the weed "nut grass" (Cyperus rotundus), in the stems of which the larvae bore. In the years 1922-1926 the species was introduced from the Philippine Islands to Hawaii, where it became established. Later followed introductions to the Fiji Is. and Australia. The measure, however, was not a great success, apparently due to parasites which affect eggs and larvae of $B$. venosana.

\section{Bactra (Chiloides) orbiculi minax Diakonoff, 1964 \\ Figures 80,538}

Bactra (Chiloides) orbiculi minax Diakonoff, 1964, Zool. Verh., no. 70, p. 51, figs. 45-47 ( $\sigma^{\top}$, Luzon).

Distribution: Philippine Is., Luzon.

Material examined: Luzon, Benguet, Klondyke, 800 ft., 9.V.1912 (A.E. Wileman), $1 \sigma^{7}$, holotype, genit. slide 5529 (BM). The nominate form occurs in East and South Borneo. The present subspecies differs by the stronger armature of the valva.

\section{Subgenus Nannobactra Diakonoff, 1956}

Bactra (Nannobactra) phaulopa Meyrick, 1911

Figure 537

Bactra phaulopa Meyrick, 1911, Proc. Linn. Soc. New South Wales, vol. 36, p. 253 ( $q$, Kei Is.).-Diakonoff, 1950, Bull. British Mus. Nat. Hist., Ent. ser., vol. 1, p. 288 , pl. 8 , fig. 42 (lectotype selected, genitalia figured).

Bactra (Nannobactra) phaulopa.-Diakonoff, 1956, Zool. Verh., no. 29, p. 52, figs. $50-51$; 1964, op. cit., no. 70, p. 77.

Distribution: Java, Sumatra, Celebes, Kei Is. North Moluccan Is., Philippine Is.

Material examined: Luzon, Manila, XII. 1945 (CNHM Philippine Zool. Exped. 1946-47, H. Hoogstraal), $6 \sigma^{7}$, genit. slides 5761, 5762 (CNHM).

\section{Bubonoxena, new genus}

Head with roughly appressed scales forming a small tuft on forehead, face smooth. Antenna in male slightly thickened and serrulate, pubescent. Ocellus posterior. Proboscis very short. Palpus subascending, basal segment roughish, median segment moderately long, slender anteriorly, abruptly and strongly dilated and triangular posteriorly, rough along apex, terminal segment slender, subobtuse, moderate. Thorax without a crest. Hindtibia normal.

Forewing elongate, rather narrow, apex subobtuse, termen gently rounded, oblique. Vein 2 from $3 / 5,3$ from angle, 3 to 5 moderately 
approximated at base and equidistant, 7 separate, to termen, 11 from before middle.

Hindwing with a cubital pecten, vein 2 from $2 / 3,3$ from angle, 4 separate from 3, remote from 5 at base, 6 and 7 stalked.

Male genitalia: Tegumen weak, higher than broad, top obtuse. Uncus absent. Tuba analis moderate, developed, supported by a transverse band (subscaphium). Valva characteristic, triangular, outer angle produced, with a long pencil of bristles $\left(\mathrm{Spc}_{2}\right)$, with a strong triangular blade at its foot, a large patch of bristles in disc $\left(\mathrm{Spc}_{1}\right)$; cucullus thinly bristled, sacculus narrow, complete. Aedeagus very short, anellus broad, cup-shaped.

Type species: Bubonoxena spirographa, new species.

A specialized genus, belonging to the Olethreutini, with a characteristic neuration. The nearest genus is Syntozyga Lower from Australia. There seems also to be a connection with Bactra Stephens, and with the Eucosmini.

\section{Key to the Philippine Species of Bubonoxena}

1. Forewing narrow, transverse fascia not reaching dorsum; hindwing whitish.

B. spirographa, new species

Forewing moderately broad, transverse fascia interrupted in middle; hindwing fuscous ........... . . . . endaphana, new species

\section{Bubonoxena spirographa, new species}

Figures $82,103-104,540$

Male, $10 \mathrm{~mm}$. Head and thorax ochreous whitish. Palpus ochreous whitish, median segment with base and a suffused subapical band dark fuscous, terminal segment fuscous above. Abdomen pale fuscous.

Forewing elongate and rather narrow, costa gently curved at extremities, little curved in middle, apex subobtuse, termen gently rounded. Ochreous whitish, markings dark fuscous. Basal patch over $1 / 4$, its edge distinct along costa and across wing, where it is tolerably vertical, with a small truncate process in middle, edge obliterate on dorsum; upper posterior angle of patch indicated by a small spot before $1 / 4$ of costa; costa posteriorly with some eight moderate oblique wedge-shaped dark marks, alternating with minute strigulae; ultimate mark large, rhomboidal, in apex; transverse fascia indicated by a large and conspicuous inverted-triangular spot on costa beyond middle, reaching halfway across wing; top of spot truncate, posterior edge convex, with three small teeth; a small longitudinal and slightly upwards-curved mark almost connecting top of costal patch with two subfasciate spots posteriorly, first resting on lower part of termen and rising obliquely, sinuate-spindle-shaped; 
second spot rising from dorsum before tornus, inwards-oblique, with a dilated top, connected by a slender line with tornus; the three last mentioned spots converging more or less in middle of wing halfway between cell and termen; an ill-defined suffusion or irroration on dorsum, reaching to fold. Cilia whitish with fuscous tips.

Hindwing fuscous grey. Cilia pale fuscous with a white base and a darker fuscous subbasal line.

Male genitalia as described with the genus.

Material examined: Luzon, Mt. Makiling, $1 \sigma^{x}$, holotype, genit. slide 5078. Los Baños (Baker), 1 ๙ $\sigma^{7}$, paratype, genit. slide 4932; another $\sigma^{\urcorner}$, paratype, without abdomen (USNM). Luzon, Los Baños, VII.1911 (A.E. Wileman), 1 ơ , paratype, genit. slide 5526 (BM).

\section{Bubonoxena endaphana, new species}

Figures 66, 539

Female, $14 \mathrm{~mm}$. Head and thorax pale ochreous, slightly mixed with tawny. Palpus pale ochreous, median segment strewn with dark brown at base, lower edge and a transverse preapical band suffused fuscous, terminal segment almost concealed, infuscated. Abdomen grey, anal tuft pale at base.

Forewing oblong-truncate, rather narrow, costa gently curved throughout apex obtusely pointed, termen gently concave, oblique. Pale ochreous, terminal third ochreous whitish, ground color obscured by a fine fuscous marbling. Anterior half of costa with numerous, equidistant small dark strigulae, oblique and slightly curved; posterior half of costa dark fuscous, with four pairs of ochreous-whitish slender marks; basal patch well defined, with edge strongly prominent in middle to $1 / 3$ of wing, upper half of this edge convex, with three regular scallops, lower half concave; this patch rather bright tawny, transversely strigulated by dark brown fine undulate strigulae, running more or less parallel to complicated edge of patch; transverse fuscia formed by an obliquely clavate somewhat suffused dark fuscous spot from middle of costa, stalk darker, on costa; and by a large subquadrate, somewhat irregular patch on 3rd fourth of dorsum; upper edge of this patch slightly concave, almost touching costal spot, posterior edge well defined, irregular, with a process below middle; upper posterior angle of patch slightly produced obliquely upwards as a small tooth; an elongate wedge-shaped fuscousgrey spot with base extending over lower half of termen, top pointed, reaching about middle of vein 8 ; this spot narrowly edged pale ochreous. Cilia (imperfect) sordid pale ochreous, with a fuscous subbasal band. 
Hindwing fuscous bronze, cilia concolorous, with a pale ochreous basal line.

Female genitalia: Sterigma much extended and corrugated, evenly covered throughout with numerous dense and short hairs. Posterior edge with a $V$-shaped excision beset with a row of bristles. Ostium small, cup-shaped. Signa absent.

Material examined: Luzon, Rizal, Montalban, 4.I.1914 (A.E. Wileman), 1 o, holotype, genit. slide 5530.

Allied to B. ephippias (Meyrick), new combination, but larger, brighter colored, with quite distinct genitalia.

\section{Bubonoxena ephippias (Meyrick, 1907), new combination \\ Figures 81, 99, 801-802}

Chrosis ephippias Meyrick, 1907, Journ. Bombay Nat. Hist. Soc., vol. 17, p. 731

( ơ $\$$ Ceylon, India).-Diakonoff, 1954, Zool. Verh., no. 22, p. 57 (no Lo-

besia).-Clarke, 1955, Catalogue . . Microlepidoptera . . Mey rick, vol.

1, p. 128.

Polychrosis ephippias.-Meyrick, 1909, Journ. Bombay Nat. Hist. Soc., vol. 19,

p. 587 ; 1918, Ann. Transvaal Mus., vol. 6, p. 11; 1923, Trans. Roy. Ent.

Soc. London, p. 547.-Fletcher, 1932, Imp. Counc. Agric. Res., Sci. Mon., no. 2 , p. 26 , pl. 17 , figs. a-d (life hist., stages, India).

Distribution: India, Ceylon, Tonkin, Java, Philippine Is. (occurrence not proven), Natal, Rodriges Is.

Very probably more than one species is involved.

Using this opportunity the lectotype of "Chrosis" ephippias Meyrick, 1907, is selected herewith, a male syntype specimen, labelled as follows: "Puttalam, Ceylon, Pole, 10.04" (small printed label), "Polychrosis ephippias Meyr., 22/4, E. Meyrick det., in Meyrick Coll.," "Meyrick Coll., B.M. 1938-290," genit. slide 5687. A syntype female specimen studied, with similar labels, but number " $22 / 5$," has the genit. slide 5688 .

\section{Tetramoera, new genus}

Head with roughly appressed scales, parted on vertex, tufts on crown appressed and broadly spreading. Ocellus posterior. Proboscis very short. Antenna in male slightly thickened, serrulate except along basal fifth, minutely pubescent. Palpus porrected, triangularly dilated, with a roughish upper edge of median segment and a projecting small tuft at apex below, terminal segment moderate, pointed, more or less concealed. Thorax smooth. Posterior tibia with bristly scales projecting beyond its apex.

Forewing elongate; markings usually numerous longitudinal lines. Vein 2 from 3/4, 4 separate, closer to 3 than to 5, 7 free, to termen, 9 separate, 10 from before $2 / 3$ distance between 11 and 10, 11 from before middle, parting veins complete, lower of these from close to 
base, to just above base of 4 , upper parting vein from beyond middle distance 10-11, to above middle distance 6-7.

Hindwing with 2 from $2 / 3,3$ and 4 connate, 5 moderately approximated, 6 and 7 approximated toward base but well separated.

Male genitalia: Tegumen slender and elongate. Uncus bandlike, curved, crowned with two long, divergent pencils of hairs. Vinculum depressed. Valva deeply cleft into an oval and hairy sacculus and a more or less hooked and ventrolaterally dilated, rather rigid cucullus. Aedeagus large, gradually attenuated. Cornutus, a long spine. Female genitalia: Sterigma little modified, lamella antevaginalis being a slender crescentic sclerite; lamella postvaginalis a weak and broad transverse band, rounded at the sides and broadly excised in middle of lower edge. Colliculum absent. Ductus bursae rather long, gradually dilated. Corpus bursae ovoid, with a finely punctulate wall. Signum single, an oval, colored sclerite with well-defined edges, a central small hollow spine.

Type species: Grapholitha schistaceana Snellen, 1890.

A peculiar small genus; the bifid valva and the long-tufted uncus are characteristic, as well as the markings of the forewings. Excepting the type species, Cydia isogramma Meyrick, 1908 (Ceylon and South Africa) belongs to this genus.

\section{Tetramoera schistaceana (Snellen, 1890), new combination}

Figures 87-90, 97-98, 541

Grapholitha schistaceana Snellen, 1890, Meded. Proefstat. suikerriet West Java, Kagok-Tegal, p. 95, pl. 2, figs. 5-7 (Schönfeld, Dresden); 1890, op. cit., pp. 76, 85, pl. 3, fig. 2 (Nijhoff, The Hague); 1891, Tijdschr. Ent., vol. 34, p. 353 , pl. 17, figs. 5 (larva), 6 (pupa), 7 ( $\left.\sigma^{7}\right)$.-Van Deventer, 1912, Dierl. Vijanden Suikerriet, 2nd ed., p. 142, pl. 21, figs. 1-14 (biology).-Dammerman, 1919, Landbouwdierk. Oost-Indië, p. 57, pl. 7, fig. 2.

Argyroploce schistaceana.-Meyrick, 1930, Trans. Roy. Ent. Soc. London, vol. 78 , p. 312 (Mauritius).

Distribution: Java; Malaya; Mauritius; Réunion; Madagascar; Hawaii, Micronesia; Kwantung; Loochoo Is.

Food plant: Sugar cane.

Material examined: Luzon, Los Baños, 12 and 16.XI.1920, 3 \%, genit. slide 5370-5372 (D.I. Aquino). Same locality, 4.I.1928 (F.N. Fernandez), 1 ○'. Canlubang, 11-23.II.1928, 27.XI.1927 (L.B. Uichanco), $1 \sigma^{7}, 5$ 우 (USNM). Mindanao, Davao Prov., east slope of Mt. McKinley, $3000 \mathrm{ft}$., at light, 13.IX.1946 (CNHM Philippine Exped. 1946-47, Axonvero), 1 \%, genit. slide 5743.

References to this species are scattered through the applied entomological literature. It is a notorious pest, a borer of the young shoots of sugar cane plants (Saccharum dulce). 
This opportunity is used for the selection of a lectotype. This is a male, labelled as follows: "Java, Tegal, o [sic], Lucassen" "Lucassen, Kemanglen, Tegal, Java, 9.1888, Boorder, Pl. II Fig. 7, o $^{7}$ " (a handwritten green label, referring to the original figure of 1890). "Museum Leiden. schistaceana. Det. Snell."

\section{Argyroptocha, new genus}

Head with dense, appressed scales forming a short roughish crest on forehead, face smooth. Ocellus posterior. Proboscis developed. Antenna pubescent in male. Palpus moderate, porrected, slightly curved upward, median segment rough below and along apex, gradually dilated apicad, terminal segment very short, concealed. Thorax without a creast (hindtibia missing).

Forewing elongate, subtruncate, termen sinuate. Vein 2 from $2 / 3$, 3 and 4 connate from angle, 5 approximated, 6 and 7 closely approximated toward base.

Male genitalia. Tegumen large and high. Uncus quadrate, broad, not clearly separated, densely haired on top. Socius probably represented by a row of bristles on each side. Gnathos indefinite. Valva slender, moderately sclerotized throughout; sacculus $1 / 2$, ending in a triangular patch of bristles. Cucullus hairy, narrowed, curved inwards, top bifurcate, upper hook with a short tooth. Anellus, a long and strong band. Aedeagus straight and broad, rather weak. Cornuti, a sheaf of thin spines.

Type species: Argyroptocha phalaenopa, new species $\left(\sigma^{\top}\right)$.

A curious genus with a general Olethreutes appearance, but nearest to the preceding; with peculiar genitalia, somewhat approaching the Laspeyresiine type. In spite of considerable differences in neuration it might be allied to Helictophanes Meyrick or Cyphophanes Meyrick, two genera which have not been sufficiently investigated so far: only a single specimen of both has ever been described, from south India and Java, respectively. The male genitalia of these three genera present marked conformity of shape and structure; the high tegumen, contrasting with the narrow valva and especially articulation of the latter, beside giving proof of far advanced specialization, also suggest a relation with the tribe Laspeyresiini. The widely diverse superficial appearance of the species may point towards considerable antiquity of the fascinating group.

\section{Argyroptocha phalaenopa, new species}

Figures 91-93, 542

Male, $19 \mathrm{~mm}$. Head and thorax light ochreous olive, thorax with a pale spot in center. Palpus light ochreous olive, median segment 
with a blackish dot at base laterally and on middle of upper edge, its posterior lower part suffused with grey, terminal segment grey. Abdomen fuscous.

Forewing elongate-subtruncate, costa gently curved, more so toward extremities, apex rectangular, termen sinuate, vertical, rather prominent below. Light ochreous olive, partly streaked with brownish, irrorated with dark krown. Costa with numerous oblique dark brown strigulae, along its anterior half single and more distant; along posterior half of costa these marks becoming double, approximated and thickened, longer and less oblique; each pair is separated by a white streak; ultimate pair united into a single vertical wedge-shaped streak, top dilated, in apex, lower part slender, submarginal, edged posteriorly by a silvery-white line; the pair of marks on middle of costa giving rise to a long, very oblique white line, slightly curved and running into upper fourth of termen, posteriorly mixed with a few shining silvery scales, this streak surrounded on both sides by a greyish-tawny suffusion; below end of this streak on termination of vein 5, a small wedge-shaped black spot, with a truncate top and point running along terminal edge; a broad horizontal streak or rather series of sparse and irregular dark brown spots and points, running from base to termen and just above middle of disc, extending over one fourth of its breadth; a faint darker transverse blotch on end of cell; some more small spots and dots scattered along and above dorsum; a moderate semioval dark brown spot on $1 / 3$ of termen; ocellus well defined, centered with a black round dot with a small strigula above, one below it, both edges rather thick, shining leaden, curved, posterior thicker. Cilia whitish ochreous, opposite ocellus suffused with slate grey.

Hindwing fuscous grey, semipellucent, veins darker brownish fuscous. Cilia pale grey, with a whitish-ochreous basal line and a fuscous-brownish subbasal suffused band.

Male genitalia, as described for the genus.

Material examined: Luzon, Mr. Makiling (Baker), $1 \sigma^{7}$, holotype, genit. slide 5019 (USNM). Also $1 \sigma^{\top}$, paratype, from West Sumatra Fort de Kock, 920 m, V.1921 (E. Jacobson, LM).

\section{Gnathmocerodes, new genus}

Head with roughly appressed scales, tufts on vertex broadly spreading, face roughish. Ocellus posterior. Antenna slightly thickened, rather short, serrulate, pubescent in male. Proboscis weak. Palpus rather short and moderately broad, sinuate, subporrect. Thorax with a double posterior crest. Hindtibia normal. Abdomen normal.

Forewing elongate-subtruncate, moderately broad. Vein 2 from beyond $2 / 3,3$ from angle, $3-5$ remote, 4 closer to 3,7 to termen, 8 
and 9 closely approximated toward base, 10 closer to 11, 11 from middle of cell. Upper parting vein from before base of 10 to below base of 8 , close to upper angle of cell, lower parting vein from halfway between base of wing and base of 11 to just below base of 5 . Hindwing with vein 2 from beyond $2 / 3$ of cell, 3 and 4 short-stalked from angle, 5 closely approximated at base, 6 and 7 closely approximated toward base.

Male genitalia: Tegumen rather high, slender. Uncus peaked, hairy, membranous. Gnathos (or subscaphium) well developed and strong, arms sclerotized, forming a pending semicircle, hook porrect, strong, ending in two diverging and long horns. Valva rather narrow, with a very deep primary incision, sacculus triangular, cucullus ovate, on a narrow stalk, a projection with modified spines at its base. Anellus strongly extended, forming a concave plate covering the entire aedeagus from above. The gender of the generic name is feminine.

Type species: Gnathmocerodes petrifraga, new species.

A small and very natural group of species, characterized by the unique forked gnathos or subscaphium and the constricted unequal valvae. The type species and the following two belong here:

Argyroploce lecithocera Meyrick, 1937, Exotic Microlepidoptera, vol.

5, p. 60 (=A. lecythophora Meyrick, 1939, Trans. Roy. Ent. Soc.

London, vol. 89, p. 49), from Java.

Argyroploce tonsoria Meyrick, 1909, Journ. Bombay Nat. Hist. Soc., vol. 19, p. 592.

\section{Gnathmocerodes petrifraga, new species}

Figures 76, 116, 543

Male, 13-15 mm (type $13 \mathrm{~mm}$ ). Head and thorax ochreous grey, mixed with darker grey, thorax irrorated with dark fuscous. Palpus grey suffused and mixed with darker grey, tip of terminal segment whitish. Abdomen fuscous.

Forewing elongate-subtruncate, dilated, moderately broad, costa gently curved throughout, apex obtuse, termen gently curved, convex, little oblique. Pale grey, suffused with fuscous, whitish and fuscous black. Basal patch large, almost $1 / 3$, grey, centered with paler scales, edge angulate, with a deep oblique excision at $1 / 4$; upper half of space between basal patch and transverse fascia almost white, finely parted by a black line from a dark dot on costa; transverse fascia well defined, angulate above middle of wing, not reaching dorsum, lower extremity gradually rounded with deep oblique excision in posterior edge just above angulation; this fascia narrow above, twice as broad below, olive grey, finely edged with blackish, lower part of excision filled out with white; posterior half of costa 
with four grey marks, alternating with minute strigulae, exterior two marks small, interior larger, triangular; space beyond upper half of transverse fascia as far as third costal mark filled with dark slate grey, forming a triangular patch; this patch and lower part of transverse fascia bordered posteriorly by a conspicuous inwards-oblique fascia of whitish ground color from costa before apex to $3 / 4$ of dorsum, parted above by an olive fasciate mark, below by a grey line; terminal area beyond this pale fascia separated in two parts by a triangular blackish spot just above middle of wing, with erected angles, posterior angle resting on middle of termen, continued downward as a short marginal streak, base of triangle horizontal; apex above triangle dark grey; tornal area below triangle pale grey posteriorly, pale olive anteriorly; a small dark transverse strigula in apex, continued downward so as to form a suffused terminal fascia to tornus. Cilia dark grey with a whitish basal line and a black subbasal band.

Hindwing dark fuscous, darker toward margin, paler toward base and dorsum. Cilia whitish grey, with an ochreous-whitish basal line and a darker grey subbasal band, cilia opposite apex suffused with dark grey.

Male genitalia: Very similar to those of $G$. lecithocera Meyrick, but with left valva only slightly asymmetrical, both sacculus and cucullus being a trifle broader left than right; the knob with black spines at the bottom of the primary incision is larger than in lecithocera; $\mathrm{Spc}_{1}$ right is rather short and small, left it is double: a pencil of long hairlike bristles, and above it a large patch of shorter ones. Uncus, gnathos, aedeagus and anellus are very much the same, and striking, as in that species.

Material examined: Luzon, Mt. Apo 70, 7.III.1945 (J.G. Franclemont), $1 \sigma^{\top}$, holotype, genit. slide 5097 (CUI). India, Bengal, Calcutta, 1858 (Atkinson, Fernald collection), $1 \sigma^{\top}$, paratype (USNM).

\section{Peridaedala Meyrick, 1925}

Peridaedala Meyrick, 1925, Exotic Microlepidoptera, vol. 3, p. 139.-Diakonoff, 1941, Treubia, vol. 18 , p. $186 ; 1953$, Verh. Ned. Akad. Wet., Nat. ser. 2, vol. 49 , no. 3 , pp. 88,$114 ; 1955$, op. cit., vol. 50 , no. 3 , p. $172 ; 1966$, Zool. Verh., no. 85 , p. 32 .

Type species: Peridaedala hierograpta Meyrick, 1925 (New Guinea).

The genus represents a natural group; the species can easily be recognized. Until recently, it was known only from New Guinea where five species occur. Now there is also a species from Assam and another from Java which have been attributed to Peridaedala.

It is of considerable interest that a series of six closely allied species appear to inhabit the Philippine Islands. I regard these species as 
the most pronounced Papuan element in the present collection-and with it, in the microlepidopterous fauna of the Philippines.

\section{Key to the Philippine Species of Peridaedala}

1. Forewing with ground color ochreous orange. . . P. crocoptila, new species Forewing with ground color green . . . . . . . . . . . . . . 2

2. Forewing with black markings . . . . . . . . . . . . . . . . . . . 3 Forewing with not only black markings . . . . . . . . . . . . . . . 4

3. Forewing with numerous rounded spots . . . P. melanantha, new species Forewing with several partly furcate short and narrow strigulae.

P. stenoglypha, new species

4. A small species $(13 \mathrm{~mm})$, with a narrow pale green forewing and a thickened costal fold reaching to beyond middle . . . . P. physoptila, new species Larger species (19-21 mm) with a moderately broad, deeper green forewing.

5. Forewing with an almost vertical clavate subapical costal spot.

P. dendrochlora, new species

Forewing with this spot fasciate, inwards-oblique.

P. thylacophora, new species

\section{Peridaedala dendrochlora, new species}

Figures $86,544-545$

Male, 19-21 mm. Head whitish green. Antenna tawny, finely ringed with pale ochreous, base of flagellum with a moderate notch, suffused with blackish, scape whitish. Palpus whitish, median segment touched with orange, with a jet-black elongate, wedge-shaped longitudinal mark towards middle of upper edge, basal segment with black tip; palpus long, porrected, apical segment slender, obtuse, slightly drooping, long. Thorax whitish green, mixed with light olive green, center whitish, apex deep ochreous tawny. Abdomen pale slate grey, towards base becoming touched with ochreous, pencils of long blackish hair-scales along sides, directed caudad.

Forewing elongate-subtruncate, dilated, costa with a moderately broad, thickened fold to $1 / 2$, moderately curved along this fold, less curved posteriorly, apex pointed, termen sinuate, concave above, abruptly rounded beneath. Pale moss green, markings well defined, blackish brown, on the inside narrowly edged with black, on the outside broadly edged with glossy greenish white. Costal fold unmarked, tawny, becoming darker at base, along extreme costal edge black; dark markings shaped as follows: a small vertical lozenge beyond base, a vertical pair of larger semioval spots beyond $1 / 4$; a crescentic mark from $3 / 5$ of costa, lower portion dilated and semioval, directed basad and filling out upper part of posterior third of cell, a long wedge-shaped process below costa posteriorly; a smaller crescentic spot below preceding, parallel to cell; a round spot beyond end of cell; a dot below end of fold, three equidistant marks on posterior fourth 
of costa, first of these small, second continued as a strong, inwardsoblique, slightly curved transverse fascia to $3 / 4$ of dorsum, broadly interrupted below middle, so as to form a semioval isolated spot on dorsum; third costal spot apical; some blackish suffusion before termen; a black narrow line along lower fourth of termen and in tornus; some faint ferruginous suffusion along base of dorsum; a couple of black dots on middle of dorsum. Cilia whitish green, in apex white.

Hindwing dark grey, cilia pale fuscous greyish, glossy.

Female, $20 \mathrm{~mm}$. Markings similar to those in the male, but instead of a costal fold there is a small spot on costa beyond base and a larger outwards-oblique spot on $1 / 4$. Palpus light green, median segment with a transverse sparse brownish dusting.

Male genitalia: Uncus broadly truncate, with membranous lateral flaps. Socius, a large, inwards-curved arm. Gnathos, a sclerotized, erected-trapezoidal plate, constricted below top, lower edge with a split in the middle and small emarginations at the sides. Valva strongly narrowed in middle, cucullus sinuate, slender; sacculus with a small median prominent process.

Female genitalia: Genital ventrite sclerotized. Sterigma formed by a median suboval aciculate mold, surrounded by a furrow, being the ostium bursae. Colliculum, an irregular sclerite with longitudinal folds, occupying almost the entire ductus bursae, which is short. Signa rather small unequal straight thorns with moderate basal plates.

Material examined: Luzon, Benguet Subprov., Haights Place, Pauai, 3.XII.1912, $1 \sigma^{\top}$, holotype, genit. slide 5531; $3 \sigma^{\top}$, paratypes, 15, 16 and 17.XI.1912; 1 \%, allotype, 14.XI.1912, genit. slide 5527; 2 o, paratypes, 7.XI and 1.XII.1912 (the last, without abdomen). $4 \sigma^{7}, 3$ ㅇ (BM). Allied with $P$. hierograpta (Meyrick) from New Guinea.

\section{Peridaedala physoptila, new species}

Figures 113, 803

Male, $13 \mathrm{~mm}$. Head greenish white, forehead with a suffused dark grey transverse band, sides of crown mixed with black. Antenna dark fuscous grey, scape greenish white mixed with black. Palpus rather short and slender, white touched with greenish, slightly mixed with black. Thorax whitish. Abdomen glossy whitish olive, anal tuft light olive.

Forewing elongate, rather narrow, costal fold moderately broad, but strongly blown up and bladder-like, reaching well beyond middle of costa; apex pointed and produced, termen sinuate. Pale green, markings dark fuscous. Costal fold dark fuscous, strewn with paler fuscous; this fold edged below with a moderate stripe, ending in a 237-168-67-6 
large regularly circular patch in center of wing reaching to vein $1 \mathrm{~b}$; costa beyond fold with three pairs of rather widely spaced white marks, posterior pair triangular; about apical fifth of wing filled out with dark fuscous, this color narrowly connected with central spot in middle of wing breadth, and emitting from base of this connection an inwards-oblique and slightly curved fascia to $3 / 4$ of dorsum; termen with a darker fuscous line. Cilia pale green (partly rubbed).

Hindwing normal; pale fuscous. Cilia whitish, glossy.

Male genitalia: Tegumen slightly constricted above middle. Uncus short and broad, top appearing concave, bent forward, lobes slender. Socius slightly sclerotized, pending, curved, slender. Gnathos darkly sclerotized, shaped as neck of a bottle. Valva rather narrow; knob at top of sacculus thick and obtuse; cucullus moderate, oval, lower half with short spines.

Material examined: Mindanao, Davao Prov., near summit of Mt. Apo, 7000 ft., at light (CNHM Philippine Zool. Exped., Alcasid leg.), $1 \sigma^{7}$, holotype, genit. slide 5727.

Closely related with $P$. hierograpta Meyrick, from New Guinea.

\section{Peridaedala thylacophora, new species}

Figures 136, 546

Male, $19 \mathrm{~mm}$. Head light ochreous strewn with tawny; forehead with dense slightly raised scales, vertex with rising side tufts enclosing a median cavity. Antenna slightly thickened; ochreous, scape and base of flagellum strewn with brown (palpi missing). Abdomen dark, fuscous olive grey, at base light olive above, anal tufts blackish, complicated.

Forewing elongate-subtriangular, dilated, broadest before termen; costa with a narrow, thickened fold to $1 / 2$, rather curved throughout, apex rounded-rectangular, termen hardly rounded, straight in middle, little oblique. Glossy light grey, suffused with dull fuscous, except edges to markings. Costal fold dark grey, transversely dusted with whitish grey; an olive-green suffused patch occupying about the middle third of costal half of wing, marbled in center with darker olive (lower half of disc anteriorly strongly denuded); costa beyond fold with two fuscous subquadrate spots; an inwards-oblique, slightly inwards-concave transverse band from costa before apex to $3 / 4$ of dorsum, fuscous, edges narrowly dark fuscous and strongly undulate; this band interrupted below middle, its lower part slightly broader and darker brown; a semioval erect spot in apex; remains of an irregular brown patch in center of disc; a semioval brown spot on $2 / 3$ of dorsum; traces of black suffusion on base of wing below base of fold; a narrow dark brown line along termen, dilated on veins, almost 
or entirely interrupted between veins. Cilia pale greenish olive, partly infuscated, tips slightly mixed with brown.

Hindwing modified, venation reduced, cell open, termen incised on vein 5, dorsum curved downward and forming scent pouches. Pale ochreous orange, edge with a broad continuous band of blackish suffusion, upper edge of cell and veins 7 and 8 darker. Cilia pale ochreous orange with white tips, a paler basal line and a dark suffused subbasal band.

Male genitalia: Tegumen elongate, strong. Uncus bipartite, flattened above and bent forward. Socius large, with sclerotized upper edge. Gnathos darkly sclerotized, with a median split, crowned with two oval lobes. Valva rather slender, sacculus knob moderate, cucullus elongate-oval, oblique, lower angle with short spines.

A single specimen with rubbed dorsum. The genitalia show a close relationship with Peridaedala crastidochroa Diakonoff, from New Guinea.

Female, $18 \mathrm{~mm}$. Similar to the male, but deeper colored, with markings darker, confluent in center of disc and suffused with brown along median third of wing. Palpus with median segment about the half of that in $P$. dendrochlora.

Unfortunately both specimens lack the abdomen and one hindwing also; therefore it is not possible to describe the female genitalia.

Material examined: Mindanao, Davao Prov., east slope of Mt. McKinley, 17.IX.1946 (CNHM Philippine Zool. Exped. 1946-47, H. Hoogstraal), $1 \sigma^{7}$, holotype, genit. slide 5729. Luzon, Benguet Subprov., Haights Place, Pauai, 7000 ft., 7.XI. 1912, 1 ? , allotype; 12.XI.1912, 1 o, paratype.

\section{Peridaedala melanantha, new species}

Figures 124-125, 547

Female, $30 \mathrm{~mm}$. Head and scape of antenna pale whitish green, face greenish white. Flagellum of antenna fuscous. Palpus long, sinuate-porrected, pale whitish green, basal segment, and basal half of median except below, black. Thorax bright greenish yellow, narrow edges to markings pale whitish green; a large black spot on shoulder; anterior half of thorax black with a narrow greenish white median line, collar mixed with black. Abdomen fuscous grey, with a faint bronze gloss.

Forewing oblong subtriangular, dilated, broadest before angle; costa moderately curved, more so before apex, apex subrectangular, obtuse, termen gently convex, little oblique. Bright greenish yellow, dull, narrow edges to markings pale whitish green, glossy; markings velvety black, well defined. An irregular trapezoidal spot on base of costa, followed by six costal spots; two anterior of these subclavate, 
(in paratype subquadrate), third semicircular, just beyond middle; three posterior spots smaller, irregularly rounded; an erected-rectangular spot in apex and along upper part of termen, leaving a very narrow mark in its middle on wing edge; a longitudinal series of five spots above middle of disc, first small, at $1 / 4$, second large, subquadrate, in cell; third oblique, in end of cell, extending over upper angle, constricted above middle; fourth large, subtriangular, beyond cell; fifth smaller, rounded, halfway between preceding and apical spot; a second longitudinal series of four spots below cell, first beyond base, all rounded, except posterior which is largest, irregularly triangular and obliquely transverse, above dorsum before tornus; a small dot above and beyond preceding; a series of three spots along anterior half of dorsum, first of these elongate, submarginal, from base, other rounded; an elongate spot along termen below middle, a small round terminal dot above this, a larger round dot in tornus. Cilia pale yellowish green, a small black bar above apex.

Hindwing greyish fuscous with a faint bronze gloss. Cilia concolorous, with a pale basal and a darker subbasal line.

Female genitalia: Sterigma formed by a broadly emarginate posterior edge of the seventh sternite, containing a weak subtriangular sclerite with wrinkled lower edges with rows of small bristles, and a round central prominence, being an aciculate lamella postvaginalis. Apophyses slender and rather short, darkly sclerotized, anapophyses abruptly dilated into subquadrate basal plates. Ductus bursae sclerotized, forming a tubular cestum. Signa, two small thorns on globular bases.

Material examined: Mindanao, Davao Prov., east slope of Mt. McKinley, $7000 \mathrm{ft}$., mossy stunted forest, at light, 19.IX.1946 (CNHM Philippine Zool. Exped. 1946-47, H. Hoogstraal and D. Heyneman). 1 ㅇ, holotype, genit. slide 5725; 1 ㅇ, paratype (CNHM).

An elegant, very large, and distinct species.

\section{Peridaedala stenoglypha, new species}

Figures 119-120, 548

Female, $22 \mathrm{~mm}$. Head pale milky green, orbits more or less black. antenna blackish, scape pale green. Palpus pale milky green, basal segment and basal half of median segment black. Thorax pale milky green, shoulder with a black spot. Abdomen pale ochreous.

Forewing oblong-suboval, dilated, costa gently curved, apex obtuse, termen gently concave above, rounded below, moderately oblique. Pale milky green, markings black, narrowly edged with whitish. Costal edge between markings narrowly white; a pair of moderate transverse marks on base of costa, interconnected below costa by a subcostal streak; six rather slender, triangular or wedge-shaped 
transverse marks along costa, first and third of these largest, slightly oblique, posterior three more slender and vertical; anterior three spots preceded by, alternating with, and followed by, black marginal dots; a small triangular mark on middle of dorsum and two irregular transverse markings on both sides of this, reaching to or above fold; first of these straight, dilated at extremities, second angulate, narrowly connected with a semioval spot in disc; third mark calyciform, with an almost circular irregular and slender discal mark above and beyond it; fourth mark inverted $Y$-shaped; an anteriorly angulate, transverse subterminal line from angle to above tornus, with a small triangular dilatation above its middle. Cilia pale milky green.

Hindwing light purplish grey with a slight silky gloss, cilia concolorous.

Female genitalia: Sterigma hardly sclerotized. Lamella antevaginalis shaped as a shallow cup, lamella postraginalis strongly aciculate. Colliculum narrow and weak. Cestum cylindrical, rather wider, lower half with a sclerotized split, lower halves pointed. Signa absent.

Material examined: Luzon, Benguet Subprov., Haights Place, Pauai, 7000 ft., 26.VII.1912 (A.E. Wileman), 1 o, holotype, genit. slide 5755 (Rothschild bequest, BM). An elegant species, except for distinct coloring and markings, characteristic by the absence of signa.

\section{Peridaedala crocoptila, new species}

Figures 110, 549

Female, $20 \mathrm{~mm}$. Head light tawny orange, face whitish. Palpus pale tawny orange, basal segment mixed with purplish, median segment with an oblique median transverse band extending over a tuft on lower edge and apex purplish fuscous; terminal segment very small, slender. Thorax pale ochreous tawny, marbled with light tawny orange, more so anteriorly; a narrow black anterior edge and a minute median longitudinal line along anterior half; a black, irregular spot on each tegula. Abdomen ochreous olive suffused with black, anal tuft pale ochreous above.

Forewing oblong, dilated, costa curved anteriorly, almost straight posteriorly, apex tolerably pointed, produced, termen rather deeply sinuate above, obliquely rounded beneath. Rather bright tawny ochreous, deeper colored posteriorly, markings well defined, blackish brown. A pair of small transverse marks on costa beyond base, continued to middle of wing, thence continued by a series of equidistant irregular transverse marks, which are arranged in a submedian horizontal series, to $2 / 5$ of disc; another pair of transverse marks on $1 / 4$ of costa, larger, more distant, posterior of these broader and 
obliquely continued across wing as a slightly sinuate transverse fascia, dilated in middle, attenuated to an acute point at end which is below fold well beyond middle of wing; an irregular central patch from middle of costa, oblique, to below cell before its lower angle; anterior edge concave, posterior with two posterior processes, one from middle, slender and acute, another from lower end, thicker; posterior half of costa with five pairs of short, white strigulae, first and second pairs approximated; ocellus formed by two rather short leaden-metallic vertical streaks, enclosing two points and a crescentic longitudinal mark in between, the latter interrupting posterior metallic streak below its middle; ocellus crowned by a circular large mark and preceded by a large triangular spot, its extended acute anterior point touching lower end of transverse fascia; these dark markings strewn with scales of ground color; a curved, outwards-concave line from apex to below middle of termen, with two transverse bars below; a streak along dorsum from base to middle, before end connected with markings in disc; followed by three dorsal dots. Cilia (damaged) tawny orange, a deeper subbasal band, a black bar in apex.

Hindwing glossy light fuscous grey purple, cilia concolorous.

Female genitalia: Ninth tergite sclerotized. Anal lobe broad and rounded, lower extremity forming a slender process. Lamella antevaginalis represented by a narrow sclerotized and $U$-shaped rim; lamella postvaginalis triangular, upper edge with an obtuse, aciculate prominence, lower edge with a point flanked by excavations. Colliculum and cestum sclerotized, with a median split and two points at lower end. Ductus bursae short. Signa two, almost similar, finely scobinate.

Material examined: Mindanao, Davao Prov., east slope of Mt. McKinley, 7000 ft., 22.IX.1946 (CNHM Philippine Zool. Exped. 1946-47, H. Hoogstraal), 1 \%, genit. slide 5730.

A distinct species, characteristic by the yellow-orange ground color and the produced apex of forewings.

\section{Costosa, new genus}

Head with loosely appressed scales, side tufts on vertex rather long, pressed together and forming a rising keel. Antenna hardly thickened, minutely ciliate in male. Palpus moderate, subascending, almost porrected, slender at base, median segment short, rather slender, dilated towards apex by short appressed scales, terminal segment short, rather slender, drooping. Thorax with a double posterior crest.

Forewing with cell abruptly narrowed towards base along basal half. Vein 2 from slightly beyond $3 / 4$ of cell, 3 from angle, approximated to 4, 7 separate, to termen, 11 from beyond middle, parting 
veins strong, upper halfway between 10 and 11 to base of 7 , lower from base, running close along upper edge of cell, thence strongly sinuate, to just below base of 5 .

Hindwing with a cubital pecten; 2 from before middle of lower edge of cell, 3 and 4 short-stalked, 5 closely approximated at base, 6 and 7 separate, closely approximated towards base.

Male genitalia peculiar, with a bipartite long and porrect uncus and a long hairy basal process of the costa of the valva, as described with the species.

Type species: Costosa allochroma, new species $\left(\sigma^{7}\right)$.

A specialized form of obscure affinity, apparently belonging to the tribe Olethreutini.

\section{Costosa allochroma, new species}

Figures 69, 114-115, 550

Male, $19 \mathrm{~mm}$. Head bright ochreous, face whitish, tufts on vertex pressed together to form a high keel, ochreous fulvous. Antenna ochreous tawny. Palpus ochreous orange. Thorax fuscous tawny, anteriorly suffused with ochreous, shoulder ochreous yellow, tegula whitish touched with pink with pale violet reflections, anteriorly suffused with ochreous; a posterior loose tuft whitish pink with pale violet reflections. Abdomen light greyish fuscous, anal tuft ochreous orange.

Forewing rather broad, truncate, costa considerably curved anteriorly, little curved before apex, apex rounded-rectangular, termen straight, little oblique, rounded beneath. A large, irregularly semicircular patch, occupying less than median half of costa and almost reaching middle of vein $1 \mathrm{~b}$; this patch pale violet pink, on posterior half becoming deeper pinkish purple and suffused with ferruginous; remainder of wing bright ochreous yellow along middle of disc, towards anterior part of dorsum gradually becoming olive grey, towards costa, except at base, reddish ferruginous; apical sixth forming a conspicuous well-defined ochreous whitish triangle, slightly suffused with ferruginous anteriorly; its lower edge well defined, straight, bordered below by reddish suffusion which extends downwards, along termen, halfway towards cell; terminal edge suffused with reddish purple, this color slightly dilated on veins, and forming two small dots: on ends of veins 6 and 7 , respectively, on the pale apical patch. Cilia greyish olive in tornus, purplish violet along lower half of termen, whitish along upper half.

Hindwing rather dark, glossy grey, becoming fuscous bronze on posterior half, $2 / 3$ of costa whitish grey. Cilia fuscous grey with a pale basal line and a darker grey subbasal fascia, cilia in apex whitish throughout. 
Male genitalia as described for the genus.

Material examined: Mindanao, Davao Prov., east slope of Mt. McKinley, 5600 ft., 16.IX.1946 (CNHM Philippine Zool. Exped. 1946-47, H. Hoogstraal), $1 \sigma^{\top}$, holotype, genit. slide 5733.

A peculiar, unusually colored insect with the facies of a Tortricine. The coloring reminds one of an Articolla species.

\section{Eucoenogenes Meyrick, 1939}

Coenogenes Meyrick, 1937 (not Coenogenes Walsingham, 1887), Exotic Microlepidoptera, vol. 5, p. 159 [preoccupied] (type species: Coenogenes melanancalis Meyrick, 1937, India).

Eucoenogenes Meyrick, 1939, Trans. Roy. Ent. Soc. London, vol. 89, p. 49 (emend.).-Clarke, 1958, Catalogue . . . Microlepidoptera . . . Meyrick, vol. 3, p. 344, pl. 171, figs. 1-1d (neuration, genit. $\$$, head).

Type species: Coenogenes melanancalis Meyrick, 1937 (India).

The identity of this genus is somewhat dubious. Clarke's illustrations of the type specimen show that the original description of the neuration is not correct: neither vein 8 in the forewing nor vein 5 in the hindwing are absent. The densely scaled, unusually looking palpi only remain for the characterization of the genus; and indeed they are very peculiar. There are, however, no males of the type species at hand to support the separation of the genus by peculiarities of the genitalia. The genitalia of the female are not very instructive, being but little modified.

The remarkable palpi may be redescribed as follows. Basal segment moderate, elongate and porrect. Median segment strongly dilated anteriorly, triangular, slightly ascending, with rather closely appressed scales along the whole edge, smoothly appressed along the upper edge, upper and lower angles rounded; terminal segment very small, entirely concealed, the whole palpus compressed laterally, but less compressed along its upper edge. Forehead with a dense, thickened, and appressed tuft, projecting in a slender, separate, and darkly colored pencil above middle of face.

On the strength of the remarkable palpi, I attribute the following species, represented by a single male specimen, to the present genus. I trust that the genital characters of the male of $C$. melanancalis, still to be discovered, will prove the correctness of this step.

\section{Eucoenogenes deltostoma, new species}

Figures 68, 102, 105, 551

Male, $11 \mathrm{~mm}$. Head fuscous olive, face white, except along edges, a small tuft above middle of face jet black. Antenna fuscous olive, scape moderate, flagellum slightly thickened, minutely ciliate. Palpus as described for the genus; fuscous olive, basal segment whitish 
except base, median segment suffused with white, except a lateral spot at base and at upper angle, lower angle blackish, a few orange scales along outer edge of median segment internally. Thorax with a slight posterior crest. Posterior tibia with closely appressed scales.

Forewing with a long and rather narrow costal fold, reaching beyond middle; costa slightly curved throughout, apex rounded and prominent, termen concave above, obliquely rounded beneath. Pale whitish olive, appearing ribbed by dark fuscous (dark fuscous scaples with pale bases), strongly marbled and transversely strigulated with dark fuscous, spaces between markings on posterior half of wing filled out with grey. Costa dark fuscous, towards base suffused with olive; a somewhat oblique quadrate spot of white irroration before middle of costa, extending across wing to upper edge of cell, five pairs of white strigulae along posterior $2 / 5$ of costa, each pair continued across wing by very oblique leaden-grey streaks, all converging in one point before apex of wing; anterior two pairs of white markings very small, the following two pairs moderate, the ultimate pair longest; apex of wing dark fuscous, lower half filled out with olive, dark fuscous marbling tending to form irregular transverse inwardsoblique lines; ocellus ill defined, oblique, transversely oval, pale leaden grey, cut by a slender, wedge-shaped dark fuscous mark, penetrating from termen; a distinct dark fuscous marginal line, cut below apex by a small white bar, extending over cilia. Cilia along upper $3 / 4$ of termen fuscous, becoming whitish olive along its lower fourth; a faint supramedian pale line, beyond this cilia dark fuscous.

Hindwing dark fuscous with a bronze gloss, ribbed (scales with light bases), becoming pale fuscous grey on basal half, veins dark fuscous throughout. Cilia brown fuscous with a darker subbasal line.

Male genitalia: Of Olethreutine type, in spite of a Eucosmine neuration! Tegumen rather high. Uncus slender, bicornute, points curved. Socius large, pending. Gnathos slender, sacculus 1/2, ending in a curved, porrect hook, top bristly. Cucullus with a strongly constricted base. $\mathrm{Spc}_{2}$, a patch of stiff bristles, $\mathrm{Spc}_{3}$, a bunch of long, curved bristles. Aedeagus moderate, caulis long, cornuti, a sheaf of spines.

Luzon, Mt. Makiling (Baker), 1 o $\sigma^{\top}$, holotype, genit. slide 5154 (USNM).

\section{Strepsicrates Meyrick, 1887}

Strepsicrates Meyrick, 1887, Trans. New Zealand Inst., vol. 20, p. 73 (type species: Sciaphila ejectana Walker, 1863, Australia); 1911, Proc. Linn. Soc. New South Wales, vol. 36, p. 227 (syn. of Spilonota Stephens).- 
Heinrich, 1923, U.S. Nat. Mus. Bull. 123, p. 31, figs. 3, 3a, 23, 306 (distinct; syn., Phthinolophus Dyar).-Fletcher, 1929, Mem. Dept. Agric. India, Ent. Ser., vol. 11, p. 211 (syn. of Spilonota Stephens).-Clarke, 1958, Catalogue ... Microlepidoptera . . Meyrick, vol. 3, p. 596 (distinct genus).

Strepsiceros Meyrick, 1881, Proc. Linn. Soc. New South Wales, vol. 6, p. 678 (type species: S. ejectana Walker, preoccupied); 1911, Proc. Linn. Soc. New South Wales, vol. 36, p. 227 (preoccupied and syn. of Spilonota Stephens).-Fletcher, 1929, Mem. Dept. Agric. India, Ent. ser., vol. 11, p. 211. Phthinolophus Dyar, 1903, Proc. Ent. Soc. Washington, vol. 5, p. 307 (type species: $P$. indentanus Dyar, 1903, N. America).-Heinrich, 1923, U.S. Nat. Mus. Bull. 123, p. 31 (syn. of Strepsicrates).-Fletcher, 1929, Mem. Dept. Agric. India, Ent. ser., vol. 11, p. 175.

\section{Key to the Philippine Species of Strepsicrates}

1. Forewing whitish, densely strewn with dark grey; a conspicuous, $\Gamma$-shaped black transverse mark well before tornus . . . S. discobola, new species Forewing dark fuscous . . . . . . . . . . . . . . . . . . 2

2. Forewing with costal fold reaching to middle of costa . . . . . S. ejectana Forewing with costal fold reaching well beyond middle of costa.

S. inobtrusa, new species

\section{Strepsicrates ejectana (Walker, 1863)}

\section{Figures 75, 552}

Sciaphila ejectana Walker, 1863, List Lepidopterous Insects British Mus., pt. 28, p. 350 ( $\sigma^{\top}$, Sydney).

Strepsiceros ejectana.-Meyrick, 1881, Proc. Linn. Soc. New South Wales, vol. 6, p. 681 (synonyms: servilisana, saxana, ligniferana; food plants). Strepsicrates ejectana.-Meyrick, 1887, Trans. New Zealand Inst., vol. 20, p. 73. Spilonota ejectana.-Meyrick, 1911, Proc. Linn. Soc. New South Wales, vol. 36 , p. 299.

Sciaphila servilisana Walker, 1863, List Lepidopterous Insects British Mus., pt. 28, p. 356 ( $\sigma^{\top}$, New Zealand).

Sciaphila saxana Walker, 1863, op. cit., pt. 28, p. 357 ( $\uparrow$, New Zealand).

Conchylis ligniferana Walker, 1863, op. cit., pt. 28, p. 363 ( $\sigma^{\top}$, Sydney).

Spilonota holotephras Meyrick, 1925, Exotic Microlepidoptera, vol. 3, p. 67 ( б Fiji) [new synonym].-Clarke, 1955, Catalogue ... Microlepidoptera . . . Meyrick, vol. 1, p. 161.

Strepiscrates holotephras.-Clarke, 1958, Catalogue . . Microlepidoptera . . . Meyrick, vol. 3, p. 596, pl. 292, figs. 1-1a (type illustr., syn.: eumarodes). Eucosma eumarodes Meyrick, 1925, Exotic Microlepidoptera, vol. 3, p. 68 ( $\sigma^{\top} \%$, Fiji).-Clarke, 1955, Catalogue ... Microlepidoptera ... Meyrick, vol. 1, p. 134 ; 1958, loc. cit., vol. 3 , p. 596 , pl. 292 , figs. $2-2$ b (type illustr.; syn.: holotephras).

Distribution: Australia, Tasmania, New Zealand, Fiji.

Food plants: Kunzea capitata, Darwinia fasciculata, Leptospermum ericoides, Psidium guajava (all Myrtaceae).

Material examined: Occidental Negros, Victorias, 12.V.1961, on guava (Psidium guajava) "LL 220," 1 " genit. slide 10, 19 Sept. '30, empty pupa; “gen. slide, female, no. 9, 19 Sept. '30," “W.D. Pierce 
leg.," "moth not kept." Luzon, Mt. Makiling (Baker), 1 o $\sigma^{7}$, genit. slide 5080. (USNM).

\section{Strepsicrates inobtrusa, new species}

Figures 84, 553

Male, $16 \mathrm{~mm}$. (Head damaged.) Palpus dark grey with whitish base (median segment with a suprabasal and a subapical white transverse streak). Thorax dark fuscous (partly denuded). Abdomen dark grey.

Forewing oblong, dilated, broadest at $3 / 4$, with a large flat costal fold to beyond $1 / 2$, costa tolerably straight, apex obtusely pointed, termen straight, oblique. Rather dark fuscous. Costal fold strongly marbled and dusted with leaden grey; ill-defined series of 4 or 5 suffused dark grey spots along costa posteriorly; an ill-defined longitudinal dark grey streak in center of disc below fold extending over base of dorsum (cilia rubbed).

Hindwing fuscous with a bronze gloss, semipellucent, veins darker.

Male genitalia: Uncus halves forming at each side a moderate, pointed, and hairy process-but less long-pointed than in Strepsicrates ejectana. Socius, a nob at the base of each arm of uncus. Gnathos indefinite. Transtilla present, straight, sclerotized. Valva more slender than in S. ejectana, more constricted, apex with cucullus almost similar, external point somewhat longer. Aedeagus with juxta, anellus, and caulis all strongly sclerotized.

Material examined: "Philippine Is., Acc.C.M.6151", 1 o , holotype, genit. slide 5704. In the single specimen available the dorsum of the forewings is strongly denuded. The genitalia, however, are distinct.

\section{Strepsicrates discobola, new species}

Figures 85, 554

Male, $22 \mathrm{~mm}$. Head black slightly mixed with white, more so along orbits. Antenna somewhat thickened and compressed, grey, narrowly ringed with whitish. Palpus ferruginous black, more or less strewn with white. Thorax black mixed with white, anterior half with a large white patch, anterior half of tegula ferruginous. Abdomen dark grey, anal tuft blackish.

Forewing oblong, moderate, costa gently and irregularly curved, apex obtusely pointed, termen gently convex, almost straight, little oblique. Pale ochreous, densely strewn with black and ferruginous, less obscured along dorsal third of wing. A transverse constricted black blotch just before middle of costa, preceded by six almost equal and equidistant transverse streaks; posterior half of costa less obscured, with four subquadrate and suffused ferruginous-blackish 
spots, posterior of these apical and fasciate; a large black blotch along lower edge of cell from well beyond base to middle, edged below by a large, strongly raised and expanded tuft of black and white scales; another such blotch, shorter, in lower angle of cell; an undulate black fascia along closing vein, with several slender branches in cell, upper half of fascia much dilated; a longitudinal grey suffused blotch from lower angle of cell almost to termen; a well-defined black transverse blotch parallel to termen, on $3 / 4$ of dorsum, its posterior edge with a strong semioval excision from below top almost to base; top of this mark connected by grey suffusion with apical patch; terminal edge irregularly white except below middle, dorsum paler, with four transverse wedge-shaped light tawny marks and a blackish suffused basal spot. Cilia grey mixed with white, tips white, basal third unicolorous dark grey, three slender dark grey bars opposite middle of termen, extending from base to top of cilia.

Hindwing dark purplish fuscous, darker towards apex, cilia paler, with a light basal line and a darker subbasal band.

Male genitalia: Uncus halves moderate, attenuated, tips acutely produced and slightly sinuated. Gnathos traceable, slightly sclerotized, triangular. Valva narrower at base than in $S$. ejectana but less constricted; cucullus with a single triangular and submembranous ventral process, thorn above this rather small and not depressed.

Material examined: Mindanao, Davao Prov., east slope of Mt. McKinley, $7200 \mathrm{ft} .$, 10.IX.1946, mossy stunted forest (CNHM Philippine Exped. 1946-47, H. Hoogstraal), $1 \sigma^{\top}$, holotype, genit. slide $5728 ; 1 \sigma^{\Upsilon 7}$, paratype.

The species is nearly allied to $S$. poliophora Bradley from New Hebrides Is. but is larger and differently marked.

\section{Petrova Heinrich, 1923}

\section{Petrova scalaris, new species}

FiguRes 109, 555

Female, $22 \mathrm{~mm}$. Head white, touched pale yellow. Antenna black, scape white; face white, lower part with a pair of small black marginal dots. Palpus black, basal segment mixed with white, median segment with an oblique large white apical patch; terminal segment white. Thorax white, with collar and shoulder, a large round central patch and apex, black. Abdomen light fuscous grey.

Forewing oblong, dilated, moderately broad. Costa gently curved anteriorly, almost straight posteriorly, apex obtusely pointed, termen sinuate, slightly oblique. White with a trace of pale yellow tinge, densely spotted with jet black and with a few leaden-grey spots. 
A small longitudinal mark on middle of base of wing; less than basal third of costa with three transverse spots, anterior subbasal, posterior extended so as to form a zigzag transverse fascia, its upper third running obliquely to fold, median third along fold, lower third parallel to first third, to $3 / 4$ of dorsum; second third with a blunt tooth below, a spot on dorsum opposite this; lower third of fascia with two dentations anteriorly, three posteriorly; irregular leaden-grey spots before origin of fascia, below costa; three small dots on costa beyond middle, becoming smaller posteriorly, interconnected by leaden-grey patch just below costa, also connected with a triangular larger spot in disc below them; this triangular spot in turn narrowly connected with the triangular anterior prominence of the top of a transverse vertical blotch, almost reaching dorsum before tornus, more or less mixed with leaden grey posteriorly; three triangular spots on posterior fifth of costa, ultimate of them apical, their angles interconnected by a subcostal leaden-grey spot which is also connected with a triangular or suboval spot well before upper part of termen which in turn may be connected with the preceding transverse blotch; an irregularly oval oblique spot, rising from $2 / 3$ of termen, sometimes connected with lower edge of preceding subcostal spots; spaces of white color on costa parted by smaller black series of dots, flanked with black points or lines. Cilia white, lower third with a diversely sized and spaced series of black bars along middle portion of termen, each bar continued over posterior $2 / 3$ of cilia by a narrower grey bar; a black bar above apex.

Hindwing pale grey, towards apex becoming darker glossy fuscous grey. Cilia concolorous.

Female genitalia: Lobus analis elongate, attenuated at extremities. Sterigma little modified, lamella antevaginalis, a semioval weak sclerite with a small pointed process on each side below; lamella postvaginalis, a pair of erect little sclerotized plates, flanking the ostium. Ostium bursae rather long, calice-shaped, finely aciculate and well defined. Cestum, a weak tube in the middle of ductus bursae. Corpus bursae spheroidal, signa, two small rounded scobiations.

Material examined: Luzon, Mountain Province, at base of Mt. Data, 5500 ft., 22.IV.1946 (CNHM Philippine Zool. Exped. 1946-47, H. Hoogstraal), 1 \%, holotype, genit. slide 5726 (CNHM). Benquet Prov., Bahio (Baker), 1 \%, paratype, without abdomen (USNM).

Without the knowledge of the male genitalia it is not possible to ascertain the true position of the species. Tentatively it is attributed to the present genus which has been confined so far to the Northern Hemisphere. 


\section{Eucosma Hübner 1823}

\section{Eucosma iographa, new species}

Figures 83, 556

Male, $18 \mathrm{~mm}$. Head and scape of antenna white, flagellum fuscous. Palpus dark grey, tip of median segment and entire terminal segment white. Thorax white, collar and tegulae fuscous. Abdomen fuscous, anal tuft whitish ochreous.

Forewing moderately broad, costa gently curved, apex subfalcate, produced, pointed, termen sinuate above, rounded beneath. White, costal half strongly suffused with darker. Anterior half of costa greyish, irregularly suffused and transversely strigulated with rather dark purplish grey; posterior half of costa dark purplish grey with five white pairs of markings, the ultimate mark extended and forming a subquadrate subapical spot; two darker, fuscous-purplish marks on costa: at $1 / 4$, wedge-shaped and in middle, irregularly transverse, both suffused (in paratype basal fourth of costa dark grey); a longitudinal broad streak of contrasting fuscous-brownish color just above middle of wing, from middle of cell to before upper part of termen, thence abruptly narrowed; to apex; some paler (partly rubbed) connection of this streak with base of wing, three small brownish arrowhead-shaped dots before lower half of termen, directed outwards; a very narrow and interrupted marginal line, along upper part of termen. Cilia pale fuscous greyish with a white basal third, above this barred with dark grey.

Hindwing rather dark grey, thinly scaled. Cilia paler fuscous grey, with a whitish basal and a darker fuscous subbasal line.

Male genitalia: Uncus apparently absent, tegumen with a deeply emarginate top, on each side a pointed-triangular process. Socius large, porrected and hairy, a thick pad. Gnathos, a slender but distinct semiannular rod. Valva moderate, clavate, cucullus densely haired and bristled; sacculus triangularly projecting, crowned with a bristly pointed process, top of sacculus with a blunt knob. Bases of valvae and juxta sclerotized. Aedeagus moderately long, gradually attenuated.

Material examined: Mindanao, Davao Prov., La Lun Mts., Calian, 5500 ft., 29-31.XII.1930 (Clagg, CM Acc. 9163) (CMP), $1 \sigma^{\top}$, holotype, genit. slide 5702, $1 \sigma^{\top}$, paratype.

\section{Cryptaspasma Walsingham, 1900}

\section{Cryptaspasma (Allobrachygonia) hesyca Diakonoff, 1959}

Figure 558

Cryptaspasma (Allobrachygonia) hesyca Diakonoff, 1959, Zool. Verh., no. 43, p. 24, pl. 5, fig. 37 , pl. 7, figs. 52-53, 57 ( ఠㅇ, Philippine Is., Luzon). 
Distribution: Philippine Is., Luzon.

Material examined: The original material was from Luzon, Subprov. Benguet, Pauai, Haights Place, 7000 ft., 12.XII.1912 (A.E. Wileman), 2 ơ , 5 ㅇ (Rothschild bequest, BM).

The printed label of this locality spells "Panai" for Pauai.

\section{Cryptophlebia Walsingham, 1899}

Cryptophlebia Walsingham, 1899, Indian Mus. Notes, vol. 4, p. 105.-Fletcher, 1929, Mem. Dept. Agric. India, Ent. ser., vol. 11, p. 61 (syn. of Argyroploce Hübner).-Swezey and Zimmerman, 1946, Proc. Hawaiian Ent. Soc., vol. 12, p. 629.-Bradley, 1953, Bull. Ent. Res., vol. 43, p. 682 (Pogonozada Hampson, syn.).-Diakonoff, 1953, Verh. Ned. Akad. Wet., Nat. ser. 2, vol. 49, no. 3, p. 156 (syn. of Pseudogalleria Ragonot); 1957, Tijdschr. Ent., vol. 100, p. 136, figs. 11-15, 20, 22.-Clarke, 1958, Catalogue . . . Microlepidoptera . . . Meyrick, vol. 3, p. 324 .

Pogonozada Hampson, 1905, Ann. Mag. Nat. Hist., ser. 7, vol. 16, p. 586 (type species, P. distorta Hampson, 1905, China)-Bradley, 1953, Bull. Ent. Res., vol. 43, p. 682 (syn. of Cryptophlebia Walsingham).-Diakonoff, 1953, Verh. Ned. Akad. Wet., Nat., ser. 2, vol. 49, no. 3, p. 156 (syn. of Pseudogalleria Ragonot).

Pseudogalleria (part), Diakonoff, 1953 (not Ragonot 1885), Verh. Ned. Akad. Wet., Nat., ser. 2, vol. 49, no. 3, p. 156, fig. 369.

Type species: Cryptophlebia carpophaga Walsingham, 1899 (India) [=C. ombrodelta Lower, 1898].

\section{Key to the Philippine Species of Cryptophlebia}

1. Forewing with apical spot dark fuscous, finely obliquely strigulated; disc with groups of numerous parallel lines . . . . . . . . . . . C. tetraploca

Forewing with apical spot ochreous fuscous, sometımes pinkish; disc without such groups of lines . . . . . . . . . . . . . . . . . . 2

2. Male hindwing with a black raised spot in disc; female with a small irregular mark above tornus . . . . . . . . . . . . . . . . . . . C. encarpa

Male hindwing without such spot; female with a ferruginous triangular spot on dorsum before tornus . . . . . . . . . . . . . C. ombrodelta

Cryptophlebia (Cryptophlebia) tetraploca (Meyrick, 1928), new combination FigURES 100, 557

Argyroploce tetraploca Meyrick, 1928, Exotic Microlepidoptera, vol. 3, p. 446. ( $\sigma^{7}$, Mt. Makiling; New Ireland).-Clarke, 1955, Catalogue . . . Microlepidoptera . . Meyrick, vol. 1, p. 306.

Distribution: Philippine Is., ? New Ireland.

Material examined: Luzon, Mt. Makiling (Baker), $3 \sigma^{x}$, genit. slide 5012 (USNM). Luzon, Benguet Subprov., Palali, 2000 ft., 3.VIII.1913, $1 \sigma^{7}$, genit. slide 5541; Rizal, Montalban, 17.VI.1914, $1 \sigma^{\nearrow}$, Mindanao, Lanao, plains, 19.V.1914 (A.E. Wileman) (BM).

Three specimens in the USNM doubtlessly belong to the type lot. The present material forms a welcome addition to that available 
of the species. The second male specimen cited in the original description is from New Ireland; it may prove to be a distinct species. One of the present specimens is labelled "paratype", but again, since only a single specimen has been sent to Meyrick for identification, no syntypes from Luzon were cited by him; so, formally, the present material is only topotypic.

The male genitalia may be described thus. Tegumen moderate, subtrapezoidal, its dorsal portion slightly broader than its legs. Uncus indicated by a small quadrate prominence or fold. Gnathos rather well developed for the genus, indicated by short, pointed lateral processes each ending in a dark point to which are attached a strongly folded and well-defined tuba analis, as well as a transverse sclerite, probably the gnathos hook proper, with a triangular excision in front. Vinculum strong, angularly bent. Valva moderate, straight, slightly clavate; its top vesicular, with a moderate cavity internally, containing a single large spine and a marginal rounded subtriangular ridge beyond it. Caulis very strong. Aedeagus narrow, dilated at base (slide 5012).

\section{Cryptophlebia (Cryptophlebia) ombrodelta (Lower, 1898)}

Figures 559-560

Arothrophora (?) ombrodelta Lower, 1898, Proc. Linn. Soc. New South Wales, vol. 23, p. 48 (ơ', Victoria).-Diakonoff, 1953, Verh. Ned. Akad. Wet., Nat., ser. 2 , vol. 49 , no. 3 , p. 157.

Cryptophlebia ombrodelta.-Bradley, 1953, Bull. Ent. Res., vol. 43, p. 682, fig. 1 (genit. $\sigma^{7}$ ), pl. 24, fig. 1 ( $)$ ), pl. 25, figs. 1, 1a (genit. $\%$ ) (syn.: carpophaga Walsingham).-N.B. Tindale, 1955, Trans. Roy. Soc. South Australia, vol. 78, p. 97, fig. (lectotype $\subsetneq$ selected).-Diakonoff, 1957, Tijdschr. Ent., vol. 100 , p. 139, figs. 11-15, 20, 22.

Cryptophlebia carpophaga Walsingham, 1899, Indian Mus. Notes, vol. 4, p. 106 ( $\sigma^{7}$ ९, India).-Barlow, 1903, op. cit., vol. 5, p. 121, pl. 15, figs. 2, 2a, 2b.Maxwell-Lefroy, 1909, Indian Insect Life, p. 531, pl. 28, figs. 11, 12.Diakonoff, 1953, Verh. Ned. Akad. Wet., Nat., ser. 2, vol. 49, no. 3, p. 157. Argyroploce illepida Meyrick, 1910 (not Butler, 1882), Proc. Linn. Soc. New South Wales, vol. 36, p. 265 (syn. ombrodelta Lower and carpophaga Walsingham); 1911, Indian Mus. Notes, vol. 5, p. 218.-Fletcher, 1914, South Indian Insects . . . , p. 449, fig. 327; 1917, Rep. Proc. 2nd Ent. Meeting Pusa, pp. 230, 234, 257; 1920, Mem. Dept. Agric. India, Ent. ser., vol. 4, p. 56 (life hist., foodplant); 1932, Imp. Counc. Agric. Res., Sci. Mon., no. 2, p. 29, pl. 19 (stages $~$ ).--R. Ayyar, 1921, Rep. 4th Ent. Meeting Pusa, p. 364 (parasite, Euagathis cryptophlebiae Viereck).- Van der Goot, 1940, Landbouw, vol. 16, pp. 507, 514, figs. 1-7 (also as Meded. Algemeen Proefst. Batavia no. 46= Med. Inst. Plantenziekten no. 99), pp. 1-43 (life hist., foodplant, parasite, Java).-Clarke, 1951, Journ. Washington Acad. Sci., vol. 41 , p. 299 , figs. $5,6,13$.

Distribution: South India, Ceylon, Formosa, Java, Borneo, Siam, Philippine Is., Guam, Dampier Is., Queensland, New South Wales, Victoria, Northern Territory of Australia. 
Food plants: Parkinsonia aculeata (leaves, pods), Cassia fistula, C. occidentalis (pods), Bauhinia purpurea (pods), Sesbania aculeata (pods), S. grandiflora (seeds), Tamarindus indica (fruits); Acacia arabica, Acacia spp., Adenanthera pavonia, Pithecolobium dulce (Leguminosae); Nephelium litchi (fruits, seeds) (Sapindaceae); Aegle marmelos (fruits), Teronea elephantum (fruits) (Rutaceae).

Lectotype, $\circ$, in the South Australia Museum.

Material examined: Luzon, Agoo, La Union, 8.IV.1945, 1 o genit. slide 5094; same locality, 1.V.1945, $1 \sigma^{7}$, genit. slide 5095 (J.G. Franclemont, CUI). Luzon, Benguet Subprov., Palali, 3000 ft., 28.VI.1913 (A.E. Wileman), 1 б (BM).

\section{Cryptophlebia (Cryptophlebia) encarpa (Meyrick, 1920)}

Figures 106-108, 561-562

Argyroploce encarpa Meyrick, 1920, Exotic Microlepidoptera, vol. 2, p. 349 ( $q$, Bengal, Ceylon).-Clarke, 1955, Catalogue .... Microlepidoptera ... Meyrick, vol. 1, p. 125.

Crytophlebia encarpa Bradley, 1953, Bull. Ent. Res., vol. 43, p. 686.-Clarke, 1958, Catalogue . . . Microlepidoptera . . . Meyrick, vol. 3, p. 324, pl. 161, figs. 3-3b.-Diakonoff, 1959, Zool. Verh., no. 43, p. 52, pl. 9, figs. 76-77.

Distribution: South India, New Hannover, Sudest Is., Celebes.

Food plants: Zizyphus jujuba (fruits and leaves), Citrus (fruits). Material examined: Luzon, Mt. Makiling (Baker), 1 ᄋ, genit. slide 5062 (USNM).

The female genitalia are characterized by a narrow, darkly sclerotized edge to the ostium, in the shape of a wide numeral 8, with open top (lamella antevaginalis), while the colliculum is short and slender, a sclerotized small tube. Corpus bursae is subovoid, with both extremities narrowed. Signa extremely strong, almost equal hooks, with round and large basal plates.

\section{Erinaea Meyrick, 1907}

\section{Erinaea amphigonia, new species}

Figures 94, 563

Female, $15.5 \mathrm{~mm}$. Head white, side tufts on vertex black. Antenna black, scape white with a black subapical ring. Palpus blackish, apical portion of median segment and entire terminal segment white. Thorax black, tips of tegulae light grey. Abdomen dark fuscous, venter paler.

Forewing elongate, suboval, broadest beyond middle, narrowed thence, rather narrow, costa curved along basal half, almost straight along apical half, apex moderately pointed, termen sinuate, oblique. Pure white, except area of the ocellus which is with a faintest pinkish tinge; markings jet black slightly mixed with anthracite color. Basal 
patch rather small (1/9), edge tolerably straight, oblique; an oblique, subquadrate spot from $1 / 4$ of costa to upper edge of cell, lower edge rounded; an oval spot just above dorsum below preceding, connected with a narrow line along anterior part of dorsum; a semicircular spot on middle of costa, to upper edge of cell; an inwards-oblique, strong transverse fascia, from $5 / 6$ of costa to $3 / 4$ of dorsum, anterior edge tolerably straight, its upper half serrulate; posterior edge of this fascia with two large rectangular projections, one on dorsum, another in middle of disc; an elongate spot in apex; two minute longitudinal marks beyond ocellus; a tawny sinuate line from below costa beyond apex, to middle of termen, thence marginal, to tornus; dark markings on costa alternating with minute single black dots; beyond semicircular spot there are two of these dots. Cilia white with two large black spots, beyond apex and middle of termen, respectively.

Hindwing dark fuscous grey, becoming somewhat lighter towards base. Cilia dark fuscous grey with a whitish basal line.

Female genitalia: Genital sternite moderate, sclerotized only along caudal edge, sides sinuate, upper angles rounded. Sterigma represented by a large, subcrescentic sclerite with thickened edges. Colliculum, a wide, sclerotized tube, its lower portion with deep longitudinal folds. Corpus bursae with the characteristic bent sclerite. Signa rather slender, subequal, curved thorns with moderate basal plates.

Material examined: Luzon, Benguet Subprov., Haights Place, Pauai, 7000 ft., 15.XI.1912 (A.E. Wileman), 1 ఠ', holotype, genit. slide 5533 (BM).

\section{Crocidosema Zeller, 1847}

\section{Crocidosema plebejana Zeller, 1847}

Figure 564

Crocidosema plebejana Zeller, 1847, Isis, p. 721.-Heinemann, 1849, Schmetterlinge Europas, p. 241.-Staudinger and Wocke, 1871, in Cat. Lepidopteren europaeischen Faunengebiets, p. 263, no. 1269.-Eppelsheim, 1881, Stettiner ent. Zeitschrift, p. 379.-Meyrick, 1881, Proc. Linn. Soc. New South Wales, vol. 6, p. 659; 1886, Trans. Roy. Ent. Soc. London, p. 276; 1928, Rev. Handbook British Lepidoptera, p. 539.-Walsingham, 1891, Proc. Zool. Soc. London, p. 506; 1897, op. cit., p. 127, no. 174; 1907, in Sharp, Fauna Hawaiiensis, vol. 1, pt. 5, p. 675, pl. 10, fig. 15.-Staudinger and Rebel, 1901, in Cat. Lepidopteren palaearktischen Faunengebietes, vol. 2, p. 110, no. 1968.Kennel, 1910, Palaearktischen Tortriciden, p. 468, pl. 18, figs. 66, 67; 1910, in Spuler, Schmetterlinge Europas, vol. 2, p. 273, pl. 85, fig. 45.-Philpott, 1923, Trans. New Zealand Inst., vol. 59, p. 475, fig. 10.-Heinrich, 1923, U.S. Nat. Mus. Bull. 123, p. 190, figs. 10, 29, 29a, 325.-Lhomme, 1935, Cat. Lépidoptères France et Belgique, vol. 2, p. 330.-Clarke, 1958, Catalogue . . . Microlepidoptera ... Meyrick. vol. 3, p. 319, pl. 158, figs. 1-1a, 2-2a, 
3-3a.-Hannemann, 1961, Tierwelt Deutschlands, vol. 48, p. 154, no. 315 (also spelled plebeiana by some authors).

Penthina alteana Mann, 1855, Verh. Zool.-Bot. Ges. Wien, p. 555.

Paedisca lavaterana Milliere, 1862, Iconographie et déscription chénilles et Lépidoptères inédits, pp. 290, 310, pl. 34, figs. 9-13.

Grapholitha peregrinana Möschler, 1866, Berliner ent. Zeitschrift, p. 139.

Stenoptycha obscura Wollaston, 1879, Ann. Mag. Nat. Hist., ser. 5, vol. 3, p. 341. Proteopteryx blackburni Butler, 1881, Ann. Mag. Nat. Hist., ser. 5, vol. 7, pp. 393394.-Willcocks, 1916, Insect Pests Egypt, vol. 1, p. 390, pl. 7, fig. 5.

Crocidosema ptiladelpha Meyrick, 1917, Trans. Roy. Ent. Soc. London, p. 18.Clarke, 1955, Catalogue . . . Microlepidoptera . . . Meyrick; vol. 1, p. 264; 1958, op. cit., vol. 3, p. 319, pl. 158, figs. 1-1a (syn. of plebejana).

Crocidosema synneurota Meyrick, 1926, Trans. Roy. Ent. Soc. London, vol. 74 , p. 276.-Clarke, 1955, Catalogue ... Microlepidoptera . . Meyrick' vol. 1, p. 301; 1958, op. cit., vol. 3, p. 319, pl. 158, figs. 2-2a (syn. of plebejana)'

Distribution: Cosmopolitan.

Material examined: Luzon, Los Baños (Baker), 1 \%, genit. slide 5087 (USNM).

\section{Loboschiza, new genus}

Head with appressed scales. Ocellus posterior. Proboscis developed. Antenna in male short-ciliate. Palpus moderate, ascending, appressed to face, not reaching top of eye, smoothly scaled, median segment moderate, little dilated and slightly roughish at apex, terminal segment small, subacute, smooth and exposed. Thorax without a crest. Posterior tibia normal.

Forewing broad, suboval, apex obtusely pointed, termen rounded. Vein 2 from beyond $2 / 3$ of cell, 3 from angle, only slightly sinuate, 4 more sinuate, closer to $3,3-6$ remote, 7 separate, to termen below apex, 8 from angle, 9 rather close to 8,10 from midway distance $11-9,11$ from $2 / 5$ of cell. Upper parting vein from $2 / 3$ distance between 11 and 10, vestigial except extreme origin, lower parting vein from toward base to between 4 and 5 .

Hindwing with cubital pecten, rather short, broadly semioval; 2 from 2/3, 3 and 4 stalked from angle, 5 approximated at base, 6 and 7 closely approximated toward base.

Male genitalia: Tegumen broadly conical. Uncus absent. Socius a moderate, appressed, elongate-oval flap. Gnathos paired, a moderate semioval sclerite on each side. Valva oblong, dilated and clavate; sacculus with a prominent and large semioval lobe, beset with dense long bristles, processus basalis long. Cucullus strongly dilated and bilobed, upper lobe projecting, semioval, sparsely bristled over the disc; lower lobe more pointed, densely bristled; with a curved spine on top. Aedeagus rather long, straight and narrow, gradually tapering; caulis long and bandlike.

Female unknown. 
Type species: Argyroploce clytocarpa Meyrick, 1920 (Philippines).

A distinct monotypic genus with Eucomine affinities, characterized by the peculiarly shaped valva and the unusual origin of vein 11 in the forewing.

\section{Loboschiza clytocarpa (Meyrick, 1920), new combination}

Figures 837,842

Argyroploce clytocarpa Meyrick, 1920, Exotic Microlepidoptera, vol. 2, p. 349 ( $\sigma^{7}$, "Philippines").-Clarke, 1955, Catalogue . . . Microlepidoptera . . . Meyrick, vol. 1, p. 94 .

Olethreutes clytocarpa.-Clarke, 1958, Catalogue . . Microlepidoptera . . . Meyrick, vol. 3, p. 496, pl. 247, figs. 3-3b (holotype and genitalia figured).

Distribution: "Philippines."

The holotype, $\sigma^{\nwarrow}$, unique, is labelled "Philippines. M.-10"; genit. slide 7338 (BM).

\section{Laspeyresia Hübner, 1826}

\section{Key to the Philippine Species of Laspeyresia}

1. Forewing bright brassy yellow with posterior half dark purplish leaden grey. L. gratulata

Forewing fuscous with faint greyish markings . . . . . . . L. inflata

\section{Laspeyresia inflata Meyrick, 1916}

Laspeyresia inflata Meyrick, 1916, Exotic Microlepidoptera, vol. 2, p. 23 ( , Mindoro, Butas River).-Clarke, 1955, Catalogue . . . Microlepidoptera . . . Meyrick, vol. 1, p. 171 ; 1958, op. cit., vol. 3, p. 440, pl. 219, figs. 3-3a (wings, genitalia $\sigma^{\top}$ ).

Distribution: Philippine Is., Mindoro.

The generic position of this species is uncertain.

\section{Laspeyresia gratulata Meyrick, 1916}

FIGURE 567

Laspeyresia gratulata Meyrick, 1916, Exotic Microlepidoptera, vol. 2, p. 23 ( Mindanao, Daron).-Clarke, 1955, Catalogue . . . Microlepidoptera . . . Meyrick, vol. 1, p. 149; 1958, op. cit., vol. 3, p. 439, pl. 218, figs. 4-4b (wings, genitalia \&).

Distribution: Philippine Is., Mindanao.

The generic position of this species is uncertain.

\section{Pammene Hübner, 1926}

\section{Key to the Philippine Species of Pammene}

1. Hindwing fuscous, paler towards base; cilia grey . . . . . . . P. ionia Hindwing black with basal half white; cilia white . 


\section{Pammene ionia Wileman and Stringer, 1929}

Figures 838-841

Pammene ionia Wileman and Stringer, 1929, The Entomologist, vol. 62, p. 67 ( $\sigma^{x}$, Luzon).

Distribution: Philippine Is., Luzon.

Material examined: Luzon, Manila, XII.1945, at light $(\mathrm{H}$. Hoogstraal), $1 \sigma^{7}$, neallotype, hereby selected, genit. slide 5764, $2 \sigma^{7}$, genit. slide 6032 (figured) (CNHM).

Holotype, female, labeled thus: "Pammene ionia Wileman," "Baguio, Subprov. Benguet, Luzon, P.I., 23.V.1913, A.E. Wileman." slide BM 12025 (BM).

Male genitalia: Coremata on the eighth segment present, rather small, fan-shaped. Tegumen moderate, a smooth arch. Uncus, socii absent. Tuba analis large, hyaline; membrane between this and inner circumference of upper part of tegumen distinctly sclerotized. Valva robust, rather short and broad, primary emargination beyond middle, reaching above middle of width of valva; sacculus with a few bristles; cucullus rounded, spined; costa with a row of bristles. Aedeagus long, moderately curved, sclerotized and gradually narrowed. Cornuti, a sheaf of long and slender, straight spines.

Female genitalia: Sterigma, a subcardiform elevated field, at the sides with finely wrinkled surface. Ostium, semioval, rather wide. Corpus bursae oval, signa two large flat hooks.

Belongs to a large group of similarly looking small species, inhabiting grass land and probably feeding on Gramineae.

\section{Pammene leucodora Meyrick, 1928}

Figures $96,470,565-566,804$

Pammena leucodora Meyrick, 1928 [sic], Exotic Microlepidoptera, vol. 3, p. 447 ( $\sigma^{\top}$ ㅇ, Luzon).

Pammene leucodora, Clarke, 1955, Catalogue ... Microlepidoptera ... Meyrick, vol. 1, p. 185; 1958, op cit., vol. 3, p. 564, pl. 281, figs. 2-2a (lectotype $\sigma^{7}$ selected, figured).

Distribution: Philippine Is.

Material examined: Luzon, Mt. Makiling, "feeds on Monophlebus," "par. on scale on Pithecolobium scutiferum, 7.VII.1913" (C.F. Baker), $2 \sigma^{\top}, 3$ ㅇ. Los Baños, "feeds on Monophlebus (Baker)," $1 \sigma^{7}, 2$ ㅇ, gen. no. 5015 ช , 5775 o. Acc. no. 18472, Coll. of Agric. Univ., P.I., "moth parasitic in scale no. 9483," "on Peressopneumon convexa, on Pithecolobium scutiferum" 2 ㅇ. 3 ㄱ, 6 우 (USNM).

The present series forms an important addition to the two original specimens, which were sent to Meyrick and described by him. Three specimens from Los Baños are topotypes. 
The data on the remarkable entomophagous habits of the species are not recorded in the original description. They are the more unexpected because the closely allied Javanese species, $P$. rescissa Meyrick, simply feeds on fruits of Cynometra edulifolia.

Male genitalia: Tegumen erected-triangular, high and rather slender, right and left halves slanting slightly towards each other, basal angles prominent. Uncus and gnathos absent. Valva simple, rather long, sacculus $1 / 3$, incision moderate, semioval, cucullus elongate oval, with long bristly hairs along ventral side. Aedeagus moderate and slender, apical third, a narrow tube. Sclerotized edge of the eighth sternite (mensis ventralis) narrow and long, $\Gamma$-shaped, each leg ending in a very long and slender corema.

\section{Chlidanotinae}

\section{Key to the Philippine Tribes of Chlidanotinae}

1. Forewing with veins 8 and 9 stalked or 9 out of the stalk of 7 and 8 ; lower parting vein to above origin of vein $5 . . . . .$. Chlidanotini Forewing with vein 9 separate; lower parting vein absent. . SchoenoteninI

\section{Chlidanotini}

\section{Key to the Philippine Genera of Chlidanotini}

1. Forewing with vein 4 present, 8 and 9 out of 7 . . . . . Caenognosis Forewing with vein 4 absent, 7 free, 8 and 9 stalked . . . . . . Trymalitis

\section{Caenognosis Walsingham, 1900}

Caenognosis Walsingham, 1900, in Andrews, Monograph Christmas Is., p. 79.Meyrick, 1912, in Aurivillius, Lepidopterorum Catalogus, pars 10, p. 53; 1913, in Wytsman, Genera Insectorum, fasc. 149, p. 52.-Fletcher, 1929, Mem. Dept. Agric. India, Ent. ser., vol. 11, p. 37 (Epirrhoeca syn.).-Diakonoff, 1956, Proc. Ned. Akad. Wet., ser. C, vol. 59, p. 640, figs. 9, 16 (neur., genitalia $\left.\sigma^{\top}\right)$.

Epirrhoeca Meyrick, 1911, Proc. Linn. Soc. New South Wales, vol. 36, p. 293 (type species: neoris Meyrick=incisa Walsingham, Australia).-Tillyard, 1926, Insects Australia and New Zealand, p. 427.

Type species: Caenognosis incisa Walsingham, 1900 (Christmas Is.).

\section{Caenognosis incisa Walsingham, 1900}

Figures 127-128, 568

Caenognosis incisa Walsingham, 1900, in Andrews, Monograph Christmas Is., p. 79. ( $\sigma^{\top}$ \& , Christmas Is.)-Meyrick, 1912, in Aurivillius, Lepidopterorum 
Catalogus, pars 10, p. 53; 1913, in Wytsman, Genera Insectorum, fasc. 149, p. 52.-Diakonoff, 1956, Proc. Ned. Akad. Wet., ser. C, vol. 59, p. 640, figs. 9, 16 (figs. neur., genitalia $\sigma^{7}$, New Guinea).

Epirrhoeca neoris Meyrick, 1911, Proc. Linn. Soc. New South Wales, vol. 36, p. 293 ( $\sigma^{\top}$, Australia) [new synonym].

Distribution: Christmas Is., Australia, New Guinea.

Material examined: Luzon, Mt. Makiling (Baker), $3 \sigma^{7}, 1$ 우 (USNM). Although the generic name Epirrhoeca has been sunk as a synonym of Coenognosis long ago (Fletcher, 1926), the validity of the specific name neoris apparently has not been questioned before.

\section{Trymalitis Meyrick, 1905}

\section{Trymalitis cataracta Meyrick, 1907}

Figure 569

Trymalitis cataracta Meyrick, 1907, Journ. Bombay Nat. Hist. Soc., vol. 18, p. 153 (ơ, Ceylon).-Bradley, 1957, Nat. Hist. Renell Is., vol. 2, no. 19, p. 97 (optima, macarista synonyms).-Clarke, 1963, Catalogue . . Microlepidoptera . . Meyrick, vol. 4, p. 80, pl. 38, figs. 3-3c.

Trymaltis optima Meyrick, 1911 [sic], Proc. Linn. Soc. New South Wales, vol. 36, p. 294 ( $\sigma^{\top}$, Queensland; generic name misspelled, Trymaltis).

Trymalitis optima.-Fletcher, 1931, Cat. Indian Insects, fasc. 22, p. 13.-Meyrick 1939, Trans. Roy. Ent. Soc. London, vol. 89, p. 53 (macarista synonym).Clarke, 1963, Catalogue ... Microlepidoptera . . Meyrick, vol. 4, p. 80, pl. 38, figs. 2-2b.

Trymalitis macarista Meyrick, 1934, Exotic Microlepidoptera, vol. 4, p. 489.

Distribution: Andaman Is., Ceylon, Java, Siam, Queensland, New Guinea, Fiji, Bismarck Is.

Material examined: Luzon, Mt. Makiling (Baker), $1 \sigma^{7}$, genit. slide "July 29, 1935, A. B." Fiji (Wm. Schaus), 1 व (USNM).

In the initial line of the original description of T. optima (fig. 569) the generic name is misspelled, "Trymaltis," while in the second line and in the index this name is spelled correctly, Trymalitis. The erroneous spelling is used by Tillyard, 1926 (Insects Australia and New Zealand, p. 427) and by Neave, 1940 (Nomenclator Zoologicus, vol. 4 , p. 584).

\section{Schoenotenini}

\section{Key to the Philippine Genera of Schoenotenini}

1. Hindwing with veins 6 and 7 short stalked, connate or closely approximated from upper angle of cell or from obliquely running upper edge of cell, remote from 5............... . . . Schoenotenes

Hindwing with veins 6 and 7 very long-stalked, seemingly from base of wing, stalk sometimes connected with middle of cell by a vertical cross bar.

Stenarchella, new genus 


\section{Schoenotenes Meyrick, 1908}

\section{Schoenotenes collarigera, new species}

Figures 47, 571

Female, $16 \mathrm{~mm}$. Head greyish-creamy white. Antenna with scape whitish, flagellum pale grey. Palpus rather long and slender; whitish, partly suffused with pale grey; terminal segment moderately long. Thorax greyish-creamy white, suffused with grey anteriorly. Abdomen white.

Forewing elongate, broadest before middle, costa gently curved anteriorly, straight posteriorly, rather curved before apex, apex moderately rounded, termen little rounded, oblique, veins raised and roughish. Creamy white, with fine interrupted transverse pale grey strigulae; markings pale grey, edged and marbled with darker grey. Basal patch indicated by a triangular spot on costa from just beyond base, extending over more than $1 / 5$, below limited by fold, outer edge inwards-oblique, rather straight; lower and outer edges of this patch blackish, costal edge with four transverse dark strigulae; transverse fascia narrow and sinuate, from before middle of costa to dorsum before tornus; upper half of this fascia wedge-shaped, pale grey, narrowly dark edged; lower half in right wing formed only by pale grey edges, irregular in left wing; a white raised tuft on closing vein, edged except anteriorly with black; some irregular dark grey, fuscous and black dotting above, in, and below fold at $2 / 3$ of wing and an elongate black strigula below fold at $1 / 3$; costal patch rather small, semioval, almost semicircular, anterior and posterior edges truncate, rather darkly suffused with fuscous, pale-centered; preterminal blotch moderate, rather rounded, pale grey; a series of blackish marginal dots on ends of all veins, from vein 9 to tornus. Cilia white, barred with grey.

Hindwing white, extreme edge around apex and along upper half of termen suffused with dark grey. Cilia white, around apex pale grey.

Female genitalia: Ninth segment hemispheroid with a flattened edge, rather sclerotized and slightly colored. Lobus analis with a rounded upper and a more slender lower half. Sterigma triangular, ostium, a curved slit in its lower part; lamella antevaginalis thus being narrow and rodlike; lamella postvaginalis shaped as a strong band. Ductus bursae short, simple. Corpus bursae ovoid. Signum, a curved, hollow tooth.

Material examined: Oriental Negros, Mt. Talinas, 1020 m, 28.VI.1958 (light trap, H. E. Milliron), 1 o, holotype, genit. slide 5318 $(\mathrm{BMH})$. 


\section{Stenarchella, new genus}

With the external characters and neuration of Proactenis Diakonoff, 1941 , but with a quite different type of male genitalia.

Tegumen rather high, cylindrical. Uncus strong, sclerotized, a simple hook with a rounded top. Socius moderate, free, pending. Gnathos strong, arms converging and porrected, corrugated, point pending, obtuse, triangular, a small additional blade arising from the bent of the pending portion. Transtilla, a moderate, trapezoidal band. Vinculum small, subtriangular. Valva of Protarchella type, but with a strongly dilated basal half and a more slender cucullus. Sacculus 2/3, its apical hook blunt and strong. Aedeagus little curved, rather broad, top with a short upper and a long lower lip.

Type species: Stenarchella eupista, new species.

Apparently nearest to Cornuticlava Diakonoff, 1969, but less specialized.

\section{Stenarchella eupista, new species}

Figures 121-123, 574

Male, $20.5 \mathrm{~mm}$. Head white, slightly touched with fuscous. Antenna white, median segment with a large black spot on upper side, not reaching apex nor lower edge, terminal segment with a black median ring. Thorax whitish, with a pale purple gloss. Abdomen white.

Forewing suboval, slightly dilated, broadest at $3 / 4$, costa little curved, apex rounded, termen rounded, little oblique, with slight raised scale tufts in disc. Snow white, markings formed by short and slender strigulae along raised veins, more or less interrupted between veins, therefore appearing grey. A small transverse mark beyond base of costa, preceded and followed by a minute dot; a large transverse and slightly undulate streak at $1 / 5$ reaching to fold; transverse fascia formed by three or four transverse strigulae or dots on costa, preceded by two distant costal dots, and followed by one more dot; these dots emitting almost vertical faint strigulae, becoming longer on posterior part of wing, to form together a triangular transverse fascia, strongly narrowed below, anterior edge very oblique, posterior slightly so, end on dorsum before tornus; costal patch formed by a small quadrate costal dot before apex, connected with a larger subcostal one before preceding which is also connected by two lines with costa; a slender wedge-shaped preterminal mark, little oblique, resting with acute base on termen just above tornus; a faint zigzag preapical streak, from costa to before middle of termen; a subtriangular spot on middle of dorsum, reaching above middle of wing, but not touching transverse fascia. Cilia snow white with a submedian row of black dots. 
Hindwing and cilia white.

Male genitalia as described with the genus above.

Material examined: Mindanao, Davao Prov., La Lun Mt., Calian, 5000 ft., 29-31.XII.1920 (Clagg, CM Acc. 9163), 1 o', holotype, genit. slide 5700 (CMP).

\section{Carposinidae}

\section{Key to the Philippine Genera of Carposinidae}

1. Valva short, sacculus extended, cucullus with an additional lobe.

Campylarchis, new genus

Valva not thus

2. Valva with base soldered to vinculum, cucullus with a strong lateral clasping hook .

Metacosmesis

Valva without such hook . . . . . . . . . . . . . . . . . . 3

3. Forewing with veins 8 and 9 separate. . . . . . . . . Heterogymna

Forewing with veins 8 and 9 stalked

Meridarchis

\section{Campylarchis, new genus}

Head with appressed scales. Ocellus absent. Proboscis developed. Antenna in male $3 / 4$, filiform, ciliated, ciliations over 1 ; scape elongate, clavate. Labial palpus moderate, subascending, median segment spindle-shaped, with closely appressed short scales, roughish below, terminal segment about $1 / 3$, spindle-shaped, subacute, slightly rough (thorax rubbed). Posterior tibia with very long, fine hairs above.

Forewing elongate-sublanceolate, dilated, pointed, 2 from toward angle, 3 from angle, 4 and 5 connate, 6 remote, 7 separate, to apex, 8 and 9 stalked, 11 from $3 / 4$ of cell. Hindwing semioval-lanceolate, pointed, over 1 , cilia $1 / 2$. Vein 2 from $1 / 2,3$ and 4 stalked, from angle, 6 and 7 parallel.

Male genitalia. Tegumen small, rounded. Saccus developed, $3 x$ as long as tegumen. Valva strong, very short, sclerotized, sacculus extended; cucullus small, hairy, with an additional, distal lobe.

Type species: Campylarchis acuta, new species.

The genus is very characteristic by reason of the male genitalia. It is allied to Xyloides Diakonoff and Metacosmesis Diakonoff, closer to the latter but not very near.

The following earlier described species also belong here judging from Clarke's illustrations of their male genitalia.

Meridarchis phaeodelta Meyrick, 1906, Journ. Bombay Nat. Hist. Soc., vol. 17, p. 138.-Clarke, 1963, Catalogue . . . Microlepidoptera . . . Meyrick, vol. 4, p. 57, pl. 27, figs. 4-4b (Ceylon). Meridarchis picroscopa Meyrick, 1930, Exotic Microlepidoptera, vol. 3, p. 588.-Clarke, 1963, Catalogue . . . Microlepidoptera . . . Meyrick, vol. 4, p. 58, pl. 28, figs. 1-1b (New Guinea). 
Meridarchis vitiata Meyrick, 1913, Exotic Microlepidoptera, vol. 1, p. 72.-Clarke, 1963, Catalogue . . Microlepidoptera . . . Meyrick, vol. 4, p. 61, pl. 29, figs. 1-1b (Assam).

\section{Campylarchis acuta, new species}

Figures 129-130, 471, 471a, 577

Male, $23 \mathrm{~mm}$. Head and thorax pale ochreous, slightly suffused with tawny. Palpus fuscous tawny, dusted with brown, dusting becoming less dense towards apex. Abdomen pale ochreous.

Forewing elongate, dilated, pointed, costa curved at extremities, straight in middle, apex pointed and produced, termen sinuate, concave above, rounded beneath. Pale ochreous (worn), markings tawny fuscous and purplish brown. Indication of an invertedtrapezoidal patch on middle of costa reaching to middle of cell; a light tawny suffusion beyond cell; a bright tawny suffused marginal streak along termen and in tornus, from apex to dorsum; a spot of deep purple sparse dusting opposite middle of termen. Cilia pure white with a brown apical third (imperfect).

Hindwing and cilia pale greyish.

Male genitalia sclerotized. Tegumen short, strongly rounded, with juxta forming a complete circle. Uncus indicated by a small bicuspid prominence, gnathos, by a short process at each side. Saccus long, narrowed, about $3 \times$ as long as tegumen. Sacculus strong, semioval, top with two rounded processes. Cucullus short, rounded, bristly. External lobe of valva triangular, upper edge concave, point acute, a rounded knob at base apparently forming an articulation with sacculus. Anellus lobes moderate, slender, bristly. Aedeagus very large, with a hollow, egg-shaped body on a slender stalk; cornuti, two opposite patches of very dense spiny bristles.

Material examined: Luzon, Benguet Subprov., Pauai, $7000 \mathrm{ft}$., Haights Place, 17.XI.1912 (A.E. Wileman), $1 \sigma^{7}$, holotype, genit. slide $5581(\mathrm{BM})$. The specimen is rather rubbed, with left pair of wings not quite spread, but with the genitalia very characteristic.

\section{Peragrarchis Diakonoff, 1959}

Peragrarchis Diakonoff, 1959, Bull. British Mus. Nat. Hist., Ent. ser., vol. 8, p. 124, figs. 1, 2, pl. 5, fig. 7 ( $\left.\sigma^{7}\right)$.

Type species: Meridarchis rodea Diakonoff, 1950 (New Guinea). Now that the status of several earlier-described species of Meridarchis is clarified in Clarke's monograph (1963, vol. 4), the following two species may be transferred from Meridarchis to the present genus.

\section{Peragrarchis pelograpta (Meyrick, 1929), new combination}

Meridarch is pelograpta Meyrick, 1929, Trans. Roy. Ent. Soc. London, vol. 76, p. 502 ( $\sigma^{\top} \%$, Austral Is., Polynesia).-Clarke, 1963, Catalogue ... 
Microlepidoptera ... Meyrick, vol. 4, p. 57, pl. 27, figs. 3-3b (wing, genitalia illustr.).

\section{Peragrarchis syncolleta (Meyrick, 1928), new combination}

Meridarchis syncolleta Meyrick, 1928, Exotic Microlepidoptera, vol. 3, p. 404 ( $\sigma^{\nearrow}$ \% Andaman Is.).-Diakonoff, 1950, Bull. Brit. Mus. Nat. Hist., Ent. ser., vol. 1, p. 297.-Clarke, 1963, Catalogue . . Microlepidoptera . . . Meyrick, vol. 4, p. 58, pl. 28, figs. 4-4b (wing, genitalia illustr.).

These species have male genitalia of a very characteristic type, showing that the group is natural and compact. They differ from one another by reason of minor points of genital structure and also by coloring and markings.

\section{Metacosmesis Diakonoff, 1949}

Metacosmesis Diakonoff, 1949, Treubia, vol. 20, p. 48, figs. 5, 6, 10 (type species: Metacosmesis barbaroglypha Diakonoff, 1949, Treubia, vol. 20, p. 48, Java).

The genus is better characterized by the genitalia of the males than by the superficial characters, e.g., the neuration, which is subject to some variation, which may be either between species or between the sexes of a single species, as has been described in $M$. barbaroglypha.

In that species veins 3 and 4 of the forewing are connate in male, closely approximated in female; in $M$. illodis, new species, they are stalked. Veins 8 and 9 are closely approximated in both sexes of $M$. barbaroglypha and stalked in $M$. illodis. Vein 11 originates from $4 / 5$ of cell in $M$. barbaroglypha female, from $3 / 4$ in male, while in other species its origin is situated at $2 / 3$ of cell.

These variations appear to be less important in the present genus and do not affect its homogeneity, because the male genitalia in the two known species are of a similar characteristic and remarkable shape, with the bases of valvae entirely jointed to the vinculum and the valvae themselves having large clasping hooks.

\section{Metacosmesis illodis, new species}

Figures 133-134, 579

Male, $23 \mathrm{~mm}$. Head white, a median longitudinal streak on vertex and orbits slightly infuscated. Palpus moderate, subascending, dilated, roughish towards apex above, terminal segment very short, drooping. Antenna light tawny, ciliations over 1, scape white. Thorax white, shoulder mixed with blackish, a median irregular broad band of light fuscous dusting, apex in middle slightly infuscated. Abdomen silvery white.

Forewing with veins 3 and 4 stalked, 8 and 9 stalked, 11 from $2 / 3$; narrowly elongate-subtriangular, costa moderately curved toward extremities, hardly curved in middle, apex moderately rounded, ter- 
men hardly sinuate, almost straight, strongly oblique. Snow white with a brilliant gloss, markings dark fuscous, dull. Fine and irregular dusting all over the wing; basal patch small, edge straight, strongly inwards-oblique; pale fuscous, containing a triangluar dark costal spot, narrowly produced along edge to base of costa and an irregular dark fuscous double mark: in fold and on dorsum; a rather narrow inwards-oblique transverse fascia before $1 / 3$, moderately curved and concave anteriorly, not quite reaching dorsum but merging in a large patch of sparse fuscous dusting extending over dorsum along its median three fifths; a streak along median fifth of costa, its posterior end connected with a large irregularly triangular transverse patch over end of cell, not reaching margins of wing; this patch with upper half dark fuscous, upper angles well defined and rounded, posterior connected with a roundish spot on costa at $2 / 3$; two smaller round costal dots between preceding and apex; a light fuscous strongly suffused broad curved fascia, outwards-concave, first almost horizontal from apex, then inwards-oblique, almost parallel to termen, finally curving into tornus; some five roundish terminal dots between veins, interconnected by a darker marginal line. Cilia white, median third suffusedly pale greyish fuscous.

Hindwing whitish, cilia white.

Male genitalia: Tegumen weak, broadly oval. Uncus small, triangular, with a pointed top. Vinculum broadly semioval. Valvae tightly joined to vinculum; sacculus broadly egg-shaped and flat. Cucullus smaller than sacculus, moderately haired and concave, with a very large, strongly curved prong, being continuation of the strong costa, with one or two triangular toothlike processes at base, turned inwards. Aedeagus rather small, spoon-shaped, with a slender stalk. Cornuti, a patch of very fine spines in the vesica.

Material examined: Luzon, Benguet Subprov., Pauai, Haights Place, $7000 \mathrm{ft}$, 4.XIII.1912 (A.E. Wileman), 1 ๙ , holotype, genit. slide 5573 (USNM).

\section{Meridarchis Zeller, 1867}

\section{Key to the Philippine Species of Meridarchis}

1. Whitish grey with round black dots .

M. alta, new species Not so colored

2. Forewing with a large dark subtriangular patch on costa .

Forewing with a series of costal dots and two irregular spots in disc.

M. bifracta, new species

3. Light ochreous touched with tawny; subterminal fascia very faint; a dark basal streak along costa . . . . . . . . M. oxydelta, new species

Pale fuscous ochreous; subterminal fascia well defined, base of costa not marked 


\section{Meridarchis alta, new species}

Figures 141-142, 578

Female, $22 \mathrm{~mm}$. Head white. Palpus white, basal half black above. Antenna whitish. Thorax white, a single round spot anteriorly. Abdomen white.

Forewing moderate, suboval, costa gently curved, more so towards apex, apex rounded-rectangular, termen gently convex, almost straight, oblique. Pale slate grey with a faint purplish tinge. Costa broadly, termen less distinctly, suffused with white. Markings black, narrowly edged with white suffusion. Costa with seven spots, posteriorly becoming slightly elongate and oblique; first spot basal, ultimate, subapical; five subtriangular spots on termination of veins 4-8, becoming larger towards apex, two upper ones broadly interconnected; a trace of a sixth spot on vein 3 ; discal spots six, larger: two in an oblique series beyond base, roundish; four in a quadrangle, anterior in cell at $2 / 5$, upper beyond this, above cell, posterior on upper angle of cell, these three spots circular; fourth smaller, elongate, between cell and fold, beyond upper spot; a small elongate mark along lower half of discoidal vein. Cilia slate grey with white base.

Hindwing slate grey, becoming silvery towards base, paler than forewing and glossy; a very irregular darker grey interrupted marginal strigula along costa, in apex and along upper half of termen. Cilia concolorous.

Female genitalia: Resembling those of M. globosa Diakonoff. Ninth segment moderately, but distinctly sclerotized throughout. Sterigma shaped as a simple moderate plate, rounded beneath, upper edge with a semicircular excision flanked by rather long and slender projections which are considerably longer than in globosa. Apophyses and bursa similar, but corpus bursae finely aciculate throughout except the extreme end (in globosa there is a ring of stronger scobinations before the end).

Material examined: "Philippine Ids., Acc. C. M. 6151," 1 ㅇ, holotype, genit. slide 5716 (CMP). Allied to $M$. globosa Diakonoff, from New Guinea.

\section{Meridarchis bifracta, new species}

Figures 131-132, 580

Male, $18.5 \mathrm{~mm}$. Head creamy, tips of scales on vertex black. Palpus porrect, median segment slender at base, dilated by loose scales toward apex above, terminal segment moderate, spindleshaped; blackish fuscous, apical half of median segment and terminal segment except at base above, dusky creamy. Antenna infuscated, scape with creamy top; flagellum with a dark fuscous, elongate spot above apex, ciliations 1 . Thorax creamy, shoulder appearing tawny 
in certain lights, a creamy transverse antemedian streak, an oblique dark fuscous lateral streak on each side, tips of tegulae and tufts on metathorax white. Abdomen glossy whitish ochreous.

Forewing with veins 3 and 4 stalked, 8 and 9 stalked; oblong subtriangular, costa gradually curved throughout, apex pointed, termen sinuate, oblique. Whitish, densely suffused with pale tawny and slightly dusted with dark fuscous; markings dark brown. Two small distant spots at base of costa connected by darker suffusion; a third, larger costal dot at $2 / 5$; three smaller, more approximated dark brown dots along third fourth of costa, and three or four suffused and faint grey dots along posterior fourth; an inwards-oblique slender transverse crest in disc beyond base; a patch of irregular dark markings and crests in posterior two-thirds of cell, becoming paler and suffused posteriorly; anterior edge of this patch formed by two small, high, semilunar transverse crests, concave outwardly, one in cell, another below cell; an irregular dark brown terminal line from apex to tornus. Cilia greyish creamy tawny.

Hindwing with veins 3 and 4 stalked; glossy ochreous white. Cilia ochreous white.

Male genitalia: Tegumen broad, cylindrical, ventrally a long curved bristly "socius-lobe" and below this another, small, narrowed "gnathos lobe". Uncus strong slender, little hooked. Saccus large, triangular. Valva with sacculus part dilated and oval, concave, to $1 / 3$, top forming a sclerotized blunt knob, separated by a split; cucullus very slender, clavate, with a moderate transverse not modified ridgelike fold at base. Aedeagus rather short, spoon-shaped, body broad, oval, concave, with a thick fringe of bristles along apical half, stalk slender.

Material examined: Mindanao, Davao Prov., east slope of Mt. McKinley, 5600 ft., 16.IX.1946 (CNHM Philippine Exped. 1946-47, H. Hoogstraal), $1 \sigma^{\top}$, holotype, genit. slide 5738; same locality, 14.IX.1946, $1 \sigma^{7}$, paratype, without abdomen.

\section{Meridarchis oxydelta, new species}

Figures 138, 143, 581

Female, $24.5 \mathrm{~mm}$. Head creamy white. Antenna brown, scape mixed with creamy white. Palpus long, subascending along basal half, porrected posteriorly; dark brown, less than apical half of median segment creamy white, sprinkled with dark brown, terminal segment creamy, slightly sprinkled with brown, flattened laterally, obtuse, oval. Thorax creamy, in center and along edge slightly suffused with brownish. Abdomen creamy, laterally dark brown by more or less confluent dark brown transverse stripes.

Forewing oblong, rather narrow, moderately dilated, costa gently curved at base, little curved posteriorly, apex pointed and produced, 
termen strongly sinuate, rounded below, moderately oblique. Creamy white, anteriorly tinged deeper, pale tawny. Basal fourth of costa with a dark brown streak, at posterior extremity emitting a more or less continuous but ill-defined inwards-oblique transverse shade; more than median half of costa occupied by a brown triangular patch, its anterior edge with a rounded projection along its median part, posterior edge with a smaller rounded projection, limited above and beneath by a small triangular incision; this brown patch including dark brown, almost blackish markings: moderate costal spots on its extremities, two costal dots beyond its middle, and a broad longitudinal streak in cell; point of triangle acutely attenuated and narrowly continued almost to $4 / 5$ of dorsum; a round black spot on costa well before apex; a suffused fuscous spot before apex; a series of small irregular dark brown marks along fold; edge of wing along posterior part of costa and along termen suffused with light fulvous, the suffusion extending along posterior parts of terminal veins; an irregular dark grey subterminal suffusion, forming a more or less interrupted transverse band from well below the costal subapical spot. Cilia pale greyish tawny creamy with a light tawny median line and a few brown specks opposite tornus.

Hindwing creamy whitish with a strong slivery gloss, cilia dull creamy.

Female genitalia: Genital segment sclerotized, conical. Sterigma formed by two cup-shaped and aciculate deep folds, one on each side; these folds, when expanded, apparently form a large vesicular prominence. Colliculum long, strong, tubular, with a finely reticulate wall; top of colliculum tube projecting, its lower edge straight, upper edge trapezoidal; a strong and narrow ventral split with thickened and corrugate edges, ending caudally in a free pointed process. Ductus bursae and upper part of corpus bursae pustulate. Signa absent.

Material examined: Luzon, Subprov. Benguet, Haights Place, Pauai, 7000 ft., 30.XI.1912 (A.E. Wileman), 1 o, holotype, genit. slide 5750 (Rothschild bequest, BM).

A distinct species, the true affinity of which, however, cannot be ascertained without the males being known.

\section{Meridarchis scythophyes, new species}

Figures 139-140, 582

Female, $21 \mathrm{~mm}$. Head white, sprinkled with vinaceous brown. Antenna brownish vinaceous, striped with white above, white beneath. Palpus long, porrect, median and terminal segments gently curved downwards, flattened laterally, median segment moderately broad, broadest in middle, terminal segment gently narrowed, obtuse. 
Thorax brownish vinaceous, with faint and suffused whitish markings: a large circle in middle, touching sides and emitting a single longitudinal streak anteriorly, a pair of such streaks posteriorly. Abdomen pale fuscous greyish.

Forewing oblong, pointed, moderately dilated, broadest in tornus, costa little curved anteriorly, gently prominent at $1 / 2$ and $2 / 3$, apex produced and pointed, termen sinuate, strongly oblique. Glossy white, densely strewn with vinaceous tawny; markings vinaceous tawny and dark brown. Basal patch vinaceous brown, on costa extending to $1 / 5$, on dorsum to $1 / 3$ (in middle rubbed); an invertedtrapezoidal patch occupying rather more than median third of costa, almost reaching lower edge of cell, paler along costa and bearing four dark brown elongate costal spots, one on anterior extremity, and three equidistant, along posterior half; upper half of patch below costa light tawny, lower half dark brown; lower angle of cell with an extension of patch, emitting an acute, sickle-shaped, almost vertical streak to dorsum beyond $2 / 3$; an elongate spot of dark grey dusting on costa before apex, posteriorly traversing wing to termen below apex; apex strewn with light tawny; a vinaceous-brownish transverse suffused band from below costa to tornus, slightly concave posteriorly; a vinaceous terminal line with triangular spots on ends of veins; terminal veins themselves paler tawny. Cilia creamy greyish, a broad but faint interrupted band along lower $2 / 3$, except light bases, cilia on costa strewn with grey.

Hindwing greyish white, with a vinaceous-purplish gloss, cilia concolorous.

Female genitalia: Ninth segment broadly conical and sclerotized. Sterigma formed by a subquadrate, coarsely punctulate plate. Lamella antevaginalis, a triangular, weak sclerite. Colliculum broad, cylindrical, narrowed along lower half, wall finely punctulate. Signa rather short, prongs finely dentate along edges.

Material examined: Mindanao, Davao Prov., east slope of Mt. McKinley, 7200 ft., 10.IX.1946 (CNHM Philippine Exped. 1946-47, H. Hoogstraal), 1 \% genit. slide 5737.

\section{Heterogymna Meyrick, 1913}

\section{Heterogymna melanocrypta, new species}

Figures 126, 575-576

Male, $20 \mathrm{~mm}$. Head and thorax silvery white, shoulder with a black spot. Antenna white, ciliations about 5. Palpus rather short, median segment moderately dilated in middle, terminal segment short, obtuse, black, posterior halves of median and terminal segments white. Abdomen white. 
Forewing suboval, broadest at $1 / 3$, costa rather curved anteriorly, less so posteriorly, apex tolerably pointed, termen gently curved, oblique. Silvery white, with a distinct purple gloss, markings black. Extreme edge of base of costa black; two small round spots, on base of costa and beyond base just below costa, respectively; a narrow elongate spot below these, above middle of disc; a large semioval spot beyond preceding, just above cell, at $1 / 3$ of wing; three very faint equidistant dots along posterior $2 / 5$ of costa; three round dots in a straight, inwardly oblique row across middle of disc, the lower pair approximated, just above and below middle of fold, third on upper edge of cell; a pair of round dots on each upper and lower angle of cell; a less regular dot before middle of termen. Cilia white. Underside of wing light fuscous grey, with a large elongate-oval patch of modified very short black scales edged narrowly by naked area; this patch extending halfway above, halfway inside cell, from beyond base to middle of wing.

Hindwing glossy white, with a faint yellowish tinge, towards apex becoming very pale purplish. Costa with an elongate-oval dilatation, forming a shallow pocket along its basal half, concave and filled with very dense short whitish-ochreous scales. In repose this pocket apparently fits exactly over the patch of modified scales on the under side of the forewing. Cilia concolorous.

Male genitalia: Tegumen broad and rounded, with a prominence on top, flanked by small folds. Uncus present, hooked, slender and curved down, top bifid. Socius, a semioval, aciculate lobe. Valva with basal half rigid and moderately broad, sacculus not modified anteriorly, posteriorly forming a slender, free curved process. Cucullus under $1 / 2$, oval and hairy, with a constricted and keeled base, bearing below two slender teeth. Aedeagus small, slender, top dilated and submembranous, base narrower, spoon-shaped, curved.

Material examined: Mindanao, Davao Prov., east slope of Mt. McKinley, 5600 ft. 25-27.VIII.1946 (CNHM Philippine Exped. 1946-47, H. Hoogstraal), $1 \sigma^{7}$, holotype, genit. slide 5739.

An interesting form, showing well-developed and complicated scent organs between wings; however, these manifest sexual dimorphy and are only of specific, not of generic importance. Therefore, I prefer to include the present species in Heterogymna Meyrick, 1913.

Remotely allied with $H$. chorospila Meyrick, from India and Java.

\section{Copromorphidae}

\section{Copromorpha Meyrick, 1886}

Copromorpha Meyrick, 1886, Trans. Roy. Ent. Soc. London, p. 281; 1905, Journ. Bombay Nat. Hist. Soc., vol. 16, p. 106.-Fletcher, 1929, Mem. Dept. 
Agric. India, Ent. ser., vol. 11, p. 55 (Trychnostola syn.).-Clarke, 1955,

Catalogue . . Microlepidoptera . . Meyrick, vol. 2, p. 516.

Trychnostola Turner, 1916, Trans. Roy. Soc. South Australia, vol. 40, p. 502 (type species: lichenitis Turner).

\section{Type species: Copromorpha gypsota Meyrick, 1886 (Fiji).}

Since apparently a very old group of the Lepidoptera is concerned, variability of the genital structures may be expected. This variation, however, in the males at least, is so great that at present the genus Copromorpha seems to be heterogeneous. There are forms with simple, bifid or trifid valvae, with simple or furcate uncus. Our present knowledge of the group is not sufficient, though, for a subgeneric division of the known species - unless almost every species of which males are available be indicated as a type of a new subgenus; this would hardly be natural. Discovery of additional material will eventually bring a solution to this problem.

\section{Key to the Asiatic Species of Copromorpha}

1. Ground color of forewing dark reddish grey or fuscous . . . . . . . . 2 Ground color of forewing yellowish green, olive green or fuscous olive green . . . . . . . . . . . . . . . . . . . . . 3

Ground color of forewing light, whitish ochreous or pale grey, without any olive or green tinge . . . . . . . . . . . . . . . . . . . . . 5

Ground color of forewing pure white, slightly dusted and further marbled dark fuscous. . . . . . . . . . . C. mistharnis, new species

2. Forewing dark reddish grey, with rows of whitish dots, edged with fuscous posteriorly (Fiji) . . . . . . . . . . . . . . C. pyrrhoscia

Forewing fuscous (dark fuscous scales with light bases), with about seven series of ochreous-yellow tufts, edged fuscous and metallic purple (Ceylon).

C. efflorescens

3. Forewing rather dark fuscous olive green, with several emerald green metallic, narrow, transverse streaks; smaller species, $14.5 \mathrm{~mm}$.

C. smaragdarcha, new species

Forewing light yellowish green with dark markings; larger species, 24-27 $\mathrm{mm}$. . . . . . . . . . . . . . . . . . . . . . . 4

4. Uncus, a long and slender hook; transtilla unarmed, inverted-cardiform (Java).

C. phytochroa

Uncus shorter, top arrowhead-shaped; transtilla with two sclerotized lateral spines (Borneo) . . . . . . . . . . . . . . . C. bryanthes

5. Forewing only with a blackish-fuscous large spot on base of costa, mixed with emerald-green scales . . . . . . . C. dialithoma, new species

Forewing without a basal patch or with a basal patch and other markings . . . . . . . . . . . . . . . . . . . . . . . 6

6. Forewing with distinct spots or blotches in disc . . . . . . . . . . . 7

Forewing without dark discal markings, whitish ochreous, with numerous yellowish scale tufts, edged fuscous and metallic purple (Ceylon).

\section{C. metallitis}

7. Large markings only costal, along anterior, or along anterior and posterior parts of costa. . . . . . . . . . . . . . . . . . . . . . 8

Large markings either only in disc or only along posterior part of costa . 9 
8. A subrectangular transverse blotch on costa at $3 / 4$, a broad terminal band; ground color whitish ochreous (New Guinea) . . . . C. lignisquama

No large blotches along posterior part of costa, no terminal band. Ground color white (Fiji) . . . . . . . . . . . . . . . . . . . . C. gypsota

9. More than one larger dark spot in disc . . . . . . . . . . . . . . . 10

Only one larger dark patch or suffusion in disc . . . . . . . . . . . 11

10. Some four discal spots of diverse size; very large species $(36 \mathrm{~mm})$ (Solomon Is.) . . . . . . . . . . . . . . . . . . . . . . . . C. tetrarcha

About 16 raised big scale tufts, edged with whitish and with metallic violet. A species of moderate size (16-18 mm) (India) . . . . . C. myrmecias

11. Small dark fuscous or blackish irregular dots along costa in 2-3 transverse rows beyond cell and raised tufts along edges of cell . . . . . . . . 12

No raised dark tufts along edges of cell . . . . . . . . . . . . . . 13

12. Transtilla circular, with two pairs of sclerotized or spined cusps (Assam).

C. pleurophanes

Transtilla, two semicordiform plates, with only one pair of sclerotizations (Java) .

C. roepkei

13. An invert-trapezoidal well-defined dark patch in center of disc, a dark streak along basal third of dorsum (New Ireland) . . . . . . . C. nesographa

Discal patch irregular, no dorsal streak . . . . . . . . . . . . . . . 14

14. Antenna in both sexes lamellate (Solomon Is.) . . . . . . C. thrombota Antenna in $\sigma^{\top}$ unipectinate $\left(2 \frac{1}{2}\right)$, in $q$ stout, serrulate (New Guinea).

C. narcodes

\section{Copromorpha smaragdarcha, new species}

Figures 137, 572

Male, $14.5 \mathrm{~mm}$. Head light ochreous. Antenna light ochreous, banded with brown above (imperfect). Palpus with median segment roughly edged below, terminal segment over $1 / 2$; dark fuscous olive, median segment with a light ochreous apical ring, terminal segment whitish, with a dark fuscous-olive median ring. Thorax olive, paler at apex (abdomen mounted).

Forewing ovate-subtruncate, dilated, broadest at $2 / 3$, costa little curved at extreme base, straight along $2 / 3$, gently angulate and prominent at that point, last third slightly slanting but little curved, apex broadly rounded, termen rounded, vertical. Greenish olive, indistinctly spotted and clouded with fuscous-green tinge, more distinct in certain lights; indication of raised tufts of scales, especially along the closing vein; posterior fourth of wing less olive, more fuscousbrown tinged; costa with a suffused dark olive-green-fuscous streak, becoming paler posteriorly; four small subtriangular white spots along posterior third of costa, first of these ill defined; seven or eight slender unequally spaced, undulating transverse streaks of shining emerald green and prismatic scales, irregular, partially obliterate, some of them interconnected; small tufts of blackish-fuscous scales on veins, forming an irregular somewhat zigzag transverse band halfway between cell and termen. Cilia dull dark greyish fuscous with little contrasting basal, postmedian, and subapical fuscous-olive lines. 
Hindwing glossy, fuscous bronze, tinged orange between veins $1 \mathrm{~b}$ and 2 , basal half of costa glossy whitish. Cilia fuscous bronze with a pale basal line.

Male genitalia: Uncus long, slender, pointed and smooth, bent down. Vinculum quadrate. Transtilla, a large urn-shaped sclerite with a long neck. Sacculus ending in a triangular process, hairy along the lower edge. Cucullus long and slender with a rounded top. Aedeagus long, straight, with a truncate top. There is a slender longitudinal, little sclerotized rod along the entire length of the aedeagus.

Material examined: Luzon, Los Baños, XII.1930, in Ficus endothrix figs, o plant, $2 \sigma^{7}$ : holotype, genit. slide "A.B. Oct. 11, 1926," paratype (head missing), genit. slide "A.B. Oct. 12, 1926” (USNM).

\section{Copromorpha dialithoma, new species}

\section{Figures 145, 573}

Male, $13 \mathrm{~mm}$. Head glossy white touched with ochreous, vertex pale ochreous. Antenna with scape and base of flagellum white, remaining part dark fuscous. Palpus rather long, curved and ascending, white, touched with ochreous. Thorax olive, suffused with dark fuscous, anterior edge and the large apical tuft glossy white touched with ochreous. Abdomen light fuscous, sides and anal tuft fuscous ochreous with a strong golden gloss, venter pale ochreous.

Forewing (left wing missing) suboval, costa distinctly curved and prominent beyond base and at $3 / 4$, gently concave in middle, apex broadly rounded and indefinite, termen rounded, almost vertical; veins raised, with small tufts of scales along them. Rather bright golden olive ochreous, slightly suffused with purplish fuscous and scattered with sparse brilliant green scales here and there; a patch of blackish-fuscous suffusion on basal fourth of costa extending almost to middle of wing breadth, containing a spot of brilliant shining green scales on base of costa; lower edge of patch indefinite, posterior edge preceded by two large raised scale tufts, upper of these centered with olive ochreous. Posterior third of wing, semipellucent, dull pale fuscous, darker fuscous along veins, without any ochreous or olive tinge. Cilia (imperfect) pale ochreous, slightly infuscated along their middle.

Hindwing semipellucent, fuscous, veins dark fuscous; an elongated patch of thickened and modified golden-ochreous scales along basal third of costa from beyond base (upperside), middle of costa as far as cell, pale ochreous. Cilia fuscous with a whitish basal line.

Male genitalia: Tegumen subspherical. Uncus, a long scythelike hook, bent down. Gnathos represented by a strong tooth at each side of the base of uncus. Vinculum slender, V-shaped, separated 
in two at base. Valva narrow, cucullus part with a submembranous costal part and a sclerotized slender ventral part ending in a long point, sacculus well defined, ending in a free process with a triangular point. Transtilla, a subquadrate, simple sclerite, with a thickened center. Aedeagus rather long, with a longitudinal median undulate sclerotization, slightly dilated apicad and with three differently shaped points. Intersegmental membrane between the 8 th segment and the genitalia with deep pockets at the sides, containing a long and slender pencil-like corema.

Material examined: Luzon, Los Baños (Baker), 1 ๙ $\sigma^{7}$, holotype, genit. slide 5141 (USNM).

\section{Copromorpha mistharnis, new species}

Figures 135, 570

Female, $18 \mathrm{~mm}$. Head whitish ochreous, collar slightly suffused with grey. Palpus dark fuscous, median segment with a broad whitish apical band. Antenna posteriorly flattened laterally; fuscous, finely ringed with whitish ochreous. Thorax whitish ochreous, suffused with grey, strongly mixed grey towards apex. Abdomen pale fuscous.

Forewing rather narrow, elongate-ovate, dilated, apex rounded, termen strongly convex. Ochreous white, markings dark fuscous. Costa with some five elongate spots, first spot ill defined, other becoming less flattened but shorter posteriorly, last spot small, preapical; numerous fine transverse strigulae and points scattered over wing; larger markings formed by very slender transverse strigulae arranged close together; these larger markings are, a round spot in middle of wing beyond base; an elongate spot between veins 11 and 12 at 1/4 of wing; some fine strigulation giving rise to an ill-defined triangular patch on dorsum extending to upper edge of cell, anterior edge obliterate, posterior accentuated by two raised dark fuscous tufts, one on each upper and lower angles of cell, indistinctly extended basad as short streaks; posterior third of wing with some three irregular transverse series of dark dots on veins, more or less interconnected in each series and sometimes across one to another series, by minute transverse strigulae; a similar series of irregular dark spots along terminal edge. Cilia whitish ochreous, except along base, with suffused broad light grey bars.

Hindwing pale grey, with purple gloss in certain lights, semipellucent. Cilia dull pale grey.

Female genitalia: The eighth and the ninth ventrites moderately specialized. Sterigma simple, lamella antevaginalis, a moderate, W-shaped band, lamella postvaginalis, a small trapezoidal tumescense. Ventral pair of lobes of the eighth sternite strong, with a row of long 
bristles along the caudal edges; ninth segment strongly elongate, a membranous spheroidal aciculate fold ventrally. Apophyses long. Ductus bursae rather wide and long. Bursa copulatrix elongate, punctulate, with a curved patch of verrucose structures, without signa.

Material examined: Luzon, Mt. Makiling (Baker), 1 \%, holotype, genit. slide 5024 (USNM).

\section{Xyloryctidae}

\section{Key to the Philippine Genera of Xyloryctidae}

1. Hindwing $1 \frac{1}{2}$ times as broad as forewing . . . . . . Thymiatris Hindwing not so much broader than forewing . . . . . . . . . . 2

2. Gnathos absent (except in brachyclista); uncus, a slender, porrect beak; tegumen seemingly truncate . . . . . . . . . . . . Odites Gnathos present ......................... . . 3

3. Harpe, a characteristic, crescentic raised crest, beset with spines; uncus truncate, broad, and bidentate........... Metathrinca

Harpe, a toothed blade; uncus bifid . . . . . . . . . . Amorbaea

\section{Thymiatris Meyrick, 1907}

Thymiatris Meyrick, 1907, Journ. Bombay Nat. Hist. Soc., vol. 17, p. 738.Fletcher, 1929, Mem. Dept. Agric. India, Ent. ser., vol. 11, p. 222.-Clarke, 1955, Catalogue . . Microlepidoptera . . Meyrick, vol. 2, p. 502, pl. 250, figs. 1-1d (wings, head, neuration, genit.).

Type species: Thymiatris melitacma Meyrick, 1907 (Assam).

Although gigantic forms of the family Xyloryctidae are confined to the Australian and Papuan regions, the large representatives of the present genus form an exception, occurring throughout the Malay Archipelago as far westward as Assam. According to Meyrick, these regions were inhabited by a single wide-spread species, Thymiatris melitacma Meyrick, originally described from the Khasi Hills, Assam. It appears to me now, however, that the material from the Philippine Islands belongs to a closely allied but distinct species differing not only in minor characters of the male genitalia, but also, and surprisingly, by certain superficial features. The description of the genus, therefore, needs to be extended as follows.

Labial palpus with median segment rather smooth, terminal segment slightly over $1 / 2$. Forewing sometimes with veins 4 and 5 separate (in the type species these veins are stalked, a fact not mentioned in the original description), vein 9 separate.

\section{Thymiatris arista, new species}

Figures 156, 583

Male, $40 \mathrm{~mm}$. Head light ochreous. Antenna glossy tawny ochreous, ciliations 1, scape light ochreous. Palpus light ochreous, 
median segment mixed with dark fuscous on basal half above, with some minute dark fuscous specks elsewhere; terminal segment over 1/2. Thorax white sprinkled with dark brown, especially along outer edges of tegulae, anterior edge dark brown, sometimes a dark brown spot below center, collar light ochreous. Abdomen white, posterior edges of segments strongly mixed with fuscous, basal tergite pale grey, third tergite shining golden yellow mixed with dull light fuscous, anal tuft light ochreous, venter light ochreous with a fuscous median streak.

Forewing elongate-truncate, long and narrow, dilated, broadest at termen; veins 3 and 4 , and vein 9 separate. Costa almost straight throughout, gently concave in middle, apex rounded, termen little rounded, slightly oblique. White, costa as far as upper edge of cell irregularly suffused with dark brown, this color extending toward base to fold, but interrupted by white irregular suffusion between veins above cell; all veins on lower $2 / 3$ of disc marked by series of dark brown scales; a dark brown streak along closing vein; dark brown scales rather regularly scattered over dorsal part of wing; rather broad transverse and inwardly oblique subterminal fascia of dark fuscous suffusion, more or less interrupted between veins, from costa before apex; another such fascia, from the same point of costa, but gradually diverging with the first, curved outwards, below running along termen, formed by a series of more or less interconnected round spots; posterior fourth or third of costa, apex, and termen beyond preceding fascia tawny ochreous. Cilia with basal third white, edged by a dark brown interrupted band, cilia beyond this band dull light, fuscous brownish.

Hindwing glossy pale greyish bronze, slightly infuscated along edge. Cilia concolorous with a narrow whitish base, which is edged by a broadly interrupted dark brown line.

Male genitalia similar to those of Thymiatris melitacma Meyrick from Assam, but differing as follows. Anellus tube wider but hardly half as long as in that species. Hook of the harpe thicker and more curved towards apex. Sclerotized processus basalis (articulations of the legs of vinculum) larger. Valva broader, cucullus more rounded, costa being distinctly more convex.

Material examined: Luzon, Mt. Makiling (Baker), 1 व , holotype, genit. slide $5156 ; 8 \sigma^{\top}$ paratypes, from the same locality. $9 \sigma^{\top 7}$ (USNM). Closely related to T. melitacma Meyrick, from Assam.

\section{Amorbaea Meyrick, 1908}

Amorbaea Meyrick, 1908, Journ. Bombay Nat. Hist. Soc., vol. 18, p. 627.Clarke, 1955, Catalogue . . Microlepidoptera . . Meyrick, vol. 2, p. 413, pl. 205, figs. 1-1f. 
Type species: Amorbaea hepatica Meyrick, 1908, India.

Recently the genus has been removed from the synonymy of Ptochoryctis Meyrick by Clarke because of slight differences in venation. There was only one species, the males of which were not yet known. Now the following species proved to belong here. The male (subtusvena) appears to have vein 8 not connected with the upper edge of cell in the hindwing by an oblique bar, but fused with it toward base, which somewhat resembles the situation in certain Noctuidae (Phalaenidae). This venation proves that Amorbaea is indeed very close to Ptochoryctis; however, the male genitalia are quite distinct from any other genus in the family.

Male genitalia: Uncus strongly sclerotized, bifid, two robust hooks. Vinculum long, erected. Valva sclerotized throughout, except extreme top of cucullus, strongly narrowed, costa concave; harpe, a longitudinal toothed blade. Sacculus broad at base, with a prominence beyond middle of upper edge. Anellus tubular, curved, strongly narrowed. Aedeagus one third longer than anellus, slender.

\section{Key to the Philippine Species of Amorbaea}

1. Head and thorax snow white; genital segment in female with caudal edge slightly emarginate, rostral edge rounded . . A. subtusvena, new species

Head and thorax creamy colored; caudal edge of genital segment in female deeply emarginate, rostral edge with two submedian emarginations.

A. subusta, new species

\section{Amorbaea subtusvena, new species}

Figures 149, 157, 584, 807

Male, $22 \mathrm{~mm}$. Head, palpus and thorax snow white. Antenna white above, flattened dorsoventrally, long-bipectinated, pectinations unequal, outer 2, inner 4, black, ciliations white. Abdomen glossy white, bands of bristles coppery, except narrow white posterior edges of segments.

Forewing glossy white, veins thickened, raised, dull white. Costa moderately curved at base, more so towards apex, apex obtusely pointed, termen little curved, oblique. Cilia glossy white.

Underside of wing sordid white, veins fuscous golden, becoming bronze grey in certain lights, terminal edge suffused with the same color.

Hindwing glossy white, veins yellowish tinged, underside as in forewing but less distinctly so, except lower edge of cell and veins 2-4. Cilia white.

Female, 23-27 mm. Similar to male, but forewing faintly touched throughout with yellowish golden, more so along dorsum. Underside denser suffused throughout with fuscous bronze. 
Hindwing as in male, but veins touched more clearly with golden yellowish, becoming darker in certain lights. Underside as in male.

Male genitalia as described with the genus.

Female genitalia: Eighth segment rather sclerotized throughout, upper edge of ventrite emarginate in middle, on both sides of this, a narrow strong ridge. Ostium bursae connected with emargination by a shallow impression, moderate, less than inner half formed by the sternite. Lower edge of the 8th segment normal. Signum, a strong transverse rhomboidal sclerite with serrulate edge.

Material examined: Luzon, Mt. Makiling (Baker), $1 \sigma^{x}$, holotype, genit. slide 5147, 1 ㅇ, allotype, genit. slide 5148 (USNM).

\section{Amorbaea subusta, new species}

Figures 151-152, 585

Female, $25 \mathrm{~mm}$. Head, palpus, thorax cream color. Antenna pale bronze fuscous. Abdomen glossy yellowish white, bands of bristles coppery, concealed by white scales.

Forewing suboval, slightly dilated, costa moderately curved toward extremities, apex obtusely pointed, termen straight, oblique. Creamy, with a golden gloss, becoming slightly deeper colored towards base, more so along dorsum below fold; very narrow blackish-grey suffusion along dorsum around its middle; sparse sprinkling of dark grey-fuscous scales above end of fold, sparsely extended to middle of wing breadth. Cilia white, tipped with grey.

Hindwing glossy white with a strong golden gloss. Cilia glossy silvery white.

Female genitalia: Eighth segment moderately sclerotized, upper edge broader emarginated than in Amorbaea subtusvena, lateral ridges situated inside this emargination; lower edge of sternite twice strongly emarginate, a spheroidal tumescence of intersegmental membrane in each emargination. Ostium bursae narrowly erected, almost marginal, without a furrow to the caudal edge of sternite. Signum smaller.

Material examined: Luzon, Mt. Makiling (Baker), 1 o, holotype, genit. slide 5149 (USNM). Related to the preceding species.

\section{Metathrinca Meyrick, 1908}

Metathrinca Meyrick, 1908, Journ. Bombay Nat. Hist. Soc., vol. 18, p. 625.Fletcher, 1929, Mem. Dept. Agric. India, Ent. ser., vol. 11, p. 138.-Clarke, 1955, Catalogue ... Microlepidoptera ... Meyrick, vol. 2, p. 445, pl. 221, figs. 1-1d (wings, neuration, head, genit. $\sigma^{7}$ ).

Type species: Metathrinca ancistrias Meyrick, 1908, Ceylon.

The genus has been based chiefly on the neuration. Although the neuration of the following species varies slightly and is not congruent with that of the type species, the genitalia of both sexes and the entire 
facies show that all belong to the same natural group. Therefore, I prefer to include them in Metathrinca, after a slight extension of the concept of this genus, instead of erecting a new genus which would be borne by the neuration alone, but not by the genital characters.

Antenna long-pectinate in male, pectinations biciliate.

Forewing with vein 2 from well before angle of cell or absent, veins 3 and 4 stalked from angle, 5 closely approximated at base, slightly converging with 6 posteriorly, closing vein between these veins absent or very weak, 7 and 8 stalked, 7 to termen or costa, 9 absent.

Male genitalia with tegumen moderate, uncus of diverse width, bicornute, gnathos strong, porrected, hook sometimes scobinate. Valva elongate or rounded, sacculus ending in a curved harpe, being a process of diverse length, appressed to disc of valva and bristled along inner edge. Anellus tubular, dilated at base.

Female genitalia little differentiated. The eighth segment more or less sclerotized and bristled, with diversely shaped caudal and rostral edges which provide specific differences. Signum, a transverse, concave sclerite with denticulate edges.

\section{Key to the Philippine Species of Metathrinca}

1. Palpus with median segment pure white . . . M. coenophyes, new species Palpus white, but appearing blackish or blue in certain lights . . . . . . 2

2. Palpus white, in certain lights luminescent blue.

M. iridostoma, new species

Palpus white, in certain lights appearing blackish . . . . . . . . . . . 3

3. Median segment of palpus far exceeding base of antenna, terminal segment half median .

M. sinumbra, new species

Median segment of palpus just exceeding base of antenna, terminal segment longer than half median . . . . . . . . M. pernivis, new species

\section{Metathrinca iridostoma, new species}

Figures 154-155, 159, 586

Male, 17-18 mm.; female, 16-17 mm. Head and thorax glossy snow white. Antenna in male thickened, white, pectinations black, $2 \frac{1}{2}$, in female white, slender, minutely ciliated. Palpus in male with basal and median segments strongly iridescent violet blue, greyish or completely white in certain lights, apical segment under 1, pure white; palpus in female longer and more slender; median segment iridescent grey. Abdomen glossy white, tergites with bands of spines showing through, fuscous golden.

Forewing with vein 2 present, vein 7 to termen; with costa gently curved along basal fourth and towards apex, hardly concave in middle, apex tolerably pointed, termen straight, moderately oblique. Snow white, with a silky gloss; basal fourth of costa with a narrow marginal fuscous line. Cilia white. 
Hindwing glossy silvery white. Cilia snow white.

Male genitalia: Sclerotized throughout. Tegumen gently narrowed below top. Uncus dilated apicad, bicornute. Gnathos strong, point scobinate. Vinculum rather long, triangular. Valva with a very broad, concave sacculus; harpe, an almost circular process, reaching costal edge, with a series of strong spines along the upper half of anterior edge. Anellus tube almost as long as the aedeagus, which has an annular, sclerotized top with a recurved subapical tooth.

Female genitalia: Eighth sternite sclerotized, well defined. Ostium bursae and bursa copulatrix caliciform, equally sclerotized, appressed to that sternite, ostium large. Ostium bursae with median portion minutely punctulate. Signum normal, a rhomboidal sclerite.

Material examined: Luzon, Mt. Makiling (Baker), 1 o , holotype, genit. slide 5146, 4 o paratypes; 1 ㅇ, allotype, genit. slide 5162, 2 ㅇ, paratypes. $5 \sigma^{x}, 3$ 우 (USNM). Oriental Negros, Dumaguete, 390 m, 26.VI.1958, 1 व (H.E. Milliron) (BMH).

\section{Metathrinca pernivis, new species}

Figures 144, 589

Male, $12 \mathrm{~mm}$. Head and thorax snow white. Antenna black; bipectinate, pectinations with short white cilia; outer pectinations 2, inner partly, 3. Palpus long, recurved, median segment rather slender, well exceeding base of antenna, black, covered with minute white scales, appearing dark grey or white in certain lights; terminal segment $2 / 3$ of median, more slender, white, appearing grey in certain lights. Abdomen white, costa narrow, posterior submarginal bands of orange-ferruginous spines.

Forewing obliquely oval, moderately broad, little dilated, costa gently curved at base, straight in middle, more curved before apex, apex rounded, termen little rounded, rather oblique. Glossy snow white. Cilia concolorous.

Hindwing and cilia glossy snow white.

Male genitalia: Resembling those of Metathrinca iridostoma, new species, closely, but with valva longer, more truncate, top of cucullus shorter, harpe longer and less curved, with slightly shorter bristles; instead of a hairy knob in the center of valva there is a dark, loose, triangular sclerotized lobe.

Material examined: Mindanao, Davao Prov., Maco, Tagum, sea level, 9.X.1946, at light (CNHM Philippine Exped. 1946-47, H. Hoogstraal), $1 \sigma^{7}$, holotype, genit. slide 5756. Closely allied with $M$. iridostoma, new species, but with the palpus slightly longer, median segment distinctly longer and grey instead of iridescent blue, and with the male genitalia distinct. 


\section{Metathrinca coenophyes, new species}

Figures 147, 153, 587-588

Male, $15 \mathrm{~mm}$. Head, palpus and thorax silvery white, faintly touched with yellow. Antenna black, pectinations unequal, anterior 3 , posterior very long 6 , black, ciliations white, scape white, apical half grey. Abdomen silvery white.

Forewing with vein 2 present, 7 to termen; elongate-oval, apex rather obtuse, costa gently curved, termen convex. Glossy silvery white, costal and terminal edge from end of vein 11 as far as end of fold with a fine black line, becoming very thin and brownish along termen; the faintest trace of a fuscous line, strongly angulate in middle, from beyond $3 / 4$ of costa to tornus. Cilia silvery white, with a very fine black antemedian line. Underside of forewing rather densely irrorated with dark fuscous golden.

Hindwing silky, pure white, cilia concolorous. Underside pure white.

Male genitalia with tegumen depressed, uncus erected-triangular, rather slender, top slightly clavate, short-bicornute. Gnathos strong, triangular, longer than uncus and projecting beyond it. Valva rather narrow, weak; sacculus ill defined, under $1 / 3$, harpe short. Aedeagus slender, long and straight, pointed, without apical sclerites.

Female, $18 \mathrm{~mm}$. All white, antenna simple, black, scape white. Forewing slightly broader. A transverse line of blackish irroration, from costa beyond $3 / 4$ to tornus, strongly angulate in middle, straight above and below angulation; base of costal edge and extreme edge in apex finely black. Cilia (imperfect) white, with a minute black median line opposite apex.

Hindwing white, apex and upper half of termen slightly irrorated with dark grey, this color extending along posterior part of costa and along bases of veins, $1 / 3$ toward cell. Cilia white, a greyish submedian shadow, tips greyish.

Female genitalia: Eighth segment moderately sclerotized. Upper edge with an inverted-triangular sclerite, middle of its upper edge excised. Ostium moderate, round, situated toward lower edge. Ductus bursae weak; no signum.

Material examined: Luzon, Mt. Apo, 70B, 17.III.1945 (J.G. Franclemont), $1 \sigma^{7}$, holotype, genit. slide 5098 (CUI). Mt. Makiling (Baker), 1 \%, allotype, genit slide 5150 (USNM). Benguet Subprov., Klondyke, 800 ft., 4.IV.1912, 12.IV.1912 (A.E. Wileman), 2 व , paratypes, genit. slide 5577 (BM). 


\section{Metathrinca sinumbra, new species}

Figures 163-164, 590

Male, $18 \mathrm{~mm}$. Head, palpus, and thorax snow white; palpus rather long, sickle-shaped, terminal segment just over $1 / 2$. Antenna bipectinate, pectinations long-ciliate, inner pectinations 5 , outer 3 ; white, scaled above, pectinations blackish, cilia white. Abdomen whitish.

Forewing suboval, rather broad, costa straight in middle, apex and termen rounded. Glossy snow white, edge of costa along basal sixth very narrowly dark brown. Cilia snow white.

Hindwing and cilia snow white, thinner scaled.

Male genitalia: Tegumen sclerotized, bilobed, lobes triangular. Gnathos strong, arms dilated at base, hook broad, truncate. Valva moderate, obliquely truncate, cucullus moderately pointed. Harpe, a little curved long hook with dilated and hairy base. Anellus large, dilated before base, aedeagus little curved, cornutus a single stout spike.

Material examined: Luzon, Benguet Subprov., Klondyke, $800 \mathrm{ft}$., 22.III.1912 (A.E. Wileman), 1 ○ , holotype, genit. slide 4693 (BM). Allied to Metathrinca iridostoma, new species, but with white palpi and different genitalia. Tips of wing of the unique specimen are damaged.

\section{Odites Walsingham, 1891}

\section{Key to the Philippine Species of Odites}

1. Forewing with veins 3 and 4 stalked. . . . . . . . . O. brachyclista Forewing with veins 3 and 4 separate . . . . . . . . . . . . . . 2

2. Forewing rounded, with apex indefinite . . . . . . . . . . . . 3 Forewing pointed . . . . . . . . . . . . . . . . . . . . . 5

3. Pale creamy yellowish; discal stigma black . . . . . . . . . . . . . . 4 Pale ochreous; discal stigma orange or brownish . . . . . . O. pancyclia

4. Antennal pectinations 5, flagellum and pectinations blackish or brownish; median segment of palpus thickened, spindle-shaped; hindwing cilia dark around apex .

O. periscias

Antennal pectinations 4, flagellum and pectinations whitish, pale brownish in certain lights only; median segment of palpus less thickened, less distinctly spindle-shaped; hindwing cilia light around apex.

O. homocirrha, new species

5. Forewing with vein 8 to costa just before apex, 7 and 8 longer than their stalk . . . . . . . . . . . . . O. apicalis, new species

Forewing with vein 8 to costa well before apex, 7 and 8 as long as their stalk

6. Veins 2 and 3 in forewing connate; thorax pale ochreous.

O. perissa, new species Veins 2 and 3 remote; thorax blackish . . O. perissa atrimersa, new variety 
Odites perissa, new species

Figures 160, 165, 591

Male, 16-17 mm. Head pale ochreous. Antenna brownish ochreous with a strong golden gloss, ciliations 1, pale ochreous. Palpus pale ochreous, median segment rather thickened and spindle-shaped; with basal 2/3 dark fuscous, edge of this color slightly suffused and oblique; terminal segment brighter ochreous, very slender, as long as median. Thorax light fuscous, tegulae pale ochreous. Abdomen pale ochreous, becoming brighter yellowish ochreous posteriorly.

Forewing with veins 3 and 4 separate; vein 8 to costa well before apex, stalk of veins 7 and 8 shorter than these veins; rather narrow, gradually dilated, broadest at $5 / 6$, elongate-truncate, costa gently curved at base, more so before apex, apex obtusely pointed, termen gently concave, little oblique. Pale ochreous, costal edge brighter ochreous yellow. Markings fuscous black, slightly varying. A minute dot at extreme base, often absent; first discal stigma just before $1 / 3$, slightly elongate or rounded, seldom preceded by one or two faint points; plical stigma varying, elongate or round, larger or as large as first discal, and beyond it; second discal small, round, on closing vein (before 2/3); a faint, strongly curved series of dots halfway between cell and margin, sometimes dots below veins 10 and 6 or 6 and 7 , respectively, much larger than other dots; sometimes a few dark scales scattered above and below cell, suffused grey costal spots on ends of veins 11-9, becoming smaller posteriorly, a row of well-defined dark dots on ends of veins along termen to tornus; sometimes some irregular irroration along dorsum. Cilia pale ochreous, with an ill-defined median series of dark dots.

Hindwing whitish ochreous, with a silky gloss and faint purplish reflections, ends of veins along upper part of termen minutely dotted with dark. Cilia concolorous with a pale basal band and a faint median fuscous band.

Male genitalia: Uncus rather long. Valva considerably narrowed. Labides moderate, separated from each other, erected. Vinculum strong, inverted-trapezoidal. Juxta T-shaped, stalk subquadrate, slightly depressed, arms obliquely truncate, their edges distinct, curved. Aedeagus strongly sclerotized, top exceeding labides, narrowed, orifice broad. Cornuti, 2 to 4 strong spines.

Material examined: Luzon, Mt. Makiling (Baker), $1 \sigma^{7}$, holotype, genit. slide 5152, 4 व $\sigma^{\top}$, paratypes (genit. slides 5151, 5155). $5 \sigma^{\top}$ (USNM).

Judging from the genitalia nearest to Odites perissopis Meyrick (China), which differs by more extended markings, narrower aedeagus, and differently shaped juxta and labides. Another close species is 
O. plocamopa Meyrick (Japan), with more slender valva and the same genital differences.

\section{Odites perissa atrimersa, new variety}

FigURE 592

Male, $17 \mathrm{~mm}$. Head light yellow, sides of face blackish; forehead with a roughish tuft. Antenna with ciliations 1, white; fuscous, becoming blackish towards base, whitish towards apex, spotted laterally with pale yellow in middle, scape black. Palpus rather long, light yellow, basal two-thirds suffused with dark fuscous; terminal segment shorter than median, slender, top slightly infuscated on the dorsal side. Thorax black, posterior half dark grey, apex pale grey. Abdomen light ochreous.

Forewing with veins 3 and 4 separate; subsemipellucent, veins thickened and raised, costa hardly curved at base, little curved at apex, apex slightly rounded, termen little rounded and little oblique. Pale yellow, costal edge somewhat brighter. Base of wing with a moderate black patch, edge slightly angulate, first discal stigma moderate, elongate, well before $1 / 3$; second discal stigma larger and darker, before $2 / 3$, plical stigma small, well beyond first discal but closer to it than to second; wing beyond base sprinkled with dark scales; a faint, strongly curved series of large dots and more dense sprinkling from before $2 / 3$ below costa, to dorsum before tornus, below costa containing some three larger black dots on dorsum extended into a small patch of dark irroration; posterior fourth of costa with three marginal slender streaks, a row of distinct black dots, sometimes interconnected on ends of veins along termen. Cilia glossy yellow.

Hindwing glossy yellow whitish, a faint and narrow blackish suffusion in apex and along margin of upper third of termen. Cilia yellowish white.

Male genitalia completely similar to those of $O$. perissa, new species.

Material examined: Luzon, Mt. Makiling (Baker), $1 \sigma^{\gamma}$, holotype, genit. slide 5161, $2 \sigma^{\nwarrow}$ paratypes. $3 \sigma^{\nearrow}$ (USNM).

\section{Odites apicalis, new species}

Figures 146, 593

Male, $15 \mathrm{~mm}$. Coloring and markings very similar to those of 0 . perissa, new species. In 0 . perissa, however, veins 7 and 8 in the forewing are as long as their stalk and vein 8 terminates distinctly in costa before apex; in 0 . apicalis veins 7 and 8 are longer than their stalk, while vein 8 terminates in costa just above apex of wing.

Male genitalia are slightly different from those of perissa as follows. Vinculum broader, subquadrate. Valva shorter and broader. La- 
bides shorter and rounder. Juxta higher and larger. Anellus lobes bristled. Aedeagus wider but with smaller orifice.

Material examined: Luzon, Mt. Makiling (Baker), $1 \sigma^{7}$, holotype, genit. slide 5153 (USNM). Closely allied to the preceding species.

\section{Odites pancyclia Meyrick, 1928}

Figures 148, 594

Odites pancyclia Meyrick, 1928, Exotic Microlepidoptera, vol. 3, p. 434 ( $\sigma^{7}$, Philippine Is.).-Clarke, 1955, Catalogue . . . Microlepidoptera . . . Meyrick, vol. 1, p. 233; 1955, op. cit., vol. 2, p. 477, pl. 237, figs. 1-16.

Distribution: Philippine Is.

Antenna serrate, fasciculate-ciliated, ciliations over 1, pale ochreous, flagellum dark brown above. Forewing semipellucent, nicely glossy pale yellow, veins thickened and raised. Veins 3 and 4 separate. There is a pale orange suffused spot on end of cell (not mentioned in the original description).

Material examined: Luzon, Mt. Makiling (Baker), "20558," $31 \sigma^{7}$, genit. slides "A.B. Febr. 10, 1928" and 5158 (USNM). Only the somewhat rubbed holotype has been recorded so far.

Male genitalia of a simple type. Valva simple, with a pointed, projecting and weakly hairy top, sacculus broad, but ill defined posteriorly. Vinculum small, U-shaped. Anellus lobes moderate, slightly clavate; anellus with a ventral split.

\section{Odites periscias Meyrick, 1928}

Figures 161, 596

Odites periscias Meyrick, 1928, Exotic Microlepidoptera, vol. 3, p. 481 ( $\sigma^{7}$, Philippine Is.).-Clarke, 1955, Catalogue . . Microlepidoptera . . . Meyrick, vol. 1 , p. 241 ; 1955 , op. cit., vol. 2 , p. 481 , pl. 239, fig. 5 (wings).

Distribution: Philippine Is.

Antenna serrate; dark brown, basal fourth white above, ciliations fasciculate, 3, blackish. Forewing rather opaque, white, faintly touched with yellowish, markings black, limited usually to a round second discal stigma and a few fine scales, scattered posteriorly; occasionally there is a marginal row of dark dots in apex and along upper part of termen. Veins 3 and 4 separate.

Male genitalia: Sacculus apparently broad and large, ill defined, top truncate, over 1, ventrally ending in a narrow and hairy process; cucullus with two pointed tops, median, a short cusp, dorsal, a strong and slender, outwards-curved and pointed appendage.

Material examined: Luzon, Mt. Makiling, “20560” (Baker), 14 б", genit. slides 5159,5587 (USNM). So far a single specimen, holotype, without abdomen, has been recorded. 
Odites homocirrha, new species

Figures 162, 595

Male, 15-17 mm. Head and thorax white with the slightest ochreous tinge. Antenna pale fuscous, above white, pectinations and cilia actually colorless but the former seemingly pale fuscous in certain lights; ciliations 4 . Palpus white, terminal segment slightly shorter than median; median segment variably suffused outwardly with fuscous to dark grey. Abdomen white, slightly touched with ochreous.

Forewing oval, costa rounded, apex strongly rounded, indefinite, termen less rounded, in middle straight, almost vertical. White with a slight yellowish tinge, more distinct than in the body and head; with a silky gloss. A minute blackish second discal stigma, disappearing in rubbed specimens. Cilia concolorous.

Hindwing and cilia concolorous, slightly pellucent.

Male genitalia very similar to those of Odites periscias Meyrick, but constant in both species, genitalia of which were compared side by side, and from all directions. Uncus a trifle shorter. Process of costa distinctly shorter, less acute and less curved outwards; process of sacculus shorter, straight, more acutely pointed. Anellus lobe more slender and slightly longer. The entire genital apparatus is less robust and smaller than in periscias.

Material examined: Luzon, Benguet Subprov., Klondyke, $800 \mathrm{~m}$, 6.IV.1912, $1 \sigma^{7}$, holotype, genit. slide $5569 ; 5 \sigma^{7}$, paratypes, 10.IV3.V.1912, genit. slides 5570 and 5572. 6 व ○ $^{7}(\mathrm{BM})$.

Nearly allied to the more robust and slightly larger 0 . periscias. The slight genital differences are constant.

\section{Odites brachyclista Meyrick, 1928}

Figures 150, 599

Odites brachyclista Meyrick, 1928, Exotic Microlepidoptera, vol. 3, p. 434 ( $\sigma^{7}$, Philippine Is.).-Clarke, 1955, Catalogue . . . Microlepidoptera . . . Meyrick, vol.1, p. 66 ; 1958, op. cit., vol. 2, p. 461, pl. 229, figs. 2-2b (genit. illustr.).

Distribution: Philippine Is.

Antenna serrate, dark fuscous along posterior $2 / 3$ above, ciliations over 1, dark fuscous. Forewing semipellucent, with thickened and raised veins; glossy pale yellow, with dark brown or blackish markings and dark fuscous scales scattered over the wing. Veins 3 and 4 short-stalked.

Material examined: Luzon, Mt. Makiling, "20559” (Baker), 12 ه , genit. slides "A.B. Febr. 18, 1928" and 5160 (USNM).

Male genitalia complicated. Valva with a well-defined sacculus to $1 / 2$, top triangularly extended, crowned with a long, curved process, with a long spine on top. Cucullus divided into three parts, ventral 
with a dilated base and a few bristles, median sublanceolate, and dorsal acute. Anellus not developed. Aedeagus rather long, but weak.

\section{Timyridae}

\section{Key to the Philippine Genera of Timyridae}

1. Forewing with a subdorsal groove in $\sigma^{7}$, scaled from base to tornus; labial palpus with median segment bearing a dense projecting tuft of scales.

Frisilia

Forewing without such groove; labial palpus with median segment sometimes thickened, but if tufted, then flagellum of antenna dilated . . . . . . 2

2. Labial palpus in male sometimes strongly tufted, with an apical pencil of hairs; antenna in male with flagellum dilated, in female thickened with scales

Tisis

Not thus . . . . . . . . . . . . . . . . . . . . 3

3. Hindwing with apex strongly narrowed, forming a slender process $1 / 3$ the length of wing, termen rectangularly bent below this . . . . Placanthes

Hindwing with apical third not so much narrowed. . . . . . . . . . . 4

4. Forewing with vein 3 separate . . . . . . . . . . Homaloxestis

Forewing with vein 3 stalked with 2 or absent . . . . . . . . . . . . . 5

5. Antenna $3 / 4$. . . . . . . . . . . . . . . . Prosodarma

Antenna 1 or over 1 . . . . . . . . . . . . . . . . . . . . . . . 6

6. Head smooth, shining; posterior tibia with a more or less distinct triangular stiff tuft above wing; light yellow with bluish-leaden markings.

Canthonistis

Not thus

Lecithocera

\section{Tisis Walker, 1864}

\section{Tisis auricincta, new species}

Figures 158, 199, 598

Male, female, 21-26 mm. Head in male dark purple brown, vertex, collar and thorax light fuscous, face yellow. Antenna in male with scape slightly thickened, flagellum along basal part strongly dilated and flattened into an ellipse, thence gradually attenuated; deep purple, becoming brownish posteriorly, a white band at about $2 / 3$. Palpus in male with terminal segment very long, recurved and ending in a long expanded pencil of hairs; light yellow, pencil purple fuscous mixed with pale yellow, terminal segment outwardly and externally with a well-defined streak of brilliant metallic green silver. Head in female purple greenish, shining, face yellow. Antenna in female with scape slender, elongate and clavate, flagellum thickened with roughly appressed scales except toward tip which is slender; scape light tawny with top anthracite black, with leaden shine, flagellum anthracite black, leaden brilliant above, deep purple with green and blue reflections in certain lights, top white. Abdomen in 
male dark brown, anal tuft pale fuscous, touched with ochreous laterally; in female abdomen bronze brown. Pleurae of thorax polished brilliant black. Anterior leg in male deep purple; coxa and femur elongate, flattened; tibia with a thick, triangular flat patch of purple-metallic scales, with anthracite-greenish shine; median leg yellow at base and below, above black with brilliant greenish shine; posterior tibia and first joint of tarsus elongate, thickened with roughish, dark brown hairs, purplish in certain lights. Legs in female yellow, partly suffused with deep purplish brown, with small patches of shining scales.

Forewing oblong-suboval, rather narrow, dilated along basal third, costa curved anteriorly, less curved posteriorly (more so in male), in female slightly concave in middle, apex obtusely pointed, termen gently curved, little oblique. Deep purple, posteriorly strewn with metallic purplish scales with prismatic reflections in certain lights. Markings yellow. A slender median transverse band, slightly outwards-oblique, gently outwards-convex, gradually dilated downwards; a narrow marginal streak along posterior fifth of costa, in apex and along termen to tornus, along lower half twice as broad. Cilia dark purplish brown.

Hindwing deep bronze brown, in male costal half light grey fuscous; a narrow line of yellow dusting around apex and along termen. Cilia dark bronze brown.

Male genitalia: Tegumen moderate, appearing hexagonal. Uncus, the usual beaked hook. Valva moderately broad; costa with an elongate prominence at base; harpe, a longitudinal small ridge of denticulations below and before middle of costa. Sacculus 1/2, sclerotized, with basal third slightly prominent, top gradually narrowed. Cucullus semioval, with a smooth terminal ridge, covered with short spinules. Aedeagus large and thick, with numerous transverse folds or ridges (or cornuti?). Anellus lobes unequal, left shorter and rounded at top, right longer, sickle-shaped.

Female genitalia: Ninth segment sclerotized. Ostium wide, asymmetrical, lamella postvaginalis with small verrucose folds, lamella antevaginalis only at the right side with a narrowed dark sclerite. Ductus bursae short, coiled; corpus bursae small; signum stellate.

Material examined: Mindanao, Davao Prov., east slope of Mt. McKinley, 3000 ft., IX.1946 (CNHM Philippine Exped. 1946-47, H. Hoogstraal), 1 ơ, holotype, genit. slide 5741 ; 1 \%, allotype, genit. slide $5742 ; 1$ \% , paratype.

\section{Canthonistis Meyrick, 1922}

Canthonistis Meyrick, 1922, Zool. Meded., vol. 7, p. 82; 1925, in Wytsman, Genera Insectorum, fasc. 184, p. 212-Fletcher, 1929, Mem. Dept. Agric. India, Ent. ser., vol. 11, p. 39.-Gaede, 1937, in Bryk, Lepidopterorum 
Catalogus, pars 79 , p. 494.--Clarke, 1955, Catalogue . . Microlepidoptera . . . Meyrick, vol. 1, p 43.

Type of the genus, Canthonistis amphicarpa Meyrick, 1922 (Java). The following points may be added to the description of this genus. Head smooth, polished. Antenna over 1. Labial palpi with second joint dilated and compressed laterally, with smoothly appressed short scales. Maxillary palpi short, distinct, appressed to tongue (recorded as being rudimentary). Median tuft on posterior tibia not always distinct, appressed bristly hairs on posterior part of tibia sometimes rather raised.

Forewing with vein 1c furcate at base (recorded as being simple). Vein 11 originates just before the middle of cell.

Male genitalia of the general Lecithocera type but with complicated uncus, the hooked part being subapical. Anellus has two long and slender, twice bent and sclerotized lobes. Cornuti, two clusters of small spines and one slender spine.

Female genitalia: Ovipositor short. Sterigma with a small lamella antevaginalis and large lamella postvaginalis, occupying the entire sternite. Signum, a transverse denticulate plate.

\section{Key to the Species of Canthonistis}

1. Forewing bright ochreous, purplish central part hardly divided by a very faint median transverse streak of ground color; $16-18 \mathrm{~mm}$.

C. xestocephala, new species

Forewing yellow, purplish central part distinctly divided from costa almost to dorsum by an inverted-trapezoidal patch; 15-16 mm (Java).

C. amphicarpa

\section{Canthonistis xestocephala, new species}

Figures 191, 193, 597

Male, 15-17 mm. Head bright yellow, vertex covered with a dense cap of closely appressed scales, polished, brightly shining, yellowish grey mercury. Face pale yellow. Palpus, antenna and thorax bright yellow, tip of antenna pale tawny. Abdomen sordid pale fuscous yellow, venter brighter yellow, a lateral stripe fuscous.

Forewing elongate, costa moderately curved at extremities, gently concave in middle, apex pointed, termen gently rounded, oblique. Bright yellow. Two large purplish-fuscous patches, rounded and almost entirely confluent except above, extending along dorsum beyond base to tornus and filling out the whole wing; anterior blotch almost reaching costa, posterior not reaching it. Cilia bright yellow, in tornus purple fuscous.

Hindwing glossy light yellowish fuscous, apex pale yellow. Cilia pale fuscous, becoming pale yellow along upper half of termen, around apex and along costa. 
Male genitalia: Uncus cubical, with small apical clavate process, below and ventrad of this a semicircular bow and in front of this the usual hook. Anellus large with sclerotized edges, forming on top long processes, bent twice. Valva moderately long and slender, curved upwards and finely haired along posterior half.

Female genitalia: Lamella antevaginalis half-cup-shaped, with a deep frontal excision. Signum moderate, transverse, finely denticulate.

Material examined: Luzon, Benguet Subprov., Baguio (Baker), $1 \sigma^{7}$, holotype, genit. slide 5234; 1 ㅇ allotype, genit. slide 5235; $1 \sigma^{7}$, paratype (USNM). Same locality, 1.VI.1945 (J.G. Franclemont), $1 \sigma^{\top}$, paratype (abdomen missing, right antenna intact) (CUI). Total $3 \sigma^{7}, 1$ ㅇ. One specimen was named "Canthonistis amphicarpa Meyrick," apparently by Meyrick himself; however, this Javanese species has never been recorded from the Philippine Islands. I am now satisfied that the species is distinct, although closely related with amphicarpa.

The male genitalia are less robust than those of the Javanese species and differ also slightly but distinctly as follows. The cucullus is more slender and stronger curved. The vinculum is less sclerotized, inverted-subtrapezoidal (in amphicarpa triangular and pointed). The juxta is weaker, slightly narrower, its lobes more slender and less sclerotized. The gnathos hook is larger, its stalk not narrowed at base. The aedeagus with cornuti forming three slender, pointed sheafs (in amphicarpa one slender and long and two thick pointed sheafs discernible).

The genitalia of Canthonistis amphicarpa Meyrick used for comparison are those of the lectotype, in the Leiden Museum, herewith selected: a male, with a handwritten label "W. Java, Preanger, 5000 vt. (Sythoff) ơ," genit. slide 5510.

\section{Frisilia Walker, 1864}

\section{Frisilia drimyla, new species}

Figures 194, 600

Female, $15 \mathrm{~mm}$. Head ochreous grey whitish, face greyish white. Antenna pale ochreous, finely ringed with darker, scape grey. Palpus with a very long, pointed tuft at apex of median segment below, terminal segment long, recurved, very narrow; median segment ochreous tawny, upper edge posteriorly infuscated and with a white submarginal horizontal line; long hair-scales, which are appressed posteriorly, raised anteriorly; terminal segment dark brown, silvery white above. Thorax pale ochreous, suffused with pale grey except on tegula. Abdomen pale ochreous. Posterior tibia light yellowish ochreous. 
Forewing lanceolate, acutely pointed, broadest before middle. Rather light ochreous tawny, irregularly suffused with fuscous. Base of costa with a fuscous, attenuated streak; dorsum from base to beyond middle with a faint fuscous suffusion, discal stigmata alike, rather large, very faint, suffused, brownish: first at $1 / 4$, a similar spot below and before it; second in middle; a third similar faint spot in disc at $3 / 4$; plical stigma conspicuous, elongate, dark brown, slightly closer to second discal than to first discal stigma; posterior third of costa with a faint tawny very elongate subtriangular spot, cut in two beyond its anterior extremity, and containing a minute white longitudinal marginal mark beyond its middle; apex and termen with a marginal row of very small brownish longitudinal (marginal) marks on ends of veins. Cilia light ochreous tawny fuscous, tips whitish around apex.

Hindwing with strongly produced apex and twice sinuate termen; veins 3 and 4 coincident. Semipellucent with distinct blue reflections; veins streaked, margin and apex suffused or irrorated, with dark fuscous bronze (hindwing appearing dark grey). Cilia grey with a pale ochreous basal line.

Female genitalia: Eighth segment moderately sclerotized, lower edge concave. Sterigma, a small and short funnel. Colliculum, a sclerotized, inverted funnel with oblique lower edge. Signum small, rounded, cup-shaped.

Material examined: Luzon, Mount Makiling (Baker), 1 우, holotype, genit. slide 5208 (USNM).

In all respects fitting in the description of the genus, except for the lanceolate, pointed forewing with an indefinite tornus. All other species have an obliquie termen with a distinct tornus.

\section{Homaloxestis Meyrick, 1910}

\section{Key to the Philippine Species of Homaloxestis}

1. Forewing light tawny fuscous, apex light ochreous yellow.

H. aganacma, new species

Not thus colored

2. Forewing greyish fuscous, base suffused with dark fuscous.

H. surrepta, new species Forewing ferruginous brown, a small dark fuscous mark along closing vein.

H. alopecopa, new species

\section{Homaloxestis aganacma, new species}

Figures 188, 601

Female, $13 \mathrm{~mm}$. Head glossy light grey, face light yellow. Antenna light yellow, scape pale grey. Palpus with median segment spindle-shaped, with a small roughish tuft in middle above, terminal 
segment 1; golden brownish, median segment light yellow below and inwardly. Thorax rather pale tawny greyish. Abdomen glossy light ochreous fuscous, venter light ochreous, anal tuft yellow. Legs bright yellow.

Forewing elongate-sublanceolate, apex moderately rounded, termen straight, oblique. Veins 4 and 5 separate, 7 to termen, 9 free. Light tawny greyish; base of costal edge with a narrow dark fuscous line, followed by a yellow streak, gradually dilated posteriorly and running along the course of vein 7 ; a black marginal line around apex between the ends of veins 7 and 8. Cilia fuscous grey, along costa yellow, opposite apex yellow with grey tips.

Hindwing with veins 3 and 4 stalked; rather deep brownish fuscous bronze, appearing semipellucent (transparent bases of scales). Cilia grey with a whitish basal line.

Female genitalia: Eighth segment sclerotized all around, rather finely bristled along upper half, caudal edge of sternite slightly emarginate in middle, side lobes short and obtuse. Ostium bursae, a rather large funnel with finely punctulate sides. Ductus bursae undulate. Signum moderate, narrow and transverse.

Material examined: Luzon, Mount Makiling (Baker), 1 ㅇ, holotype, genit. slide 5209 (USNM).

\section{Homaloxestis alopecopa Meyrick, 1929}

Figure 828

Homaloxestis alopecopa Meyrick, 1929, Exotic Microlepidoptera, vol. 3, p. 518.Gaede, 1937, in Bryk, Lepidopterorum Catalogus, pars 79, p. 502.-Clarke, 1955, Catalogue ... Microlepidoptera ... Meyrick, vol. 1, p. 41.

Distribution: Philippine Is., Mindanao.

\section{Homaloxestis surrepta, new species}

FiguRes 186-187, 602

Male, $13 \mathrm{~mm}$. Head ochreous white, crown fuscous. Antenna with scape and basal portion of flagellum ochreous white (apical part missing). Palpus ochreous white, basal segment and basal half of median, fuscous. Thorax fuscous with purple gloss. Abdomen light ochreous fuscous.

Forewing with veins 8 and 9 out of 7,7 to termen; sublanceolate, slightly dilated, costa slightly curved at extremities only, apex obtusely pointed, termen rather long, moderately oblique, convex. Pale fuscous, rather densely and irregularly clouded with dark fuscous, with a distinct purple gloss. Basal fourth of wing stronger suffused with dark purple fuscous; second discal stigma small, round, not conspicuous (absent in right wing). Cilia greyish fuscous with a pale basal line. 
Hindwing glossy pale grey fuscous, somewhat darker towards apex, cilia concolorous, with a pale basal line.

Male genitalia: Tegumen slender and rather short as compared with the large, semioval vinculum. Uncus exactly as in Lecithocera: top of tegumen being bilobed and hairy, uncus projecting as an extensive body, supported above and below by slender sclerotized rims, and with a more or less free beaklike hook with a dilated base. Valva moderate, costa with a rectangular excision beyond base, sacculus broad but only slightly sclerotized, ending in a triangular process, cucullus truncate, top concave. Aedeagus very large, thick, slightly curved. Cornuti, a large number of equal small teeth. Eighth and seventh abdominal segments modified, eighth sclerotized and elongatecylindrical, seventh segment with a pair of oblique lateral ribs, and a tubular concavity in the middle of the sternite, extending into the sixth segment, and containing a long extensile hair-pencil.

Material examined: Luzon, Mt. Apo 70 B, 8.V.1945 (J.G. Franclemont), $1 \sigma^{7}$, holotype, genit. slide 5117 (CUI).

\section{Placanthes Meyrick, 1923}

\section{Placanthes xanthomorpha Meyrick, 1923}

Figure 763

Placanthes xanthomorpha Meyrick, 1923, Exotic Microlepidoptera, vol. 3, p. 42; 1925, in Wytsman, Genera Insectorum, fasc. 184, p. 232.-Gaede, 1937, in Bryk, Lepidopterorum Catalogus, pars 79, p. 511.-Clarke, 1955, Catalogue . . Microlepidoptera . . Meyrick, vol. 1, p. 327; 1965, op. cit., vol. 5, p. 208, pl. 104, figs. 1-1a (holotype figured).

Distribution: Philippine Is., Mindoro.

\section{Lecithocera Herrich-Schäffer, 1853}

\section{Key to the Philippine Species of Lecithocera}

1. A transverse fascia and other markings leaden metallic . . . . . . . . 2

No metallic markings . . . . . . . . . . . . . . . . . . . . . . . 3

2. Hindwing strongly narrowed, acutely pointed, termen irregularly concave; cilia yellow ........... . . . . . strenua, new species

Hindwing little narrowed, apex moderately pointed, termen almost straight; cilia black . . . . . . . . . . . . . . . . . . L. cassiterota

3. Cilia along termen white or pale ochreous, contrasting with blackish or dark fuscous cilia above apex, thus exaggerating falcate shape of wing (cf. also under 7) . . . . . . . . . . . . . . . . . . . 4

Cilia not thus . . . . . . . . . . . . . . . . . . . . . . . . 7

4. Large species $(24 \mathrm{~mm})$, ochreous with a golden gloss, a triangular fuscous suffusion from center of wing, resting on termen and contrasting with pale cilia; costa without a pale mark . . . L. phanerostoma, new species Moderate species $(16 \mathrm{~mm})$, ochreous fuscous, with a small pale mark on 4/5 of costa . . . . . . . . . . . . . . . . L. ochrocapna Moderate species (11-17 mm), not thus colored . . . . . . . . 5 
5. Unicolorous deep fuscous, terminal cilia conspicuously white . L. recurvata

Not unicolorous . . . . . . . . . . . . . . . . . 6

6. Fuscous, with base, a median fascia and apical fifth white, first discal stigma obliterate . . . . . . . . . L. acribostola, new species

Fuscous, with costa suffused with white, a white transverse line at $4 / 5$, first discal stigma well defined . . . . . . L. decorosa, new species

7. Fuscous, cilia along costa and termen white, only opposite apex a dark attenuated bar, exaggerating falcate shape of wing . L. niphotricha, new species

Cilia not contrasting white . . . . . . . . . . . . . 8

8. Rather dark fuscous, markings ill defined . . . . . . . . . . . . . . 9

Pale ochreous, more or less infuscated, stigmata often distinct . . . . 11

9. Unicolorous dark fuscous, termen rounded . . L. leucomastis, new species

Not unicolorous, if dark fuscous, then discal stigmata distinct . . . 10

10. Termen convex; discal stigmata black, paler encircled; hindwing whitish with darker veins . . . . . . . . . . L. telosperma, new species

Termen concave; discal stigmata faint, not encircled with paler; hindwing unicolorous light fuscous. . . . . . . . L. activata, new species

11. Discal stigmata large, conspicuous, rounded, second largest, a dark dorsal suffusion below this; plical stigma absent . . . . . . L. megalopis

Discal stigmata small, weak or absent; plical stigma often present . . 12

12. A well-defined series of dark fuscous dots along end of costa, around apex and along termen, forming an almost continuous marginal streak.

L. sophronopa, new species

Marginal dots either absent or minute, sparse and ill defined . . . . . 13

13. Forewing pale ochreous, not infuscated . . . . . . . . . . . . . . 14

Forewing light or pale ochreous, distinctly suffused with darker fuscous or brownish................... 15

14. Discal stigmata fuscous, small, plical stigma absent; antenna distinctly thickened, pale ochreous; terminal segment of palpus slender, little longer than median . . . . . . . . . . . L. docilis, new species

Discal stigmata black, distinct, plical distinct, below second discal. Antenna less distinctly thickened, whitish; terminal segment of palpus less slender, being slightly thickened towards base, distinctly shorter than median segment . . . . . . . . . . . . . L. goniometra

15. Plical stigma present, sometimes contiguous with second discal stigma . 16 Plical stigma absent; a shade between second discal stigma and dorsum.

L. fausta

16. Plical stigma contiguous with second discal stigma . L. luteola, new species Plical stigma large, before first discal stigma . . L. improvisa, new species

\section{Lecithocera sophronopa, new species}

Figures 202-203, 603

Female, $15 \mathrm{~mm}$. Head light fuscous, vertex darker. Antenna pale fuscous, finely dark ringed, scape purplish. Palpus long, recurved, median segment exceeding base of antenna, dilated by closely appressed scales, fuscous, top whitish; terminal segment pale ochreous strewn with fuscous, slender, pointed, almost 1 . Thorax and abdomen fuscous, with faint lilac reflections, anal tuft tawny ochreous.

Forewing with vein 7 absent, 8 separate; oblong, costa curved at extremities, apex obtusely pointed, termen sinuate, rounded beneath, 
little oblique. Pale fuscous touched with creamy, strewn throughout with rather dense fuscous scales. Markings dark fuscous. An illdefined triangular small basal patch with very inwards-oblique edge and obliterate lower third; a well-defined, somewhat irregular interrupted marginal narrow streak around more than posterior fourth of wing; stigmata irregular, about equal, first discal beyond $1 / 3$ of wing, plical below and a trifle before it, second discal before $2 / 3$. Cilia light greyish fuscous.

Hindwing fuscous, rather thinly scaled. Cilia lighter fuscous with a whitish basal line.

Female genitalia: Ovipositor conical. Genital segment strongly narrowed in middle (in ventral aspect), annular. Sterigma shaped as a small, simple cap around the ostium bursae, distinctly sclerotized. Colliculum long, tubular, constricted in middle, with slight longitudinal ribs. Cestum, a slender elongate sclerite. Signa, two scobinate patches.

Material examined: Luzon, Benguet Subprov., Klondyke, $800 \mathrm{ft}$,, 15.III.1912, 1 ㅇ, holotype, genit. slide 5654; 11.III.1912, 1 ㅇ, paratype (A.E. Wileman) (BM).

An obscure, pale fuscous species. The genitalia suggest a relation of Lecithocera Herrich-Schäffer with Hypodrasia, new genus.

\section{Lecithocera activata, new species}

Figures 206, 604

Male, $16 \mathrm{~mm}$. Head glossy pale grey fuscous, face whitish. Antenna ochreous whitish, glossy, towards base slightly mixed with dark fuscous. Palpus moderately long, recurved, ascending, median segment $2 \times$ face, moderately thickened, purplish grey, apex white with a semiannular dark submarginal mark above; terminal segment slender, whitish, anterior edge narrowly dark brown. Thorax glossy pale grey fuscous. Legs fuscous, whitish inwardly, posterior leg dark purple fuscous, top of tibia and entire tarsus white; tibia with roughly projecting hairs above and beneath. Abdomen fuscous, venter paler, with posterior half blackish.

Forewing elongate, moderately broad, little dilated, costa moderately curved throughout, apex pointed and slightly produced, termen sinuate, concave above, little rounded beneath. Evenly deep fuscous with a purplish hue in certain lights. Costa with a small wedgeshaped oblique transverse mark before $4 / 5$, continued across wing by a minute and faint pale line, inwards-angulate below costa, broadly outwards-convex in middle, sinuate above dorsum, to dorsum before tornus; stigmata vague, little darker than ground color, rounded: first discal at $1 / 3$, plical slightly larger, beyond this; second discal 
represented by a narrow dark strigula along closing vein; a minute pale spot in apex. Cilia (strongly rubbed) dark fuscous.

Hindwing and cilia fuscous bronze.

Male genitalia of Crocanthes type, sclerotized throughout. Tegumen depressed, heavily edged, top strong, slender and conical. Gnathos hook of usual shape. Uncus single, slender, pointed and straight, bristly at the sides. Vinculum strong, quadrate. Juxta + anellus a very large subquadrate plate, anellus lobes, small hairy processes. Valva rather short, curved, sacculus not indicated, harpe absent, cucullus obliquely subtruncate. Aedeagus large, little curved, narrowed, top sclerotized, with an angulate process above; cornuti, several ridges of short teeth.

Material examined: Luzon, Benguet Subprov., Baguio, $5000 \mathrm{ft}$., 23.IV.1912 (A.E. Wileman), 1 o ○ $^{\top}$ holotype, genit. slide 5656 (BM). A small, obscure species.

The genitalia are surprisingly similar to the genitalia found in the genus Crocanthes Meyrick. That is a very natural group of large species often brightly adorned with orange or yellow, a quite different facies, in fact. Still the genus is closely allied with Lecithocera Herrich-Schäffer, in spite of the disappearance of two veins (4 and 7) in the forewing of Crocanthes; as an exception also in Lecithocera vein 7 may be missing, as in the following species. Furthermore, the genitalia of the present and the following species bear clearly evidence of this relationship.

\section{Lecithocera strenua, new species}

Figures 177-179, 605

Male and female, $20 \mathrm{~mm}$. Head glossy golden fuscous with purplish reflections, face yellow. Antenna orange yellow, finely fuscous-ringed on basal half, tip blackish above, scape fuscous. Palpus bright orange yellow, terminal segment blackish in front. Thorax fuscous. Abdomen dark fuscous, anal tuft ochreous, venter pale yellowish.

Forewing narrow, oblong, costa little curved at extremities, slightly concave beyond middle, apex subobtuse, termen sinuate or rather inbent in middle, oblique. Blackish brown, dull. Slender yellow streaks arranged as follows: one short, from beyond base to $1 / 5$ just below fold; another, parallel to this from base, running below costa, to $1 / 3$, merging into a third, transverse, slightly curved fascia, dilated on costa, slender below; a rounded conspicuous black patch on dorsum, between first and third fascia; shining metallic-leaden streaks with bluish or greenish tinge: along basal $1 / 3$ of costa above second yellow streak, another below this; a broad submedian transverse band, immediately following transverse yellow streak; a slender streak below posterior half of costa to well before apex, encircled by yellowish- 
tawny color, forming an elongate oval, edged posteriorly with black; a broad metallic marginal band in apex and along termen, irregularly dentate anteriorly, sharply and narrowly edged posteriorly by dull black. Cilia dark fuscous, basal half suffused with yellow.

Hindwing 1, narrower and more pointed than in L. cassiterota, deep fuscous with a faint bronze tinge, cilia pale yellow, opposite apex barred with fuscous, along termen fuscous with a dilating yellow basal band, along lower half of termen and on dorsum fuscous.

Male genitalia: Valva curved, little dilated, harpe, a single huge spine towards ventral margin. Gnathos, a long, slender hook. Anellus lobes long, straight. Aedeagus moderate, cornuti several complicated sclerotized folds, beset with slender spines.

Female genitalia: Sterigma, a large, bristly plate, tops, two triangular points separated by a deep incision. Several longitudinal folds visible at the proximal extremity of sterigma represent a colliculum. Corpus bursae coiled. Signum single, a moderate, scobinate patch.

Material examined: Mindanao, Mt. Apo, Baroring, $7000 \mathrm{ft}$., 8.XI.1930 (CMP, Acc. 9163); 10 allotype, genit. slide 5708 (CMP).

Superficially resembling $L$. cassiterota Meyrick, but larger, with differently shaped termen of the forewings, quite different shape of the hindwings, and different coloring. The male genitalia suggest little relationship with that species.

\section{Lecithocera cassiterota Meyrick, 1923}

Figures 176, 200, 201, 606

Lecithocera cassiterota Meyrick, 1923, Exotic Microlepidoptera, vol. 3, p. 40; 1925, in Wytsman, Genera Insectorum, fasc. 184, p. 240.-Gaede, 1937, in Bryk, Lepidopterorum Catalogus, pars 79, p. 518.-Clarke, 1955, Catalogue ... Microlepidoptera ... Meyrick, vol. 1, p. 75; 1965, op. cit., vol. 5, p 115, pl. 57, figs. 4-4d (holotype figured).

\section{Distribution: Philippine Is., Luzon.}

The elegant species may be redescribed as follows. Male and female $15 \mathrm{~mm}$. Head with closely appressed, broad scales; shining pale blue, orbits and edge of face pale ochreous, dull. Palpus orange ochreous, median segment suffused with tawny on basal half, terminal segment finely edged with blackish; palpus internally orange. Antenna pale ochreous, glossy, apical eighth suffused with blackish above, scape and base of flagellum also suffused above with black. Thorax grey with a strong bluish gloss in certain lights. Posterior leg with an expansile tuft of long and fine fuscous hairs. Abdomen glossy bronze grey, anal tuft yellowish grey, a broad, dull black band over pregenital ventrites.

Forewing narrow, elongate-subtriangular, costa gently curved, apex rounded-pointed, termen broadly excised triangularly in middle, 
rounded along lower half. Veins 4 and 5 connate, 3 absent, 7 and 9 stalked, 8 absent. Bright orange, mixed with black scales, markings shining metallic silvery blue, more blue anteriorly, more silvery posteriorly; $2 / 3$ of edge of costa narrowly black; basal third of wing with three longitudinal streaks, first subcostal, moderate, top rounded; second median, dilated, top truncate; third narrow and shorter, along dorsal edge from base; a slightly submedian, almost vertical broad transverse fascia, gently dilated downward, its top on costa gently rounded, a slight posterior prominence in fold; more than posterior third of wing marked thus; a moderate longitudinal streak well below costa to well before apex, slightly pointed at posterior end; a transverse spot in apex, a parallel streak of black suffusion, ending in a metallic obliquely oval spot in apex and along upper half of termen; a small wedge-shaped horizontal mark in middle of disc below anterior end of preceding black streak, pointed posteriorly; a black horizontal broad streak edging preceding spot anteriorly and below and running to middle of termen; a large metallic spot in tornus, occupying less than lower half of termen and tornus and emitting anteriorly two pointed horizontal processes further than halfway towards cell, continued by blackish lines; all markings narrowly, and those in apex and termen broadly, edged with black; a jet-black spot on costa before apex connected by a line of the same color along apex and termen with a similar smaller spot on dorsum before tornus. Cilia bright orange, apical half fuscous grey with a strong pale blue gloss in certain lights.

Hindwing semipellucent, dark bronze brown. Cilia concolorous, with a pale basal line.

Male genitalia. Tegumen rather small, triangular (flattened in mount). Uncus, a slender hook. Gnathos, a more slender and longer, pending hook. Vinculum erected, with a moderate signum. Valva short, strongly narrowed, cucullus bifid: a ventral, semioval bristly part and a dorsal strong digitoid process. Sacculus indefinite. Anellus, an inverted-trapezoidal plate, lobes slender, moderate, acute and slightly diverging. Aedeagus moderate, cylindrical, cornutus a long sinuate blade with pointed and serrulate top.

Material examined: Luzon, Mt. Makiling (Baker), 1 o $\sigma^{\top}$ genit. slide $5210 ; 1$ o genit. slide 5519 (USNM).

The species is closely allied with L. lamprodesma Meyrick, from Java but is larger, deeper orange, the markings differ slightly. The genitalia show considerable differences from those of the above named Javanese species and are quite distinct. Apparently Meyrick refers to this species in his description of lamprodesma, where he states: "I have a closely allied undescribed species from the Philippines" (Zool. Meded., vol. 7, p. 85, 1922). The long tufts of the hindtibia are peculiar. 
Two closely allied, undescribed species occur in both Java and Borneo.

\section{Lecithocera phanerostoma, new species}

Figures 207-208, 607

Male, $24 \mathrm{~mm}$. Head pale fuscous ochreous, orbits white. Antenna whitish. Palpus very long, curved, ascending, median segment over $3 \times$ face, moderately thickened and spindle-shaped, dark grey fuscous, with golden gloss in certain lights, apex white; terminal segment slender, slightly shorter than median, whitish with a strong golden gloss. Thorax pale golden fuscous ochreous. Legs fuscous, whitish inwardly, posterior tibia fuscous, becoming deep purplish fuscous posteriorly, top white, tarsus (imperfect) white. Abdomen fuscous.

Forewing oblong-subtriangular, broadest in tornus, costa gently curved anteriorly, more curved before apex, apex obtusely pointed, termen gently concave above, little rounded beneath, moderately oblique. Rather light tawny with a strong golden gloss. A large triangular patch of dark fuscous suffusion with base extending along entire termen, with acute top resting on middle of closing vein, deep purple along extreme termen, veins posteriorly also streaked darker purple. Cilia along termen white with pale fuscous apical half, along costa and apex deep purple, in tornus fuscous purplish.

Hindwing brown fuscous with a strong golden-bronze gloss. Cilia brownish fuscous with a narrow whitish basal line.

Male genitalia: Even more suggestive of a species of Crocanthes Meyrick. Sclerotized throughout. Tegumen broader. Gnathos with an obtuse broad top (base!) and the usual pending hook. Uncus hooked, slender and strong. Vinculum ovate-truncate. Juxta + anellus smaller, convex, quadrate, anellus lobes long, slightly curved, with rounded top. Valva longer, narrower, more curved. Aedeagus more slender, stronger curved, top denticulate above and beneath; cornuti, several ridges of short teeth and two patches of scobinations.

Material examined: Luzon, Benguet Subprov., Haights Place, Pauai, 7000 ft., 17.XI.1912 (A. E. Wileman), $1 \sigma^{\top}$, holotype, genit. slide 5657 (BM).

Female, $24 \mathrm{~mm}$. Very similar to male, slightly lighter colored. Posterior tibia (damaged in male) dilated with roughish scales, pale fuscous becoming darker fuscous grey posteriorly, top with a snowwhite band, tarsus pale ochreous.

Female genitalia: Ninth segment sclerotized, sternite hairy along edge, with two additional sclerotized semioval plates, bristly throughout, a slender dark ridge, longitudinal and median, along their lower halves. Ostium not modified, lamellae aciculate. Ductus bursae 
plicate, with a longitudinal patch of small thorns. Corpus bursae strewn with larger sparse thorns.

Material examined: Luzon, Mountain Province, at base of Mt. Data, 5500 ft., 22.IV.1946 (CNHM Philippine Exped. 1946-47, H. Hoogstraal), 1 \% , allotype, genit. slide 5744 .

A large and distinct species of recurvata group, differing from the last mentioned species by larger size and coloring.

\section{Lecithocera megalopis Meyrick, 1916}

FIgURE 608

Lecithocera megalopis Meyrick, 1916, Exotic Microlepidoptera, vol. 1, p. 575; 1925, in Wytsman, Genera Insectorum, fasc. 184, p. 239.-Gaede, 1937, in Bryk, Lepidopterorum Catalogus, pars 79, p. 518.-Clarke, 1955, Catalogue . . Microlepidoptera . . Meyrick, vol. 1, p. 198; 1965, op. cit., vol. 5, p. 143, pl. 71, figs. 3-3b (lectotype select.).

Distribution: Philippine Is., Luzon.

Material examined: "Mindanao, Mt. Apo, $6500 \mathrm{ft} .$, M., 5.10" (in Meyrick's hand), in Meyrick collection, 4/3, 1 우 (without abdomen) (BM).

\section{Lecithocera fausta Meyrick, 1910}

Figures 168-169, 197-198, 617

Lecithocera fausta Meyrick, 1910, Trans. Roy. Ent. Soc. London, p. 449; 1925, in Wytsman, Genera Insectorum, fasc. 184, p. 239.-Gaede, 1937, in Bryk, Lepidopterorum Catalogus, pars 79, p. 520.-Clarke, 1955, Catalogue . . Microlepidoptera . . Meyrick, vol. 1, p. 140; 1965, op. cit., vol. 5, p. 131 , pl. 65 , fig. 2 (holotype flgured).

Distribution: Philippine Is., Luzon (?Brazil, Argentina).

Material examined: Luzon, Mt. Apo, 70 B, 8.III.1945, 1 व genit. slide 5110, 1 ㅇ, genit. slide 5114 (J.G. Franclemont). 1 ơ , 1 우 (CUI).

The occurrence of this species in South America seems to be most improbable. Luzon is the typical locality. Two females from Argentina studied by me appeared to have vein 9 in the forewing originating free from cell (Meyrick coll., BM). This is a redescription of the present material.

Male and female, $13.5 \mathrm{~mm}$. Head and thorax whitish ochreous, with a fuscous median shadow. In female with terminal segment slightly under 1 ; dark fuscous, median segment with a small pale ochreous apical dot, terminal segment pale ochreous, frontal edge with a black line. Abdomen light ochreous.

Forewing moderate, sublanceolate-truncate, pointed. Veins 2 and 3 stalked, 9 out of stalk of 7 and 8 . Pale ochreous greyish, strewn with fuscous scales. Markings blackish. Shoulder and anterior fifth of costal edge black; first discal stigma beyond $1 / 3$, small, 
elongate and narrow; second discal before 2/3, larger, rounded; a slightly outwards-oblique and outwards-curved small transverse streak of black suffusion between second discal stigma and dorsum; six dark brown dots on ends of veins $3-8$, larger in female. Cilia dull pale ochreous with two darker, ochreous olive parting lines.

Hindwing pale ochreous fuscous, slightly darker in female, somewhat transparent, veins appearing darker. Cilia glossy pale ochreous, with a brighter ochreous and with two dull pale ochreous-fuscous bands.

Male genitalia: Tegumen moderately high, shoulders dilated and rounded. Uncus rather strong, top triangular, with two subapical small lateral teeth. Vinculum large, oval, lower portion, a strongly dilated band, excised in middle of upper edge. Valva broad, rather short, cucullus strongly upturned; harpe, a moderate patch of thin bristles in disc on base of cucullus. Aedeagus huge, slightly curved. Cornuti, a group of large flat sclerites with sharply pointed edges and a patch of fine rounded scobinations.

Female genitalia: Sterigma, a moderately sclerotized, erected sclerite with folds at the sides, evenly aciculated throughout. Ninth segment elongate, flattened and sclerotized. Ductus bursae very short. Corpus bursae, a wide tube, coiled once. Signum, a small dark transverse sclerite.

A small species, judging by the genitalia, belonging to the L. rhabdostoma group of species. Closely allied to goniometra Meyrick, differing by a broader and shorter cucullus with a more rounded top, and dilated base, less angulate costa, different arrangement of cornuti and more depressed eighth segment of the abdomen.

\section{Lecithocera ochrocapna Meyrick, 1923}

\section{Figure 638}

Lecithocera ochrocapna Meyrick, 1923, Exotic Microlepidoptera, vol. 3, p. 40; 1925, in Wytsman, Genera Insectorum, fasc. 184, p. 237.-Gaede, 1937, in Bryk, Lepidopterorum Catalogus, pars 79, p. 524.-Clarke, 1955, Catalogue . . Microlepidoptera . . . Meyrick, vol. 1, p. 222; 1965, op. cit., vol. 5 , p. 147 , pl. 73 , fig. 4 (holotype figured).

Distribution: Philippine Is., Mindanao.

\section{Lecithocera acribostola, new species}

Figures 180-181, 611

Female, $15 \mathrm{~mm}$. Head and antenna glossy snow white (tips broken), middle of head slightly touched with tawny, face pale ochreous tawny; forehead with very dense appressed scales. Palpus with median segment rather slender, smooth-scaled; glossy pale tawny ochreous, apical third white; terminal segment slender, blackish. 
Thorax light bronze fuscous, tegula white. Abdomen yellowish fuscous, anal tuft fuscous.

Forewing with veins 2 and 3 coincident, 4 and 5 short-stalked, 9 out of stalk of 7 and 8; narrow, sublanceolate, apex pointed and slightly produced, termen concave and sinuate, moderately oblique. Greyish bronze fuscous, with a silky gloss. Markings white. A moderate, pointed and suffused streak from base to $2 / 5$ of costa, containing a fuscous short streak along base of costal margin; a direct transverse submedian fascia, with slightly suffused and serrulate edges, strongly extended posteriorly along upper third, slender elsewhere; more than apical fifth of wing white, anterior edge straight, well defined, slightly outwards-oblique; apex and termen with a narrow blackish fascia; a series of irregular subtriangular fuscous small spots between veins, forming a straight series beyond anterior edge of white apical patch. Cilia pale ochreous, a broad blackish bar opposite apex, a greyish broad subbasal band along termen, cilia in tornus grey fuscous.

Hindwing rather dark fuscous bronze, darker fuscous towards apex, paler in center, seemingly semipellucent, bases of scales being transparent. Cilia pale tawny fuscous with a whitish basal line, pale ochreous whitish along dorsum, suffused with dark grey along termen, with a pale submedian line along upper third of termen.

Female genitalia: Eighth segment not sclerotized, costal edge with a rounded excision, bottom with a second smaller narrow excision. Lobes little rounded, densely bristled, gently sclerotized. Ostium bursae not modified, minutely aciculate. Ductus bursae moderate, tortuous. Corpus bursae elongate pear-shaped. Signum moderate, rounded, close to top of corpus.

Material examined: Luzon, Mt. Makiling (Baker), 1 o , holotype, genit. slide 5212 (USNM).

\section{Lecithocera goniometra Meyrick, 1929}

Figures 170-171, 192, 614

Lecithocera goniometra Meyrick, 1929, Exotic Microlepidoptera, vol. 3, p. 523 ( $\sigma^{7}$, Philippine Is.).-Gaede, 1937, in Bryk, Lepidopterorum Catalogus, pars 79, p. 520.-Clarke, 1955, Catalogue ... Microlepidoptera . . . Meyrick, vol. 1, p. 149 ; 1965 , op. cit., vol. 5, p. 132 , pl. 66, figs. 4-4b (holotype figured).

Distribution: Philippine Is., Luzon.

A slightly variable species, males with the dark fuscous suffusion of the base of the forewing diversely extended. Usually plical stigma replaced by a slender suffused streak from lower angle of cell to $3 / 4$ of dorsum, in other specimens (slides 5196, 5199) the plical stigma is distinct, of diverse size, and the streak absent. The marginal series 
of blackish dots in apex and along termen may be strongly reduced or altogether absent.

Female $15 \mathrm{~mm}$, neallotype. Very similar to male, but vertex without a longitudinal infuscation. Dark suffusion along base of costa in the forewing not extended; stigmata moderate, well defined; apical and terminal dots entirely absent. Otherwise similar to male.

Male genitalia: Valva moderate, costa with an angular prominence beyond base, cucullus much narrower, moderately curved upwards, rather pointed above middle of disc. Aedeagus rather slender, curved. Cornuti, two patches of fine spines melted together and a pair of small separate spines.

Female genitalia: Sterigma rather weak, an inverted-truncate cone. Signum moderate, transverse.

Material examined: Luzon, Mt. Makiling, $1 \sigma^{7}$, genit. slide 5219, $1 \sigma^{\top}$, genit. slide 5199. Los Baños, $2 \sigma^{\nearrow}$, genit. slides 5198, 1 ㅇ, no. 5196, 1 \%, neallotype, genit. slide 5218; total $4 \sigma^{7}, 2$ ㅇ (USNM). The male genitalia most closely resemble those of L. capra Diakonoff.

\section{Lecithocera decorosa, new species}

Figures 204-205, 612

Female, $13 \mathrm{~mm}$. Head pale golden fuscous, whitish at the sides. Antenna (broken in type specimen) white, pale whitish fuscous below, tip pale fuscous, scape moderately flattened, white, with a narrow pale fuscous postmedian longitudinal strigula above. Palpus with median segment strongly dilated posteriorly, apex oblique; light tawny ochreous, apex white, terminal segment very slender, fuscous anteriorly, white laterally and posteriorly. Thorax pale ochreous greyish, anteriorly whitish. Abdomen pale yellow ochreous, yellow towards apex.

Forewing elongate, narrow, sublanceolate, apex pointed, termen sinuate; veins 2 and 3 coincident, 4 and 5 stalked, 9 out of stalk of 7 and 8. Pale ochreous greyish. A pointed rather narrow white streak from base of costa to its middle, containing a dark fuscous narrower streak along base of costal edge; base of white streak indistinctly dilated, (an excurved whitish band from middle of costa to middle of disc at $2 / 3$ must be due to denuding); an outwards-oblique dark fuscous mark just below $2 / 5$ of costa, edged posteriorly with white, first discal stigma blackish, elongate, at $1 / 3$, an irregular fuscous transverse mark on dorsum slightly beyond stigma; second discal stigma at about $3 / 5$, very faint, roundish (in left wing transverse, more distinct in one paratype); a blackish triangular spot on $3 / 4$ of costa, extended over cilia; a strongly and regularly undulate direct white line from costa beyond that patch to tornus, outwards concave above 
and beneath, outwards convex in middle; apical part of wing beyond this line suffused with slate grey, apex black, three black marginal dots on termen. Cilia light yellow, a black bar opposite apex, opposite tornus cilia with light greyish posterior half, on dorsum becoming entirely greyish with a darker subapical line opposite lower half of termen.

Hindwing pale bronze fuscous, glossy, seemingly semipellucent (bases of scales transparent). Cilia pale yellowish fuscous, along upper part of termen tips coarsely mixed with grey, towards dorsum cilia becoming pale yellowish with grey apical fourth.

Female genitalia: Eighth segment not sclerotized; lamella postvaginalis simple, finely punctulate, caudal edge of eighth sclerite with a small but deep incision with a convex bottom, lobes flanking it rounded mesially, densely bristled, but little sclerotized. Ostium not modified. Ductus bursae moderate, tortuous. Signum small, angulate, transverse.

Material examined: Luzon, Mt. Makiling, (Baker), 1 \%, holotype, genit. slide 5211. Los Baños, 2 ㅇ, paratypes. 3 ㅇ (USNM).

\section{Lecithocera recurvata Meyrick, 1923}

Figures 174-175, 616

Lecithocera recurvata Meyrick, 1923, Exotic Microlepidoptera, vol. 3, p. 39 ( $~$, Philippine Is.); 1925, in Wytsman, Genera Insectorum, fasc. 184, p. 237.Gaede, 1937, in Bryk, Lepidopterorum Catalogus, pars 79, p. 526.-Clarke, 1955, Catalogue . . Microlepidoptera . . Meyrick, vol. 1, p. 269; 1965, op. cit., vol. 5, p. 163, pl. 81, figs. 3-3d (lectotype selected).

Distribution: Philippine Is.

Material examined: Luzon, Mt. Makiling (Baker), 2 o, genit. slide 5197 (USNM).

I compared the above mentioned slide with the photograph of the slide of the female lectotype published by Clarke (1965). The rather large pointed spines appearing in that photograph in the ductus bursae close under the ostium bursae must be there accidentally; they are all broken off at the base and must, in my opinion, be simply displaced spines originating from the abdominal tergites. They are absent in mount no. 5197 which otherwise is similar to the photograph (Clarke, 1965, fig. 3c).

Female genitalia with the ductus with a large widening covered with sparse short teeth with dilated bases.

\section{Lecithocera niphotricha, new species}

Figdres 166-167, 615

Female, $14 \mathrm{~mm}$. Head shining whitish fuscous, vertex blackish. Antenna whitish ochreous. Palpus pale ochreous fuscous, median 
segment slender (terminal segment missing). Thorax light fuscous ochreous with a golden gloss. Abdomen pale ochreous.

Forewing with veins 4 and 7 absent, 9 out of 8 ; narrow sublanceolate, gently dilated, costa very gently curved at extremities, apex pointed, termen gently concave, little oblique. Glossy fuscous, edge of posterior half of wing narrowly and suffusedly margined with dark fuscous. Cilia dark fuscous, from apex to end of vein 5 , snow white.

Hindwing paler fuscous with a coppery gloss, cilia fuscous.

Female genitalia: Ovipositor slender, extensile and long. Sterigma hardly modified, an elongate-rectangular small sclerite. Ductus bursae strongly undulating, beset with many small irregular teeth. Signum single, a stellate patch of usual shape.

Material examined: Luzon, Benguet Suprov., Klondyke, $800 \mathrm{ft}$., 9.V.1912 (A.E. Wileman), 1 \%, holotype, genit. slide 5658 (BM).

The species resembles Lecithocera recurvata Meyrick but is smaller, more fuscous and is distinct by neuration and genitalia.

\section{Lecithocera telosperma, new species}

Figures 182-183, 613

Female, $17 \mathrm{~mm}$. Head dark fuscous, orbits and lower part of face whitish, forehead paler fuscous. Antenna dark fuscous, minutely ringed with whitish. Palpus very long, strongly compressed laterally, median segment slightly curved, broadest in middle, rather broad, smooth; terminal segment just under 1 , moderate at base, acutely pointed; dark fuscous grey, median segment marbled with yellowish white on lower half, and along apex, terminal segment dark brown fuscous with faint purple tinge, whitish internally. Thorax dark fuscous. Abdomen fuscous, venter paler.

Forewing sublanceolate, narrow, hardly dilated, apex subobtuse, termen moderate, rounded, little oblique; veins 2 and 3 stalked from before angle, 4 from angle, 5 from above angle, 7 and 8 stalked, 7 to apex, 9 connate with stalk. Pale fuscous grey olive, strongly suffused with dark fuscous purple, and partially, with brighter olive. An elongate patch of brighter olive suffusion along basal third of costa extending $1 / 3$ across wing; lower half of wing from base to end of cell rather evenly suffused with dark fuscous purple; discal stigmata large, elongate, first blackish purple, edged with olive, with a few white scales posteriorly, second discal stigma olive, anteriorly mixed with white scales, and centered with blackish purple along veins; posterior third of wing minutely strewn with white; a distinct marginal series of black dots on ends of veins along posterior part of costa, in apex and along termen, round dots becoming narrow strigulae downwards. Cilia grey finely sprinkled with white, a pale ochreous basal line and a narrow whitish submedian line. 
Hindwing with 2 from just before angle, 3 and 4 long-stalked from angle, 5 straight, horizontal, submedian, cell apparently open between 3 and $6+7$. Whitish, suffused along edges with bronze grey, veins streaked with this color. Cilia pale ochreous, along costa in apex, and along termen rather infuscated and with a pale basal line.

Female genitalia: Eighth segment moderately sclerotized. Sterigma little developed, shaped as a small spindle-like concave sclerite, its upper edge ill defined. Ductus bursae and corpus not clearly separated, forming a rather thick straight tube, moderately dilated at the end. Signum, a small rounded and finely denticulate sclerite.

Material examined: Luzon, San Miguel, Tarlac, 1-21.X.1945 (J.G. Franclemont), 1 \%, holotype, genit. slide 5118. Mt. Apo, 70, Dau, Pampanga Prov., 7.III.1945 (J.G. Franclemont), 1 \%, paratype, genit. slide 5132 (CUI). Belongs to the group of $L$. orbata Meyrick (Borneo) or L. percnobela Meyrick (southern India), but not close to these two species.

\section{Lecithocera docilis, new species}

Figures 172-173, 609

Male, $14 \mathrm{~mm}$. Head pale ochreous, vertex slightly brighter, a roughish tuft over face; orbits fuscous. Antenna pale ochreous, slightly thickened. Palpus with median segment spindle-shaped, pale tawny, a small pale dot at apex above, terminal segment light ochreous. Thorax and abdomen pale ochreous.

Forewing (rubbed) with veins 2 and 3 stalked, 9 out of stalk of 7 and 8, 7 to termen; with costa curved at base, straight beyond base, apex pointed, termen sinuate. Pale ochreous. A narrow fuscous streak along base of costal edge; second discal stigma small, light fuscous. Cilia concolorous.

Hindwing with veins 3 and 4 coincident; semipellucent, pale fuscous grey, apical half tinged pale ochreous. Cilia pale ochreous.

Male genitalia: Valva broad at base, costa angulate beyond base, with strong sclerotized edge. Sacculus short, triangular. Patch of spines rather small, bristles at the base of cucullus transverse-median, triangular, anterior edge of patch vertical and straight. Anellus rather broad and low, with a triangular excision in middle of upper edge, side projections truncate. Vinculum broad, without an excision of upper edge, point rounded, arms broad.

Material examined: Luzon, Mt. Makiling (Baker), 1 o', holotype, genit. slide 5195 (USNM).

Judging from the genitalia, allied to Lecithocera protolyca Meyrick (China), to L. caustopila Meyrick (Assam) and closest to L. megalopis Meyrick (Philippine Islands), differing from the last species by 
reduced markings, shorter and broader cucullus, more angulate costa, smaller patch of cucullus bristles and different cornuti.

\section{Lecithocera luteola, new species}

Figures 184-185, 618

Male, $11 \mathrm{~mm}$. Head pale ochreous, vertex except at the sides, suffused with glossy grey. Antenna pale ochreous. Palpus ochreous fuscous, terminal segment pale ochreous, slightly mixed with fuscous anteriorly and toward apex. Thorax pale ochreous, shoulder fuscous. Abdomen pale ochreous.

Forewing suboval, rather broad, costa gently curved toward extremities, straight in middle, apex moderately pointed, termen hardly convex, almost straight, oblique. Veins 2 and 3 stalked, 7 and 8 long-stalked, 9 out of stalk. Light yellowish ochreous, costa narrowly suffused with brighter ochreous and also narrowly infuscated except before apex; base of wing indistinctly infuscated; traces of fuscous sprinkling over the wing; veins on upper half of wing halfway between cell and margin slightly streaked with brownish; first discal stigma minute, well beyond $1 / 3$ and above middle, second discal somewhat irregular, transverse, larger and slightly lower than first, continued by a short outwards-oblique small mark; apex and termen with a narrow marginal line. Cilia (imperfect) pale ochreous, around apex tipped with fuscous.

Hindwing glossy, whitish golden, fuscous, paler than forewing. Cilia concolorous.

Male genitalia: Rather similar to those of Lecithocera docilis, new species, but valva less dilated beyond base, not markedly narrowed toward base, costa beyond base gradually sinuate, without an angulate prominence, as in $L$. docilis; cucullus slightly narrower and less curved upwards. Aedeagus rather similar to that of docilis.

Material examined: Luzon, Agoo, La Union, 1.V.1945 (J.G. Franclemont), $1 \sigma^{\top}$, holotype, genit. slide 5239 (CUI). A small and obscure species. Nearest to the preceding.

\section{Lecithocera leucomastis, new species}

Figures 189-190, 610

Female, $15.5 \mathrm{~mm}$. Head and thorax fuscous with a golden gloss, vertex of head broadly edged by pale yellow. Antenna pale ochreous, flagellum anteriorly and posteriorly finely striped with dark fuscous. Palpus fuscous; median segment moderately broad, flattened laterally, slightly roughish at apex below, terminal segment very slender, about 1. Abdomen dark bronze fuscous. Posterior tibia with upper 
edge and hair tuft along it, pale yellow; posterior tarsus pale yellow, faintly fuscous ringed.

Forewing sublanceolate, moderately broad, costa slightly curved at extremities, apex subobtuse, termen gently rounded, little oblique. Veins 2 and 3 stalked, from angle, 4 and 5 approximated, 7 and 8 stalked, 7 to termen, 9 out of middle of stalk. Rather dark purple fuscous with a distinct gloss. Base of wing slightly darker. Cilia fuscous, with two darker fuscous bands.

Hindwing glossy pale bronze fuscous, cilia darker fuscous with a pale basal line.

Female genitalia: Ninth segment distinctly sclerotized. Sterigma shaped as a wide funnel, with a finely punctulate wall, lower edge more sclerotized not punctulate. A slender cestum indicated in ductus bursae. Signum, a semistellate small sclerite.

Material examined: Luzon, Mt. Apo, 70 B, 9.V.1945 (J.G. Franclemont), 1 \% , holotype, genit. slide 5119 (CUI). Judging from the genitalia, closely related to $L$. crypsigenes Meyrick, from Ceylon.

\section{Lecithocera improvisa, new species}

Figures 195-196, 620

Female, $13.5 \mathrm{~mm}$. Head pale ochreous, slightly strewn with pale tawny. Antenna fuscous, scape darker fuscous. Palpus dark fuscous, extreme tip of median segment whitish ochreous; terminal segment whitish ochreous with a few dark specks; median segment thick, dilated toward base (in lateral aspect). Thorax and abdomen fuscous.

Forewing oblong-suboval, costa gently curved at base, more curved towards apex, in middle straight, apex subacute, termen rounded. Pale fuscous, irregularly clouded and dusted with darker fuscous. Stigmata small, black; first discal ill defined, second discal at $3 / 5$, rounded; plical slightly larger, suboval, beyond $1 / 4$, terminal edge with a series of rather suffused, not distinctly separate subtriangular small dots. Cilia fuscous with a paler base, barred faintly with darker fuscous.

Hindwing with a prominent tornus; glossy pale fuscous, finely dusted with darker fuscous. Cilia concolorous, with a paler base.

Female genitalia: Ovipositor rather cylindrical. Sterigma formed by a small rounded paler plate with a cardiform thickening. Ductus bursae rather short, coiled. Signa two, rounded, denticulate patches.

Material examined: Mindanao, VII-VIII.1917, 1 , holotype, genit. slide 5719 (USNM). An obscure species. 


\section{Prosodarma Meyrick, 1925}

Prosodarma Meyrick, 1925, in Wytsman, Genera Insectorum, fasc. 184, p. 244.Fletcher, 1929, Mem. Dept. Agric. India, Ent. ser., vol. 11, p. 186.-Gaede, 1937, in Bryk, Lepidopterorum Catalogus, pars 79, p. 530.

Type species: Onebala fibularis Meyrick, 1921 (Java, Celebes).

The description of this genus needs a slight correction. In one of the two female specimens recorded below the venation of the hindwings is as follows: veins 3 and 4 very long-stalked, vein 5 closely approximated to the base of the stalk and united with it along its base. This peculiar situation proves that the normally absent vein in the hindwing is not vein 5, as Meyrick presumed, but either 3 or 4 , these veins being coincident and stalked with vein 5 .

\section{Prosodarma fibularis (Meyrick, 1921)}

Figures 212-213, 621

Onebala fibularis Meyrick, 1921, Zool. Meded., vol. 6, p. 167 ( (๑ণ , Java, Celebes).Clarke, 1955, Catalogue . . Microlepidoptera . . Meyrick, vol. 1, p. 141. Prosodarma fibularis.-Meyrick, 1925, in Wytsman, Genera Insectorum, fasc. 184, p. 244.-Gaede, 1937, in Aurivillius, Lepidopterorum Catalogus, pars 79, p. 530 .

Distribution: Java, Celebes.

Material examined: Luzon, Mt. Makiling (Baker), 2 ㅇ, genit. slide 5226 (USNM). Compared with a female specimen from Buitenzorg, Java, genit. slide 5232 (Bryant and Palmer) (USNM). Luzon, Rizal, Montalban, 6.III.1914 and 28.IV.1914, 2 우 (A.E. Wileman, Rothschild bequest) (BM).

One female syntype specimen is hereby selected as lectotype; it is labelled as follows: a green label of the Leiden Museum "TYPE"; “Java, Toeban, '79, б" (perhaps in Snellen's or in Piepers' hand), "M 295" (in Meyrick's hand), slide 5514 (LM).

\section{Gelechiidae}

\section{Key to the Philippine Genera of Gelechiidae}

1. Forewing with vein 7 to termen or apex or 7 , or 8 , or 9 , absent . . . . 2 Forewing with vein 7 to costa . . . . . . . . . . . . . . . . . . . . 6

2. Antenna more or less thickened and compressed throughout in male . . . 3 Antenna, if thickened, not compressed in male . . . . . . . . Thiotricha* Antenna not thickened at all . . . . . . . . . . . . . . . 4

3. Antenna thick, flatly compressed throughout; forewing with all veins present.

Euhomalocera, new genus

Antenna moderately thickened and compressed throughout; forewing with vein 7 absent

Hypodrasia, new genus

*The present material contained only one badly damaged and untdentifiable specimen, undoubtedly belonging to this genus. 
4. Terminal segment of palpus with a tuft, at least at base . . . . . . . . 5

Terminal segment of palpus without a tuft; forewing with vein 7 to apex.

5. Forewing with tufts of raised scales .

Brachmia

Forewing without tufts of scales .

Hypatima

6. Forewing in male with a reflected fringe of scales from anterior half of costa.

Forewing not thus modified

Stegasta

7. Median segment of palpus furrowed beneath, thickened with scales.

Phthorimaea

Median segment of palpus not furrowed beneath . . . . . . . . . . . 8

8. Hindwing with a cubital pecten. . . . . . . . . . . . . . Acribologa

Hindwing without a cubital pecten . . . . . . . . . . . . . . . . . .9

9. Median segment of palpus expanded towards apex by dense scales, tufted beneath. . . . . . . . . . . . . . . . . Brachyacma Median segment of palpus not expanded towards apex, smooth. Stomopteryx

\section{Stegasta Meyrick, 1904}

\section{Stegasta variana Meyrick, 1904}

FiguREs 472,622

Stegasta variana Meyrick, 1904, Proc. Linn. Soc. New South Wales, vol. 29, p. 314 ( $\sigma^{\top}$ \% , East Australia); 1906, Journ. Bombay Nat. Hist. Soc., vol. 17, p. 140 (Ceylon); 1909, Ann. Transvaal Mus., vol. 2, p. 12 (S. Africa); 1911, op. cit., p. 65; 1914, Ent. Mitt., Suppl., vol. 3, p. 50 (Formosa); 1920, in Alluaud and Jeannel, Voyage . . . en Afrique Orientale (1911-12), Insectes Lépidoptères, no. 2, p. 71; 1925, in Wytsman, Genera Insectorum, fasc. 184, p. 87, pl. 2, fig. 31; 1935, in Caradja and Meyrick, Materialien Microlepidopteren-Fauna . . . , p. 68.-Janse, 1917, Check-List South African Lepid. Het, p. 182.-Fletcher, 1921, Mem. Dept. Agric. India, Ent. ser., vol. 6, pp. 83, 202, pl. 62, figs. 1a-d; 1932, Imp. Counc. Agric. Res., Sci. Mon., no. 2, p. 42.-Corbett and Bates, 1926, Bull. Dept. Agric. Federated Malay States, no. 38, p. 8.-Gaede, 1937, in Bryk, Lepidopterorum Catalogus, pars 79, p. 238.

Distribution: Australia, Ceylon, India, Malayan Peninsula, South Africa.

Food plants: Cassia tora, C. fistula, C. mimosoides, Jasminum sp.

Material examined: Luzon, Agoo, La Union. 1.V.1945 (J.G. Franclemont), 1 ㅇ (CUI). Benguet Subprov., Klondyke, 800 ft., 11.V.1912 (A. E. Wileman), 1 옹 genit. slide 5777 (BM). Compared with a $\sigma^{7}$ from Java, genit. slide 5776 (LM).

\section{Phthorimaea Meyrick, 1902}

\section{Phthorimaea heliopa (Lower, 1900)}

Figures 211, 214, 222-223, 624

Gelechia heliopa Lower, 1900, Proc. Linn. Soc. New South Wales, vol. 25, p. 417. Gnorimoschema heliopa.-Meyrick, 1904, Proc. Linn. Soc. New South Wales, vol. 29, p. 320; 1905, Journ. Bombay Nat. Hist. Soc., vol. 16, p. 592.-Maxwell- 
Lefroy, 1906, Indian Insect Pests, p. 156; 1906, Mem. Dept. Agric. India., Ent. ser., vol. 1, p. 224; 1909, Indian Insect Life, p. 534; 1933, Agric. Journ. India, vol. 3, table.-Fletcher, 1914, South Indian Insects . . ., p. 454, pl. 43.-Janse, 1917, Check-List South African Lepid. Het., p. 182.

Phthorimaea heliopa.-Sitowski, 1908, Agric. Journ. India, vol. 3, pt. 1.-Fletcher, 1916, Entom. Note 18; 1917, Rep. Proc. 2nd. Ent. Meeting Pusa, p. 272; 1921, Mem. Dept. Agric. India, Ent. ser., vol. 6, p. 73.-d'Angremond, 1920, Meded. Proefstat. Vorstenl. Tabak, vol. 42, p. 3; 1922, Agric. Circ. Dept. Agric. Fiji, vol. 3, p. 19.-Palmer and Fulmek, 1924, Meded. Deli-proefstat., Medan, vol. 2, ser. no. 35, p. 27.-Sorauer and Reh, 1925, Handbuch Pflanzenkrankheiten, vol. 4, p. 298.-Meyrick, 1925, in Wytsman, Genera Insectorum, fasc. 184, p. 94; 1927, Insects Samoa . . ., vol. 3, fasc. 2, p. 79.Hopkins, 1927, Bull. Ent. Res., vol. 18, p. 30.-Roberts, 1930, Bull. Ent. Res., vol. 21, p. 180.-Bodenheimer, 1930, Iris, vol. 44, p. 174; 1930, Schädl.Faun. Palaest. p. 314.-Gaede, 1937, in Bryk, Lepidopterorum Catalogus, pars 79 , p. 261.

Lita heliopa.-Amsel, 1935, in Veröff. Deutschen Kolonial-Mus., vol. 1, no. 2, p. 263.

Teleia heliopa.-Bodenheimer, 1935, Animal Life Palaest., p. 230.

Gelechia aptatella Walker, 1864, List Lepidopterous Insects British Mus., pt. 29, p. 636.

Distribution: Australia, India, Ceylon, Burma, Sumatra, Java (probably throughout tropical Asia, everywhere on tobacco, Nicotiana tabacum), Samoa, South Africa, New Zealand.

Food plant: Minor pest of tobacco plant, causing stem galls.

Material examined: Luzon, Los Baños (Baker), $\sigma^{x}$, genit. slides

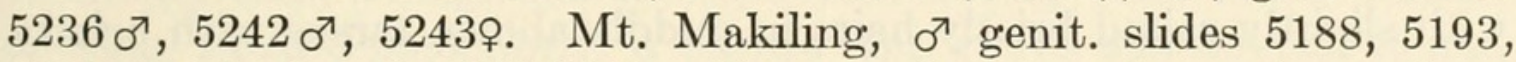
5237; total: $80^{7}, 5$ 우 (USNM). Compared with male specimens from Sumatra, Deli (de Bussy), genit. slides 5187, 5192 (LM).

\section{Stomoptery $x$ Heinemann, 1870}

\section{Stomopteryx subsecivella (Zeller, 1852)}

Figures 210, 215, 623

Gelechia (Brachmia) subsecivella Zeller, 1852, Lepidoptera Microptera . . . Caffrorum . . ., p. 113 (South Africa).

Brachmia subsecivella.-Walsingham, 1891, Trans. Ent. Soc. London, p. 94. Anacampsis subsecivella.-Janse, 1917, Check-List South African Lepid. Het., p. 179.

Stomopteryx subsecivella.-Meyrick, 1925, in Wytsman, Genera Insectorum, fasc. 184, p. 111.-Fletcher, 1932, Imp. Counc. Agric. Res., Sci. Mon., no. 2, p. 45, pl. 31, figs. 1-4.-Gaede, 1937, in Bryk, Lepidopterorum Catalogus, pars 79, p. 334 .

Xystophora modicella Deventer, 1904, Tijdschr. Ent., vol. 47, p. 4, pl. 1, figs. 2, 2a (Java).

Anacampsis nerteria Meyrick, 1906, Journ. Bombay Nat. Hist. Soc., vol. 17, p. 139 (Ceylon); 1909, Rec. Indian Mus., vol. 5, p. 220 (India); 1909, Ann. Transvaal Mus., vol. 2, p. 11 (South Africa).-Maxwell-Lefroy, 1906, Mem. 
Dept. Agric. India, Ent. ser., vol. 1, p. 226 (India); 1910, Bull Imperial Inst., vol. 8 , p. 166; 1909, Indian Insect Life, p. 534.

Aproaerema nertieria.-Fletcher, 1914, South Indian Insects . . ., p. 457, fig. 333 ; 1917, Rep. Proc. 2nd Ent. Meet. Pusa, pp. 43, 47, 92.

Stomopteryx nerteria.-Fletcher, 1921, Mem. Dept. Agric. India, Ent. ser., vol. 6, p. 717.

Distribution: India, Ceylon, Malaya, Java, South Africa.

Food plants: Minior pest of Arachis hypogaea, Soya hispida, also on Sesamum indicum, Psoralea corylifolia.

Parasite: Chelonella species (India).

Material examined: Luzon (Baker), "1 $\sigma^{7}, 2$ ㅇ. Camp Ord, Tarlac, p. I., 20.IX.1940," "Acc. no. 4126, Bur. of Plant Industry, P. I.," genit. slides $5202 \sigma^{7}, 5203 \sigma^{\nearrow}, 5204$; $1 \sigma^{7}, 4$ ․ Total $2 \sigma^{7}, 6$ ㅇ (USNM).

\section{Euhomalocera, new genus}

Head with face smooth (vertex rubbed). Proboscis developed. Ocellus apparently absent. Antenna in male about 1, minutely ciliate, flagellum strongly laterally compressed, ribbon-like, broad, gradually narrowed toward extremities, scape normal, without pecten. Labial palpus rather short, curved, subascending, slender; median segment slightly thickened with scales, roughish along lower edge, terminal segment slender, smooth, acute, shorter than median. Maxillary palpus minute, vestigial, appressed to proboscis. Posterior tibia with slightly raised bristly hairs in middle above, tarsus with bristly hairs above.

Forewing lanceolate, all veins present, $1 \mathrm{~b}$ very short-furcate at base, 2 and 3 stalked from angle, 7 and 8 stalked, stalk 1/3, 7 to costa, 11 from beyond middle of cell.

Hindwing sublanceolate, pointed, termen straight above, gently rounded below; about 1, cilia under 1 . Vein 2 from well before angle, 3 and 4 stalked from angle, 5 parallel, median discoidal obliterate, 6 and 7 long-stalked.

Male genitalia of the type of Promalactis Meyrick; as described under the species below.

Type species: Euhomalocera heliosema, new species.

Seemingly a near relative of Narthecoceras Meyrick from India, which has similarly flattened and ribbon-like antennae. The differences of external structure are much shorter palpi, and the semiovallanceolate hindwing with veins 3 and 4 stalked (in Narthecoceras connate). In addition the type species has a rather different faciesthat, in fact, of a Heliodinid.

The genitalia certainly suggest a relationship either with Xyloryctidae or with Oecophoridae. 


\section{Euhomalocera heliosema, new species}

Figures 217-219, 625

Male, $16 \mathrm{~mm}$. Head (rubbed) with bluish reflections, vertex purple, side tufts yellow. Antenna purplish bronze, tip slightly mixed with white, scape light ochreous. Palpus purplish, upper half of posterior edge of median segment and terminal segment pale ochreous. Collar yellow with bright blue reflections. Thorax dark purple brown (rubbed). Abdomen black, tergites with faint leaden-greenish bands, posterior halves of segments pale yellow, venter leaden grey, posterior half pale yellow, anal tuft black. Posterior leg purple, femur entirely yellow and tibia with a yellow spot on upper half above.

Forewing lanceolate, dilated, broadest at $3 / 4$, point long, acute, termen hardly curved, very oblique. Black with strong purple reflections except on broad dull edges to markings. Markings bright yellow. A rather slender semiclavate longitudinal median mark from beyond base to $1 / 3$ of wing, its anterior end touching a shorter wedgeshaped parallel streak above preceding; a streak along dorsum from well beyond base to before tornus, containing a semioval spot of ground color on $1 / 4$ of dorsum; this streak gently narrowed posteriorly, but on middle of dorsum dilated into a triangle with acute top reaching middle of disc; an elongate-triangular patch on costa occupying less than its 3rd fourth, anterior edge little, posterior strongly oblique, top to closing vein; a longitudinal stripe from closing vein, below middle of wing, furcate posteriorly, a narrow line above and beyond it and another, shorter, below it. Cilia (damaged) blackish.

Male genitalia: Tegumen slender, long, its ventral (forward) part slightly compressed below top, probably thus forming the uncus which is otherwise not indicated; top shortly bilobed, with a few small bristles. Saccus elongate V-shaped, well sclerotized. Valva moderate at base, sacculus $1 / 2$, well defined, sclerotized, with an apical small hook on top of an emarginate bladelike structure. Cucullus long and slender, gently curved. Anellus lobe strong, moderately long, elongatetriangular and bristly. Juxta small, trapezoidal. Aedeagus slender, straight, slightly dilated at both ends.

Hindwing and cilia deep blackish brown with purple reflections.

Material examined: Mindanao, Lanao, plains, Kolambugan, 25.V. 1914 (A.E. Wileman), $1 \sigma^{\top}$, holotype, genit. slide 5582 (BM). A slender, elegant insect with the appearance of a Heliodinid.

\section{Atasthalistis Meyrick, 1886}

\section{Key to the Philippine Species of Atasthalistis}

1. Hindwing orange with a blackish posterior half . . . . A. ochreoviridella Hindwing entirely blackish .

A. diacrita, new species 
Atasthalistis ochreoviridella (Pagenstecher, 1900)

Figures 473, 473a, 805-806,845-846

Ceratophora ochreoviridella Pagenstecher, 1900, in Zoologica, vol. 29, p. 236 (sex?, New Britain).

Croesopola ochreoviridella.-Durrant, 1915, in Ogilvie-Grant, Rep. British Ornithologists' Union and Wollaston Exped. . . . Dutch New Guinea, 19101913, vol. 2, pt. 15 , p. 152.

Atasthalistis ochreoviridella.-Caede, 1937, in Aurivillius, Lepidopterorum Catalogus, fasc. 79 ,p. 374 .

Atasthalistis euchroa Lower, 1900, Proc. Linn. Soc. New South Wales, vol. 25, p. 47.

Croesopola euchroa.-Meyrick, 1904, Proc. Linn. Soc. New South Wales, vol. 29, p. 410.

Atasthalistis euchroa.-Meyrick, 1925, in Wytsman, Genera Insectorum, fasc. 184, no. 7, p. 136, pl. 3, fig. 75 .

Distribution: Queensland, Bismarck Is.

Material examined: Mindanao, Zamboanga del Sur, Lemesahan, $600 \mathrm{~m}$, 7.IX.1958, 1 ㅇ (H.E. Milliron) (BMH). Compared with a ? specimen from Aru Is., genit. slide 5513 (LM). Further material studied, North New Guinea, Dampier Island, Kar Kar, II. 1914 (Meek), 2 ఠ', genit. slide 5786. New Hannover, III-IV.1923 (A.S. Meek), 1 \%, genit. slide 5787 (BM).

Male genitalia: Very similar to those of $A$. diacrita, new species, but differing by the following points. Anellus lobes shorter, distinctly shorter than the finger-shaped stalks of the coremata (indicated in figures by a small arrow). The upturned paired saccus is more sclerotized, left arm shorter than right, each with a more prominent process beyond middle.

Female genitalia show more differences; sterigma, similarly weak but less broad; cestum-like sclerite much narrower, semitubular. Ductus bursae not markedly separated from corpus burase, the latter less scobinate.

\section{Atasthalistis diacrita, new species}

Figures 226-230,627-628

Male, $14.5 \mathrm{~mm}$. Head light green, face becoming pale ochreous below, edges of head throughout dark fuscous; roughly spreading side tufts behind bases of antennae slightly suffused with grey fuscous. Antenna pale green, banded with dark fuscous. Palpus with basal and median segments glossly light brown outside, light ochreous inside, apex of median segment above mixed with pale green; this segment gradually dilated to middle and slightly expanded, apex gently rounded in lateral aspect; terminal segment slender, acute, glossy whitish, basal third and a narrow line along anterior edge, dark brown. Thorax pale green, apex fuscous, whitish-edged. Abdo- 
men fuscous, sides bright ochreous, becoming whitish towards base, anal tuft ochreous, venter light ochreous. Legs ochreous, anterior leg suffused, tarsi banded with fuscous, posterior spurs blackish fuscous.

Forewing elongate-truncate, rather narrow, narrowed in middle, broadest before termen, costa moderately curved at base and before apex, apex pointed, termen strongly concave, vertical, tornus projecting. Light milky green. Markings blackish and white. A slightly oblique and outwards-convex transverse series of minute blackish scales at $1 / 5$, interrupted above middle, ill defined below fold; another, more extended similar transverse series from below $2 / 3$ of costa, interrupted in middle and above dorsum; a short transverse mark on dorsum beyond middle (all these markings obliterate in left wing); an elongate-semivoal spot occupying less than median third of costa, anterior end acute and continued as a very narrow marginal line based, posterior end rounded, slightly irregular by dark irroration; this patch extending less than $1 / 3$ across wing and edged by white; this edge is continued as a marginal line to base of costa; posterior part of costa, apex, and termen with a thicker white line. Cilia pale ochreous, irregularly mixed with blackish scales along bases and tips.

Hindwing dark bronze blackish fuscous. Cilia grey with a whitish basal line.

Male genitalia: Tegumen with two lateral prominences towards the top, lower of these with a pending, spatulate arm. Uncus broad, top rounded. Gnathos strong, a curved, pending hook. Valva slender, elongate-clavate; sacculus well defined, about $1 / 3$, slightly irregular, base dilated, top flattened. Anellus lobes very long and slender, top slightly haired. Aedeagus large, irregularly sclerotized, this portion with two ventral short and broad processes, and two long, acute dorsal ones. Cornutus, a single spine.

Female, $20 \mathrm{~mm}$. Head brighter milky green, face pale greyish green. Terminal segment of palpus whitish dotted black, basal third black. Thorax brighter green with a milky tinge, apex of thorax with a black dot. Abdomen dark fuscous. Legs grey fuscous, posterior tibia light ochreous above and laterally. Forewing brighter green with a milky tinge, transverse series of dots obliterate, but there are several minute transverse lines, rising from posterior half of dorsum and almost reaching lower edge of cell; plical stigma elongate, at 2/5, followed by a snow-white dot; another snow-white dot on middle of closing vein; costal spot larger, jet black, more shifted basad; marginal white line along posterior part of costa, in apex and along termen to tornus with a series of equally spaced black points extending over the external half of the width of white line; some black marginal irroration along posterior part of dorsum, beginning with an elongate mark on 
end of fold. Cilia whitish with a submedian black band, followed by a pink line and two tawny lines, respectively; cilia in tornus pinkish. Hindwing as in male.

Female genitalia: Eighth segment moderately sclerotized, anapophyses short; postapophyses twice as long. Seventh sternite, a moderate band, lower edge broadly concave. Bursa copulatrix very large, ductus bursae wide, with an additional sack towards base, with a strong irregular cestum which is dilated and plicate along its lower third, the fold forming three free lobes, triangular and pointed, at the distal end. Corpus bursae ovoid, signum of lamina dentata type, transverse.

Material examined: Luzon, Mt. Makiling (Baker), $1 \sigma^{7}$, holotype, genit. slide $5184 ; 1$ \%, allotype, genit. slide 5185 (USNM).

An elegant species, closely related to Atasthalistis viridella (Snellen) (fig. 225) but differing by a larger costal spot not continued posteriorly, by color of the cilia in the female and by the genitalia. The male specimen may have been bleached by light. The female genitalia have been compared with those of $A$. viridella (Snellen) $\circ$, holotype, from Java in the Leiden Museum (slide 5512). In this species the cestum-like sclerotizations of the bursa copulatrix are complicated. Their central part, the cestum proper, is less sclerotized and distinctly shorter than in $A$. diacrita. The end lobes of the folds, only two of which are discernible, are much larger and semicircular. The sclerotizations of the wall of the ductus bursae, more or less encircling the cestum, are lacking in $A$. diacrita. The hindwings are exactly similar.

The occurrence of $A$. viridella in the Philippine Islands has not been proven.

\section{Hypatima Hübner, 1825}

\section{Hypatima heterostigma, new species}

Figures 220-221, 626

Male, 15-17 mm. Head creamy, vertex laterally strewn dark purplish grey; forehead with a broad transverse dark grey band, lower edge triangularly prominent; face in middle below with a transverse black stripe not reaching edges. Antenna creamy faintly ringed pale tawny. Palpus, median segment with a flat, moderate, triangular tuft at apex below; lower two thirds pale ochreous mixed with tawny, with a black median ring, upper third black, slightly strewn with white; terminal segment longer than median, thickened and with a median and an apical rough tuft posteriorly; black strewn with white, lower edge white strewn with dark and with two dark rings, tip of segment slender, acute, white. Thorax creamy, shoulder mixed dark fuscous. Abdomen creamy, posterior half dusted with fuscous, denser toward apex, anal tuft bright ochreous. 
Forewing rather narrow, sublanceolate, dilated; costa abruptly curved at base, emarginate along median third, gradually curved before apex, apex moderately pointed, termen rounded, oblique. Veins 3 and 4 stalked, 2 rather from before angle, 6 separate, 7 and 8 stalked, to costa. Creamy, irrorated with light tawny, this irroration tending to form transverse bands; extreme base of costa with a small ferruginous mark; some slight purplish-black suffusion across costa at $1 / 6$; a large semioval brown spot along costal excavation, slightly marbled with white, narrowly extended along costa anteriorly; four light tawny costal dots before apex becoming smaller posteriorly and a series of similar dots along termen to tornus; first discal stigma large, circular, anthracite black, preceded by a transverse suffusion, an elongate spot below and slightly before stigma, another smaller dot below this on dorsum, all anthracite black; an interrupted fuscous transverse streak forming continuation of anterior edge of costal patch, to fold; an irregular, white-marbled roundish dark grey spot over closing vein; a jet-black, anthracite oval spot in apex with a small dot above, a larger one below this, on wing margin; a strongly curved transverse series of fuscous-suffused dots halfway between cell and apex, suffused with pale fuscous tawny. Cilia creamy, lower half broadly barred with tawny.

Hindwing light fuscous, glossy, cells semipellucent with pale blue reflections. Cilia pale fuscous.

Male genitalia: Of the usual characteristic build. Valva elongate, with a narrow basal half strengthened by a median keel; posterior half, the cucullus proper, dilated, oval. Labides long slender and straight, minutely dentate on top. Anellus lobes similar, but shorter, minutely haired. Uncus bristly. Gnathos hooked. Aedeagus short, very slender, only basal half abruptly dilated and vesicular, flattened laterally.

Material examined: Luzon, Benguet Subprov., Baguio, $5000 \mathrm{ft}$., 29.IV.1912, $1 \sigma^{7}$, holotype, genit. slide 5665; Benguet Subprov., Klondyke, 800 ft., 21.III.1912, $1 \sigma^{\top}$, paratype (A.E. Wileman). $2 \sigma^{x}(\mathrm{BM})$.

The peculiar feature of the veins 3 and 4 in the forewing being stalked separates this species from all others, and would, in fact, assign it to the South American genus Parastega Meyrick. However, in all other respects being a true Hypatima it rather shows the dubious validity of the latter genus.

\section{Hypodrasia, new genus}

Head with dense, closely appressed scales descending over forehead and face. Ocellus absent. Proboscis developed. Antenna 4/5, in male moderately thickened and laterally compressed throughout, 237-168-67-11 
subserrulate, simple, scape moderately elongate, with a tuftlike small pecten toward apex, in female antenna slender, scape without pecten. Labial palpus long, recurved, median segment moderately thickened with appressed scales, forming a small roughish tuft at apex above, terminal segment shorter than median, rather slender, acute. Maxillary palpus small, scaled, appressed to proboscis. Thorax without a crest. Posterior tibia thickened with smoothly appressed scales.

Forewing suboval, short-pointed. Vein 1a strong, long-furcate at base, 2 and 3 stalked from angle, 4 and 5 approximated to each other at base, 6 to termen, 7 absent, 8 to apex, 9 moderately approximated at base, 11 from middle.

Hindwing slightly over 1 , cilia $3 / 4$, trapezoidal, without cubital pecten. Vein 2 from before $3 / 4,3$ and 4 very short-stalked, 5 slightly submedian, parallel, 6 and 7 connate.

Male genitalia with tegumen triangular, uncus strong with a dilated top, gnathos normal. Valva triangular, rather broad, with a triangular knob at base of costa. Anellus lobe broad and rounded. Saccus rather short. Aedeagus curved, moderate, without cornuti.

Female genitalia with ovipositor large, cylindrical, apophyses moderate. Ostium, a small cup. Ductus bursae tortuous. Corpus bursae inverted pear-shaped. Signa, two separate stellate sclerites.

Type species: Hypodrasia acycla, new species ( $\left.\sigma^{7} \circ\right)$.

A peculiar form, probably of Brachmia group, but not fitting in any of the described genera. Perhaps it is closest to Pachnistis Meyrick, differing by separate veins 8 and 9 , and the presence of a pecten of the antenna (in male only).

\section{Hypodrasia acycla, new species}

Figures 209, 241-244, 629

Male, $11 \mathrm{~mm}$; female $13-16 \mathrm{~mm}$. Head pale grey, forehead and vertex suffused with darker grey in middle. Antenna greyish, finely dark-ringed, scape dark fuscous. Palpus with basal and median segments blackish fuscous, irrorated, tip of median white; terminal segment pale ochreous with two faint rings in $\sigma^{x}$, speckled with dark fuscous anteriorly in $\circ$. Thorax pale grey, tips of tegulae and hair tufts of metathorax ocherous whitish. Abdomen fuscous.

Forewing elongate-suboval, costa rather curved toward extremities, straight in middle, apex obtusely pointed, termen slightly curved, oblique. Sordid greyish white or ochreous white, densely suffused and irrorated with grey and dark fuscous, more so along costa and especially on posterior sixth of wing. A rather faint, sinuate and vertical transverse darker grey fascia at $3 / 4$, upper fourth straight 
and darker, lower $3 / 4$ strongly convex posteriorly, suffused and fainter; this fascia suffusedly edged with paler posteriorly; a series of faint darker dots along costa before apex, in apex and along termen to tornus; base of costa suffused with blackish; a faint darker spot on costa before middle; two round black dots in an inwards-oblique series in disc beyond base; a large, conspicuous black spot in fold before $1 / 3$, sometimes reaching dorsal edge and rising above middle of disc; shape of this patch slightly variable, transverse, top usually with an anterior rectangular excision; second discal stigma very small, before $2 / 3$, a small elongate mark right below it, sometimes beyond it. Cilia pale grey with a whitish-ochreous basal and a darker grey submedian band.

Hindwing glossy pale bronze grey, finely irrorated with fuscous, more so towards apex. Cilia fuscous grey, with a pale ochreous basal line.

Male and female genitalia as described for the genus.

Material examined: Luzon, Los Baños (Baker), 1 o $\sigma^{7}$, holotype, genit. slide 5205, 1 \%, allotype, genit. slide 5206; 1 \%, paratype, wings on slide 5206a; $3 \sigma^{x}, 5$ ㅇ, paratypes. Total $4 \sigma^{x}, 7$ ㅇ (USNM). Luzon, Rizal Prov., Montalban, 17.III.1914 (A.E. Wileman), 1 \%, paratype, genit. slide 5575 .

\section{Brachyacma Meyrick, 1886}

\section{Brachyacma palpigera (Walsingham, 1891)}

Figures 216, 619

Gelechia palpigera Walsingham, 1891, Trans. Ent. Soc. London, p. 94, pl. 4, fig. 31 (Delagoa, $\sigma^{\top} \uparrow$ ).--Janse, 1917, Check-List South African Lepid. Het., p. 181.

Paraspistes palpigera.-Busck, 1915, Proc. U.S. Nat. Mus., vol. 47, no. 2043, p. 10 (British W. Indies, Bahamas, Panama).-Fletcher, 1921, Mem. Dept. Agric. India, Ent. ser., vol. 6, p. 88 (India, foodplants).

Lathontogonus palpigera.-Walsingham, 1915, in Godman and Salvin, Biologia Centrali-Americana, vol. 42, p. 409.-Bottimer, 1926, Journ. Agric. Res., vol. 33 , p. 812 .

Brachyacma palpigera.-Meyrick, 1925, in Wytsman, Genera Insectorum, fasc. 184, p. 168; 1930, Ann. Soc. Ent. France, vol. 99, p. 725; 1935, in Caradja and Meyrick, Materialien . . . Microlepidopteren-Fauna . . ., p. 72.Leonard and Miles, 1931, Journ. Econ. Ent., vol. 24, p. 472.

Lathontogonus adustipennis Walsingham, 1897, Proc. Zool. Soc. London, p. 88. Paraspistes ioloncha Meyrick, 1905, Journ. Bombay Nat. Hist. Soc., vol. 16, p. 600 (Ceylon); 1911, Trans. Linn. Soc. London, ser. 2, vol. 14, p. 274 (Seychelles).

Lipatia crotalariella Busck, 1910, Bull. Dept. Agric. [Trinidad], vol. 9, no. 66, p. 243 (British W. Indies).

Brachyacma epichorda Turner, 1919, Proc. Roy. Soc. Queensland, vol. 31, p. 163 (Queensland). 
Distribution: Central and South America, Puerto Rico, East Africa, Seychelles, India, Andamans, Ceylon, Burma, Tonkin, Queensland.

Food plants: Indigofera, Cassia corimbosa, C. flora, Crotalaria, Parkinsonia aculeata, Vachellia farnesiana, pigeon pea.

Material examined: Luzon, Canlubang, 11.XI.1927 (L.B. Uichanco), "Acc. No. Ec. 479, Coll. of Agri. Univ. P. I," $1 \sigma^{x}$, genit. slide "A.B. July 13, 1928." "In pods of Tephrosia" (In Busck's hand) (USNM). Luzon, Prov. Benguet, Klondyke, 800 ft., 8.V.1912 (A.E. Wileman), $1 \sigma^{\top}$, genit. slide 5663 (Rothschild bequest, BM).

\section{Acribologa Meyrick, 1923}

\section{Acribologa malacodes (Meyrick, 1910)}

Figures 474,630

Nothris malacodes Meyrick, 1910, Trans. Roy. Ent. Soc. London, p. 451 ( $\sigma^{\top} \uparrow$, Borneo, India, Ceylon).-Clarke, 1955, Catalogue . . . Microlepidoptera . . . Meyrick, vol. 1, p. 195.

Acribologa malacodes.-Meyrick, 1923, Exotic Microlepidoptera, vol. 2, p. 622; 1925, in Wytsman, Genera Insectorum, fasc. 184, p. 171.-Gaede, 1937, in Bryk, Lepidopterorum Catalogus, pars 79, p. 426.

Distribution: India, Ceylon, Java, Borneo.

Material examined: Luzon, Los Baños (Baker), 1 ㅇ (USNM).

\section{Brachmia Hübner, 1826}

\section{Key to the Philippine Species of Brachmia}

1. Forewing, with a transverse and a dorsal pale streak.

B. heterotoma, new species

Forewing without such streaks

B. tristella

\section{Brachmia tristella (Snellen, 1902)}

Figures 245, 631

Ceratophora tristella Snellen, 1902, Tijdschr. Ent., vol. 44, p. 85, pl. 6, fig. 2 (ơ or Java).

Brachmia tristella.-Meyrick, 1925, in Wytsman, Genera Insectorum, fasc. 184, p. 249.-Gaede, 1937, in Bryk, Lepidopterorum Catalogus, fasc. 79, p. 546.

Distribution: Java.

Material examined: Luzon, Los Baños (Baker), 5 \%, genit. slide 5190 (USNM).

Compared with lectotype, o, herewith selected, labelled with handwritten labels "Java, Batavia, 1892" and "Ceratophora Tristella Sn.," (in Snellen's hand), genit. slide 5511우 (LM).

\section{Brachmia heterotoma, new species}

Figures 224, 632

Male, $11 \mathrm{~mm}$. Head and collar pale brownish olive, face becoming 
whitish downwards. Antenna rather glossy, dark fuscous (incomplete). Labial palpus robust, median segment compressed laterally; shining pale greyish ochreous, terminal segment dark brown along anterior edge. Thorax blackish fuscous, tegula white. Abdomen pale grey with a silvery gloss, anal tuft light bronze brown.

Forewing sublanceolate, moderately broad, pointed, termen slightly convex and very oblique. Veins 7 and 8 stalked, 7 to costa just above apex. Black, partially turning dark grey. Dorsum with a rather broad, very pale ferruginous-white streak from base to tornus, slightly attenuated towards extremities and with a small white tooth on upper edge along fold; a rather broad and straight, oblique white transverse fascia with parallel and well-defined edges, anterior just postmedian; lower third of this fascia extended as a horizontal band posteriorly; about apical sixth of wing white, containing a suffused grey-black rounded blotch, filling out apex and connected with ground color in disc below middle of wing. Cilia (imperfect) dark grey, sordid fuscous in tornus, black in and around apex.

Hindwing with vein 3 and 4 stalked, 5 rather closely approximated; closing vein ill defined; 1 , trapezoidal, apex slightly produced and pointed; light greyish fuscous, cilia concolorous.

Male genitalia: Tegumen constricted below base of gnathos. Uncus spatulate, not bristled, gnathos long and slender, darkly sclerotized. Sacculus lobes with a constricted base and a sharp point. Anellus lobes, complicated, sclerotized and triangular hairy plates. Aedeagus short and rather broad.

Material examined: Luzon, Los Baños (Baker), 1 or, holotype, genit. slide 5139 (USNM). A small, distinctly colored species.

\section{Orneodidae}

\section{Orneodes Latreille, 1802}

\section{Key to the Philippine Species of Orneodes}

1. Head white; forewing ochreous whitish, crossed by light ochreous-yellow bands and a darker central narrow fascia . . . . . . . . . O. toxophila Head pale yellowish, with blackish transverse bands; forewing ochreous yellow, sprinkled with dark fuscous . . . . . . . . . . O. spilodesma

\section{Orneodes toxophila Meyrick, 1906}

Figure 343

Orneodes toxophila Meyrick, 1906, Journ. Bombay Nat. Hist. Soc., vol. 17, p. 133 ( $\sigma^{7}$, Ceylon).-Clarke, 1955, Catalogue . . Microlepidoptera . . Meyrick, vol. 1, p. 313.

Distribution: Ceylon. 
Material examined: Mindanao, Davao Prov., La Lun Mts., Calian, 5500 ft., 20-21.VII.1931 (Clagg, CM Acc. 9163), 1 o', genit. slide 5722 (CMP). Compared with type in the British Museum.

\section{Orneodes spilodesma Meyrick, 1908}

Orneodes spilodesma Meyrick, 1908, Trans. Roy. Ent. Soc. London, 1907, p. 508 ( o o , S. India, Assam).-Clarke, 1955, Catalogue . . . Microlepidoptera . . . Meyrick, vol. 1, p. 291.

Distribution: South India, Assam.

Material examined: Luzon, Mountain Province, Baguio, 10.VI. 1945 (J.G. Franclemont), $1 \sigma^{7}$, genit. slide 5137 (CUI).

\section{Cosmopterygidae}

\section{Scaeosophinae, new status}

Scaeosophides Meyrick, 1922, in Wytsman, Genera Insectorum, fasc. 180, p. 48. Scaeosophidae Meyrick, 1932, Exotic Microlepidoptera, vol. 4, p. 332.

Cosmopterygidae.-Clarke, 1955, Catalogue . . Microlepidoptera . . Meyrick, vol. 1, p. 21.

This peculiar, very natural group of closely allied genera with the general appearance of the Oecophoridae had been first attributed to that family, later separated as a "group" of it, subsequently defined as a distinct family, and finally transferred by Clarke to the family Cosmopterygidae on the basis of characteristic male genitalia. The last measure seems to be entirely correct. The group, however, does not resemble the general type of the Cosmopterygidae; besides it is very consistent in the type of the male genitalia and even more so in the unusual and aberrant venation of the hindwing. Therefore I propose to reestablish Meyrick's concept of this group being independent to a considerable degree, but under an emendated name and in a different family: as a subfamily of the Cosmopterygidae.

\section{Key to the Philippine Genera of Scaeosophinae}

1. Hindwing with veins 4 and 5 long-stalked. . . . . Scaeothyris, new genus Hindwing with veins 4 and 5 separate, parallel . . . . . . . Syntomaula

\section{Syntomaula Meyrick, 1914}

FIGURE 234

Syntomaula Meyrick, 1914, Exotic Microlepidoptera, vol. 1, p. 235 (type species: S. tephrota Meyrick, 1914, Ceylon); 1922, in Wytsman, Genera Insectorum, fasc. 180, p. 51.-Fletcher, 1929, Mem. Dept. Agric. India, Ent. ser., vol. 11, p. 214.-Gaede, 1937, in Bryk, Lepidopterorum Catalogus, pars 88, p. 93.Clarke, 1965, Catalogue ... Microlepidoptera . . Meyrick, vol. 5, p. 542, pl. 267, figs. 1-1f. 
Bathraula Meyrick, 1919, Exotic Microlepidoptera, vol. 2, p. 237 (type species: Cryptolechia simulatella Walker, 1864, Sarawak); 1922, in Wytsman, Genera Insectorum, fasc. 180, p. 49.-Fletcher, 1929, Mem. Dept. Agric. India, Ent. ser., vol. 11, p. 31.-Gaede, 1937, in Bryk, Lepidopterorum Catalogus, pars 88, p. 91.-Clarke, 1965, Catalogue . . Microlepidoptera . . Meyrick, vol. 5, p. 485, pl. 238, figs. 1-1e (syn. of Syntomaula Meyrick).

Bathybalia Diakonoff, 1954, Verh. Ned. Akad. Wet., Nat., ser. 2, vol. 50, no. 1, p. 86 (type species: B. microsperma Diakonoff, 1954, New Guinea). [new synonym].

I am now satisfied that the genus Bathybalia is a synonym of Syntomaula. Clarke pointed out to me that Bathraula is another synonym. This remarkable genus is puzzling by aberrant neuration of the hindwing; the species have the size and appearance, and one of them also the coloring and markings of a Palaearctic Yponomeuta. One would not attribute them to the Cosmopterygidae lightly. The male genitalia, however, are convincing, although they are strongly specialized and aberrant. Both Syntomaula and "Bathraula" were originally attributed to the Oecophoridae, the latter genus subsequently relegated to the subfamily or tribe Scaeosophides by Meyrick which he later raised to the family rank Scaeosophidae. I placed "Bathybalia" also in the last mentioned family. Clarke, however, pointed out (1955, vol. 2, p. 21-22) by his study of the type species of Scaeosopha Meyrick that it was a true Cosmopterygid and that the family name "Scaeosophidae" should be suppressed.

At present there are three known species of Syntomaula.

\section{Key to the Species of Syntomaula}

1. Whitish or greyish, dotted with black . . . . . . . . . . . . . 2 White, mixed with pale greyish ochreous, markings fuscous (Ceylon).

S. tephrota

2. Eighth tergite with the hook-shaped dorsal process slightly shorter than the remaining sclerotized part of tergite; one short ventral process only.

S. microsperma

Eighth tergite with the dorsal process less curved, longer than the rest of tergite; one ventral and one dorsal short process.

S. simulatella, new combination

\section{Syntomaula simulatella (Walker, 1864), new combination}

Figures 235-240, 633

Cryptolechia simulatella Walker, 1864, List Lepidopterous Insects British Mus., pt. 29, p. 747 ( $q$, Sarawak).

Bathraula simulatella.-Meyrick, 1919, Exotic Microlepidoptera, vol. 2, p. 237.1922, in Wytsman, Genera Insectorum, fasc. 180, p. 49.-Gaede, 1937, in Bryk, Lepidopterorum Catalogus, pars 88, p. 91.

Cryptolechia niveosella Walker, 1864, List Lepidopterous Insects British Mus., vol. 29 , p. 747 ( $q$, Sarawak).

Distribution: Borneo, New Guinea. 
Material examined: Luzon, Mt. Makiling (Baker), 1 ९, genit. slide 5116. Mindanao, Surigao, 4.XI.1915, $1 \sigma^{7}$, genit. slide 5112. Occidental Negros, Bacolod, 4.III.1929, on bark of mango (Mangifera indica), 1 앙 total: 1 ๙ $\sigma^{\top}, 2$ 우 (USNM). Luzon, Benguet Subprov., Baguio, 17.IV.1912, 1 \%; Benguet Subprov., Klondyke, $800 \mathrm{ft}$., 11.V.1912, 1 ㅇ (A.E. Wileman) (BM).

The species seems to share the bark-living habits with several South Asiatic species of the genus Limnaecia. It may be redescribed after the Philippine material as follows.

Male and female, $20 \mathrm{~mm}$. Head and palpus white, palpus with basal segment, and lower third of median, black; terminal segment with a small blackish basal ring and blackish tip. Thorax white, with a curved median transverse series of (apparently) four black dots (damaged). Abdomen sordid white, tergites with brassy-golden bristled areas, venter yellowish.

Forewing ovate-lanceolate, moderately broad. Snow white, markings black and well defined or grey with a ferruginous tinge, and slightly suffused. Basal fourth of costa or less, narrowly black. A black spot on base of costa, another smaller one below and beyond it; a separate, oval larger spot beyond the first pair below costa, followed by two dots, all in an oblique series; a series of four dots, first elongate below and before $1 / 3$ of costa, second slightly before it, in cell, third elongate, rather beyond and slightly below the second, also in cell, and fourth in fold at middle of wing length; a rounded conspicuous dot on end of cell; some five or six elongate somewhat suffused dots in a submarginal strongly curved row, arranged between ends of veins, from $2 / 3$ of costa, to below middle of termen; some seven or eight black spots or bars from costa before apex along termen to tornus and a small dot on end of dorsum. Cilia snow white, with small black subbasal dots opposite veins.

Hindwing pale grey, tinged fuscous towards apex, throughout with a strong silvery-metallic gloss. Cilia whitish fuscous grey, less glossy.

Male genitalia of the closely allied S. microsperma (Diakonoff) have been described at some length (Diakonoff, 1954, p. 88). Little can be added, except that my figure 631 represents the total view of the genitalia not in ventral aspect, as is stated in the caption and in the text, but in dorsal aspect; the remainder of the description is correct; figure 632 represents not the valva, as stated, but a lateral aspect of the right halves of the eighth sternite (below) and tergite (above it). At the time I noticed the similarity with the Cosmoptergid type of the genitalia and was in favor of separating the Scaesophidae from the Oecophoridae, not knowing yet that Scaeosopha itself was a Cosmopterigid. 
Male genitalia: It may be sufficient to describe the differences of the male genitalia of Syntomaula simulatella with those of S. microsperma. Sclerite of the eighth tergite with a longer and sinuate process, and with two short processes (ventral and dorsal) instead of one. Tegumen is similar, but left process of uncus is longer and strongly clavate. Aedeagus longer. Anellus rounded with a small notch at the top (in microsperma regularly conical). Cucullus longer. Two slender processes, hairy at the top, which I identified previously as anellus lobes, actually are not connected with anellus but are appendages of the costal edge of the valva.

Female genitalia, which have not been described before, are comparatively little modified. Seventh and eighth segments moderately sclerotized. Ovipositor and apophyses very long. Sterigma shaped as a simple round cup. Ductus bursae for a short stretch simple, thence double, a strongly plicate blind sack at the left, and the ductus proper, plicate above, simple beneath; corpus bursae large and ovoid. Signa, two large and straight thorns with funnel-shaped bases.

\section{Scaeothyris, new genus}

Head flattened, with dense appressed scales, very dense and long on vertex. Ocellus small, posterior. Proboscis developed, dilated and flattened at base. Antenna 3/4, slightly thickened, serrulate, shortciliate, scape elongate, rather stout, with long pecten. Labial palpus moderate, little curved, median segment thickened, not reaching base of antenna, terminal segment slender, acute, shorter than median (thorax damaged). Maxillary palpus short, slightly brushy, appressed to proboscis. Posterior tibia with smoothly appressed long and bristly scales, projecting beyond apex.

Forewing moderate, oblong, pointed, termen slightly rounded, very long and oblique; without tufts of scales. Vein $1 \mathrm{~b}$ long-furcate, 2 from beyond 4/5, 3 from far before angle, 4 from angle, 7 and 8 long-stalked, 7 to costa, 11 from before middle.

Hindwing semioval, slightly over 1 , cilia $1 / 2$; a corrugated, transversely striated thin patch below $1 / 3$ of cell, lower edge of cell thickened and strong, vein 2 from $2 / 3$, strongly bent at base, 3 from angle, 4 and 5 long-stalked, 6 and 7 parallel.

Type species: Scaeothyris pseusta, new species.

An interesting addition to the peculiar subfamily. The genus is characterized by the long-stalked veins 4 and 5 in the hindwing. It is nearest to Archisopha Meyrick, differing by the presence of an antennal pecten, by shorter palpi, smooth posterior tibiae and neuration of the hindwing. 


\section{Scaeothyris pseusta, new species}

Figures 382-383, 477, 634

Male, 21-24 mm; holotype, $24 \mathrm{~mm}$. Head light ochreous yellow, antenna dark fuscous. Palpus fuscous. Thorax dark purplish brown, metathorax pale yellow posteriorly. Legs yellowish fuscous. Abdomen fuscous.

Forewing oblong, broadly sublanceolate, costa little curved, apex pointed, termen long, gently rounded, very oblique. Unicolorous glossy light tawny with a slight pale fulvous tinge, faintly suffused with darker tawny fuscous towards base; a minute faint fuscous line along discoidal vein. Cilia brighter, light fulvous tawny.

Hindwing whitish fulvous, with a faint vinaceous tinge, veins and margin narrowly darker. Cilia light ochreous.

Male genitalia: Tegumen and uncus symmetrical, the latter double, two curved, sclerotized arms. No gnathos. Valva with a strongly sinuate, membranous sacculus half and a weaker cucullus half, ending in a short and knoblike, punctulate cucullus. Annellus strong, dorsally developed into a sclerotized and projecting roof, anellus lobes rising, slender, S-shaped, tips bristly. Aedeagus huge, curved dorsoventrally and also to the left side; cornuti, two slender unequal streaks of fine spines.

Material examined: Mindanao, Davao Prov., east slope of Mt. McKinley, 3000 ft., 14.IX.1946 (CNHM Philippine Exped. 1946-47, H. Hoogstraal), $1 \sigma^{7}$, holotype, genit. slide 5790; 13 and 25.IX.1946, $2 \sigma^{7}$, paratypes, genit. slide 5760 .

Superficially the species resembles Haplotinea subochraceella (Walsingham), a very common species.

\section{Cosmopteryginae, new status}

\section{Key to the Philippine Genera of Cosmopteryginae}

1. Forewing with vein 6 stalked with other veins . . . . . . . . . . . . 2 Forewing with vein 6 separate . . . . . . . . . . . Limnaecia

2. Forewing with 7 and 8 out of 6,5 separate . . . . . . . . Cosmopteryx Forewing with 5,7 and 8 out of 6 ........... Pyroderces

\section{Limnaecia Stainton, 1851}

\section{Limnaecia acontophora Meyrick, 1922}

Figures 233, 635

Limnaecia acontophora Meyrick, 1922, Exotic Microlepidoptera, vol. 2, p. 573 (६).-Clarke, 1955, Catalogue ... Microlepidoptera ... Meyrick, vol. 1, p. 34 .

Distribution: Luzon, Manila. 
The type specimen, unique, is in the Paris Museum. The elegantly colored species is very distinct. The holotype studied, , genit. slide 5507, labelled "Philippines, Manilla."

Female genitalia: Ovipositor moderate, lobi anales semioval, slightly pointed. Anapophyses very slender, moderately long, postapophyses similar, twice as long. Ductus bursae extremely long, tortuous and coiled simultaneously. Corpus bursae with a reticulate wall, signa elongate, moderately scobinate plates. Abdominal wall sclerotized throughout.

\section{Pyroderces Herrich-Shäffer, 1853}

\section{Pyroderces simplex Walsingham, 1891}

Figure 636

Pyroderces simplex Walsingham, 1891, Trans. Roy. Ent. Soc. London, p. 119, pl. 6, fig. 58 ( $\sigma^{\top}+$, Gambia).-Durrant, 1912, Bull. Ent. Res., vol. 3, p. 206, fig. 2 (India, Egypt).-Lamborn, 1914, Bull. Ent. Res., vol. 5, p. 201 (Egypt, E. Africa).-Willcocks, 1916, Insect Pests Egypt, vol. 1, pt. 1, p. 317, pl. 7, figs. 7-9 (Egypt).-Fletcher, 1933, Imp. Counc. Agric. Res., Sci. Mon., no. 4, p. 4.

Anatrachyntis simplex.-Fletcher, 1917, Rep. Proc. 2nd Ent. Meeting Pusa, p. 114.-1921, Mem. Dept. Agric. India, Ent. ser., vol. 6, p. 98.-Corbett and Gates, 1926, Bull. Dept. Agric. Federated Malay States, no. 38, p. 8 (Malaya). Batrachedra coriacella Snellen, 1901, Tijdschr. Ent., vol. 44, p. 95, pl. 6, figs. 7, 7a ( $\sigma^{7}$, head, Java).

Stagmatophora coriacella.-Maxwell-Lefroy, 1909, Indian Insect Life, p. 536.Meyrick, 1910, Trans. Roy. Ent. Soc. London, p. 372 (Mauritius).

Pyroderces coriacella.-Fletcher, 1914, South Indian Insects . . ., p. 458, fig. 334

(India).-Meyrick, 1914, Ent. Mitt. Suppl., vol. 3, p. 52 (Formosa).

Anatrachyntis coriacella.-Meyrick, 1915, Exotic Microlepidoptera, vol. 1, p. 325. Stagmatophora gossypiella Walsingham, 1906, Ann. Mag. Nat. Hist., ser. 7, vol. 18, p. 178 (Egypt).-Morstatt, 1912, Pflanzer, vol. 8, p. 253 (East Africa).

Distribution: India, Burma, Java, Formosa, Mauritius, throughout Africa. Probably everywhere in the Old World where cotton is grown.

Food plant: Cotton (Gossypium, seeds). African oil palm (Elaeis guineensis), Eriodendron frondosum.

Material examined: Luzon, Manila, 15.VII.1917, on cotton boll (D.B. Mackie), "Acc. No. 2980," 10 specimens. Santos, Cotabato, October 1954 (V.J. Madrid), "No. Ec. 7," "7a." 2 rubbed specimens (USNM).

\section{Cosmopteryx Hübner, 1826}

\section{Key to the Species of Cosmopteryx}

1. Forewing, transverse band yellow, with a black dot; median white line from base to middle of wing . . . . . . . . . . . . . . . C. dulcivora

Forewing, transverse band orange, without dot, median white line short, before $1 / 4$. . . . . . . . . . . . . . . . . . C. basilisca 


\section{Cosmopteryx dulcivora Meyrick, 1919}

Figures 231-232, 637

Cosmopteryx dulcivora Meyrick, 1919, Exotic Microlepidoptera, vol. 2, p. 233 ( $\sigma^{\Im} \%$, Fiji).-Diakonoff, 1940, Verh. Proefstat. Java Suikerindustrie, no. 24, pp. 907-923, figs. (Java) ; 1941, Archief Suikerindustrie Nederlandsch-Indië, vol. 1941, no. 2, pp. 34-41, figs.-Clarke, 1955, Catalogue . . Microlepidoptera . . Meyrick, vol. 1, p. 122. Literature on occurrence, biology etc.: Jarvis, 1916, Queensland Bur. Sugar Exp. Sta., Ent. Div. Bull. 3, p. 15 (Queensland).-Veitch, 1919, Bull. Ent. Res., vol. 10, p. 36 (Fiji); 1923, Colon. Sugar Refg. Co. Ltd., Agr. Rep. no. 7, p. 17-Swezey, 1924, Hawaiian Planters' Rec., vol. 28, p. 214 (Samoa).-Dormer, 1924, Queensland Agric. Journ., vol. 21, p. 367.-Burns and Mungomery, 1925, ibid., vol. 24, p. 335.-Jarvis and Mungomery, 1926, Queensland 26th Ann. Rep. Sugar Exp. Sta., pp. 23, 25.-Mungomery, 1927, Queensland Agric. Journ., vol. 28, p. 104 (Queensland).-Hopkins, 1927, Bull. Ent. Res., vol. 18, p. 30 (Samoa).-Bolle, 1934, Archief Suikerindustrie Nederlandsch-Indië, vol. 1934, p. 332.

Distribution: Fiji, Samoa, Queensland, Java.

Food plant: Sugar cane (minor pest), mining in leaf and tunnelling through the midrib.

Material examined: Negros, Victorias, "cc iis c" and "d," "cane leaf," "LL 163," 14.VI.1928, "Cosmopteryx dulcivora Meyr.," "Cosmopteryx pallifasciella." $2 \sigma^{\top}$, genit. slide 5259, 3 क genit. slides 5260, 5261. 2 ఠ ○ $^{7} 3$ ㅇ (USNM).

Male genitalia: The left half of gnathos developed, strongly sclerotized, clavate, with one angle obliquely produced into a slender process. Valvula oblong-semioval. Valva large, semicircular, upper end of cucullus angulate. Lobes at the base of the aedeagus very large, larger than valvulae, almost semicircular. Aedeagus moderate.

Female genitalia of the usual Cosmopteryx pattern. Signa small ill defined and unequal.

\section{Cosmoptery $x$ basilisca Meyrick, 1909}

Cosmopteryx basilisca Meyrick, 1909, Journ. Bombay Nat. Hist. Soc., vol. 19, p. 416 ( $\sigma^{7}$, Ceylon).-Clarke, 1955, Catalogue ... Microlepidoptera ... Meyrick, vol. 1, p. 64 .

Distribution: Ceylon, India, Philippine Is.

The distribution record is derived from Meyrick's unpublished notes in the British Museum (Natural History). I did not see evidence of the occurrence outside Ceylon.

\section{Oecophoridae}

\section{Key to the Philippine Genera of Oecophoridae}

1. Forewing with raised tufts of scales . . . . . . . . . . . . . . . 2

Forewing without tufts . . . . . . . . . . . . . . . 3 
2. Scape of antenna without a pecten of hairs . . . . . . . . . . . Tonica

Scape of antenna with a pecten of hairs . . . . . . . . . . Psorosticha

3. Antenna thickened with scales on back . . . . . . . . . . . Astiarcha

Antenna not thickened with scales on back . . . . . . . . . . . . . . 4

4. Forewing with veins 2 and 3 stalked; very large species. . Epimecyntis

Forewing with veins 2 and 3 separate . . . . . . . . . . . . . . . . 5

5. Labial palpus very long, median segment $2-3$ times length of face . . . . . 6

Labial palpus moderate, median segment less than twice length of face . . 7

6. Posterior tibia smooth; maxillary palpus moderate; proboscis developed; labial palpus more than 3 times length of face . . . Diploclasis, new genus Posterior tibia with long projecting hairs above and beneath; maxillary palpus minute; proboscis weak; labial palpus less than 3 times length of face.

Tanyzancla

7. Labial palpus with terminal segment about as long as median . Chrysonoma Labial palpus with terminal segment decidedly shorter than median.

Philobota

\section{Epimecyntis Meyrick, 1924}

Epimecyntis chlorogenes Meyrick, 1928

Figure 639

Epimecyntis chlorogenes Meyrick, 1928, Exotic Microlepidoptera, vol. 3, p. 470 ( $\%$, Philippine Is.).-Clarke, 1955, Catalogue . . Microlepidoptera . . . Meyrick, vol. 1, p. 86 .

Distribution: Philippine Is.

Material examined: Luzon, Mt. Makiling (Baker), 1 앙 topotype and second specimen known (USNM). An extremely large species.

\section{Diploclasis, new genus}

Head with appressed scales, side tufts moderately spreading. Ocellus posterior. Proboscis developed. Antenna 4/5, in male long-ciliated throughout, scape elongate, with a brushy long pecten along basal half. Labial palpus very long, porrected-recurved, median segment very long, little curved, smooth, moderately thickened before apex, terminal segment slender, acute, $2 / 3$ median, rising. Maxillary palpus moderate, pending, appressed to proboscis. Thorax smooth. Posterior tibia smooth.

Forewing elongate, without tufts of scales on surface. Vein $1 \mathrm{~b}$ furcate, 2 from before angle, 3 and 4 approximated, from angle, 7 and 8 stalked, 7 to termen just below apex, 11 from middle. Hindwing: elongate-semioval, under 1 , cilia $1 / 2 ; 3$ and 4 connate, 5-7 tolerably parallel, 5 submedian, 6 and 7 running close along basal third.

Male genitalia as described with the species.

Type species: Diploclasis balbidophora, new species.

Probably allied with Tanyzancla Meyrick, but differing by long ciliate antennae in male, very long median segment of palpus and entirely smooth posterior tibia. 


\section{Diploclasis balbidophora, new species}

Figures 246, 249-252, 257, 640

Male, $16 \mathrm{~mm}$. Head light orange, face yellow, a rounded brown spot on vertex and forehead. Antennal ciliations over 1; scape elongate, clavate, yellow, with a brown mark on basal half above, flagellum dark grey, ringed with black, towards base yellow, along apical third pale yellow. Labial palpus very long, recurved, median segment slightly thickened, rather smooth, subascending, over $3 \times$ face, orange yellow; with a faint transverse purplish subapical mark anteriorly; terminal segment over $1 / 2$, orange yellow; a subbasal ring, anterior streak and four small dentations of the internal edge of this streak blackish purple. Thorax brown, tip and posterior half of tegula orange, three longitudinal orange-brownish lines, lateral short, median complete. Abdomen dark purple, irregularly banded with yellow, venter yellow.

Forewing with veins 3 and 4 moderately approximated, from angle; suboval, moderately broad, costa curved, apex subobtuse, termen rounded, oblique. Bright yellow orange, markings dark purple. A subbasal transverse fascia, strongly curved, from base of costa to dorsum beyond base, with an acute posterior angulation above middle, and extended along dorsum so as to form a semioval spot reaching to base of fold; an $\mathrm{N}$-shaped zigzag mark, from $2 / 5$ of dorsum to middle of costa, thence to $3 / 4$ of dorsum and finally to costa before apex; points of contact with costa slightly extended along costal edge; anterior arm of the $\mathrm{N}$ narrower, vertical along lower half, with the base narrowly and strongly extended along dorsum, a posterior horizontal branch from this arm running just below cell and almost touching the median branch of the N. Cilia dark purple, basal half yellow around apex and along upper part of termen.

Hindwing elongate, semioval, about $2 / 3$, cilia $1 / 2$; veins 3 and 4 connate. Deep bronze brown, cilia bright yellow with basal fourth bronze brown and with a whitish basal line, entirely bronze brown opposite apex, pale yellow along costa.

Male genitalia: Tegumen moderate, top rounded. Uncus not separated or absent. Transtilla absent. Valva elongate, moderate, rather thickened, dilated. Sacculus sclerotized, over 1, ending in a sharp point; cucullus equally sclerotized, with a separate rounded top. Aedeagus moderate, curved, its base extending into a tortuous ductus ejaculatorius as a tortuous, bandlike sclerite.

Material examined: Luzon, Los Baños (P.J. Baker), $1 \sigma^{x}$, holotype, genit. slide 5233 (USNM). 


\section{Astiarcha Meyrick, 1914}

Astiarcha Meyrick, 1914, Exotic Microlepidoptera, vol. 1, p. 248; 1922, in Wytsman, Genera Insectorum, fasc. 180, p. 115.-Fletcher, 1929, Mem. Dept. Agric. India, Ent. ser., vol. 11, p. 26.-Gaede, 1938, in Bryk, Lepidopterorum Catalogus, pars 88, p. 194.-Clarke, 1963, Catalogue . . . Microlepidoptera ... Meyrick, vol. 4, p. 114, pl. 54, figs. 1-1c.

Type species: Harpella aureatella Snellen, 1903 (Java).

\section{Key to the Species of Astiarcha}

1. Edge of basal patch concave; orange spot on dorsum hardly reaching $1 / 2$ across wing; costal orange patch triangular; top of cucullus rounded (Java).

A. aureatella

Edge of basal patch convex; orange spot on dorsum reaching almost $3 / 4$ across wing; costal orange patch subquadrate; top of cucullus with a clavate appendix

A. praedives, new species

\section{Astiarcha praedives, new species}

Figures 248, 260-261, 641

Female, $19 \mathrm{~mm}$. Head glossy bronze polished, edged around with dull orange (palpi missing). Antenna purple, scape light orange below, flagellum with apical fifth white. Thorax glossy bronze purple, tip of thorax and apical half of tegula pale yellow. Abdomen bright golden orange, basal segment except laterally bronze brown, second and third segments slightly dusted with brown and with a brown supralateral streak, venter orange yellow.

Forewing elongate-suboval; costa little curved at extremities, straight in middle, apex obtusely pointed, termen rounded, very oblique. Bright yellow orange, markings metallic blue, edged with dull purple black. A basal patch occupying less than $1 / 6$ of wing, edge slightly convex, with a short projection in fold, above and below this edge of patch suffused; this patch containing an orange spot on upper half of base of wing; an almost vertical transverse blotch rising on dorsum well before middle, across $3 / 4$ of wing breadth, base extended along edge of wing, top rounded; this top is connected by an almost horizontal dark line with the following marking: a semicircular band from costa beyond middle ascending to dorsum before tornus and along tornus and termen to apex, dilated in tornus and in apex. Cilia (rubbed) in tornus whitish with black basal third.

Hindwing dark purple brown, rather dull, costa pale yellow. Cilia yellow orange, with a thin dark purple scaling, forming a basal band, tuft of hairs on base of vein 1a orange.

Male genitalia: Tegumen broadly conical. Uncus simple dilated and lobelike, slightly emarginate in middle. Socii and gnathos 
absent. Transtilla-like sclerotization, through and under which the aedeagus moves, shaped as a darker triangle, open below. Valva suboval, rather simple; sacculus $1 / 2$, a simple, rounded fold. Cucullus moderately sclerotized, with top constricted, so as to form a moderate, clavate appendix; costa with a subapical slender, not clavate, digit curving down over top of cucullus. Aedeagus simple, curved, not dilated. Cornutus, a single long spine, possibly not deciduous, sinuate and projecting at the top.

Female genitalia: Sterigma sclerotized, seventh segment forming a semioval strong edge around the ostium; lamella postvaginalis sclerotized, forming a rounded plate; lamella antevaginalis, a moderate oval plate with a dentoid sclerite in the middle. Ostium bursae proper, a strong funnel; colliculum, a large, erect oval sclerite. Signum rather small, stellate.

Material examined: Luzon, Mt. Makiling (Baker), 19, holotype, genit. slide 5238. Occidental Negros, Saravia, 1 \%, with only left pair of wings, labelled: "forest," "guintahu-an" (probably food plant), "7.V.1928," "485," "ㅇ genit. on slide A.B. Jun. 27, 1930, with 우 $\sigma^{7}$ and wings on sp. sent to Meyrick" (USNM), slide 4655 \%, remounted. This female and fragments of the male are paratypes. (I have remounted the left forewing and the genitalia of the male on slide 4654 and the genitalia of the female paratype on slide 4655). Since the male specimen itself is not available, I prefer to designate the female as holotype. The male genitalia, however, are characteristic and very distinct.

Compared with Astiarcha aureatella (Snellen), ơ lectotype, hereby selected, labelled" W. Java, Preanger, 5000 ft., $\sigma^{7}$, Sythoff" (genit. slide 4652, fig. 247), and with a 9 , paratype (originally syntype), with the same label (genit. slide 4653), both in the Leiden Museum.

Closely allied to A. aureatella (Snellen), differing as indicated in the key above. The female genitalia of the two species are rather similar, those of aureatella are less sclerotized.

\section{Tanyzancla Meyrick, 1918}

\section{Key to the Philippine Species of Tanyzancla}

1. Fuscous with pale markings

T. pepona, new species Pale yellowish or yellowish, with fuscous or purplish markings or without markings. . . . . . . . . . . . . . . . . . 2

2. Males ..

Females . . . . . . . . . . . . . . . . . . . . 4

3. Small species, $15.5 \mathrm{~mm}$; forewing with a slender marginal fuscous fascia in apex and along termen to tornus

T. cincta, new species Large species, $22 \mathrm{~mm}$; forewing without a marginal line.

T. catadea, new species 
4. Forewing with posterior half of costa infuscated, interrupted by a pale spot at $3 / 4$. . . . . . . . . . . . T. catadea, new species

Forewing with posterior half of costa not infuscated . . . . . . . . . . 5

5. Forewing pale yellowish, with a slender, fuscous transverse mark at $4 / 5$.

T. lanceolata, new species

Forewing yellowish, with a moderate purplish mark beyond middle, a bent longitudinal streak from base and a terminal fascia.

T. amydrographa, new species

\section{Tanyzancla amydrographa, new species}

Figures 259, 642

Female, $18 \mathrm{~mm}$. Head pale ochreous. Antenna ochreous, irrorated with dark fuscous at base, beyond base flagellum suffused and banded above with dark fuscous purple. Palpus bright yellow ochreous and shining externally, whitish internally, median segment with a faint oblique mark beyond middle of upper edge and a suffused apical purplish ring, terminal segment with a subbasal ring and tip dark purple. Thorax light yellow ochreous. Abdomen pale ochreous.

Forewing suboval, rather broad, costa gently curved throughout, apex obtusely pointed, termen rounded, very oblique. Pale ochreous, costal third suffused, rather bright ochreous; sparsely and irregularly scattered throughout except along extreme costa with dark purple scales. Markings formed by rather narrow fasciae of dark purple irroration. An outwards-concave fascia from dorsum beyond base, rising above middle of disc, thence running along upper edge of cell, gradually and rather strongly dilated towards dorsum; a straight fascia from middle of costa to dorsum before tornus, dilated at extremities so as to make the edges look concave; a second transverse fascia running parallel to the first from costa before apex to upper fourth of termen, thence along wing margin to lower extremity of the first fascia; plical stigma faint, beyond $2 / 5$; apex (below vein 8 ) and termen beyond second fascia slightly sprinkled with purple. Cilia light ochreous, becoming bright ochreous towards apex.

Hindwing glossy pale yellowish ochreous, a moderate marginal fascia of pale purplish suffusion in apex and along upper part of termen, extending over dorsum as far as vein $1 \mathrm{c}$. Cilia pale ochreous with a faint darker subbasal shadow.

Female genitalia: Ovipositor rather long, extensile. Eighth segment rather thickened. Sterigma complicated, two pairs of strong curved folds, converging in the middle, dilated into moderate sclerites laterally. Signum, a transversely oval, moderate dentate plate.

Material examined: Luzon, Mt. Makiling (Baker), 1 \%, holotype, genit. slide 5217 (USNM). 


\section{Tanyzancla pepona, new species}

Figures 256, 275, 643-644, 808

Male, 24-25 mm. Head ochreous fuscous, roughish. Antenna with flagellum ochreous fuscous, scape dark fuscous except apex, ciliations under 1 , pecten long and dense, fuscous with a pale ochreous basal half. Palpus long in male, median segment less than $2 \times$ length of face, in female longer and more slender, recurved, terminal segment $5 / 6$; dark fuscous, median segment with a subapical broad ring, below this mixed with ochreous, tip pale ochreous; terminal segment dark fuscous, median part mixed with pale ochreous, posterior edge pale ochreous. Thorax pale ochreous, patagia light ochreous, tegulae dark fuscous, with pale tips. Abdomen fuscous brownish, anal tuft and posterior edges of tergites pale ochreous.

Forewing elongate suboval, dilated, broadest at $4 / 5$, costa gently curved at base, faintly concave in middle, considerably curved before apex, apex obtusely pointed, termen hardly concave, oblique, long. Whitish ochreous, markings extended, blackish fuscous. Base with a direct transverse band, below emitting a pointed streak parallel to basal third of fold, above forming a rather narrow streak along base of costal edge, dilated beyond middle; a very irregular undulate transverse fascia of pale fuscous dusting from this dilatation to dorsum before middle, including rather large slightly elongate first discal stigma; a large rounded blackish patch in middle of disc halfway between stigma and base, emarginate posteriorly; somewhat less than posterior half of wing as far as fold blackish fuscous, including a rounded pale ochreous spot below second discal stigma which is blackish and large, but little contrasting; posterior edge of dark half of wing irregular, partly suffused, with several long and narrow teeth; a brighter ochreous triangular spot on $2 / 3$ of costa conspicuous; a whitish coarse dusting with a distinct gloss tending to form a transverse broad band from costa before apex to dorsum before tornus, gradually narrowed downwards; another band of similar glossy whitish dusting formed by a series of regular short intraneural streaks, half way between preceding and wing margin and parallel to that margin, below costa before apex, before apex and termen, to tornus. Cilia ochreous, infuscated, above apex becoming dark fuscous.

Hindwing golden ochreous, glossy, rather deeply infuscated, extreme apex fuscous. Cilia concolorous, with a pale base and a darker subbasal faint band.

Female, $28 \mathrm{~mm}$. A worn specimen, but very probably the sex partner. Pale ochreous, posterior half of wing infuscated but less dark than in male. Basal dark patch and costal streak discernible. Stigmata dark fuscous, first discal elongate, second discal rounded, plical rather beyond first discal; triangular pale ochreous costal spot 
as in male, first pale fascia obliterate, second faintly discernible. Palpus longer and paler than in male, but markings similar.

Male genitalia: Tegumen slender and long with a dilated base, top finely punctulate. Uncus sclerotized, short and rounded. Gnathos, a simple, sclerotized, suboval plate with an acute point on top. Vinculum strong, rounded. Juxta and caulis sclerotized, inverted-trapezoidal and erected-clavate, respectively. Valva sclerotized, suboval, cucullus, a strong, slightly hooked process with a subapical area of long spiny hairs. Sacculus under $2 / 3$, top truncate, moderately bristled. Aedeagus rather short, moderate, gently curved, base flattened and tortuous.

Female genitalia: Genital segment with moderately sclerotized lateral semioval sclerites. Lamella antevaginalis, a subtrapezoidal prominence. Lamella postvaginalis, a large, inverted-trapezoidal plate with rounded angles. Colliculum, small dark semicircular sclerites.

Material examined: Luzon, Benguet Subprov., Pauai, Haights Place, 7000 feet, 25.VI.1912, 1 ऽ', holotype, genit. slide 5580; 1 \%, allotype, genit. slide 5579; $1 \sigma^{7}$, paratype, slide 5588; same locality, 29.VI.1912, $1 \sigma^{\Upsilon 7}$, paratype, genit. slide 5589 and 2 \%, paratypes, 20 and 25.VII.1912 (A.E. Wileman) (BM). Holotype with left pair of wings missing.

\section{Tanyzancla cincta, new species}

Figures 253, 646

Male, $15.5 \mathrm{~mm}$. Head and thorax pale ochreous. Antenna glossy pale ochreous fuscous. Palpus very long, recurved, median segment slender, twice the length of face, terminal segment slender, acute, slightly shorter; pale ochreous, median segment slightly infuscated laterally on lower half, an incomplete fuscous subapical ring; terminal segment dark fuscous with a suffused pale ochreous subbasal band. Abdomen pale ochreous.

Forewing oblong, sublanceolate, dilated, costa gently curved throughout, apex pointed, termen gently curved, almost straight, long and oblique. Ochreous whitish, markings rather dark fuscous. A very fine sparse fuscous dusting all over the wing; costal edge suffused with pale fuscous grey; some coarse dusting below costa towards base; a small suffused spot on costa beyond middle; a larger more defined dark fuscous wedge-shaped inwards-oblique spot on costa well before apex; stigmata dark fuscous, first discal slightly elongate, at $1 / 3$, plical more elongate, somewhat cloudy, beyond first discal; second discal transverse, subcrescentic, outwards-oblique before $2 / 3$ (across upper angle of cell), connected by a strigula of fine dusting with tornus; an irregular and suffused dark fuscous marginal 
band around apex (from end of vein 8), along termen and tornus to dorsum, exceeding end of fold. Cilia ochreous whitish, a supramedian band of dark fuscous irregular fine bars, apical third of cilia touched with greyish.

Hindwing and cilia glossy whitish ochreous, extreme tip of wing touched with fuscous.

Male genitalia: Tegumen rather narrow and high. Uncus moderately long, narrowed. Gnathos present, simple, bandlike, single. Vinculum narrow. Anellus lobes short and rounded. Valva rather narrow, with costa deeply sinuate. Cucullus strongly curved, almost pistol-shaped, with a long pointed top. Sacculus narrow, top with a long three times rectangularly bent spine: upwards, outwards and finally forewards. Aedeagus little curved, moderate, cylindrical. Cornuti, two long spines and a dense patch of denticulations.

Material examined: Luzon, Benguet Subprov., Klondyke, $800 \mathrm{ft}$., 14.IV.1912 (A.E. Wileman), 1 ○', holotype, genit. slide 5584 (BM).

\section{Tanyzancla catadea, new species}

Figures 276, 645

Male, $22 \mathrm{~mm}$. Head and thorax pale ochreous. Palpus very long, recurved, median segment by far exceeding vertex; pale ochreous, basal half externally suffused with blackish fuscous towards upper edge: terminal segment slightly under 1. Antenna pale ochreous, finely ringed with fuscous. Abdomen tawny, anal tuft and venter whitish.

Forewing elongate-suboval, broadest beyond $3 / 4$, costa moderately curved throughout, apex subacute, termen hardly sinuate below apex, convex below this, oblique. Pale ochreous. Costal edge from base to beyond middle narrowly dark fuscous; a moderate suffused streak from upper edge of cell at middle of wing to costa beyond middle, pale fuscous, upwards becoming darker fuscous and more defined; stigmata irregular, fuscous, first discal in middle of cell, largest, connected with lower end of streak; second discal rounded, on closing vein; plical stigma but little beyond first discal; finest fuscous scales scattered here and there over the wing. Cilia pale ochreous.

Hindwing and cilia whitish, paler, more glossy, less ochreous and more yellowish tinged.

Male genitalia: Tegumen rather broad, triangular, with distinct articulations in the middle of pedunculi. Uncus short, triangular. Gnathos with arms running at base horizontally, then angulate, forming a pending semicircle with a short point. Vinculum broad and strong. Valva strongly sclerotized, cucullus and sacculus forming strong acute prongs. Aedeagus rather long, strong, with a conical anellus. Cornutus, a single strong spine. 
Material examined: Luzon, Benguet Subprov., Baguio, $5000 \mathrm{ft}$., 10.III.1912 (A.E. Wileman), $1 \sigma^{7}$, holotype, genit. slide 5578; $1 \sigma^{7}$, paratype, genit. slide 5597. Benguet Subprov., Pauai, Haights Place, 7000 ft., 25.VI.1912 (A.E. Wileman) (BM).

\section{Tanyzancla lanceolata, new species}

Figures 262-263, 647

Female, $23 \mathrm{~mm}$. Head, antenna and thorax pale ochreous. Palpus pale ochreous, median segment with more than basal half suffused with greyish fuscous, a subapical dark fuscous ring, terminal segment slender, under 1; infuscated throughout, base and front dark fuscous. Abdomen whitish.

Forewing ovate-lanceolate, costa moderately curved at extremities less so in middle, apex pointed, termen little curved, strongly oblique. Pale ochreous, deeper ochreous tinged towards edge of wing and towards lower half of base. Basal patch small, except extreme base of wing mixed with grey, outer edge forming three ill-defined spots: on costa, above fold and halfway between fold and dorsum; stigmata moderate, first discal rounded, about 3 times larger than plical which is just beyond it, elongate; second discal small, subtriangular; an irregular elongate patch of sparse fuscous dusting from above first discal stigma towards $3 / 5$ of costa, not reaching it; an irregular wedgeshaped mark of fuscous suffusion from costa before apex, towards cell, hardly reaching halfway towards this; an irregular submarginal series of dots between veins, from below apex to end of fold; edge of wing along end of costa, in apex and along upper small part of termen with a brownish suffused line. Cilia whitish ochreous.

Hindwing glossy whitish, gradually becoming pale ochreous towards apex, cilia ochreous whitish.

Female genitalia: Sixth sternite modified, posterior edge with rounded lateral lobes and a triangular median excision; seventh segment equally modified, edge with obtusely pointed lobes and slightly sinuate in middle. Ostium bursae shaped as a regular, slender ring; $8+9$ segment moderately sclerotized. Signum stellate.

Material examined: Luzon, Benguet Subprov., Klondyke, $800 \mathrm{ft}$., 16.III.1912 (A.E. Wileman), 1 \%, holotype, genit. slide 5599 (BM).

The affinity of this species remains obscure.

\section{Philobota Meyrick, 1883}

\section{Philobota loxographa, new species}

Figures 274, 648, 650

Male, $15.5 \mathrm{~mm}$. Head pale ochreous yellow, crown slightly infuscated. Antenna pale ochreous yellow, dark fuscous above; cilia- 
tions slightly over 1; pecten of scape broad, ochreous yellow. Palpus pale ochreous yellow, basal segment dark fuscous except lower edge, terminal segment shorter than median, dotted with dark fuscous along lower and upper edges. Thorax pale ochreous yellow, with anterior fourth, shoulders and apex infuscated. Abdomen pale ochreous, spiny tergites ferruginous, partially showing through, posterior edges pale ochreous. Posterior leg pale ochreous, tarsus and outer spurs blackish.

Forewing rather narrow, lanceolate-oval, pointed. Pale ochreous yellow. Markings rather dark fuscous. A dark fuscous basal patch, occupying about $1 / 7$ or $1 / 8$ of wing except extreme base, edge straight and direct; first discal stigma moderate, rounded, connected by a wedge-shaped conspicuous mark with the middle of costa; plical stigma small, well beyond first discal; second discal stigma about as large as first, connected by a transverse fuscous suffusion with tornus, this suffusion faintly extending to termen; an inwards-oblique dark fuscous dot on $4 / 5$, extending halfway towards second discal stigma, its lower extremity emitting a fuscous outwards-curved line to tornus; a small dot in apex. Cilia concolorous, with a broad fuscous patch in tornus.

Hindwing pale fuscous yellowish, with a bronze gloss. Cilia pale ochreous, dull.

Male genitalia sclerotized throughout. Tegumen moderate, with broad pedunculi. Uncus moderate, hooked, top truncate and rather short. Gnathos very short, a transverse ridge with angular projections at the sides and a short, blunt hook. Tuba analis distinct and wide, open below. Vinculum short, flattened, without signum. Valva strongly concave lengthwise, sclerotized throughout; sacculus, a broad fold at base, top extended into a strong spatulate and bicuspid process, costa forming a slender, bristly cucullus.

Female, 17-18 mm. Head light ochreous. Antenna dark fuscous, scape light ochreous. Palpus light ochreous, median segment with basal 2/3 fuscous, edge suffused; terminal segment densely strewn with purple fuscous. Thorax light ochreous, shoulder and a round spot on apex fuscous. Abdomen ochreous.

Forewing as in male, slightly broader. Markings very similar, differing thus. Wedge-shaped patch from middle of costa not reaching first discal stigma; plical stigma minute; suffused patch connecting second discal stigma with tornus less dense; transverse streak from posterior edge of this patch to preapical costal spot more defined than in male, slightly sinuate; apical and terminal marks minute. Otherwise similar to male.

Female genitalia: Sterigma, a subtrapezoidal sclerite with rounded lower angles and concave sides. Lamella postvaginalis, an oval padlike sclerite, flanked by rounded bristly knobs; colliculum, strongly 
sclerotized, funnel-shaped, upper edge forming a sinuate liplike fold. Segment $8+9$ moderately sclerotized. Ovipositor rather short. Signum absent.

Material examined: Luzon, Baguio, Mountain Province, 9.X.1945, $1 \sigma^{7}$, holotype, genit. slide 5111 (J.B. Franclemont) (CUI). Baguio, Benguet Subprov., 5000 ft., 19.IV and 29.IV.1912 (A.E. Wileman), $2 \sigma^{\Upsilon}$, paratypes, genit. slide 5586; 20.IV.1912, 1 ○', genit. slide 5576 (entirely whitish, glossy, devoid of any markings); same locality and date, 1 \%, allotype, genit. slide $5649 ; 1$ \%, paratype, genit. slide 5652; same locality, 29.IV.1912, 1 \%, paratype, genit. slide 5650. Same locality 19-20.IV.1912, 3 o $^{7}$, paratypes, genit. slides 5576, 5586, and 5651. Same locality, 27.IV.1912, 1 ㅇ, paratype, genit. slide 5660 (BM).

\section{Chrysonoma Meyrick, 1914}

\section{Key to the Philippine Species of Chrysonoma}

1. Markings formed by fuscous dusting, rather extended . . . . . . . . . 2

Markings very pale, purplish, limited or absent . . . . . . . . . . . . 4

2. A distinct basal patch to $1 / 4$, limited to lower $2 / 3$ or base of wing.

Basal patch ill defined . . . . . . . . . . . 3

3. Forewing with fuscous dusting only in center of base of wing; no spots on costa. . . . . . . . . . . . . C. fragmentaria, new species

Forewing with fuscous dusting spread all over; usually a triangular spot before $2 / 3$ of costa . . . . . . . . . . . . . . C. eumorpha, new species

4. Markings absent, entire wing more or less suffused with brownish.

C. aporopis, new combination

Markings present, however few, forewing not thus suffused . . . . . . . 5

5. Hindwing pale grey . . . . . . . . . . C. hypocapna, new species

Hindwing yellowish or whitish . . . . . . . . . . . . . . . . 6

6. Yellowish, a fine purplish semicircular line from $3 / 5$ of costa to above tornus, thence to costa before apex, often very pale, in females often absent.

C. hesitans, new species

Whitish, a small dark fuscous dot at $5 / 6$. . . . C. inermis, new species

\section{Chrysonoma aporopis (Meyrick, 1928), new combination}

Figures 264, 649

Cryptolechia aporopis Meyrick, 1928, Exotic Microlepidoptera, vol. 3, p. 477

( $q$, Baguio).-Gaede, 1939, in Bryk, Lepidopterorum Catalogus, pars 92,

p. 384.-Clarke, 1955, Catalogue . . Microlepidoptera . . . Meyrick, vol.

1, p. 51 .

Distribution: Philippine Is.

One male, neallotype, hereby designated, $19 \mathrm{~mm}$, rather worn. Scape of antenna with pecten. Terminal segment of palpus with a subbasal dark fuscous ring, median segment with a similar subapical ring. Forewing with vein 7 just below apex. 
Head and thorax (worn) pale sordid ochreous whitish. Abdomen pale ochreous. Fore- and hindwings glossy pale ochreous whitish, devoid of any markings. Cilia concolorous.

Male genitalia: Tegumen moderate. Uncus small, triangular; weakly haired. Gnathos slender, with a short, slender point. Transtilla, a slender and curved band, with two unequal sclerites at its base. Valva rather narrow and thickened; cucullus with a triangular and a prominently rounded top, below these dorsally there is a corona of 5 or 6 huge curved spikes. Aedeagus rather straight, attenuated.

Material examined: Luzon, Baguio, Benguet Subprov. (Baker), $1 \sigma^{7}$, neallotype, genit. slide 5191 (USNM). Luzon, Benguet, Sapiangao, 5600 ft., 17.XII.1912; $1 \sigma^{\top}$, genit. slide 5591; Benguet Subprov., Baguio, 5000 ft., 3.XI.1912, $1 \sigma^{7}$, genit. slide 5596 (A.E. Wileman) (BM).

\section{Chrysonoma eumorpha, new species}

Figures 271, 651

Male, 18-20 mm. Head and palpus light ochreous, median segment of palpus with basal half and apex infuscated, terminal segment very narrow, under 1. Thorax pale ochreous. Abdomen pale ochreous tawny.

Forewing suboval, costa curved at extremities, less curved in middle, apex tolerably rounded, termen almost straight, rather long, oblique. Pale golden ochreous yellow, rather densely dusted with fine purplishfuscous scales, markings purplish fuscous. Costa with a small spot at base and a triangular moderate spot before $3 / 5$, both strongly suffused; dense dusting on upper half of base of wing; discal stigmata rather small, roundish, second a trifle transverse; plical stigma minute, more or less fasciate, beyond first discal; dense dusting forming faint indications of: a subtriangular transverse patch before middle of dorsum, reaching to first discal stigma; an outwards-oblique fascia from costal spot across second stigma to tornus; and a very faint fascia from costa well before apex to tornus; a series of minute, elongate marks along ends of veins on termen. Cilia pale ochreous yellow, infuscated opposite tornus.

Hindwing and cilia pale ochreous with a golden gloss.

Male genitalia: Resemble those of $C$. aporopis Meyrick, but with uncus furcate, valva broader and somewhat clavate, cucullus with a dense corona of much more numerous and slender bristles.

Material examined: Mindanao, Davao Prov., La Lun Mts., Calian, 5500 ft., 28-31.XII.1930 (C. Clagg), 1 б , holotype, genit. slide 5712; $2 \sigma^{7}$, paratypes, genit. slide 5713 .

Superficially resembling $C$. aporopis, but larger and brighter colored. 
Chrysonoma poecilosema, new species

Figures 270, 652

Male, 20-21 mm. Head sordid ochreous whitish. Antenna tawny ringed with pale ochreous. Palpus long, recurved and ascending; pale ochreous; median segment outwardly with basal $3 / 4$ and a slender subapical ring dark fuscous; terminal segment with spical half except along inner edge, and a basal ring dark fuscous. Thorax light ochreous, a median band of fuscous dusting; apex moderately mixed with fuscous. Abdomen whitish ochreous.

Forewing oblong suboval, moderately broad, broadest at $3 / 4$, costa curved at extremities, straight along median third, apex obtusely pointed, termen convex, oblique. Whitish ochreous, markings brownish fuscous. Basal fourth of costal edge narrowly dark fuscous, remainder of costal edge light ochreous; three wedge-shaped suffused spots on costa: at $1 / 3$, almost horizontal, before $3 / 4$ and $4 / 5$, respectively, the two last mentioned spots slightly dilated posteriorly and strongly inwards-oblique; a large, dark fuscous, subquadrate patch at base of wing, somewhat extended over base of dorsum, along extreme base of wing continued by a fuscous suffusion to costa, posterior extremity of patch moderately pointed, in fold; stigma rather large, rounded, equal, slightly suffused; first discal beyond middle of cell, second discal on closing vein, plical, its width beyond first discal; three very irregular bands of fuscous dusting across wing at middle, connecting second costal dot, stigmata and dorsum; beyond cell, connecting third costal dot with second discal stigma and this with tornus, so as to form a more defined and darker spot halfway between them, and a cloudy, sinuate band from posterior part of third costal spot, parallel to edge of wing, to dorsum before tornus; a series of small dots on ends of veins $1 \mathrm{c}-8$, partly interconnected by a fine marginal line. Cilia pale ochreous, with a light fuscous subbasal band

Hindwing glossy ochreous whitish, towards apex with the faintest fuscous tinge. Cilia concolorous, around apex and along upper half of termen with a faint subbasal fuscous line.

Male genitalia: Tegumen elongate. Uncus triangular, short. Gnathos ill defined, semimembranous, a short hook. Vinculum rounded. Valva elongate-oval, rather narrow; cucullus narrowed, moderate, hairy; sacculus $2 / 3$, little defined, less hairy, top of triangular cusp. Aedeagus little curved, long, narrowed; cornuti, long spines in a central sheaf.

Material examined: Luzon, Benguet Subprov., Pauai, Haights Place, $7000 \mathrm{ft} ., 22 . X I .1912$ (A.E. Wileman), $1 \sigma^{\top}$, holotype, genit. slide 5583; $10^{\top}$, paratype (without abdomen) (BM). 


\section{Chrysonoma fragmentaria, new species}

Figures 265-266, 653

Male, $16 \mathrm{~mm}$. Head, thorax ochreous whitish. Antenna with scape ochreous whitish, flagellum brownish tinged: ciliations pale brownish, 1. Palpus long, median segment exceeding base of antenna, slightly spindle-shaped and laterally compressed, smooth; pale ocherous, median segment gently infuscated, a subapical dark fuscous irregular ring, tip whitish; terminal segment with some minute basal dark markings, apical third except extreme tip, dark fuscous. Abdomen whitish, dorsum light tawny.

Forewing ovate-lanceolate, rather narrow, costa gently curved, apex rounded, termen rounded, oblique. Light ochreous, towards tornus becoming whitish ochreous. Markings suffused, brownish fuscous. A narrow line along basal half of costal edge: an elongate-triangular fasciate patch on middle of costa, formed by sparse dusting; basal patch indicated by some more dusting, irregular and tending to form three longitudinal stripes, one of these probably being the first discal stigma, at $1 / 4$; second discal stigma elongate-oval, slightly before $2 / 3$; plical, horizontal, fasciate, halfway between discal stigmata; some dusting in a transverse ill-defined band, tending to connect costal patch with plical stigma and dorsum; an irregular wedge-shaped streak from above second discal stigma to costa before apex, slightly curved upwards; a subterminal line, originating from outer edge of preceding streak, running horizontally towards termen below apex, then abruptly curving down, parallel to termen, slightly converging with it, to tornus; this line tending to fall apart in a series of interneural dots; a marginal line in apex and along upper third of termen. Cilia ochreous whitish.

Hindwing and cilia ochreous whitish, glossy.

Male genitalia sclerotized. Tegumen rather short, conical. Uncus as high as tegumen, triangular, top pointed and narrow. Gnathos present, a pending hook. Vinculum strong, erected, as high as tegumen. Caulis oval. Valva elongate oval, slightly rolled towards top, costa and cucullus more sclerotized, the latter forming an apical hook. Sacculus under 1, less sclerotized towards apex which is obtusely pointed. Aedeagus moderately curved, narrowed, base compressed and tortuous. Cornutus, a single, very long spine.

Material examined: Luzon, Benguet Subprov., Klondyke, $800 \mathrm{ft}$., 8.III.1912 (A.E. Wileman), $1 \sigma^{x}$, holotype, genit. slide 5585, and $2 \sigma^{\Upsilon}$, paratypes, genit. slide 5666; total: 3 㝋 (BM).

\section{Chrysonoma hesitans, new species}

Figures 254-255, 258, 654

Male, $17 \mathrm{~mm}$. Head, scape of antenna, palpus, and thorax pale 
yellow ochreous; terminal segment of palpus with a faint basal brownish ring. Flagellum of antenna brownish. Ciliations over 1 . Abdomen pale yellowish.

Forewing elongate, suboval-lanceolate, pointed. Veins 3 and 4 separate, vein 7 to apex. Unicolorous pale yellow ochreous, rather dull, markings not showing, extreme edge of costa along basal fifth touched with dark grey. Cilia deeper light yellow, with a moderate gloss.

Hindwing under 1 , veins 3 and 4 connate. Pale whitish yellow, paler than forewing, with a silky gloss. Cilia concolorous.

Male genitalia: Tegumen small, rather weak, little dilated at base. Uncus triangular, with a short beak. Gnathos, a moderate porrect semicircle. Transtilla, a curved band, gradually dilated towards middle and concave along ventral side lengthwise. Vinculum strong. Valva long and rather narrow, strongly rolled up lengthwise. Costa with long sparse hairs. Cucullus, a very slender, hooked process. Sacculus over 1, ending in a long slender hook with darkly sclerotized base. Anellus, a rectangular plate, higher than broad. Aedeagus straight, with obliquely truncate pointed top; cornuti, a sheaf of long spines.

Female, 18-21 mm (allotype $20 \mathrm{~mm}$ ). Head and thorax pale yellowish ochreous. Antenna brownish, basal part and scape pale yellow ochreous. Palpus pale yellow ochreous, median segment very slightly sprinkled with greyish, with a broad and irregular subapical grey ring, terminal segment slender, 3/4, somewhat brighter ochreous, with a grey subbasal ring.

Forewing suboval-lanceolate, moderately broad. Veins 3 and 4 connate, vein 7 to apex. Pale yellow ochreous, rather dull, markings formed by sparse fuscous irroration. First discal stigma rounded, rather large, at $1 / 3$, first plical beneath this, irregular and elongate, more or less truncate posteriorly; a moderate transverse fascia, straight, from beyond middle of costa to dorsum before tornus, its origin on costa curved posterad; a line from costa before apex (end of vein 10), moderately outward-convex, to end of vein 3 , thence marginal, along termen and tornus to base of transverse fascia. Cilia somewhat deeper yellow, glossy.

Hindwing elongate-suboval, under 1, paler than forewing, whitish yellow with a golden gloss, along margin and in apex very faintly irrorated with golden brown; veins 3 and 4 connate. Cilia concolorous.

Female genitalia: All tergites of the abdomen brownish sclerotized and with numerous spinules of diverse sizes. Seventh segment modified, sternite and pleurites forming together two bandlike ventrolateral sclerites with thickened caudal edge, ending laterally 
into a rounded knob. Lamella postvaginalis represented by similar, but smaller sclerites, not extended laterally and without thickened caudal edge. Lamella antevaginalis, an erected, inverted-trapezoidal sclerite, with a small V-shaped sclerite below it (rostrad). Anapophyses rather short. Ductus bursae long and narrow. Bursa copulatrix moderate, ovoid. Signum, a transverse, oval plate, scobinate along edge and slightly constricted in middle.

Material examined: Luzon, Mt. Apo, 70-B, 5.III.1945, 1 б , holotype, genit. slide 5105; Babasit, Pangasinan, 16.III.1945, 1 \%, allotype, genit. slide 5103. Agoo, La Union, 4.V.1945, 3.VIII.1945, 2 \%, paratypes. Mt. Apo, 70-B, 12.V.1945, 1 \%, paratype, genit. slide 5106. $1 \sigma^{\Upsilon 7}, 4$ ㅇ (J.G. Franclemont) (CUI). Luzon, Benguet Subprov., Pauai, Haights Place, 7000 ft., 16.XI.1912 (A.E. Wileman) 1 o, paratype, genit. slide 5574. Benguet Subprov., Klondyke, 800 ft., 15.III-19.IV.1912 and 21.XII.1912, genit. slides o 5590, 5593, 5598, and 5646, ㅇ 5748; Palali, 2000 ft., 22.XII.1912 (all by A.E. Wileman), 1 ㅇ, genit. slides $5653.1 \sigma^{x}, 6$ ‥ In total $5 \sigma^{x}$, 11 우 (BM).

Probably nearest to $C$. corsota Meyrick. The holotype and the allotype show slight differences in neuration which may be due to sexual dimorphism. The male lacks any markings, but these are very faint in the three female paratypes as well. All other structures are identical; therefore, I am satisfied that the sexes belong together.

\section{Chrysonoma hypocapna, new species}

Figures 282, 655

Male, $13.5 \mathrm{~mm}$. Head and thorax whitish ochreous. Antenna whitish ochreous, flagellum greyish below. Palpus whitish ochreous, median segment with a slender fuscous ring just below apex, terminal segment with fuscous base; median segment slightly thickened, terminal slender, shorter than median. Abdomen pale ochreous.

Forewing suboval, costa moderately curved, apex rounded, termen moderately rounded, oblique. Pale yellow, markings limited and very faint, light purplish fuscous. A minute line along extreme edge of base of costa; indication of a curved line, forming a semioval mark, from before $3 / 5$ of costa to above tornus, thence to costa before apex, very faint, partly obliterate. Cilia pale yellow.

Hindwing light grey, dusted throughout with fuscous. Cilia grey fuscous.

Male genitalia: Similar to those of Chrysonoma hesitans, but with cucullus shorter than the spine of the sacculus, angulate and thickened at the angulation; sacculus spine shorter. Otherwise as in C. hesitans, new species. 
Material examined: Luzon, Benguet Subprov., Klondyke, $800 \mathrm{ft}$., 29.IV.1912, $1 \sigma^{\Upsilon 7}$, holotype, genit. slide 5594; same locality, 12.III.1912, $1 \sigma^{x}$, paratype, genit. slide $5592 ; 26$. III.1912, $1 \sigma^{x}$, paratype (A.E. Wileman) (BM).

Closely allied to $C$. hesitans, differing by grey hindwings and genitalia.

\section{Chrysonoma inermis, new species}

Figures 267-269, 656

Female, $12.5 \mathrm{~mm}$. Head and thorax whitish, touched with creamy. Antenna whitish, faintly light grey posteriorly. Palpus whitish, median segment touched with fuscous below apex; terminal segment faintly infuscated at extreme base. Abdomen whitish ochreous.

Forewing ovate-sublanceolate, costa moderately curved, more so posteriorly, apex obtusely rounded, termen rounded, rather oblique. Whitish, touched with creamy. Markings blackish fuscous. First discal stigma slightly elongate, plical stigma well beyond it, second discal larger, conspicuous, rounded; dark scales sparsely scattered so as to form irregular groups: one on costa above second discal stigma and a transverse group halfway between cell and termen, from costa to above tornus, denser above; a series of dots between veins just before tornal edge and in apex. Cilia whitish creamy with fuscous-grey tips, limited greyish dusting at base opposite apex.

Hindwing and cilia glossy whitish, faintly touched with greyish.

Female genitalia: Sixth sternite modified, with a median excision, flanked by subtriangular lobes. Lamella antevaginalis forming a small dark semioval sclerite before ostium bursae; $8+9$ segment annular, strongly depressed, hairy. Corpus bursae elongate-plumeshaped. Signum substellate.

Material examined: Luzon, Benguet Subprov., Klondyke, $800 \mathrm{ft}$. , 3.V.1912 (A.E. Wileman), 1 \%, holotype, genit. slide 5595 (BM).

A small species of obscure affinity.

\section{Tonica Walker, 1864}

\section{Key to the Philippine Species of Tonica}

1. Unicolorous white, finely dusted with pale tawny towards costa, an oblique raised transverse crest in disc . . . . . . . . T. argessa, new species

Not unicolorous white, markings distinct . . . . . . . . . . . . . . . 2

2. Markings jet black, a conspicuous spot in apex, an oblique mark at $1 / 4$ of costa; ground color white, touched with yellow.

T. citrantha, new species

Markings brownish, a marginal series of dots along posterior half of costa and in apex; ground color pale ochreous, more or less brownish suffused. 


\section{Tonica argessa, new species}

Figưres 272-273, 281, 657

Female, 30-32 mm. Head and antenna white, tinged creamy with a slight silky gloss. Palpus very long, median segment with long rough projecting scales and hairs toward apex above and beneath, terminal segment shorter than median, roughish along foreside, backside with two loose tufts of rather long hairs, just above middle and at apex; white, median segment along lower edge slightly suffused with ochreous greyish, projecting hairs at apex mixed with fuscous, a few dark fuscous scales at the base of terminal segment; terminal segment white, dark fuscous irroration along anterior edge and a median and a subapical incomplete band formed by the same irroration. Thorax creamy white, rather suffused with light ochreous grey. Abdomen pale yellowish white, dull. Legs white.

Forewing subtruncate, rather broad, moderately narrowed posteriorly, broadest at $1 / 4$, costa strongly sinuate anteriorly, less so posteriorly, rounded and prominent and with a roughish fringe along second fourth, base of costal edge smooth, apex rounded, termen rounded, little oblique. White with a creamy tinge; upper half of wing sparsely strewn with sordid pale ochreous-greyish dots and a few dark brown minute scales, this dusting becoming more dense along and towards costal prominence (from beyond base of wing) posterior third of costa and cilia to before apex with a narrow suffused rather bright tawny streak; a conspicuous outwards-oblique transverse almost straight crest of raised scales, mixed with sordid pale ochreous greyish and tawny, becoming slightly broader downwards, from upper edge of cell at $1 / 3$ of wing to middle of fold; a minute ochreous-greyish tuft on base of vein 6 ; a straight, slightly inwardsoblique streak of slightly tumescent and therefore less glossy scales well before termen, from vein 7 to end of dorsum. Cilia white.

Hindwing yellowish white, with a silky gloss. Cilia concolorous.

Female genitalia: Postapophyses moderate, anapophyses extremely short. Sterigma conical, lamellae ante- and postvaginalis almost congruent, gradually narrowed toward top, which is emarginate. Signum with basal plate strongly corrugated, hook slender.

Material examined: Luzon, Benguet Subprov., $800 \mathrm{ft}$., Klondyke, Camp 1, 10.IV.1912 (A.E. Wileman), 19, holotype, genit. slide 5522. Same data, 20.IV.1912, 2 \%, paratypes (Rothschild bequest, BM).

A very distinct species.

\section{Tonica citrantha, new species}

Figures 279-280, 658

Female, $37 \mathrm{~mm}$. Head white. Antenna white, streaked and ringed above with black. Palpus (terminal segment missing) white, 
basal segment with a black lateral spot, median segment with an irregular black patch near base above, and with a few black large specks toward middle above and in an incomplete subapical ring. Thorax white, with the faintest yellowish tinge in middle, two black spots anteriorly. Abdomen glossy fuscous white, becoming dark brown toward apex, white toward base; venter whitish irrorated with purplish, end segments dark brown. Legs yellowish white, tarsi blackish, white ringed.

Forewing suboval, rather broad, costa angularly prominent before $1 / 3$, concave in middle, straight posteriorly, apex moderately rounded, termen almost straight above, rounded beneath, vertical. White, with the faintest yellowish suffusion along middle of wing and beyond cell. Two large raised pale yellow scale tufts, the larger one above fold before its middle, the smaller on upper angle of cell; two smaller white scale tufts alternating with the other, in upper half of cell; two highly raised but loose tufts below upper edge of cell toward base, with upper half dark brown, lower white, some brown scales scattered between these; other markings jet black: a costal irregular, and a median quadrate spot at base, an obtusely wedge-shaped oblique larger mark at $1 / 6$ of costa; some irregular marbling between these marks above cell; a round dot below fold at $1 / 5$; an irregular dark grey mark on $2 / 3$ of costa; a patch of irregular jet-black irroration with bluish reflections in apex; a curved series of a few distant brownish-grey raised scales well before upper part of termen. Cilia white, around apex jet black with purplish tips.

Hindwing golden whitish, glossy, thinly irrorated with pale tawny, extreme apex suffused with jet black. Cilia pale golden yellowish, opposite apex with a broad blackish bar.

Female genitalia: Postapophyses long, with dilated bases, anapophyses very short. Eighth segment considerably sclerotized and erected-conical, with a broad triangular ventral cleft. Edge of 7 th segment with a row of strong spines. Signum strong, a denticulate hollow plate with a strong hook in middle.

Material examined: Luzon, Los Baños (Woodward), 1 \%, holotype, genit. slide 5216 (USNM).

\section{Tonica lagaropis Meyrick, 1928}

Figures 277-278, 659-660

Tonica lagaropis Meyrick, 1928, Exotic Microlepidoptera, vol. 3, p. 474 ( , Philippines).-Clarke, 1955, Catalogue . . Microlepidoptera . . Meyrick, vol. 1 , p. 181 ; 1963 , op. cit., vol. 4 , p. 458 , pl. 226 , figs. $3-3$ c.

Distribution: Philippine Is.

Male, $29 \mathrm{~mm}$, neallotype, herewith selected. Head creamy white, crown slightly mixed with dark brown. Antenna creamy white, 
finely ringed with dark brown, scape pale brown below. Palpus creamy white, sprinkled with dark brown, basal segment light brown, median segment with a suffused brownish streak along lower edge, terminal segment white, with a broad submedian and a somewhat narrower subapical dark brown ring. Thorax creamy white. Abdomen glossy yellowish white.

Forewing elongate subtruncate, costa with a broad prominence at $1 / 3$, concave beyond this, posterior third rounded and slightly scalloped, apex pointed and slightly produced (sublanceolate), termen sinuate, concave above, rounded beneath, with rough tufts of raised scales. Creamy white, raised tufts touched with yellowish. Costal edge with a brown streak, narrow at base, with a small triangular dilatation on $1 / 4$, and becoming broader towards the middle of concavity, with an elogate dark brown subcostal mark at $3 / 5$; along posterior third of costa this brown streak is moderate, interrupted three times on scallops by white raised tufts, fine sprinkling of different shades of brown, arranged more or less in longitudinal rows, parallel to veins, below costa; some finer, blackish speckling below posterior part of costa and in apex; a small transverse group of blackish scales in tornus; an elongate patch of raised scales on costal prominence, and three rounded tufts of scales on scallops of the posterior third of costa; anterior discal stigma replaced by a large elongate raised tuft, reaching to fold, above along base edged with blackish scales; a small blackish raised tuft above this; second discal stigma replaced by a smaller, roundish tuft, slightly postmedian, hardly edged with blackish; some raised tufts between preceding and costal prominence; a strongly angulate series of smaller, pure white round tufts from below $2 / 3$ of costa, running in a bow to between veins 6 and 7 , thence straight to tornus. Cilia white, around apex and along upper half of termen leaden grey, along termen with a submedian series of black strigulae, each with some irroration below it, these patches of irroration forming indistinct bars.

Hindwing glossy creamy white, toward costa and apex very faintly speckled with pale brownish. Cilia creamy, dull, along costa grey, around apex brownish grey, with very faint bars along lower half.

Male genitalia: Tegumen short, semitubular, truncate. Uncus very narrow in the middle, forming two subquadrate, hairy and large lobes. Gnathos, two hemispherical processes with finely denticulate surface. Valvae small, 2/3 length of tegumen, simple, subtruncate, fused along basal half of their inner edge. Aedeagus rather thick along basal half, apical half narrower. Neallotype, slide 5214.

Female genitalia: Resembling those of Tonica citrantha, but the sclerotized genital segment much shorter, with rostral edge of sternite less deeply incised. Anapophyses short and slender. Postapophyses 
twice as short. (In T. argessa the genital segment, especially its sternite much less sclerotized, excision shallow.) Slide 4981 studied.

Material examined: Luzon, Mt. Makiling (Baker), 1 \%, paratype, slide 5215. 5 중 20 우 (USNM).

\section{Psorosticha Lower, 1901}

\section{Psorosticha neglecta, new species}

Figures 286-288, 661-662

Male, $19 \mathrm{~mm}$; female, $20 \mathrm{~mm}$. Head and thorax fuscous grey (sometimes dark grey) mixed with white (tips of scales), appearing grey. Palpus creamy sprinkled with dark grey, median segment with a dark grey spot at base above, another, larger spot at apex above; terminal segment with a dark grey basal ring and a grey, whitishmixed median tufted ring, apical half of segment creamy. Antenna rather thickened in male, grey, scape whitish. Abdomen brownish fuscous, anal tuft pale ochreous.

Forewing oblong, broadest at $1 / 3$, costa curved at base, less curved in middle, apex rounded, termen rounded, oblique. Pale fulvous pinkish strewn with blackish-grey scales and blackish-grey raised tufts. A wedge-shaped basal patch, leaving a narrow edge of dorsum beyond base unobscured; two small dark tufts in an oblique row, on $1 / 4$ of costa and in middle of fold, respectively; a more oblique series of some five points from below the first tuft to fold well beyond the second tuft; two larger transverse tufts in a series from about $3 / 5$ of costa to $3 / 4$ of dorsum, first tuft subcostal, second largest, along closing vein, a group of minute raised scales on dorsum; posterior portion of wing from before the larger tufts to before apex and termen and not reaching tornus, denser speckled with dark scales, sometimes a cloudy triangular greyish costal patch just before apex; terminal edge with a series of narrow black marginal marks from below apex to tornus. Cilia concolorous.

Hindwing glossy, pale grey bronze, cilia paler, whitish grey, with a bronze subbasal shade.

Male genitalia: Rather similar to those of $P$. zizyphi Stainton (India) but with harpe ("clasper") more robust and straight, dilated at base. In P. melanocrepida Clarke (Japan) the clasper is longer and sinuate.

Female genitalia: Signum very long and slender, quite distinct from that in $P$. zizyphi, where it is moderate, and from that in $P$. melanocrepida, where it is short.

Material examined: Luzon, Los Baños (Baker), $1 \sigma^{7}$, holotype, genit. slide 5240, 1 ᄋ, allotype, genit. slide 5241, 1 ㅇ, paratype, "Acc. No. 225, Bur. Agr., P. I."; 1 व , "Occidental Negros, Victorias," 237-168-67-13 
"L 22, Lemon" (Citrus), 2 ఠ", 4 우 , genit. slides 우 “A.B. June 23, 1930," 우 “June 23, 1930." Total 3 ๙ , 5 ㅇ (USNM).

Superficially very similar to the common P. zizyphi Stainton. Compared with material of that species from Java, genit. slides 5550 o $^{\top}$ and 5551 ㅇ.

\section{Glyphipterygidae}

\section{Key to the Philippine Genera of Glyphipterygidae}

1. Hindwing with veins 3 and 4 connate . . . . . . . . . . . . . . . . 2

Hindwing with veins 3 and 4 separate . . . . . . . . . . . . . Imma

2. Forewing with vein 7 to costa; terminal segment of palpus very short, obtuse.

Phycodes

Forewing with vein 7 to apex or termen; terminal segment of palpus not very short.

3. Palpus with median segment distinctly tufted beneath . . . . Choreutis Palpus with median segment not tufted beneath . . . . . . . . . . . . 4

4. Terminal segment of palpus pointed . . . . . . . . . . . . . . . . . 5

Terminal segment of palpus obtuse . . . . . . . . . . . . . . . . 6

5. Hindwing ovate. . . . . . . . . . . . . . . . . Brenthia

Hindwing narrow-oblong or lanceolate . . . . . . . . . Glyphipteryx

6. Forewing with 2 from before angle... . . . . . . . . . . . 7

Forewing with 2 from angle.............. . Sagalassa

7. Antenna thickened with scales. . . . . . . . . . . . . . Tortyra

Antenna not thickened with scales. . . . . . . . . . Anthophila

\section{Phycodes Guenée, 1852}

\section{Phycodes minor Moore, 1881}

Figures 284-285, 663

Phycodes minor Moore, 1881, Proc. Zool. Soc. London, p. 378 (India); 1882, Indian Lep. Het . . . Atkinson, vol. 2, p. 152.-Cotes and Swinhoe, 1889, Cat. Moths India, p. 701.-Meyrick, 1910, Rec. Indian Mus., vol. 5, p. 226; 1914, in Wytsman, Genera Insectorum, fasc. 164, p. 18.-Fletcher, 1917, Rep. Proc. 2nd Ent. Meeting Pusa, p. 251; 1920, Mem. Dept. Agric. India, Ent. ser., vol. 5, p. 123; 1933, Imp. Counc, Agric. Res., Sci. Mon., no. 4, p. 23, pl. 21.

Choregia lucasseni Snellen. 1901, Tijdschr. Ent., vol. 44, p. 74, pl. 5, fig. 9 (Java). Phycodes cymineuta Meyrick, 1909, Journ. Bombay Nat. Hist. Soc., vol. 19, p. 424.-Clarke, 1955, Catalogue . . Microlepidoptera . . Meyrick, vol. 1, p. 110.

Distribution: India, Ceylon, Java.

Material examined: Luzon, "Los Baños, IV.1921" "on Ficus odorata" (X. Williams), $10^{7}$, genit. slide 5173 (USNM). Compared with a specimen from India, Bihar, $\sigma^{7}$, genit. slide 5183 (BM).

Male genitalia: Tegumen with very narrow legs. Uncus membranous in middle, broad and truncate, porrect. Socius small, 
rounded. Gnathos broadly bandlike, arms rounded sclerites, top a large, transverse-oval sclerite. Valva strong, oval, moderately rolled up lengthwise; sacculus distinct, trapezoidal, upper angles slightly prominent; disc of valva with a large rounded punctulate patch (insertion of bristles), costa with a long down-curved hook. Aedeagus very large, stout, gradually narrowed, top with an oblique lobe; cornuti, several patches of small spines.

\section{Sagalassa Walker, 1856}

\section{Sagalassa eubrachycera, new species}

Figures 283, 664

Male, $20 \mathrm{~mm}$. Head dark fuscous, finely dusted with pale ochreous. Antenna extremely short, over $1 / 4$, bipectinate-ciliate, pectinations over 1 ; basal $3 / 4$ densely scaled above, these scales flattened, tip rather obtuse; rather light grey, covering scales black, a broad orange band beyond $3 / 4$, followed by a broader black band, tip orange.

Palpus with lower edge yellowish white, elsewhere black, terminal segment short, obtuse, black. Thorax fuscous densely strewn with yellowish, pectus similar but darker. Abdomen black with moderate, leaden-grey posterior bands, on venter broader and pale yellowish. Posterior tibia with long bristly hairs in middle above; valva light yellow.

Forewing elongate, rather narrow, strongly narrowed at base, costa almost straight, faintly concave along more than anterior half, at base and along posterior half slightly prominent and rounded; apex and termen rounded, termen vertical. Rather dark lilac grey, regularly and densely irrorated throughout with pale orange yellowish (tips of scales). Markings rather ill defined, blackish grey, less densely irrorated with orange yellowish (tips of scales narrow here); an inwards-oblique transverse fascia from costa just beyond middle to dorsum before middle, on costa forming a rectangular extension on both sides, on dorsum a triangular one, only anteriorly an angulate narrower fascia at $3 / 4$, connected by a horizontal bar with preceding above middle of wing, preceded and followed by pale bands of denser, yellowish irroration; a rather broad terminal band of brighter yellow, fine irroration. Cilia bluish grey with a jet-black basal and a dark grey apical band.

Hindwing bronze black, a pale yellow slender line along $2 / 3$ of vein $1 \mathrm{~b}$, clavate, top truncate; a rather large pale yellow obliquelongitudinal oval patch along and below posterior half of lower edge of cell and across its lower angle. Cilia pale grey, basal half bronze blackish, tips in tornus whitish.

Male genitalia: Tegumen slender and long, moderately dilated apicad. Uncus not articulating, slightly narrower than tegumen, top 
moderately pointed, laterally with more pointed and longer processes. Tuba analis long, slender, conical, and hairy. Gnathos long, pending, furcate, actually being a membranous band supported by two slender lateral rods, parallel basally, diverging apically and ending in two acute points. Saccus slender and rather short. Valva oblong-oval, its base double, ventral edge extended; sacculus, indicated as a narrow fold along basal third, this fold abruptly but moderately thickened along median third. Cucullus simple. Aedeagus pistol-shaped, barrel part long, straight, grip part slender, short. Coremata very long inverted pencils, in finger-like impressions of the eighth intersegmental membrane.

Material examined: Luzon, Los Baños, XI.1924 (S. Cendraña), 1 male, holotype, genit. slide 5398, “000015” (USNM).

\section{Imma Walker, 1858}

\section{Key to the Philippine Species of Imma}

1. Forewing with basal half bright yellow . . . . . . . . . . . . . . . 2 Forewing with basal half not yellow . . . . . . . . . . . . . . . . 3

2. Forewing with outer half brown, edged black . . . . . . . . I. basiflava Forewing with outer half black . . . . . . . . . . I. aurantiaca

3. Hindwing with a yellow base . . . . . I. chrysocosma, new species Hindwing without yellow . . . . . . . . . . . . . . . . . 4

4. Forewing with a transverse fascia (sometimes very narrow) . . . . . . 5

Forewing without a transverse fascia . . . . . . . . . . . . 10

5. Transverse fascia white or whitish . . . . . . . . . . . . . . . 6

Transverse fascia yellow . . . . . . . . . . . . . . . . . . . 9

6. Transverse fascia direct . . . . . . . . . . . . . . . . . . . . . . 7

Transverse fascia distinctly oblique. . . . . . . . . . . . . . . . . 8

7. Transverse fascia from middle of costa to dorsum just beyond middle, moderate. . . . . . . . . . . I. macrochorda, new species Transverse fascia from beyond middle of costa to $2 / 3$ of dorsum.

I. macrochorda regmophora, new subspecies

8. Forewing with basal half lighter than outer half, a yellow mark on costa before apex . . . . . . . . . . . . . . . . . . . . I. albifasciella Forewing entirely dark fuscous, no yellow costal marks . . I. albotaeniana

9. Forewing light fuscous olive . . . . . . I. poecilostoma, new species Forewing dark purplish fuscous . . . . . . . I. pyragra, new species

10. Larger species, $28-30 \mathrm{~mm}$, a whitish irroration or $2 / 3$ of costa. Smaller species, 18-23 mm, no whitish costal irroration . . . . . . 11

I. tyrocnista

11. Hindwing fuscous grey . . . . . . . . . . . . . .

I. nephodryas Hindwing dark purplish fuscous, with a paler discal spot.

I. sarophora, new species

\section{Imma aurantiaca (Semper, 1899)}

Figures 289, 665

Sidyma aurantiaca Semper, 1899, Schmetterlinge Philippinischen Inseln, vol. 2, p. 501 , pl. 59, fig. 9 ( $\sigma^{7}$ \% , East Mindanao). 
Imma aurantiaca.-Meyrick, 1906, Trans. Roy. Ent. Soc. London, p. 190; 1913, in Aurivillius, Lepidopterorum Catalogus, pars 13, p. 27; 1914, in Wytsman, Genera Insectorum, fasc. 164, p. 10.

Distribution: Philippine Is., Mindanao.

The species may be redescribed thus. Male, $47 \mathrm{~mm}$. Head yellow. Antenna black, pectinations over 1. Palpus yellow, basal segment long, slightly drooping, upper and lower edges posteriorly and top black, median segment long, slender, vertically rising, so making an acute angle with the basal segment; terminal segment extremely short and slender, subobtuse, black. Thorax yellow orange, a suffused brown transverse band anteriorly, apex and top part of tegula brown. Abdomen yellow, anal tuft black. Legs black, tibiae dark brown.

Forewing oblong, dilated at $3 / 4$, costa gently curved, apex rounded, termen little rounded, oblique. More than basal half bright orange yellow, extreme costal edge black; apical portion brownish black, edge of this color concave and somewhat irregularly serrulate, oblique along upper third, almost straight and much less oblique along lower $2 / 3$. Cilia black.

Hindwing with a large semioval orange-yellow patch occupying almost $2 / 3$ of costa and extending over $3 / 4$ of wing breadth, anterior edge almost straight, posterior gently rounded, with a slight truncate prominence between veins 2-4; remainder of wing and cilia brownish black, becoming brown along dorsum.

Male genitalia: Tegumen moderate, submembranous, rounded. Uncus slender, top bifid and hairy. Saccus (vinculum) elongate, moderately broad, top rounded. Valva strongly concave, sacculus forming an oval membranous inner lobe, these lobes interconnected; top of sacculus sclerotized and sinuate, being a continuation of a bandlike sclerite across disc of valva, top of sacculus projecting, straight, cucullus narrow, hairy, clavate, longer than sacculus. Anellus lobes distinct, subtriangular. Aedeagus very large, sclerotized, tubular, little curved.

Material examined: Lectotype, hereby selected is a specimen from Walsingham collection (BM) labelled as follows: "521" (a small, printed label), "Mindanao, Semper" (written in ink), "Swinhoe d.d., I.1900, CO-TYPE" (a black-edged label, written in pencil, last word printed). "Tineina, Tortricomorpha Felder, teste Durrant, aurantiaca Semper (Sidyma), Schmett. Philipp. Het., p. 501, pl. 59, f. 9 (1899)" (written in ink), genit. slide 4722. Two more similarly labelled specimens (BM).

\section{Imma basiflava (Semper, 1899)}

Figures $820,832-834$

Sidyma basiflava Semper, 1899, Schmetterlinge Philippinischen Inseln, vol. 2, p. 550 , pl. 59 , fig. 8 ( $\sigma^{7}$, Northeast Luzon). 
Imma basiflava.-Meyrick 1906, Trans. Roy. Ent. Soc. London, p. 190; 1913, in Aurivillius, Lepidopterorum Catalogus, pars 13, p. 27; 1915, in Wytsman, Genera Insectorum, fasc. 164, p. 10.

Distribution: Philippine Is., Luzon.

Lectotype, ơ, herewith selected, genit. slide 5873 (SMF).

Male genitalia: The intersegmental membrane between segments 7 and 8 forming long, semi-ellipsoid pair of menses and rostrad of these a pair of long coremata, retracting into slender membranous tubes. Tegumen with short pedunculi and a membranous semioval top. Tuba analis large. Vinculum narrow, erected. Anellus strong, bivalvous, lobes short and rounded. Valva elongate, lengthwise concave; sacculus prominent mesad, membranous. Cucullus top bifid, a ventral sclerotized and a dorsal, bristly, slender process. Aedeagus little curved dorsoventrally, slightly curved laterally, top more sclerotized.

\section{Imma chrysocosma, new species}

Figures 295-296, 666

Male, $20 \mathrm{~mm}$. Head bright yellow, forehead paler. Palpus appressed to face, slightly exceeding base of antenna; bright yellow. Antenna light ochreous; long-ciliate, ciliations over one-half. Thorax and tegulae with anterior half bright yellow, posterior darker fuscous, sides of metathorax yellow. Legs yellow, posterior femur glossy grey; median tibia dilated with rough spiny scales. Abdomen fuscous with whitish reflections, segments 1-4 of venter light yellow, dorsum pale yellow at base, with a yellow median streak on tergites $5-7$, anal tuft yellow in middle.

Forewing elongate-subtruncate, dilated and rather narrow, costa straight except toward apex, apex moderately rounded, termen convex; veins 7 and 8 stalked, 8 to costa. Dark fuscous with bluelilac gloss in certain lights, markings bright yellow, well defined. A clavate patch along less than anterior half of costa, extending over upper half of base of wing, posteriorly dilated into a rounded-triangular tooth almost to middle of wing, lower edge of patch concave, posterior edge convex; a slightly oblique erect semioval moderate patch on $2 / 3$ of costa; faintest markings of lilac-blue iridescence: a short transverse streak along closing vein and a marginal line along posterior fourth of costa, in apex and along termen. Cilia dark fuscous with whitish tips.

Hindwing and cilia dark fuscous, dorsum with a narrow pale yellow streak, dorsal cilia pale yellow; a well-defined bright yellow central patch, shaped as follows: upper edge straight, along upper half of cell to beyond closing vein, with a rising tooth at end, posterior edge 
vertical to vein 2 , thence horizontal to vein $1 \mathrm{c}$, thence broadly prominent and rounded, to vein 1a and along this vein to base.

Male genitalia: Tegumen moderate, ovoid, peduncle broad; uncus, a long slender hook, with a dilated base which is membranous ventrally. Vinculum rather narrow, $V$-shaped, saccus strong, clavate-truncate. Valva elongate, sclerotized, strongly concave longitudinally, sacculus forming a large and flat fold with a rounded top, covered with short bristles. Costal half of valva well defined, costa sinuate at base, cucullus rigid and sclerotized, forming a pointed blade, with a patch of very long bristles in disc; there is a third flattened and rounded cusp below the apical one, supporting a transverse tumescence with dense long bristles. Anellus erected-quadrate, with little diverging obtuse and moderate anellus lobes. Aedeagus moderate, gradually slightly attenuated, rather straight, basal fourth bent down. Cornuti, numerous small spines. Coremata, two long and slender extensible hair-pencils in sheaths.

Material examined: Luzon, Los Baños (P. I. Baker), $1 \sigma^{x}$, holotype, genit. slide 5109 (USNM).

Apparently closely allied to "Callartona purpurascens" Hampson from Burma, differing in minor size of yellow markings, especially in the hindwing, where the central spot is less extended in that species.

\section{Imma albifasciella (Pagenstecher, 1900)}

Figures 290, 333-334, 667

Tortricomorpha albifasciella Pagenstecher, 1900, in Zoologica, vol. 29, no. 12, p. 234 (Bismarck Is., sex not indicated).

Imma albifasciella.-Meyrick, 1906, Trans. Roy. Ent. Soc. London, p. 174 (monodesma syn.); 1913, in Aurivillius, Lepidopterorum Catalogus, pars 13, p. 26; 1914, in Wytsman, Genera Insectorum, fasc. 164, p. 9.

Tortricomorpha monodesma Lower, 1903, Trans. Roy. Soc. South Australia, vol. 27, p. 70 (Queensland).

Distribution: Celebes, New Guinea, Bismarck Is., eastern Australia. Material examined: Luzon, Los Baños, 14.XII.1934 (J. L. Talon), "Acc. no. Le94, Coll. of Agr. Univ., P.I.," 1 ㅇ, genit. slide 5108; $1 \sigma^{7}$, Milne Bay, genit. slide 5176. (USNM).

Male genitalia: Tegumen short, with a truncate top. Uncus absent. Socius large, angularly projecting above and beneath, long-bristly. Membrane with a hairy clavate weak process. Valva elongatetruncate, gradually dilated, sacculus with several longitudinal folds, long, almost 1 , reaching across valva to costa, at top with a dorsal cusp and a long articulating transverse arm with a bristly top. Aedeagus slender, with a bulbous base; cornuti, fine short spines.

Female genitalia: Little modified. Ostium bursae with an irregular rim, hardly sclerotized. Ovipositor short, depressed. Corpus bursae large, simple. 


\section{Imma albotaeniana (Sauber, 1901)}

Figures 822-823, 829-831

Tortricomorpha albotaeniana Sauber, 1901, in Semper, Schmetterlinge Philippinischen Inseln, vol. 2, p. 697 ( $\sigma^{\top} \uparrow$, Luzon).

Imma albotaeniana.-Meyrick, 1906, Trans. Roy. Ent. Soc. London, p. 190; 1913, in Aurivillius, Lepidopterorum Catalogus, pars 13, p. 27; 1914, in Wytsman, Genera Insectorum, fasc. 164, p. 10.

Distribution: Philippine Is., Luzon; ?Java.

Lectotype, $\sigma^{\top}$, hereby selected, genit. slide 5872 (SMF).

Male genitalia: Menses of intersegmental membrane 7-8 well developed, dilated posteriorly and with long fringe of scales. Coremata much shorter and less dense than in I. basiflava. Vinculum long and slender, with two small sclerites at the end. Tegumen moderately sclerotized, pedunculi short, rather broad, top of tegumen semioval. Tuba analis submembranous with a medioventral subapical process with a bristly top. Valva with a broad basal half and a slender cucullus, rather sclerotized throughout, top rounded. Anellus lobes slender, small, digitoid. Aedeagus rather short, sclerotized, moderately curved ventrodorsally and laterally, with a dark lateroapical lobe.

\section{Imma macrochorda, new species}

Figures 298, 668

Male, $27 \mathrm{~mm}$. Head fuscous olive. Antenna with scape rather short, ovoid, with a pale yellowish spot on inner side, not reaching apex, flagellum pale olive, pectinations about 2, blackish. Palpus pale fuscous olive, basal segment with a long fringe directed backwards, triangular; median segment elongate, thickened, with rather smoothly appressed scales, top rounded and clavate; terminal segment short, obtusely pointed. Thorax fuscous with a purplish and an olive tinge in certain lights. Abdomen fuscous, a long slender and straight pencil of hairs from end of metathorax above, appressed to sides of abdomen and reaching segment $\mathrm{V}$; posterior edges of segments slightly paler, venter pale yellow.

Forewing rather strongly dilated, broad; with veins 7 and 8 stalked, 8 to termen; costa slightly curved at extremities, gently bent beyond $2 / 3$, apex rounded, termen convex, little oblique. Purplish fuscous. A straight, well-defined moderate transverse fascia from middle of costa to dorsum just beyond middle, yellowish white, gently narrowed along upper half, edges straight along lower, posterior half of wing paler fuscous, with veins broadly streaked with deeper purple fuscous. Cilia (imperfect) fuscous with a whitish basal line.

Hindwing fuscous, dull, without purple. Cilia slightly paler, with a whitish basal line. 
Male genitalia: Tegumen entirely membranous, indefinite. Vinculum moderate, top prominent and rounded. Valva robust, thick, costa sclerotized and forming a broad blade, cucullus rounded with two small angular prominences ventrally; sacculus broad, ending in a sclerotized, furcate process, with upper point long and curved. Upper edge of anellus with a deep W-shaped excision. Aedeagus slender, sinuate, coecum abruptly dilated. Cornuti, a series of short spines and a patch of dentations.

Material examined: Luzon, Los Baños, IX.1922 (Dr. M. Koxas). "Acc. No. Le 93, Coll of Agr., Univ., P.I.," $1 \sigma^{7}$, holotype, genit. slide 5163 (USNM). Probably nearest to I. mesochorda Meyrick, from Assam.

\section{Imma macrochorda regmophora, new subspecies}

Figure 669

Male, $25 \mathrm{~mm}$. Head pale grey fuscous, face whitish fuscous. Antenna with scape whitish fuscous but appearing darker in certain lights, flagellum dark fuscous above, yellowish below; bipectinated, pectinations 3. Palpus light fuscous grey, somewhat darker towards apex, median segment towards base below pale ochreous, exceeding base of antenna. Thorax light purple fuscous, a whitish ill-defined transverse band below apex. Abdomen purple fuscous, venter whitish ochreous.

Forewing oblong, dilated, broadest at $5 / 6$; costa rather curved at base, less so before apex, apex rounded, termen gently rounded, little oblique. Veins 7 and 8 stalked, 8 to termen just below apex. Dark fuscous with moderate purple hue; costa, dorsum, and terminal third not reaching cell suffused deeper fuscous; a whitish transverse fascia from distinctly beyond middle of costa to before $2 / 3$ of dorsum, narrow, gently dilated on costa, slightly irregularly undulate, on vein 11 slightly outwards-oblique, tolerably straight to fold, very slightly outwards convex below this, hardly dilated again on dorsum. Cilia dark fuscous (imperfect).

Hindwing dark blackish fuscous, not paler towards base, whitish along costa from base to well before apex. Cilia dark fuscous (damaged).

Male genitalia: Similar to those of the nominate form, but with the prong at the end of the sacculus somewhat less distinctly furcate. (The vinculum and the bases of the valvae are damaged).

Material examined: Mindanao, Lanao, plains, Kolambugan, 10.VI.1914 (A.E. Wileman), 1 ○ , holotype, genit. slide 5682.

In spite of a slightly different position and shape of the transverse fascia and the very slight differences of the genitalia, this form should be regarded as a subspecies of $I$. macrochorda, from Luzon. 


\section{Imma poecilostoma, new species}

Figures 291-293, 670

Male and female, $18 \mathrm{~mm}$. Head pale yellowish fuscous with some white opalescence, face pale yellow. Antenna pale yellow above, ochreous below, ciliations under 1 . Palpus yellowish white, median segment with a narrow oblique transverse streak from base above to outer edge, this edge broadly opalescent lilac grey to apex, apex lilac grey, median (remaining) portion of upper edge with a bright yellow semioval spot. Thorax pale yellowish fuscous, mixed with pale yellow hair-scales. Abdomen fuscous, venter bright yellow in male, whitish in female. Posterior tibia in male beneath with a dense and broad scale brush, white, tipped with grey.

Forewing broad, subtruncate, costa rather straight, gently bent and prominent at $3 / 4$, apex rounded, termen convex, little oblique. Pale fuscous grey with a lilac purple gloss, densely mixed with pale yellow hair-scales and appearing yellowish grey; colors on anterior half of wing coarser, on posterior more evenly mixed. A bright yellow marginal very narrow streak along anterior half of costa, edged below by a suffused narrow purplish-grey streak; posterior extremity of this marginal streak emitting a rather narrow bright yellow transverse line to just above $3 / 4$ of dorsum; this line curved outwardly, but in center of disc abruptly pressed inwardly, in order to half encircle a suffused dark brown discal dot before $2 / 3$; a faint yellowish suffusion on dorsum forming the end of this fascia; a slender oblique and wedgeshaped mark from $3 / 4$ of costa, limited by the course of vein 11 ; a somewhat lighter yellow line along posterior part of costa, dilated in apex, slightly narrowed and regularly serrate along termen, followed by a dark brown marginal line filling out the serrations. Cilia fuscous with a dark fuscous basal line and slightly paler tips.

Male genitalia: Tegumen moderate, rather broad, slightly constricted below the top which is thickened and rounded. Vinculum with rectangular top with a small triangular median prominence. Valva thick, with several complicated longitudnial folds, sacculus with an apical inwards-directed straight obtuse process ventrally, and a long sclerotized rod inwardly, at the end curved inwards and furcate. Cucullus top obliquely oval. Anellus lobes long, curved, almost reaching top of tegumen. Aedeagus long, sinuate, base bulbous. Two pairs of coremata. Eighth segment modified.

Female genitalia: Ovipositor rounded, floricomous. Ostium, a rounded cup, hairy inside. Ductus bursae extremely long, upper part sinuate, with a strong cestum, lower part strongly tortuous, almost plaited. Corpus bursae finely granulate on top and with a stronger granulate round patch obliquely opposite base of ductus.

Material examined: Luzon, Mt. Makiling (Baker), $1 \sigma^{\top}$, holotype, genit. slide $5165 ; 1$ \% , allotype, genit. slide 5174A. $4 \sigma^{\top}, 4$ \% , paratypes 
(USNM). Agoo, La Union, 2.VII.1945 (J.G. Franclemont), 1 \% genit. slide 5107 (CUI). $5 \sigma^{\text {7 }}, 6$ ㅇ. Closely allied with $I$. mylias Meyrick from Ceylon differing by minor characters of markings and by genitalia. The material from Mt. Makiling has been identified with $I$. mylias by Meyrick.

\section{Imma sarophora, new species}

Figures 301, 671

Male, $18 \mathrm{~mm}$. Head light fuscous with a trace of whitish opalescence, face light yellow, with a triangular fuscous spot from forehead. Antenna fuscous, tawny below, scape light yellow below. Thorax smoothly scaled, evenly light fuscous with purplish reflections and whitish opalescence. Palpus rather short, smooth, acutely pointed, flattened internally so as to form a distinct submedian sharp edge, terminal segment with two of these ridges or ribs; shining smooth, grey fuscous, a semioval light yellow spot on middle of upper edge, basal segment dull light yellow. Anterior leg pale yellow, other legs white, tibiae smooth, suffused with slate grey above. Abdomen fuscous purple, with distinct white opalescence, venter white.

Forewing elongate oval, costa gently curved at base, more so toward apex, straight in middle, apex rounded, termen rounded, vertical. Dark fuscous purple. Extreme costal edge along its posterior 3/4 light yellow. A large oval depression below costa at $1 / 3$, filled with light ochreous scales, covered with dark fuscous longer scales directed apicad; thus a raised oval pad of scales is formed, slate fuscous, tinged ochreous posteriorly, somewhat paler than wing. Cilia white with a dark fuscous basal third.

Hindwing dark fuscous purple, a strongly suffused whitish spot filling out posterior part of cell, between lower edge and vein 5; a paler broad streak below cell to base; costal portion whitish; basal $2 / 3$ of dorsum pale, semipellucent. Cilia white, basal half slightly infuscated in tornus.

Male genitalia: Very similar to those of $I$. otoptera Meyrick from Borneo, but with distinct, though minor, differences. Tegumen broad and low, rounded. Hook at the end of the valva with a shorter and broader stalk, outer arm of this hook longer. Anellus lobes are very small and symmetrical (while in $I$. otoptera left lobe is much longer than right, and both are more robust).

Material examined: Luzon, Los Baños (Baker), $1 \sigma^{x}$, holotype, genit. slide 5167 (USNM).

Very similar to $I$. otoptera, from Borneo, but distinct by minor details of markings and genitalia. Also close to I. chlorosphena from Ceylon, but larger, with less dilated and much more rounded forewings. 


\section{Imma pyragra, new species}

Figures 302, 672

Male, $18 \mathrm{~mm}$. Head dark fuscous, face with a large glossy yellowish-white spot. Antenna dark fuscous (partly missing). Palpi rather long, diverging at base, curved inwards, so that terminal segments overlap and a resemblence of a pair of tongs is created; basal segment rather long, over one-half of median, thickened with dense scales, median segment rather long, thickened in the same way, curved inwards, terminal segment very short, smooth, subacute, pointing mesiad; dark fuscous, median segment externally with a purple iridescence in certain lights, olive above, light ochreous inwardly. Thorax dark fuscous. Abdomen dark fuscous, paler toward base, venter tinged olive. Posterior tibiae smooth.

Forewing elongate-suboval, moderately dilated, costa little curved at extremities, apex rounded, termen rounded, almost vertical. Dark fuscous with a very faint purplish tinge. Markings pale yellow. A narrow, irregular zigzag line from middle of costa to $3 / 5$ of dorsum, upper and lower fourths more distinct, oblique, median half more slender, with two posterior curves, upper regular, to end of cell, lower less distinct and less regular; a rather bright yellow oblique pointed mark from costa before apex, continued as a narrow, more or less interrupted terminal yellow line, forming small, acute dentations anteriorly on veins. Cilia dark fuscous, basal third almost blackish, median third paler, grey.

Hindwing dark fuscous, slightly paler, less purple tinged; a slender whitish marginal mark on costa before apex. Cilia fuscous with a pale basal line and a suffused blackish subbasal band.

Male genitalia: Tegumen weak, depressed, hexagonal. Vinculum much larger, rounded below. Valva acutely pointed, sacculus hairy and broad, with a peculiar truncate prominence at base; harpe, a moderately upwards-curved hook; cucullus densely haired. Anellus lobes long, clavate and slender. Aedeagus with a dilated and rounded base, cornuti, one sheath of fine scobinations (extruded in mount) and two patches of short spinules. Intersegmental membrane with two pointed processes (bases of coremata, hairs removed).

Material examined: Luzon, Mt. Makiling (Baker), $1 \sigma^{7}$, holotype, genit. slide 5164 (USNM).

Apparently a primitive form. The peculiar palpi are very similar to those of $I$. cyclostoma Meyrick from Assam and Tenasserim, with the male genitalia of the same type.

\section{Imma tyrocnista Meyrick, 1906}

Figures 294, 310-311, 673

Imma tyrocnista Meyrick, 1906, Trans. Roy. Ent. Soc. London, p. 199 (ơ), Andaman Is.); 1914, in Wytsman, Genera Insectorum, fasc. 164, 
p. 11; Clarke, 1955, Catalogue . . Microlepidoptera ... Meyrick, vol. 1, p. 321 .

Distribution: Andaman Islands.

Material examined: Luzon, Los Baños, "July," "B. P. Clark donor," "Imma tyrocnista Meyr.," $1 \sigma^{7}$, genit. slide 5175. Also one specimen, "St. Cruz, Leyte, Philippines, .10.24" (in Meyrick's hand) (USNM) "Comp. with type, Imma tyrocnista Meyrick, Det. J.F.G.C., 1948." "Imma tyrocnista Meyr., 2/2, E. Meyrick det. In Meyrick Coll." 1 \%, genit. slide 5166 (USNM).

Male genitalia:Vinculum complicated, narrowly $V$-shaped, articulations slender and furcate. Tegumen triangular, legs robust with dilated bases. Uncus a very narrow long hook. Valva narrow, plicate lengthwise and complicated. Costa with a rounded subbasal lobe. Cucullus rectangular, more or less isolated, edges sclerotized, top truncate. Sacculus under 1, base angularly dilated, a median cylindrical haired process, posterior half of sacculus strongly sclerotized, top dilated, with two obtuse points. Anellus lobes slender. subclavate, under $1 / 5$. Aedeagus very long, sinuate. Cornuti, two blunt spikes. Coremata very large, complicated, menses of the eighth segment strongly developed. There is one median corema against the anellus, and three pairs of sublateral more rostrally situated coremata.

\section{Imma nephodryas Meyrick, 1928}

Figures 299, 674

Imma nephodryas Meyrick, 1928, Exotic Microlepidoptera, vol. 3, p. 420 ( $\sigma^{\Upsilon}$, Philippines Is.).-Clarke, 1955, Catalogue . . Microlepidoptera . . . Meyrick, vol. 1, p. 215.

Distribution: Philippine Is.

Material examined: Luzon, Los Baños (Baker), 1 ơ, genit. slide 5168. "Imma nephodryas Meyr. Paratype"=topotype, $1 \sigma^{x}$, the second specimen which becomes known (USNM).

Male genitalia: Tegumen apparently altogether absent. Valva rather broad, base and costa with a continuously thickened margin, dilated on middle of costa into an oval plate. Sacculus rather broad, gradually narrowed, densely haired. Harpe, a slender outwardscurved hook. Colliculum well separate, rounded, densely haired.

\section{Tortyra Walker, 1863}

\section{Key to the Philippine Species of Tortyra}

1. Forewing posterior half with two suffused white patches surrounded by coarse white dusting. . . . . . . . . . . T. macrospila, new species Forewing posterior half without such white markings . . . . . . 2 
2. Hindwing blackish fuscous with a yellow streak in disc; forewing with metallic streaks thick. . . . . . . . . . . . . . . . . . . . T. divitiosa

Hindwing dark bronze fuscous without yellow; forewing with metallic streaks narrow . . . . . . . . . . . . . . . T. elegans

\section{Tortyra elegans (Walsingham, 1909)}

\section{Figure 675}

Saphtha elegans Walsingham, 1909 [sic], in Swinhoe, Cat. Lep. Het. Mus. Oxon., vol. 2, p. 567 ( $\sigma^{7}$, India, Andaman Is.).

Tortyra elegans.-Meyrick, 1913, in Aurivillius, Lepidopterorum Catalogus, pars 13, p. 33; 1914, in Wytsman, Genera Insectorum, fasc. 164, p. 19.

Distribution: India, Ceylon, Andaman Is.

Material examined: Luzon, Benguet Subprov., Palali, $2000 \mathrm{ft}$, 4.XII.1913 (A.E. Wileman), 1 ơ , without abdomen. Compared with type in the British Museum.

\section{Tortyra divitiosa (Walker, 1864)}

Figures 335-337, 676

Saptha divitiosa Walker, 1864, List Lepidopterous Insects British Mus., pt. 30, p. 1015 ( $\sigma^{7}$, Ceram).

Tortyra divitiosa.-Meyrick, 1907, Proc. Linn. Soc. New South Wales, vol. 32, pp. 97, 99; 1913, in Aurivillius, Lepidopterorum Catalogus, pars 13, p. 33; 1914, Suppl. Ent., no. 3, p. 56; 1914, in Wytsman, Genera Insectorum, fasc. 164, p. 19.-Durrant, 1915, in Ogilvie-Grant, Rep. British Ornithologists' Union and Wollaston Exped . . . Dutch New Guinea, 1910-1913, vol. 2 , pt. 15 , p. 167 -Diakonoff, 1948 , Treubia, vol. 19, p. $202 ; 1955$, Verh. Ned. Akad. Wet., Nat., ser. 2, vol. 50, pt. 3, p. 25.

Distribution: India, Moluccan Is., New Guinea, Formosa, etc.

Material examined: Luzon: Mt. Makiling genit. slides 5180o, 5182ㅇ, Los Baños, slide $5178 \sigma^{\top}$, Manila (Benguet) Laguimanoc (Tayabas), Montalban, plains, Rizal prov.; Mindanao, Kolambugan. IX-IV. (Baker, R.A. Cushman, R.C. McGregor, H. Ricardo, H.E. Milliron, C.S. Banks). $8 \sigma^{7}, 10$ ㅇ (USNM) (BMH). Also from "New Britain, Talesea (AFE) II.1925," $1 \sigma^{\top}$ (Meyrick det., Meyrick coll.). Calayan Is., 13.IX.1903 (R.C. McGregor), 1 ơ , genit. slide 5181. Palawan Is., Taytay, plains, 13.IV.1913 (A.E. Wileman), $10^{7}$.

\section{Tortyra macrospila, new species}

Figures 368-369, 677

Female, $18 \mathrm{~mm}$. Head brilliant black, face iridescent green. Palpus black. Antenna with basal 2/3 dilated by roughish scales above and beneath, flattened laterally; blackish purple, mixed anteriorly with white scales. Thorax deep purple, tegulae and a narrow median streak brilliant iridescent green. Abdomen purplish black. 
Legs black, banded with white, posterior tibia with a white median and a narrow subapical white band. Pectus and coxae brilliant green.

Forewing broadly triangular, little curved anteriorly, slightly bent and prominent well before apex, apex subobtuse, termen long, vertical, little rounded. Dull fuscous. Thorax iridescent green, with narrow longitudinal streaks from just beyond base, first just below costa, third just above dorsum; median streak short, wedge-shaped, in fold; a rather thick transverse fascia at $1 / 3$, iridescent green, slightly outwards convex and gently inwardly oblique, from just below costa to dorsum; followed by a gently downwards-diverging, slightly broader, pale, prismatic-greenish fascia before middle; this fascia running from costa to dorsum, slightly narrowed in middle, with upper and lower extremities rounded; a marginal fascia of the same color, from apex to tornus, with a short subcostal appendix from apex; lower end of this fascia acutely narrowed; a subtriangular spot of same color in tornus, a roundish dot on end of cell, a few scales strewn between these spots; posterior half of wing coarsely strewn with white; an elongate semioval white spot at $3 / 4$ of disc above middle, suffused posteriorly; a triangular patch almost adjacent to median metallic fascia below fold, reaching to dorsum, upper end extended as a slender, attenuated fascia across lower $2 / 3$ of wing. Cilia dark grey with a black basal and median line.

Hindwing dark fuscous brown with a purplish gloss towards dorsum, with a narrow pale streak along lower edge of cell and pale costa. Cilia whitish mixed with grey, basal half dark fuscous with a narrow pale basal line, obliterate towards tornus.

Material examined: "Philippines. Mt. Makiling, B., .37" (in Meyrick's hand), "Tortyra centrifuga Meyr., 4/3, E. Meyrick det. in Meyrick Coll.," 1 \%, holotype, genit. slide 5772 .

The species is allied with T. centrifuga Meyrick, from Assam, but different by the following points. Forewing broader, metallic area larger, a broad band along termen and a triangle on end of dorsum, while in centrifuga there is only a short, in middle narrowed streak from apex to below middle of termen, and a few scattered metallic scales. In the present species the white coloring in disc is more extended, the dots are broader and denser; the first and second transverse fasciae are broader and straight in macrospila, while in centrifuga they are narrow and the first fascia is almost interrupted in middle.

\section{Anthophila Haworth, 1811}

\section{Key to the Philippine Species of Anthophila}

1. Hindwing white with a black broad margin . . . . . . . A. streptatma Hindwing not white and black . . . . . . . . . . . . . 2 
2. Forewing with a broad yellow submedian band, paler than other markings.

A. basalis

3. Hindwing orange or dark fuscous with orange markings . . . . . . . . 4

Hindwing sometimes tawny ochreous or pale ochreous yellow, but not orange. 5

4. Hindwing orange marked with dark fuscous and blackish.

A. anthorma, new combination

Hindwing dark fuscous with a wedge-shaped orange streak $\left(\sigma^{7}\right)$ or an orange terminal fascia $(q)$. . . . . A. xanthogramma, new combination

5. Hindwing almost unicolorous dark fuscous . . . . . . . . . A. orthogona

Hindwing not unicolorous fuscous . . . . . . . . . . . . . . . . . 6

6. Forewing with a double short basal, a double submedian, and a double postmedian deep ochreous fasciae . . A. amethystodes, new combination

Forewing with a single whitish subbasal and a similar submedian line and with a double light ochreous subterminal band turning whitish toward costa.

A. angulosa, new species

Anthophila streptatma (Meyrick, 1938), new combination

Figures 300, 679

Choreutis streptatma Meyrick, 1938, Trans. Roy. Ent. Soc. London, vol. 97, p. 523

( $\sigma^{\top}$, New Guinea).-Clarke, 1955, Catalogue . . . Microlepidoptera . . . Meyrick, vol. 1, p. 396.

Anthophila macropa Diakonoff, 1948, Treubia, vol. 19, p. 204 ( $\sigma^{\top}$, Moluccas) [new synonym].

Distribution: New Guinea; Moluccas.

Material examined: Luzon, Benguet Subprov., Klondyke, 800 ft., 24.XII.1911 (A.E. Wileman), $1 \sigma^{\top}$, genit. slide 4676 (BM).

The genitalia of the male ("macropa") have been described already, but their photograph is poorly reproduced (Diakonoff, 1948). Therefore a more elaborate figure is presented now.

\section{Anthophila angulosa, new species}

Figures 305-306, 680

Female, $13 \mathrm{~mm}$. Head whitish, vertex fuscous black. Antenna dark fuscous. Palpus rather slender; whitish, median segment with some dark fuscous subapical marks, terminal segment with apical half dark fuscous. Thorax dark fuscous, an anterior and a median white band, tegula with a broad subbasal band and top white. Abdomen light fuscous, suffused with yellow ochreous. Posterior leg (worn) light yellow, tarsus white, ends of segments ringed with yellow and fuscous.

Forewing broadly subtriangular, strongly dilated, costa curved, more so at extremities, apex tolerably pointed, termen long, irregularly rounded, little oblique. Fuscous marked with white and yellow ochreous. Two white hardly inwards-oblique transverse straight streaks, beyond base and at $1 / 3$, respectively, more or less 
edged with dark fuscous on both sides; a narrower white outwardsoblique streak from costa before $2 / 3$, directed to middle of termen, across upper third of disc, abruptly changing in a broader, bright ochreous inwards-oblique streak to $2 / 3$ of dorsum, so giving rise to an angulate complete transverse fascia; another parallel fascia, broader, entirely bright ochreous, halfway between preceding and termen, more curved at $1 / 3$ than angulate; these fasciae edged and separated by dark fuscous; termen and median part of wing tawny, slightly dusted with fuscous; ocellus in cell white. Cilia (rubbed) dark fuscous.

Hindwing yellow, marked with very pale purplish fuscous: a streak edging white costal area, a patch in apex, an almost straight preterminal streak from apical patch to tornus, some irregular suffusion along lower edge of cell and along fold and irregular dusting before termen. Cilia (rubbed) apparently yellowish with dark fuscous basal third.

Female genitalia: Seventh segment gently sclerotized, sternite gradually rounded along its posterior edge, with a deep median split flanked by small darker sclerites. Lamella postvaginalis showing a slender horizontal ridge. Colliculum formed of short irregular dark folds. Ductus bursae simple, narrow. Corpus bursae elongate-pearshaped. Signum, a horseshoe-shaped lamina dentata.

Material examined: Luzon, Benguet, Palali, 2000 ft., 26.XII.1912 (A.E. Wileman), 1 o, holotype, genit. slide 5683 (BM). Perhaps allied to $A$. inscriptana (Snellen), but quite differently colored.

\section{Anthophila basalis (Felder, 1875)}

Figures 304, 678

Simaethis basalis Felder, 1875, in Reise Fregatte Novara, vol. 2, no. 7, pl. 138, fig. 19 (Amboina).-Pagenstecher, 1900, in Zoologica, vol. 29, no. 12 p. 229.-Meyrick, 1907, Proc. Linn. Soc. New South Wales, vol. 32, p. 111; 1913, in Aurivillius, Lepidopterorum Catalogus, pars 13, p. 35; 1914, in Wytsman, Genera Insectorum, fasc. 164, p. 21; 1938, Trans. Roy. Ent. Soc. London, vol. 87, p. 523.-Turner, 1913, Proc. Linn. Soc. New South Wales, vol. 38, p. 210.

Anthophila basalis.-Diakonoff, 1948, Treubia, vol. 19, p. 204; 1955, Verh. Ned. Akad. Wet., Nat., ser. 2, vol. 50, no. 3, p. 26.

Simaethis chionodesma Lower, 1896, Trans. Roy. Soc. South Australia, vol. 20, p. 167.

Distribution: Celebes, Moluccas, Buru, Amboina, Aru, New Guinea, Philippine Is., Formosa, East Australia.

Material examined: Luzon, Mt. Makiling (Baker), $1 \sigma^{\top}$, genit. slide 5170; 1 ㅇ, Los Baños, 4.XI.1933 (E.B. Ramos), “Acc. no. F90, coll. of Agr. Univ. P.I.," 1 ㅇ (USNM), 1 ơ, 2 ㅇ. 
Male genitalia: Tegumen, an equilateral triangle. Tuba analis bristled. Transtilla broad and rather high. Anellus lobes rather small, broader at base, pointed. Valva elongate-suboval, broad. Sacculus one-half, apical patch of spines elongate-oval, submarginal, spines rather slender; top of sacculus angularly prominent. Cucullus rounded. Aedeagus straight, slender, basal half broader.

\section{Anthophila xanthogramma (Meyrick, 1912), new combination}

Simaethis xanthogramma Meyrick, 1912, Exotic Microlepidoptera, vol. 1, p. 42 ( $\sigma^{\top}$, Mindoro, Kei Is.); 1913, in Aurivillius, Lepidopterorum Catalogus, pars 13, p. 35; 1914, in Wytsman, Genera Insectorum, fasc. 164, p. 21.Clarke, 1955, Catalogue . . Microlepidoptera . . Meyrick, vol. 1, p. 327.

Distribution: Philippine Is., Mindoro; Kei Is.

\section{Anthophila amethystodes (Meyrick, 1914), new combination}

Figures 338, 681-682

Simaethis amethystodes Meyrick, 1914, Suppl. Ent., no. 3, p. 57 (, Formosa).Clarke, 1955, Catalogue . . Microlepidoptera . . Meyrick, vol. 1, p. 42.

Distribution: Formosa, Philippine Is.

The lectotype, hereby selected, is labelled thus: "Philippines, M., .10," "Simaethis amethystodes Meyr., 3/3, E. Meyrick det., in Meyrick Coll." "amethystodes Meyr." (in Meyrick's hand, BM) $1 \sigma^{7}$, genit. slide 5684. This species is of the extensive and difficult $A$. pyraustella group of species, probably nearest to A. irimochla (Meyrick).

Male, $15 \mathrm{~mm}$. Head with face yellowish, vertex fuscous mixed with yellowish. Antenna blackish, brightly ringed with white, ciliations over 1. Palpus yellow, median and terminal segments each with a blackish base and a dark fuscous subapical band, in terminal segment almost entire apical half dark fuscous. Thorax (rubbed) fuscous with an anterior and a median orange transverse band. Abdomen yellow, paler below, fuscous color showing through. Posterior leg orange yellow, femur paler, tibia with two suffused black bands, spurs whitish marked with blackish, tarsus black with yellow base, top of first segment and the whole of third segment white.

Forewing broad, subtriangular, costa moderately curved, more so at ends, apex obtusely pointed, termen long, rounded, slightly prominent above middle. Ochreous orange, marked with dark fuscous. A small spot on base of costa; a moderate, straight and little inwards-oblique transverse streak at about $1 / 5$, preceded by another narrow, irregular strigula, triangularly dilated on dorsum; an almost vertical median fascia, somewhat irregular and slightly suffused, moderately constricted above cell, gradually dilated downwards and spindle-shaped, broadest at $3 / 4$; this fascia is preceded by a straight line of fuscous irroration and followed by another complete and well-defined line, more distant from 
fascia, from $2 / 3$ of costa, upper half gently and regularly curved, outwards-convex, lower half straight, sharply twice rectangularly bent at $2 / 3$; finally a gradually sinuate, moderately broad preterminal fascia, from apex to tornus, outwards concave above, convex beneath; spaces between lines in middle of wing slightly touched with pale purplish pink, so is the "ocellus" on end of cell, being a vertical erect-suboval pale spot, followed by a few fuscous marks, space beyond ultimate transverse fascia partly mixed with dark fuscous on lower half. Cilia ochreous, along costa and opposite apex and middle of termen, suffused with black throughout, basal third black.

Hindwing fuscous with an $\lrcorner$-shaped central mark, long slender leg along lower edge of cell from beyond base, short, broad leg along closing vein; an irregular yellow band along lower half of termen, a similar spot opposite tornus, a narrow marginal streak along dorsum from well beyond base. Cilia bright orange ochreous, basal third dark fuscous.

Male genitalia: Tegumen triangular, bipartite (or broken in two at the top?). Transtilla subquadrate, each labis, a rounded, concave lobe, with a minutely haired surface. Vinculum rounded-triangular, arms strong, middle a broad plate. Valva broad, semioval, slightly dilated; sacculus well separated, under $1 / 2$, unarmed. Cucullus spiny on apical third, bristles of diverse shape and size; a separated cluster of spines just above top of sacculus.

The second syntype, a female, without abdomen, is labelled "Kosempo (Formosa), H. Sauter, X.1911," “F 113," "Meyrick det.," "Dtsch. Entomol. Institut Berlin." Although marked "Typus" this specimen ranges only as syntype (DEI). The syntype retained by Meyrick was preferable for the selection, being an intact male specimen.

\section{Anthophila anthorma (Meyrick, 1912), new combination}

Figure 683

Simaethis anthorma Meyrick, 1912, Exotic Microlepidoptera, vol. 1, p. 42 ( $q$, Mindoro); 1913, in Aurivillius, Lepidopterorum Catalogus, pars 13, p. 35; 1914, in Wytsman, Genera Insectorum, fasc. 164, p. 21.-Clarke, 1955, Catalogue ... Microlepidoptera . . Meyrick, vol. 1, p. 47.

Distribution: Philippine Is., Mindoro.

\section{Anthophila orthogona (Meyrick, 1886)}

Figures 309,800

Simaethis orthogona Meyrick, 1886, Trans. Roy. Ent. Soc. London, p. 287 ( $\sigma^{\top} \uparrow$ ); 1907, Proc. Linn. Soc. New South Wales, vol. 32, p. 114; 1910, Rec. Indian Mus., vol. 5, p. 226 (Tonga); 1913, in Aurivillius, Lepidopterorum Catalogus, pars 13, p. 35; 1914, in Wytsman, Genera Insectorum, fasc. 164, p. 21.Maxwell-Lefroy, 1909, Indian Insect Life, p. 538.-Fletcher, 1920, Mem. 
Dept. Agric. India, Ent. ser., vol. 5, p. 126.-Clarke, 1955, Catalogue . . .

Microlepidoptera . . . Meyrick, vol. 1, p. 228.

Anthophila orthogona.-Fletcher, 1933, Imp. Counc. Agric. Res., Sci. Mon., no. 4, p. 25.

Simaethis inscriptana Snellen, 1875 ( $q$ not $\sigma^{7}$ ), Tijdschr. Ent., vol. 18, p. 76, pl. 6, fig. 6 ( $q$ not $\sigma^{7}$, Celebes).-Meyrick, 1913, in Aurivillius, Lepidopterorum Catalogus, pars 13, p. 35; 1914, in Wytsman, Genera Insectorum, fasc. 164, p. 21.

Distribution: New Guinea, Celebes, India, Ceylon, Burma.

Material examined: Luzon, Rizal Prov., Pasay, 23-31.V.1911 (A.E. Wileman), $1 \sigma^{\top}$, slightly rubbed but easily recognizable; genit. slide 5685 .

Male genitalia: Tegumen and uncus simple, conical. Socius small. Vinculum robust, sclerotized. Valva moderate, concave, sacculus forming an oblique hairy process directed basad. Cucullus with a cap of dense short spines. Anellus moderate, tubular. Aedeagus pistol-shaped.

\section{Choreutis Hübner, 1826}

Choreutis Hübner 1826, Verzeichniss bekannter Schmettlinge, p. 373.

Type species: Choreutis scintilulana Hübner, 1926 (Europe, Asia Minor).

Choreutis sexfasciella (Sauber, 1902)

FIGURE 689

Choreutidia sexfasciella Sauber, 1902, in Semper, Schmetterlinge Philippinischen Inseln, vol. 2, p. 702 ( $\sigma^{\top}$, Luzon).

Choreutis sexfasciella.-Meyrick, 1913, in Aurivillius, Lepidopterorum Catalogus, pars 13, p. 38; 1914, in Wytsman, Genera Insectorum, fasc. 164, p. 24.

Distribution: Philippine Is., Luzon.

\section{Brenthia Clemens, 1860}

\section{Key to the Philippine Species of Brenthia}

1. Fore- and hindwing blackish with well-defined white spots . B. albimaculana Fore- and hindwing differently colored . . . . . . . . . . . . . . . . 2

2. Forewing with termen either entirely black or with velvet-black sometimes finely whitish-edged spots, partly or entirely occupying termen . . . . 3 Forewing and termen greyish fuscous, a series of 8 or 9 very small velvet-black spots rather before termen, each spot with a metallic point posteriorly.

B. lithocrossa

3. Forewing with terminal fifth forming a blackish fascia with only three violetmetallic marginal dots; in apex, middle of termen, and above tornus.

B. trilampas

Forewing termen with more or less separate black patches, when entirely filling out the termen then each finely edged with whitish; more than three marginal metallic dots . . . . . . . . . . . . . . . . . . . . 4

4. Forewing termen with only two separate black patches and eight metallic marginal dots. . . . . . . . . . . . . . . . . B. harmonica 
Forewing termen filled out with three or four black patches, each rounded anteriorly and pale-edged, each with one or two metallic dots posteriorly. 5

5. Forewing termen with three black patches and four or five metallic dots.

B. anisopa, new species

Forewing termen with a series of smaller black patches and more than five metallic dots

B. catenata

\section{Brenthia albimaculana (Snellen, 1875)}

FIgURE 687

Simaethis albimaculana Snellen, 1875, Tijdschr. Ent., vol. 18, p. 77, pl. 6, fig. 5 ( + , Celebes).

Brenthia albimaculana.-Meyrick, 1913, in Aurivillius, Lepidopterorum Catalogus, pars 13, p. 37 (hecataea syn.) ; 1914, in Wystman, Genera Insectorum, fasc. 164 , p. 23.

Brenthia hecataea Meyrick, 1907, Proc. Linn. Soc. New South Wales, vol. 32, p. 109 ( $\sigma^{\top}$ \% , St. Aignan Is.).

Distribution: Java, Celebes, Philippine Is., New Guinea.

This may be a complex species, the occurrence in the Philippine Islands, therefore, is not quite certain. The specimen figured is Snellen's well-preserved holotype, a female, labelled "Celebes, Makassar," in Snellen's hand (LM).

\section{Brenthia anisopa, new species}

FiguRes 342, 688

Male, $10 \mathrm{~mm}$. Head pale fuscous olive, lateral margins with narrow white streaks. Palpus with median segment white, a subbasal and a subapical blackish ring and anterior edge black; terminal segment black suffused tawny anteriorly, a white median ring open anteriorly, tip whitish. Thorax black, pectus whitish. Abdomen black. Legs black with broad white bands.

Forewing broadly truncate, dilated, apex strongly rounded, termen moderately rounded, little oblique, almost vertical. Dark purplish fuscous, moderately strewn with white scales forming ill-defined markings, especially on median third. Basal patch with few scales, only indicating a faint circle, by far not reaching base and edges of wing and centered with a more distinct, slightly inwards-oblique oval ocellus; a larger, distinct vertical ocellus in disc before $2 / 3$ and above middle, more pointed below, almost connected by a vertical fascia with $3 / 5$ of dorsum; these white markings preceded and followed by irregular and faint bands of white dusting, at $2 / 5$ and before $3 / 4$ of wing, respectively; these two fasciae originating below costa, but anterior faintly connected with it; vertical above, below middle moderately converging; above and below middle of disc these bands irregularly connected with median ocellus and fascia; more than terminal fifth of wing velvety black, this area dilated downward and incompletely divided by three pointed projections of ground color, opposite 
middle of termen, opposite apex and on end of costa, respectively, into three parts; upper of these narrowly elongate and slightly curved, other large and rounded, lower largest; these three blotches are interconnected along termen and are ornated with brilliant silverypurplish dots, arranged before termen; lower patch with two dots; upper with two smaller dots in a horizontal series; a well-defined zigzag whitish line from $4 / 5$ of costa, edging this terminal area anteriorly. Cilia (imperfect) dark fuscous, mixed with whitish, with a pale basal line.

Hindwing purplish black; a whitish, outwards-oblique oval ocellus below costa before middle, reaching to middle of disc, a narrow whitish inwards-oblique dot on costa before apex, continued by a short strigula across wing, inwards-oblique brilliant bluish purple; a narrow subterminal whitish line, from well below apex, parallel to termen as far as its middle, sinuate inwards thence, to tornus; a vertical brilliant bluish-purple strigula from costa before apex to $1 / 3$ of termen, narrowed below. Cilia whitish, basal half black except pale basal line, apical half with suffused black patches, opposite apex, middle of termen and tornus, respectively.

Male genitalia: Small and compact. Tegumen rounded. Uncus broad, truncate, with two brushes of long hairs. Socii are represented by small folded lateral angles of uncus. Vinculum large, rounded. Saccus apparently a pointed conical median process, directed rostrad. Valva small, narrowed, top bilobed, lobes concave, with sparse short bristles. Aedeagus rather short, not sclerotized, bulbous, on a narrower stalk, extreme base dilated again, with a coiled sclerite.

Material examined: Luzon, Mt. Makiling (Baker), $1 \sigma^{x}$, holotype, genit. slide 5172 (USNM). Probably allied with Brenthia quadriforella Zeller but quite distinct by three, instead of four, lobes of the black terminal band.

\section{Brenthia catenata Meyrick, 1907}

Brenthia catenata Meyrick, 1907, Journ. Bombay Nat. Hist. Soc., vol. 17, p. 748 ( + , Poona); 1913, in Aurivillius, Lepidopterorum Catalogus, pars 13, p. 37; 1914, in Wytsman, Genera Insectorum, fasc. 164, p. 23.-Clarke 1955, Catalogue . . . Microlepidoptera . . . Meyrick; vol. 1, p. 77.

Distribution: India, Ceylon, Philippine Is.

\section{Brenthia trilampas Meyrick, 1918}

Figure 685

Brenthia trilampas Meyrick, 1918, Exotic Microlepidoptera, vol. 2, p. 193 ( ${ }^{\top}$, “Philippines").-Clarke, 1955, Catalogue . . . Microlepidoptera . . . Meyrick, vol. 1, p. 316.

Distribution: Philippine Is. 


\section{Brenthia lithocrossa Meyrick, 1922}

Figures 297, 686

Brenthia lithocrossa Meyrick, 1922, Exotic Microlepidoptera, vol. 2, p. 487

(१).-Clarke, 1955, Catalogue . . Microlepidoptera . . Meyrick, vol. 1 , p. 190.

Distribution: Philippine Is., Luzon, Southwest Celebes.

Material examined: The unique type specimen is in the Paris Museum, a female from Manila, genit. slide 5508.

Female genitalia of the "floricomous" type: ovipositor broad, dilated towards top, top emarginate; lobi anales moderate, semioval. Sterigma not modified and membranous. Anapophyses rather short and slender straight rods, base flattened, dilated and rounded. Postapophyses with a similar base, but very slender elsewhere, little sclerotized, top dilated so as to form a rhomboidal small plate. Abdominal segments from the 6th on, sclerotized, their anterior edges wrinkled.

\section{Brenthia harmonica Meyrick, 1918}

FIgURE 684

Brenthia harmonica Meyrick, 1918, Exotic Microlepidoptera, vol. 2, p. 192 ( $q$, "Philippines").-Clarke, 1955, Catalogue . . . Microlepidoptera . . . Meyrick, vol. 1, p. 153.

Distribution: Philippine Is.

\section{Heliodinidae}

Key to the Philippine Genera of Heliodinidae

1. Hindwing with veins 3 and 4 connate . . . . . . . . . Trichothyrsa Hindwing with veins 3 and 4 separate... . . . . . . . . . . 2

2. Forewing with vein 6 out of 8 . . . . . . . . . . Eretmocera Forewing with vein 6 separate . . . . . . . . . . . . . . . 3

3. Antenna with a fringe of rough scales above...... . Thriambeutis Antenna without a fringe . . . . . . . . . . . . . . . . . 4

4. Hindwing with veins 6 and 7 approximated toward base . . . . . . . 5 Hindwing with veins 6 and 7 stalked . . . . . . . . . . . . . . 7

5. Forewing with vein 11 from middle of cell . . . . . . . . Lamachaera Forewing with vein 11 from beyond middle of cell . . . . . . . . . . 6

6. Forewing with vein 11 from beyond $3 / 4$ of cell; hingwing cell open between 4 and 5. . . . . . . . . . . . . . . . . . . Stathmopoda Forewing with vein 11 from beyond $1 / 2$ of cell; hindwing cell not open.

Aeoloscelis

7. Forewing with veins 8 and 9 out of $7 ; 11$ from beyond middle of cell.

Craterobathra Forewing with veins 7 and 8 stalked, 9 free; 11 from middle of cell. 


\section{Craterobathra Meyrick, 1927}

Craterobathra Meyrick, 1927, Exotic Microlepidoptera, vol. 3, p. 379 (, New Ireland).-Fletcher, 1929, Mem. Dept. Agric. India, Ent. ser., vol. 11, p. 58. Type species: Craterobathra tabellifera Meyrick, 1927 (New Ireland). The genus may be redescribed as follows. Head smooth, slightly flattened. Ocellus posterior, very small. Proboscis developed. Antenna $5 / 6$, slender, serrulate, simple, scape strongly elongate, top slightly swollen, without pecten. Labial palpus extremely long, recurved, slender and smooth, laterally compressed, terminal segment twice as long as median. Maxillary palpus very short, scaled and flattened, appressed to proboscis. Posterior tibia smooth with a moderate median more or less appressed tuft of bristly scales and a larger similar apical tuft; spurs and tarsal joints with fine spines below throughout.

Forewing with vein $1 \mathrm{~b}$ short-furcate, lower branch only a short stump. Vein 2 remote from angle, steep, 3 from before angle, 4 from angle, 5 and 6 parallel, 7 to costa, 8 and 9 out of 7,10 from well before angle, closing vein weak, 11 from beyond middle, cell strongly narrowed basad.

Hindwing over 1/2, lanceolate, cilia 2, veins 2-4 distant and parallel, 4 from angle, 5 remote, closer to 4 , hardly approximated, 6 and 7 apparently stalked, cell being open between 5 and 6 ; a parting vein present but very weak, supramedian, to above base of 5 .

Male genitalia with double pair of valvae, lower pair strongly dilated at the top. Juxta forming a straight porrect process. Aedeagus joined to its base, sclerotized. Tegumen slender, a simple narrow bow. Uncus and gnathos absent.

Female genitalia: Genital segment conical, with a median split. Lamella antevaginalis, an emarginate, calyciform plate. Signum absent.

The genus is allied to Xestocasis. Venation of the forewing is characteristic.

\section{Key to the Philippine Species of Craterobathra}

1. Forewing blackish with a white transverse band. C. demarcata, new species Forewing also with longitudinal markings . . . . . . . . . . . 2

2. Dark fuscous with longitudinal leaden streaks and sparce yellow markings.

C. argyracma, new species

Dark purple, a white subbasal spot; posterior half yellow or orange, with black longitudinal streaks ........ . C. ornata, new species 


\section{Craterobathra ornata, new species}

Figures 315-316, 692

Male, 16-20 mm; female, $17 \mathrm{~mm}$. Head dark purple, forehead shining white with prismatic reflections, face white. Antenna deep purple, yellowish below, apical third white except tip. Palpus whitish with purple reflections externally, purple internally. Abdomen deep purple, first segment with a pair of oblique lateral white stripes, anal tuft yellow, venter purple with a white transverse band across posterior half of each sternite 2,3 , and 6 , sternite 4 entirely white, in female band of sternite 6 yellow. Legs dusky yellowish white, suffused with purple, posterior leg with coxa and femur white below, tibia grey purple with a broad pale yellow subbasal band, median tuft black; posterior tarsus purple black, tip snow white. Thorax dark purple.

Forewing narrowly lanceolate, pointed. Dark purple over more than anterior third, including a conspicuous white subrectangular or irregular oval spot in center, connected with a second smaller similar dot below and before preceding; a bluish-metallic, ill-defined spot at base of costa and a few similarly colored scales strewn below costa; a larger, well-defined, erect-oval blue-metalic spot between white spot and posterior edge of black area; posterior $2 / 3$ of wing in male yellow, slightly strewn with black, in female orange; this area including a narrow supramedian longitudinal black streak, from middle of wing to apex, dilated posteriorly; this streak including a brilliant blue-metallic line along its middle, with pointed ends; a moderate black streak along termen not reaching tornus; a semioval black patch in tornus, except narrow edge filled out with metallic blue. Cilia grey mixed with white, a white bar before tornus, a broader black bar in tornus, cilia around apex black, here and there mixed with shining metallic scales.

Hindwing dark coppery bronze, cilia black.

Male and female genitalia as described with the genus.

Material examined: Mindanao, Lanao, Butig Mts., $24 \mathrm{~km}$ NE of Butig, $1080 \mathrm{~m}$, 20.VI.1958, $1 \sigma^{\top}$, holotype, genit. slide 5322, 1 ㅇ, allotype, genit. slide 5323. Zamboanga del Norte, Masawan, trail to Mt. Malindang, $1290 \mathrm{~m}$, 5.VII.1958, rain forest, $1 \sigma^{7}$, paratype (H.E. Milliron) (BMH). Davao Prov., east slope of Mt. McKinley, 3000 ft., IX.1946 (CNHM Philippine Exped. 1946-47, H. Hoogstraal), $1 \sigma^{\top}, 1$ \% , paratypes.

\section{Craterobathra argyracma, new species}

Figures 322, 694

Male, $20 \mathrm{~mm}$. Head polished, shining pale ochreous, face whitish, side tufts on vertex blackish. Antenna bronze (palpi missing). 
Thorax bronze. Abdomen bronze black, venter with pale yellow bands across posterior halves of sternites, anal tuft light ochreous.

Forewing with vein 9 out of the stalk of $7+8$; lanceolate, costa gently curved throughout, apex acutely pointed, termen slightly convex, extremely oblique. Bronze fuscous, partially strewn with light and darker yellow, slender, mixed with scales, forming the following markings. An oblong spot on middle of costa, a slender longitudinal streak above cell from middle of wing to apex; a similar streak below middle of wing, with an extension to dorsum before tornus; two large, elongate patches in fold, beyond base and beyond middle, respectively. Metallic markings pale leaden golden, arranged thus: a thick longitudinal median streak from middle of wing to apex, pointed on both sides; a transverse triangular patch on dorsum beyond base, inwardsoblique, separating two yellow patches on fold and reaching $2 / 3$ across wing; another, depressed triangular patch on end of cell; these metallic markings may appear black in certain lights; a narrow metallic streak along lower half of termen to tornus. Cilia yellow mixed with black, tips black.

Hindwing rather dark fuscous grey with a purplish-bronze gloss. Cilia dark fuscous grey.

Male genitalia: Puzzlingly almost exactly similar to those in $C$. ornata, new species. The only difference is the larger size of the upper valva and longer bristling at its base.

Material examined: Mindanao, Davao Prov., Meran, east slope of Mt. Apo, original forest, $6500 \mathrm{ft}$., 8.XI.1946 (CNHM Philippine Exped. 1946-47, H. Hoogstraal), $1 \sigma^{7}$, genit. slide 5747.

The species is more robust and quite differently marked from $C$. ornata, so its validity seems to be beyond any doubt, in spite of unexpected similarity of the genitalia.

\section{Craterobathra demarcata, new species}

Figures 325-326, 693

Female, $12 \mathrm{~mm}$. Head smooth, covered with large, oval scales; purplish blue, face white. Antenna serrulate, minutely ciliated, blackish purple. Palpus slightly compressed laterally, very long; purplish grey. Thorax purplish black, posterior edge of metathorax shining white. Posterior leg dark purple, a narrow white ring around median whorl of bristles; apical segment of tarsus white.

Forewing lanceolate, moderate, costa gently curved, apex acute. Dark fuscous, markings shining white with bluish reflections. A moderate transverse fascia at $2 / 3$, direct, slightly outwards-convex in left wing, wedge-shaped in right; a small elongate spot along median part of termen. Cilia dark fuscous, white around apex. 
Hindwing whitish, densely clothed with fuscous-bronze scales. Cilia black, towards base of dorsum becoming white.

Female genitalia: Eighth segment tubular, sclerotized. Ostium strongly modified, forming a dark, sclerotized, projecting cylinder with an obliquely truncate top. Vesiculum seminalis very large. with wall strongly plicate lengthwise. Corpus bursae but little larger than vesiculum; signa absent.

Material examined: Mindanao, Davao Prov., east slope of Mt. McKinley, IX.1946, 3000 ft. (CNHM Philippine Exped. 1946-47, H. Hoogstraal), 1 \% holotype, genit. slide 5759.

\section{Thriambeutis Meyrick, 1910}

\section{Thriambeutis coryphaea Meyrick, 1912}

Figures 313-314, 691

Thriambeutis coryphaea Meyrick, 1912, Exotic Microlepidoptera, vol. 1, p. 61 ( $\%$, Mindoro); 1913, in Aurivillius, Lepidopterorum Catalogus, pars 13, p. 19; 1914, in Wytsman, Genera Insectorum, fasc. 165, p. 23.-Clarke, 1955, Catalogue .. Microlepidoptera . . Meyrick, vol. 1, p. 101.

Distribution: Philippine Is., Mindoro.

Material examined: Mindanao, Bukidnon, Mt. Katanglad, 1480 m, 27-31.X.1959, 1 ㅇ, Malaise trap (L. Quate \& C. Yoshimoto), 1 우, genit. slide $5321(\mathrm{BMH})$.

Differs from the original description in a few minor points. Antenna blackish purple, becoming indigo blue towards apex. Forewing with the posterior third between veins 2-9 rather strongly suffused with indigo black. Hindwing with more than basal $1 / 2$ orange. Otherwise agreeing with the description. Legs (not mentioned there) purple black, outer spurs of posterior tibia dilated, having an oval shape by dense bristly scales.

A second, smaller and paler specimen is from: Mindanao, Davao Prov., east slope of Mt. McKinley, 3300 ft., 24.IX.1946 (CNHM Philippine Exped. 1946-47, H. Hoogstraal), 1 o, genit. slide 5745.

\section{Aeoloscelis Meyrick, 1897}

\section{Aeoloscelis perigrapha, new species}

Figures 307-308, 690

Female, $10 \mathrm{~mm}$. Head broad, rounded, polished, fuscous, orbits and collar yellow. Antenna dark fuscous, flattened posteriorly (labial palpi broken). Thorax dark fuscous purple anteriorly, a slender white median streak, before this thorax yellowish edged with white, a small dark fuscous spot on each side; tegulae dark, tipped with white. Abdomen blackish fuscous, anal tuft mixed with pale 
yellowish, venter pale golden yellow, as is the entire body from below and the femora. Posterior tibia light yellow with a median and a subapical blackish-fuscous band, tarsus orange yellow, suffused with blackish fuscous above.

Forewing lanceolate, costa little curved at base, base of dorsum prominent and rounded. Dark fuscous suffused with black towards base; markings extended, white strongly clouded with light yellow (perhaps entirely light yellow). A small transverse blotch at base of wing, not reaching costa and dorsum, including a quadrate black dot at base of wing above, this transverse blotch connected with an oval large spot, extending above and parallel to dorsum to less than $1 / 4$ of wing, here almost connected with a still larger subtriangular patch on dorsum, reaching to $1 / 2$ of wing and rising $3 / 4$ across wing; somewhat more than 3rd fourth of wing light yellow, almost quadrate, not quite reaching dorsal edge, lower angles slightly rounded; this patch traversed by four tolerably horizontal lines along veins; a small outwards-oblique oval mark beyond $1 / 4$ of costa, Cilia dark fuscous.

Hindwing deep fuscous bronze, cilia dull dark fuscous, darker than in forewing.

Female genitalia: Sterigma simple. Genital segment slightly sclerotized, conical. Ostium bursae flattened-annular, rather wide. Ductus bursae with numerous, short thorns. Bulla seminalis simple. Signum, an oval weak and squamose sclerite with a median straight and narrow "lamina dentata."

Material examined: Luzon, Mt. Makiling (Baker), 1 \%, holotype, genit. slide 5254 (USNM).

\section{Eretmocera Zeller, 1852}

\section{Eretmocera percnophanes Meyrick, 1929}

Figures 312, 317-318, 324, 725

Eretmocera percnophanes Meyrick, 1929, Exotic Microlepidoptera, vol. 3, p. 543.Clarke, 1955, Catalogue. . . Microlepidoptera . . . Meyrick, vol. 1 p. 240 .

Distribution: Philippine Is., Samar.

Male, $12 \mathrm{~mm}$. Head, palpus, and thorax dark blackish purple with a strong bronze gloss, palpus with basal segment and lower half of median pale yellow, breast pale yellow. Antenna black, dilated by scales along basal $4 / 5$, these scales loosely projecting posteriorly; metathorax with two yellowish sublateral spots. Abdomen slightly flattened, purple black, with a strong purple-blue shine in certain lights, tergites 5 and 8 mixed with yellow, tergites $6-7$ yellow mixed with bluish-purple scales, venter pale yellow. Legs purple black 
with a strong bronze gloss, posterior coxa, femur and basal fourth of tibia yellow whitish.

Forewing lanceolate, narrow, pointed. Black, with a moderate anthracite gloss, cilia concolorous. Hindwing fuscous purple, cilia black with a suffused, faint whitish basal band.

Male genitalia: Eighth tergite and sternite modified. Coremata large, at the foot of the 8th segment. Tegumen elongate, rather strong. Vinculum slender, triangular, without saccus. Valva little curved, very slender, lanceolate, base dilated, cucullus rounded, shortbristled. Uncus slightly asymmetrical, furcate. Gnathos huge, irregular, asymmetrical-bicuspid, left top rounded, right short-hooked. Aedeagus pointed, sinuate, very slender and sclerotized.

Female genitalia: Ovipositor moderately long. Apophyses, simple, slender rods. Sterigma represented by a subquadrate plate with a quadrate median incision of upper half occupying one third, and a triangular one over the whole breadth of lower edge. Lower half rather sclerotized, in center forming a narrow rim triangularly projecting forward. Ductus and corpus bursae membranous, bursa simple.

Material examined: Luzon, Manila, April and May, 1924, genit. slides $5432 \sigma^{7}$, 5520우 (R.C. McGregor). Mt. Apo, 70, 9.III.1945 (J.G. Franclemont), $1 \sigma^{\top}$ (CUI). Mt. Makiling (Baker) Occidental Negros, La Carlota Cen., 24 (A.W. Lopez). Many specimens (USNM).

\section{Xestocasis (Meyrick, 1914)}

\section{Key to the Philippine Species of Xestocasis}

1. Forewing with four pale transverse fasciae . . . . . . . . . X. erymnota Forewing with only two such fasciae . . . . . . . . . . X. iostroat

\section{Xestocasis iostrota (Meyrick, 1910)}

Figures 321,695

Limnoecia iostrota Meyrick, 1910, Trans. Roy. Ent. Soc. London, p. 454 (Borneo, India).-Clarke, 1955, Catalogue . . Microlepidoptera . . Meyrick, vol. 1, p. 175.

Xestocasis iostrota.-Meyrick, 1914, Suppl. Ent., no. 3, p. 54 (Formosa).

Distribution: India, Borneo, Tonkin, Formosa, Philippine Is.

Material examined: Negros, Victorias, Saravia, Silar, on sugar cane (Saccharum dulce), VI-IX.1928, genit. slides o 우, no. "A.B. June 17, 1930," 6 specimens (USNM). Mindanao, Davao Prov., east slope of Mt. McKinley, 3000 ft., IX.1946 (CNHM Philippine Exped. 1946-47, H. Hoogstraal), 2 ㅇ. 
Male genitalia: Tegumen moderate, erected-triangular, narrow, with a rounded top. Vinculum small, semicircular. Gnathos paired, arms unequal, right, short and pointed, left, longer and obtuse. Valva paired, upper pair (anellus lobes?) strongly narrowed, geniculate at base, cucullus hairy, elongate, moderate, curved throughout, more so at top. Lower pair of valvae longer, rather narrow, bristly at top; this pair is attached by an unpaired stalk to vinculum. Aedeagus and anellus sclerotized, united at their bases, together forming a single body, attached by a slender geniculate stalk to vinculum; aedeagus porrect, narrowed, top slender and hooked upwards; anellus joined to juxta which is shaped as a long median porrect process of anellus, top curved downwards.

Female genitalia: Sterigma not modified. Ostium bursae, a membranous, suboval cup. Corpus bursae minutely aciculate. Bulla seminalis longitudinally corrugated.

\section{Xestocasis erymnota Meyrick, 1917}

Figure 811

Xestocasis erymnota Meyrick, 1917, Exotic Microlepidoptera, vol. 2, p. 62 ( ๙๐ Baco River, Mindoro).-Clarke, 1955, Catalogue . . . Microlepidoptera . . Meyrick, vol. 1, p. 132.

Distribution: Philippine Is., Mindoro.

Male genitalia: Of the usual complicated type. Tegumen elongate, narrowed. Uncus, a sclerotized short knob. Gnathos paired, asymmetrical, left arm long, sinuate, with a dilated top, right arm, a small stump. Anellus lobes, long sinuate rods, with a dilated, flattened and bristly top. Upper pair of valvae, slender gently sinuate rods, bristly along posterior half. Lower pair of valvae gently curved downward, rather narrow, truncate. Aedeagus long, gradually narrowed, little curved.

Lectotype, male, herewith selected, is the male syntype, "Baco River, Mindoro, M. 10.09," “Meyrick Coll.," slide BM 11349 o' (BM). I owe the dissection of this specimen to the kindness of Mr. P.E.S. Whalley, British Museum (Natural History).

\section{Lamachaera Meyrick, 1915}

\section{Lamachaera cyanacma Meyrick, 1915}

FIgURE 812

Lamachaera cyanacma Meyrick, 1915, Exotic Microlepidoptera, vol. 1, p. 338 ( , Mindanao, Mt. Apo).-Clarke, 1955, Catalogue . . . Microlepidoptera. . Meyrick, vol. 1, p. 107.

Distribution: Phillipine Is., Mindanao. 
Female genitalia: Ovipositor moderate, gelechioid. Ninth segment cylindrical. Sterigma sclerotized, a longitudinal rigid body; lamella postvaginalis with a deep triangular incision of upper edge; ostium bursae also triangular, with lateral thickenings and curved frontal rim. Colliculum indicated by a small tubular sclerite, deeply excised above in front. Bulla seminalis and corpus bursae large, simple.

The unique female holotype specimen is labelled, "Mt. Apo, 6.500 ft., Mindanao, M., 5.10" and has the genit. slide no. BM 11350 ㅇ (BM). Also this species has been kindly dissected for me by $\mathrm{Mr}$. P.E.S. Whalley, British Museum (Natural History).

\section{Stathmopoda Herrich-Schäffer, 1853}

\section{Key to the Philippine Species of Stathmopoda}

1. Forewing dark fuscous with two white transverse fasciae . . . . S. placida Forewing fuscous with basal $2 / 5$ bright yellow . . . . . . . S. theoris

\section{Stathmopoda placida Meyrick, 1908}

Figures 319-320, 724

Stathmopoda placida Meyrick, 1908, Rec. Indian Mus., vol. 2, p. 396 ( $q$, Burma); 1913, in Aurivillius, Lepidopterorum Catalogus, pars 13, p. 13; 1914, in Wytsman, Genera Insectorum, fasc. 165, p. 12.-Clarke, 1955, Catalogue ... Microlepidoptera . . Meyrick, vol. 1, p. 250.

Distribution: Burma.

Material examined: Luzon, Manila, January 1928 (R.C. McGregor), $1 \sigma^{\top}$, genit. slide 5135 .

A badly damaged specimen, but apparently belonging to this species, which must be more widely distributed over the region than we know at present.

Tegumen narrow. Uncus pointed, rather slender. Vinculum semioval. Gnathos formed as a large semifunnel supporting anus. Valva elongate semioval, simple, sacculus not modified, top rounded; cucullus elongate-semioval, bristly. Aedeagus huge, cornuti apparently fine sclerotizations of the wall of the vesica. Anellus lobes (in figure attached to aedeagus), small.

The genitalia decidedly are of Oecophorid type.

\section{Stathmopoda theoris (Meyrick, 1906)}

Figure 323

Aeoloscelis theoris Meyrick, 1906, Journ. Bombay Nat. Hist. Soc., vol. 17, p. 410 ( $\sigma^{x}$, Ceylon).-Clarke, 1955, Catalogue . . . Microlepidoptera . . Meyrick, vol. 1 , p. 308 .

Stathmopoda theoris.-Meyrick, 1906, Journ. Bombay Nat. Hist. Soc., vol. 17, p. 983 ; 1911, Trans. Linn. Soc. London, ser. 2, vol. 14, p. 286.-1913, in 
Aurivillius, Lepidopterorum Catalogus, pars 13, p. 13; 1914, in Wytsman, Genera Insectorum, fasc. 165 , p. 12 ; 1914, Entom. Mitt., Suppl. 3, p. 56 (Formosa).-Maxwell-Lefroy 1909, Indian Insect Life, p. 537.-Imms and Chatterjee, 1915, Indian Forest. Mem., vol. 3, pt. 1, pl. 32, pl. 7, fig. 23; 1917, Rep. Proc. 2nd Ent. Meeting Pusa, p. 96.

Distribution: Throughout India and Ceylon; Formosa.

Material examined: Luzon, Agoo, La Union, 1.V.1945 (J.G. Franclemont), 1 , genit. slide 5133 (CUI).

The specimen has somewhat faded markings; the yellow of the background is also less vivid than in the examples from India at my disposal (genit. slide 5134우, Pusa). The collar is pale ochreous instead of yellow. Still, the Indian specimens are rather variable as to the markings. Therefore, I am satisfied that the present specimen does not represent a distinct subspecies. The female genitalia are identical with those of the female from Pusa.

\section{Trichothyrsa Meyrick, 1912}

\section{Trichothyrsa bicolorella (Sauber, 1902)}

Figures 821, 835-836

Eretmocera bicolorella Sauber, 1902, in Semper, Schmetterlinge Philippinischen Inseln, vol. 2, p. 698 ( $\sigma^{\top} \uparrow$, Luzon).

Trichothyrsa bicolorella.-Meyrick, 1913, in Aurivillius, Lepidopterorum Catalogus, pars 13, p. 19; 1914, in Wytsman, Genera Insectorum, fasc. 165, p. 24.

Distribution: Philippine Is., Luzon.

Lectotype, $\sigma^{x}$, herewith selected, Luzon, genit. slide 5871 (SMF).

Male genitalia: Uncus bifid, strongly sclerotized, hairy. Gnathos robust, closely appressed to uncus, sclerotized on upper surface, top ending in a down-curved thorn. Valva with sacculus half reduced to a narrow cuspidate blade. Cucullus part of valva long, slender, clavate and hairy at base and top. Aedeagus slender, sclerotized, sinuate.

\section{Aegeriidae}

The systematics of this most fascinating group are still in a state of considerable confusion. A worldwide revision of the family, based also on the genital characters, is badly needed. The study of the Aegeriidae is greatly hampered by the scarcity of tropical material available and by its usually poor condition. These insects are difficult to collect, the larvae being borers of living lignous plants while the adults usually do not come to light traps. They fly in daytime and are so vigorous that they damage themselves easily after capture. 
The large fat body, as in most wood feeders, makes the set specimens quickly greasy and hard to study.

Also the present material has other drawbacks. Several species are represented by a single worn specimen. Therefore, their generic attribution is somewhat arbitrary. For the same reason, I abstained from describing new genera.

\section{Key to the Philippine Genera of Aegeriidae}

1. Forewing with veins 7 and 8 coincident . . . . . . . . . . . Adixoa Forewing with veins 7 and 8 stalked . . . . . . . . . . . . . . . 2

2. Hindwing with veins 3 and 4 separate . . . . . . . . . . . . . . . . 3 Hindwing with veins 3 and 4 connate or stalked . . . . . . . . . . . 5

3. Hindwing with vein 3 closer to 2 than to 4 . . . . . . . . . . . Melittia Hindwing with vein 3 closer to 4 than to 2 . . . . . . . . . . . . . . 4

4. Abdomen with lateral tufts of hairs toward extremity; forewing for the greater part colored . . . . . . . . . . . . . . . Sura Abdomen without lateral tufts, but with a large, spreading anal tuft.

Paranthrene

5. Hindwing with veins 3 and 4 connate; hindtarsi with basal segments longhaired . . . . . . . . . . . . . . . . . . Trilochana Hindwing with veins 3 and 4 stalked . . . . . . . . . . . . . . . . 6

6. Basal segments of hindtarsus tufted with long hairs . . . . . Lepidopoda Basal segments of hindtarsi not tufted . . . . . . . . . . . . . . . . 7

7. Abdomen attenuated at base to a more or less slender pedicel.

Abdomen not thus attenuated ............... . . . 8

8. Forewing with vein 2 absent ............. . Bembecia Forewing with all veins present . . . . . . . . . . . . . . . . . 9

9. Forewing with veins 4 and 5 curved downward . . . . . Glossosphecia Forewing with veins 4 and 5 not curved downward . . . . Synanthedon

\section{Sphecosesia Hampson, 1910}

Sphecosesia Hampson, 1910, Journ. Bombay Nat. Hist. Soc., vol. 20, p. 93; 1919, Novit. Zool., vol. 26, p. 77.-Fletcher, 1929, Mem. Dept. Agric. India, Ent. ser., vol. 11, p. 207.

Type species: Sphecosesia pedunculata Hampson, 1910 (India).

\section{Key to the Philippine Species of Sphecosesia}

1. Abdomen attenuated to a slender, long pedicel . . . . . . . . S. aterea Abdomen distinctly attenuated, but less strongly.

S. melanostoma, new species

\section{Sphecosesia melanostoma, new species}

Figures 340-341, 696-697

Male, $28 \mathrm{~mm}$. Head dark fuscous with an anthracite gloss, face glossy pale grey, white at the sides, orbits light yellow. Antenna purple, moderately dilated and flattened (top half missing). Palpus 237-168-67-15 
rather long, subascending; light purple fuscous, median and apical segments yellow below (in front), apical segment above paler than median. Thorax fuscous purple, marked with light yellow; a lateral spot on patagium; tegula with a large basal spot, a slender mark along beginning of interior edge and a large spot at apex; mesothorax irregularly edged with yellow; metathorax with a bright yellow quadrate spot; side tufts fuscous yellow; pectus strongly mixed with yellow. Legs purplish marked with yellow, tarsi orange. Anterior coxa edged and tipped with yellow, other coxae only so tipped; median femur with a subapical spot of yellow irroration, tibia with an incomplete postmedian band and an apical fascia, yellow (tarsus missing, posterior legs missing). Abdomen fuscous purple, with a strong violet gloss; tergites 3 and 4 with irregular narrow yellow anterior bands; 7 and 8 with very narrow whitish bands; sternite $2+3$ pale yellow, sternites 3 and 4 with broad bands anteriorly, 4 and 5 with a median spot; valvae yellow.

Forewing narrow, rather pointed. Hyaline, almost colorless, clouded with yellowish throughout, especially in cell posteriorly, below vein 2 and especially beyond upper edge of cell, along veins $7+8$; rather strong prismatic reflections in certain lights; costa as far as upper edge of cell and vein 9, and base of wing brownish purple, becoming black posteriorly, with a strong gloss in certain lights which is metallic green from beyond base to beyond middle of costa, and deep blue violet purple posteriorly; all veins rather thickly streaked with blackish purple, only thin veins are 2 and 3 toward their bases and lower edge of cell anteriorly; dorsum thinly irrorated with purplish brown; discoidal thick, blackish purple, narrowed on lower angle of cell, gently angulate in middle and emitting an attenuated narrow streak along more than posterior third of cell; a moderate blackishpurple line along posterior margin of wing. Cilia dull, pale tawny fuscous.

Hindwing hyaline, faintly tinged yellowish; veins and a marginal line very narrowly black; discoidal rather oblique, slightly concave, colorless. Cilia dull, pale tawny fuscous.

Male genitalia: Tegumen compressed laterally, top semicylindrical, truncate, edge rounded in middle, upper angles with moderate socii bearing very long bristles. Tuba analis large. Saccus moderate. Valva pointed-semioval, costa rounded, sacculus edge only little curved; posterior half covered with simple bristles. Aedeagus tubular, upper third finely aciculate, inverted vesica showing as an internal tube. Cornutus, a single apical thorn.

Material examined: Luzon, Mt. Banahao, V.1914 (B.P. Clark), $1 \sigma^{7}$, holotype, genit. slide 5297 (USNM). 


\section{Sphecosesia aterea Hampson, 1916}

Figure 698

Sphecosesia aterea Hampson, 1916, Novit. Zool., vol. 26, p. 77 ( $\left.\sigma^{7}\right)$.

Distribution: Philippine Is., Mindanao.

The unique type specimen, a male, $22 \mathrm{~mm}$, is from Mindanao, Davao Prov. (Baker) (BM).

\section{Synanthedon Hübner, 1820}

Synanthedon Hübner, 1820, Verzeichniss bekannter Schmettlinge, p. 129.

Type species: Sphynx vespiformis Linné, 1761 (Europe)

The genus is used in the modern concept as revised by Engelhardt (1946, p. 81) and by Popescu-Gorj, Niculescu and Alexinschi (1958, vol. 11, fasc. 1, p. 67).

\section{Key to the Philippine Species of Synanthedon}

1. Forewing entirely suffused with dark color . . . S. chrysostetha, new species Forewing for the greater part hyaline . . . . . . . . . . . . 2

2. Forewing with dark terminal area narrow, fasciate. S. cirrhozona, new species Forewing with dark terminal area extending halfway towards cell.

S. sphenodes, new species

\section{Synanthedon chrysostetha, new species}

Figures 332, 701

Male, $12 \mathrm{~mm}$. Head shining purple blue, with prismatic reflections. Antenna fuscous, on upper side becoming shining blue along posterior half, lower side dull black. Palpus black; moderate, terminal and median segments roughish below; terminal segment over $1 / 2$, rather smooth, pointed. Thorax (rubbed) light purple blue, shining; pectus brilliant golden yellow. Abdomen long and slender; purple blue above, purple and golden below.

Forewing very narrow, dilated, broadest at $5 / 6$, apex rounded, termen rounded, very oblique. Whitish, very densely suffused with purple black, bright purple in certain lights; broadly suffused along margins of wing. Veins beyond cell streaked with purple black; an inwards-oblique rather broad transverse fascia along closing vein; trace of a yellow mark at $1 / 3$ of wing. Cilia purple, with a golden gloss.

Hindwing narrow, semioval-lanceolate, tip rather rounded. Hyaline, except purple-black edge, fuscous golden in certain lights, a broad terminal band along posterior third of costa, almost reaching to lower angle of cell, and dorsum (which is rolled up). Cilia concolorous. 
Male genitalia: Tegumen long and slender, with short prominences below middle. Gnathos ill defined. Tuba analis very long and slender, projecting beyond uncus. Uncus long and slender, separated in two halves. Vinculum small, globular. Saccus moderate, spatulate. Valva long and rather slender, cucullus $2 / 3$, elongate-ovate, covered with rather long, simple, fine bristles; no modified spines. Aedeagus long and slender. Anellus, a long slender tube, gently dilated at base. No anellus lobes.

Material examined: Biliran Is., near Leyte, Biliran, 21.X.1915 (B.P. Clark), $1 \sigma^{7}$, holotype, genit. slide 5115 (USNM). The only specimen of this somewhat obscure, tiny species is rather rubbed.

\section{Synanthedon cirrhozona, new species}

Figures $346,699-700$

Male, $22 \mathrm{~mm}$. Head shining anthracite color (vertex denuded, possibly mixed with pale yellow); orbits yellow; face whitish, mesially pale grey, a dark grey spot on forehead. Antenna blackish above, tawny below, ciliations $1 / 3$, laterally a narrow whitish serrate band, extended into a light yellow ring beyond middle of flagellum which is broad externally, narrowed internally but does not reach apex. Palpus rather long, ascending; pale yellow, median segment with a broad dark grey streak above and laterally not reaching base, terminal segment dark grey externally. Thorax purple, markings pale yellow: a spot on shoulder and narrow edges to tegula; pecten pale yellow. Legs purple, marked with light yellow. Anterior coxa, except top, tibia and tarsus yellow, tarsus mixed with purple above; median tibia and spurs yellow, except a longitudinal spot towards apex above; posterior tibia with two small yellow bands above, underside and apical tuft with spurs bright orange; tarsus elongate, orange ringed.

Forewing pale yellow hyaline; costa as far as cell and vein 9 black, so is streak along discoidal vein, which is gently narrowed below and slightly inwards-concave; a minute, yellowish-fuscous line along lower edge of cell from beyond base, continued along and between the approximated veins 2 and 3 , and a similar but broader streak along dorsum, both converging beyond cell, to tornus, thence forming a rather narrow oval spot along termen, continued as a narrow marginal band along apex and posterior part of costa to join black costal streak. Cilia pale yellowish olive.

Hindwing pale yellow hyaline, paler than forewing, a narrow marginal olive-fuscous line throughout. Veins narrowly black. Cilia light olive fuscous. 
Male genitalia: Tegumen slender. Uncus recurved, very long, lobes very slender, beset with bifid bristles. Gnathos lobes short. Subscaphium slender and long. Saccus moderate, top truncate. Anellus boat-shaped, sclerotized along edges, top obtusely pointed. Valva oblong-semioval, acutely pointed, costa gradually curved; valva covered with bifid bristles, except basal half of sacculus; these bristles becoming very dense towards base. Process of sacculus rather large, at $1 / 3$, densely spined. Aedeagus long and slender, top denticulate.

Material examined: Luzon, Sorsogon, $1 \sigma^{7}$, genit. slide 5300, holotype (USNM).

\section{Synanthedon sphenodes, new species}

Figures 350, 704-705

Male, $15 \mathrm{~mm}$. Head with face snow white, a dense flat tuft on vertex shining metallic blue green, projecting between antennae over face. Antenna black, yellowish below (flagellum broken). Palpus slender, rather long, obliquely ascending and little curved, terminal segment long, obtusely pointed; pale yellow, laterally suffused with light purplish. Thorax purplish, patagia bright coppery bronze, pleura pale yellow, pecten and coxae mixed with dark grey. Leg's bright shining purple, mixed with yellow; anterior coxa yellow, internal edge dark grey, anterior tibia suffused with yellow except a subapical purple ring; median and posterior coxae dark grey, femora dark purple; median tibia yellow with a purple apical third and purple-suffused knee; posterior tibia with narrow median and apical whorls of yellow bristly scales: spurs yellowish internally. Abdomen purple, dorsum with a strong indigo-blue shine, sternites 1-3 pale yellow, segments 3 and 5 with narrow posterior lines, sternites of other segments with golden-yellow posterior bands; valvae whitish; anal lateral tufts very large, flat, black.

Forewing narrow, costa before apex obliquely rounded. Dark purple. A triangular purple spot on extreme base; costa with a streak as far as cell and vein 9 ; posterior half of terminal area pale ochreous, more or less densely strewn with deep purple, less densely between veins 5-7; a narrow band along dorsum; a line along lower edge of cell; terminal veins blackish purple; a rather broad, slightly inwards-oblique and gently narrowed black-purple band along discoidal vein. Remaining parts of wing colorless hyaline, being the cell, a narrow subbasal area, and five slender cells beyond discoidal vein, viz., below stalk of veins $7+8,6,5$, and 4 , respectively; upper of these cells longer, top slender and rounded, three following cells equal, tops obtuse, lower cell broadest, shorter, and truncate. Under- 
side of wing, upper angle of cell and posterior half of terminal area suffused with yellow except on veins. Cilia purplish.

Hindwing colorless hyaline, with a moderate black marginal band, becoming linear along dorsum, veins black; vein 1c thicker than other; discoidal slightly curved and outwards oblique, yellowish hyaline; marginal band forming small triangles on top of discoidal vein and on ends of veins $1 \mathrm{~b}, 1 \mathrm{c}$, and 2 . Cilia purplish.

Female, $15.5 \mathrm{~mm}$. Similar to the male (antennae and abdomen broken). Metathorax with a bright yellow transverse band. Posterior tibia as in the male but also the basal half above yellow.

Male genitalia: Tegumen long, top hooded. Gnathos developed. Uncus moderate, recurved, beset with furcate bristles. Saccus rather broad, top rounded. Transtilla with triangular lateral parts and a very weak membranous median band. Valva long, narrowly semioval, sacculus edge straight, subconcave, with a wart of spines before middle; cucullus large, fanlike, somewhat irregular.

Material examined: Palawan, $1.6 \mathrm{~km}$ south of Tarumpitano Point, 28.V.1958 (H.E. Milliron), $1 \sigma^{\Upsilon}$, holotype, genit. slide 5307. Mindanao, Zamboanga del Norte, Masawan, trail to Mt. Matundang, 1290 m, 5.VII.1958 (H.E. Milliron), 1 \%, allotype, without abdomen (BMH).

\section{Lepidopoda Hampson, 1900}

\section{Lepidopoda lutescens, new species}

Figures 328, 702-703

Female, $26 \mathrm{~mm}$. Head with face silvery white, vertex black, collar yellow, along eyes suffused with white. Antenna (broken) brownish. Palpus slightly roughish; basal and median segments black, mixed with yellow above and beneath, except tip. Thorax (rubbed) bronze black, patagia edged around with yellow and with a yellow dot on each side of apex, larger lateral yellow patches in a pair on metathorax; pectus whitish, anterior edge with a large black lateral patch, yellow below this; mesopleura rather dark grey below. Legs bronze black; anterior coxa with an oblique pale yellow transverse band below middle, along external edge extending to base of coxa; median coxa grey; posterior femur grey with a yellow spot at base and a yellow band at apex; anterior femur dark bronze with a yellow patch below apical $1 / 3$; median femur dark bronze with a yellow patch below apical fourth, and with a fringe of yellow hairs along lower edge; anterior tibia yellow, black above; median tibia roughish above, with yellow median and apical bands and spurs; posterior tibia with a fanlike flat fringe of scales along inner side, extending over two basal segments of tarsus, black with a yellow streak running along upper edge from base to middle, then obliquely crossing to other side; 
a yellow apical band and a narrow streak above along tarsal segments 1 and 2 ; spurs yellow mixed with black. Abdomen bronze black, with narrow posterior segmental bands; on tergites 1 and 2 these bands obliterate in middle, on venter from sternite 3 to apex dilated and touching each other.

Forewing pale yellow hyaline, clouded in cell with deeper yellow. Costa as far as cell and vein 9 blackish bronze, a narrow marginal line around apex and along termen and a line along vein $1 \mathrm{~b}$ of the same color; veins beyond cell bronze black; a triangular patch at extreme base of wing, with top on dorsum and a slightly attenuated rather broad fascia along discoidal vein, black. Cilia ferruginous.

Hindwing pale yellow hyaline, margin, veins and cilia blackish bronze, a triangular patch at extreme upper angle of cell, remainder of discoidal vein colorless.

Female genitalia: Ovipositor slender, cylindrical. Postapophyses very long. Eighth segment elonga te, strongly sclerotized, anapophyses long. Ostium represented only by a moderate, sclerotized and subquadrangular slender tube, projecting and entirely free. Ductus bursae rather short, slender, corpus bursae simple, elongate-ovoid.

Material examined: Luzon, Mt. Makiling (Baker), 1 \% holotype, genit. slide 5305 (USNM).

Probably nearest to $L$. andrepictura Hampson, from India, but differing in coloring, with much less yellow.

\section{Glossosphecia Hampson, 1919}

Glossosphecia Hampson, 1919, Novit. Zool., vol. 24, p. 83.-Fletcher, 1929, Mem. Dept. Agric. India, Ent. ser., vol. 11, p. 99.

Type species: Sphecia contaminata Butler, 1878 (Japan).

The generic position of the following two species is not quite certain, due to the poor condition of the available specimens.

\section{Key to the Philippine Species of Glossosphecia}

1. Forewing with a bright orange marginal streak along base of costa.

G. pelocroca, new species Forewing without such streak . . . . . . G. micans, new species

\section{Glossosphecia pelocroca, new species}

Figures 344, 706-707

Female, $35 \mathrm{~mm}$. Head with vertex orange yellow, face leaden grey, sides glossy white, orbits and collar yellow. Palpus bright orange yellow (partially missing). Antenna (missing) with base bright orange yellow, slightly mixed with brown. Thorax rather light purple fuscous, with a lilac gloss in certain lights; patagium with a big 
orange-yellow spot on shoulder; tegula with an oblique similar spot on shoulder, inner edge with a narrow pale yellow straight edge, long apical tuft mixed with yellow; meso- and metathorax mixed with long orange hairs. Legs bright yellow orange, posterior tibia light bronze, irrorated with purple. Abdomen purple brown, rather dark, anterior edge of fourth tergite with a broad orange-yellow band, fifth tergite strongly mixed with orange except anteriorly, sixth so mixed only at the sides and with a narrow posterior edge, seventh segment strongly elongate, bright orange yellow at the sides, anal tuft yellow.

Forewing pale yellow hyaline; costa with a dark fuscous-brown streak from base to apex, limited by cell and vein 9 ; an attenuated bright orange-yellow streak from base along costal edge, not reaching middle of wing; all markings below the dark costal streak formed by purplish brown, tinged brown-crimson suffusion; a rather narrow streak along dorsum, gradually dilated towards base; a narrow line along lower edge of cell and vein 2 ; discoidal inwards oblique, with a thick deep purple suffused streak; all veins beyond cell streaked with deep purple, streaks thicker than along vein 2 ; cell filled with purplebrown-crimson suffusion becoming thinner or obliterate towards lower edge anteriorly; the same but thin suffusion below lower angle of cell and irregularly here and there above dorsum; the same suffusion but densely and regularly spread all over wing beyond cell, between veins 2 and 9 , except between basal half of veins $2-5$, where the wing is semitransparent. Cilia concolorous.

Hindwing hyaline pale yellow, a trifle paler than forewing; edge throughout with a narrow band of purple irroration; veins narrowly dark purple, except discoidal which is transparent yellow, not scaled, little oblique, almost vertical.

Female genitalia: Ovipositor long, top scelerotized. Genital segment elongate, somewhat narrowed posteriorly. Lamella antevaginalis with basal rods fused entirely together mesially and producing an elongate sclerite, with rounded top projecting beyond posterior margin of segment. Bursa copulatrix simple.

Material examined: Luzon, Los Baños (Baker), 19, holotype, genit. slide 5301 (USNM).

\section{Glossosphecia micans, new species}

Figures 329-330, 708-709

Female, $30 \mathrm{~mm}$. Head with vertex dark fuscous mixed with pale yellow laterally, face white with faint prismatic reflections, a big dark grey central spot. Antenna thickened and flattened beyond base (top missing) brown purple, paler toward base. Orbits pale yellow. Palpus rather light yellow, upper side with a slender fuscous streak, median segment at base above with a quadrate black spot. Thorax 
brown fuscous with a purple gloss, patagium with a yellow spot laterally, a moderate yellow anterior fascia with irregular posterior edge; tip of tegula mixed with yellow; tip of mesothorax with two yellow spots, metathorax with two bright yellow lateral tufts. Legs yellow (strongly rubbed). Pectus rather suffused with yellow. Abdomen brown fuscous with a purple gloss, edges of tergites 2-6 with narrow, somewhat interrupted yellow bands, anal tuft orange; venter from base to segment 6 , yellow.

Forewing hyaline, light yellow; a broad costal purple streak as far as cell and vein 9 ; narrow streaks along lower edge of cell from beyond base and along dorsum, the former slightly thicker; veins beyond cell narrowly streaked with dark brown purple, discoidal vein suffusedly brown purple, this suffusion not quite reaching lower angle of cell; a narrow attenuated streak from middle of discoidal along posterior third of cell; brown-purple suffusion, paler than veins, forming anteriorly attenuated streaks between veins, except below vein 3 , on lower half of wing not quite reaching cell, on upper, filling out the whole apical area; posterior half of wing membrane throughout with a brilliant purple-lilac gloss, anterior half mixed with some brilliant golden-green scales, especially above lower edge of cell and above dorsum. Cilia (imperfect) concolorous.

Hindwing hyaline, very pale yellow with pale blue reflections; veins and edge of wing narrowly brown purple, discoidal vein yellow, little oblique, strongly outwards concave. Cilia rather pale brownish purple.

Female genitalia: Ovipositor weak. Eighth segment sclerotized, sternite forming a lighter, slender sclerite, flanked by narrow longitudinal folds. Ostium bursae and colliculum entirely membranous, not modified. Cestum, a short dark tube. Corpus bursae large, elongate-ovoid, with a thin wall. Signum, a small prominence, with dark finely granulate structure.

Material examined: Mindanao, Monuangon, V.1915 (B.P. Clark), 1 \%, holotype, genit. slide 5302, (USNM). Zamboanga del Norte, $9.6 \mathrm{~km}$ east of Sindangan, 20.VII.1958 (H.E. Milliron), 1 \&, paratype, genit. slide 5306; paler, with only traces of the bluish luster of the holotype, stalk of veins 3 and 4 in the hindwings slightly longer; the genitalia, however, identical.

\section{Trilochana Moore, 1879}

\section{Trilochana triscoliopsis Rothschild, 1925}

Figure 710

Trilochana triscoliopsis Rothschild, 1925, Ann. Mag. Nat. Hist., ser. 9, vol. 16, p. 208 ( $\sigma^{\top}$, Butuan, Mindanao). 
Distribution: Mindanao.

The type specimen is in the British Museum.

\section{Sura Walker, 1856}

\section{Key to the Philippine Species of Sura}

1. Deep metallic blue; hindwing with hyaline patches forming a continuous marginal band from base to apex. . . . . . S. cyanolampra, new species Metallic blue green; hindwing with hyaline patches only on basal half.

S. tetrapora, new species

\section{Sura tetrapora, new species}

Figures 345, 713-714

Female, $48 \mathrm{~mm}$. Head, and thorax apparently black with a strong blue-metallic shine (rather strongly denuded). Palpus strongly ascending, basal segment brushy, black, median and terminal segments with appressed scales, grey mixed with whitish scales. Antenna tawny-fuscous, apex below tinged light fulvous tawny. Abdomen brilliant metallic blue black, posterior edge of second segment laterally narrowly slate grey, anal tuft apparently purple (rubbed), venter yellow. Legs purple (rubbed).

Forewing very narrow and long; purple black, rather dull, dorsum from beyond base to above lower edge of cell suffused with brilliant blue green, this color beyond cell extended and occupying entire wing breadth, limited by vein 10 and by a rounded purple-black dull patch beyond cell which extends $1 / 4$ distance between cell and termen and does not descend below vein 4 ; a narrow small hyaline streak below cell from beyond base (cilia entirely missing).

Hindwing brilliant violet blue with green gloss in certain lights, base of wing dull purple black, hyaline spots extended, glossy, very pale yellow; first in cell, from base to just before base of vein 2, end elliptical; second between fold and vein $1 \mathrm{c}$, from base to well beyond middle of this vein, end rather pointed; third below fold, from well beyond base, to before middle of fold, end truncate; fourth between $1 \mathrm{~b}$ and margin, from well beyond base to $2 / 3$ of this vein, end pointed.

Female genitalia: Ovipositor small but strong. Postapophyses with a narrow basal third. Eighth segment strongly sclerotized, lower edge forming dark rods, sternite slender, top rounded, flanked by long narrow longitudinal folds. Ostium bursae not modified. Colliculum, a small dark cup. Corpus bursae large, elongate pearshaped, simple.

Material examined: Luzon, Prov. Limay, Bataan, XI.1924 (B.C. Clark), 1 \% , holotype, genit. slide 5304. Characteristic by the hyaline streaks in the forewing, by the four hyaline fields in the hindwing and by the big size. 


\section{Sura cyanolampra, new species}

Figures 331, 711-712

Female, 32-35 mm. Head light fulvous orange, orbits except above, white, face silvery yellowish, on forehead and in center with blackish reflections. Palpus subascending, moderately long, bright orange, basal segment with a fulvous tinge. Antenna (broken in holotype) ochreous or orange, basal portion and scape blackish above. Patagia bright orange, with a big purple-blue median patch. Thorax dark purple, with prismatic reflections. Pectus dark grey with a strong slate gloss. Anterior femur and tibia with a strong fan of scales along outer edge, dark purple with some greenish gloss, tarsus bright orange except above. Median and posterior legs glossy purplish grey, femora inwardly with a white fringe; spurs whitish from above, a bunch of white scales beyond base of spurs, some yellowish hairs mixed with the top of posterior tibia; tarsi slightly mixed with yellowish. Abdomen dark purple, tergum shining deep metallic blue, second segment with a lateral patch of white hairs.

Forewing rather abruptly more dilated beyond tornus. Black, densely suffused with indigo green, turning bright indigo blue beyond cell and changing into indigo purple towards termen; a small bright purple spot on extreme base of wing; a rather short streak of brilliant shining pale green below base of cell from beyond base of wing. Cilia blackish bronze.

Hindwing black strongly suffused with indigo green, especially in center turning bright indigo blue, in extreme apex purple; a hyaline, colorless band just before termen and dorsum, from apex to vein 1a, dilated twice in cell 2,1 1/2 times in cell $1 \mathrm{c}$ and almost filling out cell $1 \mathrm{~b}$; a moderate oval hyaline spot below cell beyond base; ends of veins in hyaline band narrowly black, except veins $1 \mathrm{~b}$ and $1 \mathrm{c}$ which are broader black. Cilia black.

Female genitalia: Genital segment elongate, sclerotized, ventral split rather wide, dilated downward. Lamella postvaginalis not modified, finely aciculate. Lamella antevaginalis forming separated lower (rostral) edge of segment as a pair of strong rods, dilated and converging mesially so as to form an elongate sclerite, split above (caudally). Ostium bursae apparently situated above (caudally) of this structure, membranous. Colliculum membranous, aciculate. Cestum, short, semiannular. Ductus bursae long, simple. Corpus bursae finely aciculate, with numerous regular transverse folds.

Material examined: Luzon, Los Baños (Baker), 1 ㅇ, holotype, genit. slide 5303, 1 \%, paratype. Antimoan (B.P. Clark), 1 \%, paratype (USNM). Manila, 1.IX.1945 (H.E. Milliron), 1 \&, paratype (BMH). 


\section{Paranthrene Hübner, 1820}

\section{Key to the Philippine Species of Paranthrene}

1. Forewing metallic green, opaque. . . . . P. poecilocephala, new species Forewing for the greater part hyaline . . . P. heterodesma, new species

\section{Paranthrene heterodesma, new species}

Figures $327,339,715-717$

Male, $27 \mathrm{~mm}$. Head with vertex anthracite color, face white with a large grey spot on forehead, orbits white, collar above yellow. Antenna pale purple becoming deep metal blue. Palpus rather long, subascending, bright yellow, basal segment marked with black laterally, median laterally black except towards base, terminal segment black. Thorax (rubbed) bluish purple, marked with bright yellow; patagium with a lateral spot; tegula with inner edge (apparently) yellow, apical tufts mixed with yellow; a yellow spot above base of wing; posterior edge of mesothorax yellow; metathorax with large, fluffy white lateral tufts. Legs purple black, marked with bright yellow; anterior coxa edged with yellow, this edge broadly crossing over beyond middle; other coxae tipped with pale yellow; anterior tarsus orange; median tibia with an oblique median band, top and spurs yellow; posterior tibia yellowish in center internally, hairs above mixed in middle of tibia with yellow, apex and spurs yellow; median and posterior tarsi with yellow spots on edges of segments above. Abdomen purple black posteriorly, edges of segments except of the first, narrowly edged with yellow; anal tuft large, flattened and bilobed, black, edged with white laterally; valvae clothed with pale orange hairs.

Forewing narrow, rather pointed. Costa as far as cell and vein 9 forming a purplish-black streak with a trace of olive gloss; lower edge of cell narrowly, dorsum more widely streaked with this color, the two streaks becoming thicker posteriorly and converging beyond cell to tornus; discoidal with an oblique broad dull black band; veins beyond this band narrowly purple black. Wing membrane hyaline pale yellow, with brilliant milky-lilac, iridescent reflections in certain lights, terminal area from termen midway toward cell rather thinly suffused with light brownish purple. Cilia rather light fuscous with a purple gloss.

Hindwing hyaline pale yellow, with the same but less strong reflections, a rather narrow brown-purple marginal band along costa and termen, on dorsum dilated so as to fill out cell 1a; discoidal vein outwards oblique, thicker, purple black. Cilia fuscous purplish.

Female, $36 \mathrm{~mm}$. Head as in male, but face white, pale yellow in center, an irregular dark grey spot on forehead; palpus shaped as in 
male, bright ochreous yellow, median segment towards top laterally and above and terminal segment laterally, mixed with black. Antenna purple black with bluish gloss, apex from below tawny fulvous. Thorax blackish purple, marked with yellow: a large lateral spot on each patagium; tegula with a larger subtriangular spot just above base of wing, a narrow yellow inner edge and terminal tuft mixed with some yellow hairs; posterior edge of mesothorax broadly yellow, of metathorax with a pair of fant submedian spots, side tufts white. Legs purple black with yeliow markings as in male; apical half of upper edge of median femur with a yellow spot; tibia with long projecting bristly scales above, a broad oblique suprabasal transverse band and top bright yellow, spurs and tarsus yellow. Posterior leg, coxa with a yellow spot close to base; femur white fringed below throughout, tibia with an oblique yellow band inside, spurs yellow, outside yellow throughout, apex with tuft and spurs yellow, tarsus yellow irrorated with purple. Abdomen as in male, but posterior edges of segments, except of the first, broadly yellow, anal tuft large, black, mixed laterally with pale yellow and whitish.

Forewing narrow, spatulate, apex obtuse. Costa as far as upper edge of cell and vein 9 blackish purple, slightly mixed with yellow towards base and with a small yellow spot at the extreme base of wing; lower edge of cell with a moderate, dorsum with a broader purple streak, both becoming broader beyond cell and merging together towards tornus. Wing membrane semihyaline light yellow in and below cell, and scattered with opaque orange-yellow scales; in cell membrane with a strong milky-lilac opalescence; median band strongly inwards-oblique, broad, orange, irregularly edged anteriorly with purple, hardly edged posteriorly; area beyond cell on anterior half pale yellow with a strong milky-lilac opalescence on posterior half, strongly suffused with ochreous and violet purple; veins beyond cell streaked with dark purple. Cilia paler, fuscous yellowish.

Hindwing pale yellow hyaline, veins narrowly lined with purple, discoidal thicker, orange; cell 1a purple, mixed with some tawny scales, basal halves of anal veins and of lower edge of cell, ochreous tawny. Cilia purple.

Male genitalia: Coremata very large. Tegumen long, sclerotized, cylindrical, moderately dilated in middle, top truncate, simple; base dilated. Transtilla concave, dark, upper surface sparsely denticulate. Saccus robust, moderately long. Valva semioval, sacculus edge straight. Disc of valva except base of costa beset with stellate spines, sacculus except at base with simple bristles, a small group of dark simple spines beyond base.

Female genitalia: Coremata very large. Genital segment strongly sclerotized, ventral split wide. Lamella antevaginalis forming strong 
rods converging, but not dilated, in middle. Ostium bursae supported by two slender spindle-shaped sclerites, forming a $V$. Colliculum bulbose, inverted pear-shaped, spinulose, with a dark median groove, below bulb a ring of larger spinules. Ductus bursae long and narrow. Corpus bursae simple.

Material examined: Luzon, Mt. Makiling (Baker), $1 \sigma^{\top}$, holotype, genit. slide 5298, 1 \%, allotype, genit. slide 5299 (USNM).

\section{Paranthrene poecilocephala, new species}

Figures 349, 718, 720

Male, 27-29 mm. Head and face rounded prominent, silvery white, a small scale tuft below base of each antenna, center of face with a glossy large and round grey spot; vertex bright orange mixed with black. Antenna thickened but not markedly clavate, fasciculateciliated and pectinate, black. Palpus considerably pointed, median segment dilated at base by roughish scales beneath; yellow, white internally and towards base above, median segment mixed with black laterally from well beyond base, terminal segment mixed with black above; collar orange, white along eyes. Thorax polished purplish black; tegulae large, edged with pinkish orange; two narrow, submedian orange longitudinal streaks, dilated posteriorly; a large yellow patch under the base of wings. Legs black, anterior with base of femur pale yellow, tarsus yellow orange; median leg, tibia with a whitish, internal, subbasal, oblique spot and a white tuft at apex; posterior leg white internally, tibia with a white submedian band externally, spurs white or white-tipped. Abdomen black, with white lateral hairs at base and narrow yellow posterior segmental lines, anal tuft flat, large; valvae whitish.

Forewing metallic indigo green, costa black as far as cell and vein 10 ; a light yellow transverse wedge-shaped spot at base, cell semihyaline, a hyaline narrow and pointed field between basal half of cell and vein $1 \mathrm{~b}$; a dull black marginal narrow line around apex and along termen. Cilia black bronze.

Hindwing colorless hyaline, with a moderate black margin, an ochreous grey, rather broad, complete band along discoidal vein, lower edge of cell and basal third of vein 2 whitish, all other veins black; vein 5 strong, submedian. Cilia black with a bronze gloss.

Male genitalia: Rather similar to those of $P$. heterodesma. Tegumen stronger rounded and bulbous in middle above, subscaphium narrower. Saccus more slender. Transtilla developed, with strong, hooklike labides. Anellus tube membranous, moderate. Valva elongate-semioval, top more rounded, sacculus bristled as in heterodesma, but disc devoid of bristles, while costa bears simple fine bristles arranged in a marginal broad band from apex to middle, and has 
a patch of stellate bristles along its basal half. Aedeagus slender, shorter than in the last mentioned species.

Material examined: Luzon, Los Baños (Baker), $1 \sigma^{x}$, holotype, genit. slide $5774 \mathrm{~A} ; 1 \sigma^{7}$, paratype (USNM). Nearest to $P$. regale Butler, from India.

\section{Melittia Hübner, 1820}

\section{Key to the Philippine Species of Melittia}

1. Forewing membrane yellowish; posterior tibia black with broad yellow bands. M. gigantea

Forewing membrane almost colorless; posterior tibia not distinctly yellowbanded . . . . . . . . . . . . . . 2

2. Posterior tibia above black, mixed with white; abdomen, posterior half without bands. . . . . . . . . . . . . . . . M. eurytion

Posterior tibia above yellow mixed with white; abdomen throughout narrowly banded with whitish . . . . . . . . . . . . . . M. siamica

\section{Melittia gigantea Moore, 1879}

Figures 719, 721

Melittia gigantea Moore, 1879, Proc. Zool. Soc. London, p. 413.-Waterhouse, 1882-90, Aid Identification Insects, vol. 2, p. 16, pl. 131, fig. 4.-Cotes and Swinhoe, 1887, Cat. Moths India, p. 42, no. 198.-Hampson, 1892, [Moths British India], vol. 1, p. 204.

Melittia humerosa Swinhoe, 1892, in Cat. Lep. Het. Mus. Oxon., vol. 1. p. 38.

Distribution: Japan, Korea, Central China, Punjab.

Material examined: Luzon, Manila, 23.VIII.1945 (H.E. Milliron), 1 을 (BMH). Tip of forewing rather suffused with light fuscous and ochreous. Posterior leg black, banded with yellow.

\section{Melittia siamica Walker, 1864}

Figures 722-723

Melittia siamica Walker, 1864, List Lepidopterous Insects British Mus., pt. 31, p. 18 (Malacea).-Hampson, 1919, Novit. Zool., vol. 26, p. 88.

Melittia sumatrana Le Cerf, 1916, in Oberthür, Êtudes lépidoptèrologie comparée, vol. 12 , pt. 1 , pl. 373 , fig. 3113 .

Distribution: Malaya, Siam, Sumatra.

Material examined: Luzon, Mt. Makiling (Baker), 1 o. The hyaline area beyond cell is larger than in the type and probably indicates a subspecific difference (USNM).

\section{Melittia eurytion (Westwood, 1848)}

Figures 726-727

Trochilium eurytion Westwood, 1848, Cabinet Oriental Ent., p. 62, pl. 30, fig. 5. Melittia eurytion.-Hampson, 1892, [Moths British India], vol. 1, p. 203, fig. 131.-Le Cerf, 1916, in Oberthur, Êtudes lépidoptèrologie comparée, vol. 
12, pt. 1, pl. 373 , figs. $3114-3115$; 1917, op. cit., vol. 14, p. 176, fig. 4.-Hampson, 1919, Novit. Zool., vol. 26, p. 92.

Melittia strigipennis Walker, 1864, List Lepidopterous Insects British Mus., pt. 31 , p. 17.

Distribution: West China, Sikkim, Assam, Bombay, Burma, Java, Gilolo.

Material examined: Luzon, Mt. Makiling (Baker), $2 \sigma^{\pi}$, Mindanao, Surigao (B.P. Clark), 1 б (USNM).

\section{Adixoa Hampson, 1892}

\section{Adixoa tomentosa Schultze, 1908}

Adixoa tomentosa Schultze, 1908, Philippine Journ. Sci., ser. A, vol. 3, p. 28, pl. 1, figs. 2a-d.-Hampson, 1916, Novit. Zool., vol. 26, p. 100.

Distribution: Philippine Is.

\section{Bembecia Hübner, 1819}

\section{Bembecia fortis, new species}

Figures 347-348, 728-729

Male, $13 \mathrm{~mm}$. Head, thorax strongly denuded. Orbits white. Pleurae and anterior legs purplish. Abdomen black, sternite 4 and tip of anal tuft below, white.

Forewing narrow, blackish purple, terminal area turning brownish. An irregular, pale streak (probably partly due to rubbing) from base along lower edge of cell and veins 3 and 4, to margin; an oval patch of opaque wing membrane, devoid of scales, traversed by thick black veins 5 and 6 ; this naked area edged below by vein 4 , above by stalk of $7+8$, and extending from beyond cell to over $2 / 3$ distance toward termen; space beyond this naked spot mixed with whitish scales. Cilia blackish purple.

Hindwing colorless hyaline, narrowly edged throughout with black, veins colorless, rather beyond their bases becoming black. Cilia black.

Male genitalia: Tegumen slender, top with a pair of short hairy knobs. Subscaphium weak. Anellus strong, boat-shaped, with a long, single, ventrocaudal process with a hooked top, and a rostral saccus-like process; anellus lobes quadrate and sclerotized. Sacculus rather long and slender. Valvae soldered at base together and not separable, sclerotized and truncate, with a corona of sparse short teeth; costa straight, with an apical sharp hook. Aedeagus strong, tolerably straight, with a dilated top, formed of a sclerotized, spoonshaped ventral sclerite and a dentate and angulate double dorsal process.

Material examined: Mindanao, Zamboanga del Norte, Masawan, trail to Mt. Malindang, 1290 m, rain forest, 5.VII.1958 (H.E. Milli- 
ron), $1 \sigma^{7}$, holotype, genit. slide $5773(\mathrm{BMH})$. The unique specimen is badly rubbed, but the wings are less damaged and the genitalia are very characteristic.

\section{Yponomeutidae}

\section{Key to the Philippine Genera of Yponomeutidae}

1. Hindwing with a hyaline subbasal patch . . . . . . . Yponomeuta Hindwing without such patch . . . . . . . . . . .

2. Hindwing with veins 6 and 7 stalked, 7 connected with 8 beyond cell.

Anticrates Hindwing with 7 not connected with $8 . . . . . . . . . . . .3$

3. Hindwing with vein 4 absent . . . . . . . . . . . . . . . Prays Hindwing with vein 4 present . . . . . . . . . . . . . . . . 4

4. Forewing with veins 7 and 8 separate . . . . . . . . . . . Atteva Forewing with veins 7 and 8 stalked ...... Protorhiza, new genus

\section{Yponomeuta Latreille, 1802}

Yponomeuta Latreille, 1802, Hist. nat. Crust. Ins., vol. 3, p. 417.-Fletcher, 1929, Mem. Dept. Agric. India, Ent. ser., vol. 11, p. 238.

Yponomeuta Latreille, 1796, Précis caract. gen., p. 146 (not binom.).

Hyponomeuta Sodoffsky, 1837, Bull. Soc. Natur. Moscou, vol. 10, no. 6, p. 94 (emend.).

Hyphantes Hübner, 1806, Tentamen, p. 2 (not descr.).

Erminea Haworth, 1811, Lep. Brit., vol. 3, p. 512.

Nygmia Hübner, 1826, Verzeichniss bekannter Schmettlinge, p. 412 (preocc.).

Teinoptila Sauber, 1902, in Semper, Schmetterlinge Philippinischen Inseln, vol. 2, p. 701, pl. 66, fig. 16.-Fletcher, 1929, Mem. Dept. Agric. India, Ent. ser., vol. 11 , p. 217.

Type species: Yponomeuta evonymella Linnaeus (Europe).

\section{Key to the Philippine Species of Yponomeuta}

1. Forewing black with white spots . . . Y. interruptella, new combination Forewing dark grey with black spots . . . . . . . . . Y. melanaster

\section{Yponomeuta interruptella (Sauber, 1902)}

Figures 374-376, 476, 730

Teinoptila interruptella Sauber, 1902, in Semper, Schmetterlinge Philippinischen Inseln, vol. 2, p. 701, pl. 66, fig. 16 ( $\sigma^{\top}$, , N. Luzon).

Yponomeuta interruptellus.-Meyrick, 1907, Proc. Linn. Soc. New South Wales, vol. 32, p. 77 (New Guinea).

Hyponomeuta interruptellus.-Turner, 1923, Trans. Roy. Soc. South Australia, vol. 47 , p. 169 ( $\sigma^{\top}$ descr., Queensland).

Hyponomeuta interruptella.-Meyrick, 1914, in Aurivillius, Lepidopterorum Catalogus, pars 19, p. 19.

Distribution: Philippine Is., Luzon; New Guinea; Queensland. 
Material examined: Luzon, Atimoan (“Antimouan”), $1 \sigma^{x}$, genit. slide "A.B. Febr. 18, 1927," "Aug. 1925"; "San Miguel," $1 \sigma^{7}$, "March 30, 1916” (B.P. Clark, donor). $2 \sigma^{7}$ (USNM).

The original material described by Sauber was kindly sent to me for study. It consisted of the following specimens: $1 \sigma^{7}$, lectotype, hereby selected, labelled: "882," "Coll. C. Semper," "Teinoptila Interruptella Sauber nov. spec.," "Cotypus," and my lectotype label, genit. slide 5766. Four original syntypes, with the same labels, except the name label, 19, genit. slide $5771 ; 1 \sigma^{7}$ without abdomen, "926" and 19. The species may be redescribed as follows.

Male, $20 \mathrm{~mm}$. Head white, two black spots behind the bases of antennae, connected by a transverse band across vertex. Antenna black, apical third except the top glossy white. Palpus black with a moderate median white ring. Thorax fuscous black, patagium laterally white, tegula white-edged, mesothorax with white lateral streaks, their posterior ends interconnected by a transverse subapical white line. Abdomen black, venter with broad white bands along posterior edges of segments, dilated mesially, valva with a white edge. Legs black, white-ringed, posterior leg with white spurs.

Forewing elongate, ovate-lanceolate, narrow, costa moderately curved at extremities, straight in middle, apex obtusely pointed, termen rounded, little oblique. Purplish black, dull, markings white. A slender angulate mark below base of costa; a faint transverse-oval, slightly outwards-oblique small mark on dorsum beyond base; two elongate marks in fold, anterior large, its upper edge with two semicircular excisions, lower also with two excisions; second mark smaller, semioval, only upper edge with one excision; a submedian transverse spot above tornus. Cilia black.

Hindwing black, costa white, center of wing thinly scaled and semipellucent. Cilia dark grey with a black subbasal band and a pale basal line.

Male genitalia: Eighth abdominal segment strongly modified, forming two lateral valvae (pseudovalvae) enclosing the veritable valvae. Seventh segment with posterior edge also modified, supporting the pseudovalvae and dorsally forming an articulation for them. Tegumen narrow, together with vinculum sclerotized and forming a rostrocaudally curved piece (therefore not possible to flatten in mount), top short bicuspidate. Uncus double, arms slightly curved and rising. Tuba analis slender, rigid, rising between uncus arms. Gnathos well developed, sclerotized, with broad arms and a short bifid finely scobinate hook in which fits the aedeagus. Valva broad, oval-truncate, with sclerotized margins; the valva densely covered externally with cylindrical modified scales (removed) and a transverse subbasal series of very long modified hair-scales, 
expanded and covering the cylindrical scale layer. Anellus, a transverse membrane, with triangular pointed and porrect anellus lobes. Saccus moderate; top, a transverse round disc. Aedeagus extremely long and slender, cornuti several long ridges of fine bristles.

Female genitalia: Ovipositor weak, a single, collar-like, obtusely pointed dorsal lobe, with long and slender postapophyses. Sterigma, a pair of bandlike sclerites moderately dilated towards middle, lamella antevaginalis apparently represented by a small median oval sclerite. Anapophyses slender, shorter than postapophyses. Between sterigma and ovipositor there is an additional division, segment-like and with a pair of extra apophyses-like thin rods. Colliculum, a dark slender cylinder. Ductus bursae extremely long and narrow, spiraled, its lower portion and wall of corpus bursae finely punctulate or denticulate. Signa two, a group of sclerotized parietal folds and a huge flat hook with regularly serrate edge.

\section{Yponomeuta melanaster Meyrick, 1907}

Figures $809-810$

Yponomeuta melanaster Meyrick, 1907, Journ. Bombay Nat. Hist. Soc., vol. 17, p. 746 ( $\sigma^{7}$ \% , Ceylon).-Clarke, 1955, Catalogue . . Microlepidoptera . . . Meyrick, vol. 1, p. 198; 1965, op cit., vol. 5, p. 331, pl. 164, figs. 1-1b (lectotype select.).

Hyponomeuta melanaster.-Meyrick, 1914, in Aurivillius, Lepidopterorum Catalogus, pars 19, p. 17 (delicata syn.).

Hyponomeuta delicata Schultze, 1908, Philippine Journ. Sci., ser. A, vol. 3, p. 36, pl. 1, fig. 14 ( $\sigma^{\top}$, Manila).

Distribution: Ceylon; Philippine Is., Luzon.

Male genitalia: Tegumen moderate, rounded. Socius long, pending, obtuse and simple. Gnathos, a short but strong transverse band. Valva broadly oval, on the outer side with a fan of very long hairpencils. Saccus long and strong, apical half dilated. Aedeagus very long, slender, simple.

\section{Prays Hübner, 1826}

\section{Prays endolemma, new species}

Figures $367,731,844$

Male and female, 7-9 mm. Head and body pale grey, somewhat variably clouded with white and fuscous. Antenna glossy grey, in certain lights appearing dark grey. Palpus straight, drooping, rather long; dark grey, bases of median and terminal segments and tip white.

Forewing lanceolate, gradually narrowed from before middle to apex, apex obtusely pointed. Whitish, variably marbled and strewn with dark leaden grey or purplish grey. More or less discernible and 
constant are the following markings: a spot on base of costa, not extending below fold; an inwards-oblique interrupted streak on dorsum beyond this spot; an elongate-rectangular or inverted-trapezoidal patch on costa, occupying more than 2nd fourth of costal length, not reaching middle of wing; a similar, shorter patch beyond middle of costa, variably connected by a strongly inwards-oblique fasciate mark or marbling or reticulation, with dorsum before middle; irregular and coarse marbling in a transverse subapical band. Cilia light grey, variably clouded with darker grey.

Hindwing and cilia rather dark grey.

Male genitalia: Tegumen trapezoidal, top emarginate (uncus absent). Socii large, rounded bodies, each with a spiraled porrect projection crowned with four curved thorns of diverse size. Vinculum characteristic, divided in a dorsal inverted W-shaped part and a ventral, T-shaped part, the stalk being the slender saccus. Valva bipartite, sacculus half shorter, ending in a sinuate acute process not reaching top of cucullus; cucullus part slender, top rounded and clavate, finely haired. Anellus, an elongate, hairy sclerite supporting aedeagus from below, top emarginate, lateral lobes rounded, finely aciculate. Aedeagus slender, little curved. Cornuti, apparently one long and two short spines with dilated bases.

Female genitalia: Eighth + ninth segment sclerotized and conical. Anapophyses short, curved and flattened. Ostium bursae slender and cup-shaped. Top of this conical segment with two denticulate flattened lobes or folds. Postapophyses slender. Ductus bursae with short tubular upper third and sclerotized wide lower part formed of two broad sclerites (cestum), bearing each a dentate ridge. Corpus bursae simple, weak.

Material examined: Luzon, Los Baños, 6.X.1953, citrus rind borer, $1 \sigma^{\Upsilon}$, holotype, genit. slide 5126, 1 \%, allotype, genit. slide 5129; same locality, paratypes, genit. slides $5127 \mathrm{o}^{7}$, 5128ㅇ, $5130 \sigma^{\top}$, 5131ㅇ. 6 specimens. "On citrus flower" and "Citrus rind borer" (C.B.Macabasco). Lipa City and Lipa, Batangas, 10 and 14.IX.1953, 9-10.V.1955, 10.II.1956. 24 specimens. Same locality, 19.VII.1954 and 4.XI.1954. 56 specimens. Same locality, 14.III.1955-9.II.1956, many specimens.

The differences of the male genitalia from those of $P$. endocarpa Meyrick are as follows (cf. figs. 366 and 367).

Valva with sacculus projection exceeding cucullus; the latter with the top not clavate but with a short and sclerotized ventral process. Saccus longer. Anellus with slightly broader lobes.

The female genitalia differ thus: in P. endocarpa the cestum sclerites do not form a cone, left sclerite larger, dentations are smaller and denser (cf. figs. 843 and 844). 
The species is superficially not separable from Prays endocarpa Meyrick from Java, both these species being variable as to coloring, markings, and even shape of wing, to a large degree. The forewing, however, in the present species usually is more gradually narrowed from before the middle, while in the Javanese examples compared, it is narrowed more abruptly from a point beyond the middle, consequently, appearing slightly broader. The genitalia in the two sexes allow an easy discrimination of these two closely allied species.

The material of Prays endocarpa Meyrick, from Java (Exotic Microlepidoptera, 1919, vol. 2, p. 234, and ibid. 1928, vol. 3, p. 419), used for comparison and illustrated on figures 366 and 843 has been compared with one of the two syntypes, a male, kindly sent to me by Mr. Whalley of the British Museum (Natural History). The strongly defaced specimen ("indifferent," as recorded by Meyrick) is labelled thus: "E. Java, $\oplus$ Citrus, 1912, Dr. Van Hall, 1918-123," and bears also a black-edged label with "Prays endocarpa Meyr. PARATYPE $\sigma^{7}$," both in H. Stringer's hand; genit. slide 4982.

Another syntype proves to be a female. It has been selected recently as lectotype by Dr. J. F. Gates Clarke (1965, vol. 5, p. 375, pl. 186, figs. 1-1c).

\section{Atteva Walker, 1854}

\section{Key to the Philippine Species of Atteva}

1. Hindwing unicolorous, paler toward base . . . . . . . . . . . . . . . 2

Hindwing bicolorous. . . . . . . . . . . . . . . . . . . . . . . . 4

2. Forewing without markings, hindwing fuscous . A. holenopla, new species Forewing with white spots . . . . . . . . . . . . . . . . . 3

3. Forewing spots arranged chiefly transversely . . . . . . . . . A. brucea Forewing spots arranged chiefly longitudinally. . . . . . . A. balanota

4. Forewing basal half orange yellow from costa to dorsum . . . . . . . . 5 Forewing basal half not yellow, sometimes along dorsum only golden yellow . 6

5. Hindwing orange, apex and a marginal band fuscous. . . . . A. apicalis* Hindwing dark fuscous with a large orange basal patch not quite reaching margin .

A. basalis*

6. Forewing golden, without markings . . . . . . . . . A. scolecias Forewing deep bronze (golden along base of dorsum), with white spots.

A. triplex, new species

*Occurrence in the Philippines uncertain.

\section{Atteva apicalis Vollenhoven, 1863}

See note with the next species, Atteva basalis Vollenhoven.

\section{Atteva basalis Vollenhoven, 1863}

Atteva basalis Snellen van Vollenhoven, 1863, Tijdschr. Ent., vol. 6, p. 90, pl. 9, fig. 6 (Moluccas).-Pagenstecher, 1886, Iris, vol. 1, p. 42.-Ribbe, 1886, op. cit., p. 90.-Pagenstecher, 1886, Jahrb. Nassauischen Ver. Naturk., 
vol. 39, p. 181; 1897, Lepidoptera, in Kükenthal's Forschungsreise, p. 467.Semper, 1902, Schmetterlinge Philippinischen Inseln, vol. 2, p. 699.Pagenstecher, 1900, Zoologica, vol. 29, p. 232.-Meyrick, 1914, in Aurivillius, Lepidopterorum Catalogus, pars 19, p. 2 [see note].

Distribution: Moluccas; Philippine Is., Luzon (also Morotai, Celebes, Aru and Shorthland Is., according to Semper).

Note: Meyrick does not record this species from the Philippine Islands neither in Lepidopterorum Catalogus nor in the Genera Insectorum, but records Atteva apicalis Vollenhoven (described from Java) instead. Since these two brightly colored species, figured on a single plate, cannot be confused with one another and Semper explicitly records basalis, I am inclined to accept this record and to ascribe Meyrick's change to his confusion of the rather similar names: basalis and apicalis. I have not seen any Philippine material of either species so far.

\section{Atteva triplex, new species}

Figures 352,732

Female, $33 \mathrm{~mm}$. Head white, face with a black median vertical patch, vertex with a black U-shaped marginal spot. Palpus dark grey bronze, rather long. Antenna grey bronze, from beyond base with broad white bands above, apical fourth white above. Thorax (strongly rubbed) fulvous orange? Abdomen deep golden orange. Metasternum with a pair of lateral white spots. Posterior leg brassy grey, with a silvery gloss, tibia only with inner spurs which are short.

Forewing elongate suboval, dilated, rather narrow, apex obtuse, termen rounded. Deep brassy golden, brownish in certain lights, costal half of wing as far as fold suffused with brassy purple, somewhat less glossy; this suffusion on median third of wing breadth extending little beyond cell, in costal third reaching to apex; about costal third of wing from beyond base to before apex suffused with deep violet purple, with little gloss. Spots white; a transverse large spot before base above dorsum; three large round spots along fold, becoming larger posteriorly and alternating with two very small ones (second of these absent in right wing); three smaller less rounded spots well below posterior half of costa, median of these highest, posterior one well before apex; two small dots transversely between second and third of the preceding spots; five transverse small spots just below costa, first very small, well beyond base, three following equidistant, slender, transverse, last on middle of costa, larger, transversely oval, additional round dot below this. Cilia brassy brown.

Hindwing deep orange golden, costa as far as the course of vein 8 whitish, somewhat less than apical half dull blackish brown, as far 
as the course of vein 7 , reaching to cell above and to middle of wing on termen, but receding in middle; orange color extends as a narrow streak between veins 7 and 8 almost to costa.

Female genitalia: Ovipositor heavily bristled. Ninth segment shaped as a sclerotized collar. Lamella postvaginalis, two large oval sclerites, strongly bristled along upper and inner edges and between these. Lamella antevaginalis, a broadly curved subtrapezoidal band. Colliculum, a moderate sclerotized tube. Ductus bursae finely denticulate; corpus bursae reverted, finely striate. Lamina dentata broad.

Material examined: Calayan Is., 1 ㅇ, holotype, genit. slide 5222 (B.P. Clark); unique (USNM).

\section{Atteva brucea Moore, 1859}

FiguRe 733

Atteva brucea Moore, 1859, in Moore and Horsfield, Cat. Lep. Insects East India Co., vol. 2, p. 300, pl. 7a, fig. 8, pl. 13, figs 11-11a.-Snellen, 1895, Tijdschr. Ent., vol. 38, p. 25.-Pagenstecher, 1897, Lepidoptera, in Kükenthal's Forschungsreise, p. 467.-Semper, 1902, Schmetterlinge Philippinischen Inseln, vol. 2, p. 699.-Meyrick, 1914, in Aurivillius, Lepidopterorum Catalogus, pars 19, p. 2 (fabricella Wallengren syn.).

Amblothridia fabricella Wallengren, 1861 (not Phalaena Tinea fabriciella Svederus, 1787), in Virgin, Fregatten Eugenies Resa, vol. 2, no. 1, pt. 10, p. 385, pl. 7, fig. 5 (China).

Distribution: Java; Borneo; Celebes; Philippine Is., Luzon; China.

\section{Atteva holenopla, new species}

Figures 353, 734

Female, $26 \mathrm{~mm}$. Head and scape of antenna snow white, occiput bronze fuscous. Antenna greyish with a white gloss. Palpus grey fuscous, apical segment suffused with white. Thorax light fuscous with a bright brassy gloss, darker fuscous anteriorly. Abdomen pale fuscous.

Forewing narrow, elongate-suboval, gently dilated, costa moderately curved at base, more so before apex, very gently curved in middle, apex rounded, termen rounded, oblique. Fuscous coppery with a faint milky gloss; costal half except towards apex suffused with fuscous lilac; tornal area tinged more fuscous grey; however, these colors may change into one another in certain lights. Cilia concolorous.

Hindwing and cilia pale fuscous grey with a faint purplish gloss.

Female genitalia: Seventh sternite with a pair of rounded short submedian prominences. Sterigma, a broad transverse band, little sclerotized below, with a deep median split, flanked by moderate rounded and hairy prominences. Ovipositor rounded. 
Material examined: Luzon, Subprov. Benguet, Pauai, Haights Place, 7000 ft., 16.XI.1912 (A.E. Wileman), 1 o, holotype, genit. slide 5563 (BM). Perhaps nearest to A. scolecias Meyrick but not closely related to that species.

\section{Atteva scolecias Meyrick, 1928}

Figures 370-371, 735

Atteva scolecias Meyrick, 1928, Exotic Microlepidoptera, vol. 3, p. 419 ( $\$$, Mt. Makiling).-Clarke, 1955, Catalogue . . Microlepidoptera . . Meyrick vol. 1 , p. 280 ; 1965, op. cit., vol. 5, p. 292, pl. 145, figs. 4-4c (lectotype select.).

Distribution: Philippine Is.

Material examined: Luzon, Mt. Makiling (Baker), 3 ๙ $\sigma^{\top} 11$ ㅇ (USNM).

Male, $32 \mathrm{~mm}$, neallotype, genit. slide 5221. Forewing slightly narrower. Otherwise in all respects similar to the female holotype.

Male genitalia: Tegumen rather broad, narrowed, top truncate. Uncus absent. Socii, two large porrect processes, flattened laterally, moderately bristled throughout, top narrowed, truncate, lower edge with a band of closely set spines. Transtilla W-shaped, median process conical, finely denticulate. Saccus very narrow, straight. Valva rather short, subtruncate, cucullus gradually curved towards top. Sacculus short, with a single basal spike. Aedeagus long. Cornuti, a long narrow stretch of fine aciculae. Eighth sternite not dilated. Seventh segment enlarged, forming two additional valvae, with large coremata at their base.

\section{Atteva balanota Meyrick, 1910}

Figures 372-373, 736

Atteva balanota Meyrick, 1910, Trans. Roy. Ent. Soc. London, p. 471. ( , Manila); 1914, in Aurivillius, Lepidopterorum Catalogus, pars 19, p. 22.Clarke, 1955, Catalogue . . Microlepidoptera . . Meyrick, vol. 1, p. 63; 1965 , op. cit., vol. 5, p. 292, pl. 145, figs. 2-2c (holotype figured).

Distribution: Philippine Is.

Material examined: Luzon, Mt. Makiling (Baker), 2 o", "Atteva balanota Meyr.," "61" (USNM).

Male, $27 \mathrm{~mm}$, neallotype, genit. slide 5220. Very similar to the female, differing in the following points. Scape black, with a large white spot above. Thorax golden tawny. Abdomen glossy bright ochreous orange. Ground color of forewing bright tawny yellow golden. Cilia bright golden. White spots as in female, except that the subcostal longitudinal spot does not touch costa and is spindleshaped, and that there is a second narrow similar streak on end of vein 12 , neither touching costa. 
Male genitalia: Socius with a circular subapical band of closely set spines, extreme top of socius narrowed and projecting; bristles chiefly above and below. Central cone of transtilla narrow. Valva longer than in preceding species, more pointed, ventral side gently rounded. Sacculus with three processes, first basal, hairy, second cuspidate, third bristly. Saccus shorter and thicker. Eighth sternite dilated caudad. Seventh segment somewhat less enlarged, but coremata larger and denser (removed in figure).

\section{Anticrates Meyrick, 1905}

\section{Key to the Philippine Species of Anticrates}

1. Forewing crimson or pale purple, with yellow markings . . . . . . . . . 2 Forewing yellow with crimson network . . . . . . . . . . . . . . . . 3

2. Hindwing pale crimson; forewing with submedian transverse (sometimes narrowly interrupted) fascia . . . . . . . . . . . . A. rutilella

Hindwing pale yellow, touched with pink posteriorly; forewing with a pair of submedian spots, on costa and dorsum, respectively.

A. denticulata, new species

3. Forewing bright yellow; markings deep crimson, approximately a double X-mark, unicolorous . . . . . . . A. rhodometra, new species Forewing pale yellow; markings crimson and pink, not unicolorous, forming a more intricate network

4. Forewing with costal $2 / 3$ uninterrupted crimson . . A. digitosa, new species
Forewing with costal $1 / 4$ uninterrupted crimson . . . . . A. paratarsa

\section{Anticrates rutilella (Pagenstecher, 1900)}

Figures 360, 737

Enaemia rutilella Pagenstecher, 1900, in Zoologica, vol. 29, no. 12, p. 233 (Bismark Is.).

Anticrates rutilella.-Meyrick, 1913, in Aurivillius, Lepidopterorum Catalogus, pars 13, p. 33 .

Distribution: Bismarck Is.

Male, $15 \mathrm{~mm}$. Head and palpus bright yellow, collar and basal half of palpus crimson. Antenna yellow, crimson above except at base. Thorax with anterior half bright yellow, posterior crimson, edge of the color well defined. Abdomen pinkish fulvous, dorsum in middle suffused with crimson, venter whitish, anal tuft yellow.

Forewing elongate oval, gently curved, apex rounded and indefinite, termen strongly rounded, oblique. Fuscous violet, markings bright yellow edged with crimson, well defined. A broad yellow fascia from costa before middle, to $1 / 4$ of dorsum, rather dilated on costa, constricted in fold (in right wing crossed by a crimson line in fold), edges slightly undulate, posterior rather more inwards-oblique; basal area of ground color edged around with crimson, a triangular spot on end of dorsum reaching with top to lower angle of cell; a transverse 
spot filling out apex; dark mallet-shaped median mark of ground color edged around with crimson and containing a faint crimson dot between bases of veins 6-8. Cilia bright yellow, grey pink opposite ground color.

Hindwing transparent, thinly suffused with pink, more distinctly so along margin, veins brighter, pink.

Male genitalia: Tegumen moderate, conical-truncate. Uncus long, rather slender, top clavate. Vinculum broadly curved, strong, saccus long and slender. Valva moderate, dilated, base strongly concave. Aedeagus very long and strong, longer than tegumen and uncus together, moderately sinuate, edge ventrally with a long point. Coremata, two rounded tumescences with long hair-scales.

Material examined: Luzon, Mt. Makiling (Baker), 1 \%, genit. slide 5223; 1 ㅇ, (abdomen missing) (USNM).

\section{Anticrates denticulata, new species}

Figures 356, 361, 739

Male, $18.5 \mathrm{~mm}$. Head and patagia bright yellow, back of vertex suffused with crimson. Antenna pink. Palpus crimson, terminal segment yellow. Thorax tawny crimson, tegula with anterior $2 / 3$ bright yellow. Abdomen pale pinkish ochreous.

Forewing oblong, considerably dilated, costa gently curved, more so toward apex, apex rounded, termen rounded, oblique. Lilac purple, edges of markings suffused crimson, markings light yellow. An elongate-triangular submedian costal spot, not quite reaching middle of disc, a moderate apical area with edge very oblique and slightly concave; two elongate-depressed triangular spots, occupying dorsum from well beyond base to tornus, above reaching to fold, interconnected, first suffused with orange except anteriorly, second with anterior extremity crimson. Cilia light yellow, along lower half of termen and in tornus lilac purple.

Hindwing pale yellow, a central wedge-shaped part from veins 2 to 7 pale pink with veins deeper pink, a narrow apical area yellow, cilia light yellow, between veins $2-5$ pink.

Male genitalia: Saccus rather short, pointed. Uncus long, not sclerotized, distinctly clavate, top with a slight dorsal keel. Valva oval-truncate, top almost concave.

Material examined: Mindanao, Davao Prov., east slope of Mt. McKinley, 3000 ft., 24.IX.1946 (CNHM Philippine Exped. 1946-47, H. Hoogstraal), $1 \sigma^{7}$, holotype, genit. slide 5746.

Judging from the markings, allied with $A$. tridelta Meyrick, from India, differing by dorsal markings which in that species are more extended, broader interconnected, first mark emitting an oblique 
yellow strigula towards top of costal spot, second mark much larger than in the present species, traversed by two crimson lines. Hindwing in $A$. tridelta is light pink. The greatest difference is the genitalia: in tridelta the uncus is pointed and sclerotized and the valva is oblique and pointed.

The specimen of $A$. tridelta Meyrick compared is from: Khasis, Shillong, 10.IV.1928 (T.B. Fletcher) (BM), genit. slide $57510^{7}$.

\section{Anticrates digitosa, new species}

Figures 357-358, 362-363, 738

Male, $12.5 \mathrm{~mm}$.Head light yellow, a suffused band between bases of antennae and collar with the posterior edge of tuft on vertex crimson. Antenna pinkish, light yellow above, scape light yellow. Palpus rather long and slender, crimson, terminal segment with base and upper edge light yellow. Thorax crimson, apex yellow, patagium and tegula yellow, red edged. Abdomen crimson, tip paler.

Forewing elongate oval, costa slightly curved, apex obtuse, termen rounded and very oblique. Light yellow, with crimson reticulation. A darker streak along costa to beyond middle, thence running just below costa and concave above, to before apex (end of vein 8); an inwards-oblique, equally dark streak from end of preceding along vein 8 , thence along closing vein to lower angle of cell, furcate there and running to $2 / 5$ of dorsum, dilated on dorsum, thence along dorsum to base of wing; the other branch along vein 2 to tornus, less dilated; a second transverse streak almost parallel to preceding, from before middle of costa to $1 / 5$ of dorsum, rather narrow to fold, thick thence with a slender branch from fold to preceding transverse streak above its end; second transverse streak also emitting two almost horizontal lines to base, from $1 / 3$ and $2 / 3$, respectively; intersections of streaks being dilated, spots of ground color appear oval; a crimson line along upper edge of cell, two ill-defined pink-orange horizontal streaks in center of disc, not connected with other; all veins beyond and above cell streaked with pink orange; these streaks rather broad, clavate posteriorly, not reaching wing margin; a pink line from base of vein 4 to end of fold; streaks along veins above cell rather merged into a crimson suffusion. Cilia pink.

Hindwing semipellucent, rather bright pink, denser suffused with pink towards margin, especially towards apex and tornus; veins deeper pink. Cilia pink with a whitish basal line.

Male genitalia: Tegumen erected-suboval. Uncus shorter than tegumen, moderately curved. Vinculum small; saccus slender, moderate. Valva oblong-suboval, dilated, broadest beyond middle. Aedeagus straight, moderate, gently attenuated. Coremata, slender pencils. 
Material examined: Luzon, Mt. Makiling (Baker), $1 \sigma^{x}$, holotype, genit. slide 5224, 1 \%, allotype, genit. slide 5225; $1 \sigma^{7}$, paratype (USNM).

\section{Anticrates rhodometra, new species}

Figures 354, 359, 364, 740-741

Male, 17-18 mm. Head bright yellow, vertex and anterior edge of collar orange crimson, orbits narrowly yellow. Palpus orange crimson externally, yellow internally, terminal segment also yellow above. Thorax crimson tinged orange, collar posteriorly and a spot at apex, yellow. Abdomen crimson, tinged orange.

Forewing elongate oval, rather narrow, costa gently curved throughout, apex rounded, termen gently convex, yellow, markings well defined, unicolorous, crimson tinged with orange. Costal $1 / 3$ of wing crimson from base to about the course of vein 8 , suffused posteriorly, on costa not reaching this vein; this area containing two spots of yellow: first at $1 / 3$, semioval, second twice as large, before $3 / 4$ of costa, obliquely oval (anterior end shifted downward); the crimson area emitting from its lower edge (before $1 / 3$ and hardly before $2 / 3$ of wing length) a parallel pair of crimson streaks, running inwardly to about $1 / 4$ and $1 / 2$ of dorsum, respectively, and another pair, running outwardly to the middle of dorsum and to tornus, respectively; extremities of these streaks slightly extended, so as to separate two oval spots of ground color, one at base, another just below center of wing, and two subtriangular larger dorsal spots, before middle and before tornus respectively; terminal area and apex yellow. Cilia crimson, posterior half suffused yellow.

Hindwing deep crimson, becoming semipellucent on basal half, cilia crimson.

Male genitalia: Of the usual Anticrates type. Differing from those of earlier described digitosa as follows. Valva slightly broader, its top more oblique and less rounded; anellus lobe more pointed. Uncus more sclerotized, more abruptly dilated at base into a bulb. Sacculus shorter, with a narrower but stronger top. Coremata normal. Mensis ventralis $Y$-shaped, stalk long and straight, furcation flat and distinct.

Female genitalia: Sterigma little modified. Ostium bursae shaped as a membranous vesicular cup. Ductus bursae long, upper half with regularly punctulate wall, lower half simple, coiled once. Corpus bursae deeply constricted beyond middle. Signa, two symmetrically curved laminae dentatae.

Material examined: Mindoro, Mt. Dulangan, 4500-5500 ft., X.1895I.1896 (J. Whitehead), 1 ơ , holotype, genit. slide 5566, 1 우, allotype, 
genit. slide $5567 ; 12 \sigma^{7}, 2$ \%, paratypes (BM). An elegant, distinctly marked, uniform species.

\section{Anticrates paratarsa Meyrick, 1913}

Figures 365,742

Anticrates paratarsa Meyrick, 1913, Exotic Microlepidoptera, vol. 1, p. 141 ( Mindoro); 1914, in Aurivillius, Lepidopterorum Catalogus, pars 19, p. 33.Clarke, 1955, Catalogue . . . Microlepidoptera . . Meyrick, vol. 1, p. 235 ; 1965, op cit., vol. 5 , p. 279 , pl. 138, figs, 1-1b (holotype figured).

Distribution: Philippine Is., Mindoro.

The unique specimen, in the British Museum (Natural History), is from Laguna de Naujan, Mindoro, in March. It proves to be a male.

Male, $20 \mathrm{~mm}$. Head yellow, crimson slight suffusion on vertex and around bases of antennae. Palpus light crimson, inwardly, and terminal segment also above, yellow. Thorax yellow, collar anteriorly suffused with pale crimson, tegula light crimson with a yellow basal spot, anterior edge of thorax and a subapical transverse band suffused light crimson.

Male genitalia: When compared with those of $A$. digitosa, new species, the following distinct differences are apparent. Uncus more pointed and shorter. Tegumen more triangular, more constricted above. Valva narrower, top of cucullus, more oblique. Anellus lobe strong, triangular and pointed. Saccus more slender, clavate before end, wide and flattened above. Aedeagus more slender, long and curved. Bases of coremata rather large. Mensis ventralis a small rod, as long as the stalk of sacculus, furcate portion reduced.

Material examined: Mindoro, Mt. Dulangan, 1896 (Whitehead), $3 \sigma^{\Upsilon}$, genit. slide 5568 (Walsingham coll., nos. 16107-9, BM). Very near to A. miltochorda Meyrick from Assam, Khasis, but with slightly different markings, supported by differences of genitalia.

\section{Protorhiza, new genus}

Head smooth, tufts on vertex appressed and spreading. Antenna in female about $5 / 6$, finely serrulate, minutely ciliated, scape rather long, moderately thickened at top, base flattened dorsoventrally; with a small pecten of long hair-scales. Labial palpus long, recurved, median segment with appressed scales, hardly roughened along lower edge, hardly compressed; terminal segment slightly spindle-shaped, pointed, less than $1 / 2$ median. Thorax without a crest. Posterior tibia with long fine hairs above.

Forewing sublanceolate, moderately broad, pointed. Vein 2 from before $6 / 7,3$ from angle, 3-6 remote and equidistant, 7 and 8 long stalked, 7 to costa, 9-10 distant, 11 slightly beyond middle of cell, no accessory cell. 
Hindwing elongate semioval, pointed, under 1, cilia about 1 . Vein 2 strongly curved at base, from $4 / 5,3$ from angle, 4 remote, straight, 5 approximated at base to 4,6 remote, parallel to 7 , accessory cell distinct.

Female genitalia: Eighth segment erected-conical, broadly split on venter; edge mesially and caudally bristled. Ovipositor and postapophyses long, anapophyses moderate. Sterigma, a strongly sclerotized funnel-shaped projecting structure, with a deeply excised upper edge and an oblique rib on each side. Ductus bursae very broad, but moderately long. Corpus bursae ovoid. Signum, two boat keelshaped sclerites.

Type species: Protorhiza cyanosticta, new species (ㅇ).

Superficially suggesting a development of Ethmia stock, but differing considerably by the presence of a distinct antennal pecten, and by the position of veins 2 and 3 in both fore- and hindwing, so that a place in the present family seems more natural.

\section{Protorhiza cyanosticta, new species}

Figures 355, 475, 743

Female, $18 \mathrm{~mm}$. Head whitish ochreous. Antenna dark fuscous, mixed with some pale ochreous below. Palpus dark fuscous, tip of median segment with a pale ochreous ring, terminal segment bluish black, base pale ochreous. Thorax greyish fuscous, paler at edges, anterior edge blackish fuscous, tips of tegulae whitish ochreous, dusky pale ochreous fuscous. Abdomen fuscous.

Forewing broadly lanceolate, pointed, costa strongly curved at base, hardly curved towards apex, apex pointed, termen little curved, long, very oblique. Whitish ochreous, obscurely spotted with grey blue suffusion, scattered with dark fuscous scales, discal markings fuscous brown. Anterior half of wing along costa as far as vein 12, apex, termen, and posterior half of dorsum irregularly irrorated with fuscous brown, some scales of the same color thinly strewn over the wing. Stigmata fuscous brown, first discal moderate, elongate, before middle; plical narrow and fasciate, below this; second discal large, irregular, rounded, on closing vein, connected by a patch of denser irroration with apex. Grey blue suffusion arranged thus: a faint streak along extreme base of costal edge; three irregular rounded spots along posterior fourth of costa, faintly extended anteriorly along veins 11-9 and upper edge of cell; posterior parts of veins 1c-5 also faintly streaked with grey bluish. Cilia pale ochreous mixed with fuscous brown (imperfect).

Hindwing rather light glossy golden fuscous, with a faint purplish gloss in certain lights. Cilia light ochreous tawny.

Female genitalia as described with the genus above. 
Material examined: Luzon, Mt. Makiling (Baker), 1 ९, holotype, genit. slide $5113 ; 2$ ㅇ, paratypes (USNM).

\section{Ethmiidae}

Key to the Philippine Genera of Ethmiidae

1. Antenna in male with fringe of long cilia. Uncus V-shaped. Sterigma inverted V-shaped . . . . . . . . . . . . . . . . . . . . Agrioceros

Antenna in male normally ciliated. Uncus short-furcate. Sterigma diverse, never inverted $V$-shaped . . . . . . . . . . . . . . Ethmia

\section{Agrioceros Meyrick, 1928}

Agrioceros Meyrick, 1928, Exotic Microlepidoptera, vol. 3, p. 417 (type species: A. platycypha Meyrick, 1928).-Fletcher, 1929, Mem. Dept. Agric. India, Ent. ser., vol. 11, p. 243.

This remarkable genus, described after a single male specimen, was placed in the close vicinity of Ethmia. Meyrick even pointed out that the females of the type species, platycypha, which are still unknown, certainly would appear to have normal fore- and hindwings, not dilated as in the male.

The elegant Philippine species, "Psecadia" magnificella Sauber, which has not been adequately described, also belongs to this group and also supports the surmise that the extraordinary characters of the male of Agrioceros are due chiefly to sexual dimorphy.

The fact is that in magnificella the male genitalia are very close to those of platycypha and equally modified. I am therefore, satisfied that these two species are congeneric. However, magnificella, $\sigma^{7}$, has a normal shaft of the antennae, which is somewhat thickened and flattened, but without the peculiar raised fringe of long scales as in platycypha. On the other hand magnificella male has veins 2 and 3 in the $\sigma^{7}$ forewing short-stalked and vein 7 running to costa while there is no pecten on the scape of the antenna, all characters of Agrioceros, lacking in Ethmia; in the latter the veins 2 and 3 are separate, vein 7 runs to termen and in the male a distinct pecten of the antenna is developed.

Therefore, I am attributing E. magnificella (Sauber) to the genus Agrioceros Meyrick and amplifying its description as follows.

Antenna in $\sigma^{7}$ sometimes with a fringe of long raised scales above, sometimes flagellum only flattened, without scales. Labial palpus subobtuse. Maxillary palpus scaled, spindle-shaped; appressed to proboscis. Proboscis strongly scaled, especially at base. Posterior tibia sometimes with dense subappressed long hairs above. Thorax in male sometimes with enlarged and thickened tegulae. 
Forewing sometimes with anal area strongly dilated in male, normal in female. Veins 2 and 3 stalked in male, distant in female. Veins 7 and 8 stalked, 7 to costa in the two sexes.

Hindwing sometimes with anal area strongly dilated in male, normal in female.

Male genitalia (platycypha): Uncus big, bipartite, horns diverging, each with a median thickening followed by a sinuate slender hook. Gnathos apparently represented by a big vertical plate covering the whole tegumen from the ventral side, upper portion of this plate with a deep excision, in and behind which tuba analis is situated; lobes of the plate flanking the excision are truncate above and at the sides; transtilla, forming the base of the gnathos plate, is a simple transverse band. Valva as in Ethmia, with a more or less isolated dorsal sclerite representing the costal part, and the valva proper, with a swollen sacculus bearing a triangular process before base; sacculus is over 1, with a slender apical hook; cucullus represented by a small, isolated sclerite, forming the second (dorsal) hook of the valva. Anellus rather short, heavy and tubular with a narrowed apical part, base open ventrally. Anellus lobes long and slender, their bases shifted to bases of valvae. Aedeagus moderate, rather slender, base strongly curved.

The first and the second abdominal segments each contain a pair of expansible brushes of modified scales.

Female genitalia have a strongly sclerotized, inverted $V$-shaped sterigma as described with $A$. magnificella (Sauber) below.

The genus is closely related to Ethmia.

Key to the Philippine Species of Agrioceros

1. Males . . . . . . . . . . . . . . . . . 2

Females . . . . . . . A. magnificella, new combination

2. Antenna thickened with long hairlike white cilia . . . . A. platycypha Antenna simple. . . . . . . A. magnificella, new combination

\section{Agrioceros platycypha Meyrick, 1928}

Figures 386, 744-745

Agrioceros platycypha Meyrick, 1928, Exotic Microlepidoptera, vol. 4, p. 418 (1 o', "Kabuntug," Philippine Is.).-Clarke, 1955, Catalogue . . . Microlepidoptera . . Meyrick, vol. 1, p. 251; 1965, op. cit., vol. 5, p. 417, pl. 206, figs. 1-1d, holotype figured).

Distribution: Philippine Is., Mindanao.

Material examined: Leyte, Burauen, V.1915 (B.P. Clark, donor), "28," "Agrioceros platycypha Meyr., paratype." " "व genitalia on slide A.B. May 10, 1927" (USNM) (the specimen is not cited in the original description and apparently was not sent to Meyrick.); $1 \sigma^{7}$.

The male genitalia are described with the genus above. 
The type locality is Kabuntug (=Cabuntug=General Luna), on Siangar Is., Mindanao.

A specimen labelled Agrioceros platycypha Meyrick, was kindly sent for comparison by Mr. Whalley, British Museum (Natural History). Its genitalia were exactly similar to those of $A$. magnificella, 우, except for the slightly more elongate signum. The specimen was labelled: "Philippines," "Sta amer. [illegible], VII-6-11, o," 'Wileman Coll., B.M. 1929-261”; genit. slide 4981.

\section{Agrioceros magnificella (Sauber, 1902), new combination}

Figures 387-389, 746-747

Psecadia magnificella Sauber, 1902, in Semper, Schmetterlinge Philippinischen Inseln, vol. 2, p. 700, pl. 66, fig. 15 (Luzon, o $\sigma^{7}$ ).

Ethmia magnificella.-Meyrick, 1914, in Aurivillius, Lepidopterorum Catalogus, pars 19, p. 26.

Distribution: Philippine Is.

Material examined: Luzon, Mt. Makiling (Baker), $1 \sigma^{\text {T}}$, genit. slide "A.B. May 11, 1927," "Ethmia magnificella Saub." "21780"; 1 ㅇ, genit. slide 5249. 5 ㅇ, "58," "Ethmia magnificella Sauber, A.B. 1926, Schm. Phil. Ins. II, p. 700, 1902, pl. 36 (sic) fig. $15 \sigma^{7}$. A.B." (USNM). A part of the original series has been received for study. It contained only females: 1 ㅇ, lectotype, hereby selected, labelled thus: "880," "Coll. C. Semper," "Ethmia Magnificella Sauber, nov. spec.," "Cotypus" - and my lectotype label; genit. slide 5765; and two more females with identical labels, except the name label.

This elegant species seems never to have been recorded after the original description. The present material has been identified by $\mathrm{A}$. Busk and his identification confirmed by Meyrick. The species may be redescribed thus.

Male, $32 \mathrm{~mm}$; female, 21-32 mm. Head white, vertex with two wedge-shaped black spots, lower half of face black. Antenna in male moderately thickened, flattened laterally, not scaled; ochreous, basal part streaked transversely with white above, scape white with a black spot towards apex above. Palpus white, basal half black, except anteriorly. Thorax light ochreous yellow, extreme bases of patagia and tegulae black, o with two lateral, subapical points. Abdomen light ochreous yellow, segments $4-8$ with rows of subdorsal black dots, all segments except last, also with a sublateral row of such dots.

Forewing with veins 2 and 3 short-stalked in male, distant in female; elongate oval, light glossy ochreous yellow, male bright ochreous yellow. Extreme margin of base of costa with a narrow black streak, black dots arranged thus: two in an inwards-oblique pair just before upper half of base, sometimes a small point on base of dorsum; four 
larger dots in an elongate lozenge at about $1 / 4$, median pair slightly outwards-oblique, posterior dot slightly more distant, submedian above middle; four dots forming almost a quadra te before apex, slightly inwards-oblique, lower dot largest, shifted more basad; a point in tornus. Cilia concolorous.

Hindwing in male dull light ochreous yellow, paler than forewing. Cilia concolorous, glossy; in female of the same color, but with a central large patch of brownish suffusion, from beyond base to halfway beyond cell.

Male genitalia: Very close to those of $A$. platycypha. Uncus halves more slender, less sinuate, basal part and median thickening narrower. Halves of the gnathos plate more rounded. Valva with cucullus processes shorter, especially the dorsal process. Base of sacculus with a longer process.

Female genitalia: Seventh segment moderately sclerotized. Eighth segment shaped as an extremely heavy, inverted V, arms internally open, their tops obliquely truncate; anapophyses dilated and united with the dorsal side of the arms of the V. Ostium bursae, a small opening at the base of the V. Postapophyses slender, moderate. Lobus analis very large, floricomous, with a sclerotized edge. Ductus bursae tortuous, extremely long, corpus bursae moderate, ovoid. Signum depressed-triangular, dentate.

\section{Ethmia Hübner, 1822}

Ethmia Hübner, 1822, Verzeichniss bekannter Schmettlinge, p. 163.

Type species: Psecadia pyrausta Pallas, 1771 (Europe).

The following species of Ethmia are aptly characterized by Meyrick (1905, p. 289): “. . . species, belonging to a puzzling group of which the members are extremely similar. . .." Starting in 1910 he described a series of new Ethmia species from the Indo-Australian region, around Walker's classical species, E. hilarella. These species were described after a single or a couple of specimens, using minor differences of markings of the wings. Although the descriptions are lucid and credit should be given to Meyrick's sagacity, longer series of additional material show that the minute differences of markings indicated by him disappear entirely within the range of specific variation, and that the only means of discriminating the species with certainty are, again, the genital characters.

The male genitalia of this genus present excellent specific characters, yet they are built very much to the same plan. Uncus usually is strongly developed and bifid. Gnathos of the complicated subscaphium type, usually a more or less dentate plate supporting tuba analis, sometimes extended downward as a vertical plate and joined 
with the transtilla which then is an equally transverse plate with rising and dilated sides. Vinculum moderate but its parts dilated and strongly sclerotized. Valva separated in three more or less isolated sclerites, the basodorsal elongate one being the costa, the apicodorsal, the cucullus, and the ventral, the sacculus. Anellus lobe usually is shifted laterad, connected with the base of the disc of valva. Aedeagus is short, its base flattened dorsoventrally and curved ventrally, even rostrally; its top truncate, supported by a slender but strong ring, open ventrally. Cornuti, seemingly numerous small spines arranged in a long sheaf, actually are a single, strong, long pectinate rod! This is evident when a cornutus is ejected, in one piece, in the bursa copulatrix.

The females have a sterigma diversely shaped in each species and signum which often is a stellate, dentate plate or a smooth lengthwise corrugated sclerite; sometimes it is shaped as a "lamina dentata."

\section{Key to the Philippine Species of Ethmia}

1. Hindwing orange or yellow with black apex . . . . . . . . . . . . . 2 Hindwing grey . . . . . . . . . . . . . . . . . . . 4

2. Forewing with pretornal dot triple, seldom double; black area of hindwing well defined, inner edge concave or almost straight; a large species, 30-35 $\mathrm{mm}$. . . . . . . . . . . . . . . . . . . . . E. praeclara

Forewing with pretornal dot usually single, rounded, seldom double; black area of hindwing with a subcostal tooth . . . . . . . . . . . . 3

3. Hindwing bright orange; black area with inner edge toothed and reaching cell, below tooth concave, to end of vein 1c . . . . . . . . E. dentata

Hindwing pale orange, black area with inner edge less distinctly toothed, not reaching cell, below tooth less concave, hardly reaching end of vein 2 .

E. colonella

4. Body yellow; forewing yellowish white, one or more black longitudinal strigulae below middle third of costa . . . . . . . . . . . E. palawana

Body whitish ochreous, venter pale ochreous; forewing glossy grey with black spots . . . . . . . . . . . . E. reposita, new species

Body white or grey . . . . . . . . . . . . . . . . 5

5. Forewing grey without costal markings . . . . . E. nobilis, new species Forewing white with four large suffused costal black spots.

E. crocosoma resignata, new subspecies

Ethmia palawana Schultze, 1925

Figure 748

Ethmia palawana Schultze, 1925, Philippine Journ. Sci., vol. 28, p. 574 ( $\sigma^{7}$, Palawan).

Distribution: Philippine Is., Palawan.

The location of the type specimen is not known to me. If it was at Manila it was certainly lost during the war. The only additional material available to me is the female specimen illustrated in figure 
748. It is from Tawi-Tawi, Tarawakan, north of Batu-Batu, 26.X. 1961 (Noona Dan Exped. 1961-62, KM).

The species belongs to the lineatonotella group.

\section{Ethmia praeclara Meyrick, 1910}

Figures 391, 393, 749

Ethmia praeclara Meyrick, 1910, Trans. Roy. Ent. Soc. London, p. 460 ( $\sigma^{\top}$, Lombok; $\uparrow$, Queensland?); 1914, in Aurivillius, Lepidopterorum Catalogus, pars 19, p. 26.-Clarke, 1955, Catalogue ... Microlepidoptera . . . Meyrick, vol. 1, p. 256; 1965, op. cit., vol. 5, p. 429, pl. 212, figs. 4-4a (lectotype select.).

Distribution: Lombok Is.; ?Queensland.

Material examined: Luzon, Los Baños, (Baker), $1 \sigma^{7}$, genit. slide 5227, 1 ㅇ, genit. slide. 5228. $1 \sigma^{7}, 1$ ㅇ. (USNM) Luzon, Benguet, Klondyke, 800 ft., 17.XII.1911 and 16.III-24.X.1912, 2 o slide 5550; 20 \%, genit. slides 4934, 4935, 4936, 5545, 5546, 5550, 5554, 5556,5558 , and one without abdomen (BM). Total $3 \sigma^{\top}, 22$ ㅇ (the females apparently are much more attracted by light than the males). Oriental Negros, Mt. Talinas, 900-1200 m, 9.VII.1958 (H.E. Milliron), $1 \sigma^{7}$, genit. slide 5247 (BMH). In all respects agreeing with the original description and the male genitalia agreeing with those of the lectotype in the British Museum which is selected and will be published by Clarke.

Male genitalia: Uncus with moderate, pointed lobes. Transtilla column very strong, top inverted-trapezoidal, scobinate, upper edge dentate. Anellus lobes moderate, reaching just beyond middle of column of transtilla. Valva with costa sclerotized, elongate and narrow, gently dilated toward its subtubular base. Sacculus broadly triangular, bristly, and prominent. Cucullus bifid, a short median naked process with a triangular base, and a strongly clavate dorsal bristled projection. Anellus proper and aedeagus normal.

Female genitalia: Sterigma inverted W-shaped, with flattened top, along which is a transverse band of fine aciculae. Arms strongly projecting downward, each with a gradually dilated reticulate fold. Ventral edge dilated and sclerotized. Ostium spheroidal, with a subapical sclerotized ringlike ridge and a suprabasal band of strong dentations. Signum large, a smooth, concave plate.

\section{Ethmia colonella Walsingham, 1907}

Figures $390,395,750$

Ethmia colonella Walsingham, 1907, in Sharp, Fauna Hawaiiensis, vol. 1, no. 5, p. 507, pl. 15, fig. 6 (워, Hawaii).-Meyrick, 1910, Trans. Roy. Ent. Soc. London, p. 462 ( $\sigma^{7}$, Kei Is.) ; 1914, in Aurivillius, Lepidopterorum Catalogus, pars 19, p. 26.-Clarke, 1965, Catalogue . . . Microlepidoptera . . Mey- 
rick, vol. 5, p. 422, pl. 209, figs. 3-3a (E. meteoris Meyrick syn., lectotypes select.).

Azinis hilarella Butler, 1883 (not Walker, 1864), Ent. Monthly Mag., vol. 19, p. 180 (Hawaii, Formosa).-Walsingham, 1907, in Sharp, Fauna Hawaiiensis, vol. 1, pt. 5, p. 507 (Hawaiian species described as colonella).

? Azinis hilarella Semper, 1902 (not Walker, 1864), in Schmetterlinge Philippinischen Inseln, vol. 2, p. 700, pl. 5, figs. 12-13.

? Psecadia bicolorella Pagenstecher 1900 (not Guenée, 1879), in Zoologica, vol. 29 , no. 12 , p. 235.

Ethmia meteoris Meyrick, 1911, Trans. Linn. Soc. London, ser. 2, vol. 14, p. 289 ( $0^{7} \uparrow$, Seychelles Is.).

Whether Azinis hilarella Semper and Psecadia bicolorella Pagenstecher pertain to the present species or to Ethmia praeclara Meyrick, it is not possible to make sure without the study of the original material of Semper and Pagenstecher which is not available to me. It is equally possible that both these authors had a mixture of praeclara and colonella before them.

Distribution: Hawaiian Is.; ?Kei Is.

Material examined: Luzon, Benguet Subprov., Klondyke, $800 \mathrm{ft}$., 17.III.-16.V.1912, 1 ○', genit. slide 5552, 15 \%, slides 4933, 4937, 5551, 5553, 5559, 5560 (BM). Mindanao, Kolambugan, "June 25/15," 1 o, genit. slide 5229 (USNM). Dr. Clarke noted the synonymy of E. meteoris. Total $10^{\top}, 16$ ㅇ.

Male genitalia: Uncus bipartite, halves pressed together, tips hooked. Gnathos, a simple transverse plate, upon which is a broad membranous rising body, with a strong slender sclerite mesially, ending in a hook with curved thorns. Vinculum very narrow, angulate in middle. Anellus with a moderate conical rostral and a short, truncate caudal process. Anellus lobe long and slender. Valva semioval, costal portion simple, cucullus bristly, with a small and a large ventral part; bristles nondeciduous. Aedeagus normal.

Female genitalia: Genital sternite trapezoidal, in center an invertedtrapezoidal strongly punctulate field, flanked by rather dense patches of long bristles. Sterigma proper, being the lower (rostral) edge of sternite, strongly sclerotized, forming a narrow rod, W-shaped in middle, laterally forming two oval strongly denticulate tumescences. Colliculum distinctly weaker than in praeclara, less sclerotized, dentate bands narrow and interrupted. Signum smaller, subtriangular.

\section{Ethmia pullata Meyrick, 1910}

Figure 394

Ethmia pullata Meyrick, 1910, Trans. Roy. Ent. Soc. London, p. 460; 1914, in Aurivillius, Lepidopterorum Catalogus, pars 19, p. 26.-Clarke, 1955, Catalogue ... Microlepidoptera . . Meyrick, vol. 1, p. 264.

Distribution: Solomon Is. 
Using this opportunity the lectotype of Ethmia pullata Meyrick, 1910 , is selected herewith. This is a o syntype, in good condition, labelled thus: "Guadalcanar, Solomon Is., (A.S.M), 05." in Meyrick's hand, and "Ethmia pullata Meyr. o syntype, det. J.D. Bradley 1964, box N 11." Genitalia slide 5564 (BM).

\section{Ethmia dentata Diakonoff and Sattler, 1966}

Figures $396,406,751$

Ethmia dentata Diakonoff and Sattler, 1966, Ent. Berichten, vol. 26, p. 189, figs. 1-3.

Distribution: Formosa, Japan, Philippine Is.

Material examined: Mindanao, Zamboanga del Sur, Zamboanga, 30.VI.1958 (H.E. Milliron), 1 \%, genit. slide 5324, paratype (BMH). Luzon, Benguet Subprov., Klondyke, 800 ft., 15.III. and 6.IV.1912 (A.E. Wileman), 2 o, genit. slide 5549, allotype and paratype (Rothschild bequest, BM). Similar to Ethmia argopa Meyrick from Malaya, but with all dots smaller, hindwing orange instead of light yellow, with apical area black and reaching cell (in E. argopa paler, not reaching cell). The $\sigma^{T}$ and $q$ genitalia show great differences from those of both Ethmia praeclara and E. argopa (figs. 392, 393).

Also recorded from Formosa: Takow, and Japan: Kyushu, Amami Islands, and Toshima. The male holotype is from Takow, Formosa (BM).

\section{Ethmia crocosoma resignata, new subspecies}

Figures 398,753

Female, $28 \mathrm{~mm}$. Head grey, sides of vertex white, face light grey. Palpus black, terminal segment mixed with grey. Antenna black. Thorax grey, patagia white, anteriorly black, tegula white with a large black basal spot; two erected black spots anteriorly, one large subapical black patch, extreme apex grey. Abdomen pale ochreous, anal tuft yellow.

Forewing elongate, moderately broad, apex pointed, termen hardly convex, moderately oblique. White, markings black. A streak along anterior $3 / 5$ of costa formed by three semioval confluent spots, each following more elongate than preceding; a round spot on extreme base of dorsum, another similar spot beyond and rather above first, connected with first costal patch; a conspicuous, elongate-rectangular spot on about $3 / 4$ of costa, as far from apex as from end of costal streak; two spots in disc, in upper half of cell, posterior largest, against closing vein; three more spots in disc, below cell, first beyond $1 / 5$, each following slightly more distant, and a trifle larger, another spot opposite and close to termen, between veins $5-7$; posterior part of costa, apex and termen with a series of some eight roundish dots between veins, largest of these in apex, second large below this, other 
smaller, ultimate marks slender, fasciate. Cilia (imperfect) white mixed with black.

Hindwing whitish, becoming suffused with grey from beyond base to apex, this suffusion growing darker posteriorly. Cilia concolorous, from base of dorsum toward apex gradually turning from white to rather dark grey.

Female genitalia: Lobi anales moderate, curved lengthwise, together forming a hollow cylinder. Eighth sternite moderately sclerotized, sides emarginate. Edge of 7 th sternite strongly sclerotized, narrow, attenuated mesiad. Sterigma proper (or rather, ostium), elevated, rhomboidal, collar-like, top pointed. Ductus bursae strongly coiled. Bursa copulatrix without signum.

Material examined: Oriental Negros, Dumaguete, $390 \mathrm{~m}, 24$.VII. 1958 (H.E. Milliron), 1 \%, holotype, genit. slide 5248, "near jungle ravine" (BMH). Mindanao, Davao Prov., east slope of Mt. McKinley, $3000 \mathrm{ft}$., forest, 21 and 28.VIII.1946 (CNHM Philippine Exped. 1946-47, H. Hoogstraal), 2 ㅇ, paratypes, genit. slide 5736. The differences with the nominate form are the simple, elongate median spot of the upper discal series, which in E. c. crocosoma is longer, oblique and hooked at the end; a simple, instead of a double spot above $1 / 4$ of dorsum; larger subapical costal spot, which in E. c. crocosoma (fig. 752) is slightly subcostal; this spot is confluent with the ninth marginal dot in E. c. resignata, separate from it in the nominate form.

The female genitalia are very similar to those of the nominate form, except for the surprising absence of a signum in resignata which is well developed in crocosoma.

The specimen of E. c. crocosoma Meyrick, used for comparison is from India, Darjeeling, (F. Möller), with the name label, "Ceratophysetes crocosoma (Meyr.) o, det. K. Sattler." Dr. Sattler told me that he has now abandoned the last mentioned generic name in favor of Ethmia.

\section{Ethmia reposita, new species}

Figures 407-408, 755

Female, $25 \mathrm{~mm}$. Head black, sides above whitish. Antenna whitish grey. Palpus glossy grey, upper edge black throughout. Thorax black with anthracite gloss, collar whitish in certain lights, tegula whitish with a black tip, metathorax white. Abdomen whitish ochreous, very pale, venter pale ochreous.

Forewing suboval, moderately broad, costa gently curved at base and in middle, more curved toward apex, apex tolerably pointed, termen gently sinuate, oblique. Glossy grey, with a faintest purplish 
tinge in certain lights. Spots dull black, very faintly encircled with paler. A suffused spot beyond base of costa, connected with a narrow short marginal strigula; a round spot on fold well beyond base; two larger oval spots representing discal stigmata, first median; plical stigma elongate, obliquely before first discal; three smaller, somewhat elongate spots between cell and margin, upper close below costa before angle, second before angle, more distant from edge, third halfway between second discal and lower part of termen; some 8 or 9 small marginal subquadrate or fasciate spots along costa before apex, in apex and along termen to tornus. Cilia grey.

Hindwing light fuscous grey, becoming somewhat darker towards apex. Cilia whitish.

Female genitalia: Genital segment sclerotized, forming a distinct dark ring. Sterigma shaped as a pending subcordiform plate, with upper edge twice emarginate, sclerotized. Colliculum for a part heavily sclerotized, elongate, tortuous, asymmetrical. Posterior edge of seventh sternite also darkly sclerotized. Walls of corpus bursae granulate, without signum.

Material examined: Mindanao, Zamboanga, “Acc.5122," 1 \%, holotype, genit. slide 5715 (AMNH).

Closely allied to E. octanoma Meyrick from Formosa (the type of which seems to be lost) but differing by the coloring of head and palpi and by the arrangement of dark spots in the forewing.

\section{Ethmia nobilis, new species}

Figures 397, 409, 754

Female, 22-25 mm. Head, palpus and thorax greyish white, palpus with terminal segment black in front, thorax with a pair of black spots anteriorly, a spot on top of each tegula, a curved subapical black transverse band. Abdomen light yellow becoming whitish toward base, venter pale yellow.

Forewing oblong, moderately dilated, costa curved, apex subobtuse, termen gently sinuate and slightly convex. Glossy, light slate grey with a faint purplish hue. Markings black, faintly edged whitish, reduced in number. Three elongate plical dots, becoming larger posteriorly, first minute, beyond base, third before middle of fold, second midway the preceding, but slightly shifted towards the basal dot; a larger oval spot in cell in middle of wing, i.e., above and beyond third plical spot; three subapical dots, moderate, rounded, in a triangle, two almost in line with the discal dot, third subcostal, very near to first costal dot; a row of eleven marginal dots, three along costa, fourth apical, some terminal dots more or less interconnected, last dot minute, longitudinal, on end of dorsum. Cilia pale grey. 
Hindwing glossy light grey fuscous, basal fourth as far as lower edge of cell whitish. Cilia pale grey with whitish tips along upper half of termen and around apex, whitish elsewhere.

Female genitalia: Eighth segment evenly sclerotized. Anapophyses moderate but distinct. Ovipositor small. Postapophyses dilated and sinuate at ends. Lamella antevaginalis represented by two dark dentoid sclerites, separated by a narrow split. Colliculum elongate, with strong sclerotized longitudinal folds. Signum absent.

Material examined: Luzon, Benguet Subprov., Klondyke, $800 \mathrm{ft}$., 22.III.1912 (A. E. Wileman), 1 ㅇ, holotype, genit. slide 5555; same locality, 11.V.1912, and 16.V.1912, genit. slide 5752. 2 \%, paratypes (BM).

A distinct species with reduced number of dots. Allied to $E$. lapidella Walsingham from Assam, and to E. heptasema Turner, from Australia.

\section{Plutellidae}

\section{Key to the Philippine Genera of Plutellidae}

1. Forewing, veins 7 and 8 stalked . . . . . . Harpeptila, new genus Forewing, veins 7 and 8 separate or 7 absent . . . . . . . . 2

2. Forewing with veins 6 and 7 absent . . . . Acrocenotes, new genus Forewing with veins 6 and 7 present and separate...... Plutella

\section{Harpeptila, new genus}

Head with closely appressed scales. Ocellus absent. Proboscis? (broken). Labial palpus long, curved, and ascending, median segment roughly expanding beyond middle, forming a projecting brush anteriorly, terminal segment erect, strongly flattened rostrocaudally in front even slightly concave, under 1 , suboval, acute, with appressed scales. Antenna simple, filiform (tip broken), scape short, without pecten. Posterior tibia with appressed bristly hairs above, outer spurs with bristly hairs.

Forewing dilated, pointed, apex subfalcate; with raised tufts of scales; vein 2 from slightly before angle, 3 from angle, 4-7 tolerably equidistant and parallel, 7 to termen, 8 and 9 stalked, 10 from beyond $3 / 4$, cell before this vein considerably narrowed, 11 from about $1 / 3$, no accessory vein. Hindwing 1, pointed-semioval, apex acute; cilia 3/4, 2 from middle, 3 from angle, 3-5 parallel and widely remote, 5 and 6 parallel but closer, 7 subparallel, to apex; accessory vein in cell not furcate. 
Male genitalia: With a short and an extremely long pair of coremata which when entirely retracted reach into the first abdominal segment. Tegumen slender, uncus pointed, subconical. Anus distinct. Gnathos bipartite, arms crossed, excurved, interconnected by a membrane. Saccus short. Valva oval, with a longitudinal high double fold, in cross section being triangular. Aedeagus straight, very slender.

Type species: Harpeptila corethrodes, new species.

An interesting genus with the appearance of a large Tineid but with the wing shape of a Cerostoma. The neuration is peculiar and characteristic, as are the male genitalia. The affinity of the genus is uncertain.

\section{Key to the Species of Harpeptila}

1. Forewing pale ochreous, markings faint, fuscous . . . H. corethrodes, new species Forewing pale ochreous and yellowish olive, markings well defined, brown.

H. prasina, new species

\section{Harpeptila corethrodes, new species}

Figures 377-378, 399-400, 756

Female, $22 \mathrm{~mm}$. Head and thorax pale ochreous tawny mixed with darker fuscous or brown. Palpus rather long, median segment exceeding base of antenna, slender at basal half, strongly expanded posteriorly and with a long porrect brush of rough hairs in front; basal half of this segment whitish regularly punctate with fuscous, posterior half with large long subspatulate fuscous scales with white tips; terminal segment strongly flattened frontally, elongate-suboval, pointed, erect, $1 / 2$; ochreous whitish, dusted fuscous. Abdomen pale grey, venter pale ochreous. Hindtibia pale ochreous.

Forewing oblong-suboval, slightly dilated, costa curved at extremities, almost straight in middle, apex produced and pointed, termen sinuate, concave above, rounded beneath. Pale ochreous, very finely irrorated unevenly with dark brown (partly rubbed), this irroration condensed here and there, so as to form irregular patches. Edge of costa throughout slightly deeper fuscous ochreous. An oblique moderate transverse patch or streak from costa before middle, more or less continued to lower half of termen, entirely obliterate in cell, beyond cell forming several irregular blotches, little interconnected, last blotch fasciate, terminal; a subtriangular spot on costa before $3 / 4$, more or less connected below with preceding markings; a dark brown streak in apex, extending over cilia. Cilia pale ochreous, strewn with dark brown, in and above apex a dark fuscous-brown blotch connected with apical streak.

Hindwing dark fuscous bronze. Cilia fuscous with a darker subbasal suffused band and a narrow basal white line. 
Male genitalia: As described with the genus above. The anterior coremata are enormous. The valva also has a peculiar shape, with a high double longitudinal fold.

Material examined: Luzon, Benguet Subprov., Baguio, $5000 \mathrm{ft}$., 22.V.1912 (A.E. Wileman), 1 ○', holotype, genit. slide 5669 (Rothschild bequest, BM).

\section{Harpeptila prasina, new species}

Figures 351,757

Male, $24 \mathrm{~mm}$. Head greenish white, glossy (palpi missing). Thorax whitish, mixed with pale olive green (denuded). Abdomen light ochreous, coremata extruded, slender pencils, inner grey, exceeding valvae, outer black, twice as long as inner.

Forewing elongate-suboval, pointed, costa curved at base, almost straight in middle, apex pointed and produced, termen sinuate above, convex below, oblique. Vein 2 much more distant from 3 than vein 4 ; veins 8 and 9 stalked, stalk almost as long as free part of 8 , quite longer than free part of 9 . Glossy whitish, densely marbled with light yellowish olive, markings dark brown. Base of costa with a narrow streak, followed by two small subtriangular dots; a semicircular patch on middle of costa, extending over a little more than one fifth; its top not reaching middle of disc, preceded by a round dot; another transverse patch beyond preceding, extended in middle of disc and forming a suboval patch rounded posteriorly, anteriorly produced into a long point in cell, touching top of preceding patch; a moderate streak just above fold, from beyond base, not reaching dorsum; a small spot in apex, a series of some four horizontal marks on lower part of termen, almost confluent, quickly becoming longer downwards; in left wing second costal patch narrower and followed by a transverse costal mark. Cilia light olive greenish, on costa suffused with brownish, with large distended bars opposite marginal markings in apex and along termen.

Hindwing dark grey. Cilia pale tawny suffused with grey except along base and opposite apex, a dark spot on tips of cilia just above apex.

Male genitalia: Resembling closely those of the type species, but differing as follows. Gnathos halves less curved at base, hardly curved at top. Process of sacculus longer, especially in left valva. Two pairs of very long coremata, inner $1 / 2$ the length of outer pair.

Material examined: "Mindanao (Haslam Coll.), Acc. 5990," $1 \sigma^{7}$, holotype, genit. slide 5714 (CMP). Except for the quite different coloring and markings, this species seems to be closely allied to 
H. corethrodes. There are, however, differences in neuration, as described; in corethrodes the apex of the forewing is more produced.

\section{Acrocenotes, new genus}

Head with long appressed scales, roughly spreading at the sides. Ocellus absent. Proboscis very short. Antenna about $2 / 3$, slightly thickened throughout in female, minutely ciliate, scape elongate with a long but sparse pecten. Labial palpus long, recurved, ascending, flattened anteroposteriorly, smooth along posterior side, anterior side throughout except basal half of median segment with a long roughly projecting fringe of scales; terminal segment over $1 / 3$, slightly oval, subacute. Maxillary palpus slender, long, multisegmented, porrected. Thorax smooth. Posterior tibia smooth-scaled.

Forewing lanceolate, pointed, apex produced. Vein 1c not furcate at base, 2 from far before angle, 3 from angle, 4, 5 distant, all these veins rather short, 6 and 7 absent, cell open between 5 and 8, 9 and 10 remote, 11 from before middle of cell, upper edge of cell almost obliterate along its basal half. Retinaculum along vein 12 .

Hindwing 1 , cilia $2 / 3$; subsemioval, pointed, apex moderately produced. 1c well defined, from base, 2 from well beyond middle, 3 from angle, 4 remote, median, 5 and 6 long-stalked, 6 to costa, stalk forming continuation of upper angle of cell, 7 free from base, parallel posteriorly, slightly diverging from beyond base. Frenulum long.

Female genitalia of a simple type, apophyses very long and sclerotized, ovipositor bifid, points acute. Sterigma not modified. Ductus bursae simple and rather long. Bursa copulatrix ovoid. Signum strong, inverted mushroom-like, a rounded body with a clavate external process with a rounded top.

Type species: Acrocenotes niphochrysa, new species.

An interesting novel form with the hindwing neuration and signum as in Acrolepia (perlepidella Stainton), but with other features quite different. Unfortunately males are not available.

\section{Acrocenotes niphochrysa, new species}

Figures $413-414,758$

Female, $15 \mathrm{~mm}$. Head white touched with yellow. Palpus white, frontal tuft mixed with tawny and blackish. Antenna pale yellowish. Thorax white touched with yellow, shoulder a trifle brighter yellow. Abdomen pale ochreous.

Forewing broadly lanceolate, apex pointed and produced, termen gently curved, very oblique. Pale yellow, posterior $2 / 3$ except towards costa strewn with large rounded bright yellow-ochreous scales. Cilia pale ochreous, around apex and before upper half of termen with a supramedian band of sparse black dusting. 
Hindwing rather light fuscous purple, glossy, entire apex and edge of wing narrowly pale yellowish. Cilia pale yellow, opposite apex tipped with dark fuscous.

Female genitalia as described with the genus above.

Material examined: Luzon, Benguet Subprov., Klondyke, $800 \mathrm{ft}$., 29.IV.1964 (A.E. Wileman), 1 \%, holotype, genit. slide 5664 (Rothschild bequest, BM).

\section{Plutella Schrank, 1802}

\section{Plutella maculipennis (Curtis, 1832)}

Figure 759

Cerostoma maculipennis Curtis, 1832 [British Entomology], vol. 9, p. 2, pl. 420, explan.

Plutella maculipennis.-Maxwell-Lefroy, 1906, Indian Insect Pests, p. 152, fig. 170-171; 1906, Mem. Dept. Agric. India, Ent. ser., vol. 1, p. 225, fig. 69.Walsingham, 1907, in Sharp, Fauna Hawaiiensis, vol. 1, pt. 5, pp. 652-653.Maxwell-Lefroy, 1909, Indian Insect Life, p. 538, fig. 345.-Meyrick, 1910, Rec. Indian Mus., vol. 5, p. 229; 1914, in Aurivillius, Lepidopterorum Catalogus, pars 19, p. 59.-Fletcher, 1914, South Indian Insects . . . , p. 464, fig. 340 ; 1917, Rep. Proc. 2nd Ent. Meeting Pusa, pp. 276-277, 280, 282-283; 1920, Mem. Dept. Agric. India, Ent. ser., vol. 6, p. 170; 1933, Imp. Counc. Agric. Res., Sci. Mon., no. 4, p. 65, pl. 65.

Distribution: Cosmopolitan. Occurs everywhere where cabbage is cultivated.

Food plant: Cabbage leaves.

Material examined: Luzon, Los Baños (Baker), 2 ㅇ.

The above literature pertaining to occurrence in southern Asia has no pretence of being complete. The huge literature from other regions is omitted.

\section{Lithocolletidae}

\section{Key to the Philippine Genera of Lithocolletidae}

1. Head with appressed scales; forewing with vein 11 present . . . Epicephala Head roughly scaled; forewing with vein 11 absent... . Lithocolletis

\section{Epicephala Meyrick, 1880}

\section{Epicephala chalybacma Meyrick, 1908}

Epicephala chalybacma Meyrick, 1908, Journ. Bombay Nat. Hist. Soc., vol. 18, p. 811 (Ceylon, ơ); 1912, Exotic Microlepidoptera, vol. 1, p. 21 (biology); 1912, in Aurivillius, Lepidopterorum Catalogus, pars 10, p. 14; 1913, in Wytsman, Genera Insectorum, fasc. 128, p. 14.-Fletcher, 1920, Mem. Dept. Agric. India, Ent. ser., vol. 6, p. 142, pl. 36.-Clarke, 1955, Catalogue . . . Microlepidoptera ... Meyrick, vol. 1, p. 82.

Distribution: Ceylon, India, Burma, Java. 
Material examined: Luzon, Manila, in flower buds of Caesalpinia pulcherrima, 23.I.1918, 1 cocoon on dried leaflet, with empty exuvium sticking out (USNM).

\section{Lithocolletis Hübner, 1825}

\section{Lithocolletis triarcha Meyrick, 1908}

Lithocolletis triarcha Meyrick, 1908, Journ. Bombay Nat. Hist. Soc., vol. 18, p. 811 ( $q$, Bengal, cotton leafminer); 1912, in Wytsman, Genera Insectorum, fasc. 128, p. 8; 1921, Ann. Transvaal Mus., vol. 8, p. 121 (S. Africa). Maxwell-Lefroy, 1909, Indian Insect Life, p. 537.-Fletcher, 1921, Mem. Dept. Agric. India, Ent. ser., vol. 6, p. 137, pl. 33 (life history, India)-1933, Imp. Counc. Agric. Res., Sci. Mon., no. 4, p. 40.-Clarke, 1955, Catalogue ... Microlepidoptera . . . Meyrick, vol. 1, p. 314.

Distribution: India, South Africa.

Food plant: Cotton (Gossypium) (leaf miner).

Material examined: Luzon, May 1931 (V. Aldaba), 17 specimens, pasted, "Lithocolletis triarcha Meyr. A.B. det. 1931." Negros, Victorias, 24.VII.1928, "leaf miner in cotton" (W.D. Pierde). 3 specimens (1 $\sigma^{\top}, 2$ ᄋ) (USNM).

\section{Lyonetiidae}

\section{Key to the Philippine Genera of Lyonetiidae}

1. Forewing with apex turned upwards or downwards; head normal.

Decadarchis

Forewing with apex normal; head flattened, often a fillet on vertex.

Opogona

\section{Opogona Zeller, 1853}

Key to the Philippine Species of Opogona

1. Forewing yellow with posterior half dark fuscous-grey . . . O. dimidiatella Forewing pale yellow, with two costal, one dorsal and one discal small dark marks . O. icterica

Forewing purple with a yellow transverse band . . . . . O.flavofasciata

\section{Opogona icterica Meyrick, 1915}

Opogona icterica Meyrick, 1915, Exotic Microlepidoptera, vol. 1, p. 360 ( $\sigma^{7}$, Mindanao).-Clarke, 1955, Catalogue ... Microlepidoptera . . Meyrick, vol. 1, p. 166.

Distribution: Philippine Is., Mindanao.

The type specimen is in the British Museum (Natural History). 


\section{Opogona dimidiatella Zeller, 1853}

FIGURE 761

Opogona dimidiatella Zeller, 1853, Bull. Soc. Imp. Nat. Moscou, vol. 24, no. 3, p. 507, pl. 4, figs. 13-16.-Walsingham, 1900, Ent. Monthly Mag., vol. 36, p. 180.-Snellen, 1903, Tijdschr. Ent. 46, pp. 52, 53.-Van Deventer, 1912, Dierl. Vijanden Suikerriet (2nd ed.), p. 165, pl. 22, fig. 12 (Java).-Meyrick, 1929, in de Joannis, Ann. Soc. Ent. France, vol. 98, p. 741 (Tonkin).

Distribution: Tropical Asia.

Food plant: Pods of Poinciana pulcherrima (flamboyant); dry vegetable refuse, etc.

Material examined: Luzon, Mt. Makiling (Baker), $1 \sigma^{7}$.

\section{Opogona flavofasciata (Stainton, 1858)}

\section{Figure 760}

Lozostoma flavofasciata Stainton, 1858, Trans. Roy. Ent. Soc. London, ser. 2, vol. 5, p. 124 (sex?, India).-Walker, 1864, List Lepidopterous Insects British Mus., pt. 30, p. 1041.-Moore, 1867, Proc. Zool. Soc. London, p. 671.-Cotes and Swinhoe, 1887, Cat. Moths India, p. 722, no. 4941.Semper, 1902, in Schmetterlinge Philippinischen Inseln, vol. 2, p. 705 (Manila).-Fletcher, 1929, Mem. Dept. Agric. India, Ent. ser., vol. 11, p. 120.

Opogona flavofasciata.-Petch, 1906, Ann. Roy. Botanic Gardens Peradeniya, Ceylon, vol. 3, p. 229.-Meyrick, 1910, Rec. Indian Mus., vol. 5, p. 230.Fletcher, 1920, Mem. Dept. Agric. India, Ent. ser., vol. 6, p. 177; 1929, op. cit., vol. 11, p. 120.

Distribution: India; Philippine Is., Luzon.

Material examined: Luzon, May 1924 (R.C. McGregor), 1 \%; Palawan, Ponce Cruz, XI.1935, $1 \sigma^{\top}$ (Acc. no. 4064, Bur. of Plant Industry, P.I.) (USNM). "Opogona flavofasciata Staint. A.B." Two rubbed specimens.

In 1906, Petch wrote: 'Larva in fungus-combs of termites' nests, which they reduce to a mass of excrementitious matter in a few days when cultures of combs are attempted, the cultures being resolved into a mass of black pellets. Though the moths are apparently confined to this habitat, it is remarkable that no trace of the larvae or their work has been observed in the termites' nest under natural conditions." (See Fletcher, 1920, p. 177.)

\section{Decadarchis Meyrick, 1886}

\section{Decadarchis minuscula (Walsingham, 1897)}

Figure 762

Ereunetis minuscula Walsingham, 1897, Proc. Zool. Soc. London, p. 155 (West Indies, ( $\sigma^{\top}$ ) ; 1907, in Sharp, Fauna Hawaiiensis, vol. 1, pt. 5, p. 716, pl. 25, fig. 17 (Hawaii).- Swezey 1909, Hawaiian Sugar Planters' Assoc. Exp. Sta. Ent. Bull., no. 6, p. 12, pl. 2, figs. 7-9 (bionomics); 1910, Proc. Hawaiian Ent. Soc., vol. 2, p. 42. 
Decadarchis minuscula.-Meyrick, 1915, Exotic Microlepidoptera, vol. 1, p. 367 (Ceylon); 1918, Ann. Transvaal Mus., vol. 6, p. 43 (South Africa).-Fletcher 1921, Mem. Dept. Agric. India, Ent. ser., vol. 6, p. 179.

Distribution: West Indies, South Africa, Ceylon, Hawaii. Probably distributed throughout the Tropics.

Food: Larva feeds in dry vegetable refuse, often beneath bark of dead trees.

Material examined: Luzon, Manila, IV.1913 (O.W. Barrett), 2 \%, 1 specimen in fragments (USNM).

\section{Tineidae}

\section{Key to the Philippine Genera of Tineidae}

1. Forewing with a hyaline small spot in disc . . . . . . . . . . Monopis Forewing without such spot . . . . . . . . . . . . . . . . . 2

2. Forewing narrow and long; abdomen long and slender; head sometimes enlarged; palpus bristly and rough . . . . . . . . . . . . . . . 3

Not as above. . . . . . . . . . . . . . . . . . . . . . 4

3. Hindwing with veins 5 and 6 stalked . . . . . . . . . Ischnuridia Hindwing with veins 5 and 6 separate . . . . . . . . . . Harmaclona

4. Antenna in male bipectinate, pectinations fasciculate-ciliate . Melasina Antenna in male ciliate or simple . . . . . . . . . . . . . . . . . 5

5. Posterior tibia with very long and fine appressed hairs above, in $\sigma^{7}$ forming a long pencil; forewing covered with highly raised rough scale crests; thorax with a double posterior crest . . . . . . . . . Hapsifera

Posterior tibia with moderate hairs or without hairs; forewing not so strongly tufted

6. Forewing with veins 8 and 9 out of 7,7 to costa (seldom 8 absent) or 7 and 8 out of 9 . . . . . . . . . . . . . . . . 7

Not all these three veins stalked . . . . . . . . . . . . . . . . 8

7. Maxillary palpus absent; forewing with vein 7 to costa. . . . Setomorpha Maxillary palpus smooth, three-jointed, folded . . . . . Exaxa, new genus

8. Forewing with veins 7 and 8 or 8 and 9 stalked . . . . . . . . . . . . 9

Forewing with all veins separate . . . . . . . . . . . . . . . . 12

9. Forewing with vein 2 from $1 / 2,3$ from $3 / 4,4$ from angle of cell, vein 10 absent; apex of wing pointed . . . . . . . . Oxytinea, new genus

Veins 2,3 , and 4 with a different origin; vein 10 present . . . . . . . . 10

10. Head strongly enlarged; abdomen in two sexes with two lateral or subdorsal longitudinal crests; posterior tibia often very long; forewing narrow, with veins 7 and 8 stalked . . . . . . . . . . . . . . . . Gerontha

Head normal; abdomen without such crests; posterior tibia of normal length; forewing normal, with veins 8 and 9 stalked . . . . . . . . 11

11. Forewing with veins 3 and 4 stalked, vein 11 from $1 / 3$ of cell; maxillary palpus drooping; all tarsi rough-scaled . . . . . . . . Trachycentra

Forewing with veins 3 and 4 separate; vein 11 from $1 / 2$ of cell; maxillary palpus ascending; tarsi normal . . . . . . . . . . . Holacarta

12. Labial palpus porrected strongly flattened laterally, terminal segment oval, obtuse; large diurnal yellow and black, or orange and black colored species. 
Labial palpus ascending, not flattened laterally; nocturnal species, differently colored . . . . . . . . . . . . . . . . . . . . . . . . 13

13. Scape of antenna with pecten; labial palpus distinctly curved, ascending, median segment with a long brush of scales below, terminal segment smooth, pointed . . . . . . . . . . . . . . . . Tinissa

Scape of antenna without pecten, often flattened and dilated; labial palpus little curved, obliquely ascending, rather slender,ro ughish below, obtuse.

Haplotinea

\section{Gerontha Walker, 1864}

Gerontha Walker, 1864, List Lepidopterous Insects British Mus., pt. 29, p. 782 (type species: $G$. captiosella Walker, 1864, Ceylon).-Fletcher, 1929, Mem. Dept. Agric. India, Ent. ser., vol. 11, p. 98.-Diakonoff, 1955, Verh. Ned. Akad. Wet., Nat., ser. 2, vol. 50, no. 3, p. 115.

This remarkable genus has never been redescribed. The discovery of a couple of new species necessitates some extension of the concept of Gerontha, and I use this opportunity to present a redescription.

Head often enlarged, with dense, loosely appressed scales. Ocellus absent. Proboscis very short. Antenna under 1, ciliated in male, ciliations $1-1 \frac{1}{2}$, simple in female, scape slightly flattened, without pecten. Labial palpus curved and ascending, moderate or rather long, basal and median segments strongly dilated and expanded below by roughly projecting scales, a series of lateral bristles, sometimes also larger apical bristles; terminal segment slender, more or less pointed, hardly flattened, shorter than median. Maxillary palpus short, filiform, three-jointed and folded. Thorax without a crest. Abdomen with two lateral keels or crests along its apical half, these crests becoming subdorsal and converging on anal segments in the two sexes. (Posterior wall of mesothorax and anterior wall of metathorax partly closed by large and thin white membranes, resembling tympanal organs. Perhaps because of these membranes mounted specimens easily break at this place.) Anterior tibia sometimes with strong spines in middle, and usually with a tuft of bristly scales and a couple of spines at the apex. Posterior tibia elongate, covered with bristly hairs above and beneath, posterior tarsus often strongly elongate.

Forewing narrow and elongate, top rounded; a brush of dark hairs originating from the side of the mesothorax between bases of wings, appressed to the underside of the forewing; with large tufts of raised scales. Vein $1 b$ furcate, 2 from angle in $\sigma^{7}$, from angle or from well before angle in $\%$; veins 3 and 4 stalked, stalk out of base of 2 , or connate with 2 from angle, or stalk separate from 2, from angle (when 2 originates before angle), 5-7 parallel, 7 to apex, stalked with 8 , sometimes stalk connate with 9 from upper angle of cell, 9 out of stalk beyond its base, or 9 free, from before angle. Vein 11 from $1 / 3$ of cell. 
Hindwing with veins $1 \mathrm{a}$ and $1 \mathrm{~b}$ close together and parallel, strongly excurved and approaching $1 \mathrm{c}$ in middle, 2 from middle of cell, 3 from well beyond middle, sometimes hyaline patches between $1 \mathrm{~b}$ and $1 \mathrm{c}$, or between bases of 2 and 3, and 3 and 4, 4 from angle, 5 and 6 stalked, connate or approximated, 7 parallel.

Genitalia of the two sexes as described for the type species below. The large, long-legged species are strongly attracted by light. Therefore, they are usually present in most collections. Only two species, G. captiosella (all through tropical Asia?) and G. dracuncula Meyrick (Andamans) have been described before. However, the varied-looking "captiosella" may prove to contain several distinct species when the genitalia will be studied. The larvae bore in decaying wood.

\section{Key to the Philippine Species of Gerontha}

1. Head and palpus white; forewing with a white spot in disc at $2 / 3$.

G. nivicaput, new species Not thus .

2. Hindwing transparent, with fuscous veins and suffused margin . . . . . . 3 Hindwing not transparent . . . . . . . . . . . . . . . . . . . 4

3. Forewing strewn with numerous irregular dots of diverse size, tending to form transverse fasciae; several larger dots . . . . . . . . G. captiosella

Forewing with less numerous fine dots and a single larger spot at $2 / 3$ of costa . . . . . . . . . . . . G. monostigma, new species

4. Head and thorax pale grey, palpus mixed with white.

G. captiosella f. capna, new form Head, thorax, and palpus fuscous . . . . . . G. diascopa, new species

\section{Gerontha captiosella Walker, 1864}

Figures 415-420, 764

Gerontha captiosella Walker, 1864, List Lepidopterous Insects British Mus., pt. 29, p. 782 ( , Ceylon).-Walsingham, 1887, in Moore, Lepidoptera Ceylon, vol. 3, p. 521 (Ceylon).-Fletcher, 1933, Imp. Counc. Agric. Res., Sci. Mon., no. 4, p. 80, pl. 72 (Ceylon, India).

Distribution: Ceylon, India, Sumatra, Java, Andaman Is., North Australia.

Material examined: Luzon, Mt. Makiling (Baker), $1 \sigma^{7}, 2$ q. Mindanao, Surigao, V.1915, IX.1916. 18 o $0^{7}, 5$ 우 (USNM). Zamboanga del Sur, $11 \mathrm{~km}$ NW of Milbuk, $390 \mathrm{~m}$, 5.VIII.1958 (H.E. Milliron), 1 우 (BMH). $19 \sigma^{7}, 8$ ㅇ․ Genit. slides 5270, $5273 \sigma^{7} ; 5269$, 5273 ㅇ.

Considerably varying as to the size, while the neuration varies only slightly: in the forewing vein 2 may be connate with the stalk of 3 and 4 or out of this stalk at different distances from the lower angle of cell; the same is the case with vein 9 in reference to the stalk of veins 7 and 8 and the upper angle of cell. In the hindwing veins 
5 and 6 may be remote, connate or stalked. The distribution does not seem to be entirely certain, since $G$. captiosella may prove to be a complex of several similar species.

Male genitalia: Tegumen moderate, bases going down far ventrad. Uncus distinct, bilobed, each lobe with a small crochet, bristly. Gnathos with arms moderate, angulate hook forming a moderate rising triangular plate with a produced aciculose point. Vinculum bandlike, moderately dilated in middle. Saccus long and very slender, with a moderately dilated top. Valva rather narrow, excurved, cucullus rounded, sacculus absent. Aedeagus long, slender, tubular.

Female genitalia: Seventh segment elongate, caudal edge of ventrite rounded-prominent. Intersegmental membrane between 7 and 8 long. Eighth segment moderately sclerotized. Sterigma, a cardiform weak plate, partially covered by two large semioval lateral folds.

\section{Gerontha captiosella Walker forma $q$ capna, new form} Figure 765

Female, 28-38 mm. Similar to the typical form but with hindwing opaque, greyish bronze, with darker veins. Hairs on posterior tibia often grey.

The female genitalia show no tangible differences from those of the typical form.

Material examined: Luzon, Mt. Makiling (Baker), 1 , holotype, genit. slide $5271 ; 5$ 우, paratypes. 6 우 (USNM).

\section{Gerontha monostigma, new species}

Figures 433, 766

Male, $26 \mathrm{~mm}$. Head and thorax whitish, mixed and suffused with grey. Palpus with basal segment brushy with scales, median segment slender at base, abruptly expanded and brushy towards top; purple black, top of median segment white, terminal segment, base, middle, and tip mixed with purple. Antenna fuscous. Abdomen blackish purple. Legs, anterior and median black, tarsi white below posterior grey mixed with purple, tibia whitish, grey towards apex, long hairs above grey, posterior tarsus white, each segment with a blackish-purple wreath of short spines at the top.

Forewing narrow, sublanceolate, pointed, dorsum sinuate. Vein 2 connate with the stalk of $3+4,7$ and 8 long-stalked, 9 out of stalk close to base. Creamy white, glossy, markings dark purple. A marginal row of small dots around the wing; a larger, rather conspicuous quadrate-trapezoidal spot on costa beyond 2/3 (opposite closing vein), limited below by upper edge of cell, followed by two elongate marks posteriorly, ultimate mark smaller, subapical; irregu- 
lar small dots of diverse size scattered along veins on posterior half of wing and filling out apical area; parting vein and veins 5 and 6 narrowly dark purple; upper and lower edges of cell from beyond base to about $2 / 3$ of wing broadly suffused with light grey. Cilia (imperfect) whitish mixed with purple.

Hindwing with veins 5 and 6 stalked, stalk rather short; hindwing semipellucent; costa as far as vein 8 opaque and creamy, densely scaled; apex and dorsum with a suffused blackish band; all veins except upper edge of cell thickly streaked with blackish, except parting vein and veins $5+6$ which are very narrowly blackish.

Male genitalia: Uncus with slight excisions at bases. Gnathos broad, about $2 / 3$ length of tegumen + uncus, slightly constricted at base, gradually narrowed beyond middle, top broad, truncate. Valva curved, gently narrowed beyond base, top clavate.

Material examined: Mindanao, Zamboanga del Sur, $11 \mathrm{~km} \mathrm{NW}$ of Milbuk, 390 m, 5.VIII.1958 (H.E. Milliron), 1 ๙ , holotype, genit. slide $5325(\mathrm{BMH})$.

Very similar to $G$. captiosella, but with distinct costal stigmata before $2 / 3$ of wing, and with dark-veined hindwing.

\section{Gerontha diascopa, new species}

Figures 421-422, 767

Female, $29 \mathrm{~mm}$. Head creamy, on vertex suffused with grey lateral tufts on vertex rising and hornlike, with dark fuscous suffused apical spots, face with white lateral spots below. Labial palpus with basal and median segments brushy, apical segment slender, compressed frontocaudally; basal and median segments black, a white spot at apex of median, terminal segment whitish, with a basal, a median, and subapical somewhat suffused blackish band. Thorax whitish, finely irrorated with light brown. Abdomen dark bronze fuscous, becoming darker posteriorly, anal tuft pale ochreous, apical segments with thin lateral fins of scales, gradually becoming two slender dorsal crests on top of apical tuft, venter light greyish ochreous. Posterior tibia dark fuscous, apex pale ochreous, tarsus pale ochreous, dark ringed.

Forewing narrow, elongate-oval, costa gently concave anteriorly, almost straight, rounded-prominent beyond 3/4, apex rounded, termen rounded and oblique; with large tufts of raised scales; vein 2 from well before angle, 3 and 4 stalked from angle, 7 to apex, 9 connate with stalk of $7+8,11$ from $1 / 3$. Creamy, irrorated with dark brown, this color forming dense streaks or series of rounded spots along veins, tending to form transverse strigulation. Costa suffused along basal $3 / 4$ with pale grey and marked with numerous dark brown suffused transverse blotches; posterior fourth of costa creamy with 
three equidistant dark spots; anterior half of dorsum from beyond base as far as fold irrorated with fulvous; a large, oval raised tuft on end of cell, rather pale fuscous, becoming dark brown posteriorly, scales with white tips on lower half of tuft posteriorly; another similar but much smaller tuft above and slightly beyond it; an oblique transverse dark fuscous blotch before apex, preceded by a parallel streak of not obscured ground color, forming a rather conspicous oblique fascia; numerous variously colored smaller tufts along and between veins. Cilia greyish creamy, with a dark brown interrupted subbasal line, a faint fuscous supramedian line and interrupted dark fuscous-grey suffusion along tips of cilia.

Hindwing with a hyaline spindle-shaped patch between bases of vein 2 and 3 and a small and narrow one between bases of 3 and 4; rather dark fuscous golden, veins, costa, and dorsum suffused with purple. Cilia dull dark fuscous.

Female genitalia: Lamella antevaginalis inverted-trapezoidal, erected, upper edge gently emarginate. Ductus and corpus bursae simple.

Material examined: Luzon, Mt. Makiling (Baker), 1 ㅇ, holotype, genit. slide $5267 ; 1$ ㅇ, paratype (USNM).

Closely allied to $G$. captiosella Walker, but very distinct by the hyaline spots in the hindwings and by darker color of both foreand hindwings.

\section{Gerontha nivicaput, new species}

Figures 424-425, 768

Female, 27-28 mm. Head white. Antenna with scape white, flagellum dark fuscous, finely pale-ringed. Labial palpus dark grey, more than apical half of median segment white, terminal segment whitish; a series of large black lateral setae along basal and median segments. Maxillary palpus whitish, dark ringed. Thorax grey, strongly suffused with dark fuscous purple, apex and tips of tegulae lighter grey. Abdomen dark fuscous purple, anal tuft and venter whitish, sides whitish with dark segmental bands. Posterior tibia fuscous, top white, white spots around bases of median spurs, tibia fuscous, white ringed.

Forewing narrow, elongate-oval, costa rather distinctly concave, rounded but very faintly prominent at $3 / 4$, apex rounded, termen rounded, oblique. Vein 2 from rather before angle, 3 and 4 short stalked from angle, 7 to apex, 7 and 8 stalked, 9 free, from well before apex, 11 from $1 / 3$; with numerous large raised scale tufts. Silvery grey white, suffused with darker grey, irrorated and marked with dark fuscous purple. A series of numerous transverse suffused blotches along costa, more or less continued by series of similar 
blotches or raised tufts on veins, tending to form transverse strigulation; a dark brown-purplish suffusion on base of costa, edged by ferruginous tawny; a transverse series of two large rounded, raised ferruginous-tawny tufts, mixed with a few long white hair-scales, one tuft above dorsum, another in cell, edged posteriorly in fold by a dark purple suffusion; two similar tawny tufts, on upper edge of cell at $1 / 3$ of wing length, and on base of vein 10 , respectively; some three smaller tufts along vein $1 \mathrm{~b}$; two large white tufts, on upper and lower angles of cell, respectively, upper largest; a sometimes ill-defined slightly outwards-oblique transverse streak of pale ground color, at about $2 / 7$ of wing, followed by two broad and one narrow blackish transverse bands, last marginal, in apex; numerous smaller, variably colored tufts scattered all over the wing. Cilia pale grey, mixed and barred with darker grey except in tornus, a black interrupted subbasal line.

Hindwing with vein 2 from middle, 3 from beyond middle, 4 from angle, 5 and 6 separate; pale ochreous, irregularly marbled with bronze grey, veins bronze purple, costa and dorsum with a purple gloss. Cilia golden fuscous, with a pale basal line.

Female genitalia: Lamella antevaginalis rectangular, rather narrower and much longer than in $G$. diascopa. Anapophyses longer and more slender.

Material examined: Luzon, Mt. Makiling (Baker), 1 , holotype, genit. slide 5268; 2 \%, paratypes (USNM). Mindanao, Lanao, plains, Kolambugan, 2.VII.1914 (A.E. Wileman), 1 \%, paratype (BM).

Judging from the genitalia, closely allied to the preceding species (G. diascopa).

\section{Harmaclona Busck, 1914}

Figures $412,454-456$

Harmaclona Busck, 1914, Proc. U.S. Nat. Mus., vol 47, p. 63 (Tineidae).Fletcher, 1929, Mem. Dept. Agric. India, Ent. ser., vol. 11, p. 104 (Arrhenophanidae!). [Type species: Harmaclona cossidella Busck, 1914 (Panama).] Ptychoxena Meyrick, 1916, Exotic Microlepidoptera, vol. 1, p. 615.-Fletcher, 1929, Mem. Dept. Agric. India, Ent. ser., vol. 11, p. 192.-Diakonoff, 1955, Verh. Ned. Akad. Wet., Nat., ser. 2, vol. 50, no. 3, p. 115 [new synonym]. [Type species: Ptychoxena tephrantha Meyrick, 1916 (India, Ceylon, Australia).]

Micrerethista Meyrick, 1938, Trans. Roy. Ent. Soc. London, vol. 87, p. 527.Diakonoff, 1955, Verh. Ned. Akad. Wet., Nat., ser. 2, vol. 50, no. 3, p. 131 [new synonym]. [Type species: Micrerethista mochlacma Meyrick, 1938 (New Guinea).]

Type species: Harmaclona cossidella Busck, 1914 (Panama).

To the description of this remarkable genus should be added the following points. Labial palpi sometimes widely diverging, always 
closely appressed to face and eyes. Maxillary palpi moderately short, thick, rising, roughly scaled. Proboscis absent.

\section{Harmaclona tephrantha (Meyrick, 1916), new combination}

Figures 426, 457-458, 461, 769

Ptychoxena tephrantha Meyrick, 1916, Exotic Microlepidoptera, vol. 1, p. 616 ( $\sigma^{7}+$, Ceylon, Bhotan, Natal, Venezuela, French Guiana).-Clarke, 1955, Catalogue . . Microlepidoptera . . Meyrick, vol. 1, p. 304.

Distribution: Recorded by Meyrick from Ceylon, India, South and West Africa, South America, Bismarck Is., Northeast Australia, China, Malaya. Probably several distinct species and subspecies are concerned.

Material examined: Luzon, Mt. Makiling (Baker), $3 \sigma^{\Upsilon}$, genit. slide 5285; 1 ㅇ, genit. slide 5272 (USNM). Luzon, Benguet Subprov., Klondyke, 800 ft., 16.III.1912 (A.E. Wileman), 1 우 (BM).

Male genitalia: Tegumen, a broad and simple plate with a rounded edge. Tuba analis as long as tegumen, sclerotized, with a ventral split, extended far capitad as a sclerotized oval plate, so forming a large subscaphium. Vinculum, a narrow ring. Saccus short and pointed. Valva elongate, strongly concave longitudinally, ventral angle pointed. Cucullus long, finger-shaped. Processus basilis moderate. Juxta small, oval, directed backwards (rostrad). Anellus short, tubular. Aedeagus slender, moderately long, apical third attenuate, edge with sparse serrations.

Female genitalia: Eighth tergite sclerotized, with prominent lower angles. Ostium, a simple, rather wide funnel. Colliculum indicated, a hyaline tube. Ductus and corpus bursae simple.

\section{Ischnuridia Sauber, 1902}

Ischnuridia Sauber, 1902, in Semper, Schmetterlinge Philippinischen Inseln, vol. 2, p. 704-Fletcher 1929, Mem. Dept. Agric. India, Ent. ser., vol. 11, p. 119 (Lyonetiidae?).

Type species: Ischnuridia virginella Sauber, 1902 (Philippine Is.).

This mysterious genus has been attributed by Meyrick to the family Lyonetiidae, according to his unpublished notes, preserved in the British Museum (Natural History). Fletcher followed him (1929) but recorded the family name with a question mark. Apparently the species has never been restudied.

With the kind help of Dr. Heinz Schröder, Senckenberg Museum, Frankfurt am Main, Germany, I was able to place the insect exactly. The unique type specimen of the type species is preserved in that museum. I was allowed to dissect the distal portion of the abdomen, while Dr. Schröder kindly provided me with a photograph 
and with sketches of head and neuration of the type, so that I am able to present an approximate redescription of the genus.

It proves to belong to the Tineidae and to be closely related with Harmaclona Busck, which apparently is a circumtropical genus.

Head rough. Ocellus and proboscis probably absent or vestigial. Antenna in female simple, about 1, scape thickened, without pecten. Labial palpus long, curved, and subascending, rather smooth, median segment dilated towards apex, terminal segment moderately attenuated, subobtuse; median segment along posterior half and terminal segment beset around with not dense setae of various sizes. Maxillary palpus apparently several-jointed and folded, basal segments ascending.

Forewing narrowly elongate-oval, almost lanceolate, costa curved at extremities, especially before apex, apex obtusely pointed, termen extremely oblique, gently concave.

As far as I can read Dr. Schröder's sketch, the forewing does not possess veins 2 and 3 , vein 4 originating from angle; 7 to costa, separate from 8,11 from before $1 / 3$. Hindwing about 1 , cilia $2 \frac{1}{2}$; elongatesemioval; vein 2 about $3 / 4,5$ and 6 stalked, cell with two additional veins; the female frenulum apparently is single.

The abdomen is extremely long and slender, which is the origin of the name of the genus: "Slender as a damsel fly of the genus Ischnura" (Sauber, 1902, p. 704). The incompletely described genus was supposed to be related to Dendroneura Walsingham (Opogona Hübner) which is certainly incorrect.

\section{Ischnuridia virginella Sauber, 1902}

Figures 379-381, 401, 772

Ischnuridia virginella Sauber, 1902, in Semper, Schmetterlinge Philippinischen Inseln, vol. 2, p. 704, pl. 66, fig. 17 ( $\sigma^{7}$, S.E. Mindanao).

Distribution: Philippine Is., Mindanao.

The unique type specimen, a female, elegantly, but inadequately illustrated by its author, was stated to be a male. The forewing is $13 \mathrm{~mm}$, the exact locality and date, southeast Mindanao, Sibulan, 25.I.1882.

Female genitalia: The ovipositor apparently is destroyed, the very long postapophyses being broken distally. The seventh (or eighth?) abdominal tergite sclerotized, with a narrow membranous median split, at the end this tergite forming two strong hairy prominences. Sterigma thinly haired, lamella antevaginalis with a curved, moderately sclerotized rim, together with the colliculum $Y$-shaped; lamella postvaginalis irregular. Colliculum, a weak small cylinder. Anapophyses long and strong, united by a sclerotized small plate (genit. slide 5767). 


\section{Holacarta Meyrick, 1917}

\section{Holacarta chalcathra, new species}

Figures 402-405, 770

Male, $20 \mathrm{~mm}$. Head (rubbed) and thorax dark grey mixed with blackish. Antenna pale yellow, scape blackish grey. Palpus with median segment cylindrically thickened, roughly tufted along entire lower edge, terminal segment $1 / 2$, obliquely ascending; sordid ochreous grey, strongly mixed with blackish; terminal segment blackish, extreme tip paler, greyish. Abdomen dark bronze fuscous, sides mixed with light ochreous (posterior legs missing).

Forewing broadly lanceolate, broadest at $1 / 3$, costa little curved at base, gently prominent at $1 / 3$, moderately rounded along posterior fourth, apex acutely pointed, termen sinuate, very oblique. Rather deep brassy bronze, anterior $2 / 3$ irregularly clouded with blackish purple, edge of this color rather well defined in disc of left wing, very outwards-oblique, right wing rather obscured throughout with purplish grey and blackish purple; a conspicuous but small slightly raised elongate spot in lower angle of cell, pale ochreous, a point of the same color below it on dorsum, extending as a light bar over cilia. Cilia (damaged) dark purplish grey, mixed with blackish purple.

Hindwing black, rather dull, cilia concolorous.

Male genitalia: Tegumen semiannular, high. Uncus rounded, hairy. Gnathos paired, each arm strongly hooked, top pointed. Valva moderate, elongate, cucullus rather abruptly narrowed. Vinculum semiannular, moderate, saccus very long and slender. Aedeagus long and straight, base slightly dilated.

Material examined: Luzon, Mt. Makiling (Baker), $1 \sigma^{x}$, holotype genit. slide 5289 (USNM). An obscure insect with left pair of wings slightly rubbed. Agrees with the description of this genus, except for the pointed wing and hardly any raised scales on the wings, which may be due to rubbing.

\section{Exaxa, new genus}

Head roughly scaled. Ocellus absent. Probscis very short, vestigial. Antenna in female 4/5, subserrulate, simple, scape elongate, with pecten. Labial palpus long, curved and ascending, strongly flattened laterally, strongly dilated by long rough fringe of scales along lower edge throughout, median segment with top far exceeding base of antenna, with a single apical bristle, sometimes with a lateral bristle, terminal segment over $1 / 3$, subobtuse. Maxillary palpus smooth-scaled, three-jointed, moderately folded and pointed. Thorax 
without a crest. Posterior tibia in female with thin and long, smoothly appressed hairs above.

Forewing rather broad, oblong-ovate, apex and termen rounded. All veins present, $1 \mathrm{~b}$ furcate, 2 from about $1 / 3,3$ from $1 / 6,4$ from angle, 7 and 8 out of 9,7 to termen, 11 from middle, cell rather narrow.

Hindwing elongate-suboval, 1, cilia 1/2. Vein 2 from just beyond middle of cell, 3 from 3/4, 4 from angle, 4-7 parallel, discoidal vein receding above base of vein 6 , a parting vein in cell, single, to base of 5 .

Type species: Exaxa rectilinea, new species.

Very distinct by peculiar neuration.

\section{Exaxa rectilinea, new species}

FigURES 438-439, 465-466, 771

Female, $22.5 \mathrm{~mm}$. Head pale yellow. Antenna pale yellow, finely ringed with brownish. Palpus pale yellow, upper edge of basal and median segments brownish, spines black. Thorax deep fuscous yellowish, with broad lateral edges pale yellow, a rounded large pale yellow apical patch. Abdomen light ochreous.

Forewing elongate-oval, costa gently curved anteriorly, straight in middle, strongly curved before apex, apex rounded, termen rounded, oblique and very short. Pale ochreous yellow, markings formed by dark fuscous, brownish, and fuscous-yellowish dusting. Base of costa with a moderate dark fuscous suffused spot, rather irregular, with lower edge extended as an irregular streak or area of sparse dark brown dusting above cell; posterior half of cell with an anteriorly attenuated streak with a dark brown spot on end of cell, the streak not exceeding one-third of cell width; this streak connected posteriorly by a lighter and less dense suffusion with upper half of termen, and not exceeding vein 6 ; an irregular streak from cell to apex, between veins 6 and 7 ; irregular bands of fuscous-brownish dusting along costa before apex and along posterior half of dorsum, respectively; a broader streak along fold from base to middle of wing, at base irregularly dilated and more or less extended along and above anterior part of dorsum. Cilia pale yellow, irrorated with dark fuscous, a more or less interrupted subbasal dark fuscous band.

Hindwing pale golden yellow, suffused with pale purplish fuscous. Cilia glossy pale golden yellow.

Female genitalia: Ovipositor very long and slender. Sterigma hardly modified, indication of an oval plate. Colliculum apparently a slender long tube.

Material examined: Luzon, Mt. Makiling (Baker), 1 , holotype, genit. slide 5293 (USNM). 


\section{Hapsifera Zeller, 1847}

\section{Key to the Philippine Species of Hapsifera}

1. Forewing with strong raised crests of tufts, light fuscous, markings darker, much suffused . . . . . . . . . . . . . . . . H. rugosella

Forewing with slight tufts, ochreous whitish, markings dark brown.

H. albescens, new species

\section{Hapsifera rugosella (Stainton, 1859)}

Figures 384-385, 410-411a, 789

Cerostoma rugosella Stainton, 1859, Trans. Roy. Ent. Soc. London, ser. 2, vol. 5, p. 113 (sex?, Calcutta).-Walker, 1864, List Lepidopterous Insects British Mus., pt. 30, p. 1017.-Moore, 1867, Proc. Zool. Soc. London, p. 669.-Walsingham, 1885, op. cit., vol. 1885, p. 883.

Hapsifera rugosella Snellen, 1885, Tijdschr. Ent., vol. 28, p. 20, pl. 2, figs. 1-4 ( $\sigma^{\top}$, Celebes, new species!).-Fletcher, 1921, Mem. Dept. Agric. India, Ent. ser., vol. 6, p. 187; 1933, Imp. Counc. Agric. Res., Sci. Mon., no. 4, p. 81.-Meyrick, 1935, in Caradja and Meyrick, Materialien . . . , Microlepidopteren-Fauna . . . p. 93 (Shanghai); 1939, Expl. Parc Nat. Albert, pt. 14 , p. 27 , no. 89.

Cerostoma rugosellus.-Swinhoe, 1889, in Cotes and Swinhoe, Cat. Moths India, p. 709, no. 4839.

Dasyses rugosellus.-Durrant, 1903, Indian Mus. Notes, vol. 5, p. 104, pl. 15, fig. 3.-Fletcher, 1917, Rep. Proc. 2nd Ent. Meeting Pusa, p. 257.-1920,

Rep. Proc. 3rd Ent. Meeting Pusa, vol. 1, p. 165.

Dasyses rugosella.-Maxwell-Lefroy, 1909, Indian Insect Life, p. 540.-Meyrick, 1913, Ann. Transvaal Mus., vol. 3, p. 335 (Natal).

Psoricoptera? hirsutella Walsingham, 1881, Trans. Roy. Ent. Soc. London, p. 261, pl. 12, fig. 29.

Scalidomia hirsutella.-Walsingham, 1897, ibid., p. 65.

Distribution: Tropical Asia and Natal.

Material examined: Luzon, Los Baños, "Acc. no. 1229, Bur. Agr. P.I." (C.R. Jones), 2 ․ Luzon, Paniqui, Tavlas Prov., 22.I.1945, 1 우 (USNM). Agoo, La Union, 18.VII.1945 (J.G. Franclemont), 1 웅 (CUI).

It is remarkable that this species has been described as new two times under the same name "rugosella", first in 1859 by Stainton, as Cerostoma rugosella, new species, and afterwards by Snellen in 1885, as Hapsifera rugosella, new species!

\section{Hapsifera albescens, new species}

Figures 435, 774

Male, $17.5 \mathrm{~mm}$. Head pale fuscous grey, face with long, roughish scales, drooping down over mouth. Antenna creamy whitish. Palpi strongly diverging, pale ochreous inwardly, outwardly dark fuscous, dusted with blackish, top of median segment pale ochreous. Thorax creamy white. Abdomen pale ochreous. 
Forewing elongate-oval, costa gently curved throughout, more curved at extremities, apex obtusely pointed, termen rounded, very short. Creamy, markings formed by purplish-black dusting. Costa with a slightly postmedian irregularly semioval spot, not reaching cell; a roundish large dot on costa before apex, followed by two smaller dots, ultimate preapical; a series of very irregular spots and dots of diverse sizes along dorsum, in tornus and along termen; some 2 or 3 longitudinal marks along base of upper edge of cell; the whole wing strewn with blackish points, more numerous posteriorly and tending to form irregular spots, largest well before apex (absent in right wing). Cilia pale ochreous with a creamy-white base.

Hindwing pale greyish ochreous, finely strewn with pale fuscous, more densely so toward apex and throughout with a faint purple gloss. Cilia pale ochreous with a greyish subbasal shade and whitishcreamy base.

Male genitalia: Tegumen moderate, with rolled up edges, and an emarginate top. Uncus absent. Gnathos paired, each arm slightly sinuate, slender and pointed. Valva slender and rather long, cucullus rounded, sacculus $1 / 2$, well defined with a free obtuse top; beyond this there is a long sclerotized and slightly curved spike, reaching to the top of cucullus, with a dilated base. Vinculum V-shaped, saccus rather short, slender. Aedeagus long, moderately broad, slightly sinuate.

Material examined: Luzon, Mt. Makiling (Baker), $1 \sigma^{x}$, holotype, genit. slide 5291 (USNM).

\section{Trachycentra Meyrick, 1886}

\section{Trachycentra cicatricosa Meyrick, 1922}

Figures 446, 777

Trachycentra cicatricosa Meyrick, 1922, Exotic Microlepidoptera, vol. 2, p. 598

( + , Manila).-Clarke, 1955, Catalogue . . Microlepidoptera . . . Meyrick, vol. 1, p. 90.

Distribution: Luzon, Manila.

The type specimen, unique, is in the Paris Museum, genit. slide 5507 (the abdomen has been damaged by ?Adephaga and the bursa copulatrix is missing).

Female genitalia: Apophyses very long and strong, bases slightly dilated and truncate. Sterigma little sclerotized, V-shaped. Ductus bursae simple. Ovipositor bipartite.

\section{Tinissa Walker, 1864}

Key to the Philippine Species of Tinissa

1. Males . . . . . . . . . . . . . . . . . . . . . . 2

Females . . . . . . . . . . . . . . . 3 
2. Forewing moderately but distinctly dilated, purplish fuscous, irregularly marked with roundish black-edged dots, especially arranged along margins.

T. torvella

Forewing pale ochreous with numerous and close transverse dark fuscous strigulae . . . . . . . . . . . . . . . . T. baliomicta

3. Forewing with a narrow straight white oblique line from dorsum near base toward costa . . . . . . . . . . . . . . . . . T. baliomicta

Forewing without such line ............ T. torvella

\section{Tinissa torvella Walker, 1864}

Figures 428-432, 775

Tinissa torvella Walker, 1864, List Lepidopterous Insects British Mus., pt. 29, p. 780 (patria ignota, ) ).-Fletcher, 1929, Mem. Dept. Agric. India, Ent. ser., vol. 11, p. 224.-Diakonoff, 1948, Treubia, vol. 19, p. 218 (Buru).

Distribution: India, Ceylon, Sumatra, Borneo, Java, Buru.

Material examined: Luzon, Mt. Makiling (Baker), $10 \sigma^{7}$, genit. slide 5264, 5274, 3 ㅇ; "Tinissa baliomicta Meyr., Paratype," 1 ㅇ. Palawan, Puerto Princesa, October 1925, 1 \%, "Tinissa torvella Walk., Det. J.D. Bradley, 1949," genit. slide 5263. Mindanao, Kolambugan, 25.VI.1915, 1 우. 10 우, 6 우 (USNM).

Male genitalia: Tegumen bipartite, each half concave, semiovoid, at end sclerotized, narrowed, top dilated and truncate, bristly. Uncus absent. Gnathos, socius absent. Transtilla paired, a slender and long rod on each side, joined to the base of the costa. Vinculum large, conical, saccus broadly triangular, moderately long. Valva very small, articulate, strongly sclerotized, base cylindrical, apical part (cucullus) verrucose and bristly, top irregularly serrate. Anellus complicated, tubular, encircling aedeagus, anellus lobes rising, subcircular; distally from these, an elevated bristly knob. Aedeagus tubular, very long and slender, base dilated.

Female genitalia: Sterigma strongly sclerotized, lamella antevaginalis, a trapezoidal dark plate with two dentations at top; ostium, a dark cylinder behind this lamella. Eighth tergite modified, a dilated and cordiform plate, tops bristled. Ductus and corpus bursae simple.

\section{Tinissa baliomicta Meyrick, 1928}

Figures 423, 776, 778

Tinissa baliomicta Meyrick, 1928, Exotic Microlepidoptera, vol. 3, p. 424 ( Philippine Is.).-Clarke, 1955, Catalogue . . . Microlepidoptera . . . Meyrick, vol. 1, p. 63.

Distribution: Philippine Is., Luzon, Mt. Makiling.

Male, neallotype, $16 \mathrm{~mm}$. Head creamy white. Maxillary palpus with apical segment covered with strongly diverging scales, fanlike, pure white. Labial palpus white, median segment along upper edge 
dark purplish fuscous, fringe of lower edge suffused with fuscous on lower half throughout, terminal segment with a strongly oblique median band. Antenna creamy. Thorax creamy yellowish. Abdomen creamy yellowish, venter yellowish white with a pair of sublateral narrow black stripes, valva with a median black stripe. Posterior tibia creamy white, posterior half of upper edge with an expanded tuft of scales, triangularly prominent at the beginning, rounded at the end, pale greyish ochreous, appearing grey in certain lights.

Forewing sublanceolate, rather narrow. Creamy, with numerous fuscous-grey transverse strigulae, scattered all over the wing, except along costa anteriorly; base of costal edge suffused with grey; an inwards-oblique grey transverse mark from costa well beyond base, dilated at the end, not reaching base of wing; plical stigma larger than other markings, round, at $1 / 3$ of wing length. Cilia whitish ochreous, tinged brighter yellow along costa and around apex, opposite apex tipped slightly with dark.

Hindwing semipellucent pale golden yellowish, veins deeper yellow. Cilia whitish yellow.

The female posterior tibia (missing in the holotype) is covered with roughly rising scales along anterior half, with a triangular dense tuft well before apex and a rounded tuft at apex, in fact similar to that in the male, but more infuscated above and beneath, with a broad dark fuscous band including the triangular tuft. Spurs dilated by a fringe of bristly grey scales along posterior edge.

Male genitalia rather differing from these of the type species, $T$. torvella Walker. Tegumen similar, but less sclerotized, less narrowed tops simply truncate. Vinculum moderate, annular; saccus very long, slender. Valva semiconical, concave, broad at base, cucullus narrowed, conical, rounded. Sacculus represented by a thin marginal rod and a second ventral top of valva, with a large transverse filamentous top. Costa of valva with a moderate triangular hairy process. There is a slender process at the middle of the base of valva, directed rostrad. Anellus moderately oval, forming a central tube. Aedeagus extremely long and slender.

Female genitalia: Eighth tergite dilated, oval. Sterigma strongly sclerotized and hairy, shaped as an inverted large W. Ostium small, dilated at the top. Ductus and corpus bursae simple, unarmed, finely transversely plicate.

Material examined: Luzon, Mt. Makiling (Baker), 2 o $\sigma^{\top}$, genit. slide 5265, neallotype, 10 ㅇ, genit. slide 5266 (USNM). Benguet Subprov., Palali, 2000 ft., 20.XII.1912 (A.E. Wileman), 1 우 (Rothschild bequest, BM). Also Singapore (Baker), 1 ơ (USNM). 


\section{Monopis Hübner, 1826}

\section{Key to the Philippine Species of Monopis}

1. Forewing blackish with a light costal spot . . . . . . . . . . . . . . 2 Forewing purplish fuscous, with a pale yellow subbasal band and a costal spot.

M. avara

2. Costal spot inverted-trapezoidal, pure white M. monachella Costal spot semioval, white, centered with pale yellow suffusion.

M. hemicitra

Monopis hemicitra Meyrick, 1907

Figures 442-444, 780

Monopis hemicitra Meyrick, 1907, Journ. Bombay Nat. Hist. Soc., vol. 17, p. 417. (Ceylon, $\sigma^{7}$ \%).-Fletcher, 1921, Mem. Dept. Agric. India, Ent. ser., vol. 6, p. 194 (India).-Clarke, 1955, Catalogue . . . Microlepidoptera . . . Meyrick, vol. 1, p. 156.

Monopis prosarithma Meyrick, 1928, Exotic Microlepidoptera, vol. 3, p. 425 (Philippine Is., §).-Clarke, 1955, Catalogue . . Microlepidoptera . . . Meyrick, vol. 1, p. 260 [new synonym].

Distribution: Ceylon, India, Philippine Is.

Food: Bred from a mantid egg-mass (India).

Material examined: Luzon, Mt. Makiling (Baker), “30," "Monopis prosarithma Meyr., Paratype" (1 ) : 2 \%; Los Baños, 2 ๙ $\sigma^{7} 1$ \%, genit. slide $5283 \sigma^{\top 7}$ (USNM). Agoo, La Union, 10.VIII.1945 (J.G. Franclemont), 1 \%, genit. slide 5104. $2 \sigma^{7}, 4$ ㅇ (CUI).

The present topotypical material from Mt. Makiling proves the above synonymy. $M$. prosarithma was described after a single female (type apparently lost), which differed by the neuration of the forewing (veins 7 and 8 long-stalked, 9 separate) and by grey cilia of the hindwings. I find these veins in all the present specimens coincident (vein 7 or 8 absent), while one female has also yellow cilia in the hindwing.

Female genitalia: Sterigma weak, a slender and small flattened funnel, with a deeply emarginate ventral edge. Ductus and corpus bursae membranous. Signum absent. Lobi anales long-pointed. Anapophyses pointed at top and slightly sinuate. Both pairs of apophyses slightly and abruptly dilated at base.

Male genitalia: Tegumen and gnathos together forming a sclerotized tube. Uncus well defined, top with two small subascending processes. Hook of gnathos bipartite, halves pointed, rather short, sclerotized and united. Vinculum, a slender ring with prominent lateral angles. Saccus very long and slender, gently dilated beyond base. Valva much larger than in $M$. monachella, robust, subrectangular, cucullus slightly dilated, truncate; with inner edge forming an elevated obtuse ridge along its entire length. Aedeagus long, slender, spindle-shaped in middle, base dilated. 


\section{Monopis monachella (Hübner, 1796)}

Figure 779

Tinea monachella Hübner, 1796 [Tineae], in Sammlung Europäischer Schmetterlinge, pt. 8, p. 65, pl. 21, fig. 143.

Blabophanes monachella.-Meyrick, 1883, Ent. Monthly Mag., vol. 20, p. 36; 1894, Trans. Roy. Ent. Soc. London, p. 27.

Monopis monachella.-Meyrick, 1895, Handbook British Lepidoptera, p. 785.Semper, 1902, Schmetterlinge Philippinischen Inseln, vol. 2, p. 705.Meyrick, 1914, Ent. Mitteil. Suppl., vol. 3, p. 59; 1928, Rev. Handbook British Lepidoptera, p. 823; 1930, in de Joannis, Ann. Soc. Ent. France, vol. 99, p. 742.-Walsingham 1897, Trans. Roy. Ent. Soc. London, p. 63; 1907, in Sharp, Fauna Hawaiiensis, vol. 1, pt. 5, p. 727.-Rebel, 1901, in Staudinger and Rebel, Cat. Lepidopteren palaearktischen Faunengebietes, pt. 2, p. 236, no. 4536.-Fletcher, 1920, Mem. Dept. Agric. India., Ent. ser., vol. 6, p. 194; 1933, Imp. Counc. Agric. Res., Sci. Mon., no. 4, p. 74.-Pierce and Metcalfe, 1935, Genitalia Tineina British Is., p. 97, pl. 59-Diakonoff, 1948, Treubia, vol. 19, p. 219. [For more literature data cf. Walsingham, 1897, Trans. Roy. Ent. Soc. London, p. 63.]

Tinea longella Walker, 1863, List Lepidopterous Insects British Mus., pt. 28, p. 479.

Blabophanes longella.-Butler, 1881, Ann. Mag. Nat. Hist., ser. 5, vol. 7, p. 396, no. 29.-Walsingham, 1887, in Moore, Lepidoptera Ceylon, vol. 3, p. 503, pl. 209, fig. 1.

Distribution: Europe, Siberia, North America, Hawaii, Samoa, Philippine Is., Formosa, Tonkin, Sumatra, Java, Buru, India, Burma, Ceylon, West and South Africa.

Material examined: Luzon, Mt. Makiling (Baker) $1 \sigma^{\top}$, genit. slide 5275,1 우 (USNM).

Male genitalia: Valva with a straight costal edge, cucullus obtuse, obliquely truncate. Saccus very long and slender. Aedeagus a long and moderately wide tube. Uncus moderate, with a conical top. Gnathos, two slender, little sclerotized narrowed processes.

\section{Monopis avara Meyrick, 1919}

Figures 427, 434, 781

Monopis avara Meyrick, 1919, Exotic Microlepidoptera, vol. 2, p. 239 (Bombay, $\left.\sigma^{7}\right)$; 1929, in de Joannis, Ann. Soc. Ent. France, vol. 98, p. 742 (Tonkin).Clarke, 1955, Catalogue . . Microlepidoptera . . Meyrick, vol. 1, p. 62 (Klondyke, Benguet, Luzon 800, 1.IV.1912 (AEW), 1 \%, genit. slide 5677).

Distribution: India, Tonkin.

Female, $11 \mathrm{~mm}$. Head pale yellow, palpus very short, blackish fuscous. Antenna dark fuscous bronze. Thorax dark fuscous bronze. Abdomen glossy grey fuscous, venter and anal tuft pale yellow.

Forewing elongate sublanceolate, dilated, costa curved posteriorly, apex rather pointed, termen rounded, strongly oblique. Dark bronze 
fuscous, except at base irregularly irrorated with yellowish white, more so towards costa posteriorly. Markings white, suffused with pale yellow. A large, semicircular patch on dorsum from just beyond base to slightly before middle, above not reaching costa; a semioval, strongly inwards-oblique patch occupying 3rd fourth of costa, dotted along costa with dark fuscous, adjacent to hyaline patch which is rounded and rather large; some coarse yellowish-white marbling and dotting below costa before apex, sometimes crossing to middle of termen. Cilia dark fuscous bronze, appearing pale grey in certain lights, with several irregular pale yellowish slender bars opposite middle of dorsum and a yellowish interrupted spot in tornus.

Hindwing bright brassy, cilia paler brassy whitish.

Female genitalia: Edge of the eighth segment aciculate, with a deep excision in middle; eighth tergite narrowed and rounded, edge hairy. Colliculum moderate, cylindrical, abruptly dilated at base. Signum, a circle of radially arranged needle-shaped sclerites.

Material examined: Luzon, Los Baños (Baker), 1 \%; "Acc. No. 1266, Bur. Agr. P.I." (B. Arce) 2 \%, genit. slide 5282, 5677. Total 4 ㅇ.

Larviparity: Several tropical species of Monopis are larviparous and probably parthenogenetic as well, e.g., the four species from New Guinea, M. victa, cuspidigera, lacticaput and hypochrysa (Diakonoff, 1955 p. 188). These species were represented by females only; the entire abdomen of every one was crammed with completely developed larvae (Diakonoff, 1952). Only one species from Sumatra and perhaps also the present species, are known to me to possess males beside larviparous females.

The specimen from Luzon, genit. slide 5282, might have been freshly reared from pupa; it was devoid of larvae. But the female from Klondyke, genit. slide 5677, proved again to be stuffed with developed larvae; I roughly estimate their number up to 200.

Since the Palaearctic Monopis Hübner species do not show any signs of larviparity, it seems probable that the tropical larviparous species form together a separate biological genus or subgenus; superficially, however, they have no differences from Monopis Hübner. I hope to elaborate this point later elsewhere.

The present material was compared with the holotype, ㅇ, from Belgaum, Bombay, genit. slide 4671 (in the British Museum). Another female specimen from Shillong, Assam, genit. slide 4675 (Meyrick coll.) appeared to be conspecific. A third specimen from the same collection from Cho-Ganh, Tonkin, is a male and seems to be the sex partner (USNM). 


\section{Setomorpha Zeller, 1852}

\section{Setomorpha rutella Zeller, 1852}

Figure 773

Setomorpha rutella Zeller, 1852, Lepidoptera Microptera ... Caffrorum ..., p. 94; 1854, Handl. Kngl. Vet.-Akad. (1852), p. 94; 1873, Verh. Zool.-Bot. Ges. Wien, vol 23, p. 223.-Walker, 1864, List Lepidopterous Insects British Mus., pt. 29, p. 708.-Zeller, 1877, Horae Soc. Ent. Rossicae, vol. 13, p. 206.-Walsingham, 1881, Trans. Roy. Ent. Soc. London, pp. 274, 287.Snellen, 1885, Tijdschr. Ent., vol. 28, p. 24.-Meyrick, 1911, Trans. Linn. Soc. London, ser. 2, vol. 14, p. 302.-Diakonoff, 1938, Treubia, vol. 16, pp. 399-414. [For a more complete list of literature and the very extensive synonymy (9 generic and 15 specific names) see Diakonoff, loc. cit., pp. 405409.]

Distribution: Circumtropical, in dried tobacco (Nicotiana tabacum).

Material examined: Luzon, Manila, "Acc. No. 201, Bur. Agr. P.I.," 1913 (O.W. Barett), 2 ơ , 4 ㅇ. "Acc. No. 201 Bur. Agr. P.I." (B. Arce), $2 \sigma^{\nwarrow}, 5$ ㅇ. Los Baños (Baker), 1 o 3 ㅇ. Infanto, 29.X.1906 $\left(\begin{array}{l}2 \\ \sigma^{\top}\end{array}\right)(\mathrm{USNM})$. Benguet, Palali, $2000 \mathrm{ft} ., 21$ and 23.XII.1912 (A.E. Wileman), 2 ㅇ. Baguio, 5000 ft., 3.XI.1912 (A.E. Wileman) (BM). Mindanao, X.1906, "feeding on mounts and dried insects," 2 ㅇ. “F.H.B. nr. 38054," "Washington," "issued 1.XI.1920," "in Caryota rumphiana from Java" (H.V. Gouldman), $1 \sigma^{x}$. And also from China, Hong Kong, bred from bird seed, 27.VII.1920, "nr. 1370," $1 \sigma^{7}$; total 9 주, 14 우 (USNM).

\section{Oxytinea, new genus}

Head roughly haired. Ocellus absent. Proboscis vestigial. Antenna serrulate, minutely ciliated, scape thickened and elongate, with a slight, bristly pecten. Labial palpus rather long, longer in female, curved, ascending, flattened laterally, diverging, rather slender, lower edge throughout with a long and rough fringe, median segment with long lateral and terminal setae, terminal segment about $1 / 2$, with rough scales above and beneath, obtuse. Maxillary palpus short, apparently three-jointed, roughly scaled on upper half, ascending, appressed to face. Thorax without a crest. Posterior tibia with long loose hairs above and beneath.

Forewing elongate-oval, with a long produced, acute apex, termen sinuate; with some spots of raised scales, a projecting tuft of rough scales beyond base of dorsum, all scales in posterior half roughly raised, veins on underside elevated and thickened by scales. Vein 2 from beyond middle, 3 from before angle, 4 from angle, 7 and 8 stalked, 7 to costa, from below upper angle of cell, 9 from angle, 10 absent, 11 from middle, parting vein present, to vein 5. Frenulum in male and female similar, stout, flattened, and pointed. 
Hindwing suboval, acutely pointed, $3 / 4$, cilia $3 / 4$; vein 2 from middle, 3 from 3/4, 4 from angle, 5-7 parallel.

Genitalia as described for the species below.

Type of the genus: Oxytinea galactodelta, new species (o'o).

Possibly related to Thyrsochares Meyrick from New Guinea, but differing by neuration of the forewing.

\section{Oxytinea galactodelta, new species}

Figures 436-437, 445, 478-480, 784, 786

Male $11 \mathrm{~mm}$; female, $14 \mathrm{~mm}$. Head in male dark fuscous, in female pale fuscous. Labial palpus light fuscous, dusted with darker, terminal segment dark fuscous. Antenna fuscous, pale ringed. Thorax dark fuscous. Abdomen pale fuscous greyish.

Forewing roughly scaled, all scales more or less raised. Light fuscous grey, densely suffused, irrorated and marbled with dark purplish fuscous; an elongate area (in female) from end of cell to lower part of termen, paler grey. Median third of costa with a strongly elongate, subtriangular pale ochreous spot, with posterior half obscured with fuscous except along costal edge. Cilia fuscous marbled with dark fuscous purple (in males worn).

Hindwing pale golden greyish, glossy; cilia concolorous.

Male genitalia: Tegumen and vinculum forming a rather broad complete ring, posterior edge of tegumen slightly excised. Sacculus moderate, rather slender. Uncus bipartite, each half with a broad base, narrowed apicad to a quadrate plate. Valvae with a broad base, almost touching one another, cucullus twice as narrow, top rounded; processus basalis developed. Aedeagus moderately long, slender, straight, dilated at base.

Female genitalia: Sterigma formed by an erect sclerotized plate with emarginate upper edge. Colliculum short and slender. Ductus and corpus bursae simple.

Material examined: Luzon, Los Baños (P.J. Baker), 1 o , holotype, genit. slide 5279, 1 \% , allotype, genit. slide 5280, 1 ণ $\sigma^{7}$, paratype. $2 \sigma^{7}, 1$ ㅇ (USNM).

\section{Haplotinea Diakonoff and Hinton, 1956}

Haplotinea Diakonoff and Hinton, 1956, The Entomologist, vol. 84, p. 31, figs. 1-6 (type species: Tinea insectella Fabricius, $1794=T$. misella auct. not Zeller).

The following group of rather uniform and very common tropical species was previously simply indicated as "Tinea." The male genital characters, however, assign them without doubt to the present genus. Females sometimes show considerable specializations, e.g., in H. subochraceella (Walsingham) which possesses a remarkable triple corethrogyne: large fans of dense hairs on extensile stalks. The 
species have usually broader wings than the type species: they are mostly uniform golden colored and devoid of markings and have yellow or orange heads. Some attain considerable size.

It appears that no lectotypes have been selected so far for certain of Meyrick's species. As it was necessary to have one lectotype available for checking of synonymies, established by Meyrick, this is selected on the following pages.

\section{Key to the Philippine Species of Haplotinea}

1. Forewing light yellow, more than terminal third pale purple.

H. cymopelta, new combination Not thus colored . . . . . . . . . . . . . . . . . . 2

2. Forewing ochreous golden . . . . . . . . . . . . . . . . 3

Forewing dark fuscous . . . . . . . . . . . . . . . . . . . . . 4

3. Hindwing pale ochreous golden . . . H. subochraceella, new combination Hindwing light violet purple. . . . . . . . . H. purpurascens, new species

4. Antenna with flagellum normal, not thickened, in cross section circular; white touched with ochreous . . . . . . . . H. hemilampra, new species Antenna with flagellum dilated and thickened, in cross section oval.

H. eurycera, new species

\section{Haplotinea subochraceella (Walsingham, 1886), new combination}

Figures 440-441, 449, 782

Tinea subochraceella Walsingham, 1886, Proc. Zool. Soc. London, p. 464, pl. 41, fig. 9.-Meyrick, 1930, in de Joannis, Ann. Soc. Ent. France, vol. 99, p. 743. ?Tireola [sic] subochraceella.-Meyrick, 1935, in Caradja and Meyrick, Materialien ... Microlepidopteren-Fauna . . ., p. 92.

Distribution: Ceylon, India, Burma, Tonkin, Formosa, ?China.

Compared with the type specimen, female, genit. slide $9596 \%$ in the British Museum. Also compared with two female specimens from India, North Coorg, Dibidi, genit. slides 4673 and 4674 . The female genitalia of all these appear to be similar.

Material examined: Luzon, Los Baños, $4 \sigma^{\nwarrow}, 2$ ㅇ, genit. slide 5284 (Baker); Mt. Makiling, $1 \sigma^{7}, 3$ ㅇ, genit. slides $5290 \sigma^{7}, 5281$ ㅇ (Baker); Mt. Apo, 70-B, 4 and 5.III.1945 (J. G. Franclemont), 1 ơ 1 ㅇ (CUI). Bambang, Nuova Vicaya, 21.VIII.1945 (D. Schiffer), 1 o , genit. slide 5100. Negros, Victorias, at light, 27.IX.1927, 1 \%; 30.X.1927, $1 \sigma^{7}$; 19.IX.1927, sugar cane, $S$. dulce, Sc 17a, $1 \sigma^{x} .9 \sigma^{x}, 7$ ㅇ (USNM). Luzon, Benguet, Klondyke, 800 feet and Baguio, 5000 feet, 13.III.1912-28.V.1912 and 4.VI.1913 (A. E. Wileman), 37 ○', 51 ㅇ, genit. slide 5671 ơ, ㅇ: 5672, 5679-81 (BM). Mindanao, Davao Prov., east slope of Mt. McKinley, $3000 \mathrm{ft}$., at light, 14, 24, and 25.IX.1946 (CNHM Philippine Exped. 1946-47, H. Hoogstraal), 3 ㅇ.

Male genitalia: Tegumen and vinculum, a complete broad ring. Saccus absent. Anellus moderate, tubular, with a dilated base. 
Uncus peculiar, bipartite, each half on a slender, angulate stalk, top dilated into an oval blade with an obliquely produced top. Aedeagus rather short and wide, apical part narrowed.

The sixth abdominal segment in the female bears at its posterior portion remarkably shaped corethrogyne structures homologous with the coremata in the male. This corethrogyne is formed by three completely expansible tubes, two dorsolateral and one dorsal, each crowned with a large fan of corrugated long and dense hairs. These fans can be almost completely retracted inside the respective tube, and this can be completely retracted inside the sixth segment. Figure 441 depicts the Philippine specimen with the corethrogyne in retracted position, figure 440, one of the Coorg specimens, with these organs completely extruded. Eighth segment with a wellsclerotized tergite, with a deep and narrow longitudinal median gully, sternite little modified; ostium rather wide, simple, with a sinuate lower edge, flanked by two prominences with sparse bristles. Ductus bursae with a complicated and plicate cestum. Corpus bursae simple.

The present genus is attributed to the subfamily Nemapogoninae (Zaguljaev, 1956) the species of which have mycetophagous life habits (Zaguljaev, 1964), at least in the Palaearctic region. Whether this is true for the tropical species, remains to be investigated. The present species has been collected in sugar cane fields in the Philippine Islands, even recorded "from sugar cane" (label references). I did not encounter the species in sugar fields in Pasuruan, Java, during an intense two-years collecting but easily collected it at light in the jungle. It seems improbable, therefore, that $H$. subochraceella would cause any injury to sugar cane. The larvae may live in decaying mouldy wood.

\section{Haplotinea purpurascens, new species}

Figures 462, 788

Male, $25 \mathrm{~mm}$. Head (damaged) and thorax light tawny ochreous. Antenna pale ochreous (damaged). Palpus slender, porrect, rather short; pale ochreous, median segment except base, fuscous. Abdomen pale ochreous.

Forewing rather narrow, oblong, suboval-lanceolate, costa little curved at base, more curved before apex, apex obtus ely pointed, termen rounded, oblique. Glossy pale ochreous, with a faint pinkish tinge in certain lights, especially towards apex; a faint blackish fuscous, very suffused streak along anterior fourth of costa from beyond base; a faint elongate patch in posterior half of cell, another in apex, somewhat denser ochreous pinkish, but ill defined. Cilia pale ochreous, along costa and in apex light tawny, elsewhere strewn with li ght tawny. 
Hindwing rather broad, tip moderately rounded; rather bright tawny purple, along termen becoming pale ochreous spotted with tawny purple, spots interconnected but small. Cilia pale ochreous, strewn with tawny.

Male genitalia: Tegumen + vinculum annular, less broad than in subochraceella. Uncus longer, each half abruptly narrowed beyond middle, top rounded-clavate, finely granulate, inwardly flattened. Valva with a shorter cucullus; costa forming a short, serrulate blade with another triangular blade below that, directed inwardly. Aedeagus slender, rather long.

Material examined: Luzon, Benguet Subprov., Klondyke, $800 \mathrm{ft}$., 6.IV.1912 (A.E. Wileman), $1 \sigma^{x}$, holotype, genit. slide 5673 (Rothschild bequest, $\mathrm{BM})$.

Very similar to $H$. subochraceella (Walsingham), but with distinctly colored light purple hindwings, narrower forewings and different genitalia.

\section{Haplotinea hemilampra, new species}

Figures 451, 787

Male, $12 \mathrm{~mm}$. Head white, vertex, orbits, and face suffused with grey. Antenna with flagellum normal, not thickened; white touched with ochreous (in cross-cut circular), scape short, cylindrical. Palpus fuscous. Thorax fuscous with a strong purple gloss. Abdomen fuscous.

Forewing ovate-sublanceolate, costa gently curved, apex pointed, termen rounded, oblique. Glossy light tawny fuscous, costal half of wing evenly suffused with dark fuscous purple. Cilia fuscous, dusted with darker fuscous.

Hindwing dark fuscous with a distinct coppery hue; costa with a depressed patch of dense whitish scales between margin and cell. Cilia fuscous with darker suffused basal half and a pale basal line.

Male genitalia: Tegumen + vinculum annular, rather broad, vinculum with a deep triangular excision. Valva almost quadrate, cucullus angle slightly prominent and rounded, costa narrowly sclerotized, with an inwards-turned apical pointed process. Anellus + juxta very small, shaped as small triangles flanking aedeagus. Uncus lobes long, moderately thickened in middle, top forming a slender strong process. Aedeagus short.

Material examined: Luzon, Benguet, Klondyke, 800 ft., $23 . I V .1912$ (A.E. Wileman), $1 \sigma^{7}$, genit. slide 5678, holotype (Rothschild bequest, $\mathrm{BM})$.

Allied to the preceding and to Haplotinea nestoria (Meyrick) (fig. 783), distinct from the latter by not dilated antenna and from the former by white head and antenna and differently colored forewings. 


\section{Haplotinea platyntis (Meyrick, 1894), new combination}

FIGURE 447

Tinea platyntis Meyrick, 1894, Trans. Roy. Ent. Soc. London, p. 28; 1911, Journ. Bombay Nat. Hist. Soc., vol. 21, p. 124.-Clarke, 1955, Catalogue . . Microlepidoptera . . Meyrick, vol. 1, p. 251.

Tinea platyntis Meyrick, 1894, lectotype herewith selected: male, labelled thus: "Koni, Burma, N.M., 88" (small label written in ink in Meyrick's hand). "Tinea subochraceella Walsingham 6/12, E. Meyrick det., in Meyrick Coll." "Meyrick Coll. B.M. 1938-290"; genit. slide 4721 (in the British Museum).

This specimen and three other syntypes of T.platyntis were arranged in Meyrick collection, in the series of "Tinea subochraceella Walsingham" and were labelled as such. These syntypes are: one male, "Koni, Burma, N.M., 88," "9/12," a female, with identical label, "8/12," and finally, a male without abdomen, "Mooltan, Punjab, N.M., 86, , “"2/12."

The study of the male genitalia reveals that $T$. platyntis Meyrick is a distinct species.

Male genitalia: More robust than in the preceding. Valva more concave. Uncus lobes rounded-triangular, arranged asymmetrically, right turned down (this position was found invariable also in specimens from Java). Juxta + anellus triangular.

\section{Haplotinea eurycera, new species}

Figures 448, 785

Male, $15 \mathrm{~mm}$. Head snow white, tuft on face edged below with a few dark fuscous hairs. Antenna strongly thickened, flattened dorsoventrally, glossy snow white (oval in cross section); scape short, cylindrical. Palpus dark fuscous, tip whitish in certain lights. Thorax purplish fuscous. Abdomen pale fuscous brassy.

Forewing pale fuscous with a strong gloss, purple in certain lights, a darker fuscous streak along costa from base to apex, sometimes from base to middle. Cilia brassy fuscous with a faint darker median line.

Hindwing paler, pale brassy fuscous, becoming whitish towards base, yellowish towards edge. Cilia fuscous golden, with a pale yellowish base in certain lights.

Male genitalia: Tegumen and vinculum completely joined so as to form a broad ring. Uncus formed by two transverse small sclerites, narrowed mesiad and joined so as to form a strong furcate projecting part. Valva small, short, irregularly quadrate, thickened and padlike sacculus triangularly prominent, cucullus with an impression below top. Juxta small, transverse. Anellus short, tubular. Aedeagus rather short, not dilated. 
Material examined: Luzon, Mt. Makiling, Los Baños (Baker), $10^{7}$, holotype, genit. slide 5278; $1 \sigma^{\top}$, paratype, genit. slide 5122; $3 \sigma^{\top}$, paratypes (USNM).

Identified by Meyrick as Tinea nestoria Meyrick, 1910 (Rec. Ind. Mus., vol. 5, p. 231) (figs. 450, 783). The type of that species, apparently in the Indian Museum, Calcutta, was not available. The Philippine material was compared with three specimens available in the Meyrick collection, and proved to be distinct. The males may be discriminated immediately by conspicuously more thickened and flattened white antennae and also by slightly darker coloring in eurycera.

The material of nestoria studied was labelled thus: "Dalhousie, Kashmir (R.), 5.91" (in Meyrick's hand); "Tinea nestoria Meyr., 1/3, E. Meyrick det., in Meyrick Coll.," "Meyrick Collection, B.M. 1938-290"; 1 우 (BM). "Kasauli, Himalaya (T.B.F.), 10," “2/3," etc.; $1 \sigma^{7}$ and "Kasauli, Punjab, 6000 (P.J.B!)," (in Meyrick's hand, year illegible); “ $3 / 3$," etc., 1 o $\sigma^{\top}$, genit. slide 4672 (BM no. 10116) figured $(\mathrm{BM})$.

The species may be discriminated easily by pure white head and antennae (in Haplotinea nestoria (Meyrick) head white, antennae touched with ochreous), by broader, deeper bronze-colored forewings with stigma hardly discernible (in $H$. nestoria forewing narrow, more pointed, paler, with a distinct stigma).

The male genitalia which are distinct, are depicted on figure 450 .

\section{Haplotinea cymopelta (Meyrick, 1925), new combination}

Figures 452, 790

Tinea cymopelta Meyrick, 1925, Treubia, vol. 6, p. 432 ( ఠ’, Kei Is.).-Clarke, 1955, Catalogue . . . Microlepidoptera . . . Meyrick, vol. 1, p. 110.

Distribution: Kei Is.

Material examined: Luzon, Mt. Makiling (Baker), 2 б, 2 우 (genit.

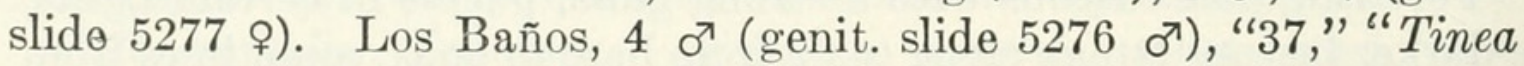
cymopelta Meyr." $6 \sigma^{\top}, 2$ ㅇ (USNM). Luzon, Benguet Subprov., Sapiangao, 5000 ft., 15.XII.1912 (A.E. Wileman), 1 o (BM). Although not yet recorded from elsewhere, probably widely distributed throughout the Indo-Malayan region.

Male genitalia: Tegumen and vinculum annular, moderately broad, vinculum ventrally is bent and convex rostrally, top of tegumen moderately and rather narrowly produced (caudad) to support the uncus. Uncus rather small, with two slender porrect points. Valva oval, rather broad, with a slender tooth in middle of disc just below outer margin of cucullus. Anellus single. Aedeagus moderate, apical third rather narrow and curved, median third spindle-shaped, basal third much dilated. 
Female genitalia: A large corethrogyne is present in a sacklike structure of the seventh sternite. Sterigma not modified, except for a spindle-shaped dilatation.

\section{Coryptilum Zeller, 1839}

\section{Key to the Philippine Species of Coryptilum}

1. Light markings bright yellow; sacculus lobe as long as cucullus.

C. luteum, new species Light markings reddish orange; sacculus lobe shorter than cucullus.

C. klugii

\section{Coryptilum klugii Zeller, 1839}

Figures 459, 791

Coryptilum klugii Zeller, 1839, Isis, vol. 32, p. 181.-Snellen, 1875, Tijdschr. Ent., vol. 19, p. 53, pl. 2, fig. 6.-Pagenstecher, 1894, Jahrb. Nassauischen Ver. Naturk., p. 43; 1897, Lepidoptera in Kükenthal's Forschungsreise, p. 467.Walshingham, 1900, Cat. Lep. Het. Mus. Oxon., vol. 2, p. 580.-Semper, 1902, Schmetterlinge Philippinischen Inseln, vol.2, p.705.-Meyrick 1907, Proc.Linn. Soc. New South Wales, vol. 32, p. 83.-Diakonoff 1955, Verh. Ned. Akad. Wet., Nat., ser. 2, vol. 50, no. 3, p. 134.

Sippharara euchromella Walker, 1866, List Lepidopterous Insects British Mus., pt. 35 , p. 1822.

Sippharara woodfordi Druce, 1888, Proc. Zool. Soc. London, p. 579. pl. 29, fig. 8.

Distribution: Malaya, Java, Sumatra, Borneo, Celebes, Moluccas, Philippine Is., Mindanao; Solomon Is., New Guinea, Rossel Is.

Material examined: "Bulacan," September 1917 (B.P. Clarke), $1 \sigma^{\top}$ (USNM) (locality uncertain; places of this name are situated in Luzon as well as in Samar).

\section{Coryptilum luteum, new species}

Figures 460, 792

Male, 40-42 mm. Head and palpi black, median segment of labial palpus internally grey. Antenna blackish grey. Thorax bright yellow, anteriorly faintly suffused with orange, anterior marginal band between tegulae and an apical spot, black. Abdomen black, venter yellow. Legs yellow more or less suffused with black.

Forewing elongate-elliptical, rather narrow, costa rounded, more so at extremities, apex rounded, termen rounded, strongly oblique. Bright yellow. Costal edge black, along posterior fifth cilia yellow, black costal edge continued as a narrow line to apex; an ill-defined orange suffusion over base of wing and narrowly below costa, against black edge turning crimson purple; an oblique transverse black patch from $4 / 5$ of costa not reaching termen, traversed by several horizontal rows of brilliant greenish blue scales; a semioval black streak along dorsum, almost touching vein 2 , its anterior half narrower, strewn 
with similar metallic scales, sometimes exceeding dark spot and reaching along dorsal margin to tornus. Cilia ochreous yellow.

Hindwing with basal $2 / 3$ black, apical $1 / 3$ ochreous yellow; edge of black part inbent below costa, thence very gently convex. Cilia concolorous with respective parts.

Male genitalia: Vinculum very strong, forming a vertical ring, upon which are implanted dorsal halves of the valvae, having a broad base and triangularly narrowed top, ending in a hairy cucullus projection; sacculus half of valva forming a separate broad oval lobe, as long as cucullus. Saccus robust, a long, dark appendix. Uncus represented by a horizontal plate, projecting craniad as a rather long obtuse lobe, caudad excavated, with a cusp on each side. Aedeagus moderately curved and gradually narrowed, with a short tooth above orifice.

Material examined: Mindanao, Mt. Apo, Todaya Plateau, 4000 ft., 8.X.1930 (C.F. Clagg), $1 \sigma^{7}$, holotype, genit. slide 5723, $1 \sigma^{7}$, paratype, worn, "Philippines, Ber. Gesh." (CMP), 2 o .

A distinct species by brighter yellow instead of red-orange color as in $C$. klugii Zeller, and also by the male genitalia. In the last mentioned species the sacculus lobe is shorter than cucullus and is more truncate. (Specimen of $C$. klugii compared, Java, genit. slide 5724, LM.)

\section{Melasina Boisduval, 1840}

\section{Melasina anarmosta, new species}

Figures 453, 793

Male, 12-14 mm. Head pale ochreous yellow, antenna dark fuscous, pectinations about 3 . Palpus rather short, straight; grey fuscous, median segment with a pale ochreous spot at apex below inwardly median segment at top and terminal segment except base, pale ochreous. Thorax dark fuscous grey, posterior half pale ochreous, edge strongly suffused. Abdomen pale greyish, anal tuft whitish.

Forewing oval, rather broad, broadest in middle. Pale ochreous, markings fuscous, purplish tinged, formed of irregular spots and marbling. An elongate spot along base of costa followed by a dot; more than central third of costa occupied by a series of more or less interconnected dots and spots; three separate and more distant dots on costa before apex; a slightly undulate and outwards-convex, spindle-shaped transverse mark, with inner edge almost straight and slightly outwards-oblique; this mark resting on dorsum before middle, reaching to below costa, and almost connected by some marbling with costal marks; about two transverse interrupted series of very slender marks between this and base; posterior third of wing dotted, marbled and strigulated, a somewhat larger rounded dot on lower angle of cell. Cilia pale ochreous yellow. 
Hindwing pale ochreous greyish. Cilia pale ochreous.

Male genitalia: Tegumen, a broad semiannular structure with a small notch at the top. Vinculum rather broad, but smaller than tegumen, saccus moderate, slender. Valva moderate, oval, concave; saccus $3 / 4$, ill defined, but with a separate clavate and denticulate top; cucullus, a slender process, bristled below except at base; harpe, a pyramidal process in disc, with a bristly top. Aedeagus simple, moderately long, straight.

Material examined: Luzon, Mt. Makiling (Baker), $1 \sigma^{7}$, holotype, genit. slide $5292 ; 1 \sigma^{\nwarrow}$, paratype. $2 \sigma^{\nearrow}$ (USNM).

\section{Adelidae}

\section{Nemophora Hofmannsegg, 1798}

Key to the Philippine Species of Nemophora

1. Forewing brilliant golden, with a basal patch and a transverse fascia dull yellow . . . . . . . . . . . . . . . N. apollonis, new species Forewing not so colored . . . . . . . . . . . . . . . . . . . . . . 2

2. Thorax yellow . . . . . . . . . N. eurycitra, new combination Thorax brilliant metallic . . . . . . . . . . . . . . . . . . . . . 3

3. Forewing with a well-defined single or double transverse band . . . . . . 4 Forewing without a well-defined transverse band.

N. chalcotechna, new combination

4. Transverse band single, yellow, edged by black lines and by silvery fasciae.

N. heliochalca, new combination Transverse band double, whitish, with greenish brilliant scales, divided and edged by black lines ... . . . . N. cantharites, new combination

\section{Nemophora apollonis, new species}

FIgURe 794

Male, 13-14 mm. Head with vertex dull light ochreous yellow, frons brilliant golden, sides of face silvery. Eyes contiguous. Antenna along basal third pale ochreous banded with glossy whitish, median third whitish, apical third suffused with dull black. Palpus short, yellowish. Thorax brilliant golden, shoulder with a luminescent light violet spot. Posterior tibia brilliant pale golden, top of tibia pale violet, hairs pale yellow (abdomen lacking).

Forewing suboval, strongly dilated, broadest at $2 / 3$, apex rather obtuse. Brilliant golden, appearing pale golden in certain lights. Markings dull light yellow, partially edged posteriorly with opalescent light purple violet. A basal patch extending on costa beyond $1 / 5$, outer edge convex and strongly inwards oblique, in certain lights luminescent pale violet on costa. This patch containing a rounded spot at extreme base and a short streak along base of costa, of bril- 
liant ground color; transverse fascia median, rather inwards-oblique, gradually narrowed from costa to fold, thence abruptly much narrower to dorsum, this part gently outwards-convex; edges well defined, slightly undulate, posterior edge and anterior edge only on costa with luminescent pale violet spots in certain lights. Cilia brilliant golden, dull whitish along costa.

Hindwing glossy fuscous golden, cilia whitish golden.

Material examined: Mindanao, Kolambugan, June 1914 (C.S. Banks), $2 \sigma^{\pi}$, holotype, $13 \mathrm{~mm}$ (USNM). Unfortunately the abdomens are lost, but the species is still very distinct.

\section{Nemophora heliochalca (Meyrick, 1928), new combination}

Figures 468-469, 799

Nemotois heliochalca Meyrick, 1928, Exotic Microlepidoptera, vol. 3, p. 464. Clarke, 1955, Catalogue . . . Microlepidoptera . . . Meyrick, vol. 1, p. 155.

Distribution: Philippine Is.

Material examined: Mindanao, Kolambugan, June 1914 (C.S. Banks), $5 \quad \sigma^{x}$, all worn, abdomens missing. Luzon, Mt. Makiling (Baker), $1 \sigma^{7}$, in excellent condition, genit. slide 5286 (USNM).

Male genitalia: Tegumen moderately rounded. Valva with a bulbous base, cucullus almost twice as narrow, top rounded. Sacculus triangular, very large.

\section{Nemophora cantharites (Meyrick, 1928), new combination}

FIgURE 797

Nemotois cantharites Meyrick, 1928, Exotic Microlepidoptera, vol. 3, p. 464.Clarke, 1955, Catalogue . . Microlepidoptera . . Meyrick, vol. 1, p. 73.

Distribution: Philippine Is.

Material examined: Mindanao, Kolambugan, June 1914, 3 ㅇ, one labelled "Nemotois cantharites Meyr. Paratype" (USNM).

\section{Nemophora chalcotechna (Meyrick, 1937), new combination}

Figures 463-464, 798

Nemotois chalcotechna Meyrick, 1937, Arb. morphol. taxon. Ent. Berlin-Dahlem, vol. 4, no. 3, p. 204.-Clarke, 1955, Catalogue . . Microlepidoptera . . . Meyrick, vol. 1, p. 81 .

Distribution: Philippine Is.

Material examined: "Mindanao, Momungan," "Staudinger \& Bang Haas dedit" "36," "type," "Nemotois chalcotechna Meyr." (in Meyrick's hand), holotype, o⿱ (DEI). A rubbed specimen with abdomen missing. Mindanao, Surigao (Baker), $1 \mathrm{o}^{x}$, strongly defaced, genit. slide 5287 (USNM). Mindanao, Lanao, plains, Kolambugan, 16.VI.1914 (A.E. Wileman), 1 \%, defaced (BM). 
The species is very similar to $N$. tristrigella Walker but male genitalia are distinct.

Male genitalia: Resembling those of $N$. tristrigella Walker, but differing as follows: Tegumen more pointed. Socius larger, transtilla ill defined. Valva over 1, without longitudinal ridges. Cucullus rounded. Sacculus distinctly rounded and prominent (in tristrigella rounding and prominence much longer); basal angles of valvae slightly produced. Aedeagus similar.

\section{Nemophora eurycitra (Meyrick, 1928), new combination}

Figures 467, 795-796

Nemotois eurycitra Meyrick, 1928, Exotic Microlepidoptera, vol. 3, p. 463.Clarke, 1955, Catalogue . . . Microlepidoptera . . . Meyrick, vol. 1, p. 135.

Distribution: Philippine Is.

Material examined: Luzon, Mt. Makiling (Baker), 1 ㅇ (with both forewings severed and glued on top of the thorax, but entirely unrubbed; redescribed below), genit. slide 5434. Mindanao, Kolambugan, June 1914 (C.S. Banks), 1 o", 2 ㅇ. "Nemotois eurycitra Meyrick. Paratype," "65" (USNM). Male abdomen is missing. Mindanao, Lanao, plains, Kolambugan, 19.X.1914, 1 б', neallotype, genit. slide 5689 (A.E. Wileman) (BM).

Male, $16 \mathrm{~mm}$, neallotype, hereby designated (worn). Head light yellow. Eyes not touching, very narrowly separated. Antenna greyish ochreous. Markings of forewings exactly similar to those of the female, except that the dark basal patch has a brilliant metallic green streak along costa from beyond base, not reaching posterior edge of patch. Hindwing paler fuscous purple.

The female specimen, genit. slide 5434, may be redescribed thus: 14 $\mathrm{mm}$. Head, palpus light ochreous. Basal portion of the antenna (apical part missing), ochreous, with long and dense hairs. Thorax yellow. Abdomen purplish, sides suffused with yellow, venter dark purple.

Forewing suboval, rather broad, dilated, broadest at $2 / 3$, obtuse. Anterior half of wing dark purple brown, with a deep metallic-blue streak along costa not reaching posterior edge of patch; this edge straight, inwards-oblique; patch containing an erected-triangular equilateral light yellow spot, with base along basal fourth of dorsum, with top to $3 / 4$ of wing width and $1 / 3$ of its length, suffusedly and faintly edged with metallic blue along upper, less so along posterior edge; an inwards-oblique bright yellow, dull transverse fascia, edged on both sides with briliant greenish-silvery streaks, anterior straight, bordering to the dark purple portion of wing, posterior metallic streak slightly undulate, short-int rrrupted above middle of wing, and minutely edged with black anteriorly; apical portion of wing beyond 
this dull olive brownish, anterior edge suffused with pale yellow, a faint transverse band of pale yellow sprinkling beyond this; containing in middle two ill-defined brilliant metallic violet-blue round spots partially edged with blackish suffusion; a series of jet-black dull narrow streaks along posterior parts of veins, abruptly dilated and partly united into an irregular black marginal band, appearing brilliant blue violet in certain lights. Cilia purplish fuscous, basal half brilliant blue violet in certain lights.

Hindwing rather dark bronze purple, cilia concolorous.

Female genitalia: Genital segments hardly modified, conical sclerotized, minutely aciculate and with regularly spread rather long bristles.

\section{References}

Clarke, J. F. Gates

1955-1965. Catalogue of the type specimens of Microlepidoptera in the British Museum (Natural History) described by Edward Meyrick, vol. 1 (1955), pp. i+332 incl. 3 pls.; vol. 2 (1955), 531 pp. incl. 263 pls.; vol. 3 (1958), 600 pp. incl. 298 pls.; vol. 4 (1963), 521 pp. incl. 252 pls.; vol. 5 (1965), 581 pp. incl. 283 pls.

Diakonoff, A.

1952. Viviparity in Lepidoptera. Trans. Ninth Intern. Congr. Ent. Amsterdam, vol. 1, pp. 91-96, figs. 1-2.

1954. Microlepidoptera of New Guinea: Results of the Third Archbold Expedition (American-Netherlands Indian Expedition 1938-1939), pt. 4. Verhand. Koninkl. Nederlandse Akad. Wet., Afd. Natuurk., ser. 2, vol. 50, no. 1, pp. 1-199, figs. 552-719.

1955. Microlepidoptera of New Guinea: Results of the Third Archbold Expedition (American-Netherlands Indian Expedition 1938-1939), pt. 5. Verhand. Koninkl. Nederlandse Akad. Wet., Afd. Natuurkunde, ser. 2 , vol. 50 , no. 3 , pp. 1-210, figs. $720-861$.

1958. A Note on Microlepidoptera from South China. Beitr. zur Ent., vol. 8, pp. 118-122.

1965. The microlepidopterous fanua of the Philippine Islands. Proc. 12th Intern. Congr. Ent. London, 1964, pp. 443-444.

Dickerson, Roy E., et al.

1928. Distribution of life in the Philippines, 322 pp., 42 pls.

Engelhardt, G. P.

1946. The North American clear-wing moths of the family Aegeriidae. U.S. Nat. Mus. Bull., no. 190, 222 pp., 32 pls.

Fletcher, J.

1920. Life histories of Indian insects: Microlepidoptera. Mem. Dept. Agric. India, Ent. ser., vol. 6, pp. 1-217, pls. 1-68.

Hannemann, H. J.

1961. Kleinschmetterlinge oder Microlepidoptera, 1: Die Wickler (s. str.) (Tortricidae). In F. Dahl, Die Tierwelt Deutschlands, vol. 48, 233 pp., 5 graphs, 22 pls., 466 figs. 
MEYRICK, E.

1905. Tortricinae and Tineina, no. 12. In The Percy Sladen Trust Expedition to the Indian Ocean in 1905, pp. 263-307.

1910. Descriptions of Malayan Micro-Lepidoptera. Trans. Ent. Soc. London, pp. 430-478.

1923-1930. Exotic Microlepidoptera, vol. 3, 640 pp.

Pagenstecher, $\mathrm{S}$.

1909. Die geographische Verbreitung der Schmetterlinge, pp. ix +451 , 2 maps.

PENCK, F. C.

1894. Morphologie der Erdoberfläche, vol. 2, 696 pp.

Popescu-GorJ, A.; Niculescu, E.; and Alexinschi, A.

1958. Lepidoptera, familia Aegeriidae. In Fauna Republicii Populare Romine. Insecta, vol. 11, fasc. 1, 195 pp., 59 figs., 5 pls.

Semper, G.

1902. Die Schmetterlinge der Philippinischen Inseln, vol. 2, pp. 382-727, pl. C-V, 50-66.

ZagulJaev, A. K.

1964. Tineidae, 2: Subfamily Nemapogoninae. In Fauna of U.S.S.R.: Lepidoptera, vol. 4, fasc. 2, pp. 1-424, figs. 1-385, pls. 1-2. [In Russian.] 


\section{Appendix 1}

Selection of Lectotypes for Some Formosan Species of Glyphipterygidae, Described by E. Meyrick

In the course of the present study, I received original series of certain Formosan species for comparison with the Philippine material, kindly sent by the Deutsches Entomologisches Institut, Berlin, Germany. This opportunity is taken for the selection of lectotypes for some of these and one more species and also to figure them and their genitalia.

\section{Imma lathidora Meyrick, 1914}

Figures 813, 824

Imma lathidora Meyrick, 1914, Suppl. Ent., no. 3, p. 56.

Male genitalia: Tegumen and uncus membranous. Valva with cucullus rather weak, entirely membranous at base; sacculus $1 / 2$, slightly sclerotized, ending in several hairy folds and prominences and with a long, curved apical spike.

The unique holotype, $\sigma^{7}$, is labelled: "Typus," "Suisharyo, Formosa, H. Sauter, X.11." "F 107," "Meyrick det," "Dtsch. Entomol. Institut Berlin," genit. slide 4949.

\section{Imma fungosa Meyrick, 1914 \\ Figure 825}

Imma fungosa Meyrick, 1914, Suppl. Ent., no. 3, p. 56.

The unique holotype, $\circ$, is labelled "Typus," "Suisharyo, Formosa, H. Sauter, .12," "F 108," "Meyrick det." "Dtsch. Entomol. Institut Berlin." The abdomen is lacking.

\section{Imma arcifraga Meyrick, 1914}

Figures 814-815, 827

Imma arcifraga Meyrick, 1914, Suppl. Ent., no. 3, p. 57.

Male genitalia: Tegumen high, submembranous, shoulders moderately sclerotized. Uncus, a large pointed hook. Vinculum moderate. Socii absent. Valva semimembranous, concave lengthwise; sacculus over $1 / 2$, a weak hairy tumescence; cucullus rounded, with a curved appressed hook. Aedeagus little curved, slightly sclerotized.

Lectotype, $\sigma^{x}$, hereby selected, labelled thus: "Typus," "F 100," "Suisharyo, Formosa, H. Sauter, .12," "Meyrick det.," "Dtsch. Entomol. Institut Berlin," genit. slide 4948. Further material: 3 \%, the same locality, X.11; marked as "paratypes." 


\section{Imma palaeodes Meyrick, 1914}

Figures $816-817,826$

Imma palaeodes Meyrick, 1914, Suppl. Ent., no. 3, p. 57.

Male genitalia: Tegumen very short, subconical. Uncus, a long curved hook. Socius long, clavate, on a slender stalk. Vinculum long, forming a considerable saccus. Valva strongly narrowed, sacculus 1 , ending in an upturned cusp, costa narrow, with a curved and obliquely truncate top. Juxa inverted-triangular, very large. Aedeagus rather narrow, long.

Lectotype, $\sigma^{7}$, hereby selected, labelled as follows: "Typus," "106," "Kankan (Koshung), Formosa, H. Sauter, VII.1912," "Meyrick det.," "Dtsch. Entomol. Institut Berlin," genit. slide 4947. Further material: $1 \sigma^{\gamma}, 1$ \% from Suisharyo, X.II, H. Sauter; marked as "paratypes."

\section{Lamprystica purpurata Meyrick, 1914}

Figures $818-819$

Lamprystica purpurata Meyrick, 1914, Suppl. Ent., no. 3, p. 58.

Male genitalia: Tegumen low, almost semicircular. Uncus apparently absent. Tuba analis moderate, narrowed, slightly sclerotized and replacing uncus. Gnathos, a large median process with a circular finely aciculate top. Vinculum semicircular. Valva simple, narrow, top obtusely pointed and finely bristled. Anellus large, circular. Anellus lobes slender, digitoid. Aedeagus huge, with a median broad circular collar of fine aciculations. Cornuti, fine scobinations.

Lectotype $\sigma^{7}$, hereby selected, labelled as follows: "Typus," "F 133," "Kosempo, Formosa, H. Sauter, VII.1911," "Meyrick det.," "Dtsch. Entomol. Institut Berlin," genit. slide 58. Further materal sent, marked as "paratypes:" $1 \sigma^{\top}$, the same locality and date as above, $1 \sigma^{\top}$, Hoozan, 1910, and 1 \%, Taihorin, I.1910. 


\section{Appendix 2}

\section{List of Selected Lectotypes}

Grapholitha (Sisona) albitibiana Snellen, 1902, ơ (Java) (LM)

Page Chrosis ephippias Meyrick, 1907, ơ (Ceylon) (BM)

Grapholitha schistaceana Snellen, 1890, סౌ (Java)

Canthonistis amphicarpa Meyrick, 1922, ơ (Java) (LM)

Onebala fibularis Meyrick, 1921, 우 (Java) (LM)

Ceratophora tristella Snellen, 1902, 우 (Java) (LM)

Harpella aureatella Snellen, 1903, ס (Java) (LM)

158

Sidyma aurantiaca Semper, 1899, ơ (Mindanao) (BM)

170

Sidyma basiflava Semper, 1899, o (Luzon) (SMF)

191

Tortricomorpha albotaeniana Sauber, 1901, o $\sigma^{7}$ (Luzon) (SMF)

192

Simaethis amethystodes Meyrick, 1914, סך (Philippines)

194

Xestocasis erymnota Meyrick, 1917, व (Mindoro) (BM)

Eretmocera bicolorella Sauber, 1902, व (Luzon) (SMF)

216

Teinoptila interruptella Sauber, 1902, o (Luzon, etc.) (SMF)

Psecadia magnificella Sauber, 1902, ㅇ (Luzon) (SMF)

236

Ethmia pullata Meyrick, 1910, ㅇ (Solomon Is.) (BM)

Tinea platyntis Meyrick, 1894, ơ (Burma) (BM)

256

Imma arcifraga Meyrick, 1914, व $\sigma^{7}$ (Formosa) (DEI)

289

Imma palaeodes Meyrick, 1914, $\sigma^{7}$ (Formosa) (DEI)

298

Lamprystica purpurata Meyrick, 1914, ơ (Formosa) (DEI) 


\section{Appendix 3}

\section{List of Species With Indications of Islands of Their Occurrence}

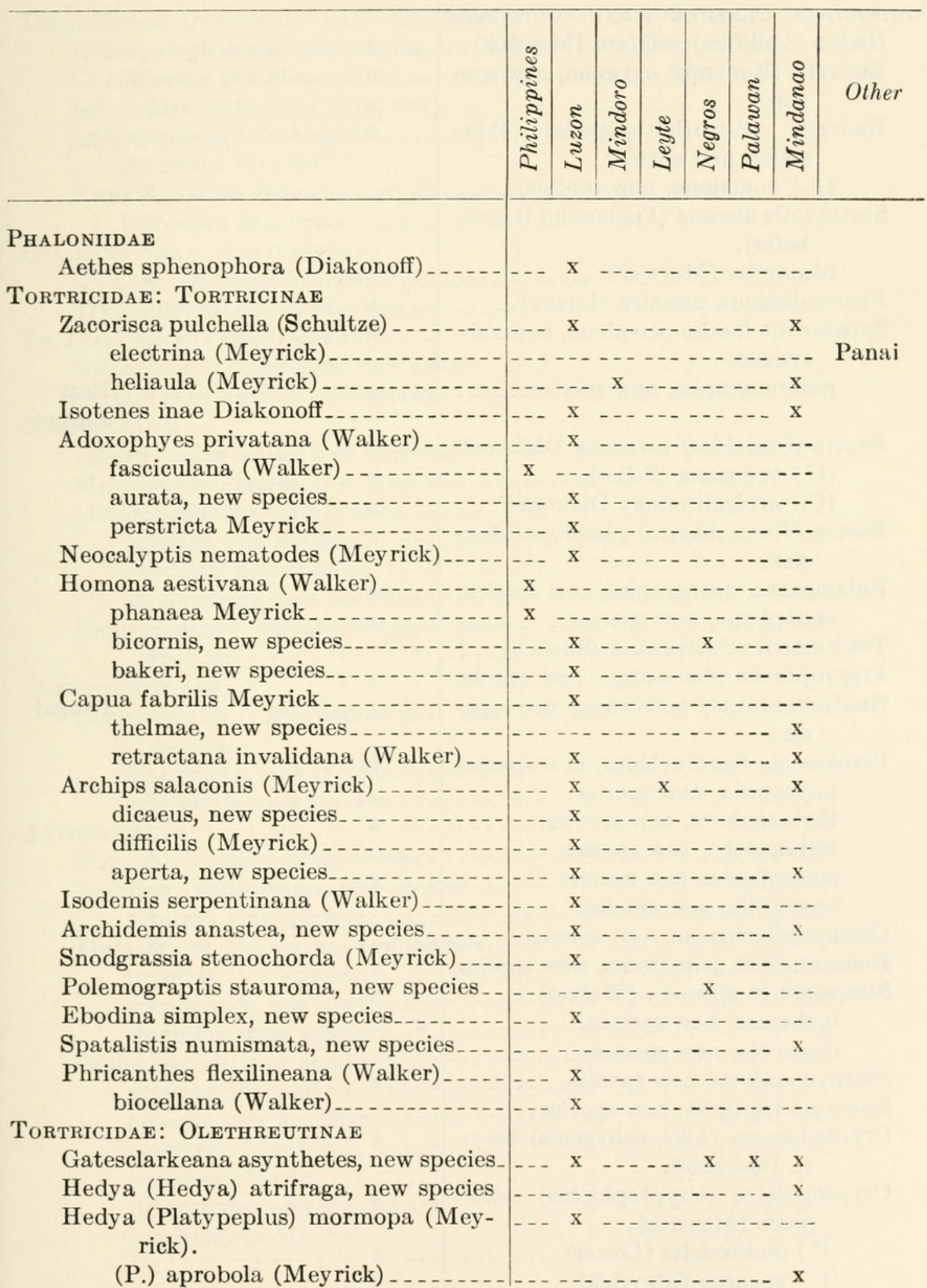


Tortricidae: Olethreutinae-Continued Hedya (Cellifera) cellifera (Meyrick) _

Eudemis (Eudemis) oxygona, new species.

Eudemis (Acanthothyspoda) chortodes, new species.

(A.) homalopa, new species

Statherotis discana (Felder and Rogenhofer).

olenarcha (Meyrick)

Phaecadophora mosaica (Lower)

Sycacantha inodes perspicua, new subspecies.

potamographa, new species

$\mathrm{x}$

Bactra (Chiloides) coronata Diakonoff-

(C.) venosana (Zeller)

(C.) orbiculi minax Diakonoff

Bactra (Nannobactra) phaulopa Meyrick.

Bubonoxena spirographa, new species. endaphana, new species

Tetramoera schistaceana (Snellen) ....

Argy roptocha phalaenopa, new species

Gnathmocerodes petrifraga, new species.

Peridaedala dendrochlora, new species physoptila, new species.

thylacophora, new species.

melanantha, new species.

stenoglypha, new species

crocoptila, new species

Costosa allochroma, new species

Eucoenogenes deltostoma, new species_

Strepsicrates ejectana (Walker)

inobtrusa, new species

discobola, new species.

Petrova scalaris, new species

Eucosma iographa, new species ......

Cryptaspasma (Allobrachygonia) hesyca Diakonoff.

Cryptophlebia (Cryptophlebia) tetra-

East

Borneo

Bengal

ploca (Mey rick).

(C.) ombrodelta (Lower)

(C.) encarpa (Meyrick)
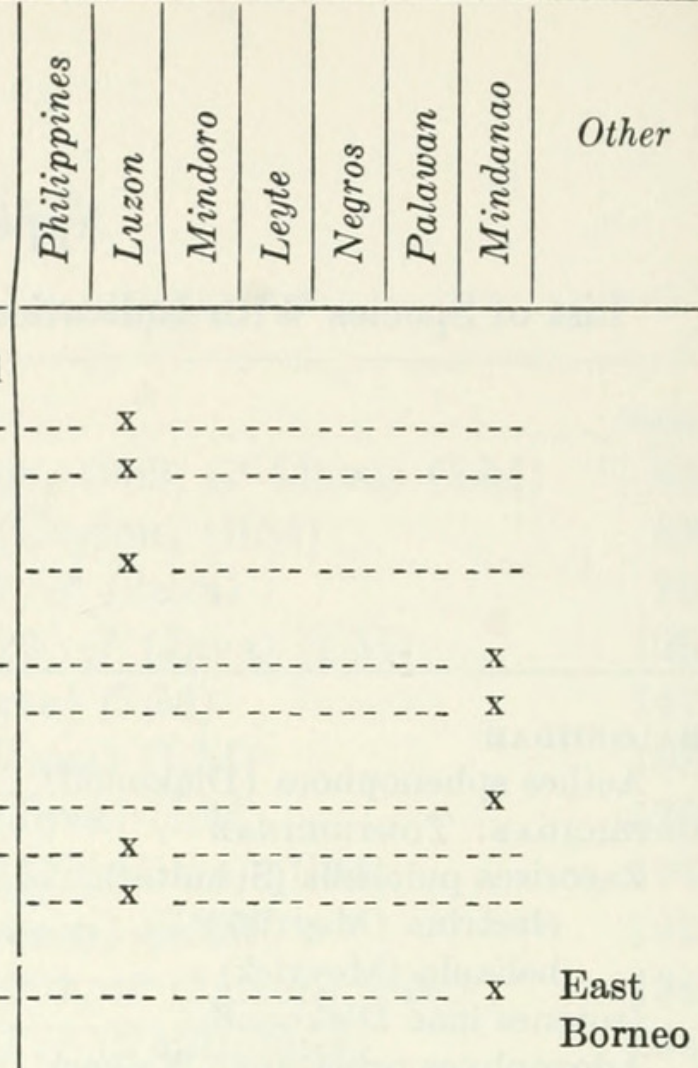

\section{Bengal}




\begin{tabular}{|c|c|c|c|c|c|c|c|c|}
\hline & 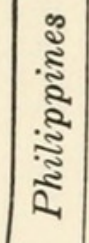 & 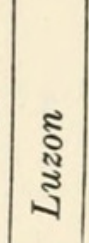 & 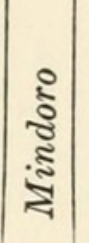 & ฐొँ & 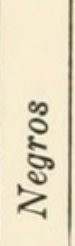 & 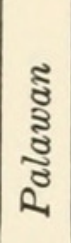 & 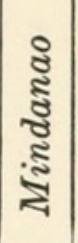 & Other \\
\hline \multirow{2}{*}{\multicolumn{9}{|c|}{$\begin{array}{l}\text { Tortricidae: Olethreutinae-Continued } \\
\text { Erinea amphigonia, new species.- }\end{array}$}} \\
\hline & -- & $\mathrm{x}$ & $-\cdots$ & $-\cdots$ & -- & -- & -- & \\
\hline Crocidosema plebejana Zeller......... & -- & $\mathrm{x}$ & $\ldots$ & $-\ldots$ & -- & -- & $\ldots$ & \\
\hline Loboschiza clytocarpa (Meyrick) & $\mathrm{x}$ & -- & $\ldots$ & $-\ldots$ & -- & -- & --- & \\
\hline Laspeyresia inflata Meyrick & -- & -- & $\mathrm{x}$ & $\ldots$ & -- & -- & --- & \\
\hline gratulata Meyrick & - & $-\ldots$ & $\ldots$ & $-\ldots$ & -- & -- & $\mathrm{x}$ & \\
\hline Pammene ionia Wileman and Stringer. & $-\ldots$ & $\mathrm{x}$ & $\ldots-$ & $-\ldots$ & -- & -- & -- & \\
\hline leucodora Meyrick & -- & $\mathrm{x}$ & $-\ldots$ & $-\ldots$ & $\ldots$ & -- & -- & \\
\hline \multicolumn{9}{|c|}{ Chlidanotinae: Chlidanotini } \\
\hline Caenognosis incisa Walsingham & --- & $\mathrm{x}$ & $-\cdots$ & $\cdots$ & $\cdots$ & - - & -- & \\
\hline Trymalitis cataracta Meyrick & -- & $\mathrm{x}$ & -- & $-\ldots$ & -- & -- & --- & \\
\hline \multicolumn{9}{|l|}{ Chlidanotinae: Schoenotenini } \\
\hline Schoenotenes collarigera, new species_- & -- & $\ldots$ & $\cdots$ & --- & $\mathrm{x}$ &.- & -- & \\
\hline Stenarchella eupista, new species.- & -- & $\ldots$ & $\ldots$ & $-\ldots$ & $\ldots$ & $\ldots$ & $\mathrm{x}$ & \\
\hline \multicolumn{9}{|c|}{ CARPOSINIDAE } \\
\hline Campylarchis acuta, new species...... & $-\cdots$ & $\mathrm{x}$ & --- & --- & $--\cdot$ & -- & --- & \\
\hline Metacosmesis illodis, new species...... & $-\ldots$ & $\mathrm{x}$ & $-\ldots$ & $-\ldots$ &.- & -- &.- & \\
\hline Meridarchis alta, new species...... & $\mathrm{x}$ & $\ldots$ & $-\ldots$ & $\cdots$ &.- & -- & -- & \\
\hline bifracta, new species... & -- & $\mathrm{x}$ & $\ldots$ & $\ldots$ & $\ldots$ & -- &.- & \\
\hline oxydelta, new species... & $-\ldots$ & $\ldots$ & $-\ldots$ & $-\ldots$ & -- & -- & $\mathrm{x}$ & \\
\hline scythophyes, new species........ & -- & $-\ldots$ & $-\ldots$ & --- & -- & -- & $\mathrm{x}$ & \\
\hline $\begin{array}{r}\text { Heterogymna melanocrypta, new } \\
\text { species. }\end{array}$ & --- & --- & $-\ldots$ & --- &.- & -- & $\mathrm{x}$ & \\
\hline \multicolumn{9}{|l|}{ COPROMORPHIDAE } \\
\hline $\begin{array}{l}\text { Copromorpha smaragdarcha, new } \\
\text { species. }\end{array}$ & --- & $\mathrm{x}$ & --- & $\cdots$ & $\cdots$ & -- & -- & \\
\hline $\begin{array}{l}\text { dialithoma, new species. } \\
\text { mistharnis, new species }\end{array}$ & -- & $\mathrm{x}$ & & & & & & \\
\hline \multicolumn{9}{|l|}{ XYLORYCTIDAE } \\
\hline Thymiatris arista, new species....... & --- & $\mathrm{x}$ & --- & -- & - & $\cdots$ & --- & \\
\hline Amorbaea subtusvena, new species...- & -- & $\mathrm{x}$. & $-\ldots$ & --- & $\ldots$ & -- & --- & \\
\hline subusta, new species & -- & $\mathrm{x}$ & $-\ldots$ & -- & -- & -- & -- & \\
\hline Metathrinca iridostoma, new species_-- & --- & $\mathrm{x}$ & --- & -- & $x$ & -- & -- & \\
\hline pernivis, new species.............. & $-\cdots$ & $-\cdots$ & --- &.-- & -- & -- & $\mathbf{x}$ & \\
\hline coenophyes, new species........... & --- & $\mathrm{x}$ & --- & --- & -- & & --- & \\
\hline sinumbra, new species & -- & $\mathrm{x}$ & $\ldots-$ & --- &.- & -- & -- & \\
\hline Odites perissa, new species & -- & $\mathrm{x}$. & --- & --- &.- & -- & -- & \\
\hline p. atrimersa, new variety & --- & $\mathrm{x}$ & -- & - & -- & -- & -- & \\
\hline apicalis, new species..... & -- & $\mathrm{x}$. & --- & & -- & & -- & \\
\hline pancyclia Meyrick & --- & $\mathrm{x}$. & --- & & & & -- & \\
\hline periscias Meyrick & --- & $\mathrm{x}$ & --- & --- & -- & -- & -- & \\
\hline $\begin{array}{l}\text { homocirrha, new species....... } \\
\text { brachvclista Mevrick }\end{array}$ & -- & $\mathrm{x}$ & -- & --- & -- & & -- & \\
\hline
\end{tabular}




\section{TIMYRIDAE}

Tisis auricincta, new species_....... _... . . . . . . $x$

Canthonistis xestocephala, new species

Frisilia drimyla, new species

Homaloxestis aganacma, new species. alopecopa Meyrick surrepta, new species

Placanthes xanthomorpha Meyrick.

Lecithocera sophronopa, new species activata, new species strenua, new species cassiterota Meyrick phanerostoma, new species megalopis Meyrick fausta Meyrick ochrocapna Meyrick acribostola, new species goniometra Meyrick decorosa, new species recurvata Meyrick. niphotricha, new species telosperma, new species docilis, new species luteola, new species leucomastis, new species

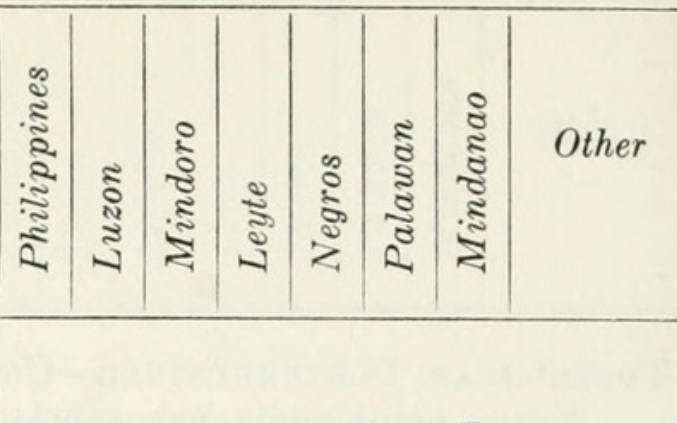
improvisa, new species

Prosodarma fibularis (Meyrick) _....... . $\mathrm{x} \ldots \ldots \ldots \ldots \ldots$ Gelechimdae

Stegasta variana Meyrick

Phthorimaea heliopa (Lower)

Stomopteryx subsecivella (Zeller)

Euhomalocera heliosema, new species

Atasthalistis ochreoviridella (Pagenstecher).

diacrita, new species

Hypatima heterostigma, new species

Hypodrasia acycla, new species

Brachyacma palpigera (Walsingham)

Acribologa malacodes (Meyrick)

Brachmia tristella (Snellen)

\section{ORNEODIDAE}

heterotoma, new species.

Orneodes toxophila Meyrick spilodesma Meyrick 
Cosmopter ygidae: Scaeosophinae

Syntomaula simulatella (Walker), new

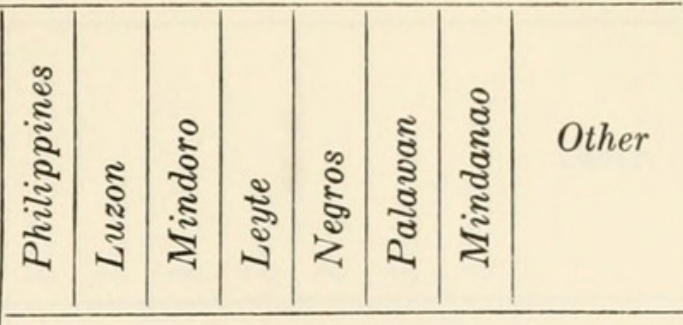
combination.

Scaeothy ris pseusta, new species.

COSMOPTER YGIDAE: COSMOPTER YGINAE

Limnaecia acontophora Meyrick

Pyroderces simplex (Walsingham)

Cosmopteryx dulcivora Meyrick

basilisca Meyrick

\section{OECOPHORIDAE}

Epimecyntis chlorogenes Meyrick

Diploclasis balbidophora, new species

Astiarcha praedives, new species

Tany zancla amy drographa, new species pepona, new species cincta, new species catadea, new species lanceolata, new species

Philobota loxographa, new species

Chrysonoma aporopis (Meyrick), new combination.

eumorpha, new species X poecilosema, new species fragmentaria, new species hesitans, new species hypocapna, new species inermis, new species

Tonica argessa, new species citrantha, new species lagaropis Meyrick

Psorosticha neglecta, new species GLyphipter ygidae

Phy codes minor Moore

Sagalassa eubrachycera, new species.

Imma aurantiaca (Semper)

basiflava (Semper)

chrysocosma, new species

albifasciella (Pagenstecher)

albotaeniana (Sauber) macrochorda, new species.

m. regmophora, new subspecies poecilostoma, new species sarophora, new species pyragra, new species tyrocnista Meyrick nephodryas Meyrick

\begin{tabular}{c|c}
\hline \\
\hline
\end{tabular}

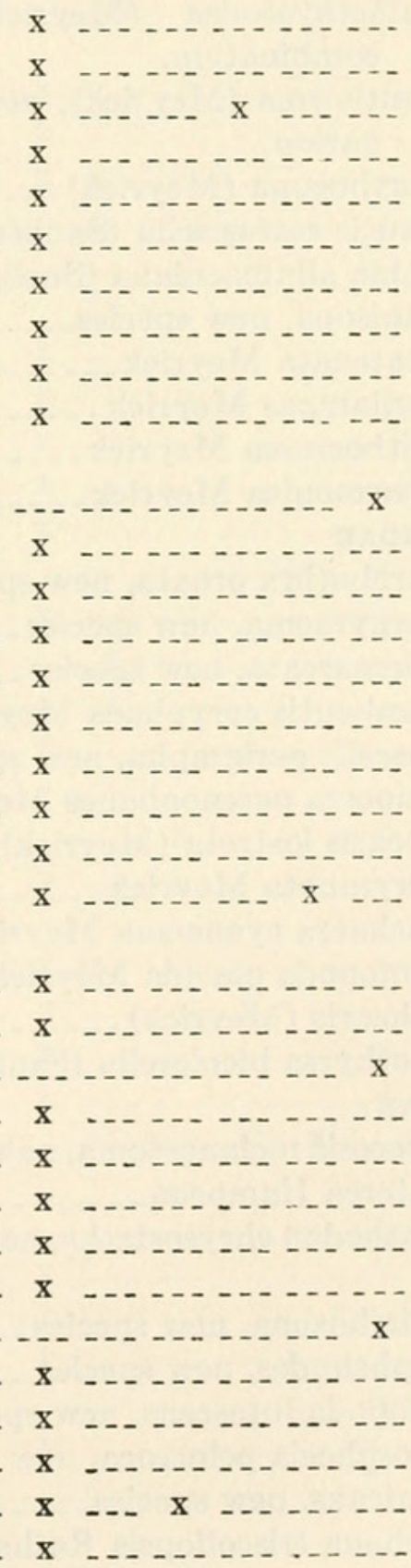




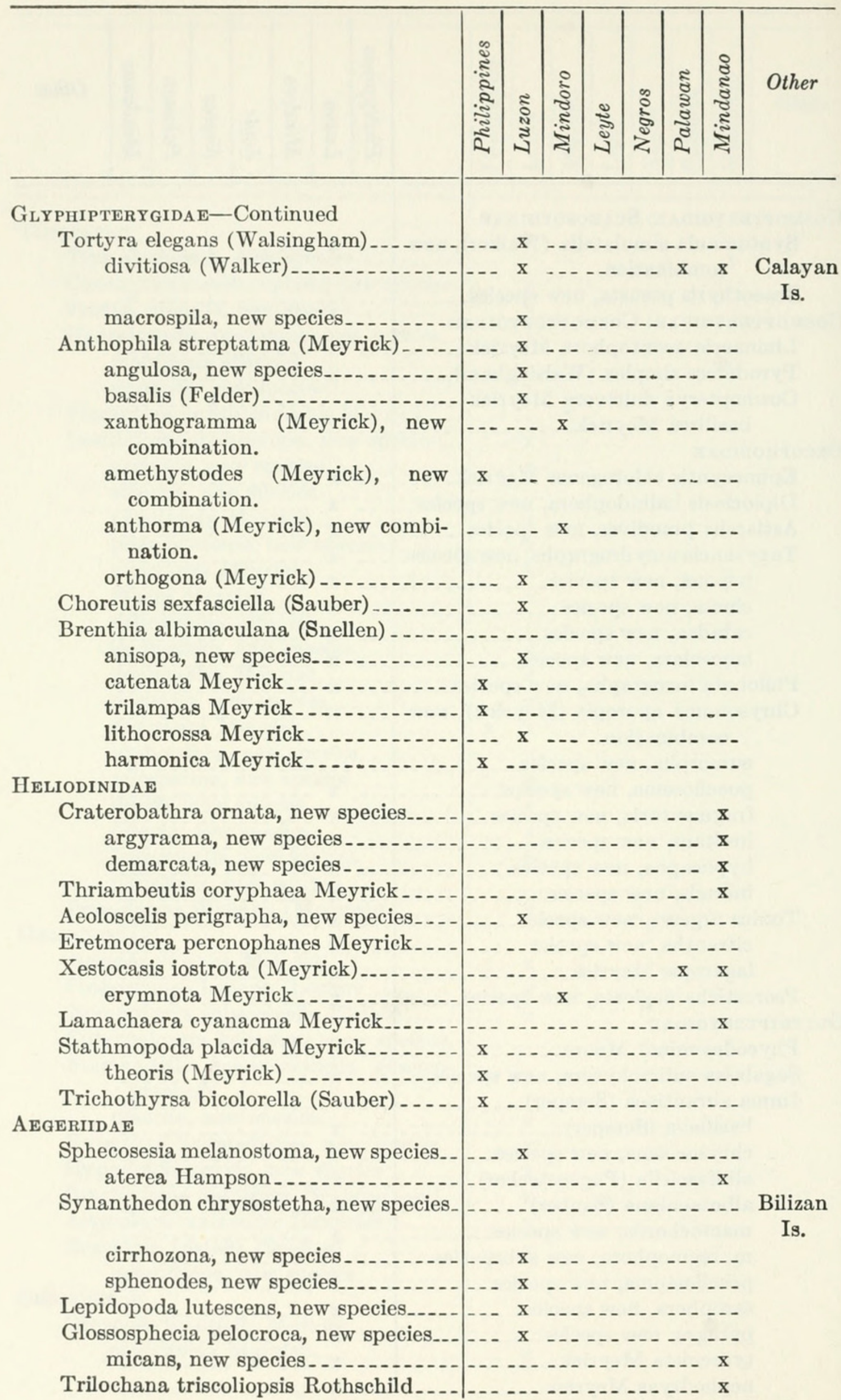




\begin{tabular}{|c|c|c|c|c|c|c|c|c|}
\hline & 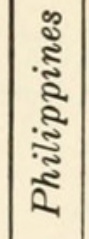 & 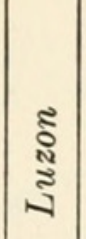 & 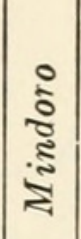 & స్తు & so & 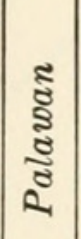 & 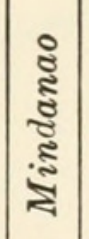 & Other \\
\hline \multicolumn{9}{|l|}{ AEgERIIDAE-Continued } \\
\hline Sura tetrapora, new species_......- & --- & $\mathrm{x}$ & -- & --- & --- & --- & --- & \\
\hline cyanolampra, new species & -- & $\mathrm{x}$ & -- & -- &.- & -- & -- & \\
\hline Paranthrene heterodesma, new species_ & - & $\mathrm{x}$ & $-\cdot-$ & -- & --- & -- & -- & \\
\hline poecilocephala, new species...... & -- & $\mathrm{x}$ & --- & -- & -- & -- & --- & \\
\hline Melittia gigantea Moore & $-\cdots$ & $\mathrm{x}$ & -- &.- & -- & -- & -- & \\
\hline siamica Walker & $-\ldots$ & $\mathrm{x}$ &.- & -- & -- &.- &.- & \\
\hline eurytion (Westwood) & $-\cdots$ & $\mathrm{x}$ &.- & -- &.- & -- & $\mathrm{x}$ & \\
\hline Adixoa tomentosa Schultze....... & $\mathrm{x}$ & -- &.- &.- & -- &.-- &.-- & \\
\hline Bembecia fortis, new species....... & $-\ldots$ &.-- &.- &.-- &.- &.-- & $\mathrm{x}$ & \\
\hline \multicolumn{9}{|c|}{ YPONOMEUTIDAE } \\
\hline Yponomeuta interruptella (Sauber) & -- & $\mathrm{x}$ &.-- & --- &.-- &.- &.-- & \\
\hline melanaster (Meyrick) & -- & $\mathrm{x}$ & -- & -- & -- & -- & -- & \\
\hline Prays endolemma, new species...... & -- & $\mathrm{x}$ &.-- & --- & -- & -- & -- & \\
\hline Atteva basalis Vollenhoven & -- & $\mathrm{x}$ & -- & -- & -- & -- & -- & \\
\hline triplex, new species........ & --- &.- & -- & --- & -- & --- & --- & $\begin{array}{l}\text { Calayan } \\
\text { Is. }\end{array}$ \\
\hline brucea Moore. & -- & $\mathrm{x}$ & -- & --- & -- & -- & -- & \\
\hline holenopla, new species...... & -- & $\mathrm{x}$ & --- & --- & -- & -.. & -- & \\
\hline scolecias Meyrick & -- & $\mathrm{x}$ & -- & -- & -- & -- & -- & \\
\hline balanota Meyrick & $-\ldots$ & $\mathrm{x}$ & -- & -- & -- & -- & -- & \\
\hline Anticrates rutilella (Pagenstecher) ....- & -- & $x$ &.- & -- & -- & -- & -- & \\
\hline denticulata, new species....... & $-\ldots$ &.- & -- & -- & -- & -- & $\mathrm{x}$ & \\
\hline digitosa, new species...... & -- & $\mathrm{x}$ & --- & --- & -- & -- & -- & \\
\hline rhodometra, new species....... & $-\ldots$ & -- & $\mathrm{x}$ & --- & -- & -- & -- & \\
\hline paratarsa Meyrick & - &.- & $\mathrm{x}$ & - & - & -- & -- & \\
\hline Protorhiza cyanosticta, new species.-.- & -- & $\mathrm{x}$ & --- &.- & -- & -- & --- & \\
\hline \multicolumn{9}{|c|}{ EтHMIIDAE } \\
\hline Agrioceros platycypha Meyrick ...... & --- & --- &.- & $\mathrm{x}$ & -- & --- & $\mathrm{x}$ & \\
\hline $\begin{array}{l}\text { magnificella (Sauber), new com- } \\
\text { bination. }\end{array}$ & -- & $\mathrm{x}$ & $-\ldots$ & -- & -- & -- & -- & \\
\hline Ethmia palawana Schultze & -- & $\mathrm{x}$ & -- & -- & --- & -- & $\mathrm{x}$ & \\
\hline praeclara Meyrick & -- & $\mathrm{x}$ &.- & -- & $\mathrm{x}$ & -- & $-\ldots$ & \\
\hline colonella Walsingham & -- & $\mathrm{x}$ & -- & & -- & -- & $\mathrm{x}$ & \\
\hline dentata Diakonoff and Sattler & -- & $\mathrm{x}$ & -- & -- & -- & -- & -- & \\
\hline $\begin{array}{l}\text { crocosoma resignata, new sub- } \\
\text { species. }\end{array}$ & $-\cdots$ &.- & -- & - & $\ldots$ & $\mathrm{x}$ & -- & \\
\hline reposita, new species $\ldots$ & $\ldots$ & -- & $\cdots$ & $-\cdots$ & $\cdots$ & & $\mathrm{x}$ & \\
\hline nobilis, new species. & -- & $\mathrm{x}$ & & & & & -- & \\
\hline \multicolumn{9}{|c|}{ Plutellidae } \\
\hline Harpeptila corethrodes, new species _.- & -- & $\mathrm{x}$ & $\ldots$ & & $\ldots$ & -- & --- & \\
\hline prasina, new species & $-\ldots$ & -- & $\cdots$ & & & & $\mathrm{x}$ & \\
\hline Acrocenotes niphochrysa, new species_- & -- & $\mathrm{x}$ & -- & & & & $-\cdots$ & \\
\hline Plutella maculipennis (Curtis) & $\ldots$ &.- & $\ldots$ & & & & -- & \\
\hline \multicolumn{9}{|c|}{ Lithocolletidae } \\
\hline Epicephala chalybacma Meyrick & -- & $\mathrm{x}$ & --- & & - & & & \\
\hline Lithocolletis triarcha Meyrick & & $\mathrm{x}$ & & & & & & \\
\hline
\end{tabular}




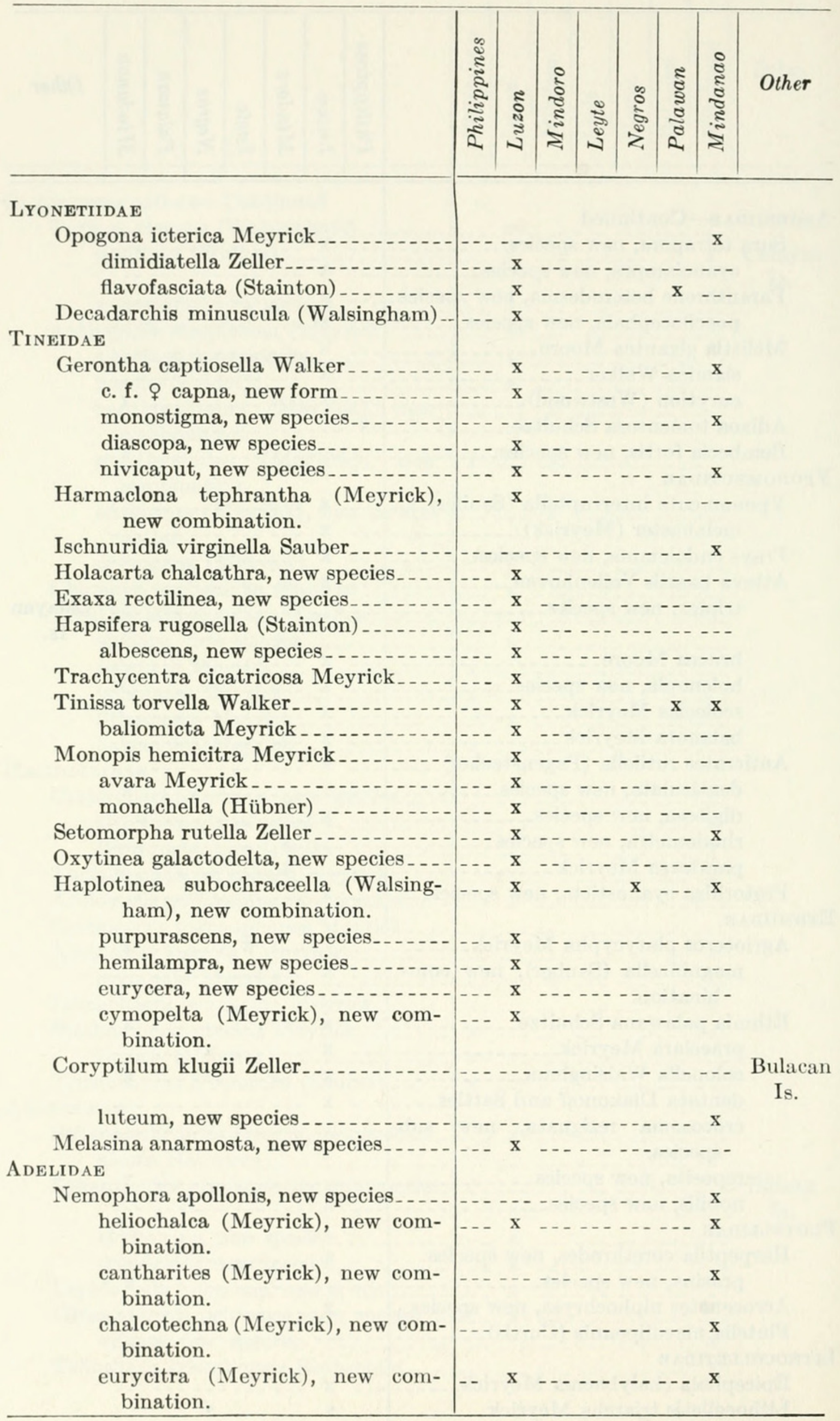




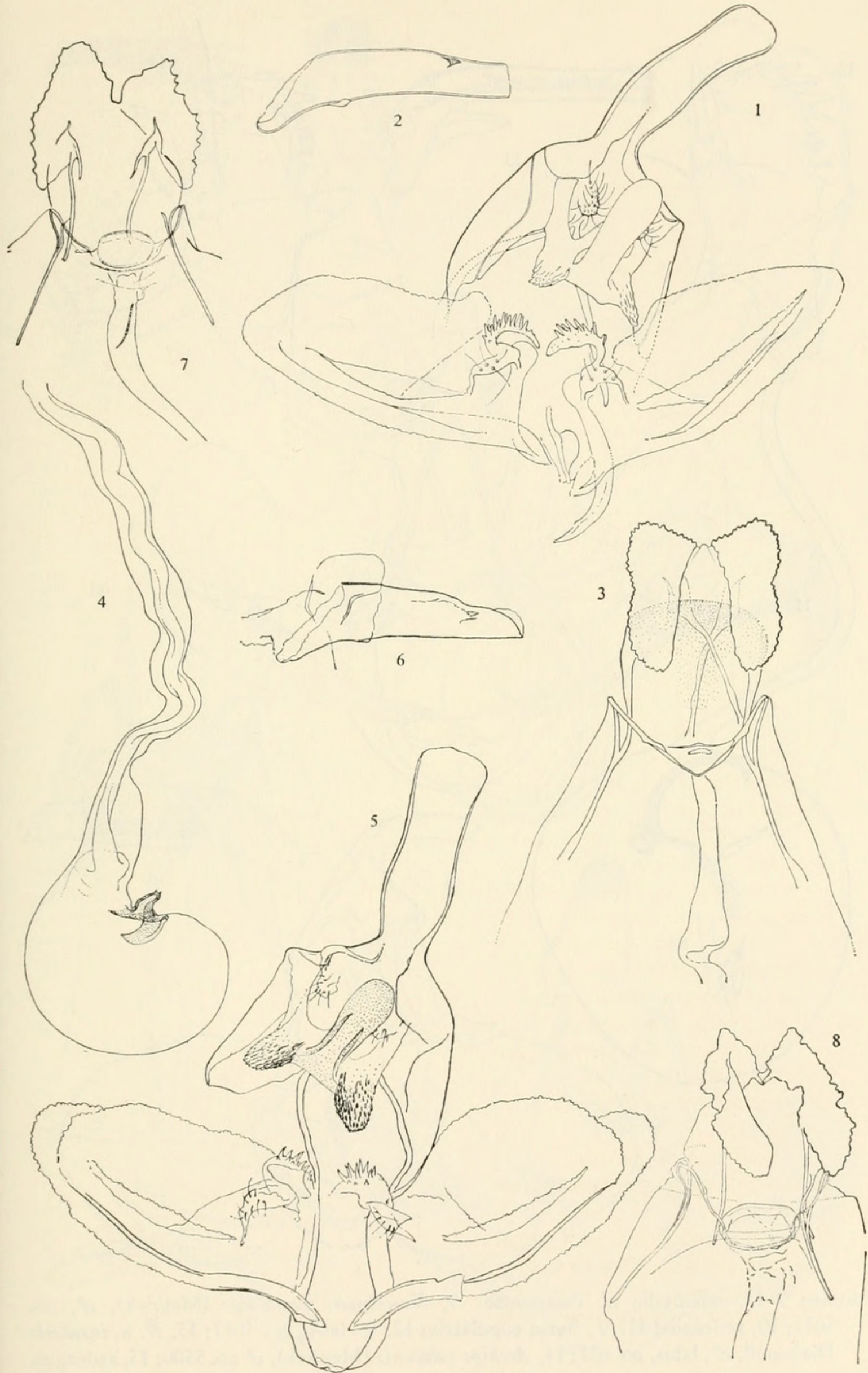

Figures 1-8.-Genitalia of Adoxophyes aurata, new species: 1, $\sigma^{\top}$, paratype; 2, aedeagus; 3 ,, , allotype; 4 , bursa copulatrix; $5, \sigma^{7}$, holotype; 6 , aedeagus; 7, Neocalyptis nematodes

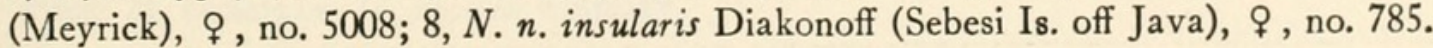




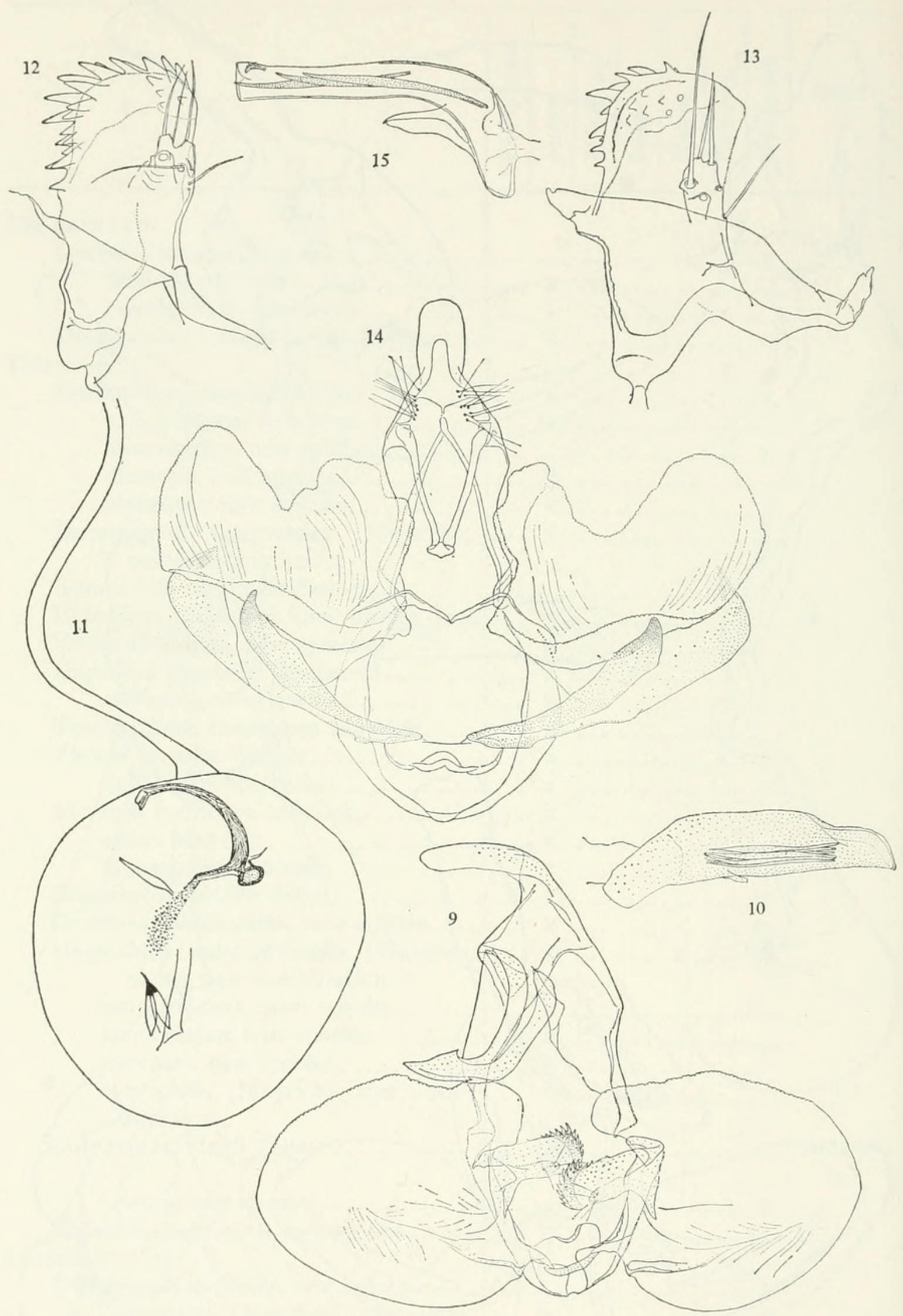

Figures 9-15.-Genitalia of Tortricinae: 9, Neocalyptis nematodes (Meyrick), ơ', no. 5011; 10, aedeagus; 11 , $q$, bursa copulatrix; 12 , $q$, labis, no. $5011 ; 13, N . n$. insularis Diakonoff, $\sigma^{7}$, labis, no. 637; 14, Archips salaconis (Meyrick), $\sigma^{7}$ no. 5506; 15, aedeagus. 


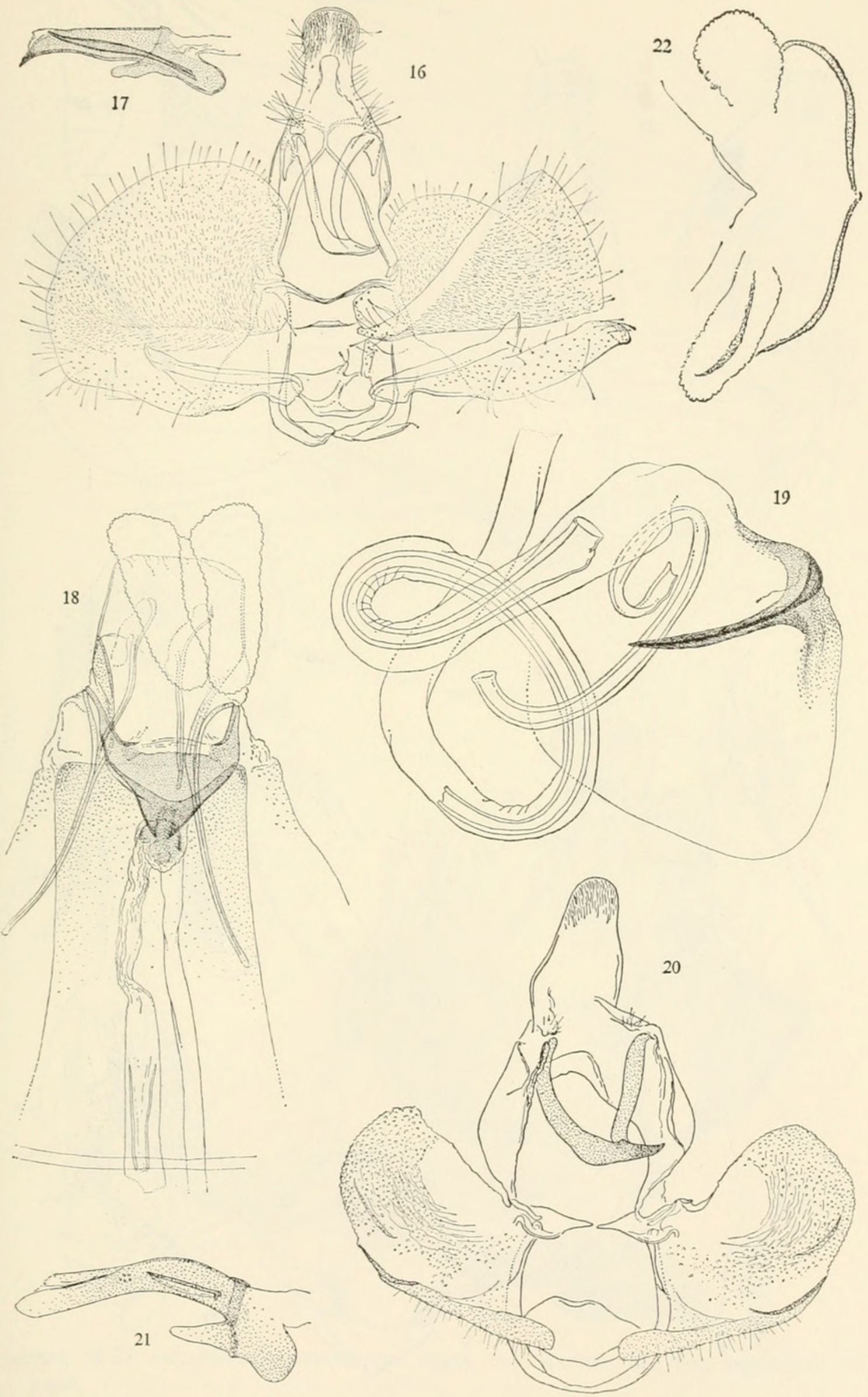

Figures 16-22.-Genitalia of Tortricinae: 16, Archips difficilis (Meyrick); 17, aedeagus; 18, $9 ; 19$, bursa copulatrix; 20, Archidemis anastea, new genus, new species, $\sigma^{\top}$, holotype; 21 , aedeagus; 22 , mensis ventralis. 


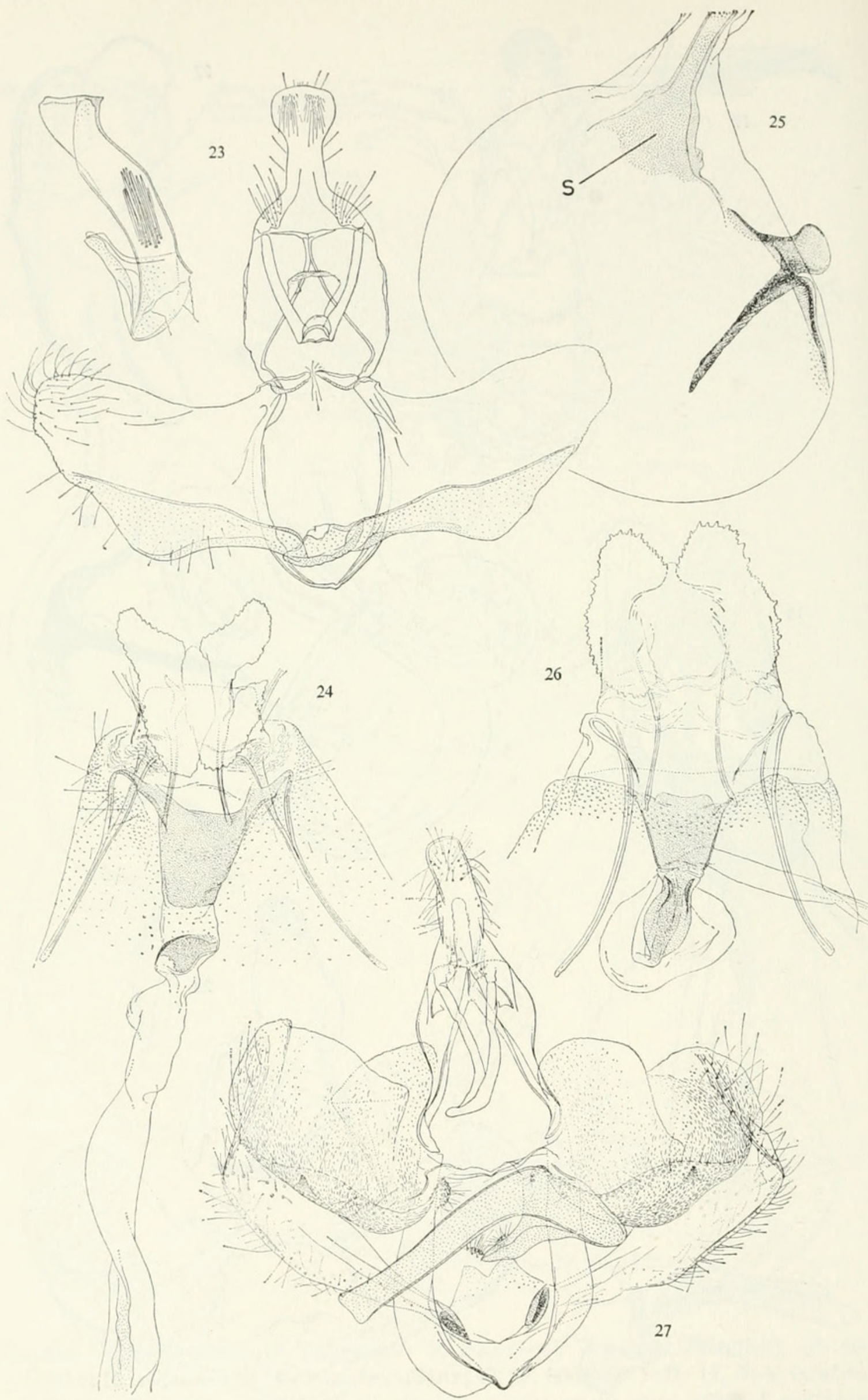

Figures 23-27.-Genitalia of Tortricinae: 23, Capua thelmae, new species, ơ', holotype, with aedeagus; 24, Archidemis anastea, new genus, new species, $q$, allotype; 25, bursa copulatrix (base of the collum of spermatophore, $S=$ punctated); 26, Archips aperta, new species, + , holotype; 27, Archips salaconis (Meyrick), $\sigma^{7}$, slide no. “June 28, 1930, A.B." 

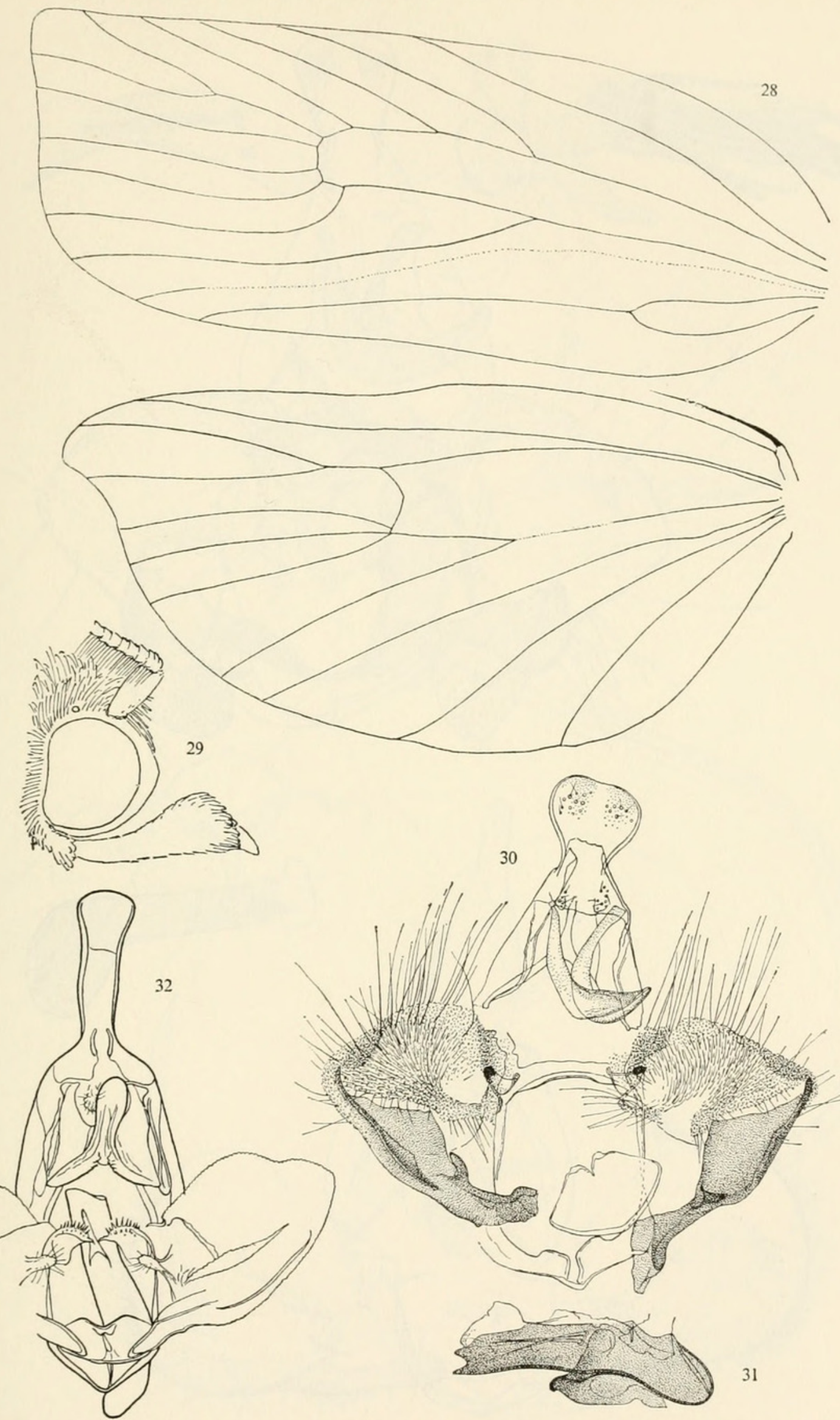

Figures 28-29.-Archidemis anastea, new genus, new species: 28, wing neuration; 29, head.

Figures 30-32.-Male genitalia of Tortricinae: 30, Homona bakeri, new species, holotype; 31, aedeagus; 32, Adoxophyes perstricta Meyrick, slide no. 1166 (Java, Surabaja, 15.VII.1939, A. Diakonoff). 

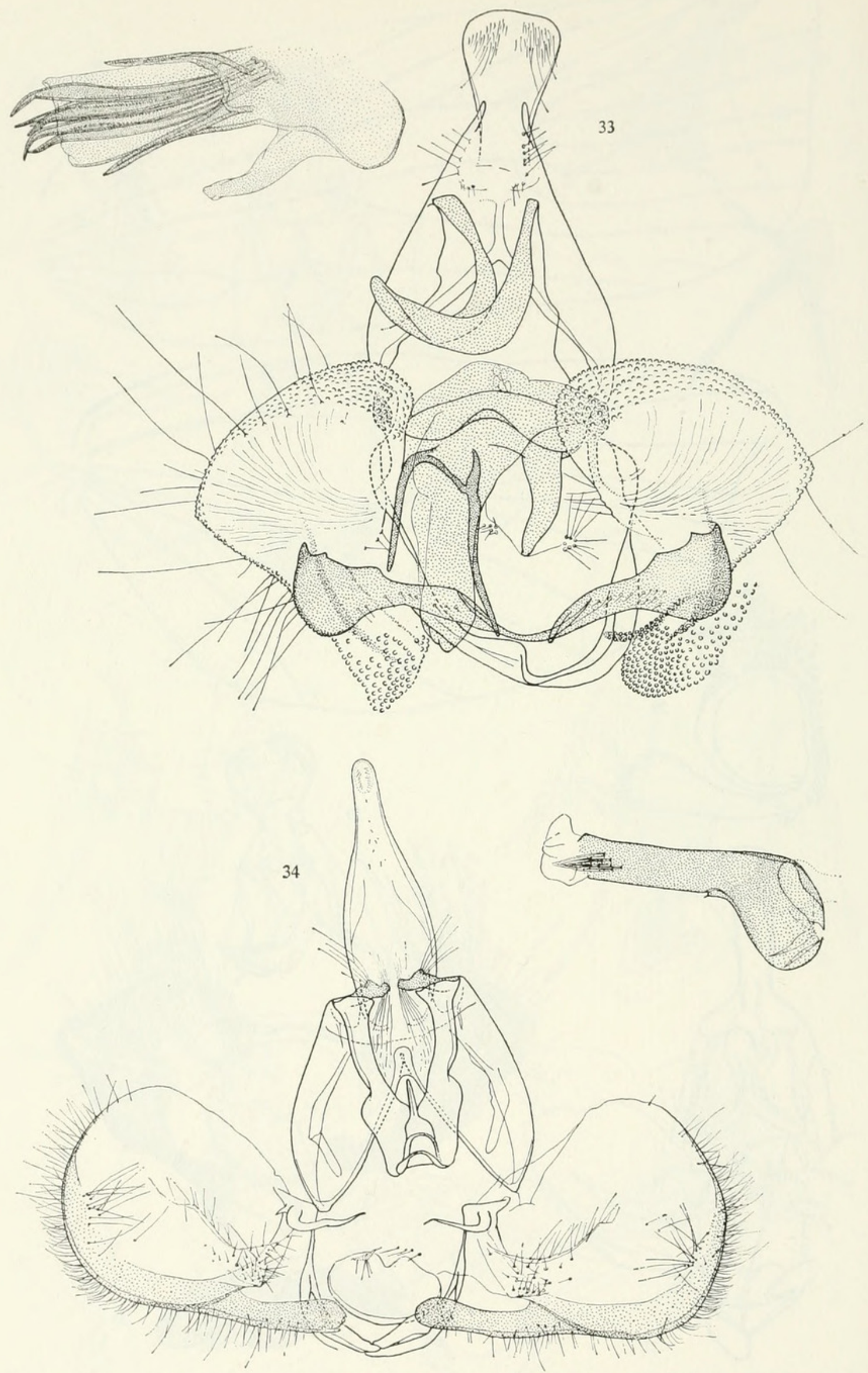

Figures 33-34.-Genitalia of Tortricinae: 33, Homona bicornis, new species, $\sigma^{7}$, holotype (aedeagus in frontal aspect), left, aedeagus of paratype, no. 5017; 34, Snodgrassia stenochorda (Meyrick), new genus, new species, $\sigma^{\top}$, no. 5010, right, aedeagus. 


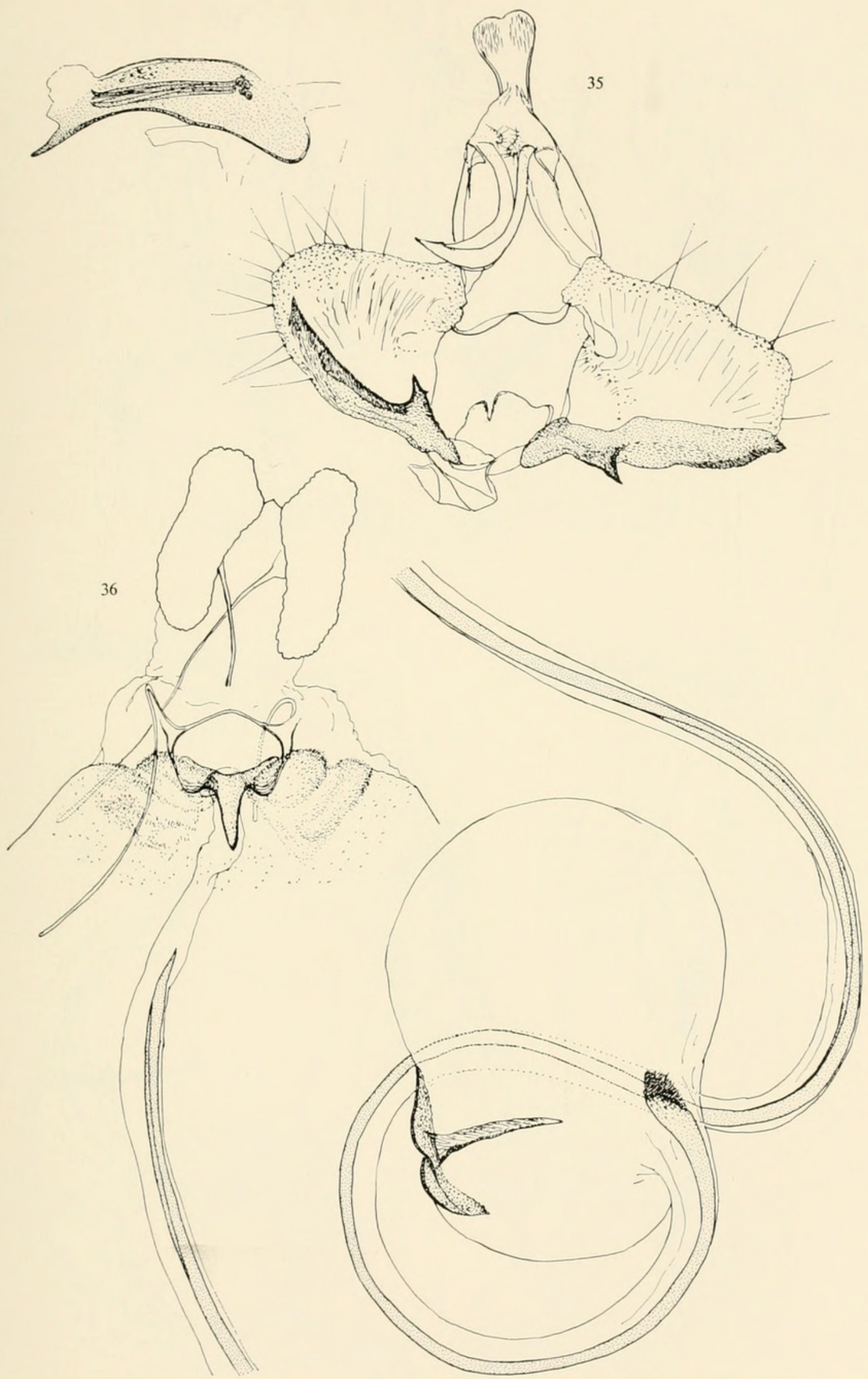

Figures 35-36.-Genitalia of Homona phanaea Meyrick: 35, ơ , slide no. 5769, with left aedeagus; $36, \&$, slide no. 5770 , with right, bursa copulatrix. 


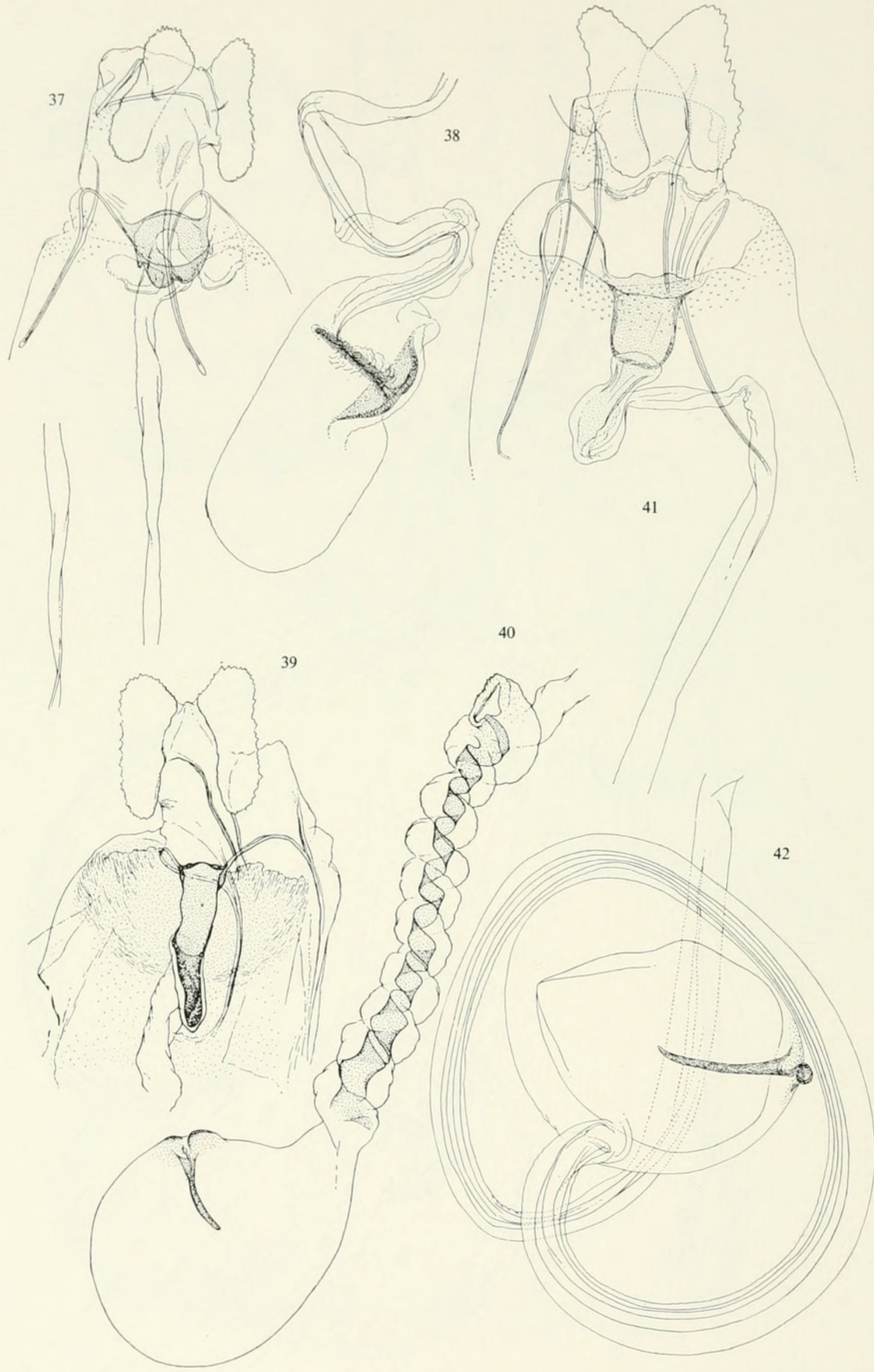

Figures 37-42.-Female genitalia of Tortricinae: 37, Homona bakerj, new species, allotype, below left, part of ductus bursae; 38, bursa copulatrix; 39, H. bicornis, new species, allotype; 40, bursa copulatrix; 41, Archips aperta, new species, holotype; 42, bursa copulatrix. 

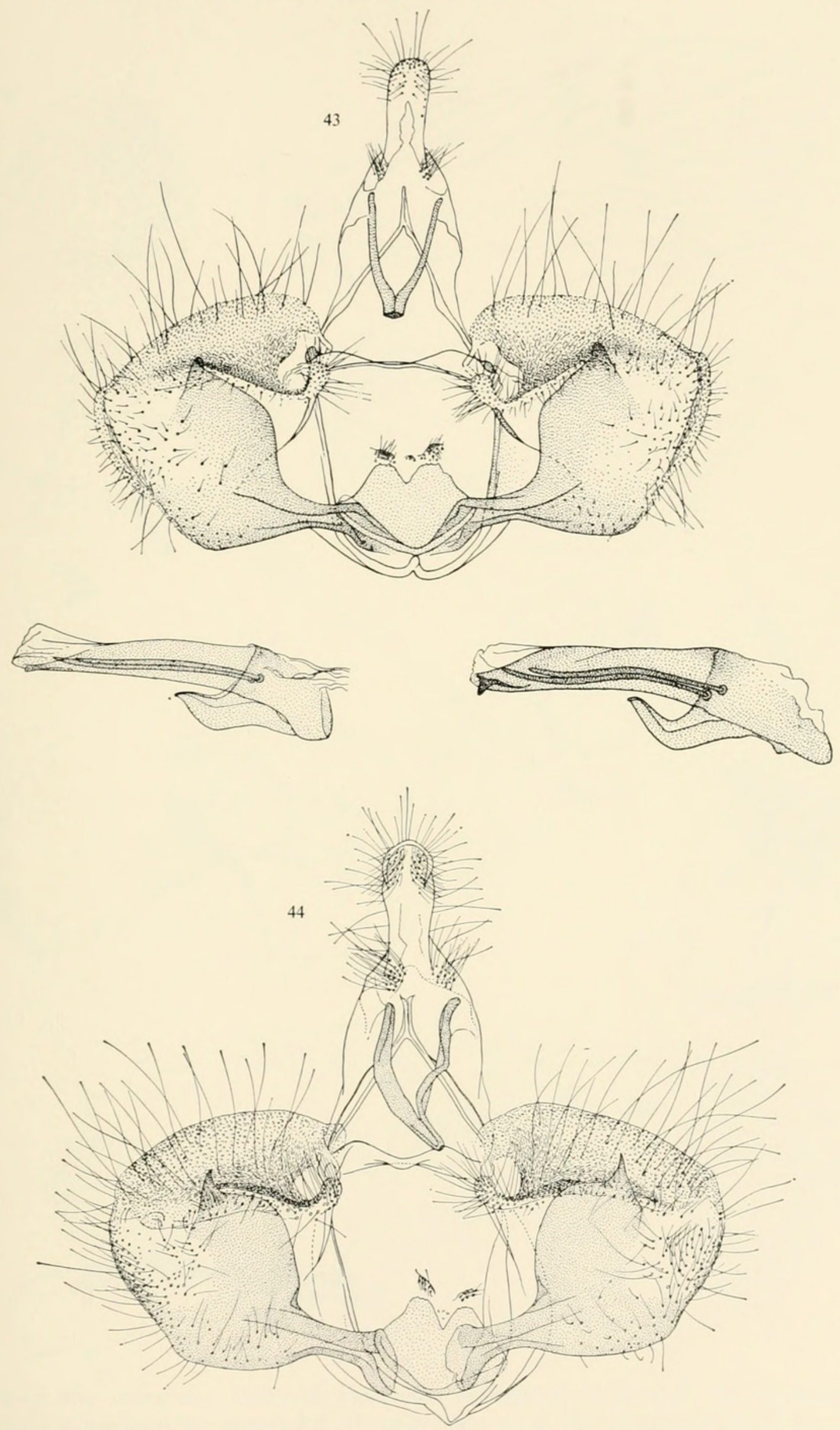

Figures 43-44.-Genitalia of Tortricinae: 43, Archips dicaeus, new species, $\sigma^{7}$, holotype, middle right, aedeagus; 44, A. encausta (Meyrick) (Ceylon), $\sigma^{7}$, no. 5028, middle left, aedeagus. 


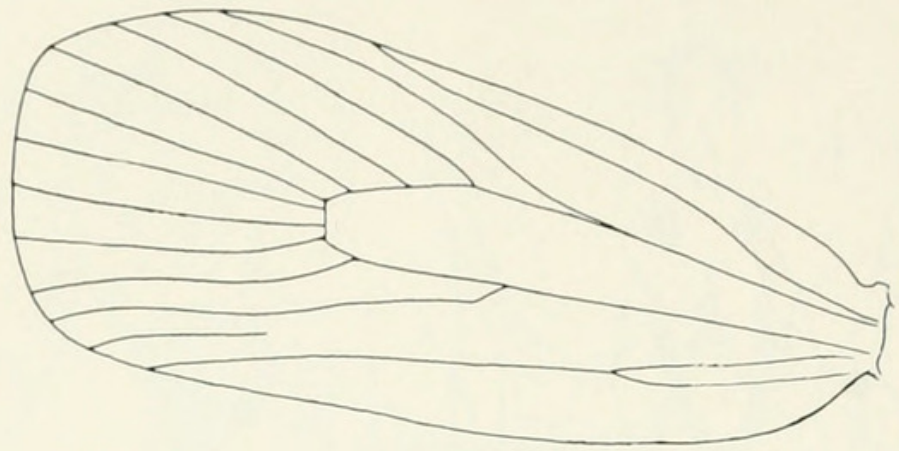

45
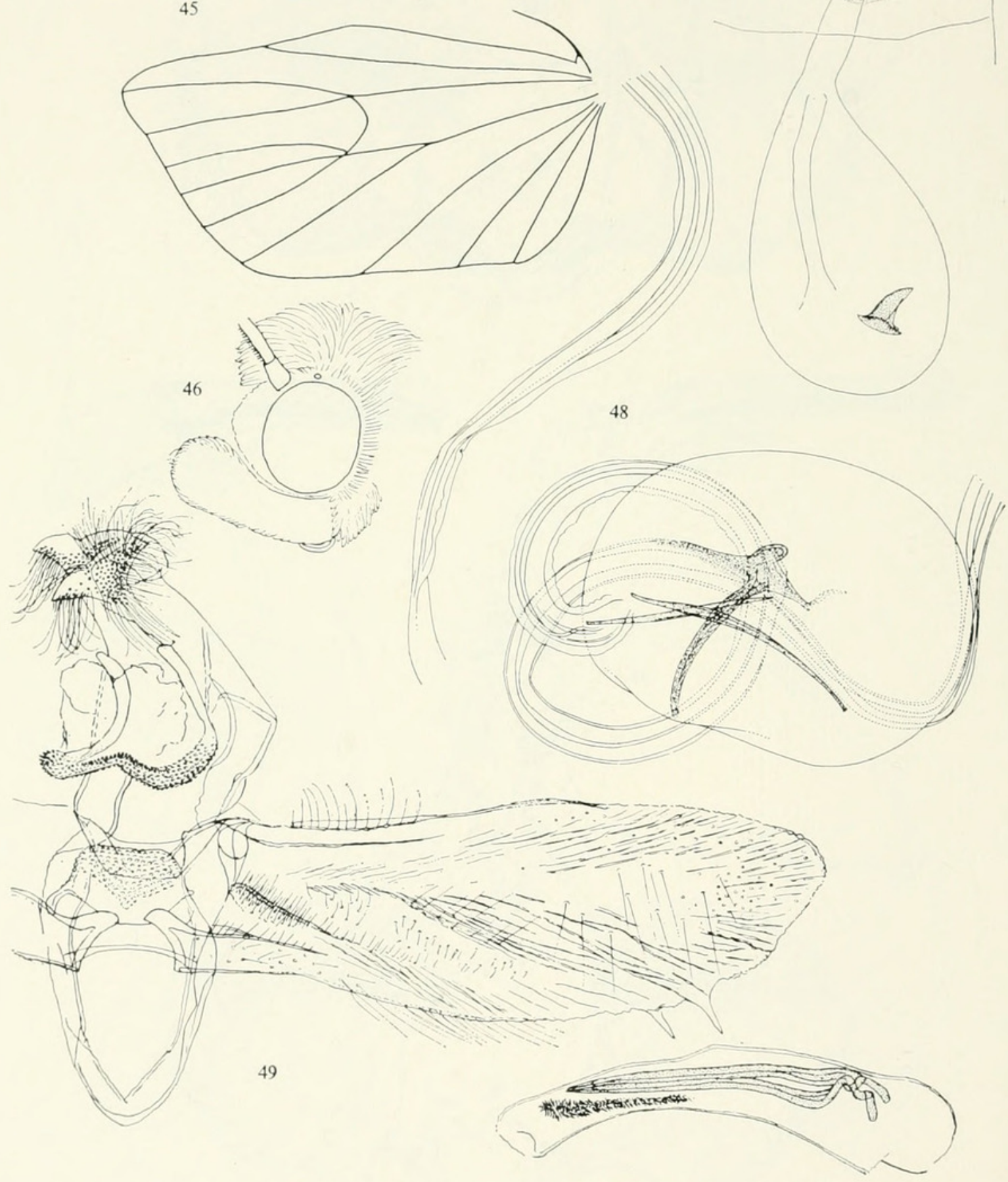

Figures 45-49.- Tortricinae, Snodgrassia stenochorda (Meyrick), new genus, new species, $\sigma^{7}$ : 45, wing neuration; 46, head. Genitalia: 47, Schoenotenes collarigera, new species, \% holotype; 48, Archips aperta, new species, fragment of ductus bursae and bursa copulatrix; 49, Phricanthes biocellana (Walker), $\sigma^{7}$, slide no. 5018, with aedeagus. 


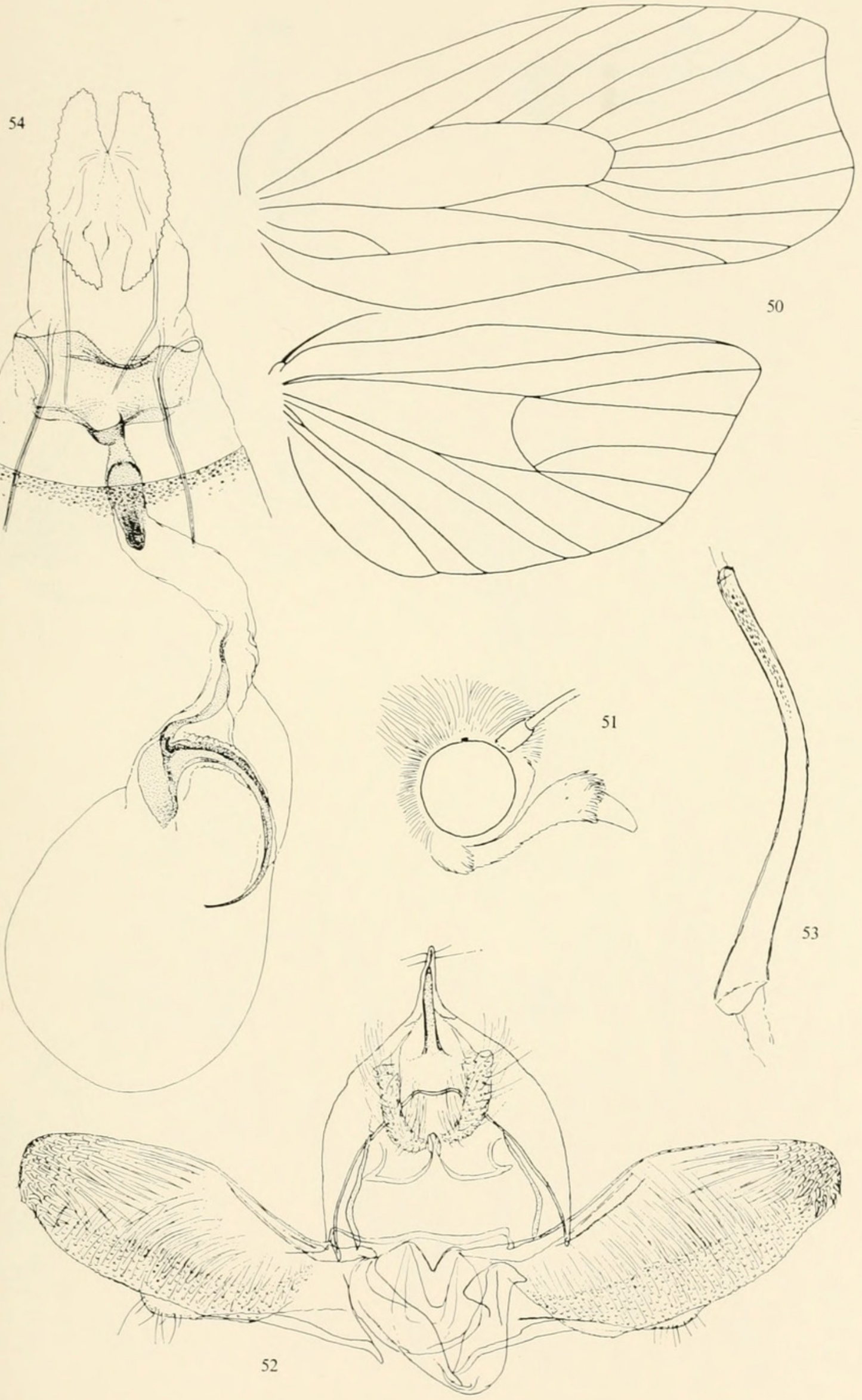

Figures 50-54.-Tortricinae: Ebodina simplex, new genus, new species: 50, wing neuration; 51, head; 52, o genitalia, holotype; 53, aedeagus; 54, Phricanthes biocellana (Walker), q genitalia. 


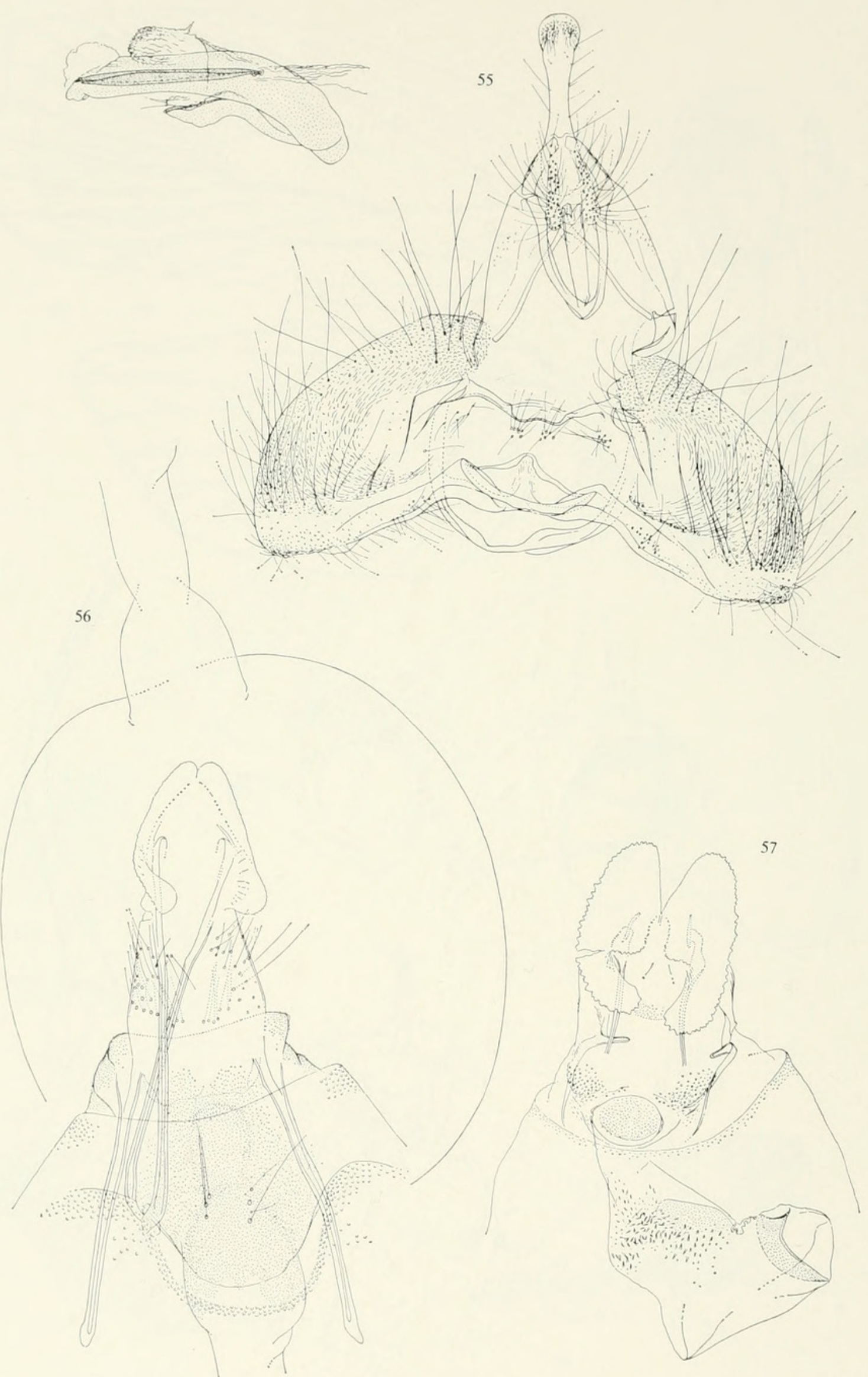

Figures 55-57.-Genitalia of Tortricinae: 55, Capua retractana invalidana (Walker), $\sigma^{7}$, left, aedeagus; 56, Polemograptis stauroma, new species, $q$, holotype, with bursa copulatrix in the background; 57, Spatalistis numismata, new sfecies, $q$, holotype. 


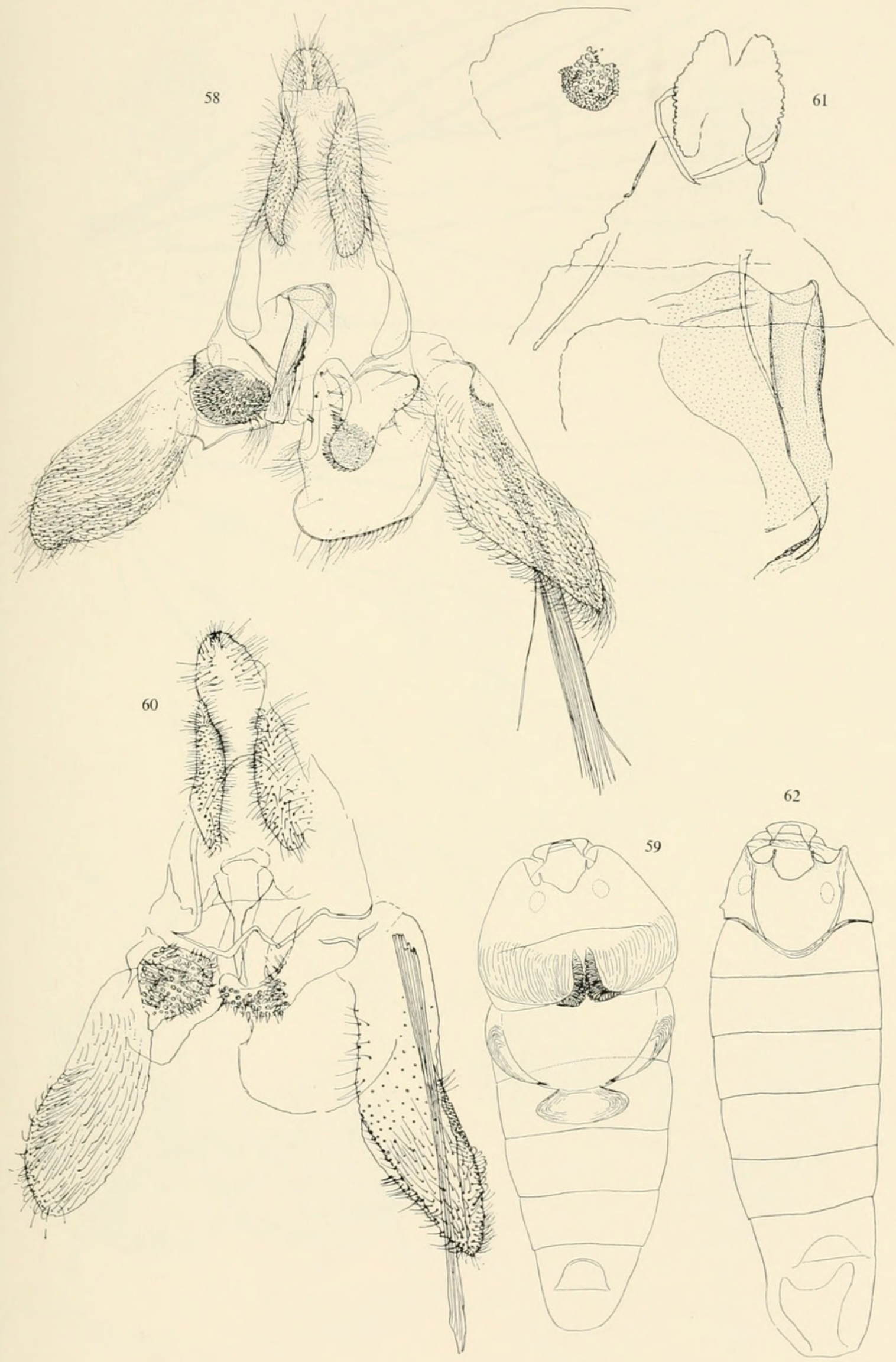

Figures 58-62.-Genitalia of Gatesclarkeana Diakonoff: 58, G. erotias (Meyrick), ơ', no. "June 20, 1930, A.B."; 59, ventral aspect of abdomen; 60, G. asynthetes, new species, $\sigma^{7}$, holotype: 61 , $q$, allotype with signum; $62, \sigma^{7}$, ventral aspect of abdomen. 

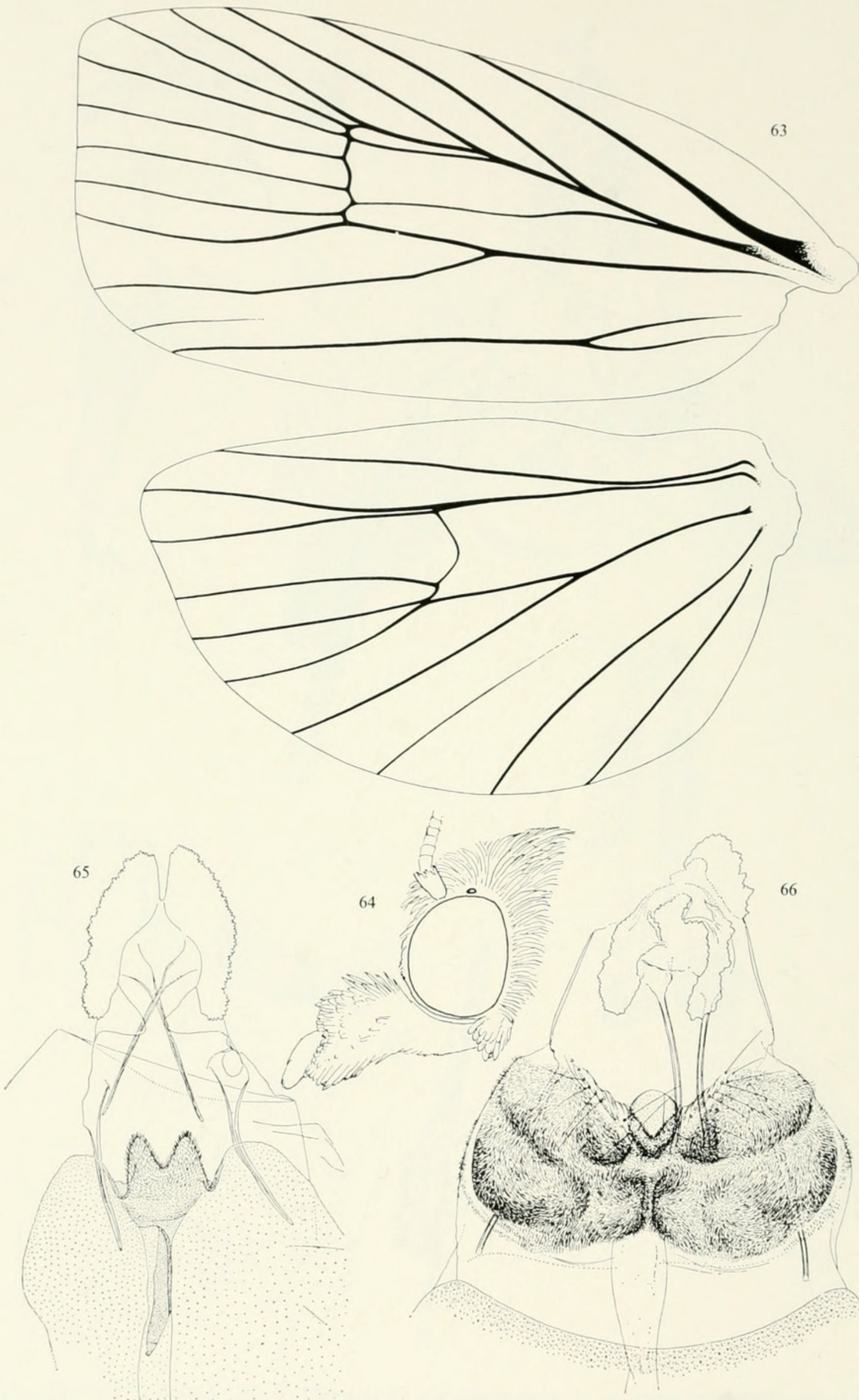

FiguREs 63-66.-Oleuthreutinae: 63, Gatesclarkeana erotias (Meyrick), $q$, wing neuration; 64, head; 65, Eudemis (E.) oxygona, new species, $q$, holotype; 66, Bubonoxena endaphana, new species, $\&$, holotype. 

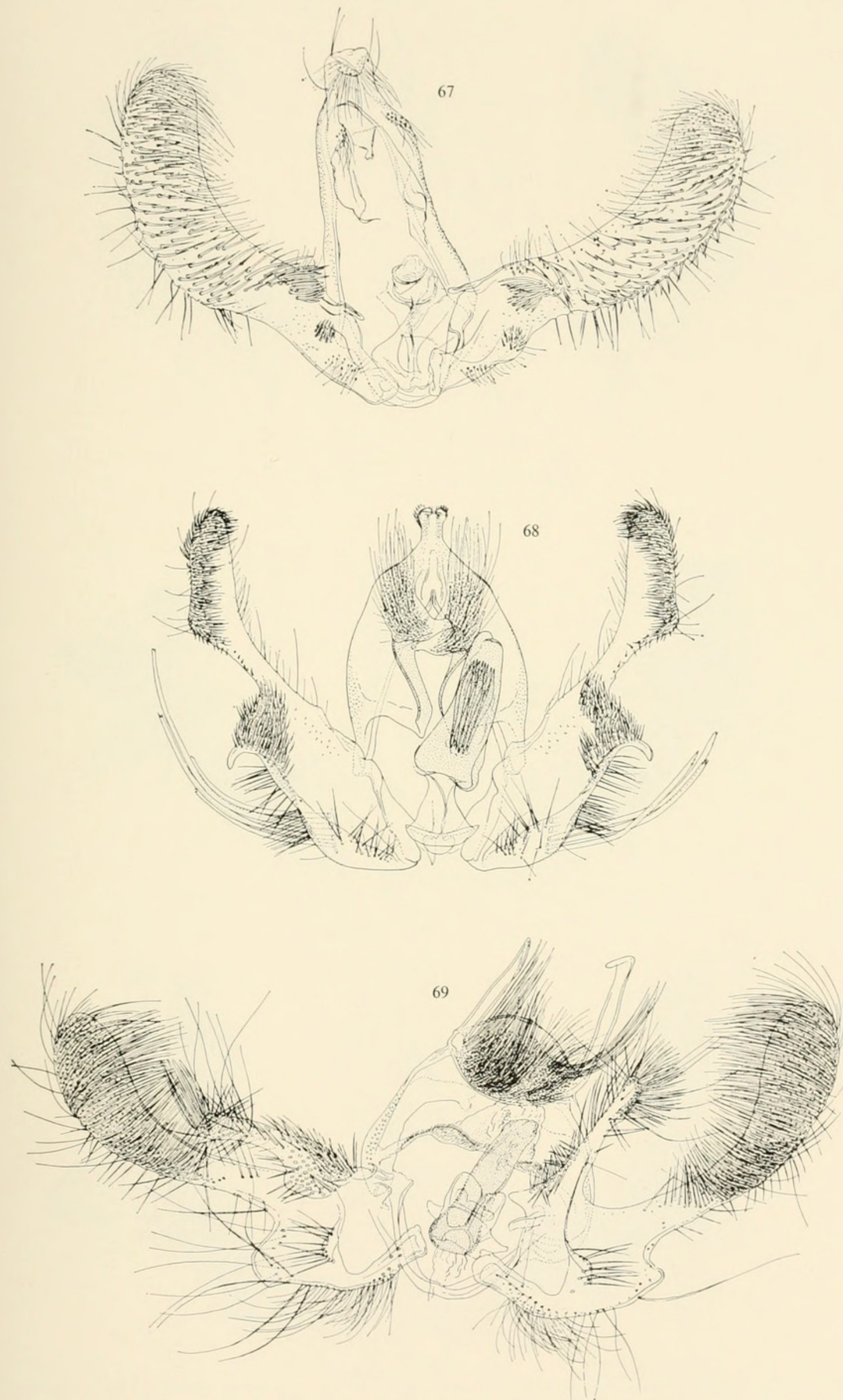

Figures 67-69.-Male genitalia of Olethreutinae: 67, Hedya (H.) atrifraga, new species, holotype; 68, Eucoenogenes deltostoma, new species, holotype; 69, Costosa allochroma, new genus, new species, holotype. 

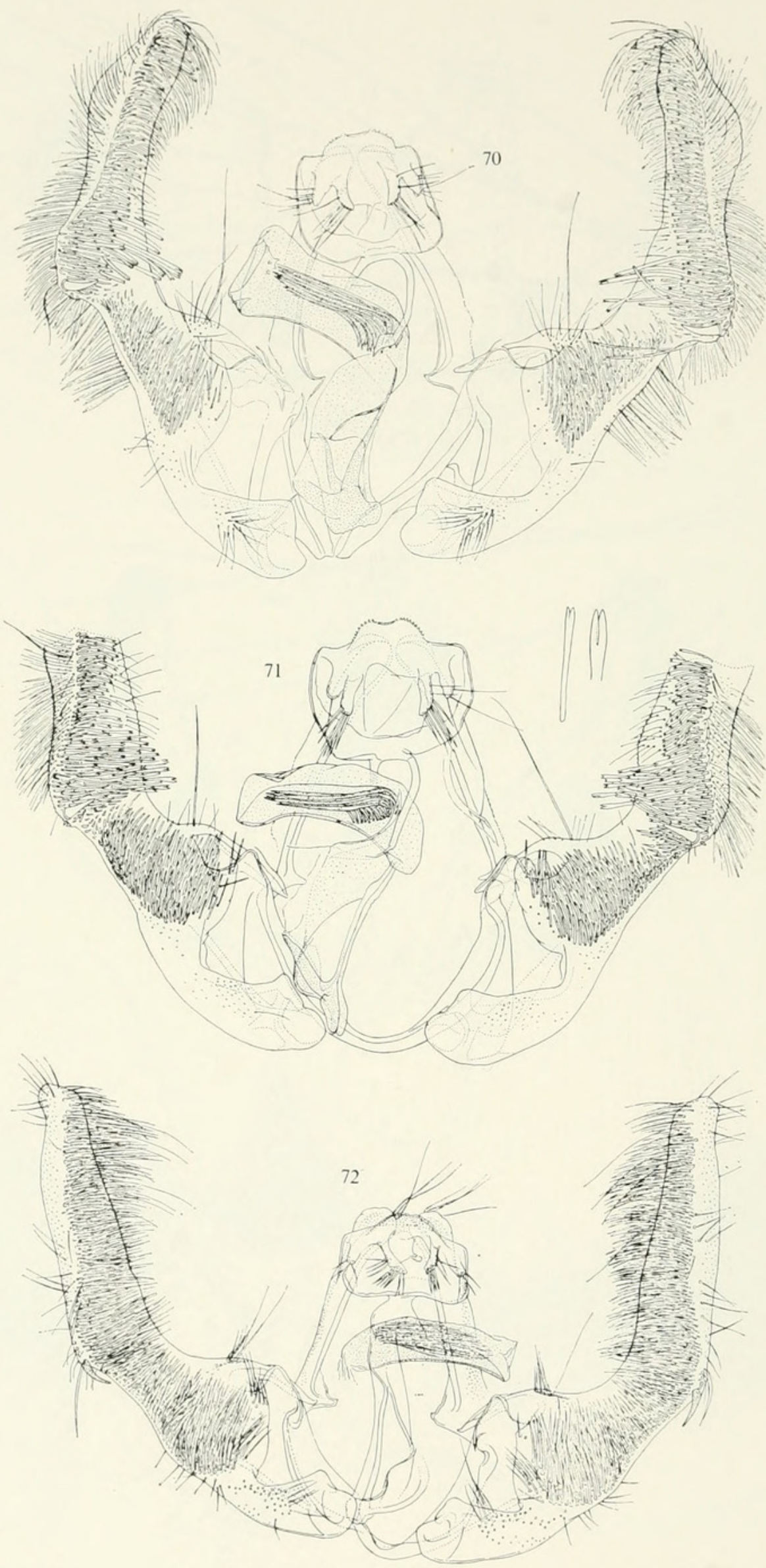

Figures 70-72.-Male genitalia of Sycacantha Diakonoff: 70, S. inodes (Meyrick) (Java); $71, S$. inodes perspicua, new subspecies, holotype; $72, S$. potamographa, new species, holotype. 

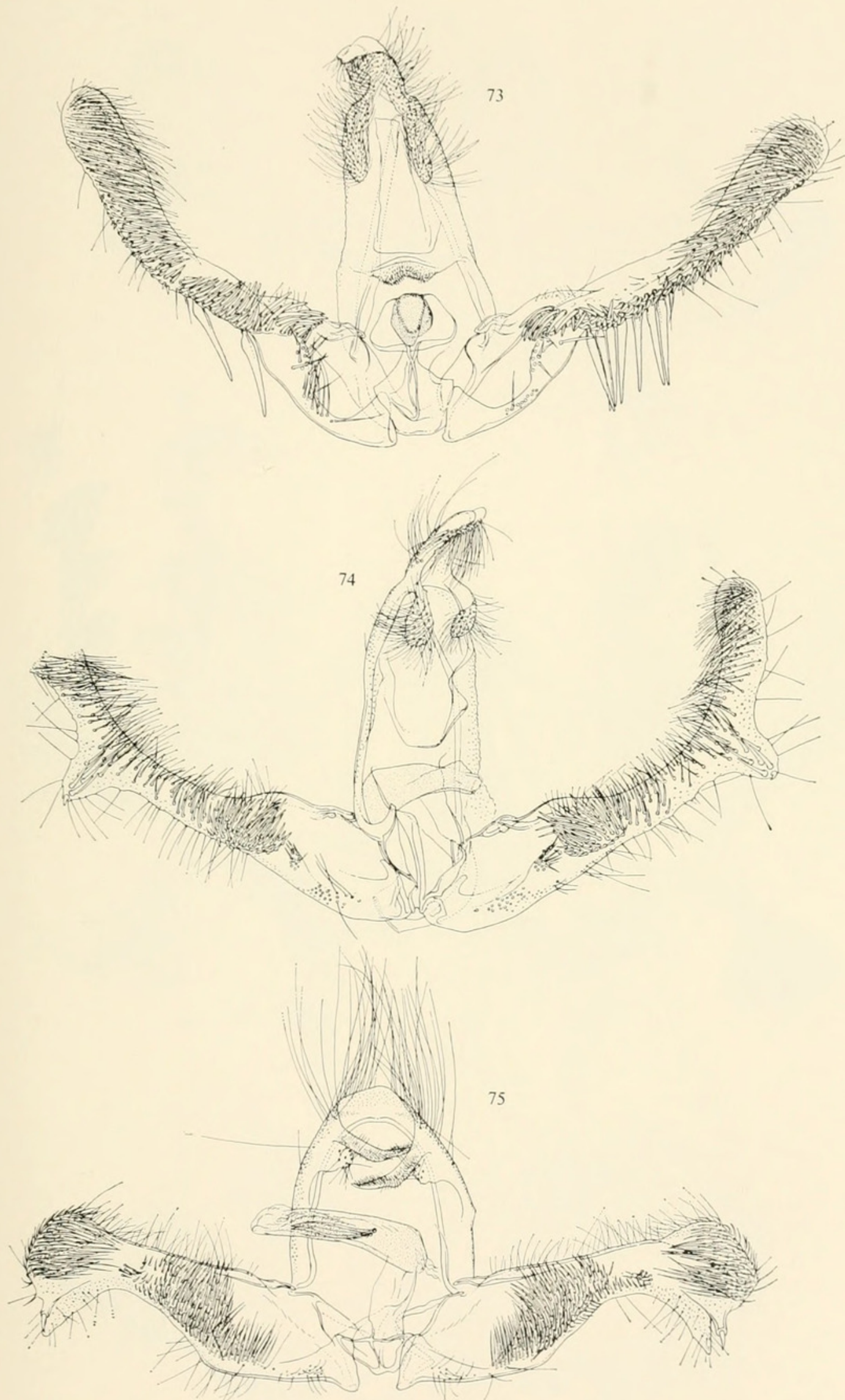

Figures 73-75.-Male genitalia of Olethreutinae: 73, Hedya (Cellifera) cellifera (Meyrick), slide no. 5376; 74, Statherotis olenarcha (Meyrick), slide no. 5317; 75, Strepsicrates ejectana (Walker), slide no. 5080. 

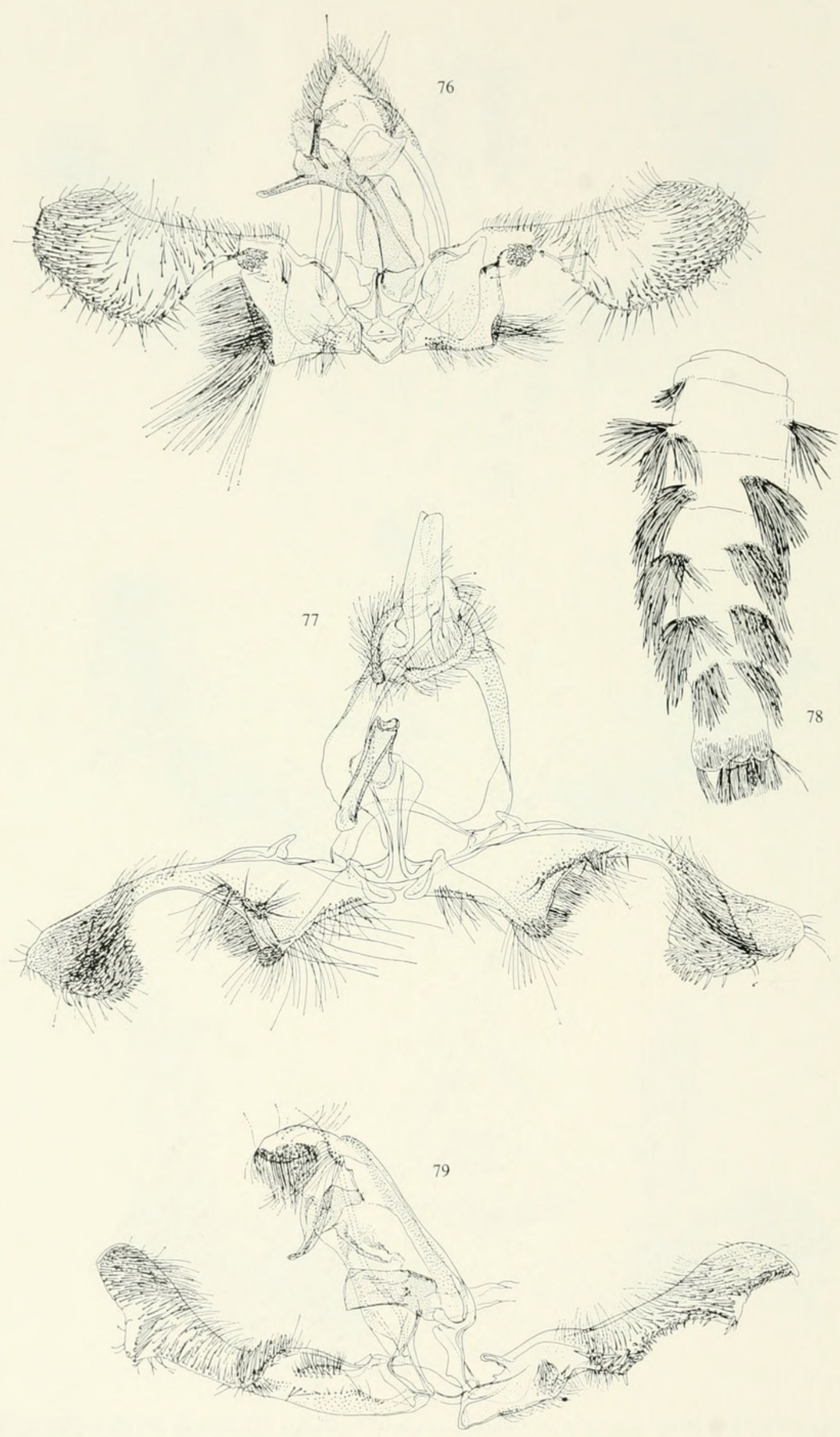

Figures 76-79.-Male genitalia of Olethreutinae: 76, Gnathmocerodes petrifraga, new species, holotype; 77, Eudemis (Acanthothyspoda) chortodes, new species, holotype; 78, abdomen; 79, Statherotis discana (Felder and Rogenhofer), $\sigma^{7}$, slide no. 5311. 

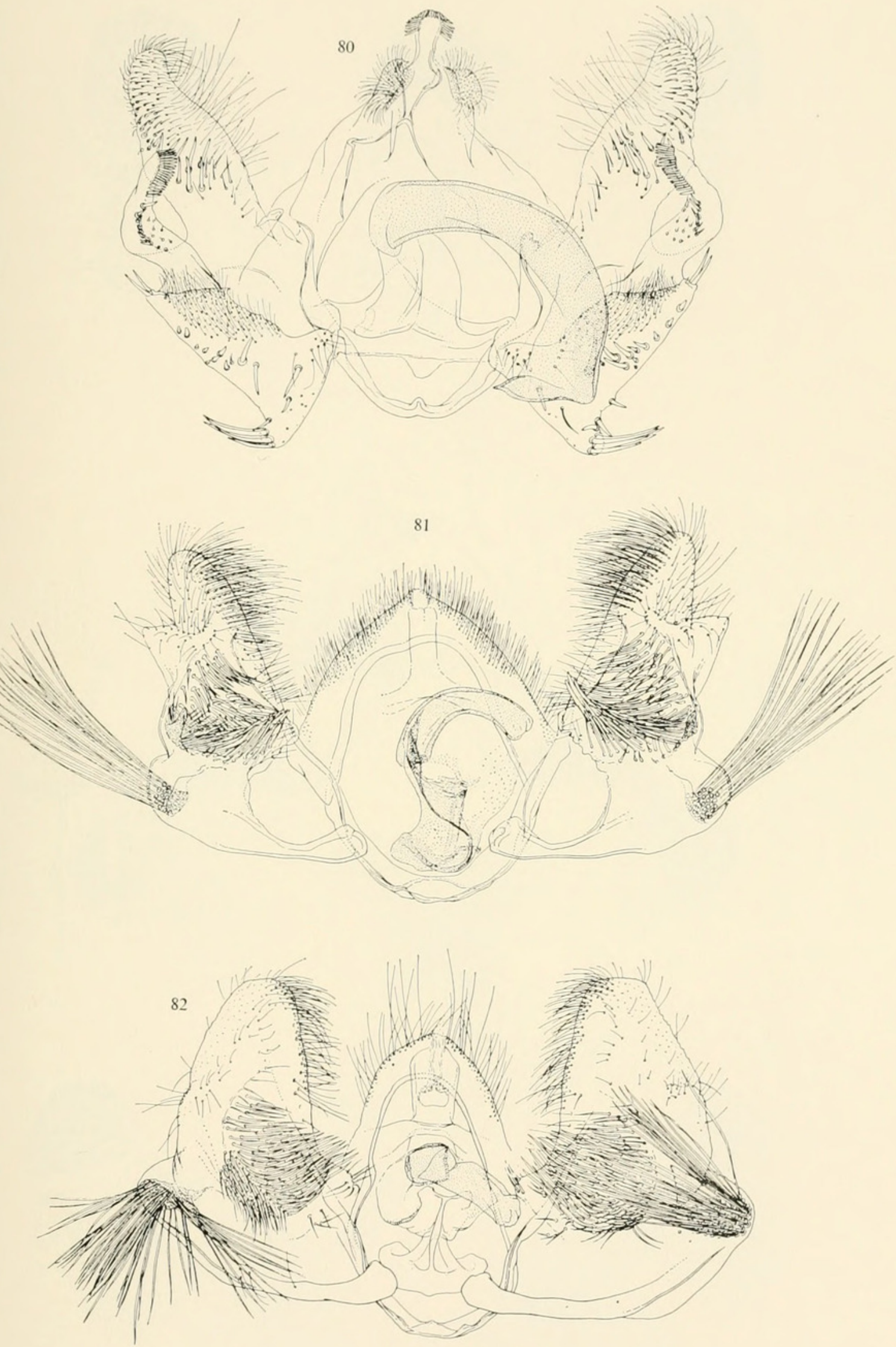

Figures 80-82.-Male genitalia of Olethreutinae: 80, Bactra (C.) orbiculi minax Diakonoff, holotype; 81, Bubonoxena ephippias (Meyrick) (Ceylon), lectotype; 82, Bubonoxena spirographa, new species, holotype. 

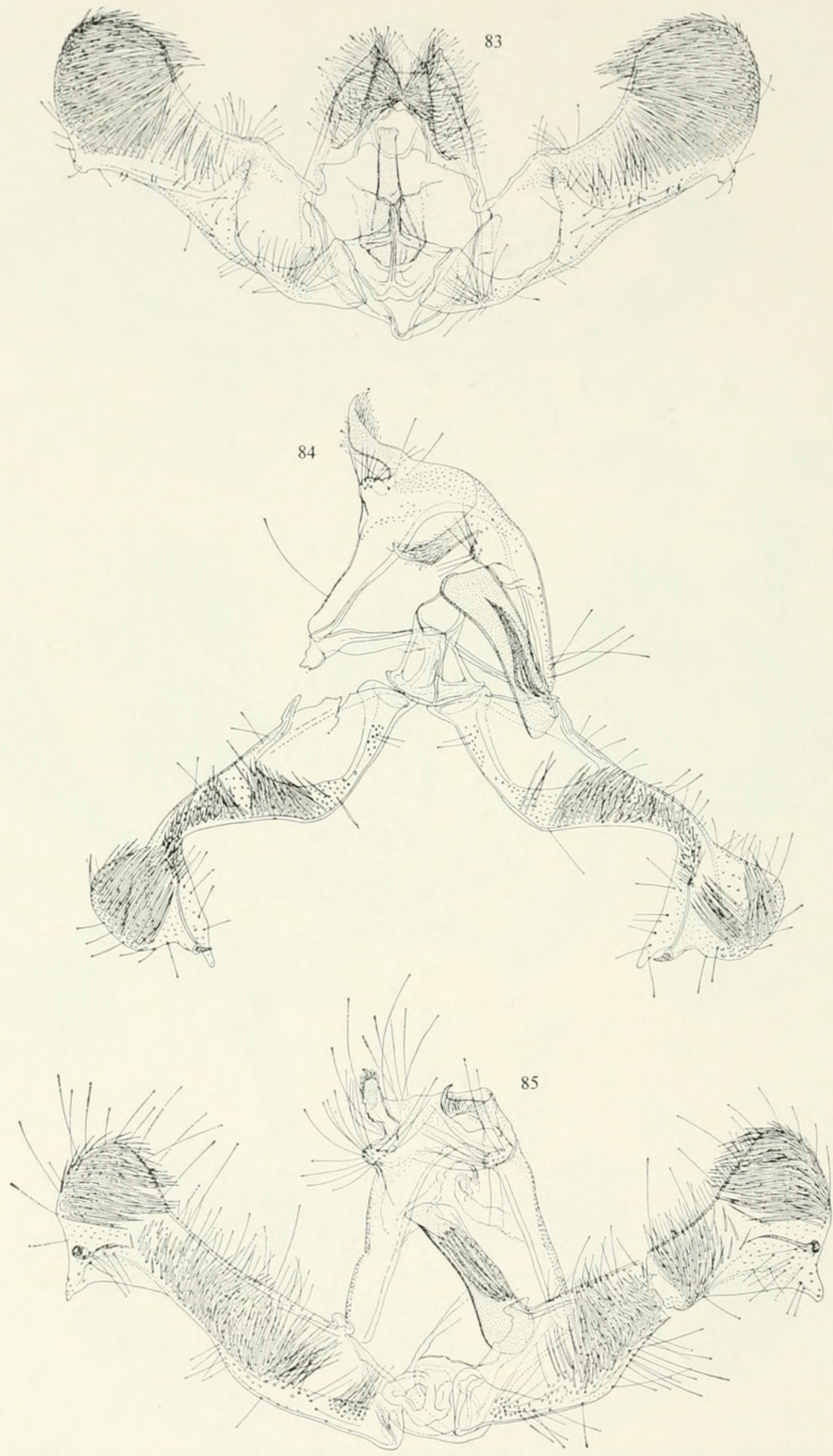

Figures 83-85.-Male genitalia of Olethreutinae: 83, Eucosma iographa, new species, holotype; 84, Strepsicrates inobtrusa, new speces, holotype; 85 , S. discobola, new species, holotype. 


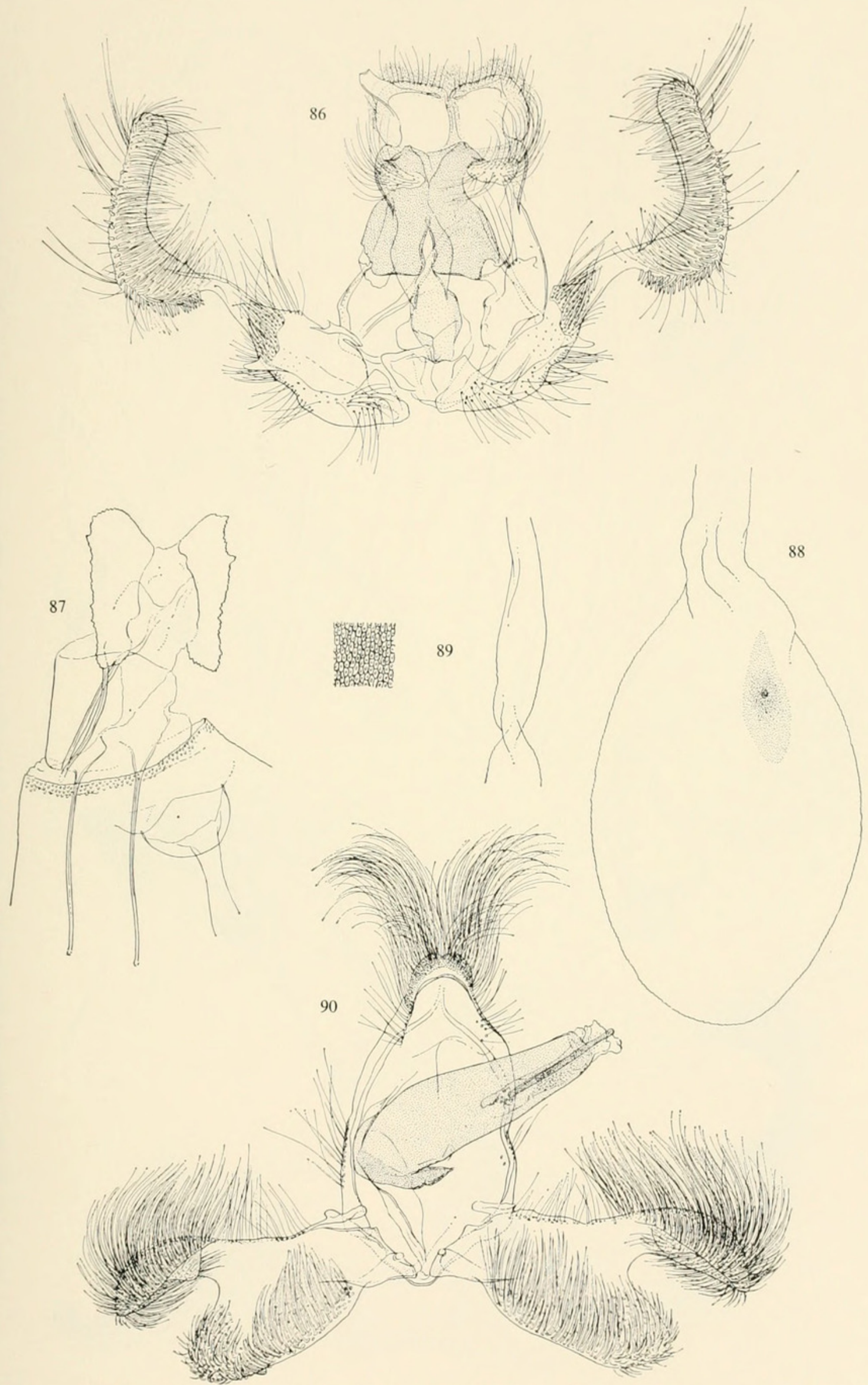

Figures 86-90.-Genitalia of Olethreutinae: 86, Peridaedala dendrochlora, new species $\sigma^{7}$, holotype; 87 , Tetramoera schistaceana (Snellen), $q$, slide no. $5372 ; 88$, bursa copulatrix; 89 , fragment of ductus bursae and structure of the wall of corpus bursae, strongly magnified; 90, ơ genitalia, no. "June 19, 1930, A.B." 

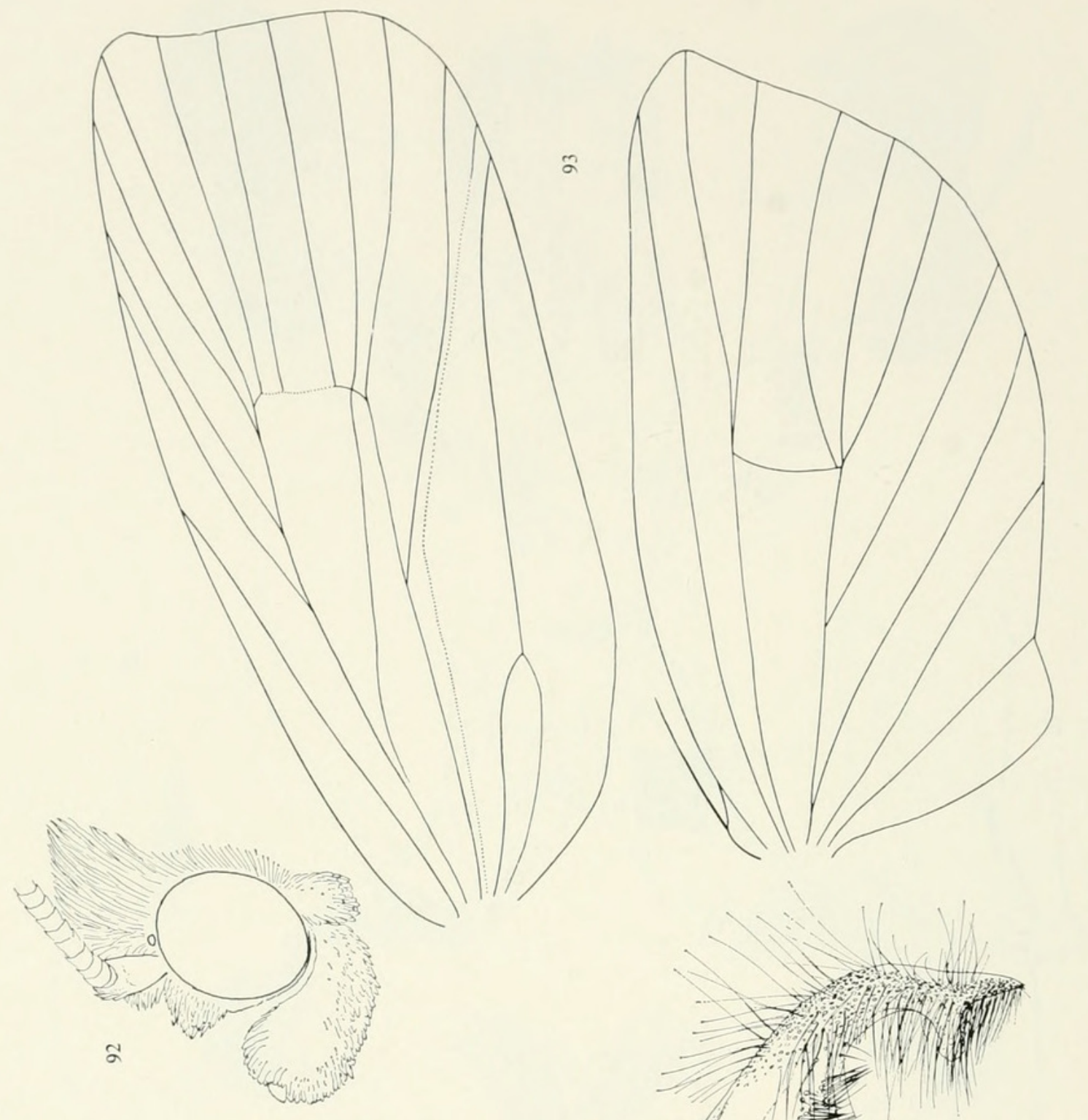

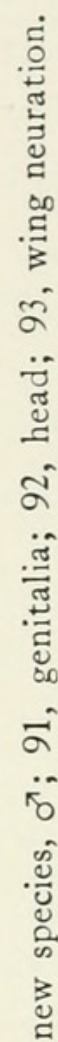

م

苂

3

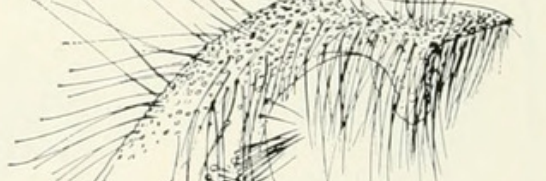

ह

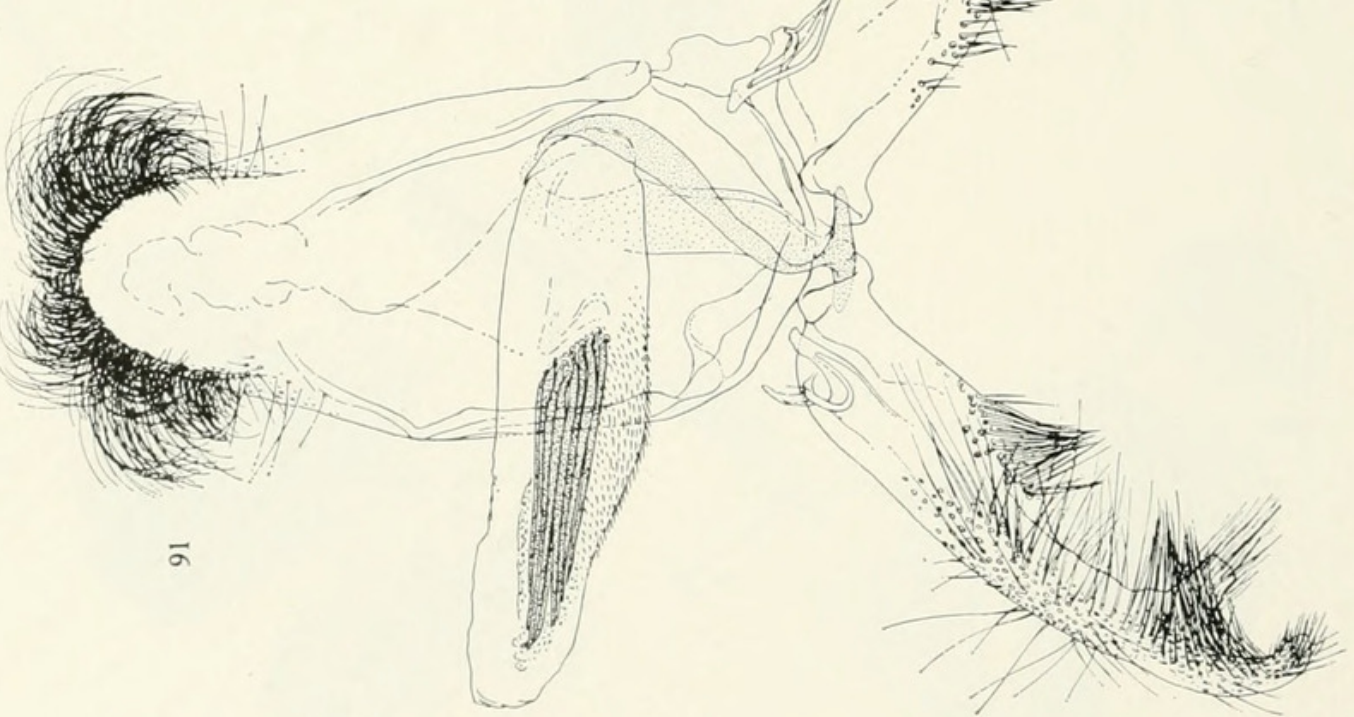

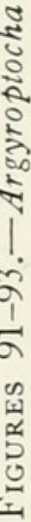




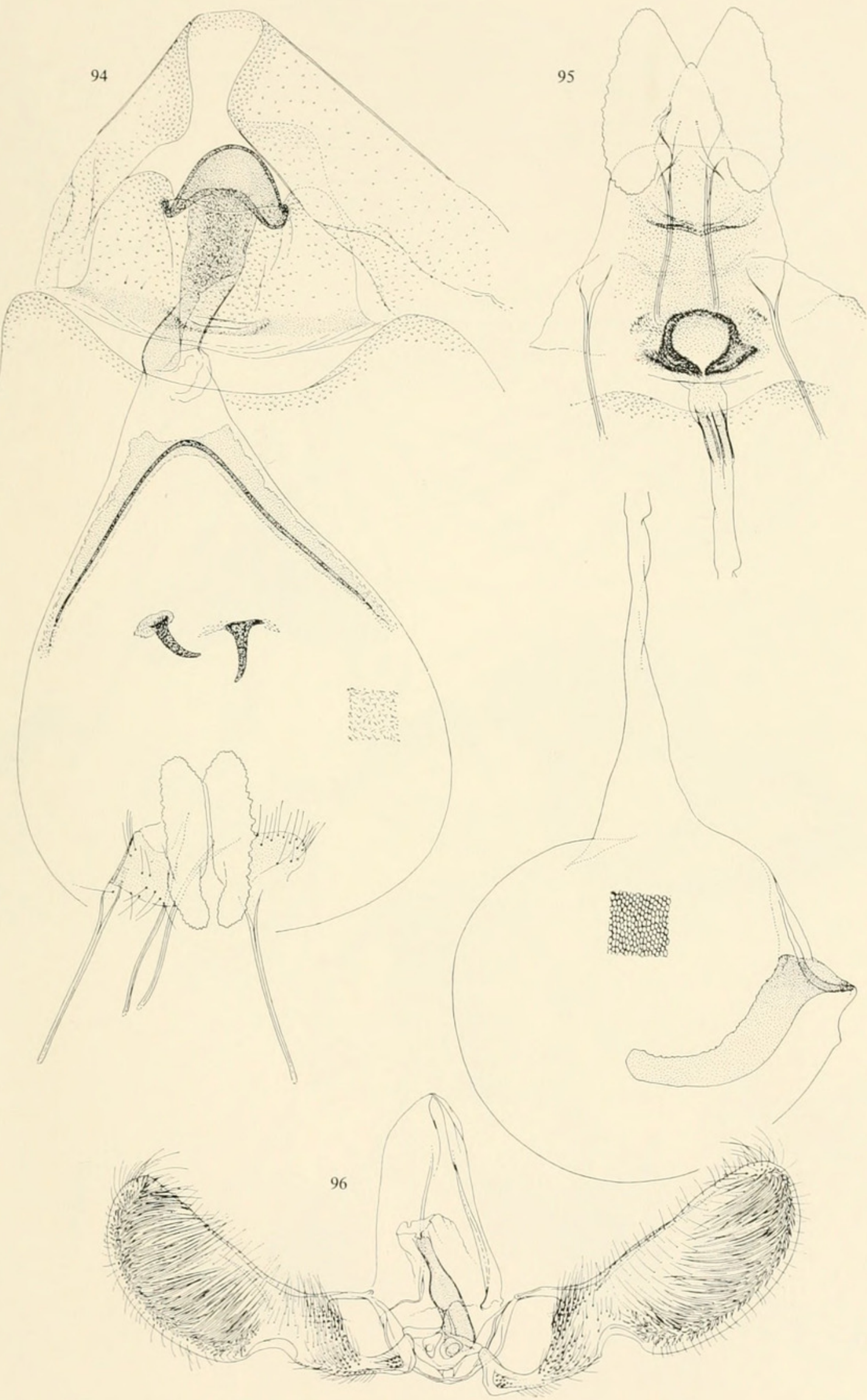

Figures 94-96.-Genitalia of Olethreutinae: 94, Erinaea amphigonia, new species, $q$, holotype (ovipositor severed and figured at the foot of the bursa, cut: structure of the wall, more magnified); 95, Hedya (Cellifera) cellifera (Meyrick), + , slide no. 5037; 96, Pammene leucodora Meyrick, ơ', slide no. 5015. 


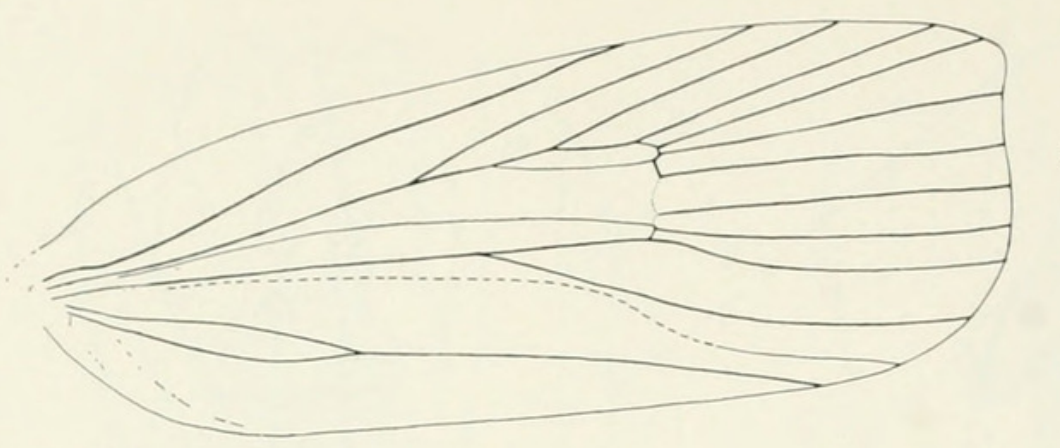

97
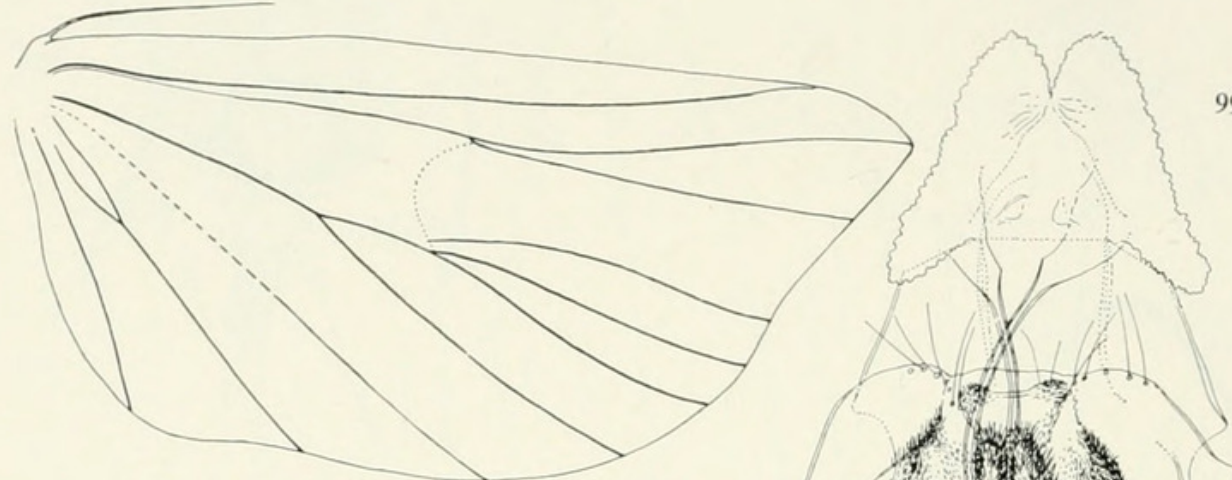

98

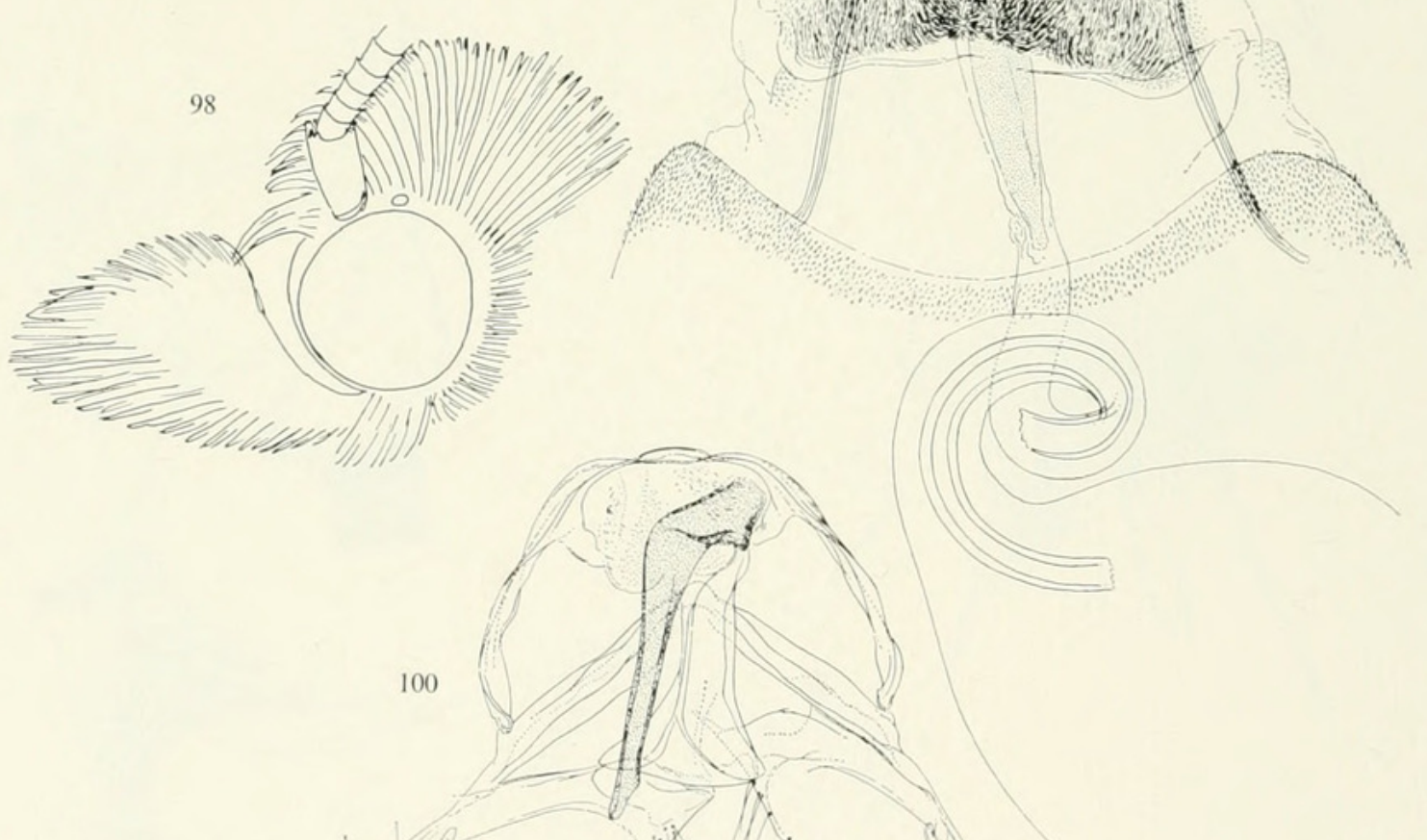

100
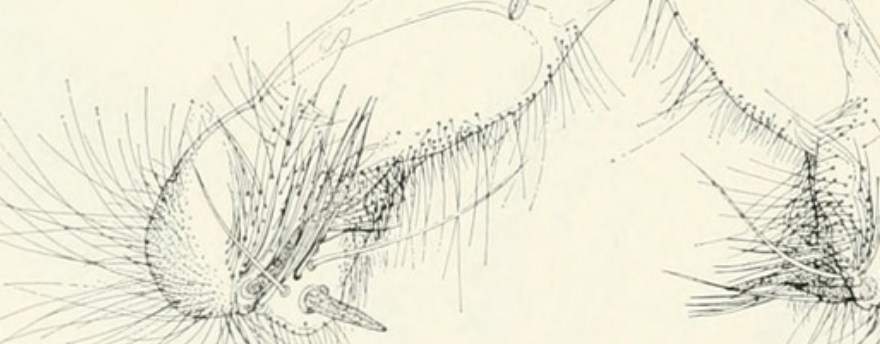

Figures 97-100.-Olethreuntinae, Tetramoera schistaceana (Snellen), $\sigma^{7}: 97$, wing neuration; 98, head. Genitalia: 99, Bubonoxena ephippias (Meyrick) (Ceylon), $q$, slide no. 5688; 100, Cryptophlebia tetraploca (Meyrick), ơ, slide no. 5541. 


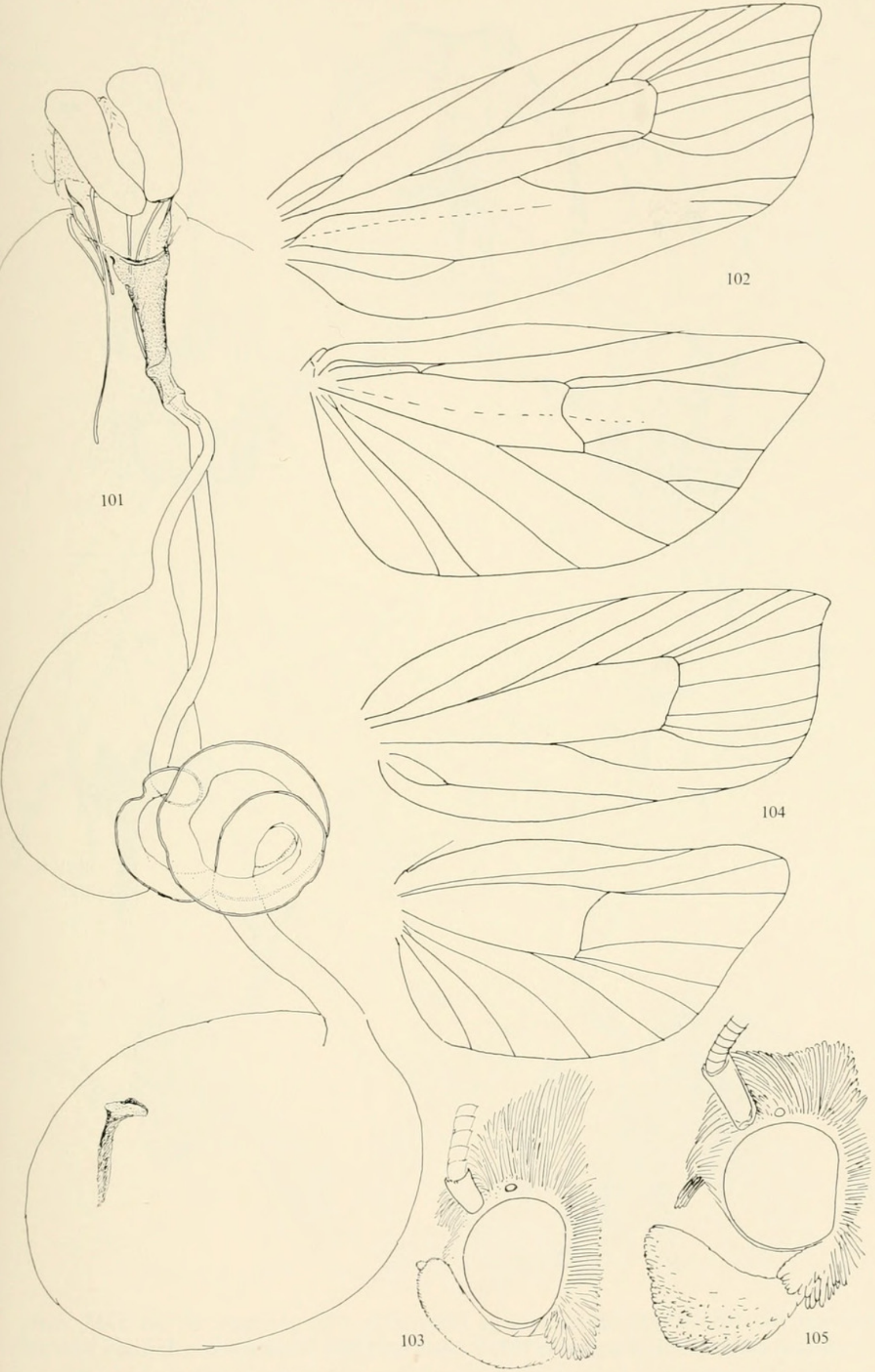

Figures 101-105.-Female genitalia, heads, and wings of Tortricidae: 101, Archips salaconis (Meyrick), + , slide no. 5783; 102, Eucoenogenes deltostoma, new species, wing neuration; 105, $\sigma^{7}$, head; 103, Bubonoxena spirographa, new genus, new species, $\sigma^{7}$, head; 104, wing neuration. 


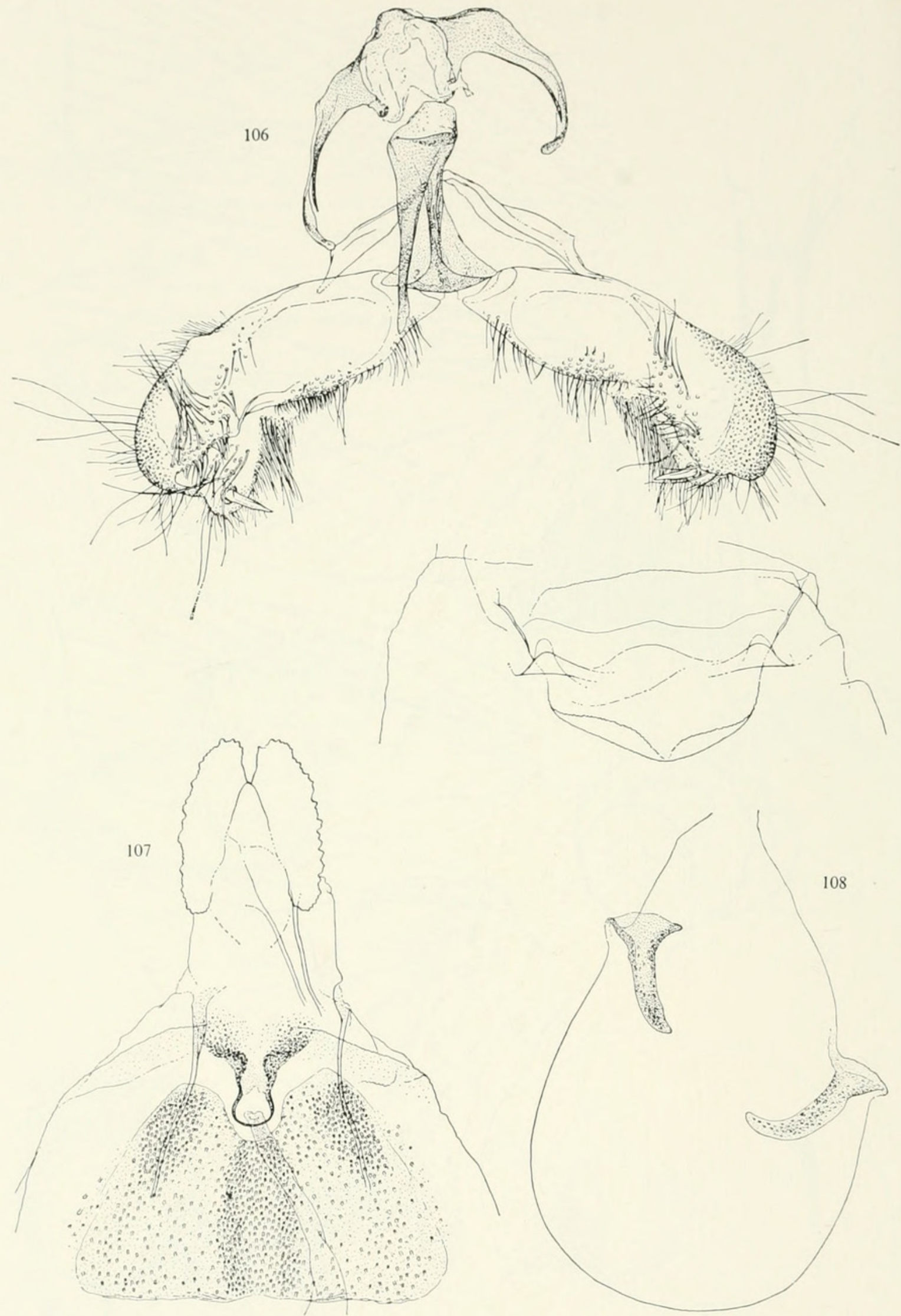

Figures 106-108.-Cryptophlebia encarpa (Meyrick): 106, genitalia, o7, no. 5143, with, below, first abdominal segment; $107, q$, slide no. $5062 ; 108$, bursa copulatrix. 


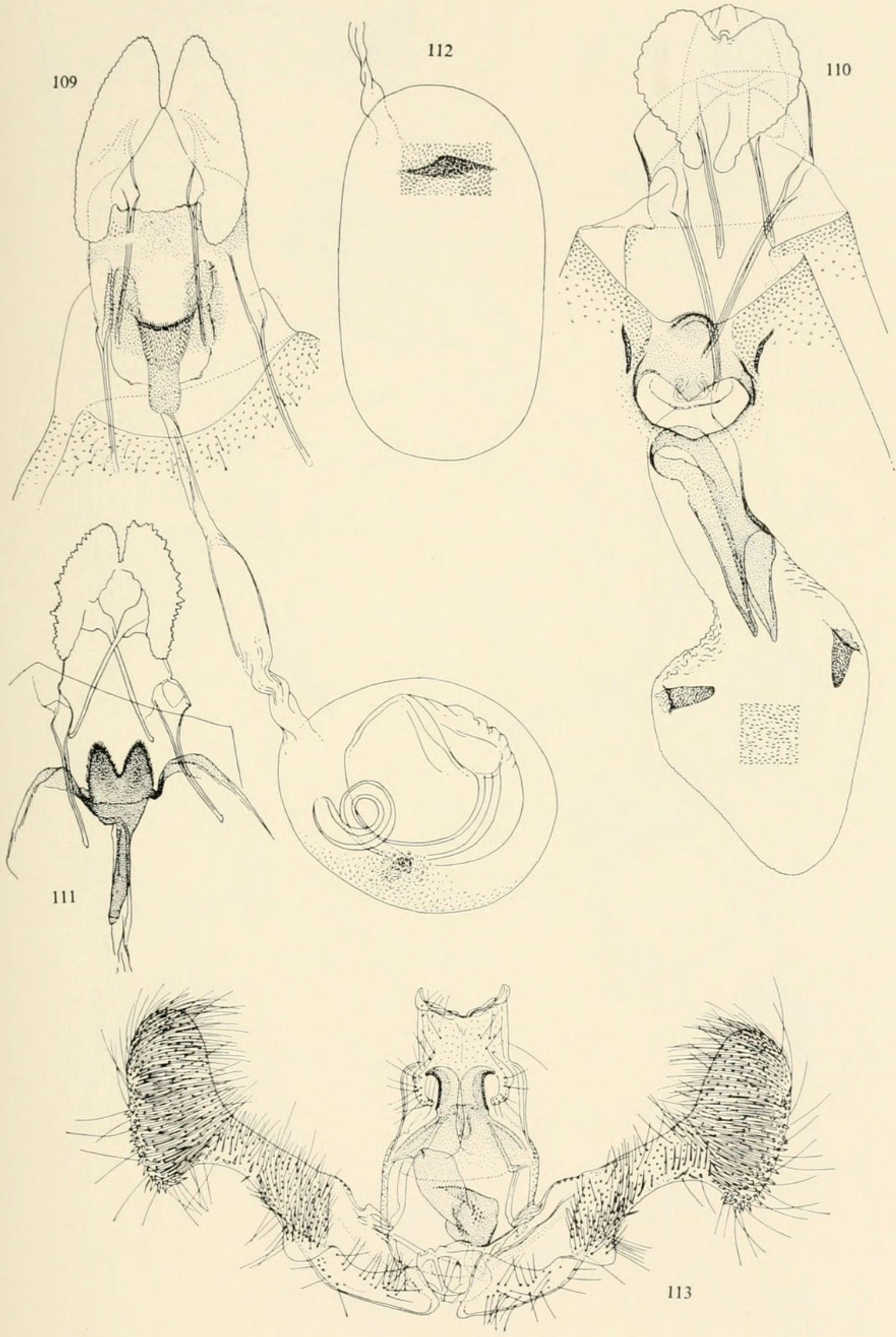

Figures 109-113.-Genitalia of Olethreutinae: 109, Petrova scalaris, new species, $q$, holotype; 110 , Peridaedala crocoptila, new species, + , holotype; 111, Eudemis (E.) oxygona, new species, $\&$, holotype; 112, bursa copulatrix; 113, Peridaedala physoptila, new species, $\sigma^{\top}$. 

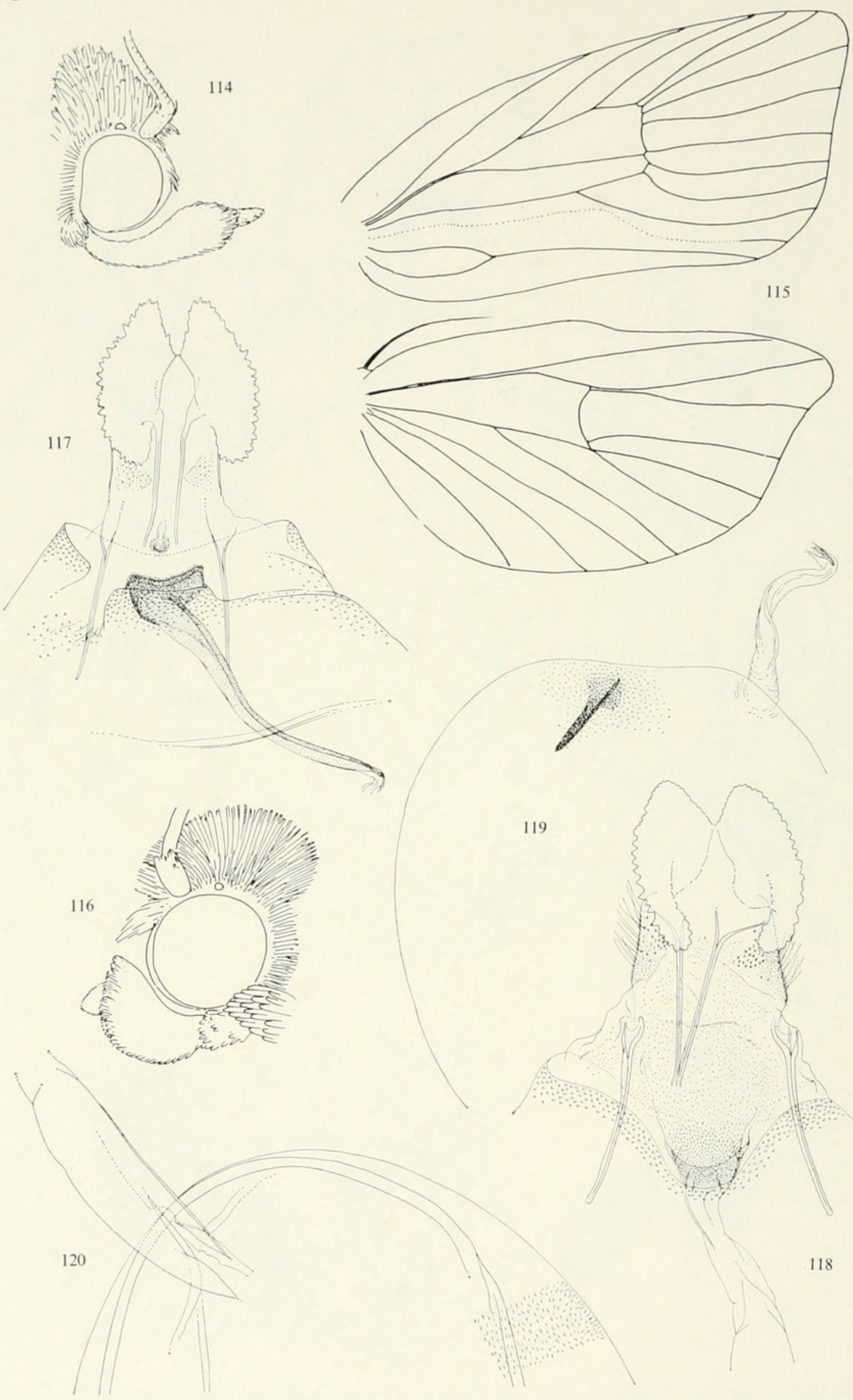

Figures 114-120.-Olethreutinae, Costosa allochroma, new genus, new species: 114, head; 115, wing neuration; 116, Gnathmocerodes petrifraga, new genus, new species, head. Female genitalia: 117, Eudemis (Acanthothyspoda) homalopa, new species, $q$, holotype; 118, fragment of bursa copulatrix with signum; 119, Peridaedala stenoglypha, new species, $\$$, holotype; 120 , fragment of bursa copulatrix, showing structure of the wall. 


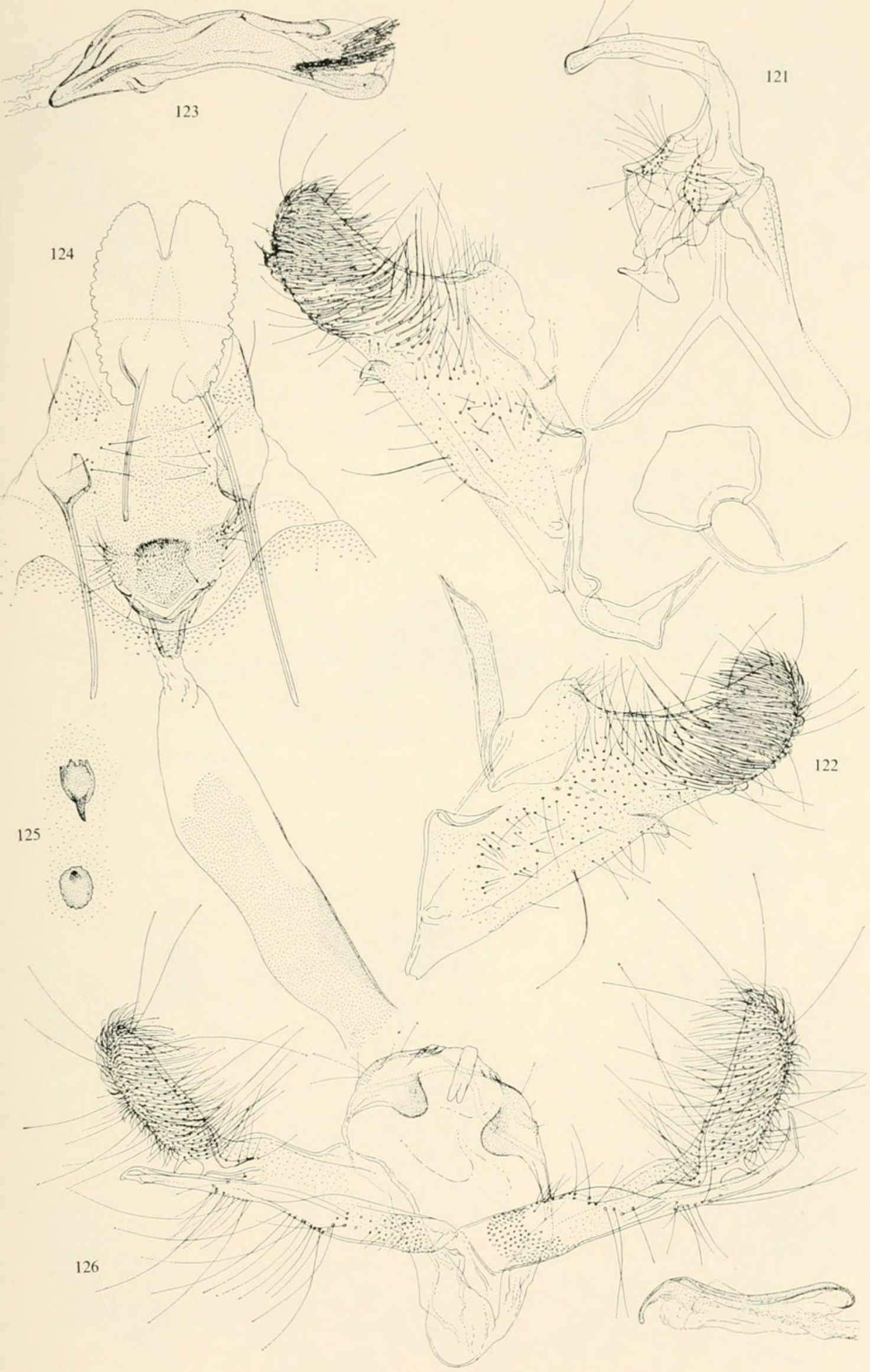

Figures 121-126. - Genitalia of Tortricidae and Carposinidae: 121, Stenarchella eupista, new genus, new species, $\sigma^{7}$, holotype, part of genitalia; 122 , right valva; 123 , aedeagus; 124, Peridaedala melanantha, new species, $q$, holotype; 125, signa; 126, Heterogymna melanocrypta, new species, $\sigma^{7}$, holotype; with aedeagus. 


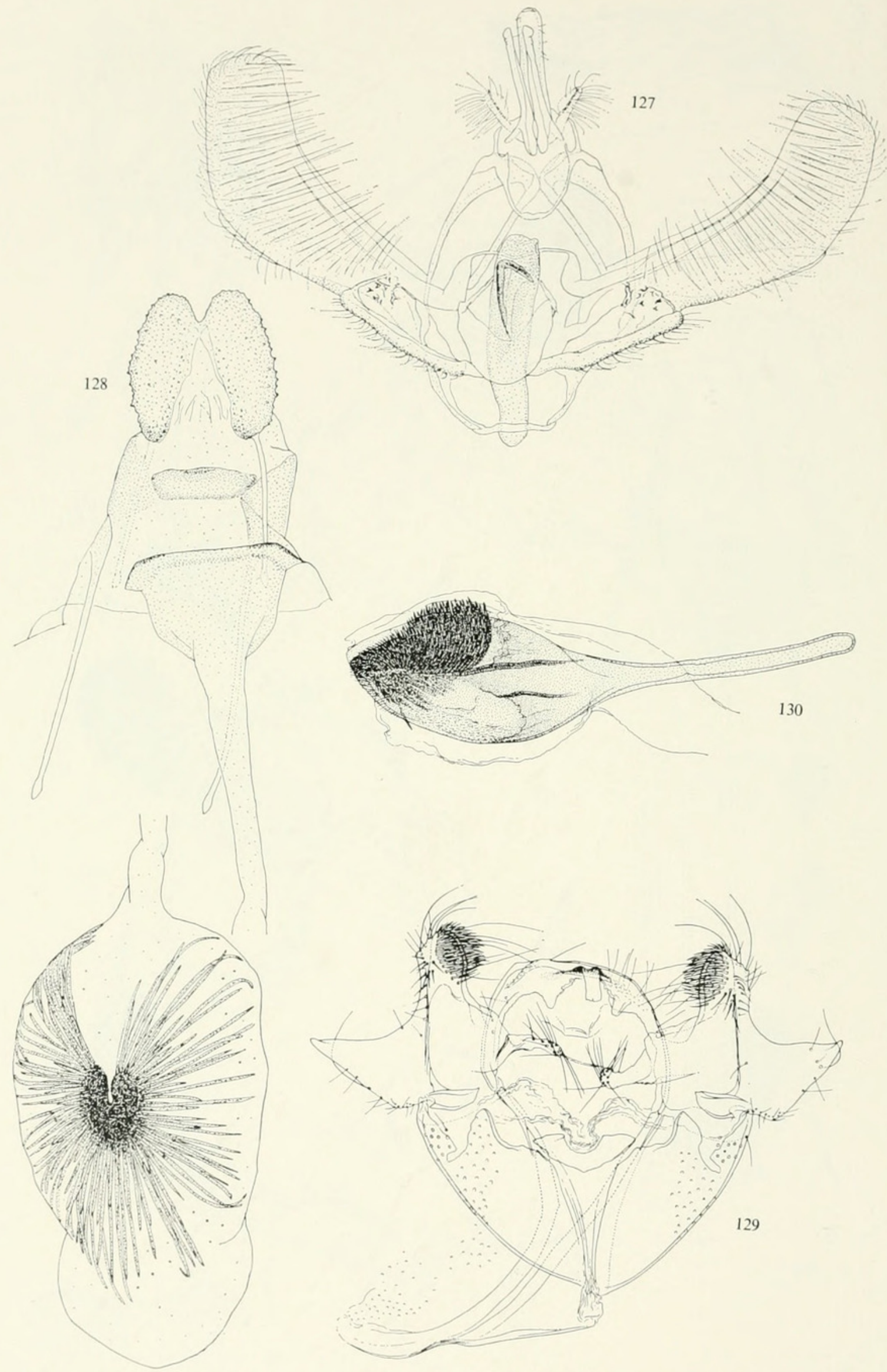

Figures 127-130.-Tortricidae: 127, Caenognosis incisa Walsingham, ơ, slide no. “Apr. 4, 1928, A.B.”; 128, \&, slide no. "4.IV.1928, A.B.” 129, Campylarchis acuta, new genus, new species, $\sigma^{7}$, holotype; 130 , aedeagus. 


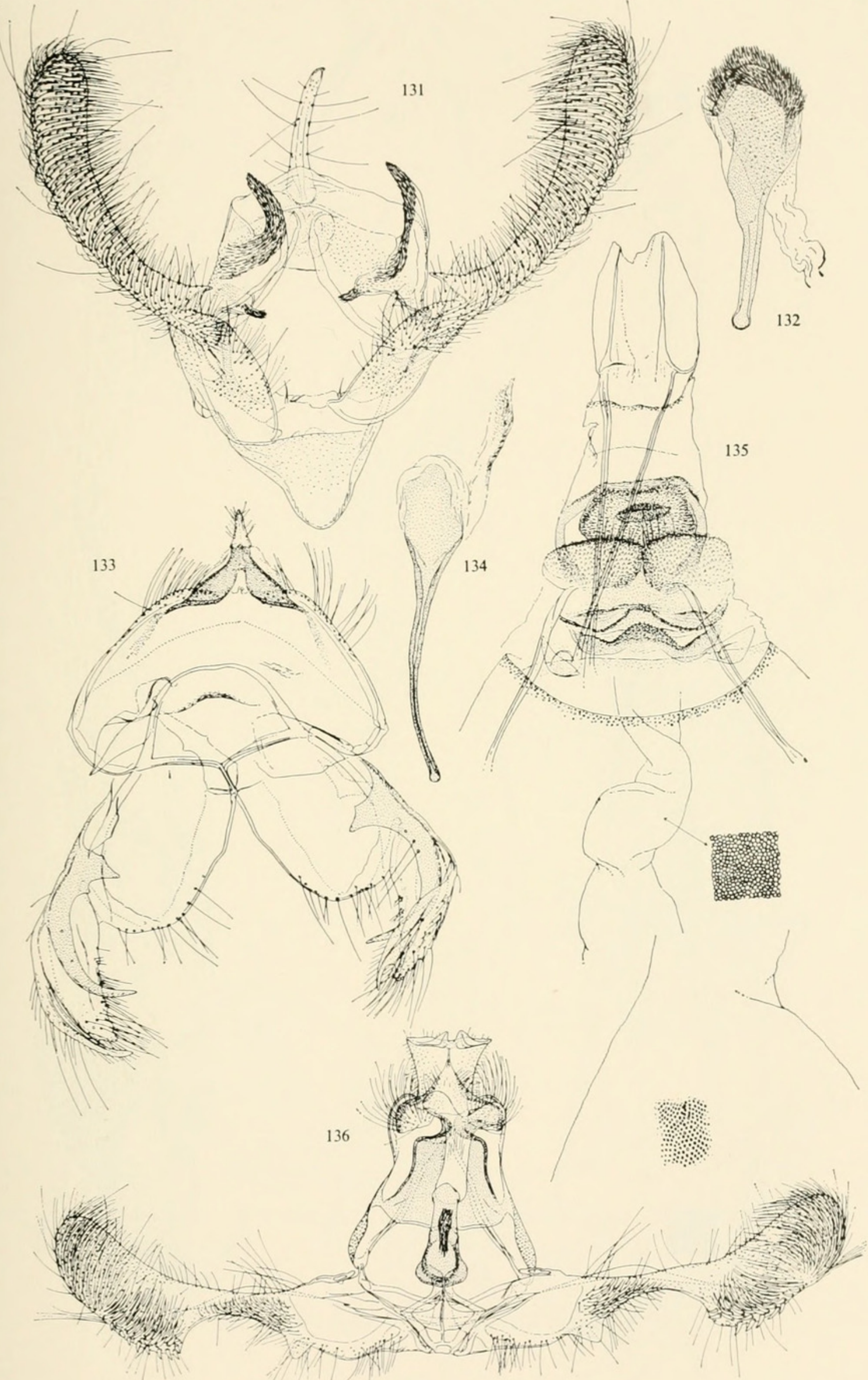

Figures 131-136.-Genitalia of Olethreutinae, Carposinidae, and Copromorphidae: 131, Meridarchis bifracta, new species, $\sigma^{7}$, holotype; 132, aedeagus; 133, Metacosmesis illodis, new genus, new species, $\sigma^{7}$, holotype; 134, aedeagus; 135 Copromorpha mistharnis, new species, $q$, holotype, fragment of wall of ductus bursae, magnified, below, fragment of wall of bursa copulatrix; 136 , Peridaedala thylacophora, new species, $\sigma^{7}$, holotype. 


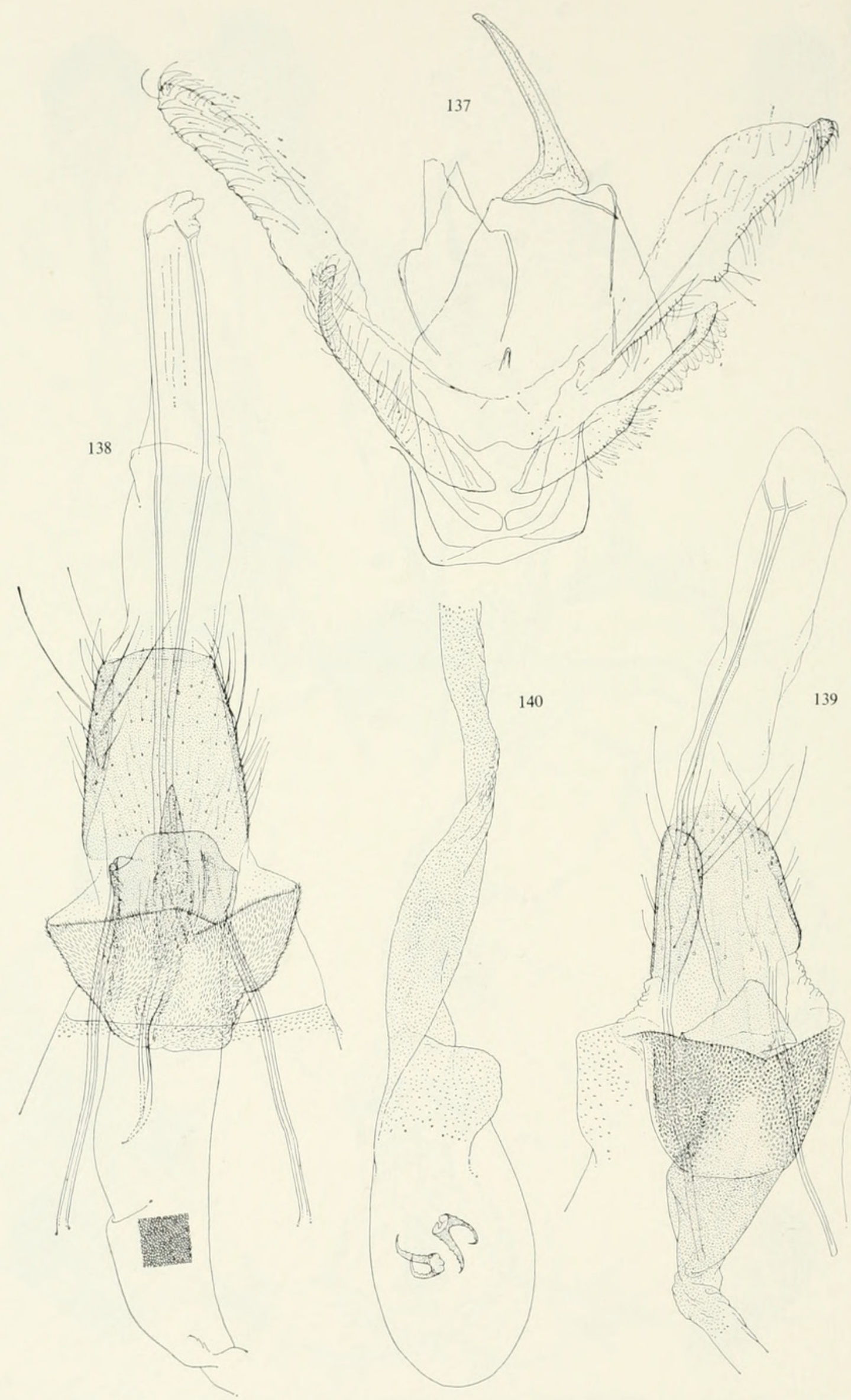

Figures 137-140.-Genitalia of Carposinidae and Copromorphidae: 137, Copromorpha smaragdarcha, new species, $\sigma^{7}$, holotype; 138, Meridarchis oxydelta, new species, $q$, holotype; 139, M. scythophyes, new species, + , paratype; 140, bursa copulatrix. 

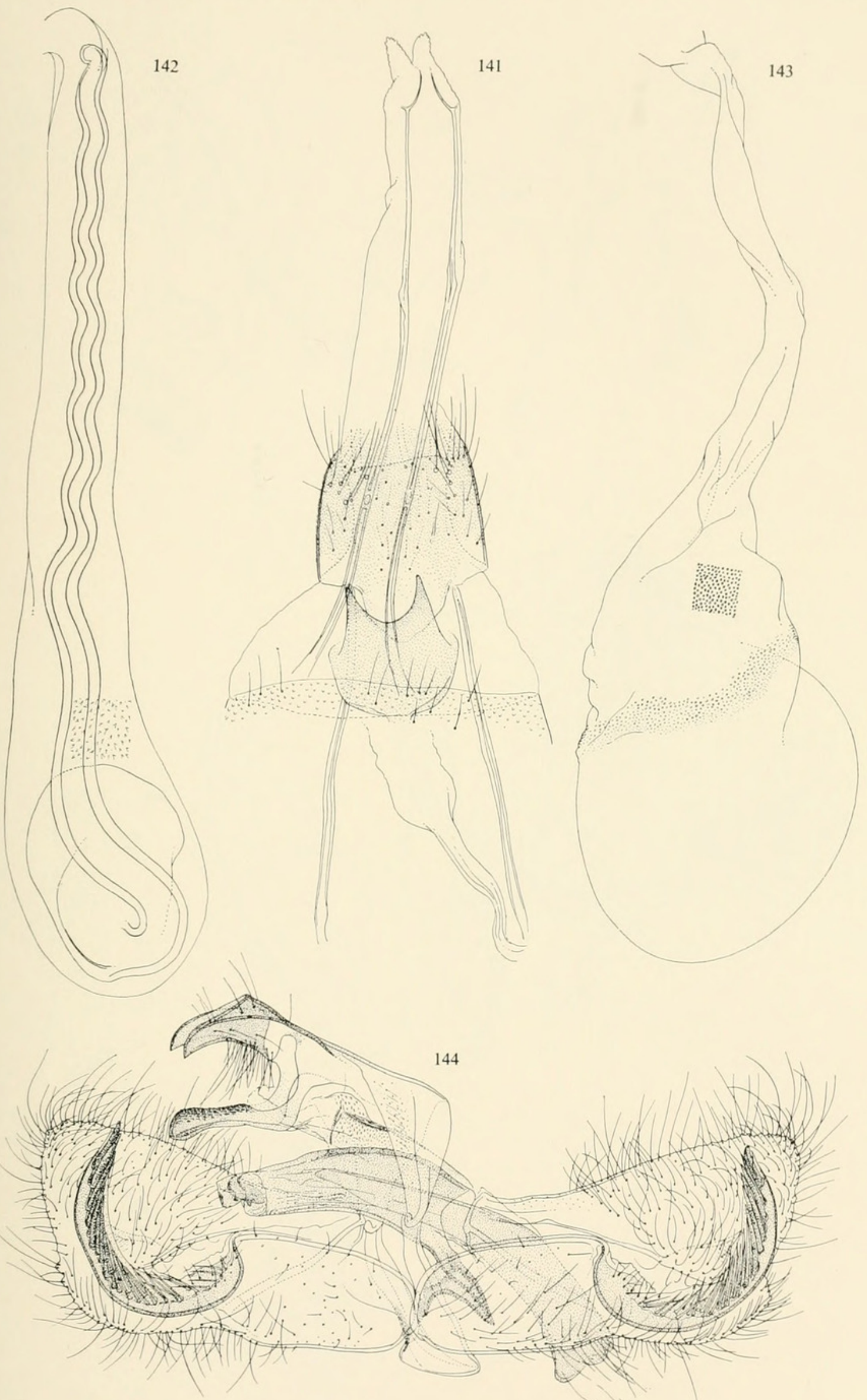

Figures 141-144.-Genitalia of Carposinidae and Xyloryctidae: 141, Meridarchis aita, new species, $\uparrow$, holotype; 142, bursa copulatrix (with spermatophore); 143, M. oxydelta, new species, $q$, holotype, bursa copulatrix; 144, Metathrinca pernivis, new species, $\sigma^{x}$, holotype. 


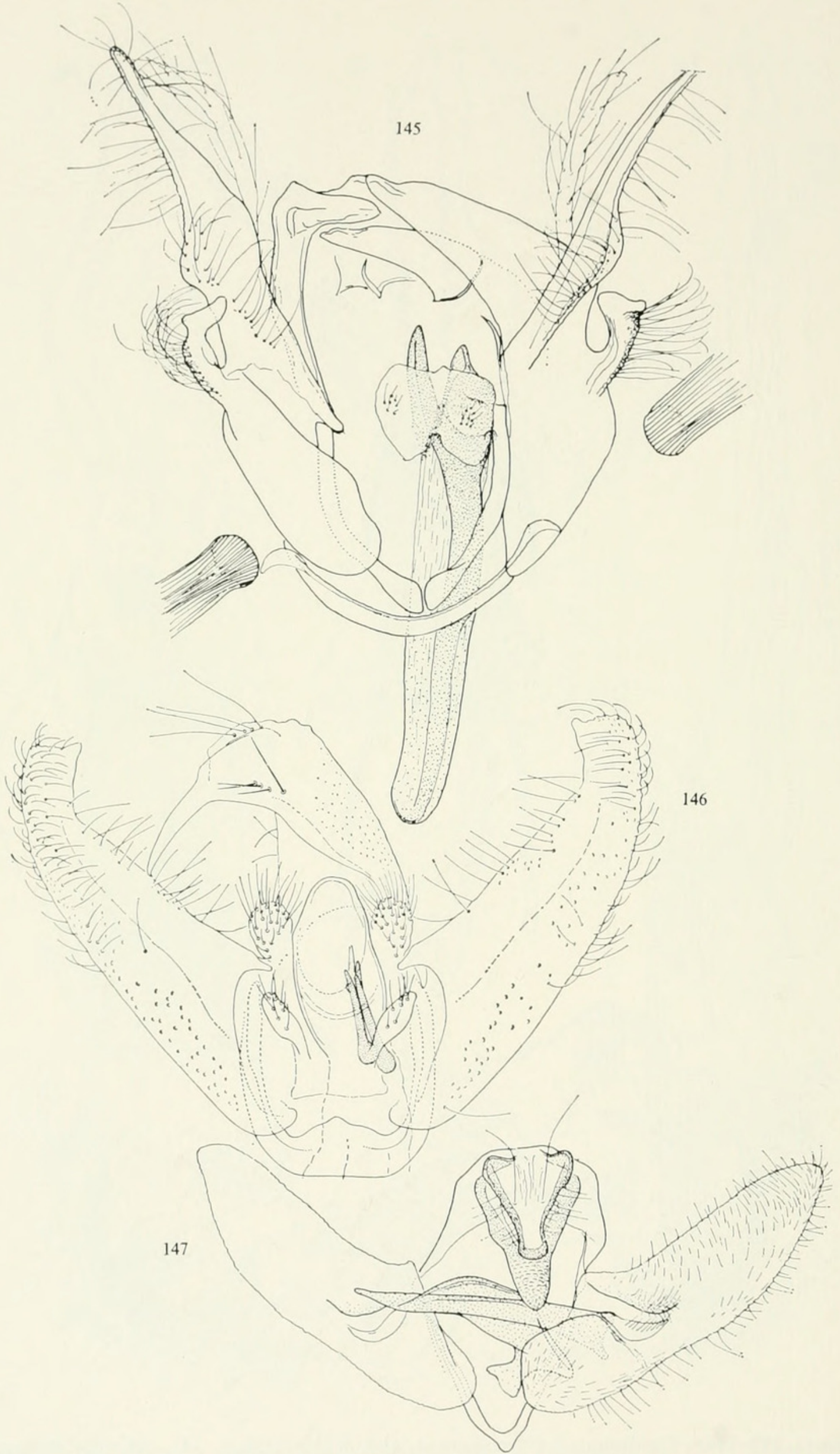

Figures 145-147.-Male genitalia of Copromorphidae and Xyloryctidae: 145, Copromorpha dialithoma, new species, holotype; 146, Odites apicalis, new species, holotype; 147, Metathrinca coenophyes, new species, holotype. 


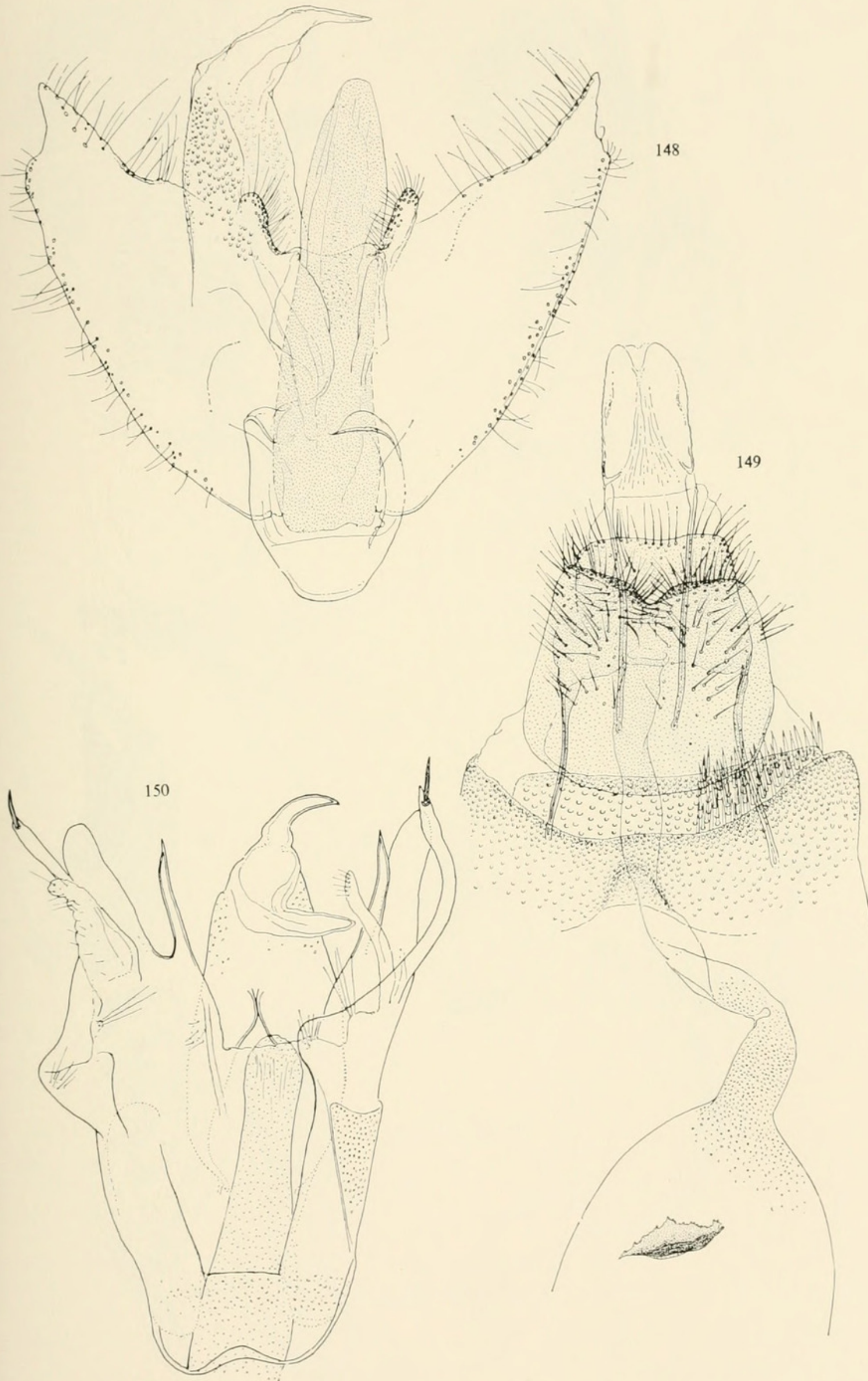

Figures 148-150.-Genitalia of Xyloryctidae: 148, Odites pancyclia Meyrick, ð7, slide no. 5158; 149, Amorbaea subtusvena, new species, + , allotype; 150, O. brachyclista Meyrick, $\sigma^{7}$, slide no. 5160. 


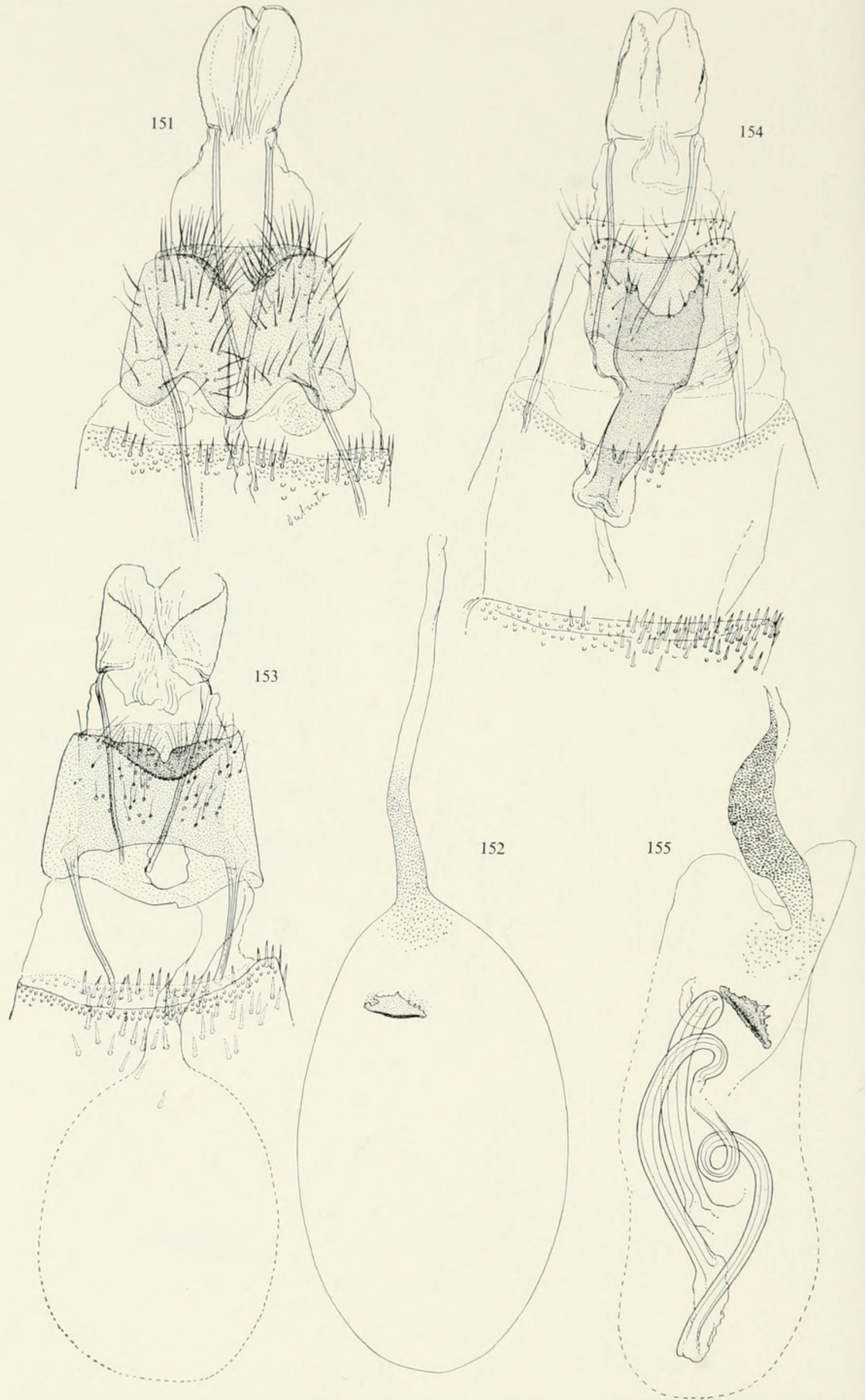

Figures 151-155.-Female genitalia of Xyloryctidae: 151, Amorbaea subusta, new species, holotype; 152, bursa copulatrix; 153, Metathrinca coenophyes, new species, allotype; $154 M$. iridostoma, new species, allotype; 155 , bursa copulatrix. 


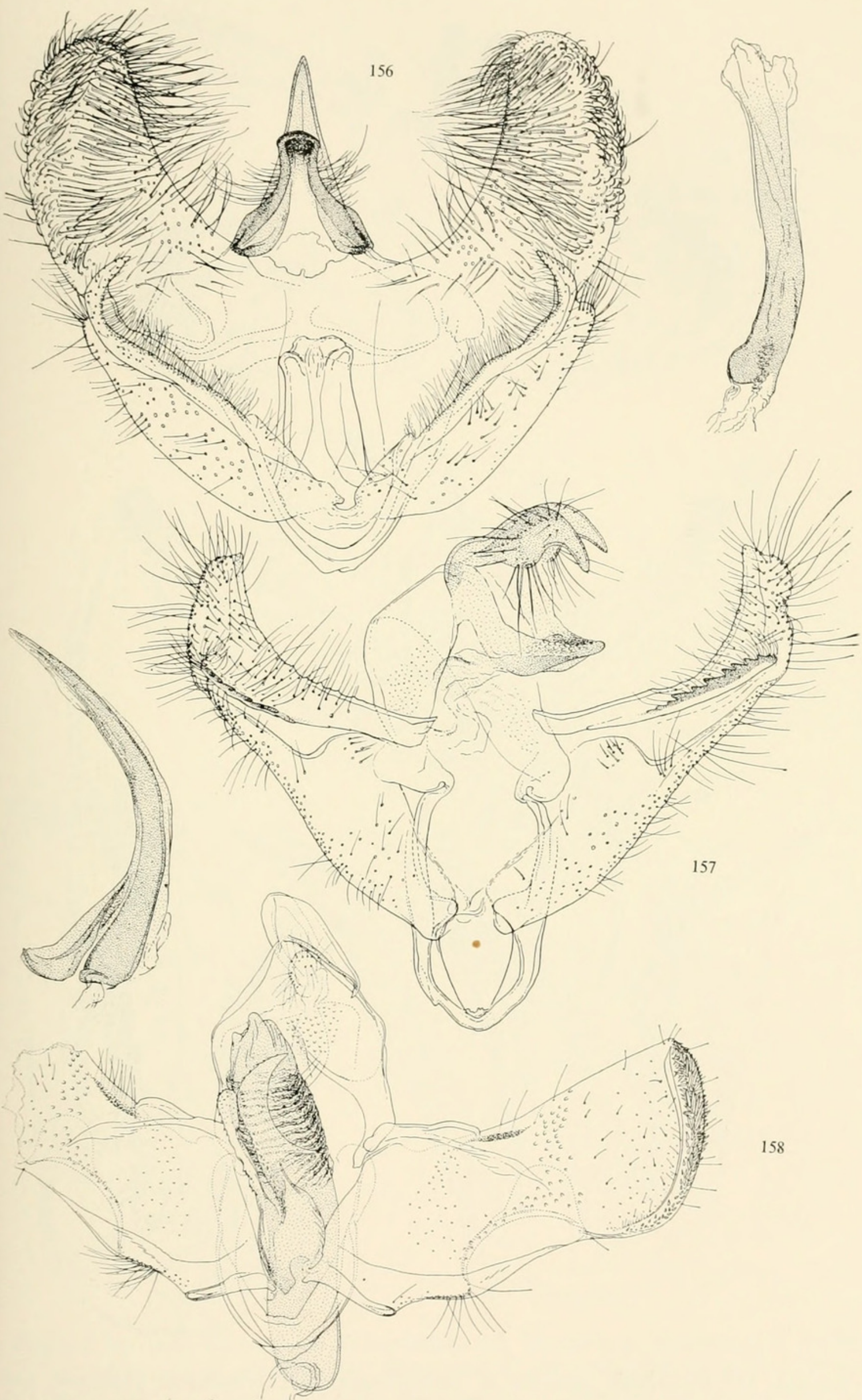

Figures 156-158.-Male genitalia of Xyloryctidae and Timyridae 156, Thymiatris; arista, new species, holotype, right, aedeagus; 157, Amorbaea subtusvena, new species, holotype, left, aedeagus; 158. Tisis auricincta, new species, holotype. 

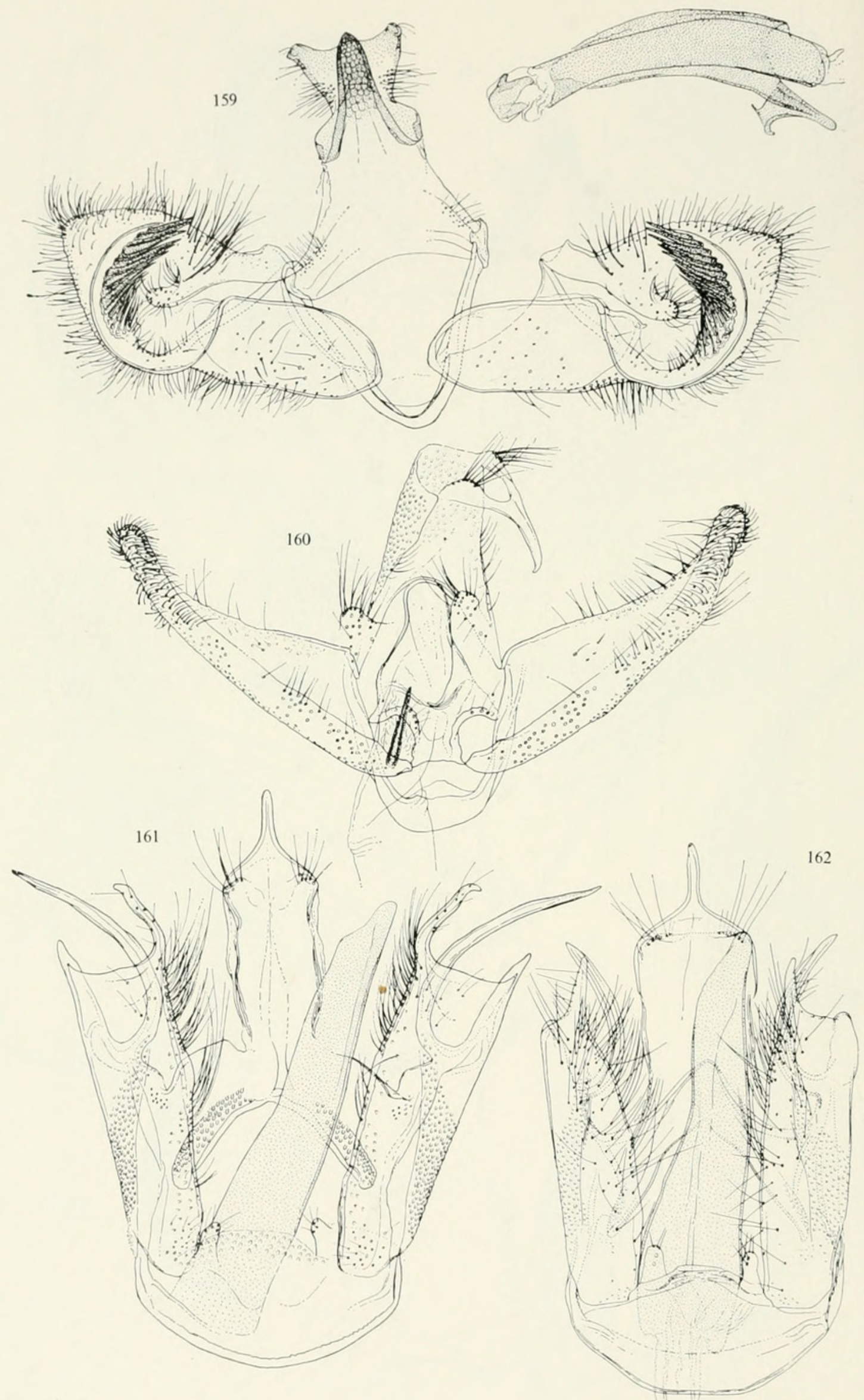

FIGURES 159-162.-Male genitalia of Xyloryctidae: 159, Metathrinca iridostoma, new species, holotype with aedeagus; 160 , Odites perissa, new species, holotype; $161, O$. periscias Meyrick, slide no. 5159; 162, O. homocirrha, new species, holotype. 


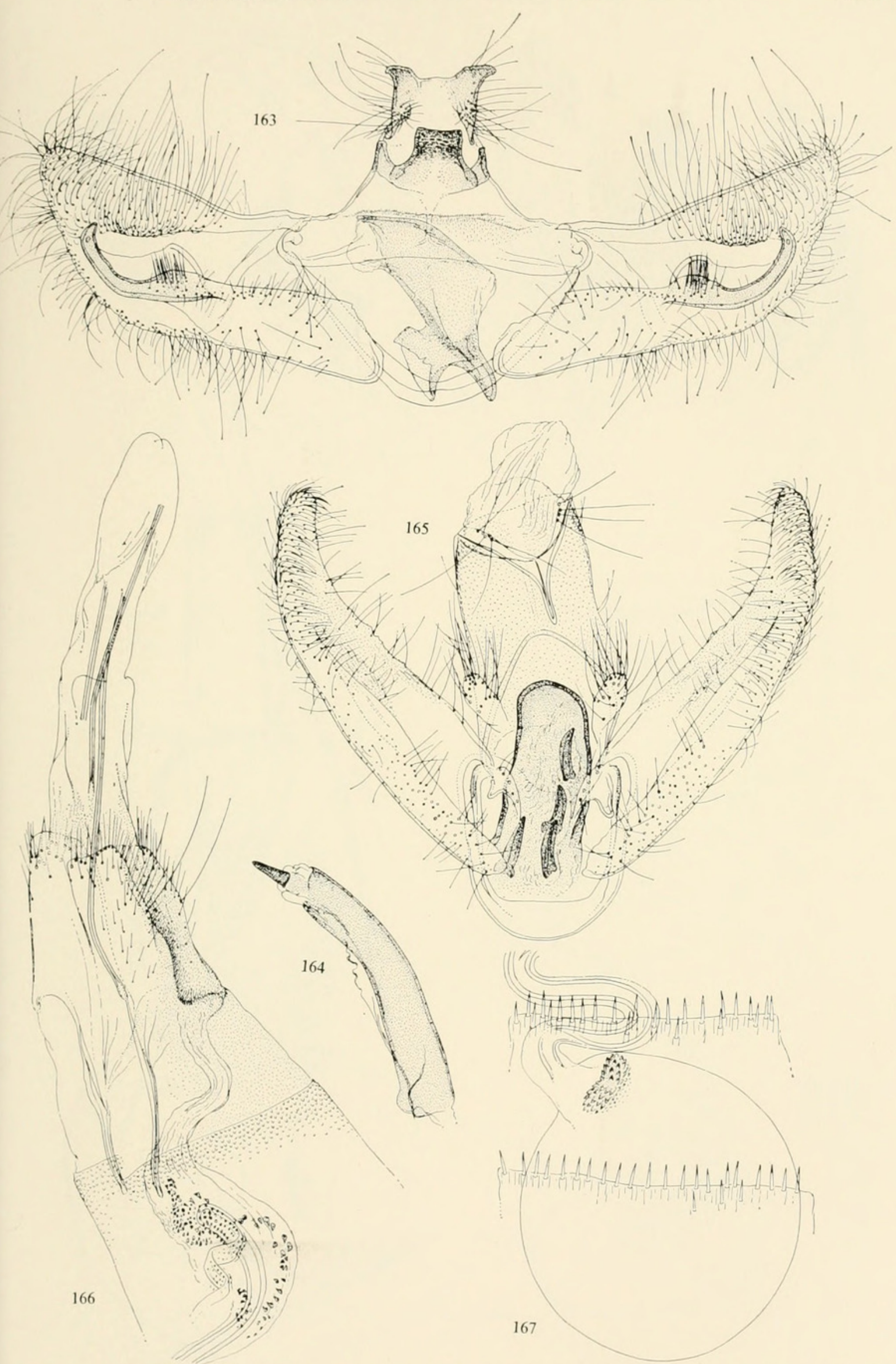

Figures 163-167.-Genitalia of Xyloryctidae: 163, Metathrinca sinumbra, new species, $\sigma^{7}$, holotype; 164 , aedeagus; 165 , Odites perissa, new species, $\sigma^{7}$, paratype, slide no. 5151; 166, Lecithocera niphotricha, new species, + , allotype; 167, bursa copulatrix. 

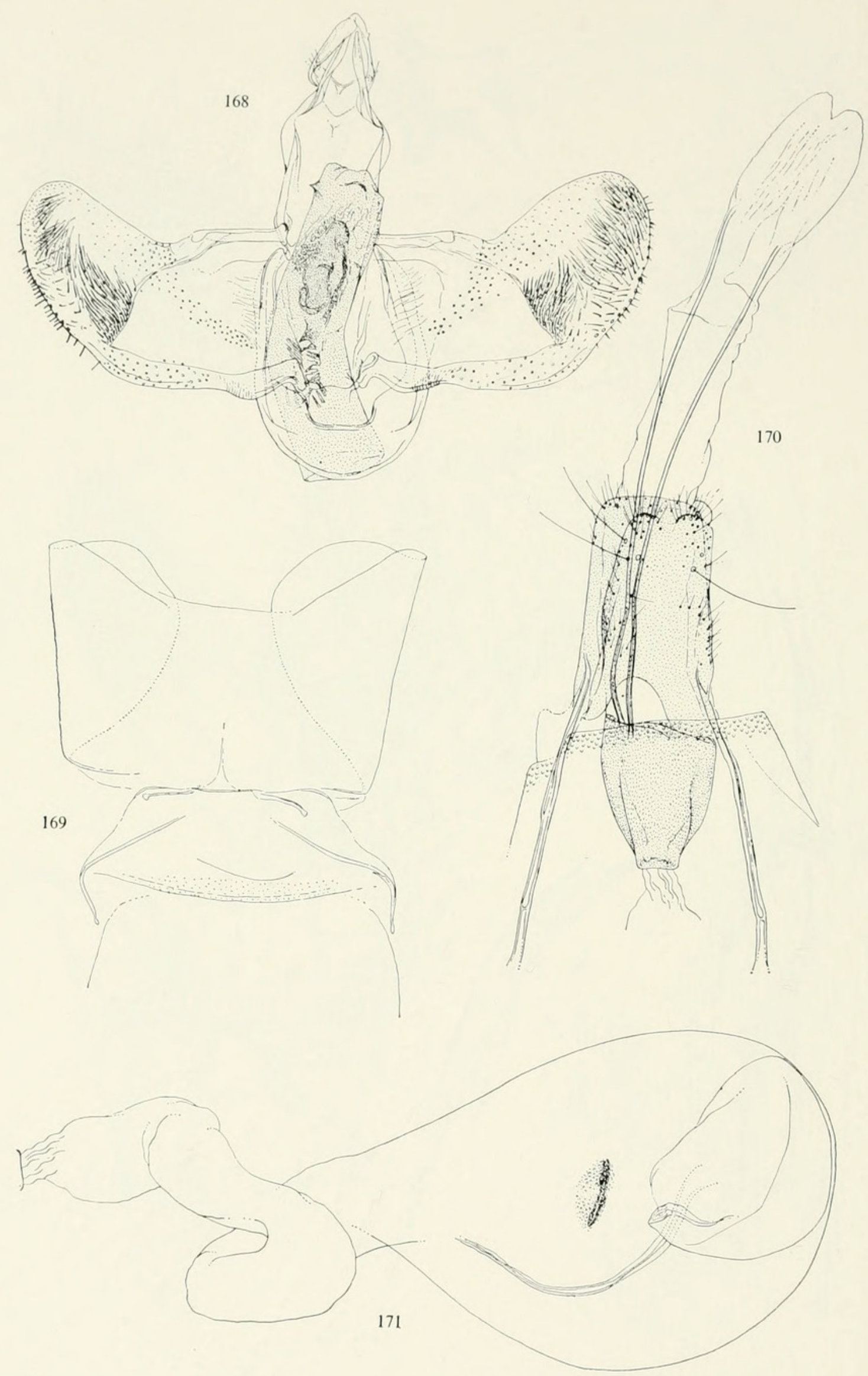

Figures 168-171.-Genitalia of Lecithocera Herrich-Schäffer: 168, L. fausta Meyrick, $\sigma^{7}$, holotype; 169, praegenital segment; 170, L. goniometra Meyrick, + , neallotype; 171 , bursa copulatrix. 


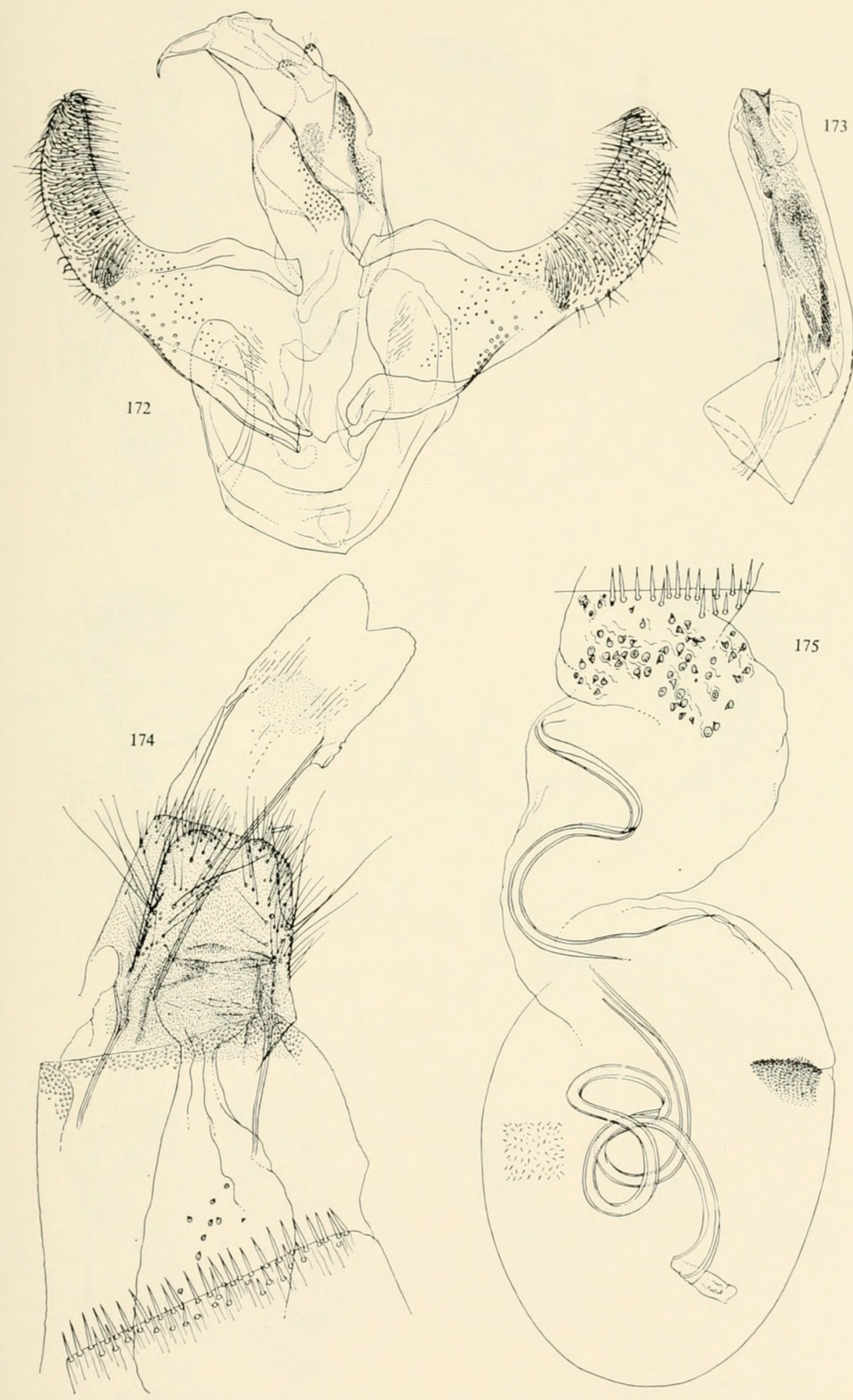

Figures 172-175.-Genitalia of Lecithocera Herrich-Schäffer: 172, L. docilis, new species; $\sigma^{7}$, holotype; 173 , aedeagus; 174, L. recurvata Meyrick, $ๆ$, slide no. $5197 ; 175$, bursa copulatrix. 


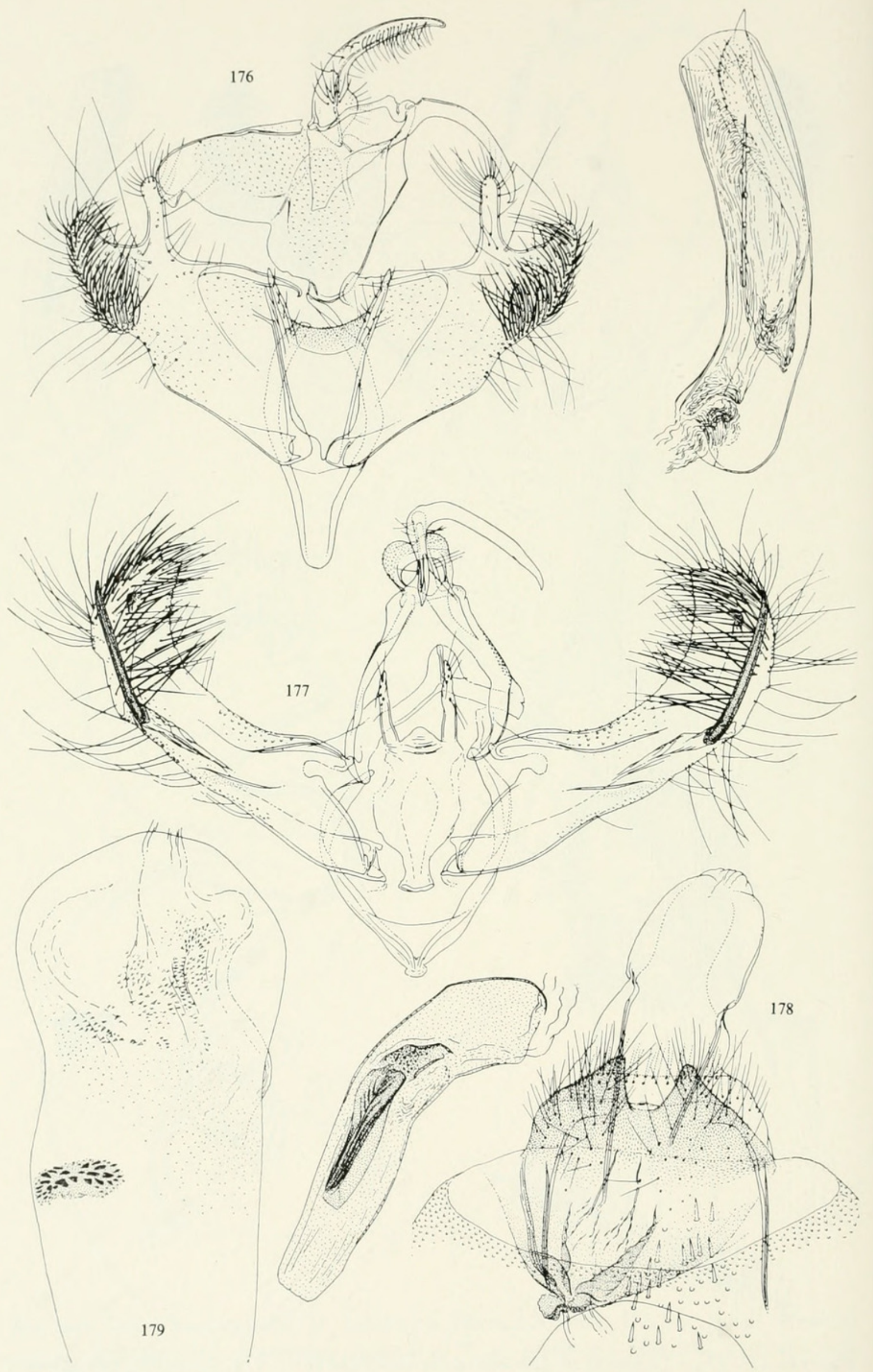

FIgURES 176-179. Genitalia of Lecithocera Herrich-Schäffer: 176, L. cassiterota Meyrick, $\sigma^{7}$, slide no. 5210, right, aedeagus; $177, L$. strenua, new species, $\sigma^{7}$, holotype, below, aedeagus; 178 ,, allotype; 179 , bursa copulatrix. 


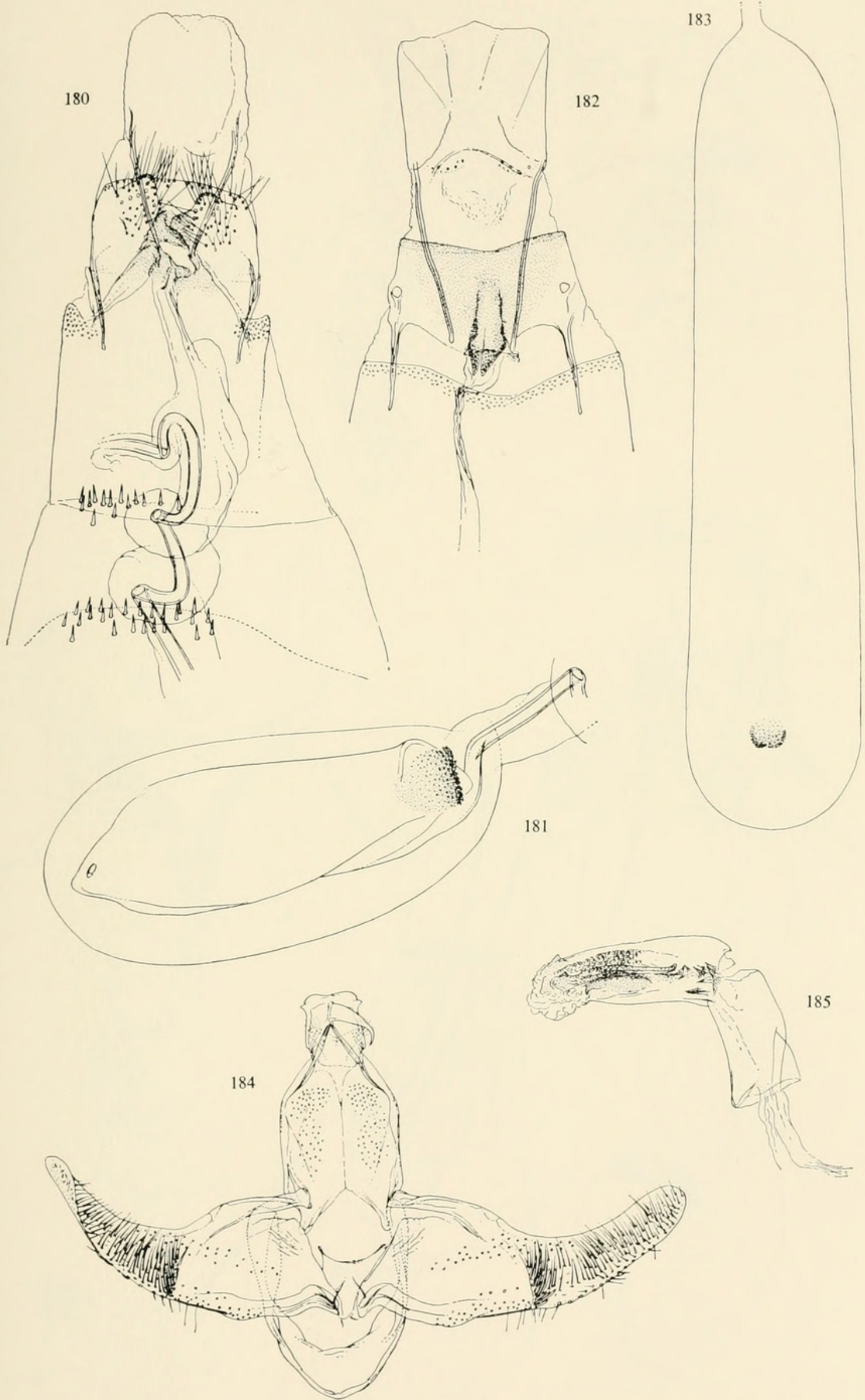

Figures 180-185.-Genitalia of Lecithocera Herrich-Schäffer: 180, L. acribostola, new species, $q$, holotype; 181 , bursa copulatrix 182 , L. telosperma, new species, $q$, holotype; 183 , bursa copulatrix; 184, L. luteola, new species, $\sigma^{7}$, holotype; 185 , aedeagus. 


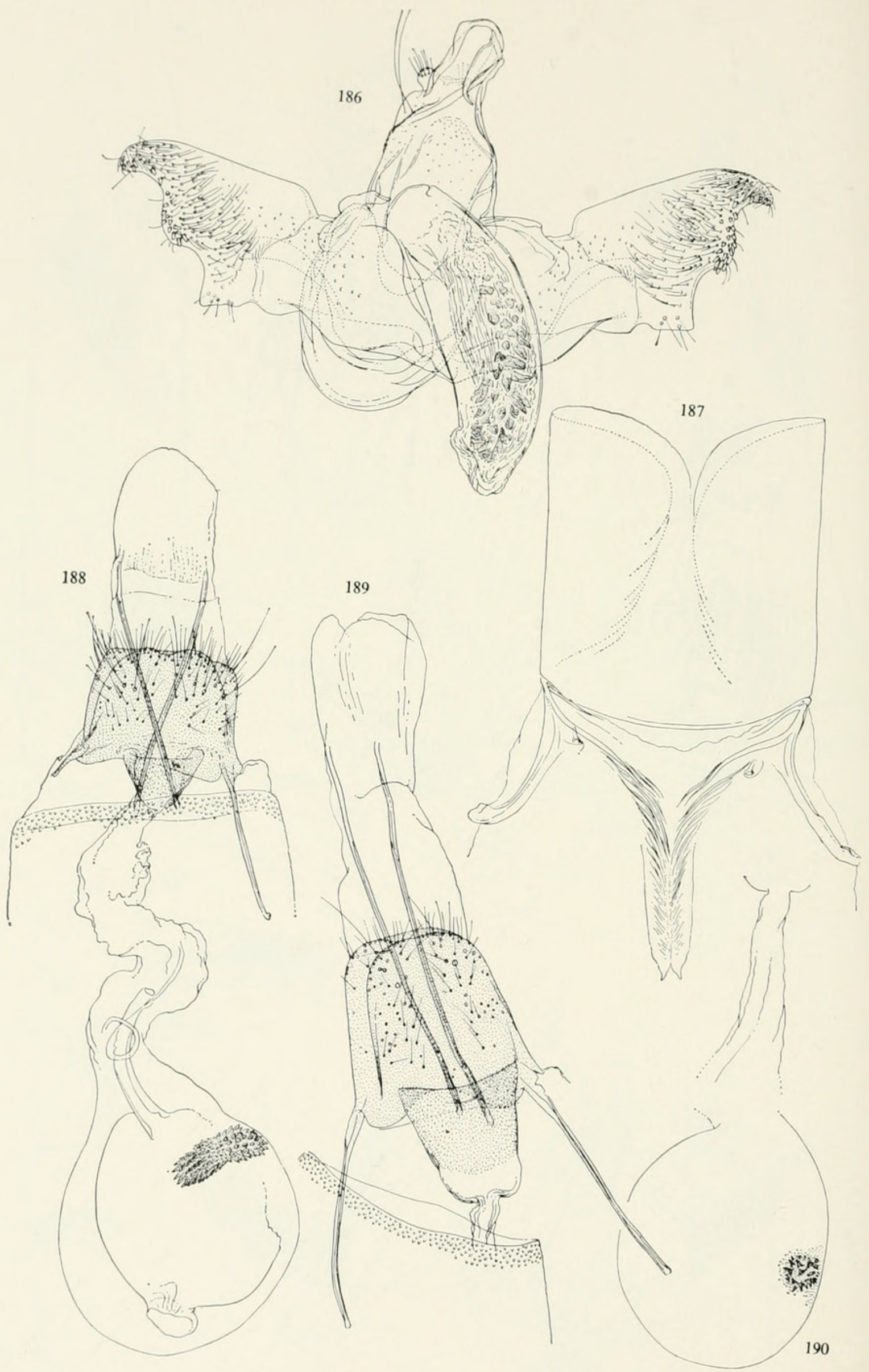

Figures 186-190.-Genitalia of Timyridae: 186, Homaloxestis surrepta, new species, ơ', holotype; 187, pregenital segment; 188, H. aganacma, new species, $q$, holotype; 189, Lecithocera leucomastis, new species, $q$, holotype, 190. bursa copulatrix, with, above, ductus bursae. 


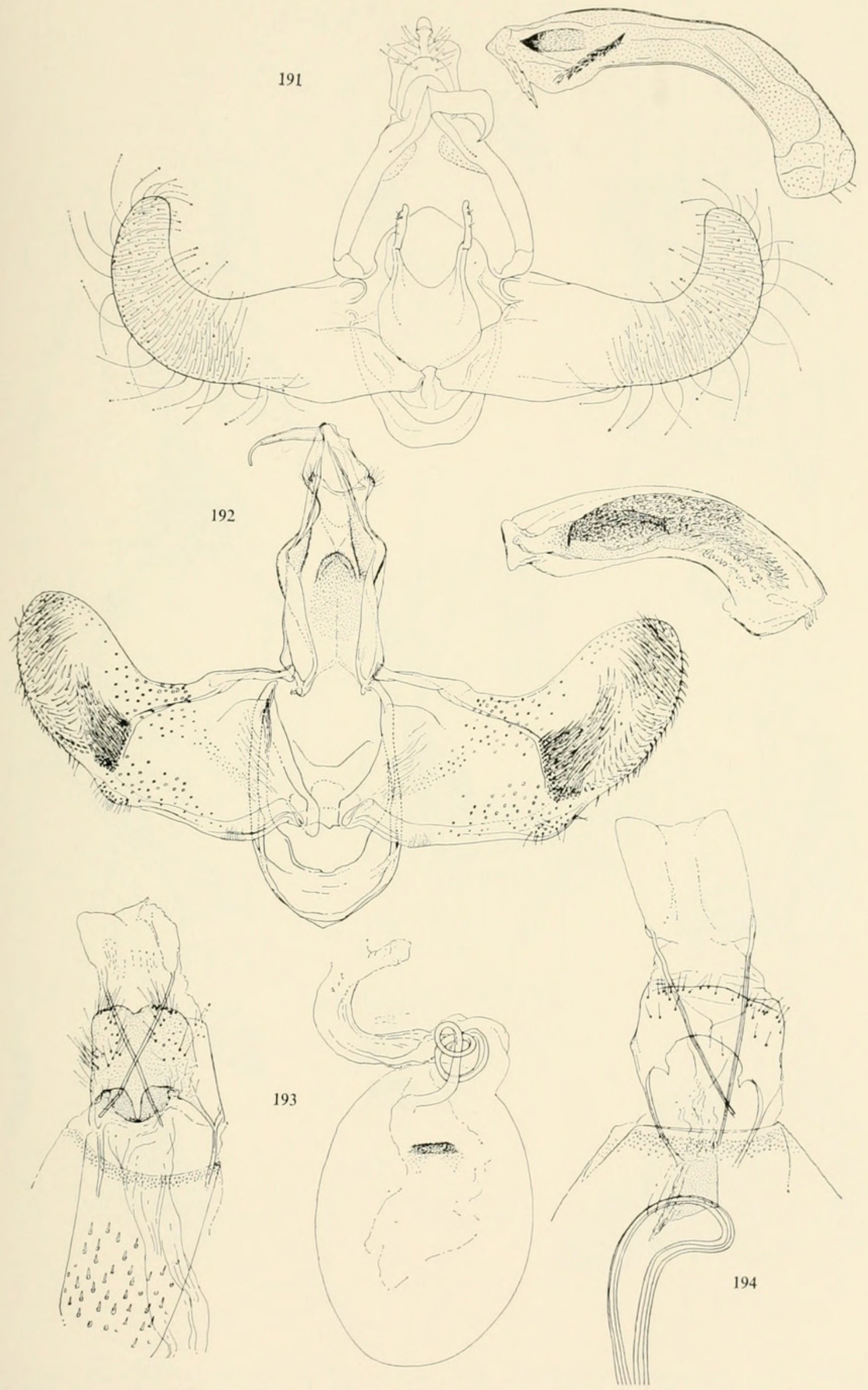

Figures 191-194.- Genitalia of Timyridae: 191, Canthonistis xestocephala, new species, $\sigma^{7}$, holotype, with, right, aedeagus; 192, Lecithocera goniometra Meyrick, $\sigma^{7}$, slide no. 5219, with aedeagus; 193, C. xestocephala, new species, $\uparrow$, allotype, with, right, bursa copulatrix; 194, Frisilia drimyla, new species, $q$, holotype. 


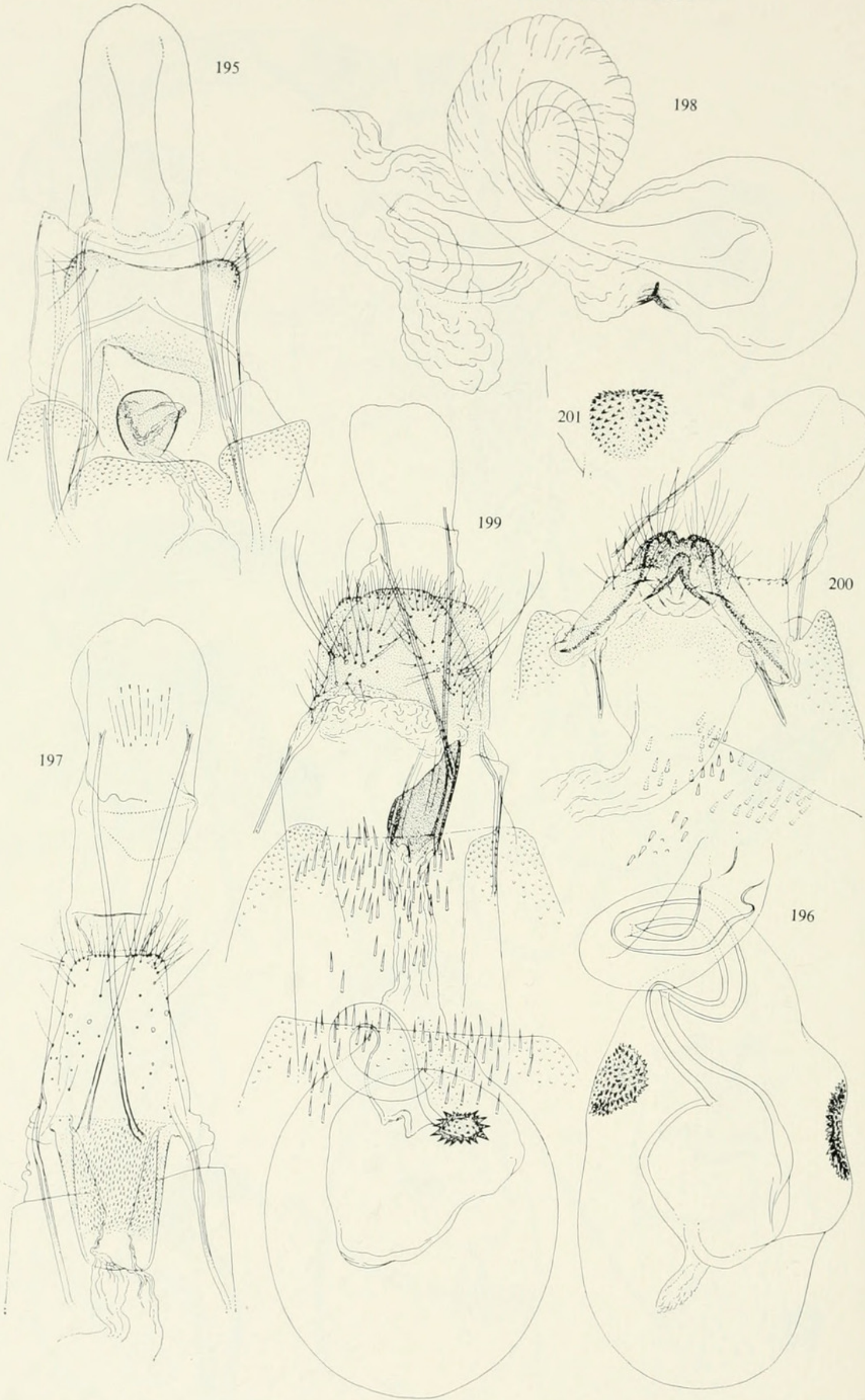

FiguRES 195-201.-Female genitalia of Timyridae; 195, Lecithocera improvisa, new species, holotype; 196, bursa copulatrix; 197, L. fausta Meyrick, $\%$, slide no. 5114; 198, bursa copulatrix; 199, Tisis auricincta, new species, $\uparrow$, allotype; 200, L. cassiterota Meyrick, † , slide no. $5519 ; 201$, signum. 


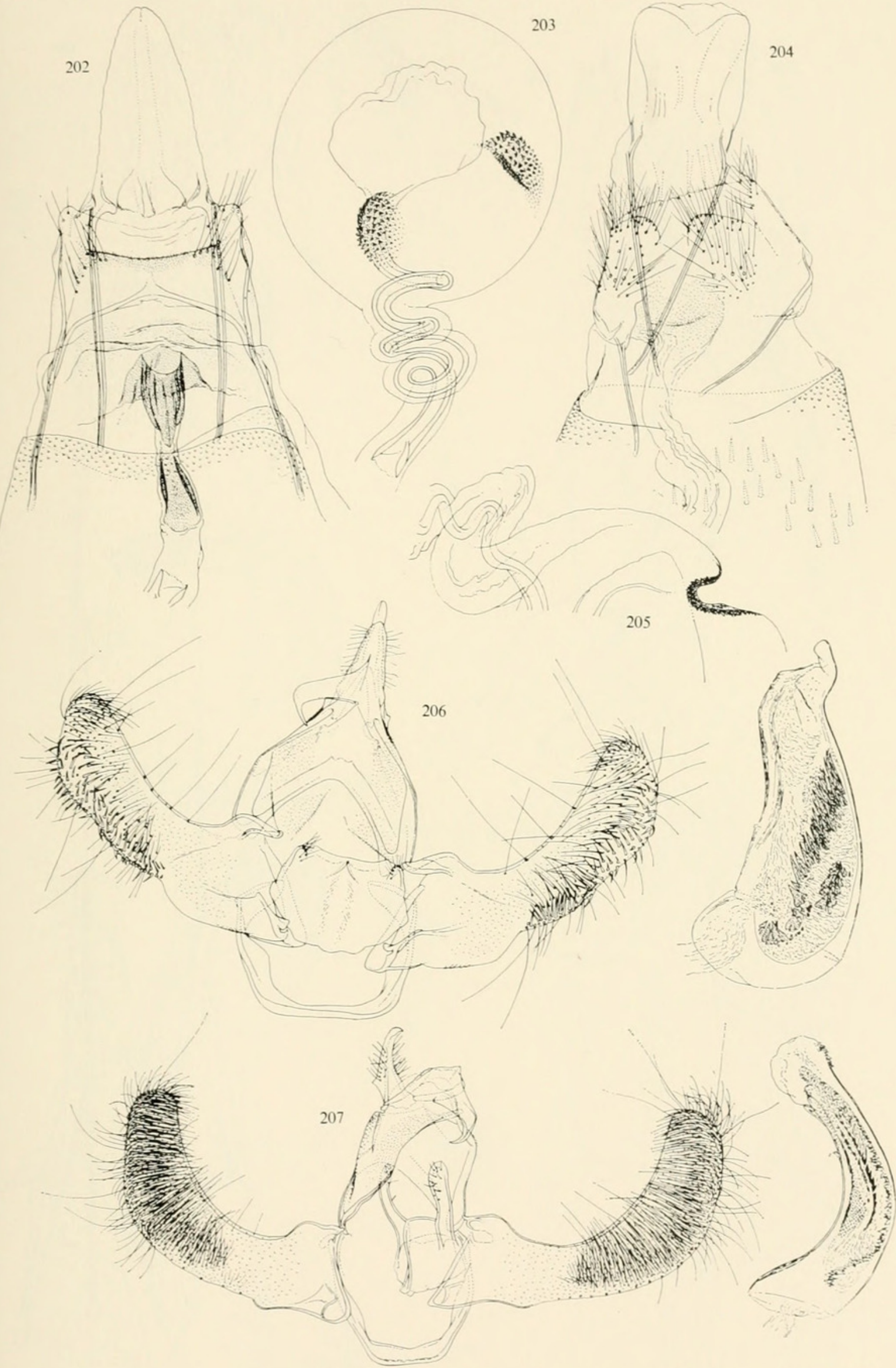

Figures 202-207.-Genitalia of Timyridae: 202, Lecithocera sophronopa, new species, \% holotype; 203, bursa copulatrix; 204, L. decorosa, new species, $\uparrow$, holotype; 205, part of bursa copulatrix with signum; 206, L. activata, new species, $\sigma^{7}$, holotype, right, aedeagus; 207, $L$. phanerostoma, new species, $\sigma^{7}$, holotype, right, aedeagus. 


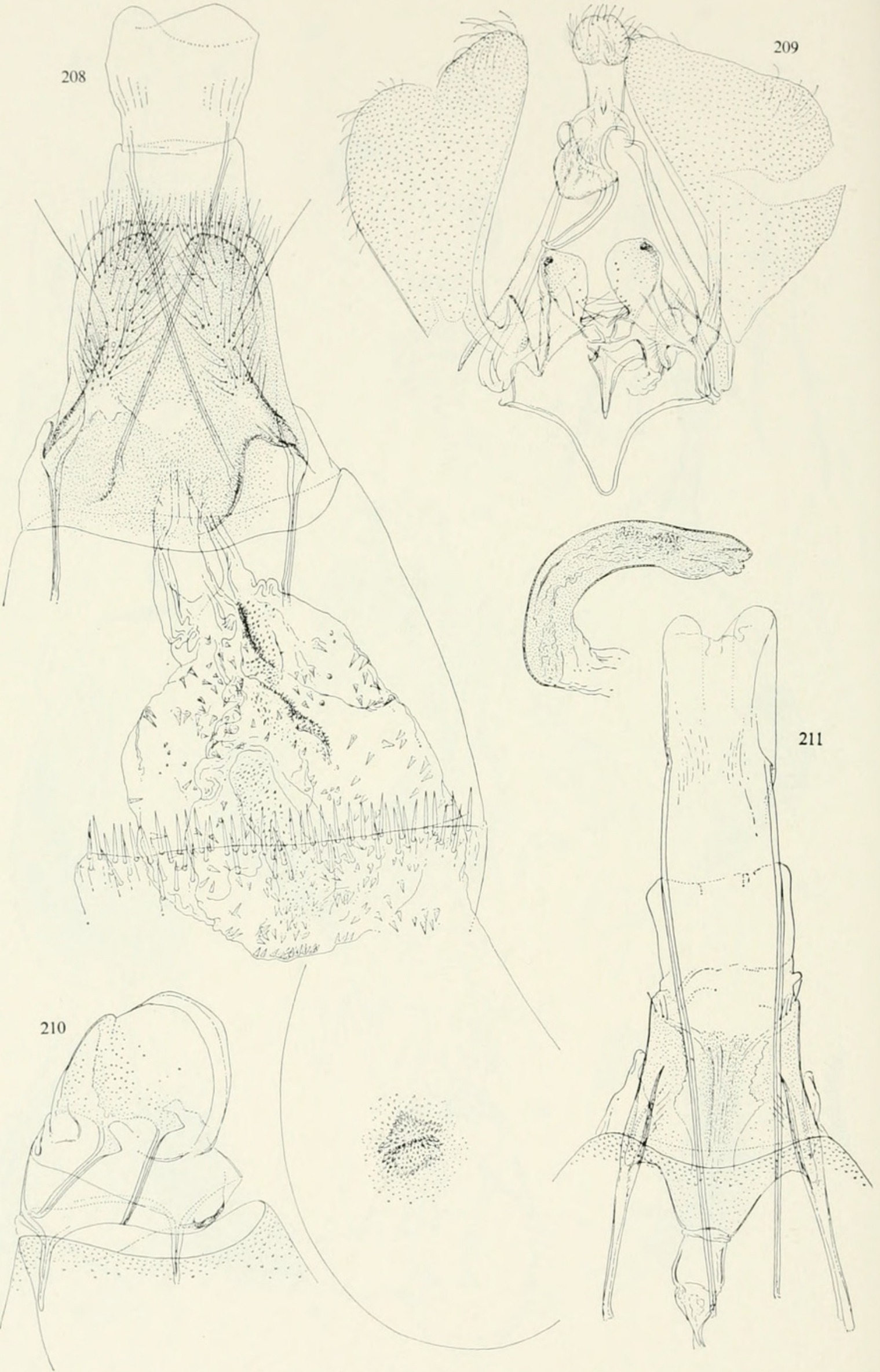

Figures 208-211.-Genitalia of Timyridae and Gelechiidae: 208, Lecithocera phanerostoma, new species, 9 , holotype; 209, Hypodrasia acycla, new genus, new species, $\sigma^{7}$, holotype, below, aedeagus; 210, Stomopteryx subsecivella (Zeller), + , slide no. 5202; 211, Phthorimea heliopa (Lower), \& , slide no. 5243 . 


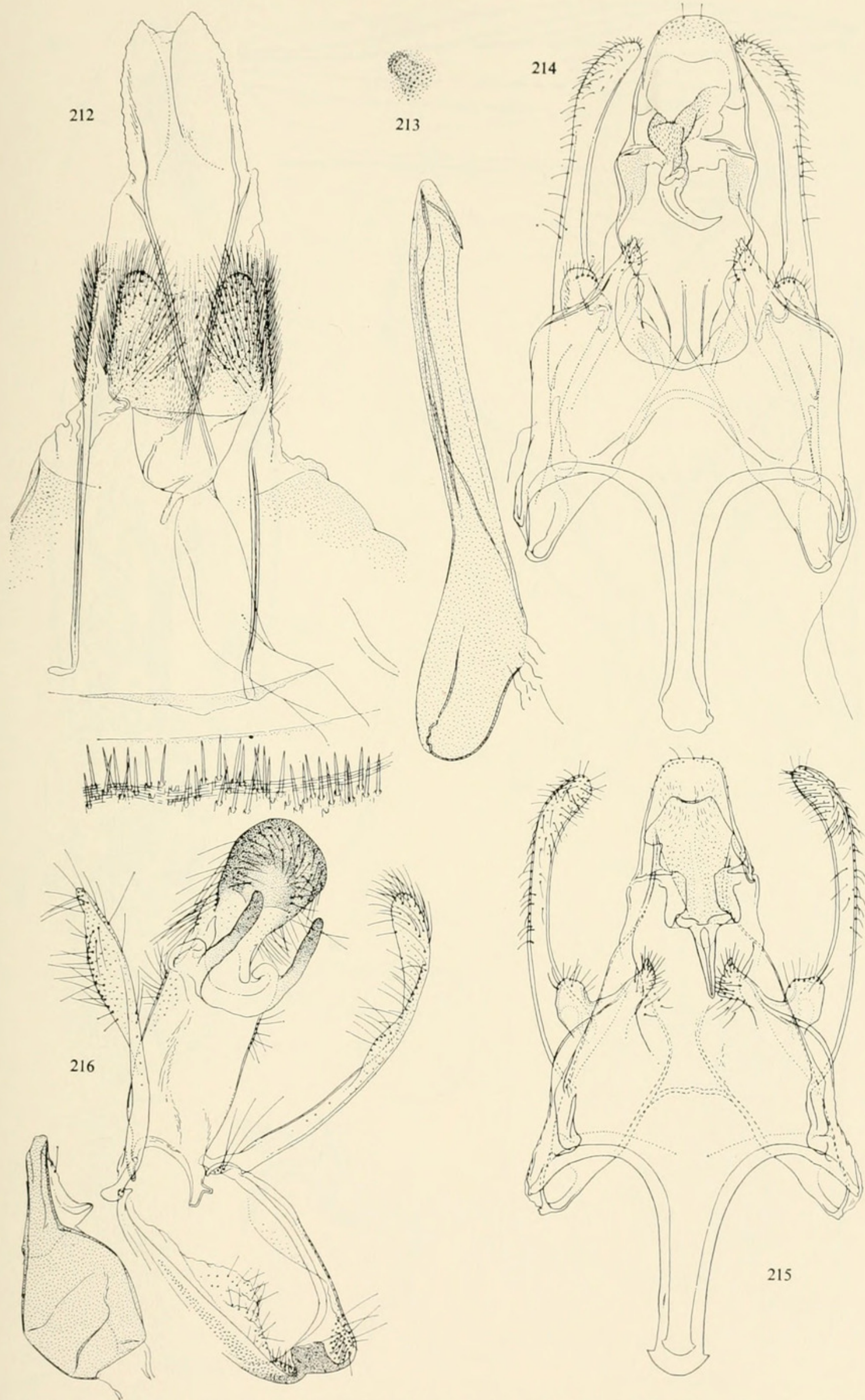

Figures 212-216.- Genitalia of Timyridae and Gelechiidae: 212, Prosodarma fibularis (Meyrick), $q$, slide no. 5226; 213, signum; 214, Phthorimaea heliopa (Lower), ơ, slide no. 5242, left, aedeagus; 215, Stomopteryx subsecivella (Zeller), o , slide no. 5203; 216, Brachyacma palpigera (Walsingham), †, slide no. "July 13, 1928, A.B.," left, aedeagus. 


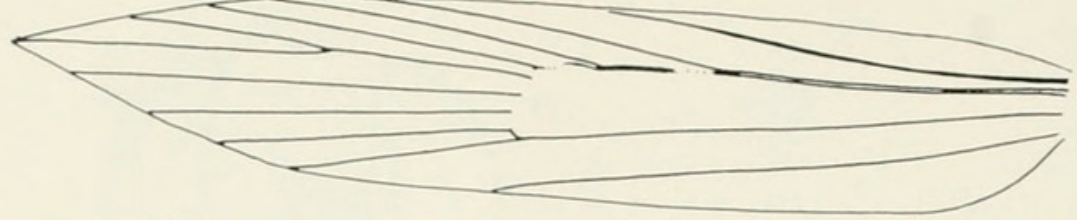

217
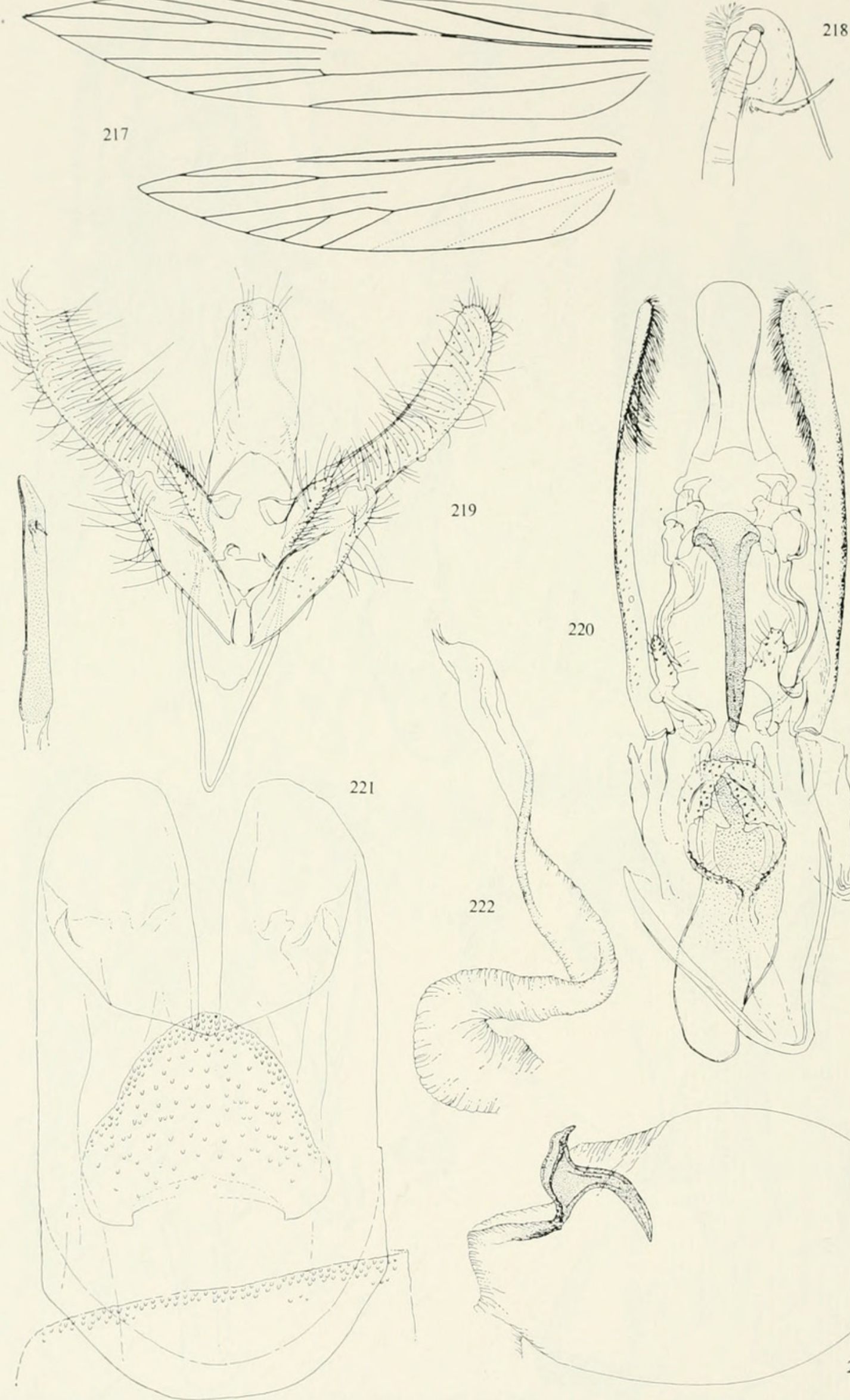

219

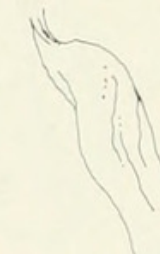

220

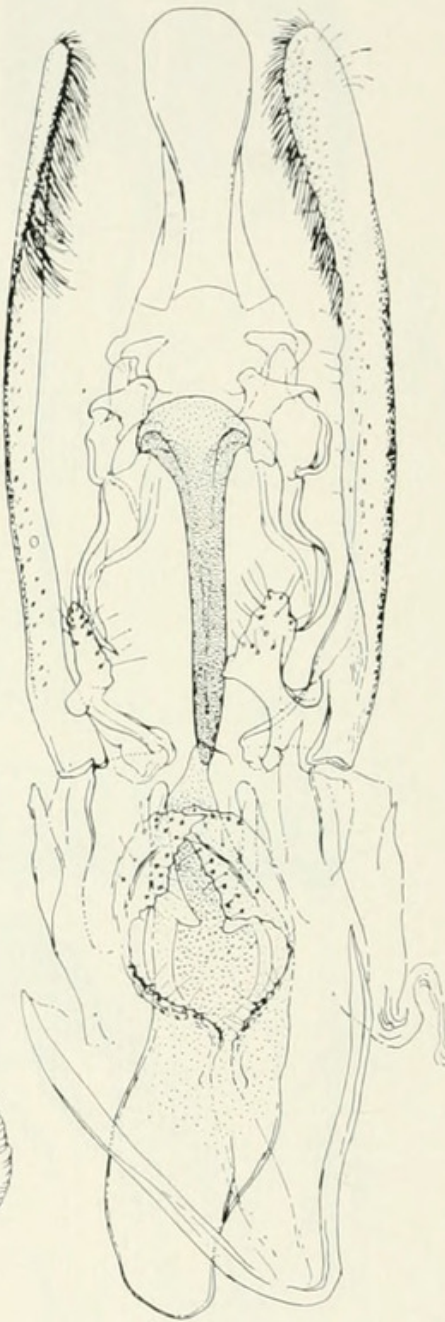

222

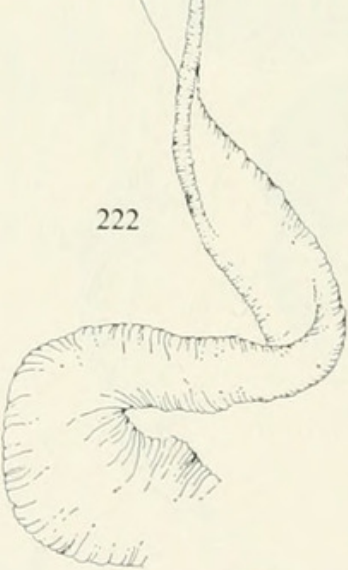

Figures 217-223.-Gelechiidae: 217, Euhomalocera heliosema, new genus, new species, wing neuration; 218, head; 219, genitalia, $\sigma^{7}$, holotype, left, aedeagus. Genitalia: 220, Hypatima heterostigma, new species, holotype; 221, pregenital segment; 222, Phthorimaea heliopa (Lower), $\uparrow$, no. 5243, ductus bursae; 223, corpus bursae. 


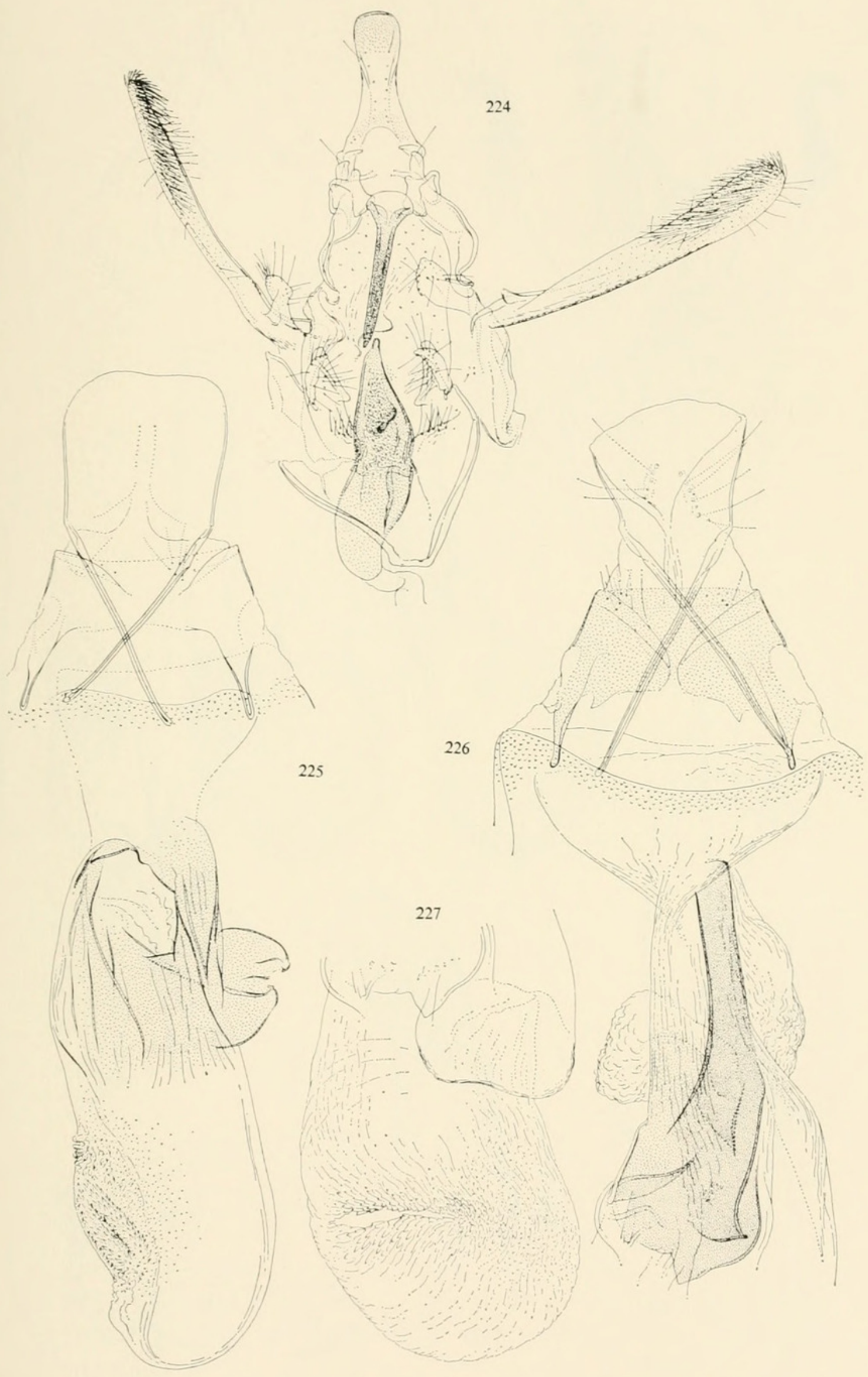

Figures 224-227.- Genitalia of Gelechiidae: 224, Brachmia heterotoma, new species, ơ', holotype; 225, Atasthalistis viridella (Snellen), $q$, holotype; 226, A. diacrita, new species, \& , allotype; 227, lower part of corpus bursae. 


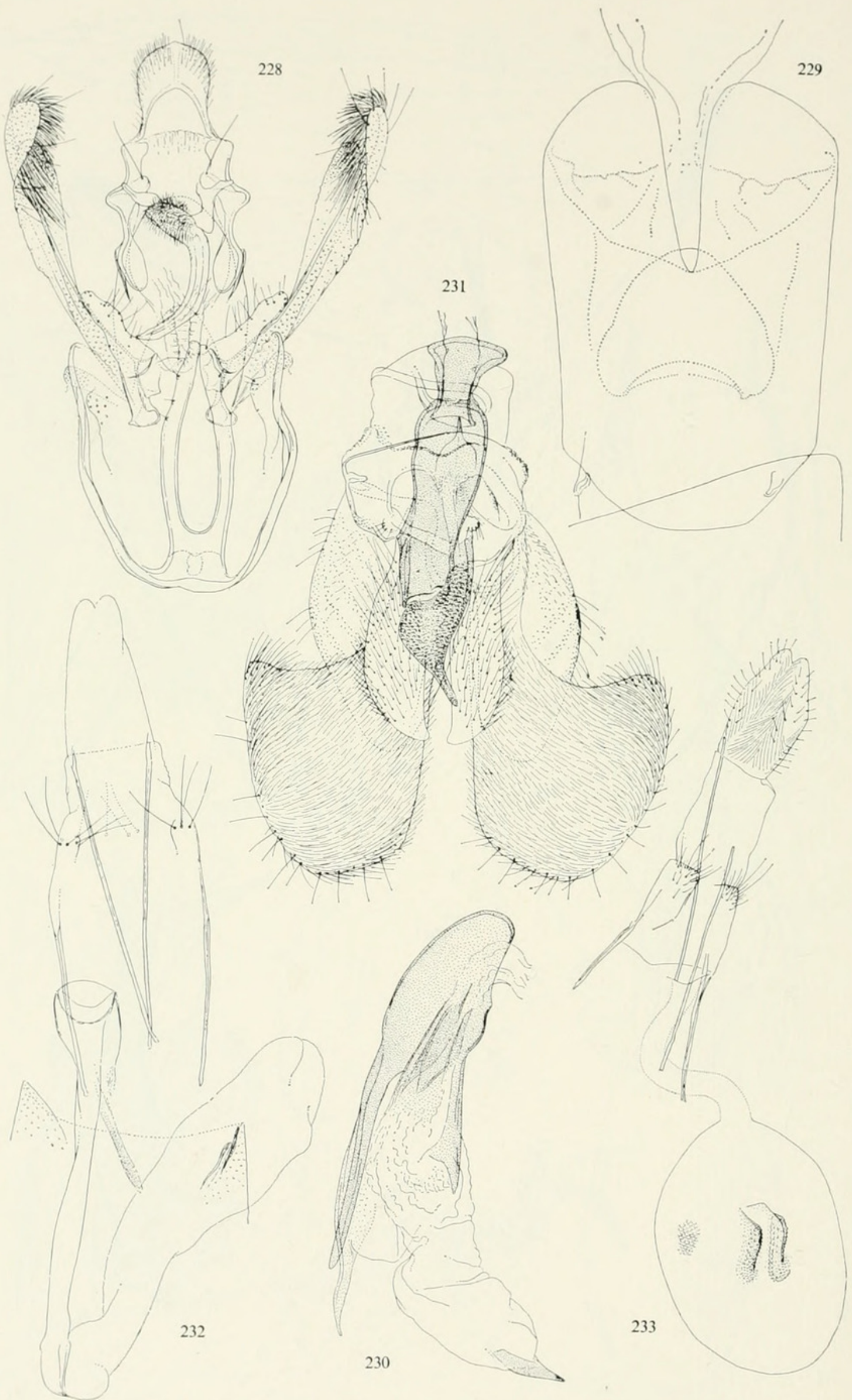

Figures 228-233.- Genitalia of Gelechiidae and Cosmopterygidae: 228, Atasthalistis diacrita, new species, $\sigma^{\Upsilon}$, holotype; 229, pregenital segment; 230, aedeagus; 231, Cosmopteryx dulcivora Meyrick, ơ', slide no. 5259; 232, $q$, slide no. 5260; 233, Limnaecia acontophora Meyrick, $\uparrow$, holotype. 


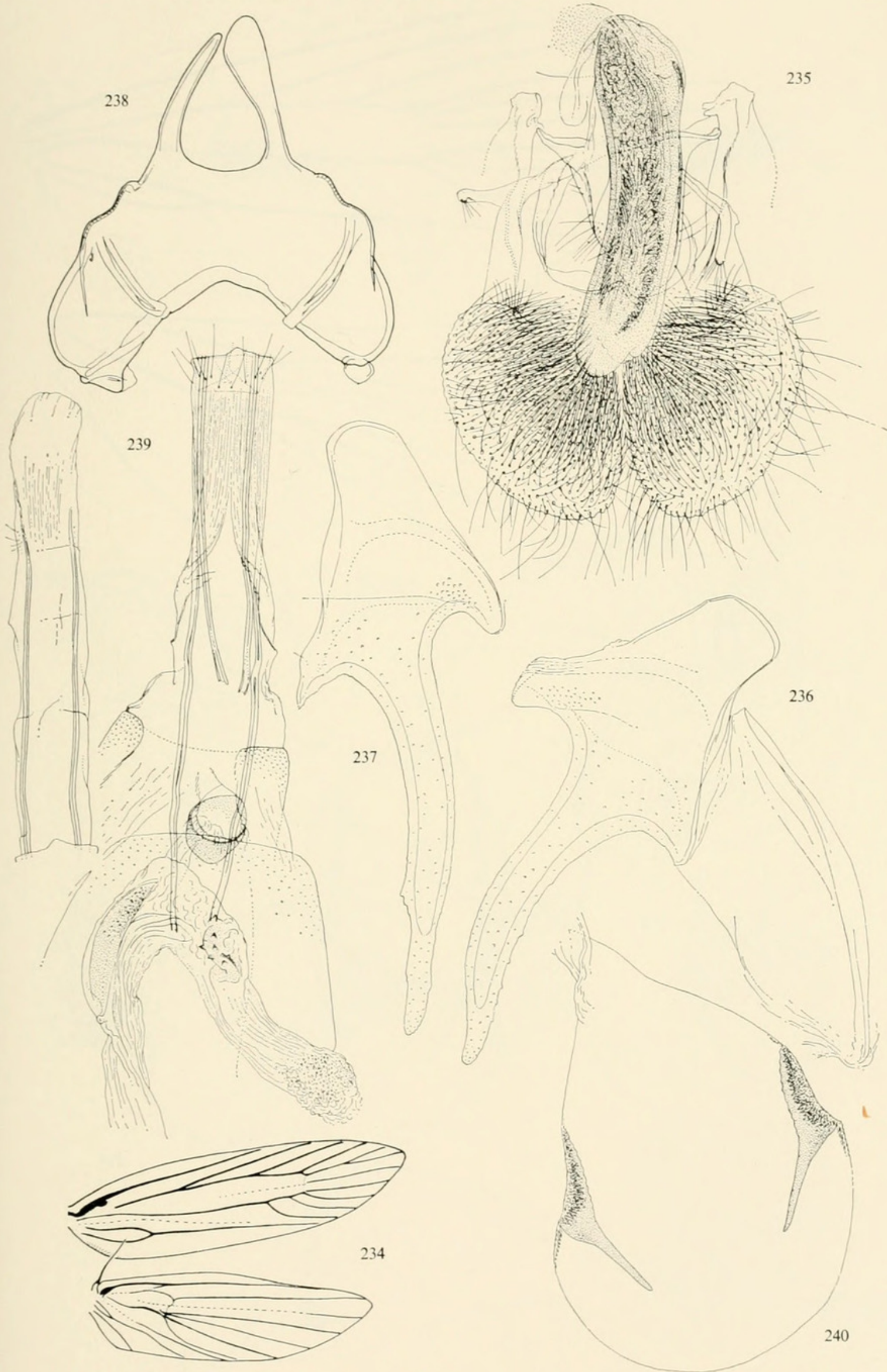

Figures 234-240.-Syntomaula Meyrick: 234, wing neuration of S. tephrota Meyrick (courtesy of the Smithsonian Institution, Washington, D.C.); 235, S. simulatella (Walker), o', slide no. 5112, valvae and aedeagus; 236 , right half of the 8 th abdominal sternite, and, right, tergite; 237 , left half of 8 th sternite; 238 , tegumen and uncus: 239 , $\subsetneq$, slide no. 5116 , left, tip of ovipositor; 240 , corpus bursae. 
241
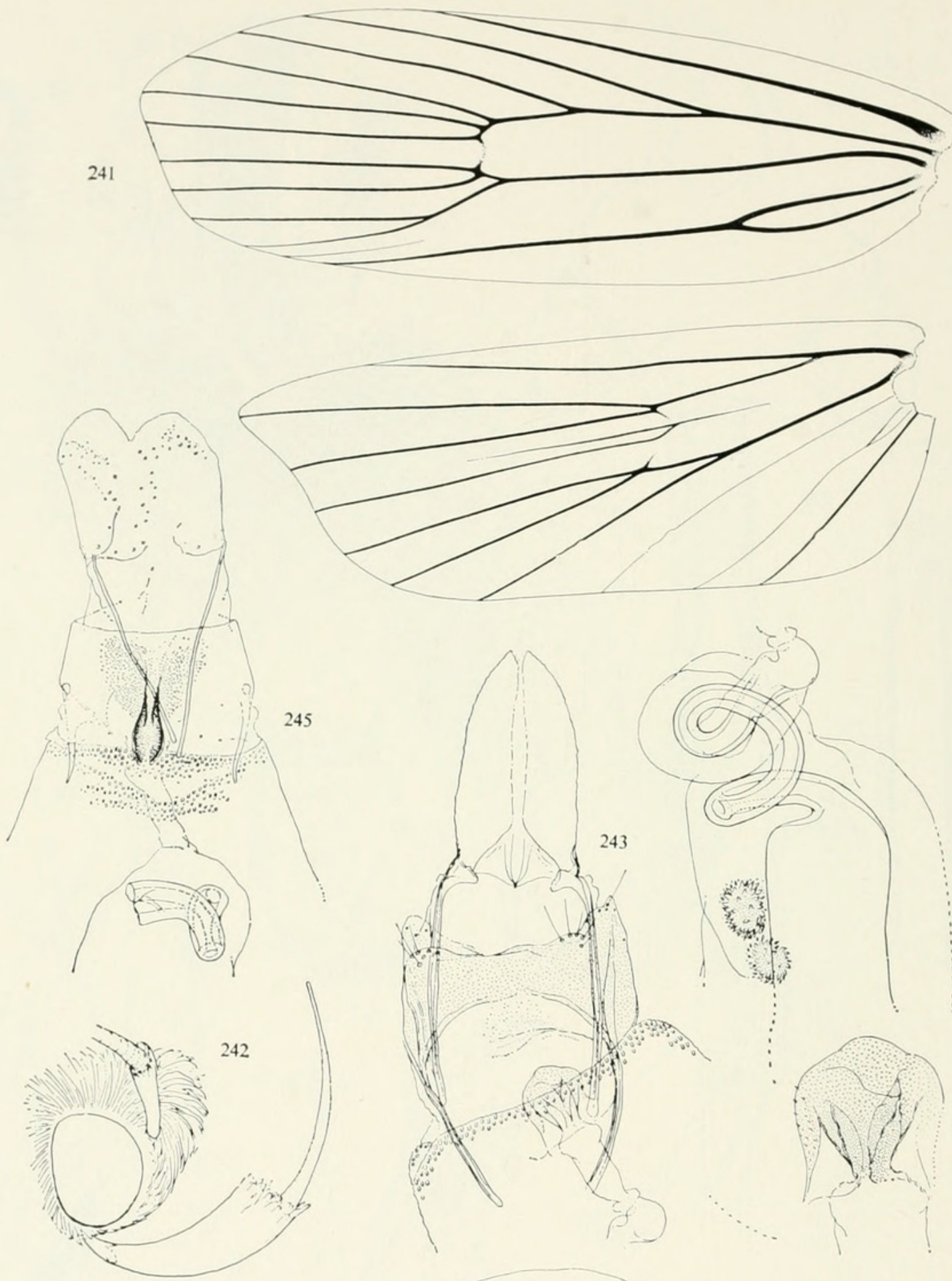

244

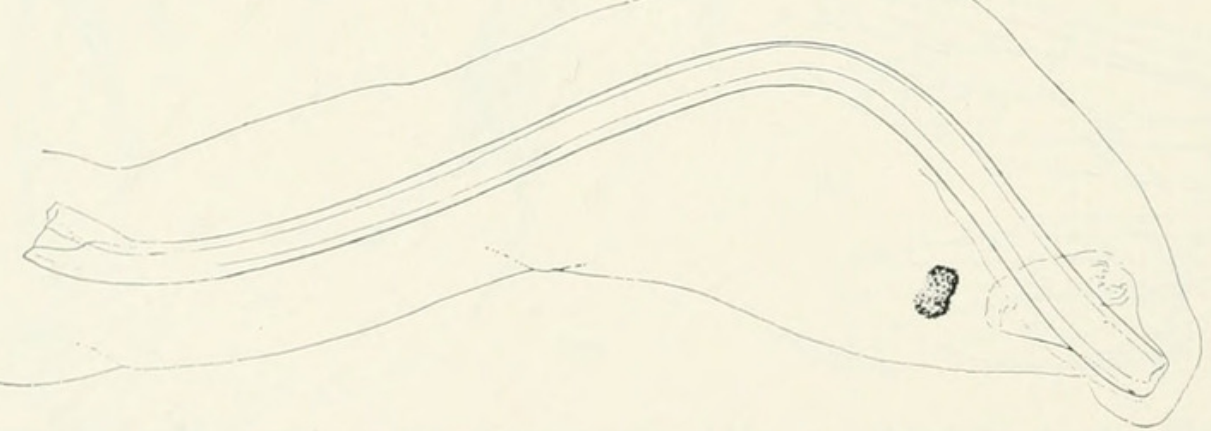

Figures 241-245.-Wing neuration and genitalia of Gelechiidae: 241, Hypodrasia acycla, new genus, new species, $\uparrow$, wing neuration; 242 , head; 243 , $q$, allotype, right, bursa copulatrix; 244, ostium bursae, more magnified; 245, Brachmia tristella (Snellen), homoeotype, slide no. 5190, below, bursa copulatrix. 


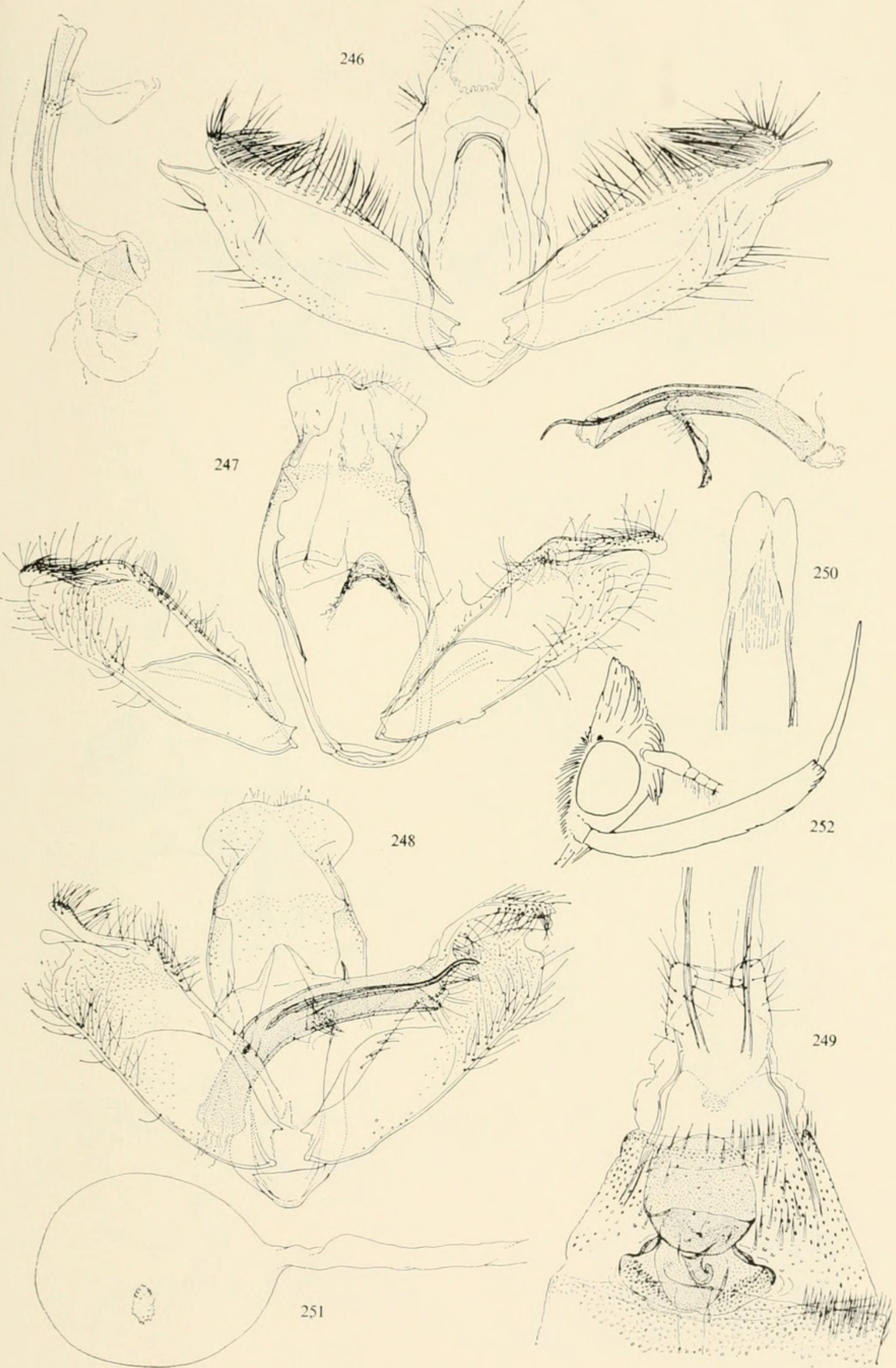

Figures 246-252.-Genitalia and head of Oecophoridae: 246, Diploclasis balbidophora, new genus, new species, $\sigma^{7}$, holotype, left, aedeagus; 247, Astiarcha aureatella (Snellen), $\sigma^{\top}$, lectotype, right, aedeagus; $248, A$. praedives, new species, $\sigma^{7}$, allotype; 249 , Diploclasis balbidophora, new genus, new species, + , holotype; 250, tip of ovipositor; 251, bursa copulatrix; 252, head. 


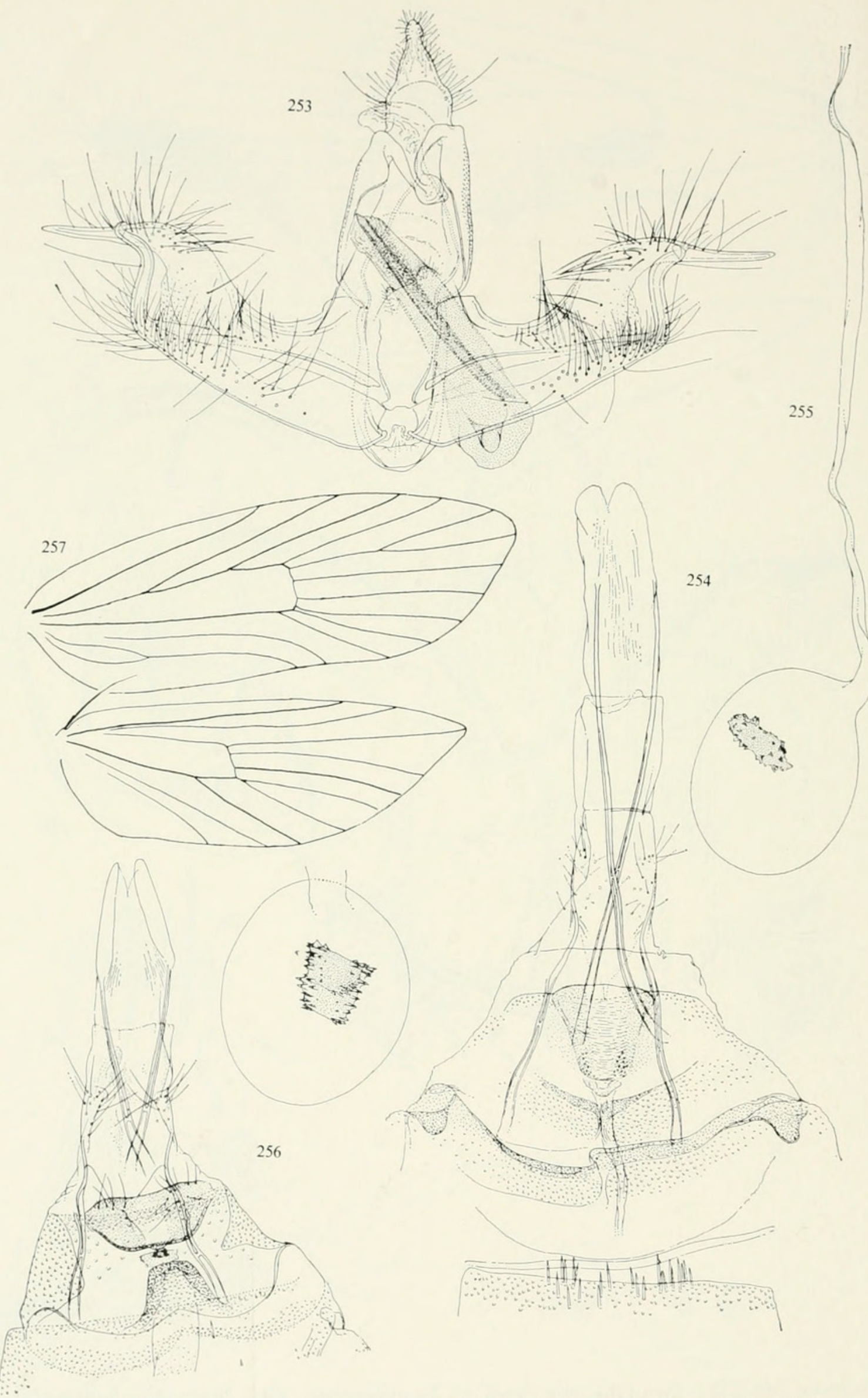

Figures 253-257.-Genitalia and neuration of Oecophoridae: 253, Tanyzancla cincta, new species, $\sigma^{7}$, holotype; 254, Chrysonoma hesitans, new species, + , allotype; 255, bursa copulatrix; 256, Tanyzancla pepona, new species, $q$, allotype, right, bursa copulatrix; 257, Diploclasis balbidophora, new genus, new species, wing neuration. 
MICROLEPIDOPTERA OF PHILIPPINE ISLANDS

365

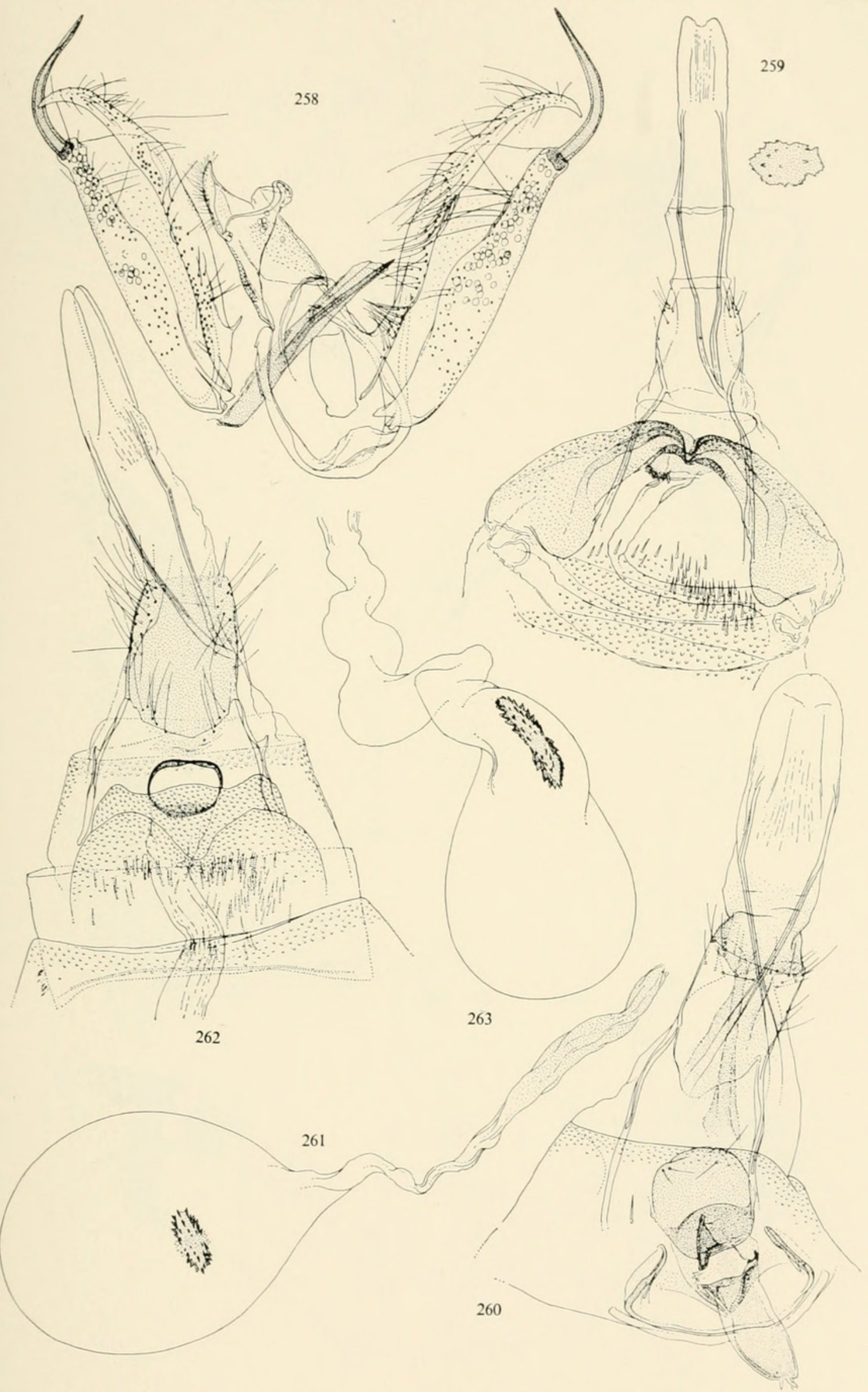

Figures 258-263.-Genitalia of Oecophoridae: 258, Chrysonoma hesitans, new species, ơ , holotype; 259, Tanyzancla amydrographa, new species, + , holotype; 260, Astiarcha praedives, new species. + , holotype; 261, bursa copulatrix; 262, T. lanceolata, new species, $q$, holotype; 263 , bursa copulatrix. 


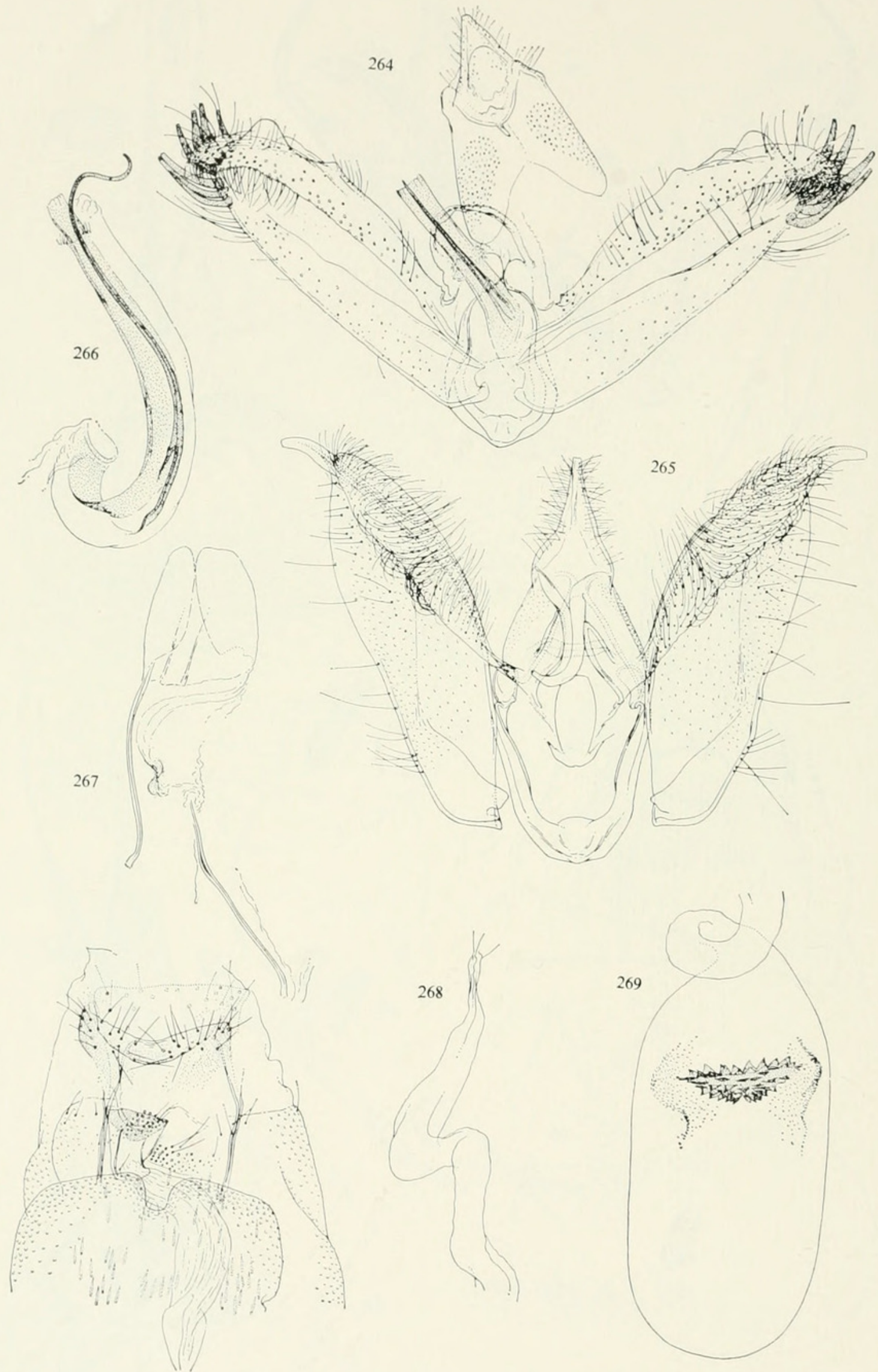

Figures 264-269.- Genitalia of Oecophoridae: 264, Chrysonoma aporopis (Meyrick), ơ', slide no. $5191 ; 265, C$. fragmentaria, new species, $\sigma^{7}$, holotype; 266 , aedeagus; $267, C$. inermis, new species, $q$, holotype; 268, upper part of ductus bursae; 269, corpus bursae. 


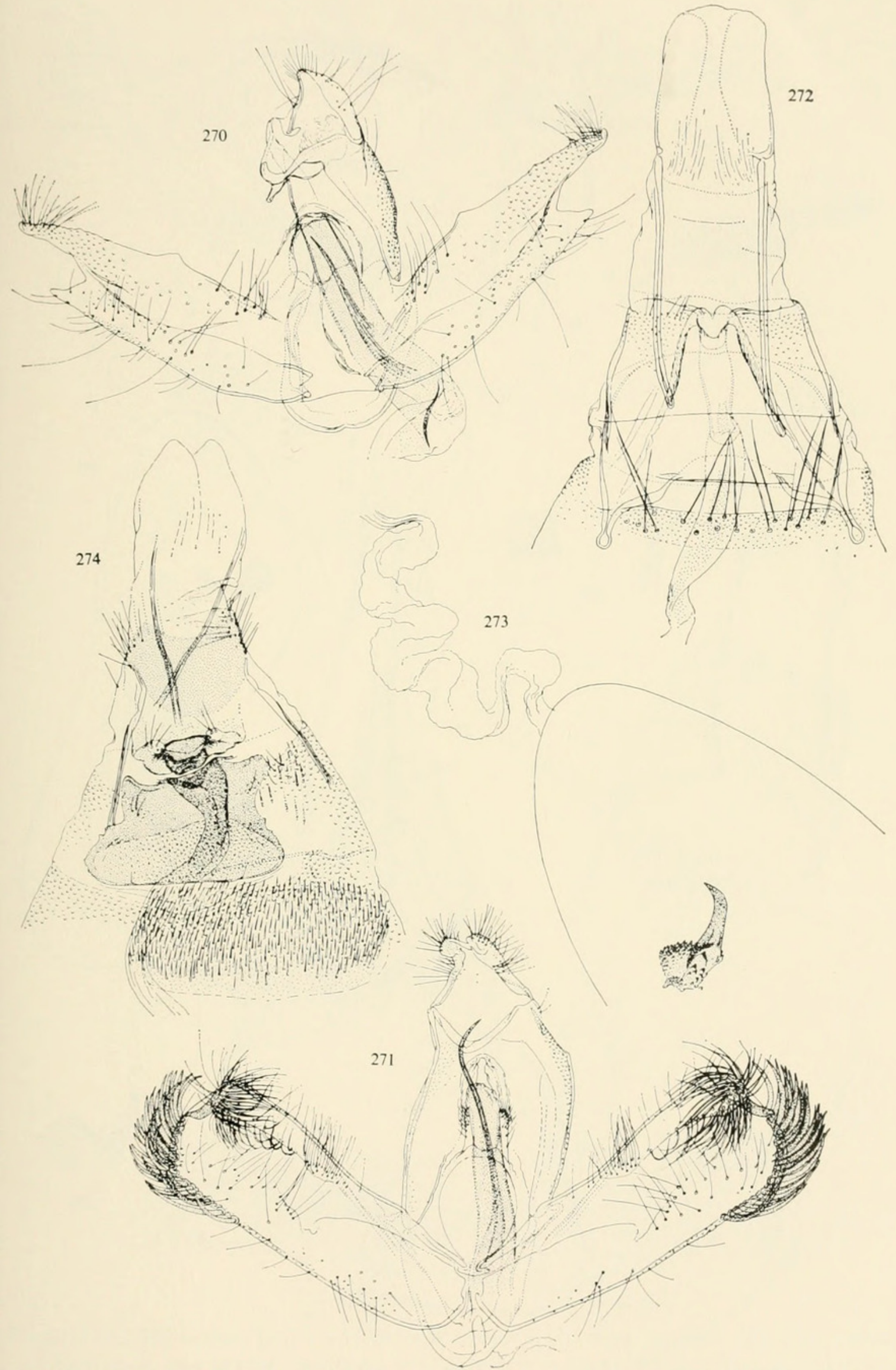

Figures 270-274.-Genitalia of Oecophoridae: 270, Chrysonoma poecilosema, new species, $\sigma^{7}$, holotype; $271, C$. eumorpha, new species, $\sigma^{7}$, holotype; 272, Tonica argessa, new species, $\uparrow$, holotype; 273 , part of bursa copulatrix, with signum; 274, Philobota loxographa, new species, + , allotype. 


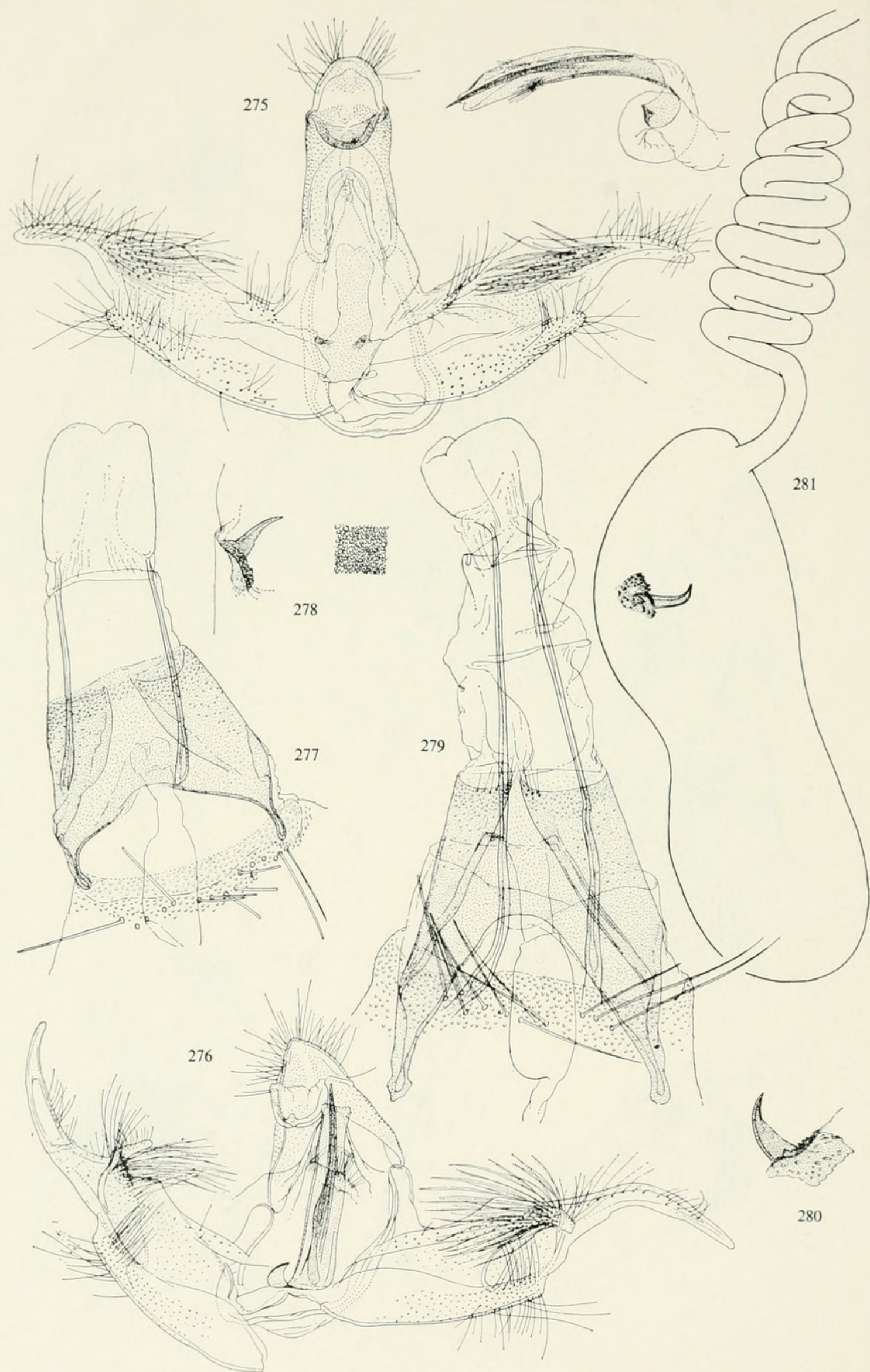

Figures 275-281.-Genitalia of Oecophoridae: 275, Tanyzancla pepona, new species, $\sigma^{7}$, holotype, right, aedeagus; 276, Tanyzancla catadea, new species, $\sigma^{7}$, holotype; 277, Tonica lagaropis Meyrick, $\uparrow$, slide no. $5215 ; 278$, part of corpus bursae, with signum and structure of the wall; 279 , Tonica citrantha, new species, $q$, holotype; 280 , signum; 281 , Tonica argessa, new species, $q$, holotype, ductus bursae intact, with corpus bursae 


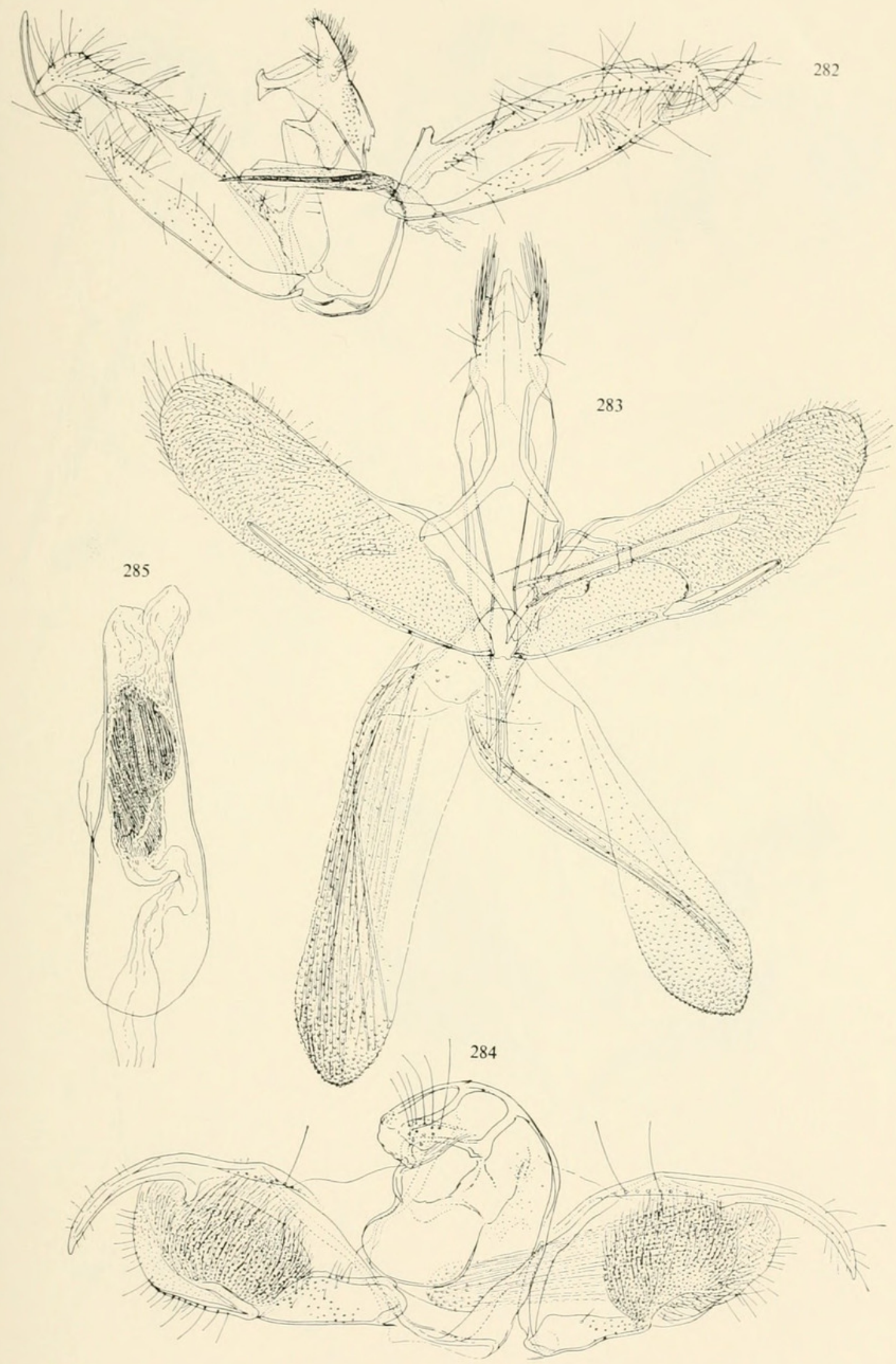

Figures 282-285.-Male genitalia of Oecophoridae and Glyphipterygidae: 282, Chrysonoma hypocapna, new species, holotype; 283, Sagalassa eubrachycera, new species, holotype; 284. Phycodes minor Moore, slide no. 5183; 285, aedeagus. 


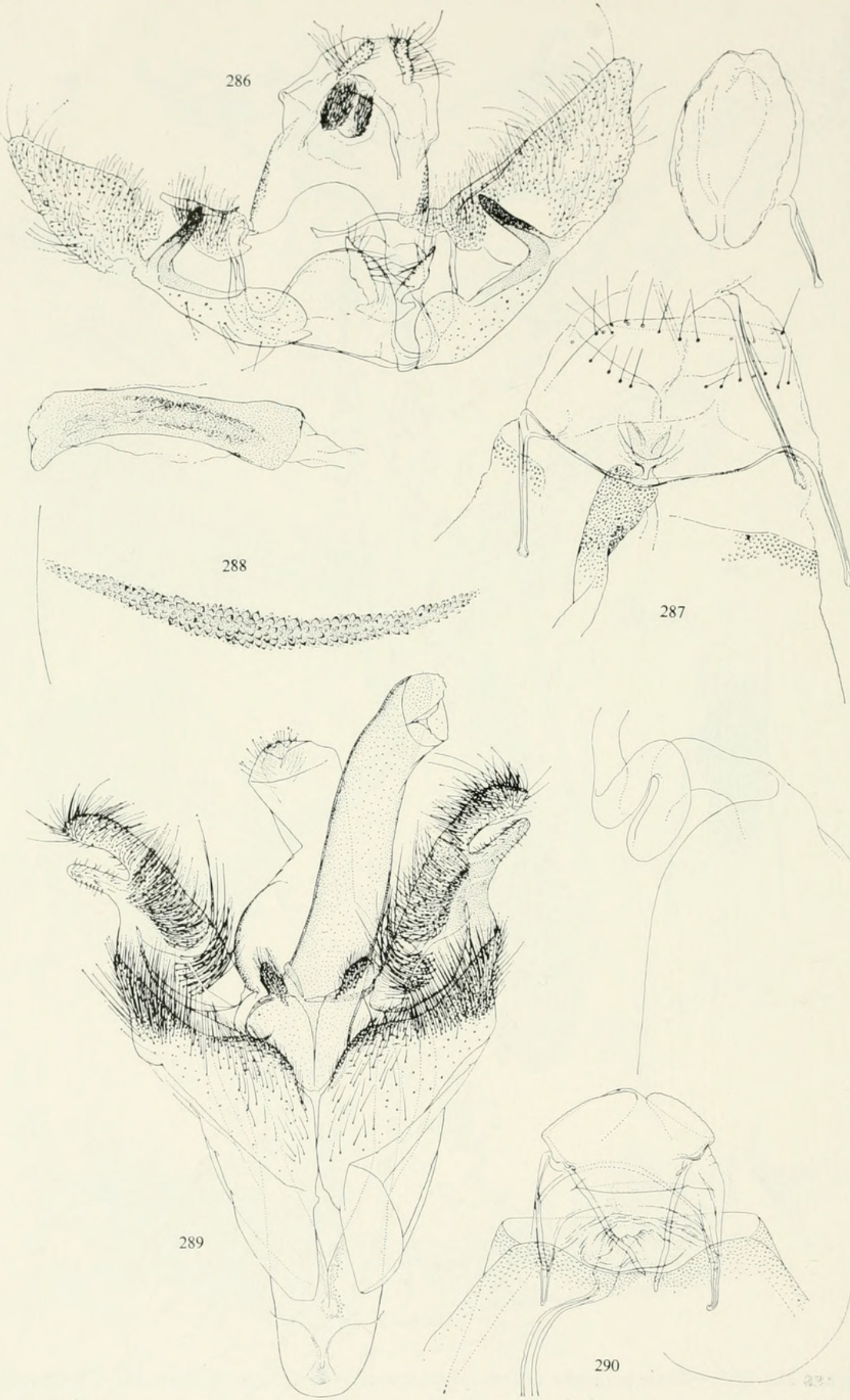

Figures 286-290.-Genitalia of Oecophoridae and Glyphipterygidae: 286, Psorosticha neglecta, new species, $\sigma^{7}$, holotype, below, aedeagus; 287 , $q$, allotype with ovipositor; 288, signum; 289, Imma aurantiaca (Semper), $\sigma^{7}$, paratype, slide no. 4722; 290, Imma albifasciella (Pagenstecher), $q$, slide no. 5108, bursa copulatrix in background. 


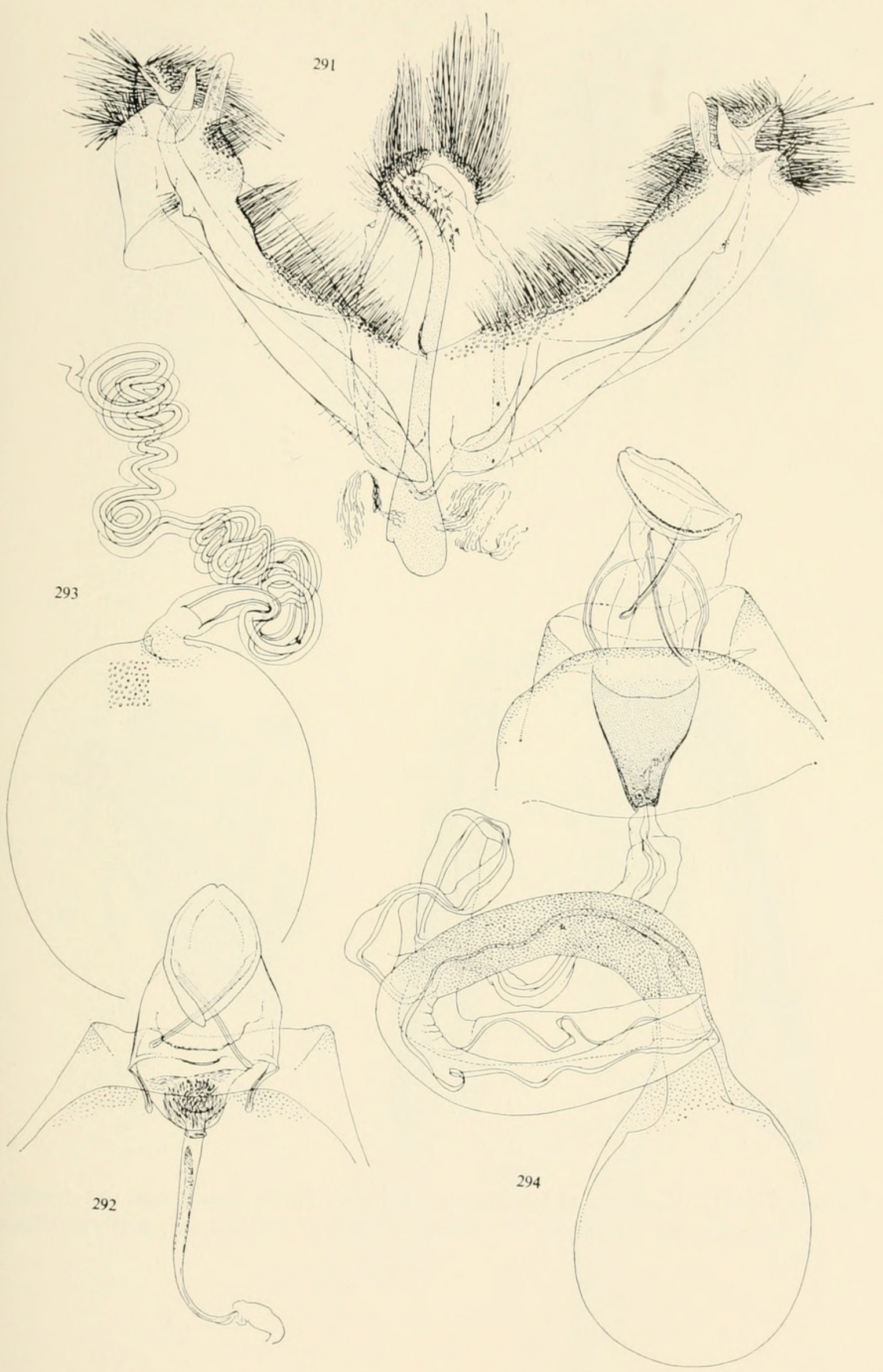

Figures 291-294.-Genitalia of Imma Walker: 291, I. poecilostoma, new species, ơ', holotype; 292, + , allotype; 293, bursa copulatrix; 294, I. tyrocnista Meyrick, $q$, slide no. 5166. 


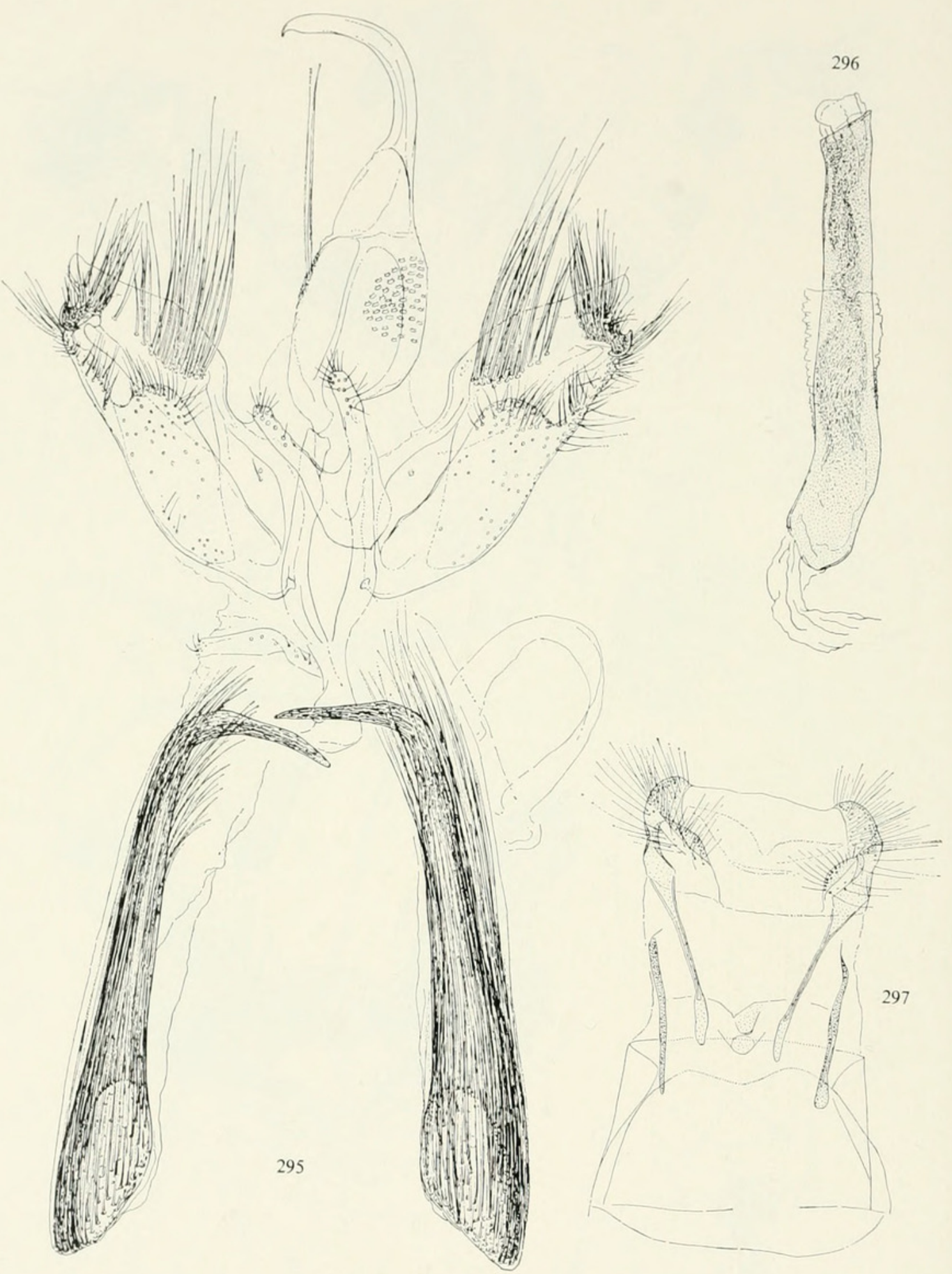

Figures 295-297.-Genitalia of Glyphipterygidae: 295, Imma chrysocosma, new species, $\sigma^{7}$, holotype; 296, aedeagus; 297, Brenthia lithocrossa Meyrick, $q$, holotype (Paris Mus.). 

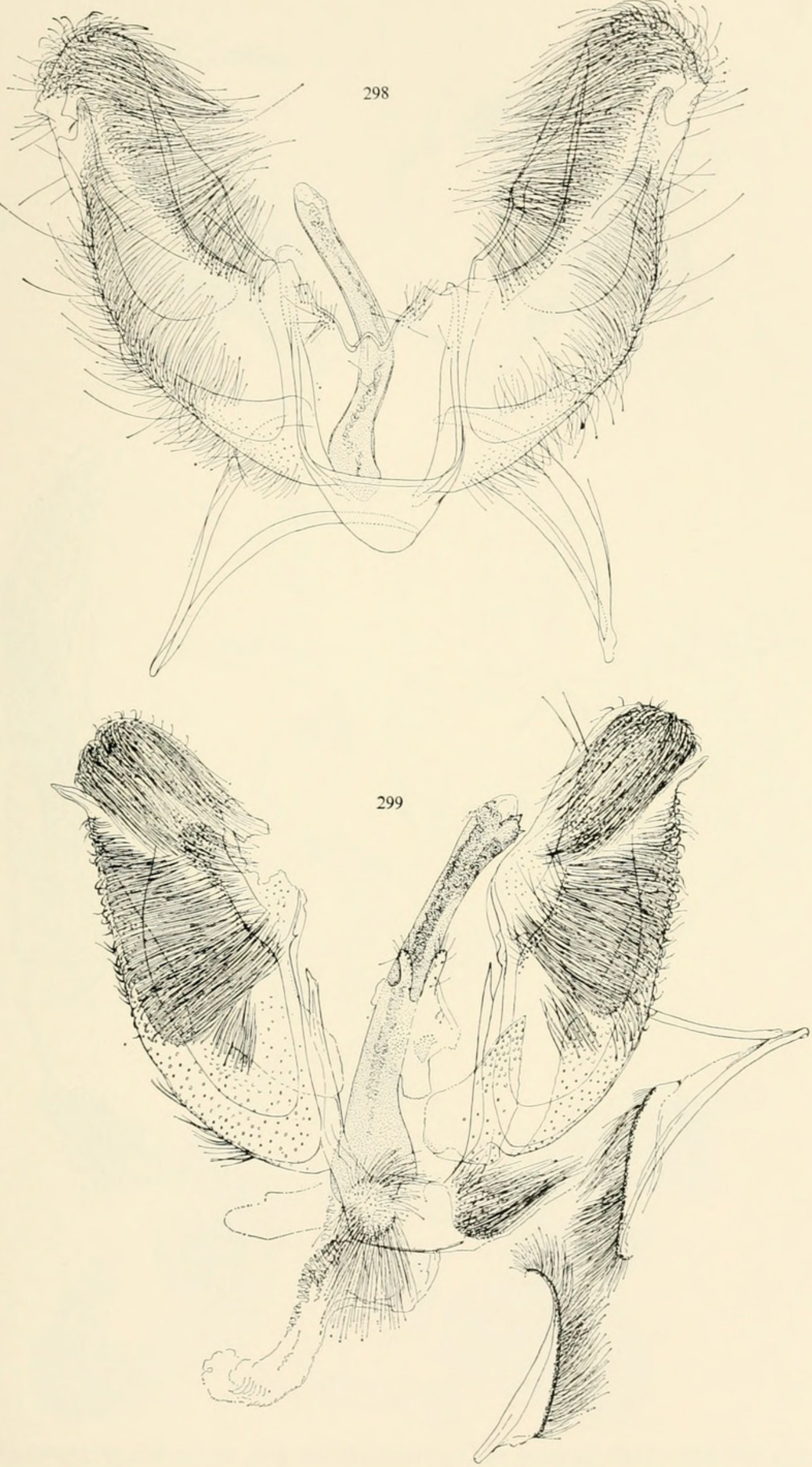

FiguREs 298-299.-Male genitalia of Imma Walker: 298, I. macrochorda, new species, $\sigma^{7}$, holotype; 299, 1. nephodryas Meyrick, ơ , holotype. 

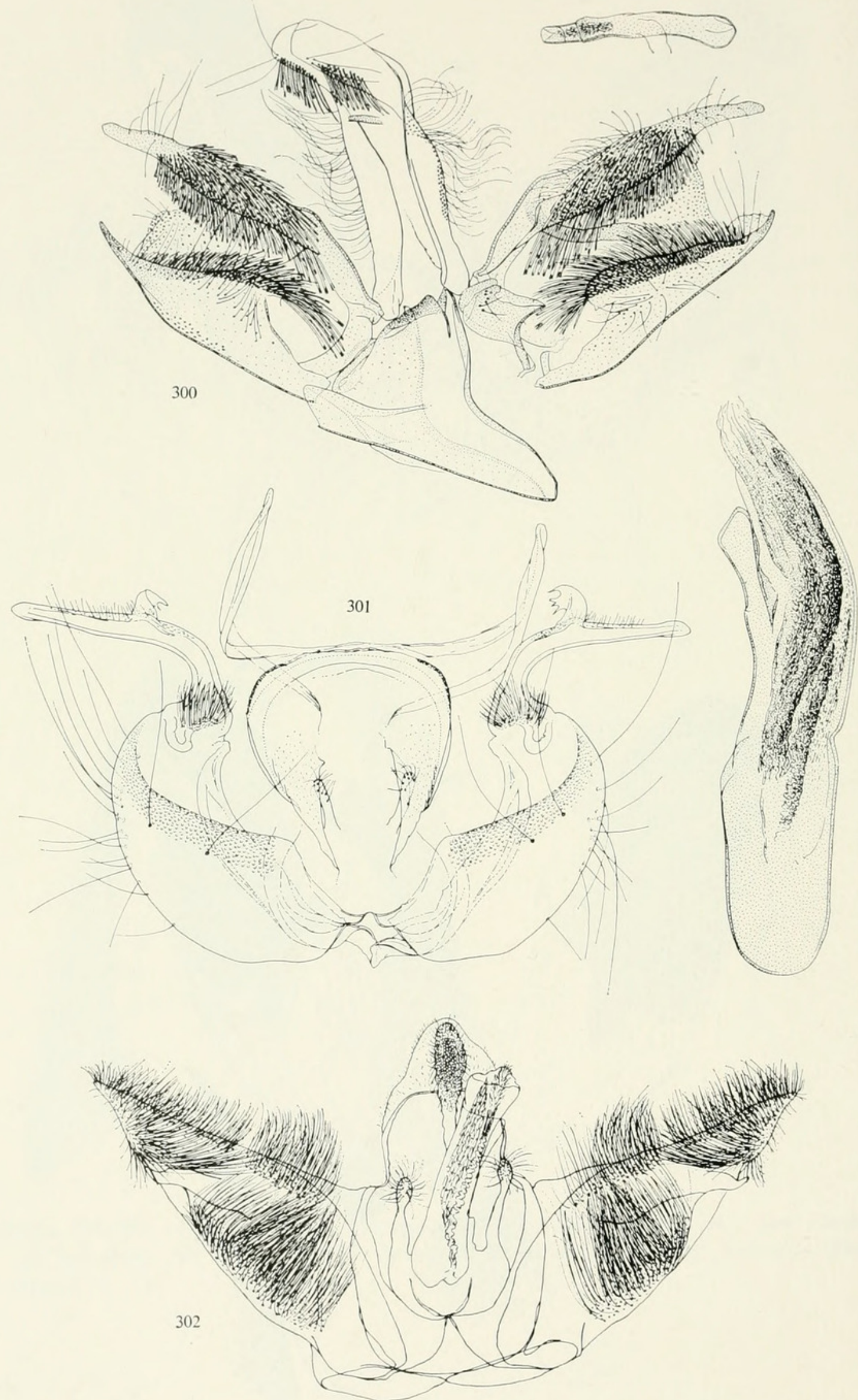

Figures 300-302.-Male genitalia of Glyphipterygidae: 300, Anthophila streptatma (Mey rick), holotype, above, aedeagus; 301, Imma sarophora, new species, holotype, right, aedeagus; $302, I$. pyragra, new species, holotype. 


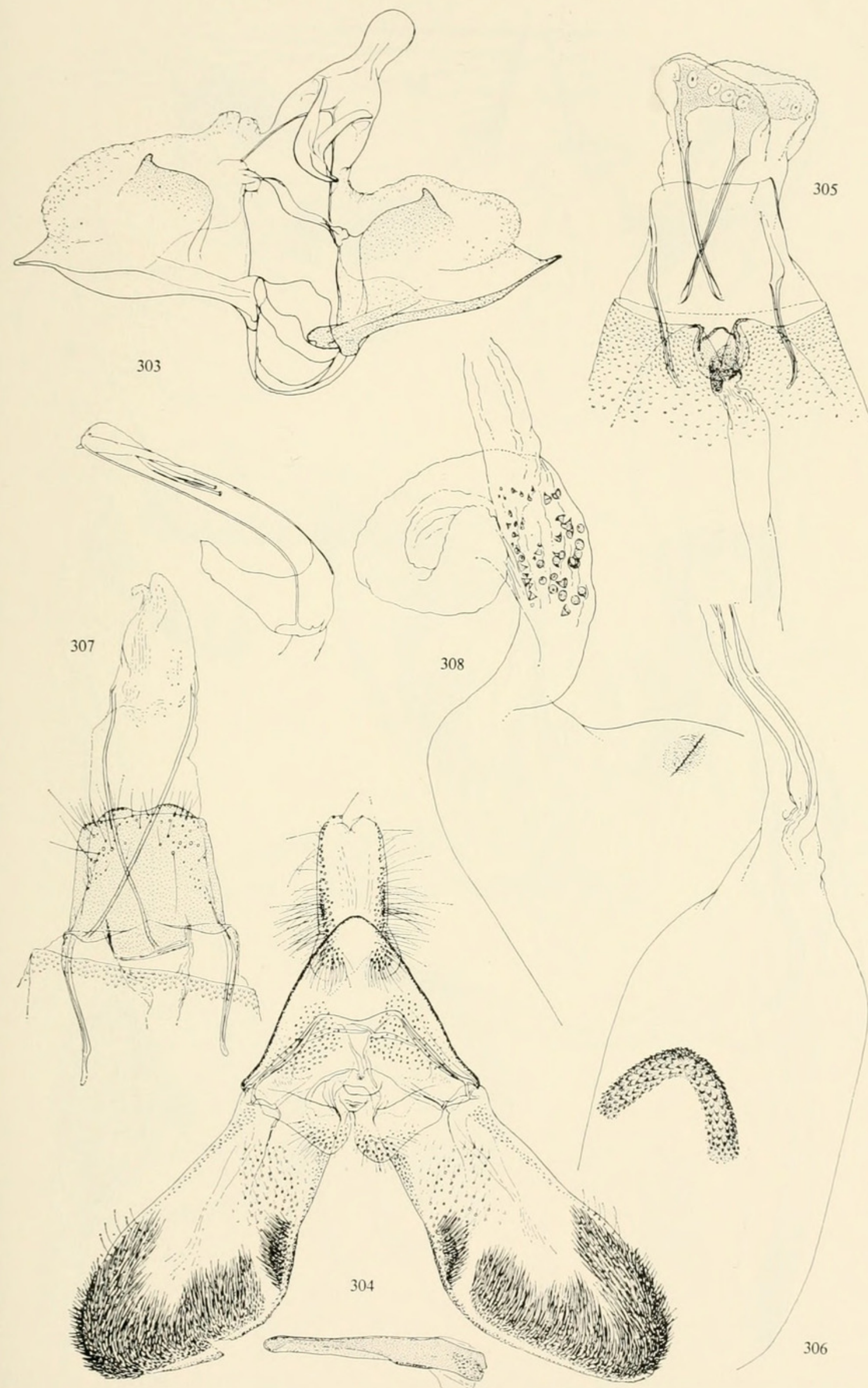

Figures 303-308.-Genitalia of Tortricidae, Glyphipterygidae, and Heliodinidae: 303, Homona aestivana (Walker), below, aedeagus; 304, Anthophila basalis (Felder), ơ, slide no. 5170 , below, aedeagus; $305, A$. angulosa, new species, + , holotype; 306 , part of bursa copulatrix; 307, Aeoloscelis perigrapha, new species, + , holotype; 308, part of ductus and corpus bursae. 


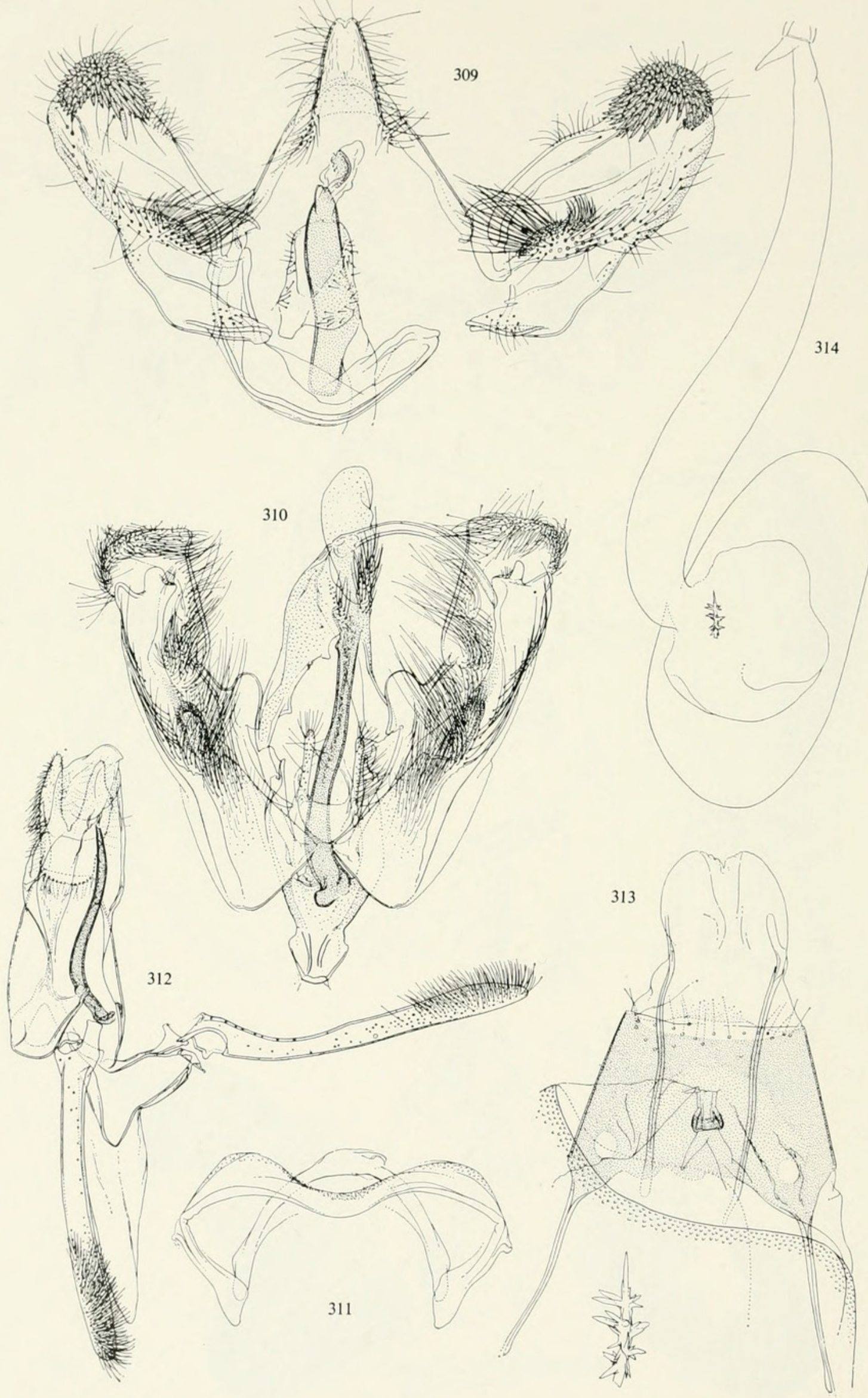

Figures 309-314.-Genitalia of Glyphipterygidae and Heliodinidae: 309, Anthophila orthogona (Meyrick), $\sigma^{\top} ; 310$, Imma tyrocnista Meyrick, $\sigma^{\top}$, slide no. 5175; 311, mensis ventralis; 312, Eretmocera percnophanes Meyrick, o', slide no. 5432; 313, Thriambeutis coryphae a Meyrick, + , slide no. 5321, below signum, strongly magnified; 314 , bursa copulatrix. 

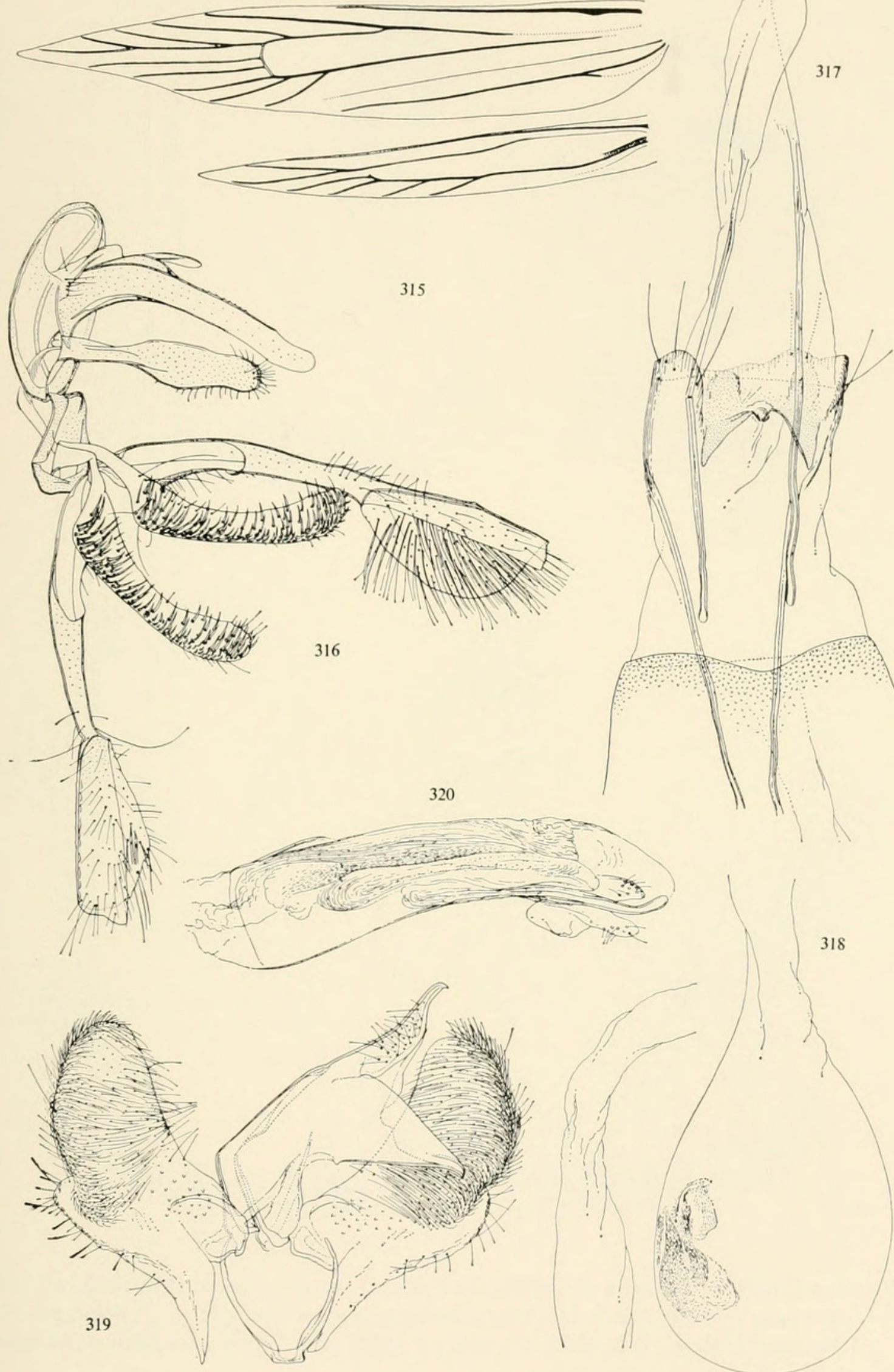

Figures 315-320.-Heliodinidae: 315, Craterobathra ornata, new species, wing neuration, $\sigma^{7}$, holotype; 316, genitalia. Genitalia: 317, Eretmocera percnophanes Meyrick, $q$, slide no. 5520; 318, bursa copulatrix and, left, part of ductus bursae; 319 , Stathmopoda placida Meyrick, $\sigma^{7}$, slide no. $5135 ; 320$, aedeagus. 


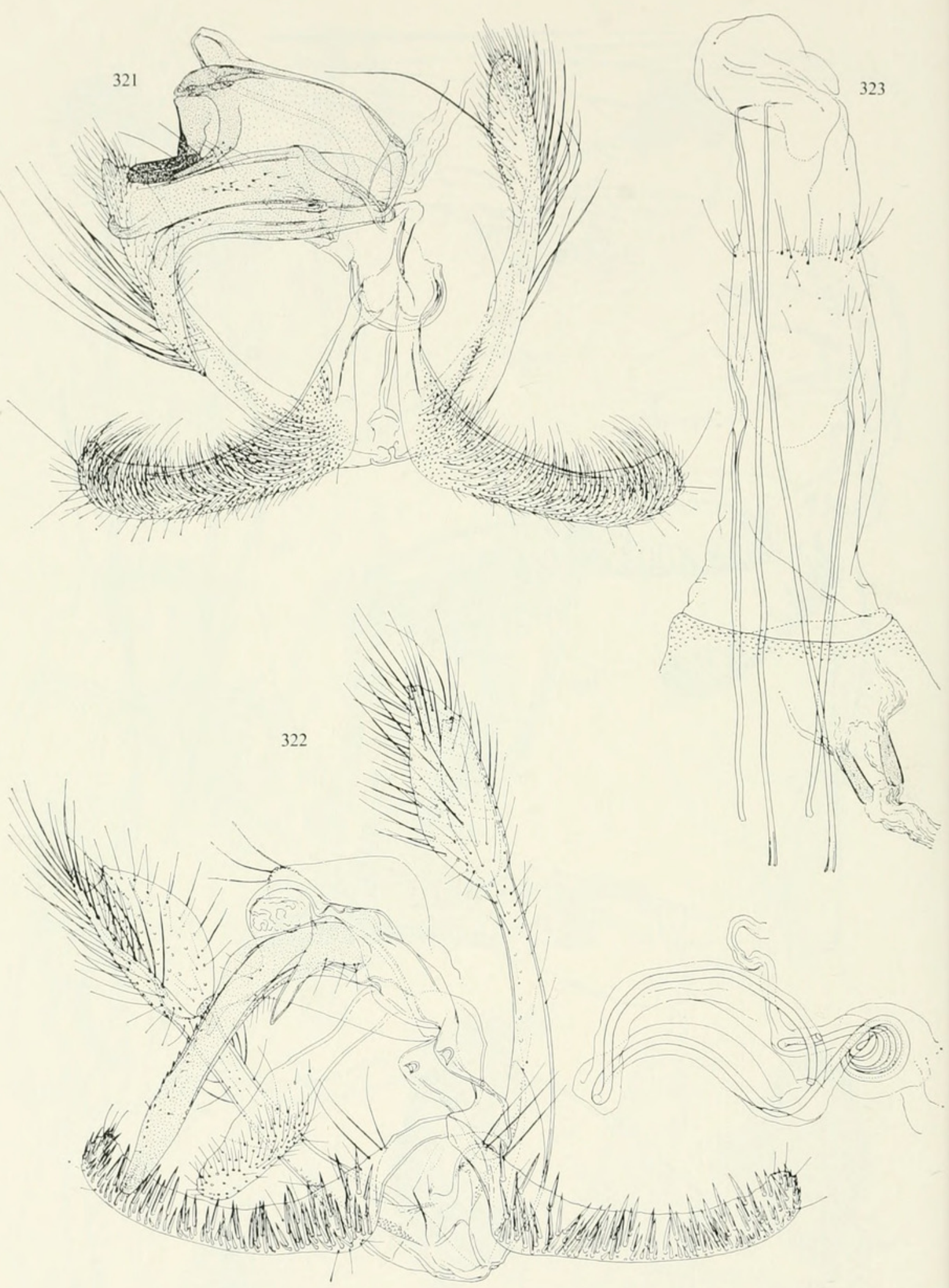

Figures 321-323.-Genitalia of Heliodinidae: 321, Xestocasis iostrota (Meyrick), ơ. slide no. “June 17, 1930, A.B.”; 322, Craterobathra argyracma, new species, o', holotype; 323, Stathmopoda theoris (Meyrick), $q$, slide no. 5133, with, below, part of ductus bursae. 

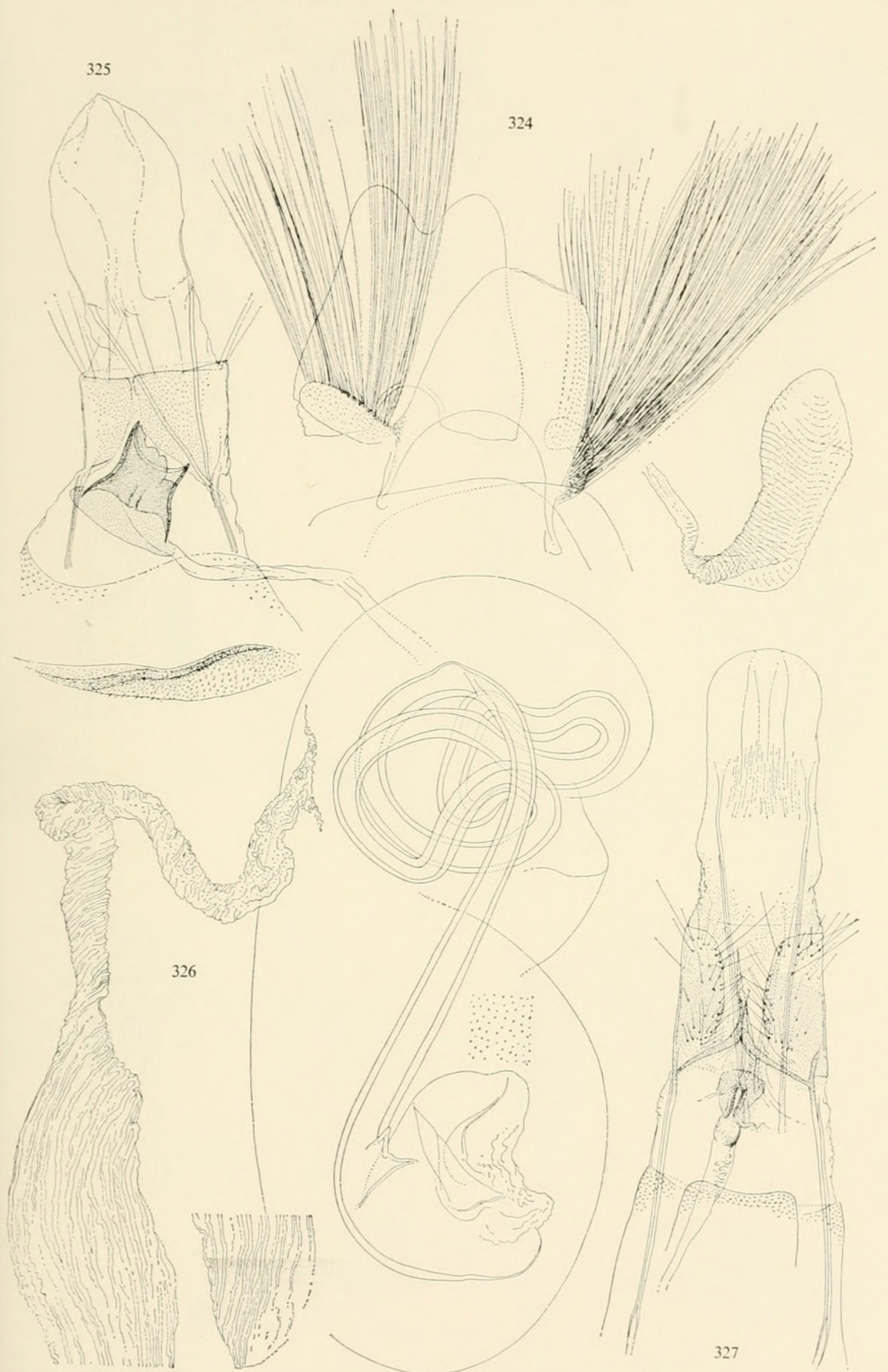

Figures 324-327.-Genitalia of Heliodinidae and Aegeriidae: 324, Eretmocera percnophanes Meyrick, $\sigma^{7}$, slide no. 5432, coremata; 325, Craterobathra demarcata, new species, $\$$, holotype, below, spines of the tergite; 326 , bursa copulatrix (reconstrued), with spermatophore and separate chamber (tip dislodged); 327, Paranthrene heterodesma, new species, $q$, allotype, above, corpus bursae (contracted). 


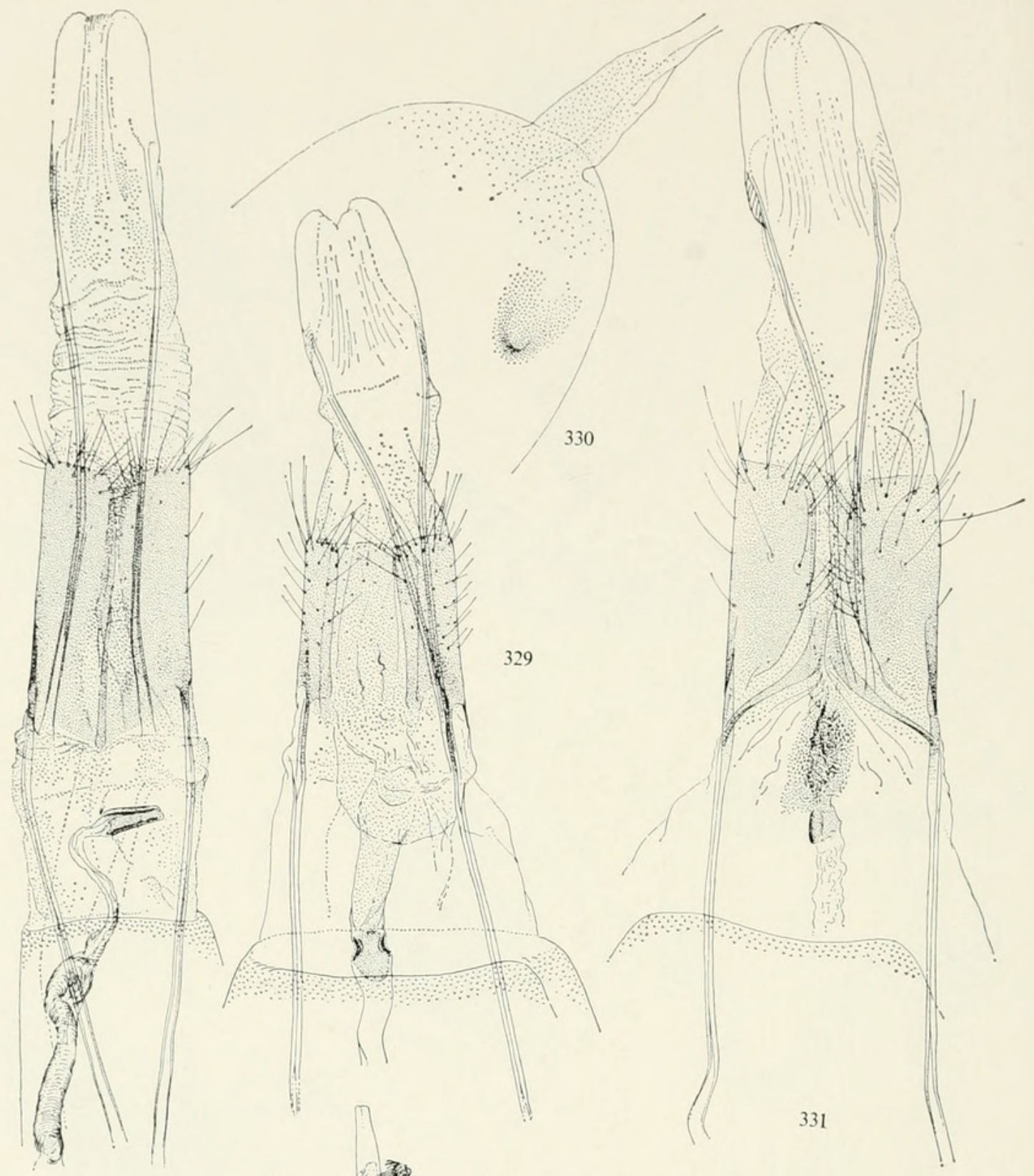

328

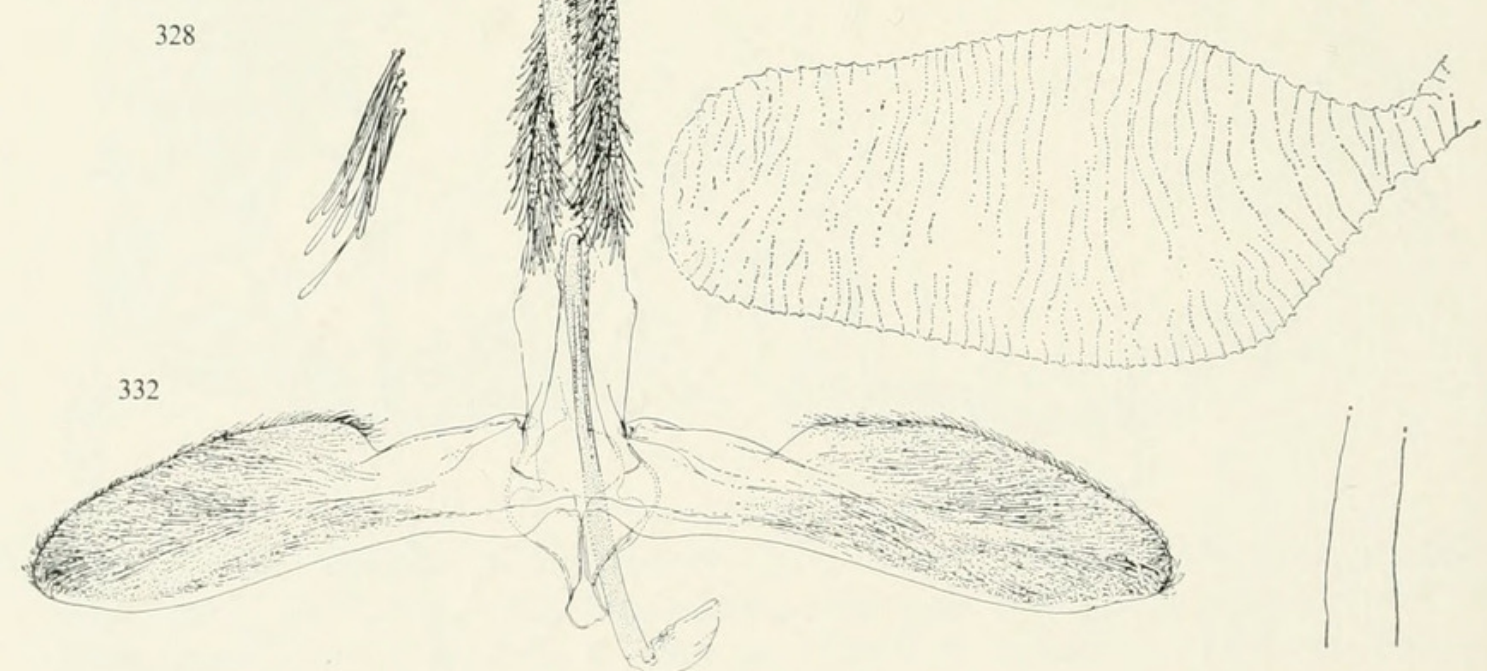

Figures 328-332.-Genitalia of Aegeriidae: 328, Lepidopoda lutescens, new species, $\uparrow$, holotype; 329, Glossosphecia micans, new species, + , holotype; 330, part of bursa copulatrix with signum; 331 , Sura cyanolampra, new species, $q$, holotype, below, corpus bursae (contracted) and part of ductus bursae; 332. Synanthedon chrysostetha, new species, $\sigma^{\Upsilon}$, holotype, left, scales of uncus, more magnified. 


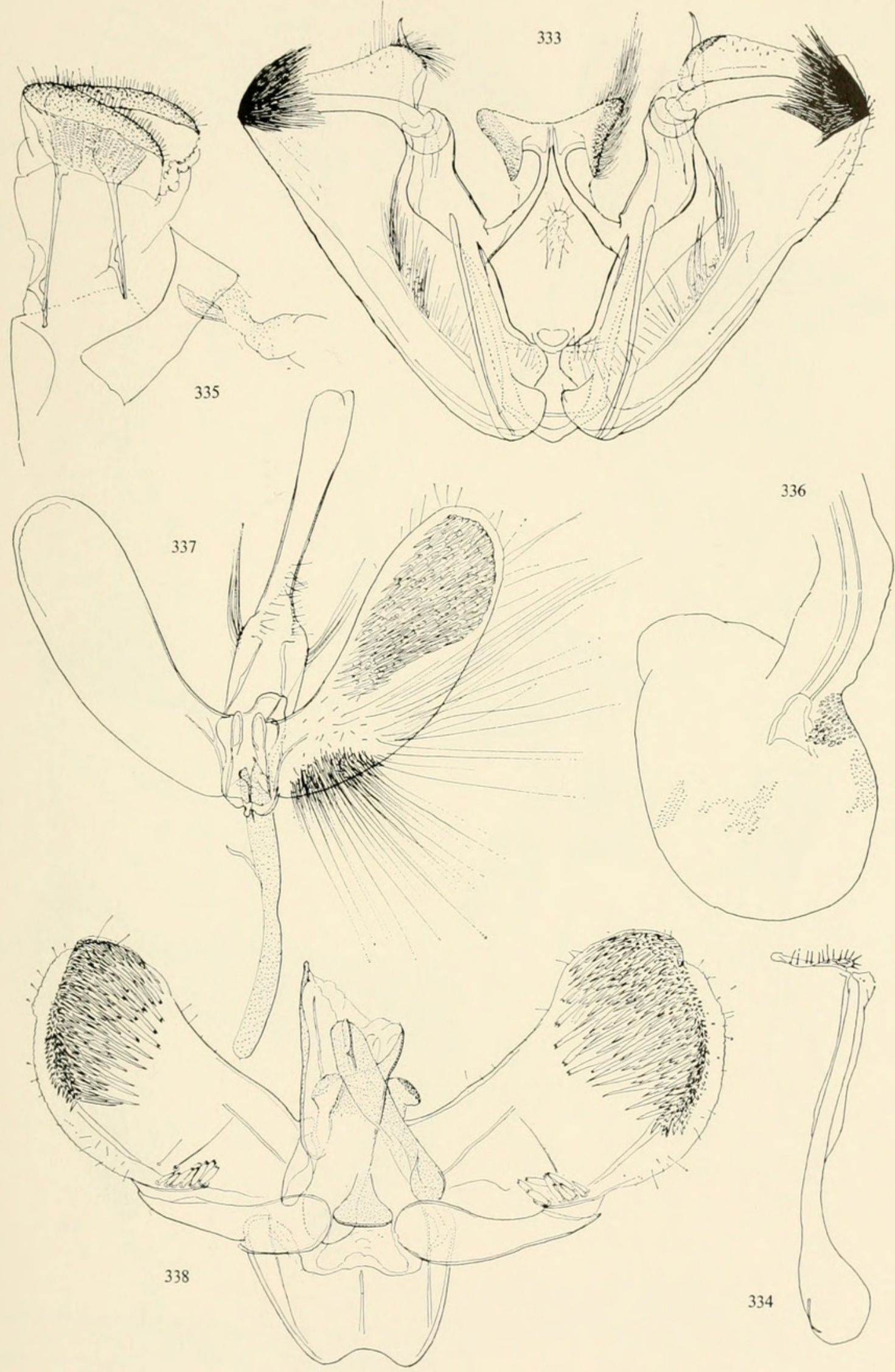

Figures 333-338.-Genitalia of Glyphipterygidae: 333, Imma albifasciella (Pagenstecher), $\sigma^{\top}$, slide no. $5176 ; 334$, aedeagus; 335 , Tortyra divitiosa (Walker), \& , slide no. 5182; 336, bursa copulatrix; 337, $\sigma^{7}$, slide no. 5178; 338, Anthophila amethystodes (Meyrick), o'. slide no. 5684 . 

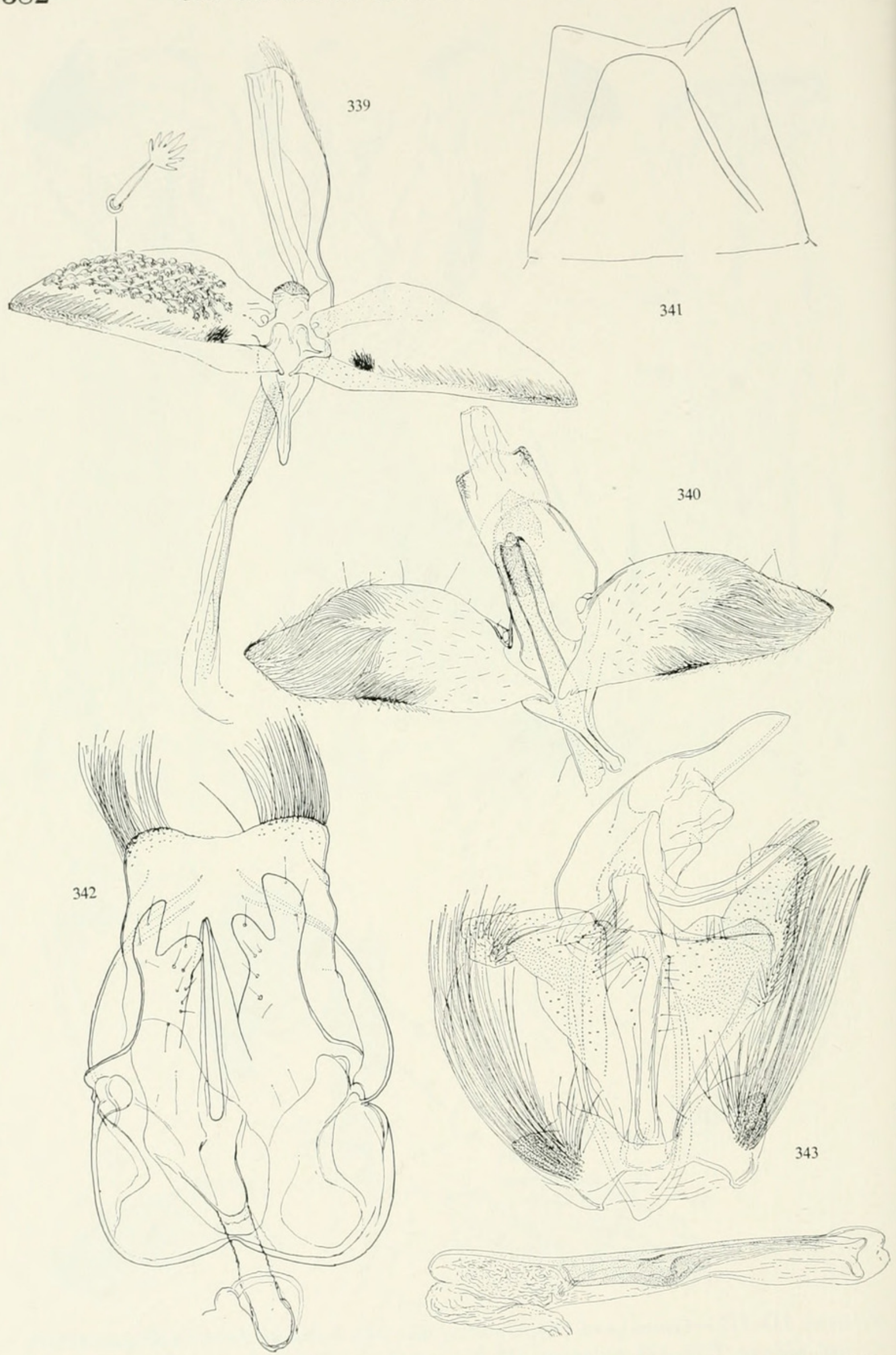

Figures 339-343.-Male genitalia of Aegeriidae, Glyphipterygidae, and Orneodidae: 339, Paranthrene helerodesma, new species, $\sigma^{7}$, holotype; 340, Sphecosesia melanostoma, new species, $\sigma^{7}$, holotype; 341, pregenital sternite; 342, Brenthia anisopa, new species, $\sigma^{7}$, holotype; 343 , Orneodes toxophila Meyrick, ơ slide no. 5722 , below, aedeagus. 

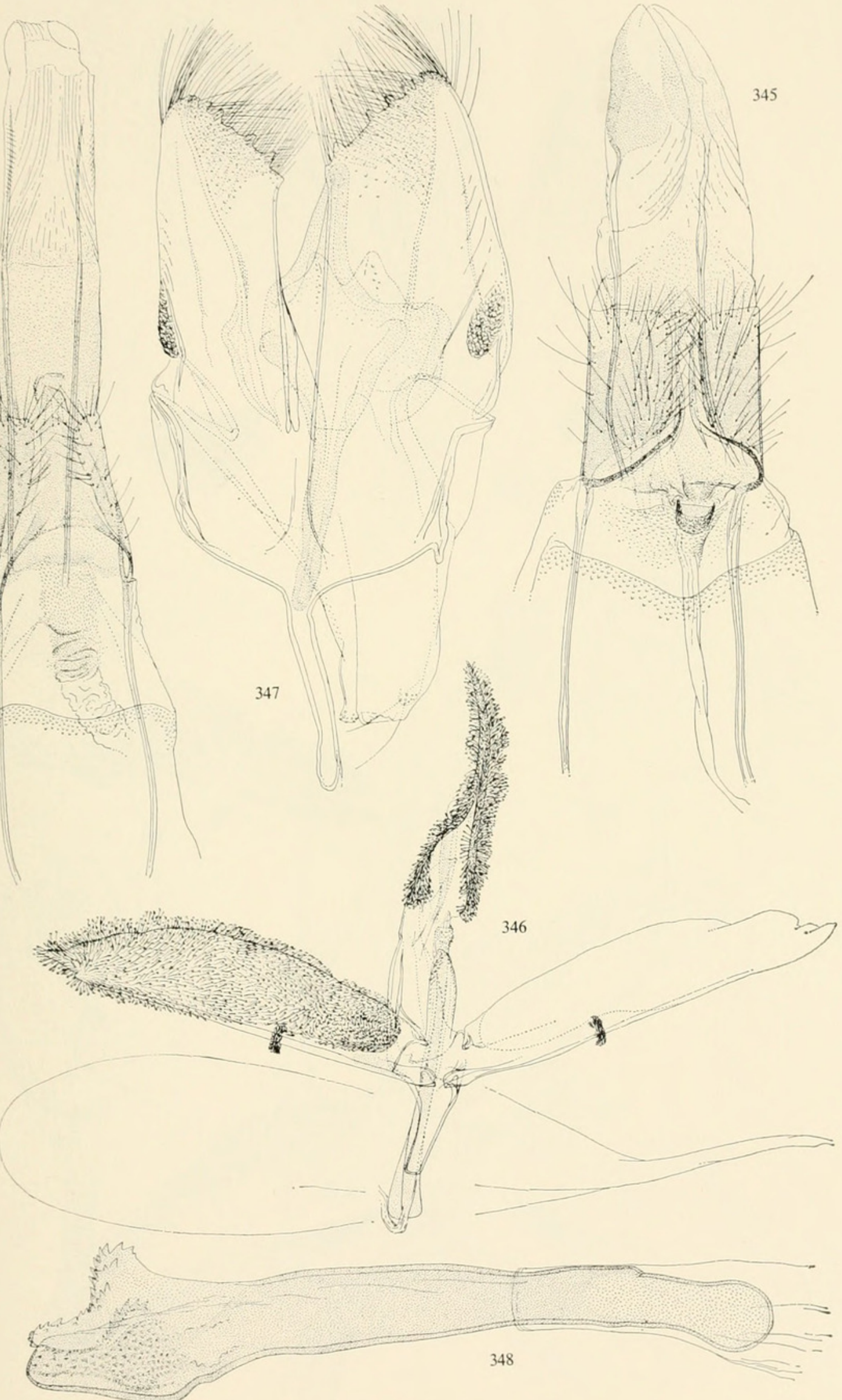

Figures 344-348.-Genitalia of Aegeriidae: 344, Glossosphecia pelocroca, new species, $q$, holotype; 345 , Sura tetrapora, new species, $q$, holotype, with, below, bursa copulatrix; 346, Synanthedon cirrhozona, new species, $\sigma^{7}$, holotype; 347 , Bembecia fortis, new species, $\sigma^{7}$, holotype; 348 , aedeagus. 


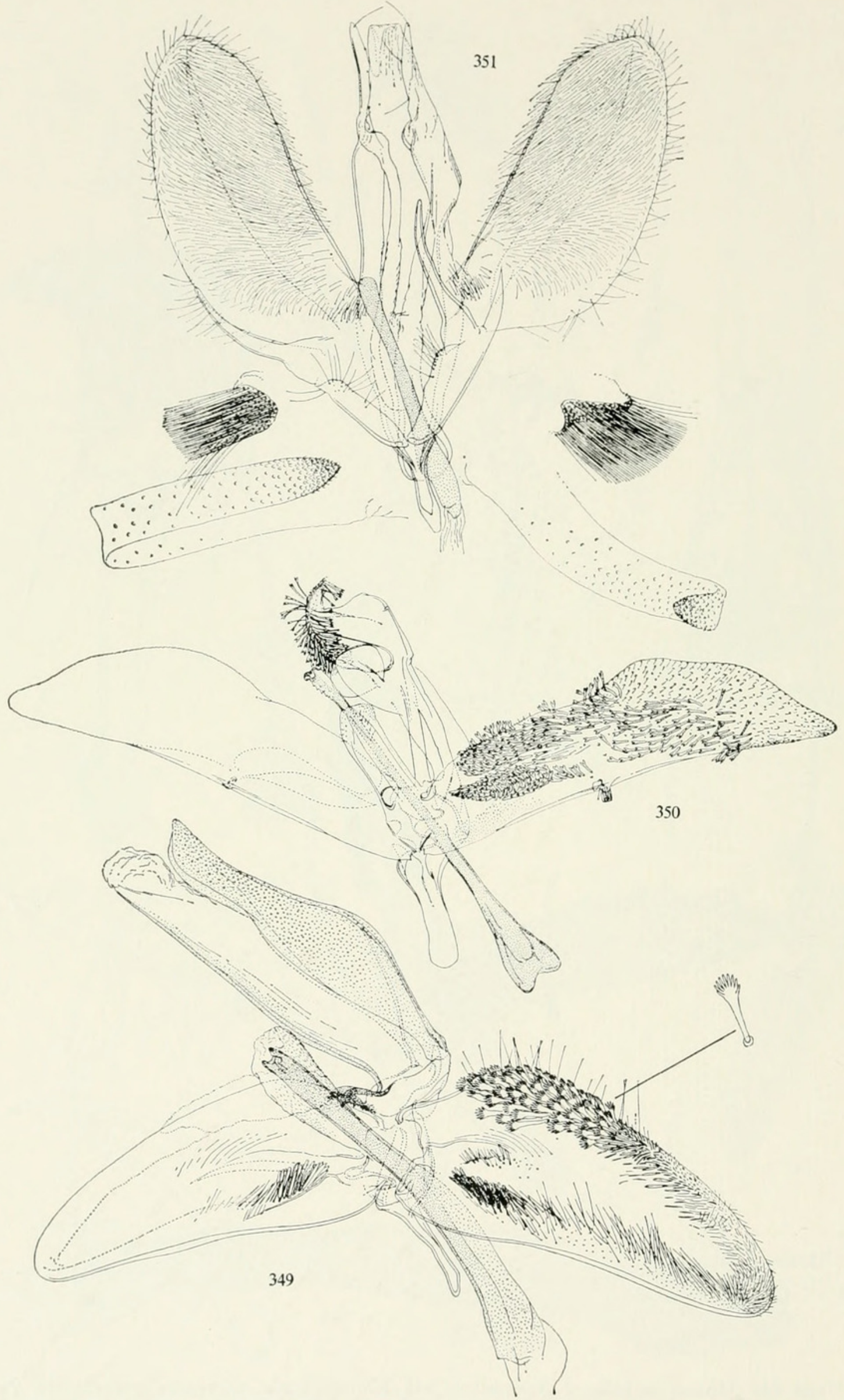

Figures 349-351.-Male genitalia of Aegeriidae and Plutellidae:349, Paranthrene poecilocephala, new species, holotype; 350, Synanthedon sphenodes, new species, holotype; 351, Harpeptila prasina, new species, holotype. 

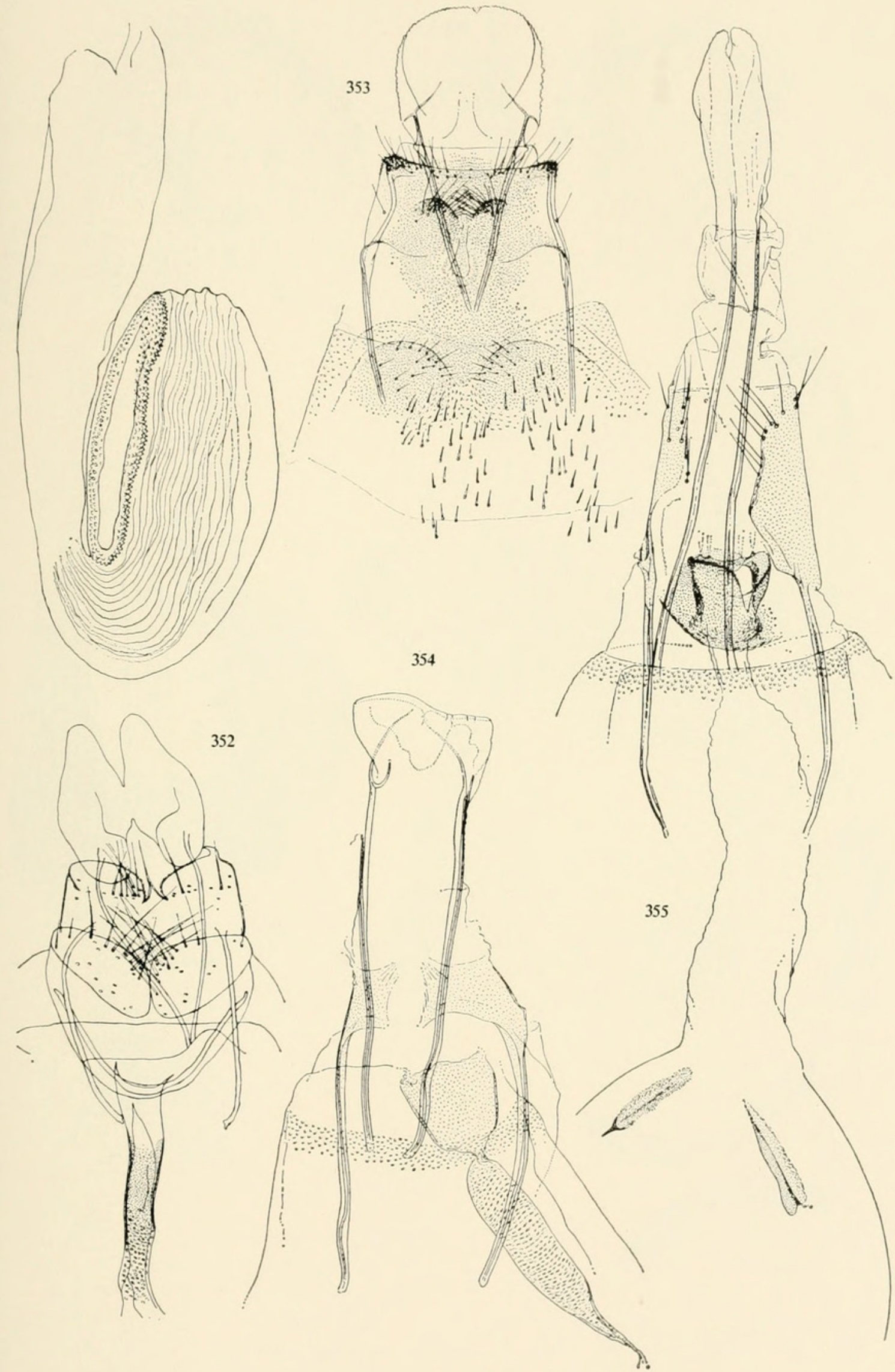

Figures 352-355.-Genitalia of Yponomeutidae: 352, Atteva triplex, new species, $q$, holotype; $353, A$. holenopla, new species, $\$$, holotype with, left, bursa copulatrix; 354, Anticrates rhodometra, new species, + , allotype; 355, Protorhiza cyanosticta, new genus, new species, $q$, holotype. 


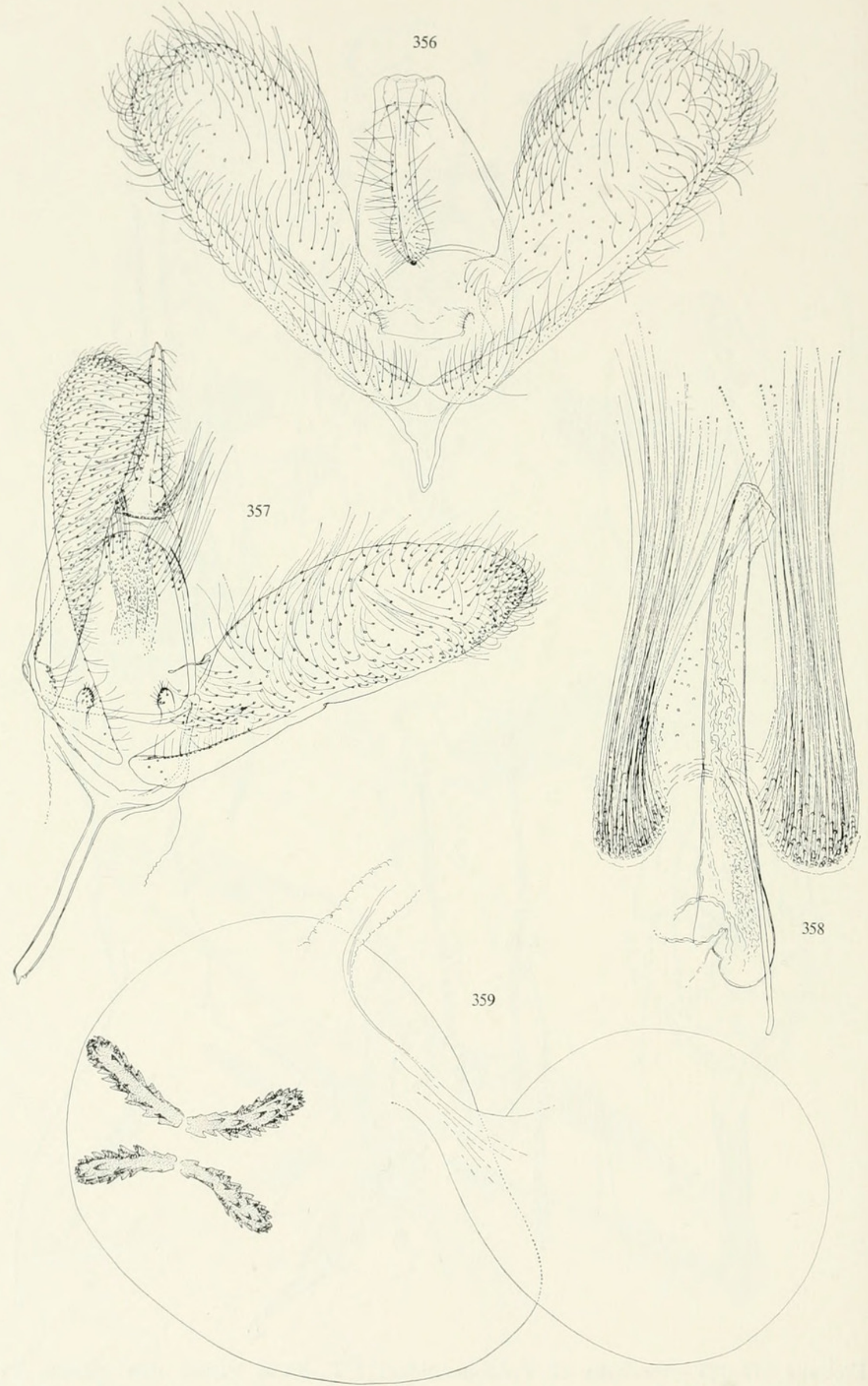

Figures 356-359.--Genitalia of Yponomeutidae: 356, Anticrates denticuluta, new species, $\sigma^{7}$, holotype; $357, A$. digitosa, new species, $\sigma^{7}$, holotype; 358 , aedeagus and coremata; $359, A$. rhodometra, new species, $ᄋ$, allotype, bursa copulatrix. 


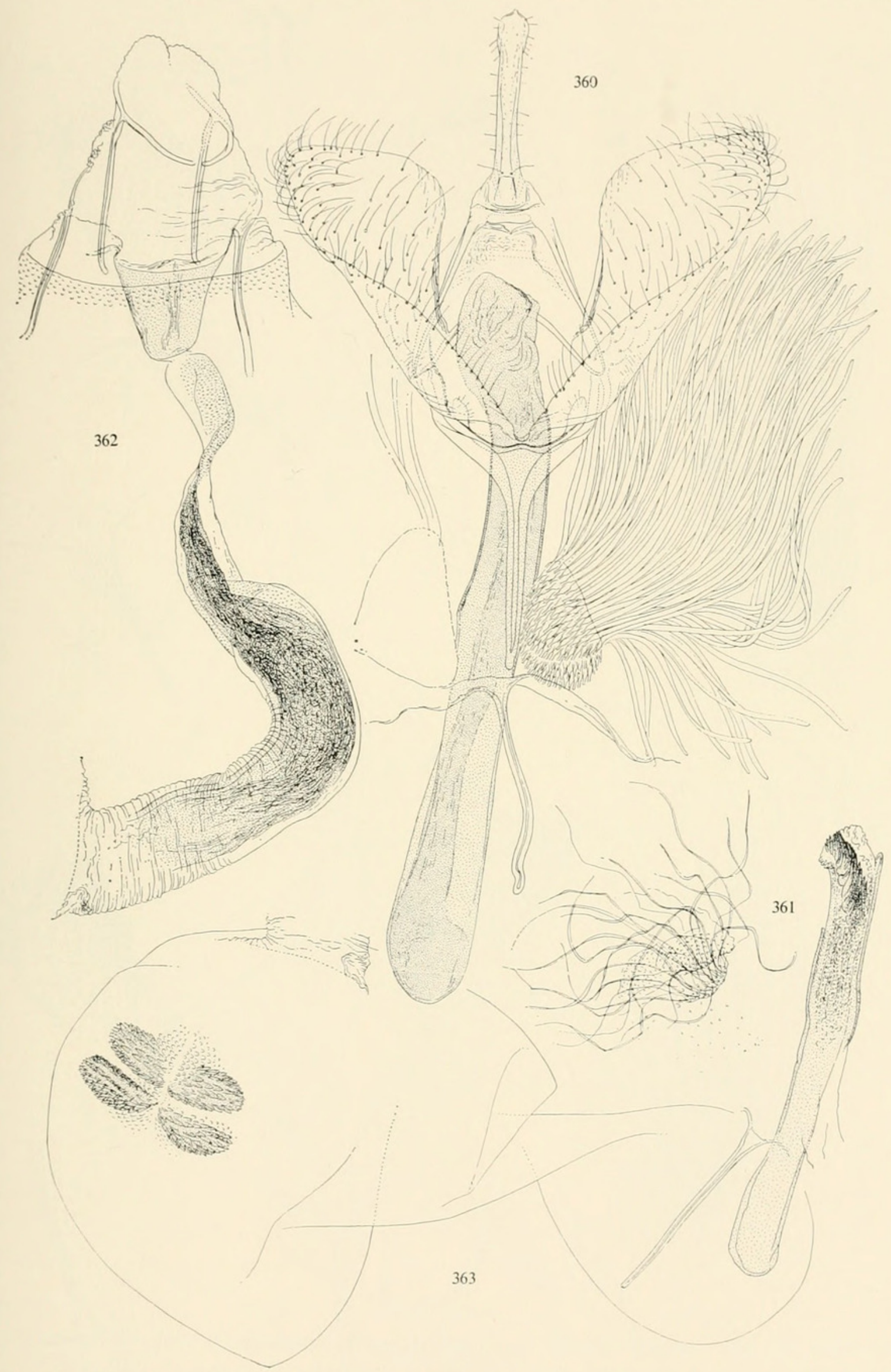

Figures 360-363.- Genitalia of Yponomeutidae: 360, Anticrates rutilella (Pagenstecher), $\sigma^{7}$, with right corema, slide no. $5223 ; 361, A$. denticulata, new species, aedeagus and left corema, partly denuded; $362, A$. digitosa, new species. + , allotype; 363 , bursa copulatrix. 


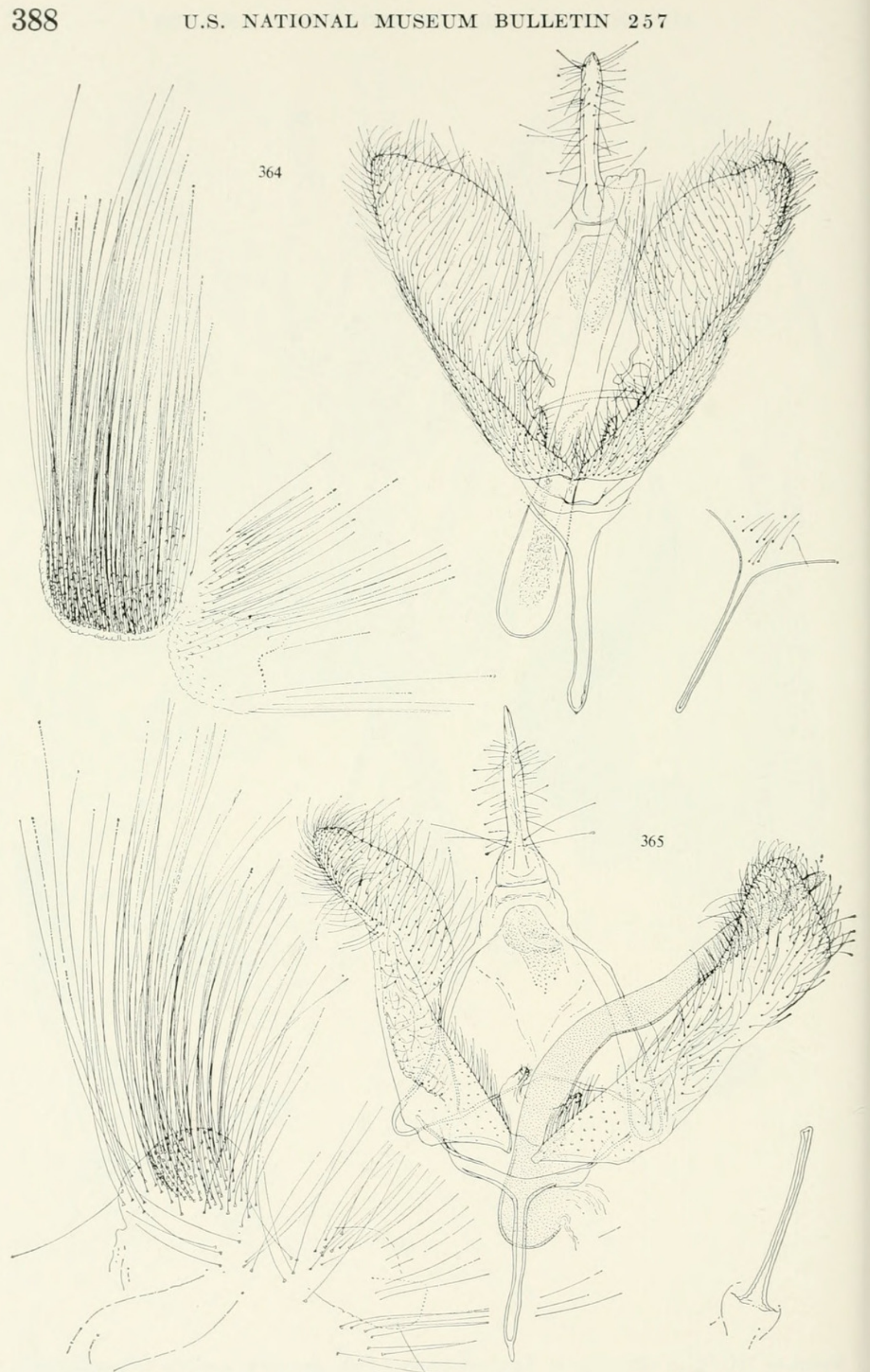

Figures 364-365.-Male genitalia of Anticrates Meyrick: 364, A. rhodometra, new species, $\sigma^{7}$, right, saccus-like median appendix of 7 th sternite, left, coremata; $365, A$. paratarsa Meyrick, $\sigma^{\top}$, right, "pseudo-saccus," left, coremata. 

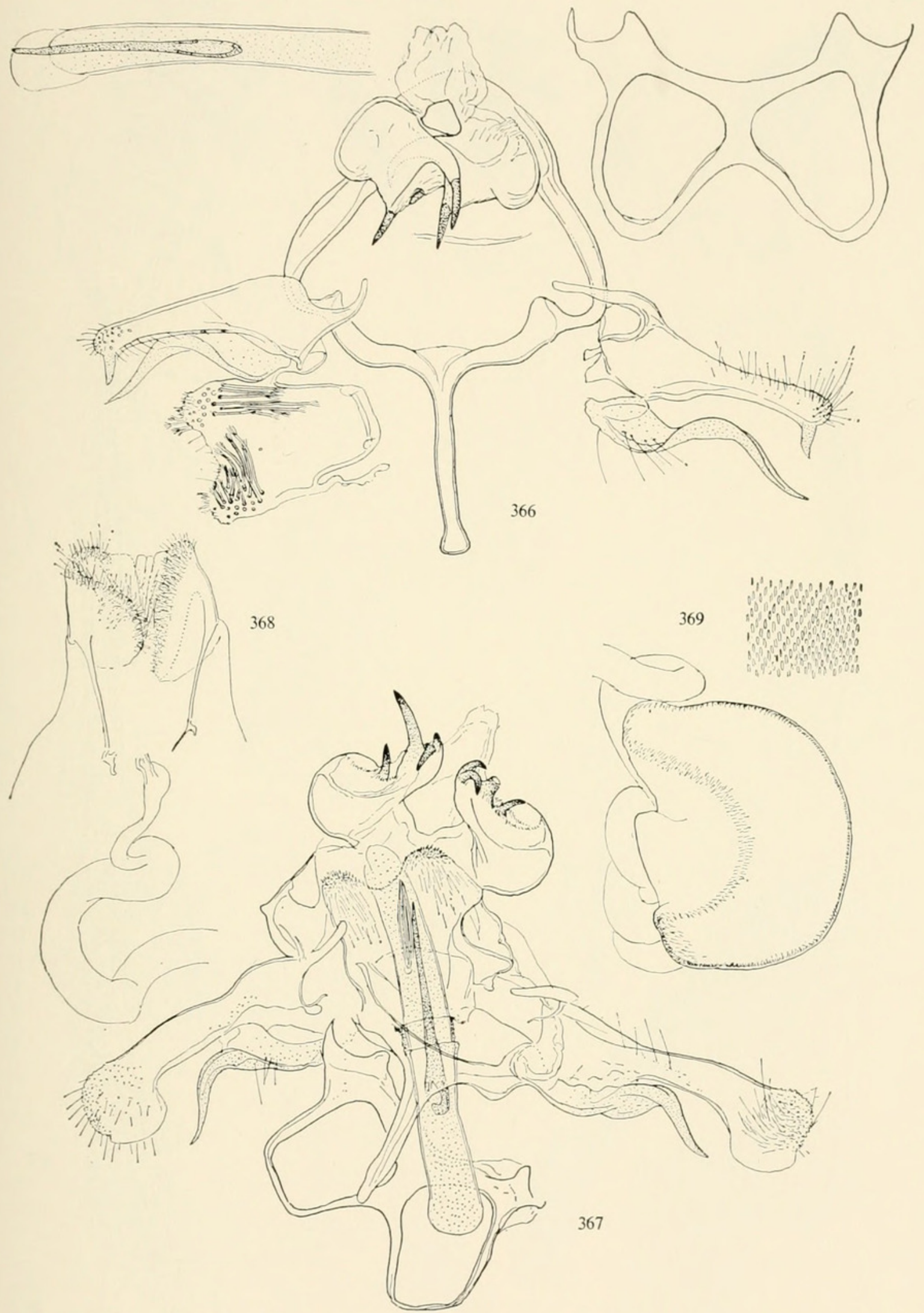

Figures 366-369.-Genitalia of Prays Hübner and Tortyra Walker: 366, P. endocrapa Meyrick, $\sigma^{7}$, anellus plate displaced to left below; with, left above, fragment of aedeagus, right above, tergite of vinculum; $367, P$. endolemma, new species, $\sigma^{7}$, with aedeagus and anellus in place; 368, Tortyra macrospila, new species, + , upper part; 369, lower part, with, above, more magnified, fragment of wall of bursa copulatrix. 


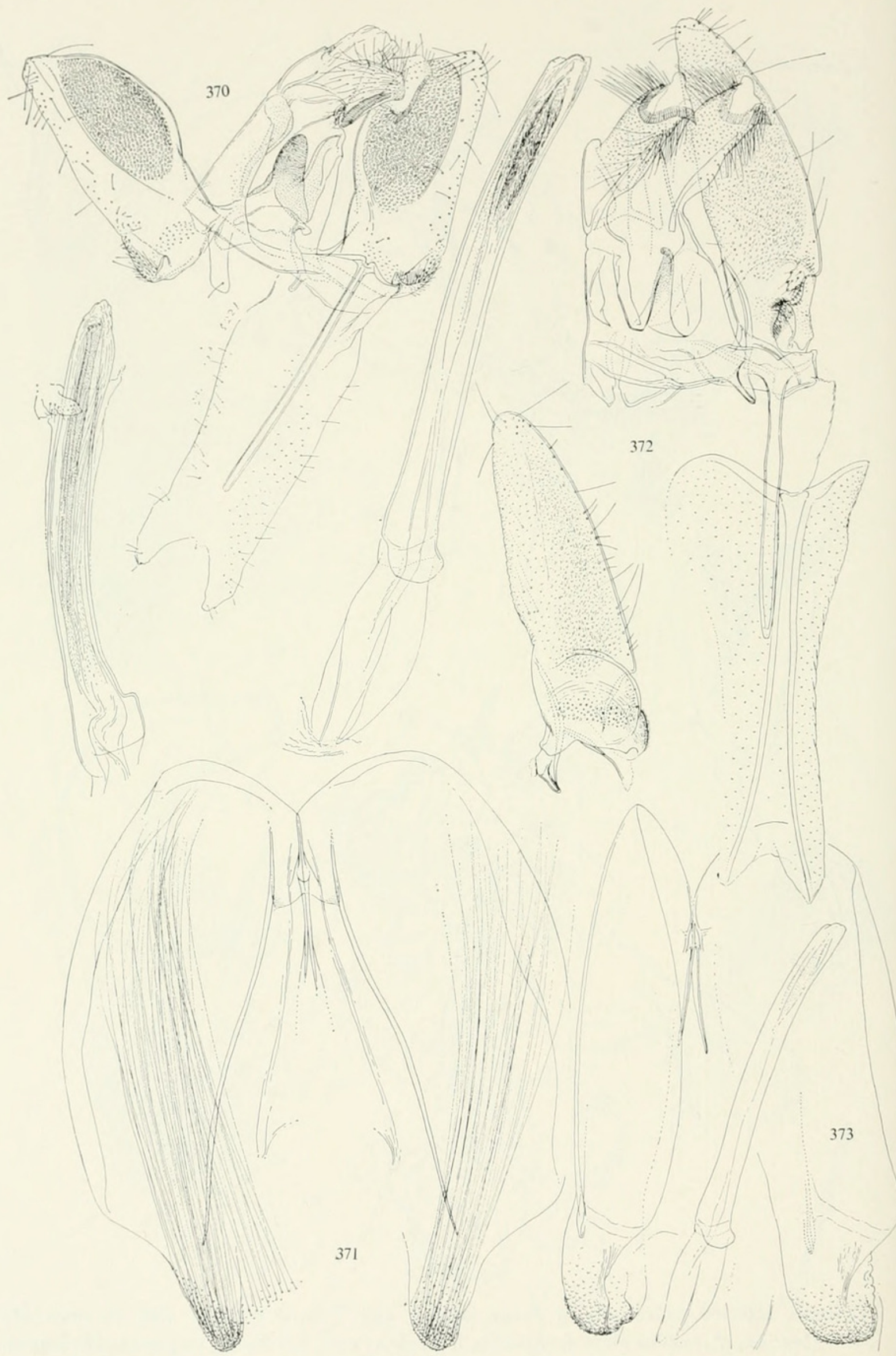

Figures 370-373.-Male genitalia of Atteva Walker: 370, A scolecias Meyrick, slide no. 5221, left, aedeagus; 371 , pregenital segment with coremata; 372, A. balanota Meyrick, slide no. 5220, left, aedeagus and left valva; all at the same magnification; 373, pregenital segment, less magnified, with across it aedeagus, for size. 


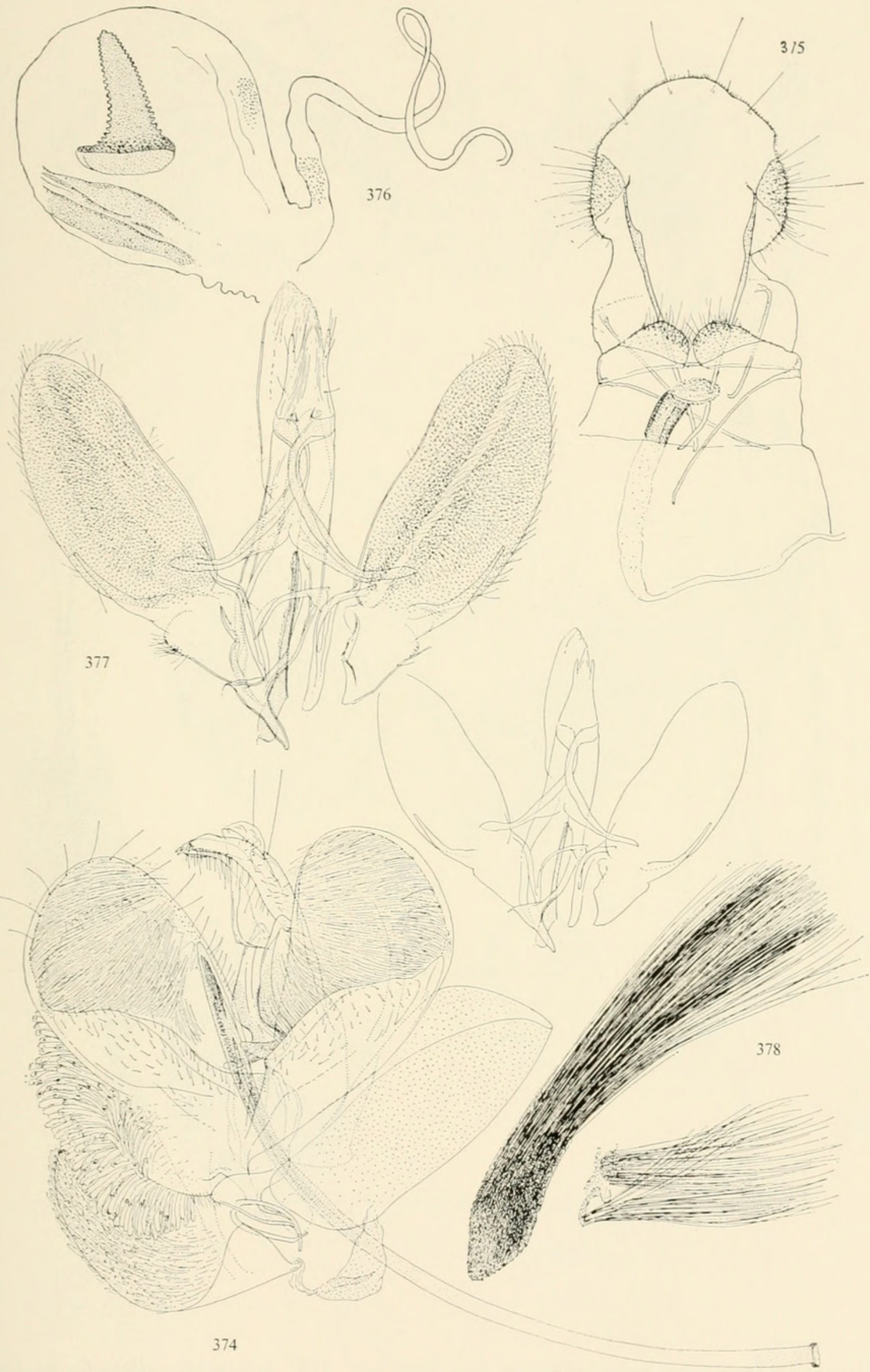

Figures 374-378.-Genitalia of Plutellidae: 374, Yponomeuta interruptella (Sauber), $\sigma^{7}$, slide no. $5766 ; 375$, + , slide no. $5771 ; 376$, bursa copulatrix; 377 , Harpeptila corethrodes, new genus, new species, $\sigma^{7}$, holotype; 378 , right pair of coremata with above, sketch of genitalia, for size, all in natural position. 


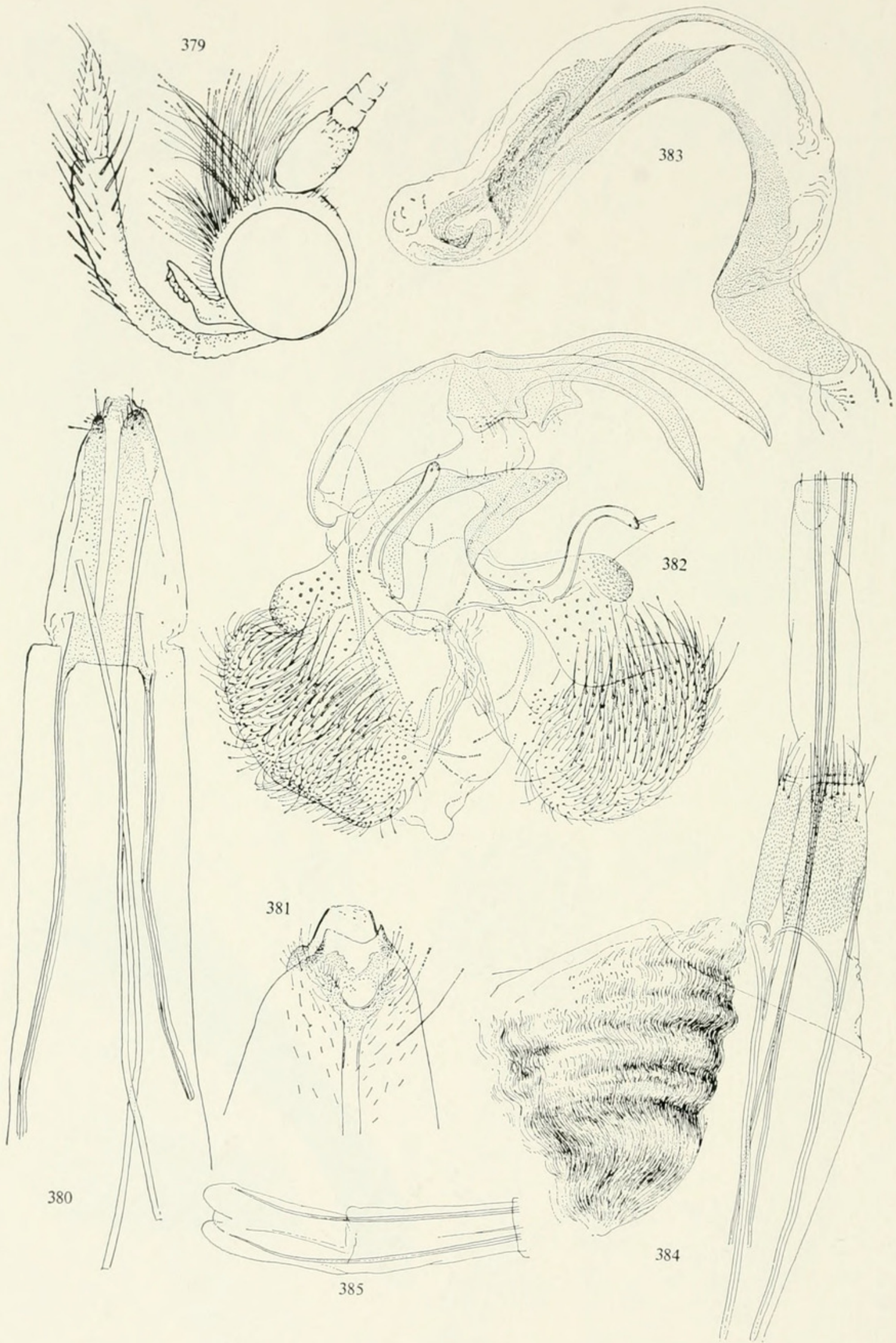

FigURES 379-385.-Cosmopterygidae and Tineidae: 379, Ischnuridia virginella Sauber, holotype, $\subsetneq$, head (by Dr. H. Schröder); 380, dorsal aspect of tip of abdomen; 381, sterigma; 382, Scaeothyris pseusta, new genus, new species, $\sigma^{\top}$, holotype, genitalia; 383, aedeagus; 384, Hapsifera rugosella (Stainton), + , slide no. 5102; 385, tip of ovipositor. [Fig. 379, by courtesy of Senckenberg Museum, Frankfurt a. M.] 

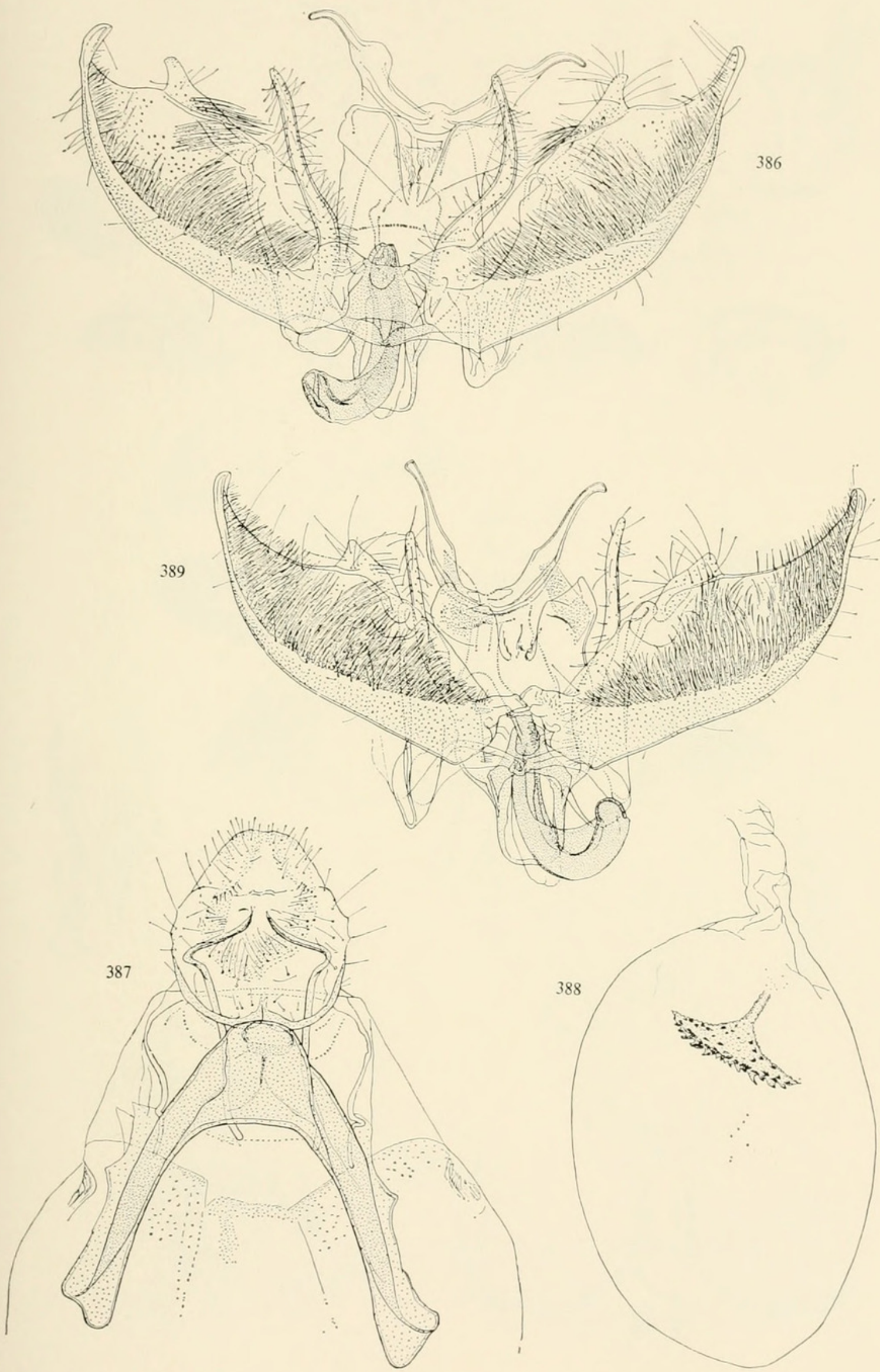

Figures 386-389.-Genitalia of Ethmiidae: 386, Agrioceros platycypha Meyrick, ơ, slide no. "10. May, 1927. A.B.”; 387, A. magnificella (Sauber), ơ, slide no. "11 May, 1924, A.B.”; 388, bursa copulatrix; 389, ㅇ, slide no. 5249. 

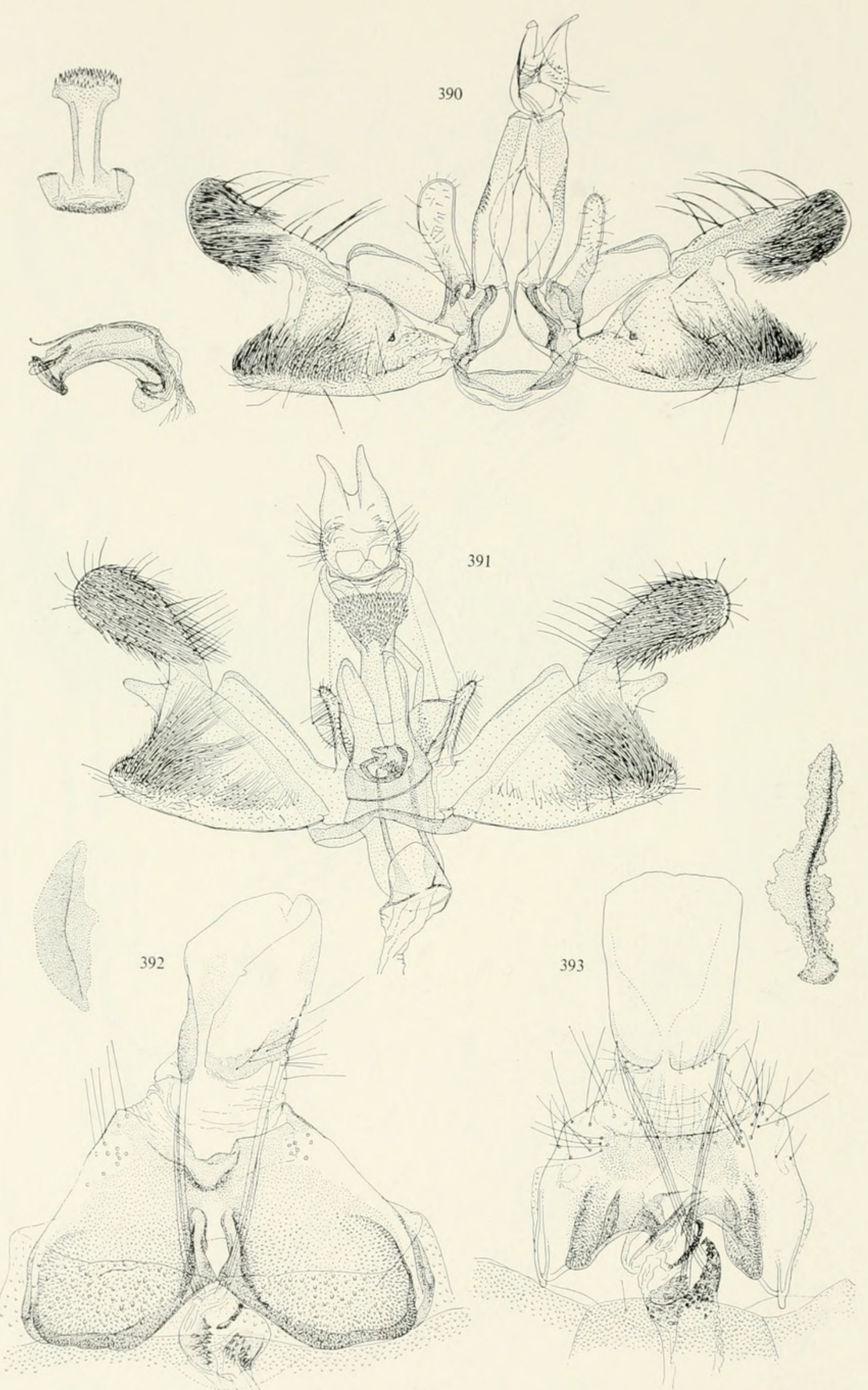

Figures 390-393.-Genitalia of Eihmia Hübner: 390, E. colonella Walsingham, ơ', slide no. "Sept. 17, 1930, A.B.," left, above, gnathos, below, aedeagus; 391, E. praeclara Meyrick, $\sigma^{7}$, slide no. 5552; 392, E. argopa Meyrick, + , paratype with signum; 393, E. praeclara Meyrick, + , slide no. 5545 , with signum. 


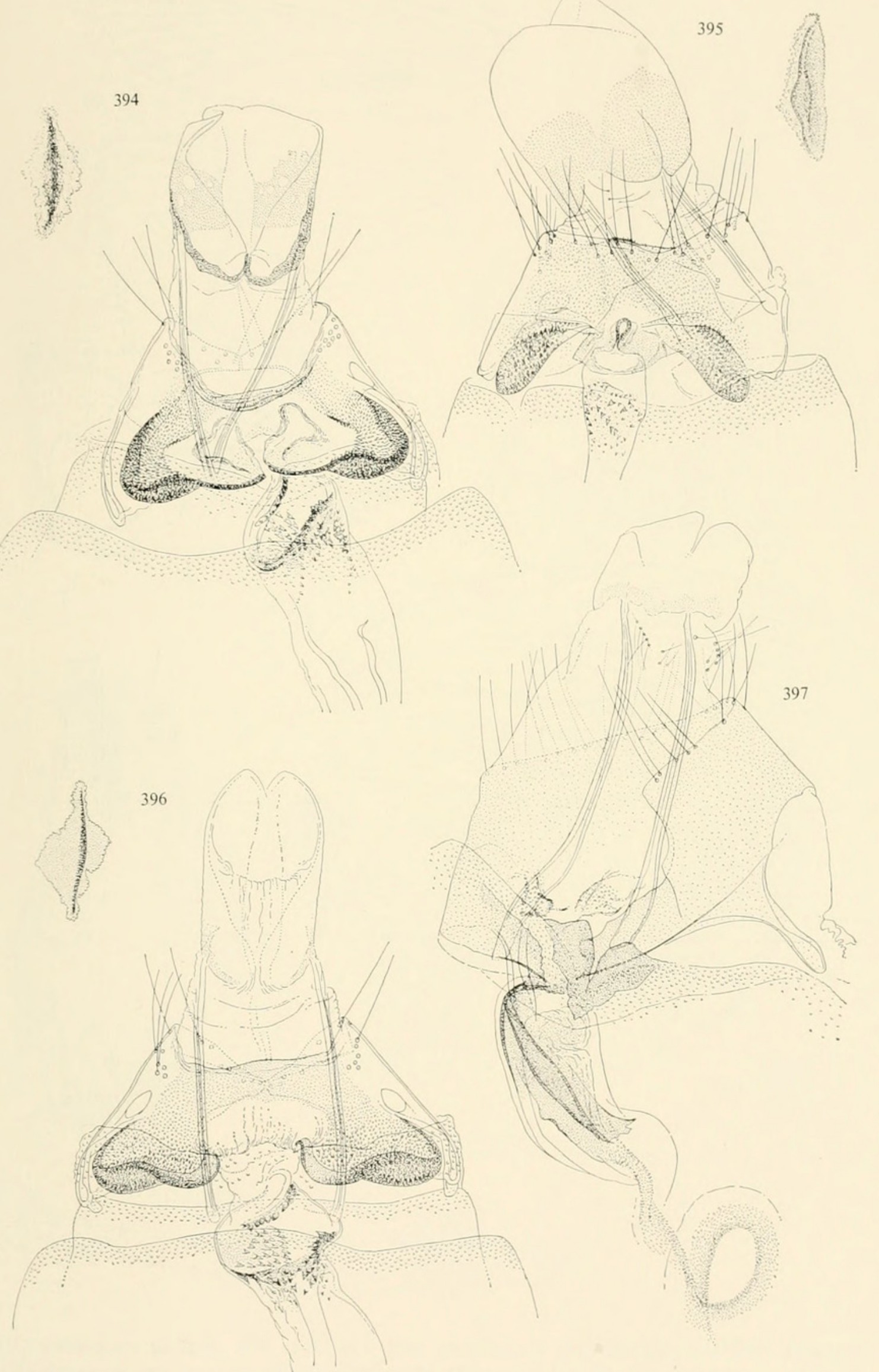

Figures 394-397.-Female genitalia of Ethmia Hübner: 394, E. pullata Meyrick, + , lectotype left, signum; 395, E. colonella Walsingham, \&, slide no. "Sept. 10, 1940," right, signum; 396, E. dentata, Diakonoff and Sattler, + , holotype, left, signum; 397, E. nobilis, new species, ㅇ holotype. 


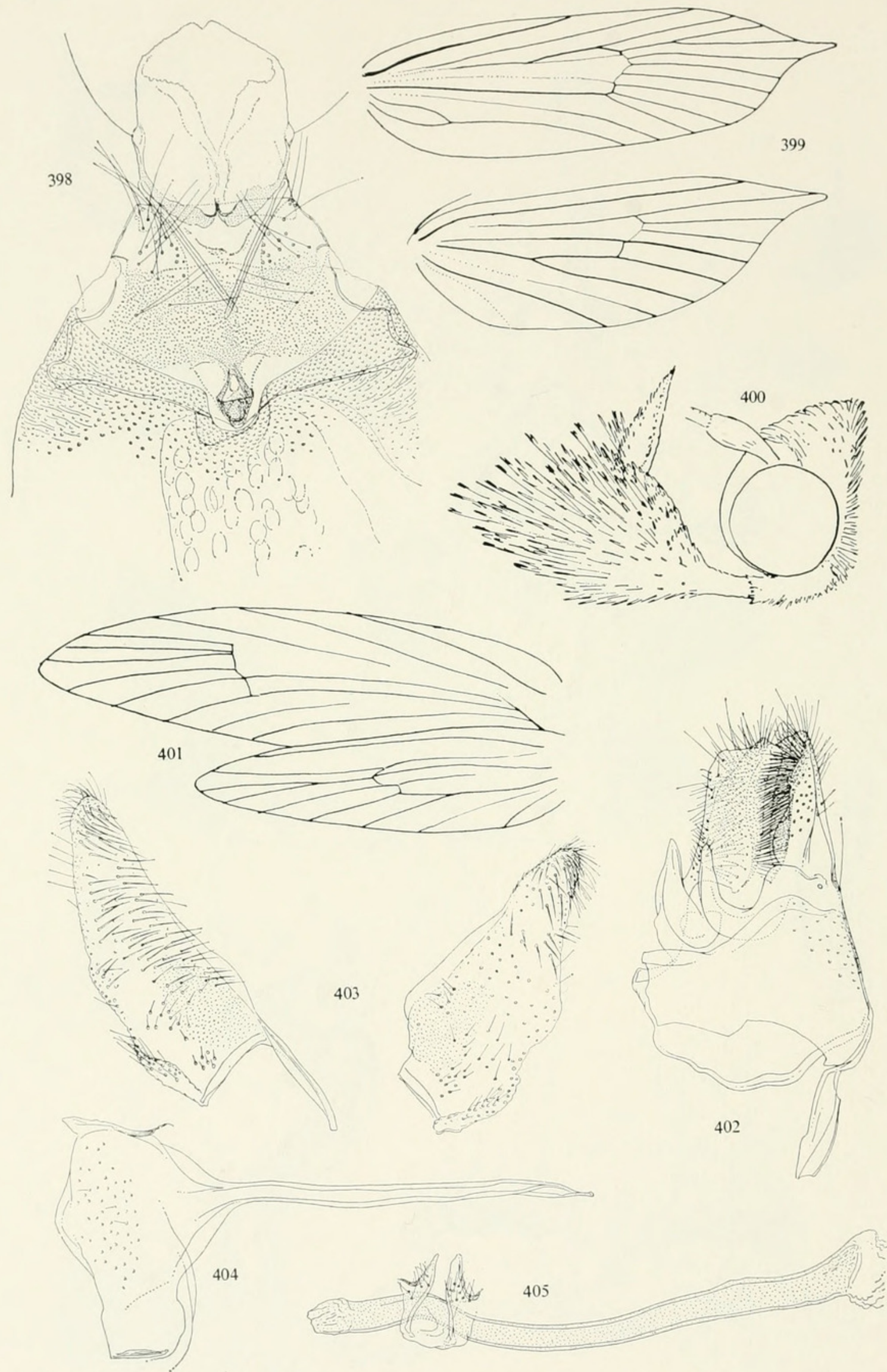

Figures 398-405.-Ethmiidae, Plutellidae, and Tineidae: 398, Ethmia crocosoma resignata, new subspecies, $\varsubsetneqq$, holotype; 399 , Harpeptila corethrodes, new genus, new species, neuration; 400, head; 401, Ischnuridia virginella Sauber, $q$, holotype, neuration (by Dr. H. Schröder); 402, Holacarta chalcatra, new species, $\sigma^{7}$, holotype, tegumen; 403, valvae; 404 , vinculum with saccus; 405 , aedeagus with anellus. 


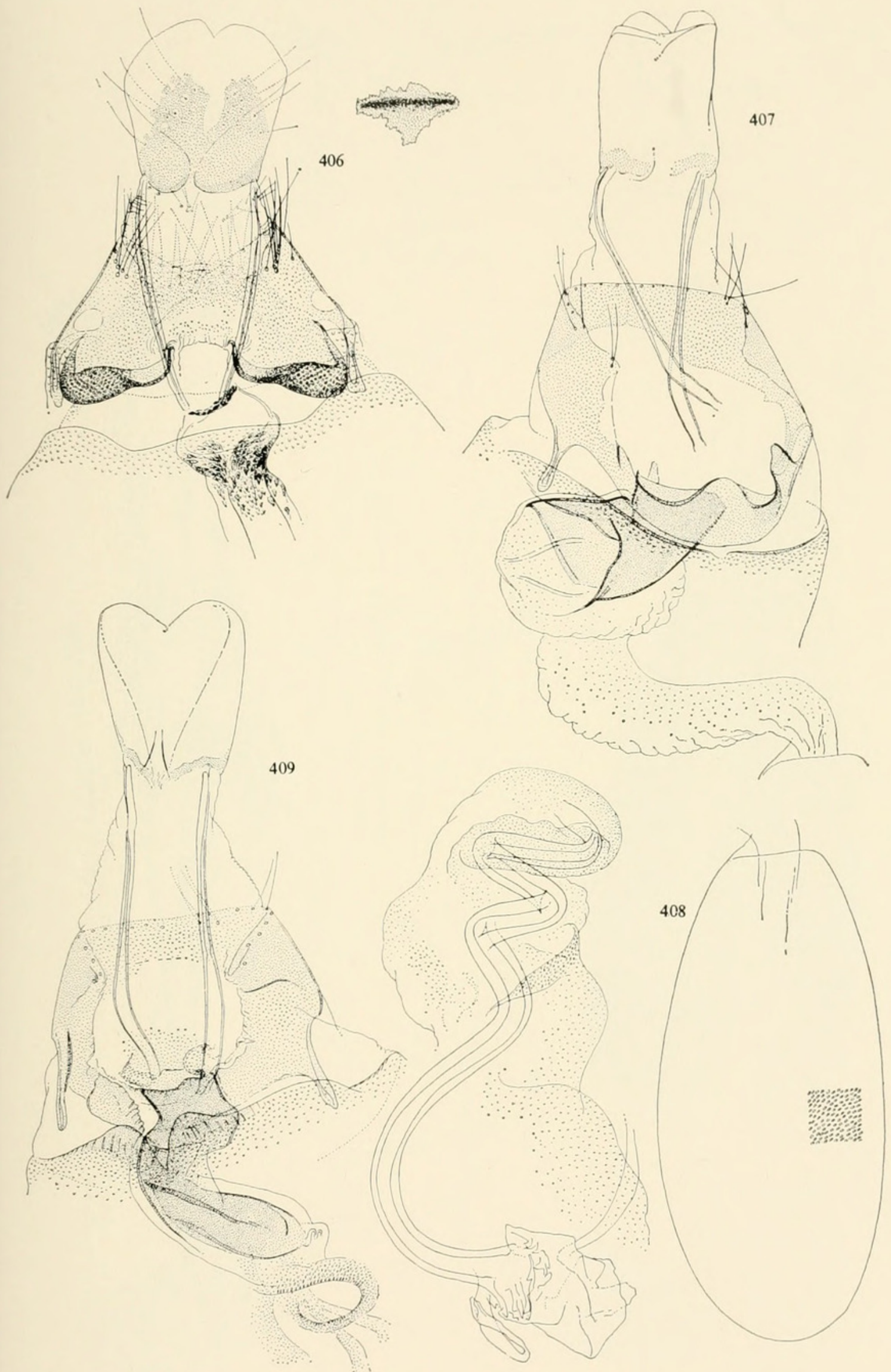

Figures 406-409.-Female genitalia of Ethmia Hübner: 406, E. dentata, Diakonoff and Sattler, $\$$, paratype, no. 5549 , with signum; 407 , E. reposita, new species, holotype; 408 , bursa copulatrix with structure of wall; $409, E$. nobilis, new species, holotype, right, corpus bursae. 


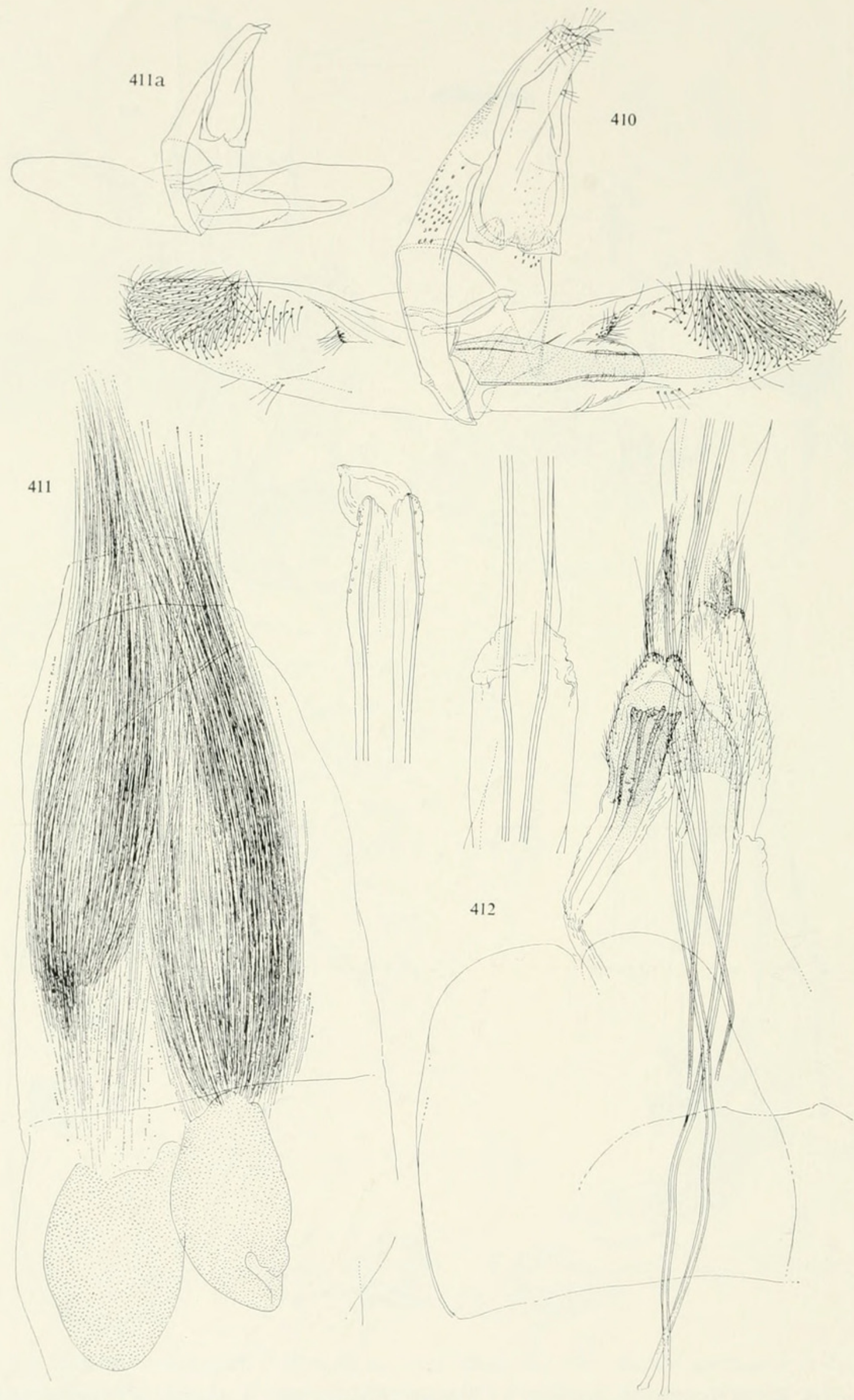

Figures 410-412.-Genitalia of Tineidae: 410, Hapsifera rugosella (Stainton), ơ, slide no. $5101 ; 411$, top of abdomen with coremata, less magnified; $411 \mathrm{a}$, male genitalia, for size; 412, Harmaclona cossidella Busck, $q$, slide no. 4944, ovipositor in three parts. 


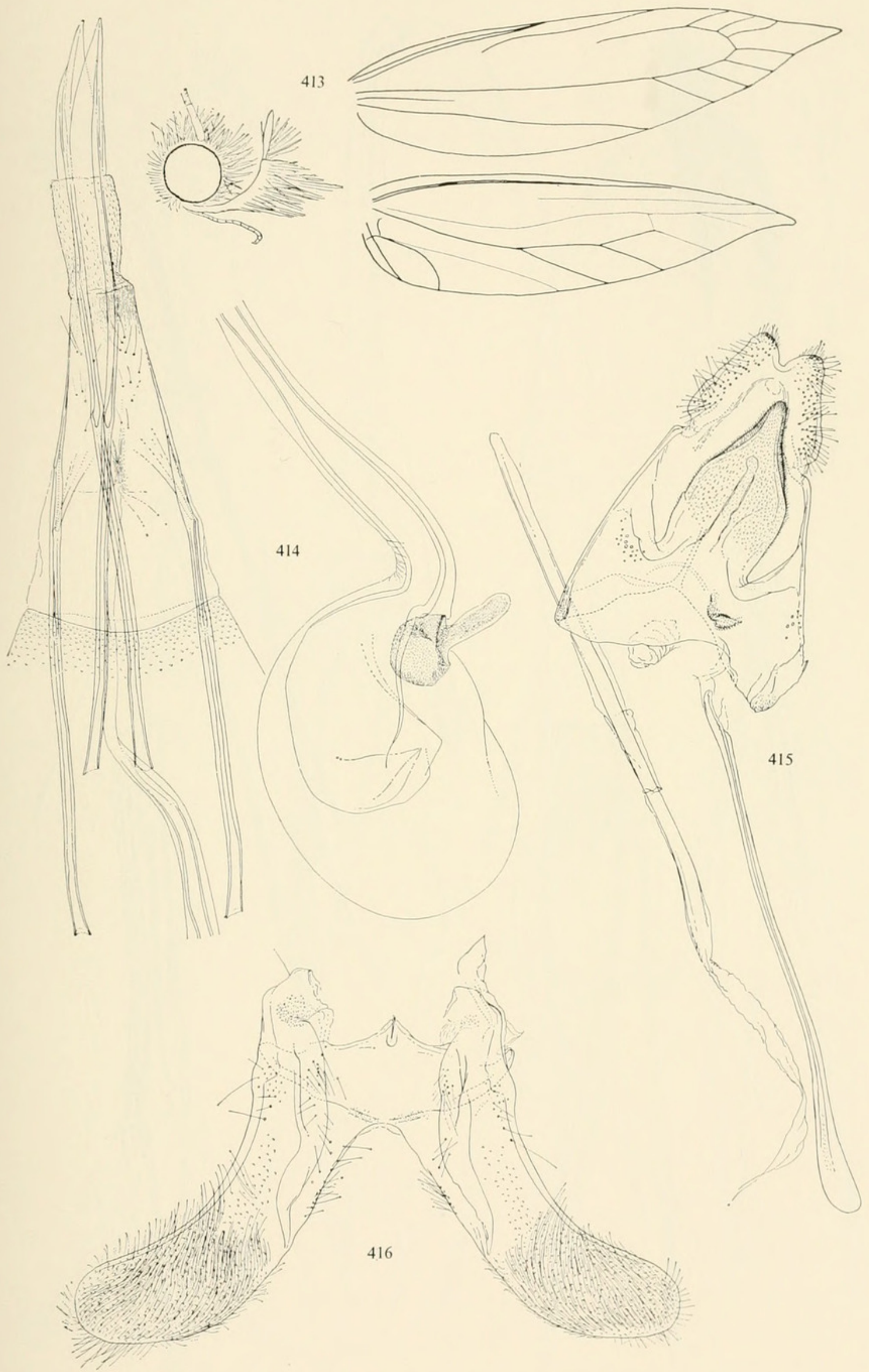

Figures 413-416.-Plutellidae and Tineidae: 413, Acrocenotes niphochrysa, new genus, new species, wing neuration and head; 414, genitalia, + , holotype; 415, Gerontha captiosella Walker, $\sigma^{7}$, slide no. 5270, tegumen portion, aedeagus and anellus tube; 416 , vinculum part with valvae. 

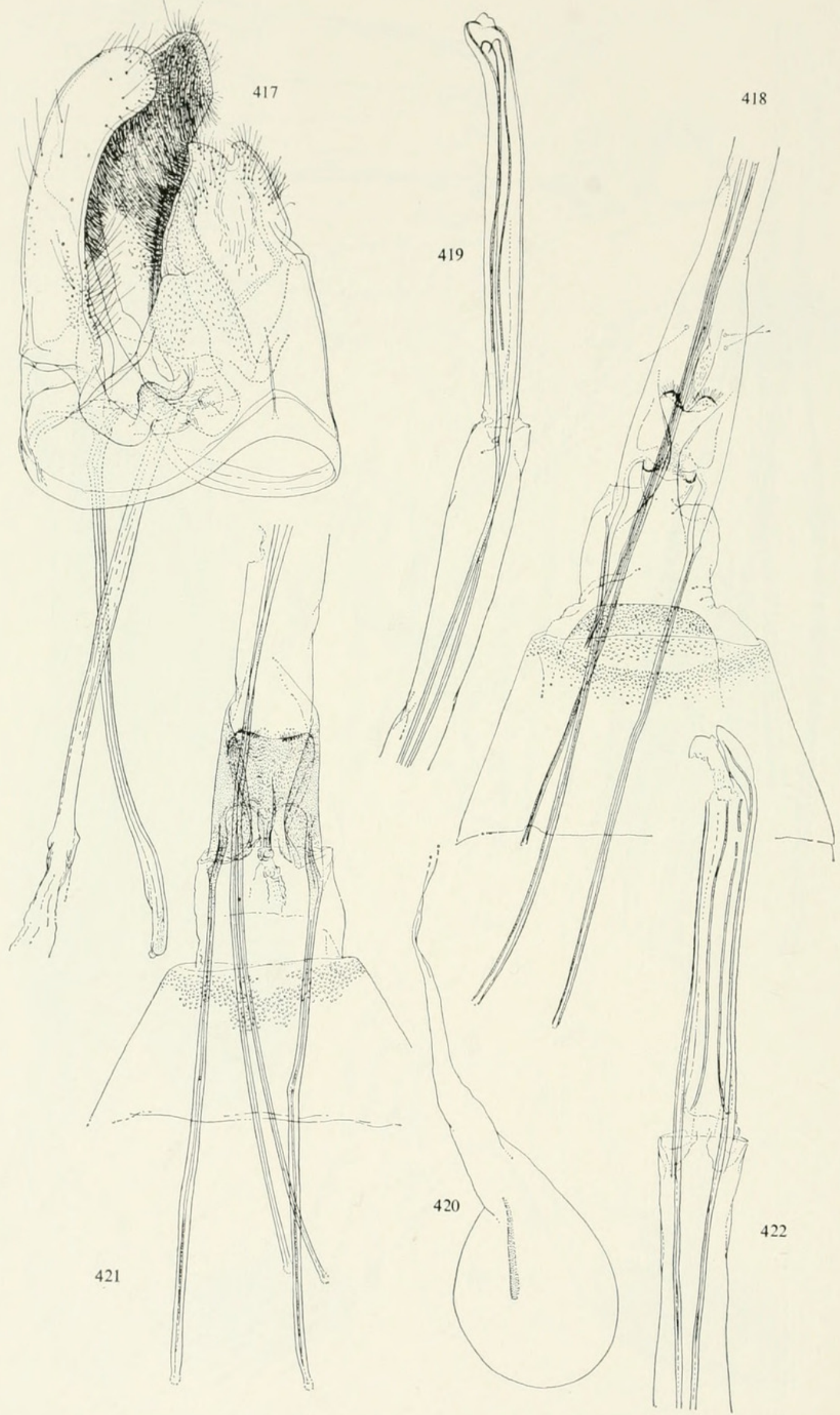

Figures 417-422.-Genitalia of Gerontha Walker: 417, G. captiosella Walker, $\sigma^{7}$, slide no. $5273 ; 418$, $₹$, slide no. 5269; 419, ovipositor; 420, bursa copulatrix; 421, G. diascopa. new species, $q$, holotype; 422 , ovipositor. 


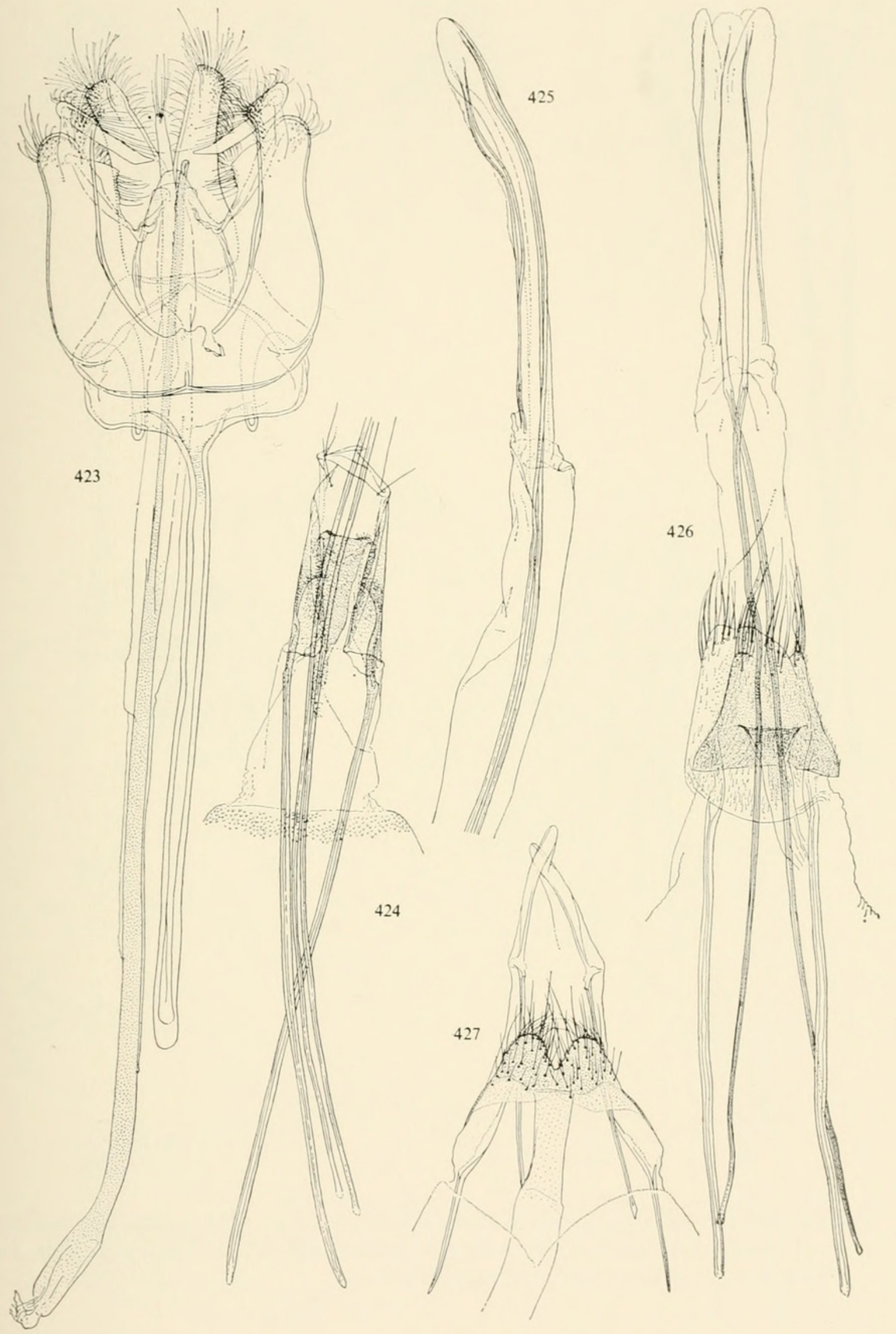

Figures 423-427.-Genitalia of Tineidae: 423, Tinissa baliomicta Meyrick, ơ , slide no. $5265 ; 424$, Gerontha nivicaput, new species, + , holotype; 425 , ovipositor; 426, Harmaclona tephrantha (Meyrick), $q$, slide no. $5272 ; 427$, Monopis avara Meyrick, $q$, holotype. 


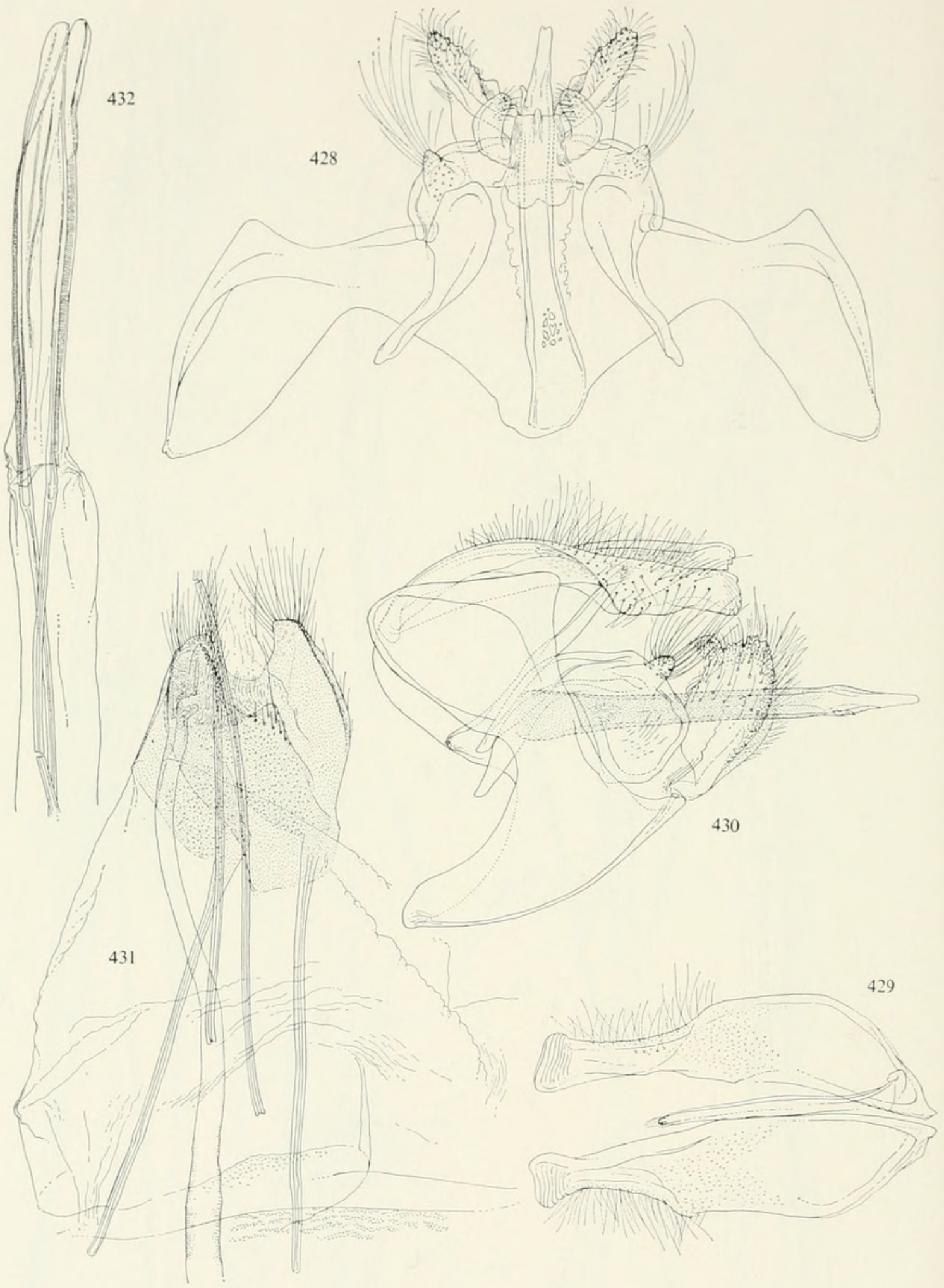

FiguREs 428-432.-Tinissa torvella Walker: 428, $\sigma^{\top}$, slide no. 5264 (saccus cut medially and pressed open, gnathos removed); 429 , gnathos; 430 , $\sigma^{7}$, lateral aspect, slide no. $5274 ; 431$, , slide no. $5263 ; 432$, ovipositor. 


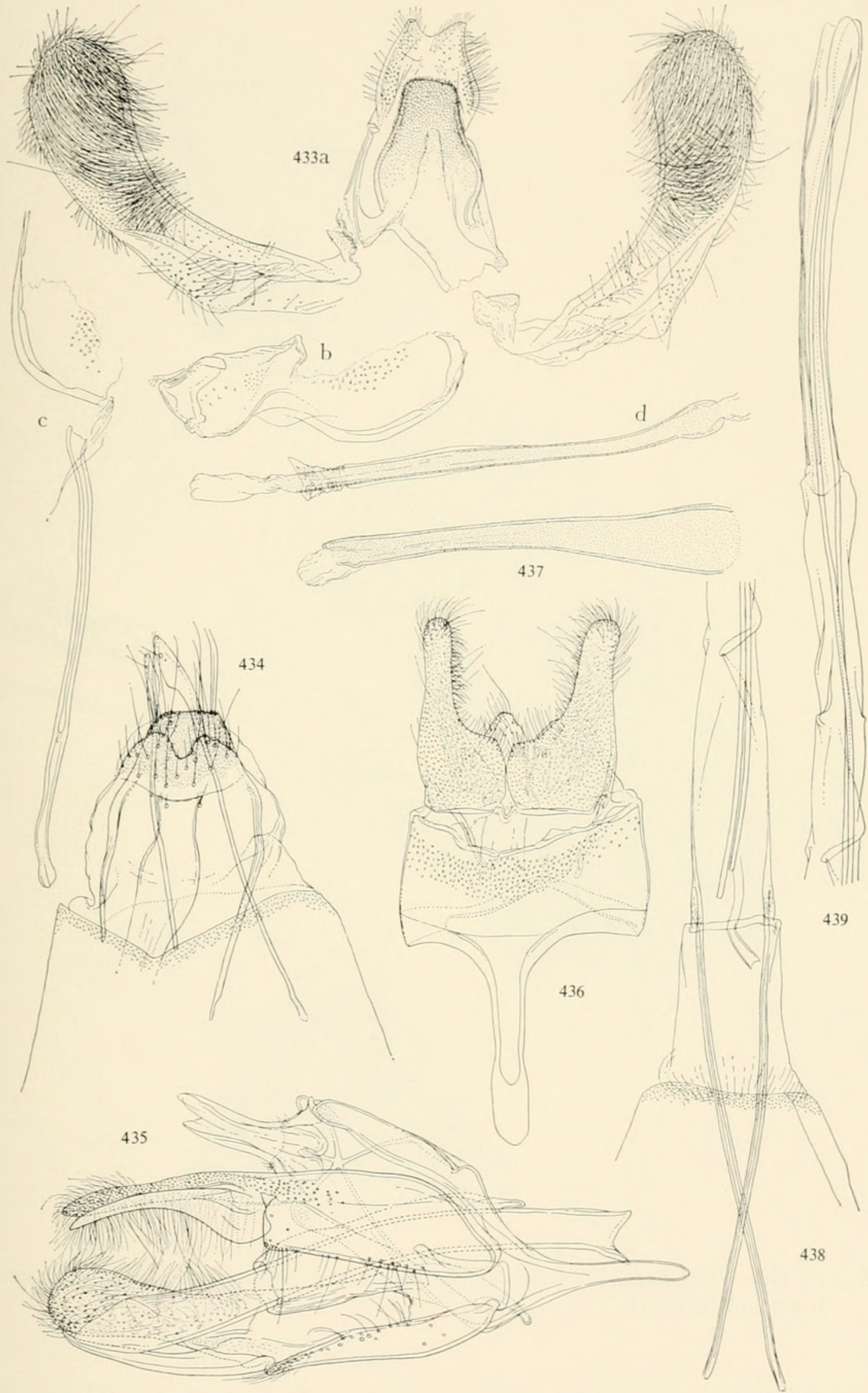

Figures 433-439.-Genitalia of Tineidae: 433, Gerontha monostigma, new species, a, $\sigma^{7}$, holotype; b, gnathos, right half; c, saccus; d, aedeagus; 434, Monopis avara Meyrick, ㅇ, slide no. 5282; 435, Hapsifera albescens, new species, $\sigma^{7}$, holotype; 436, Oxytinea galactodelta, new genus, new species, $\sigma^{7}$, holotype; 437 , aedeagus; 438 , Exaxa rectilinea, new genus, new species, $\uparrow$, holotype; 439 , ovipositor. 


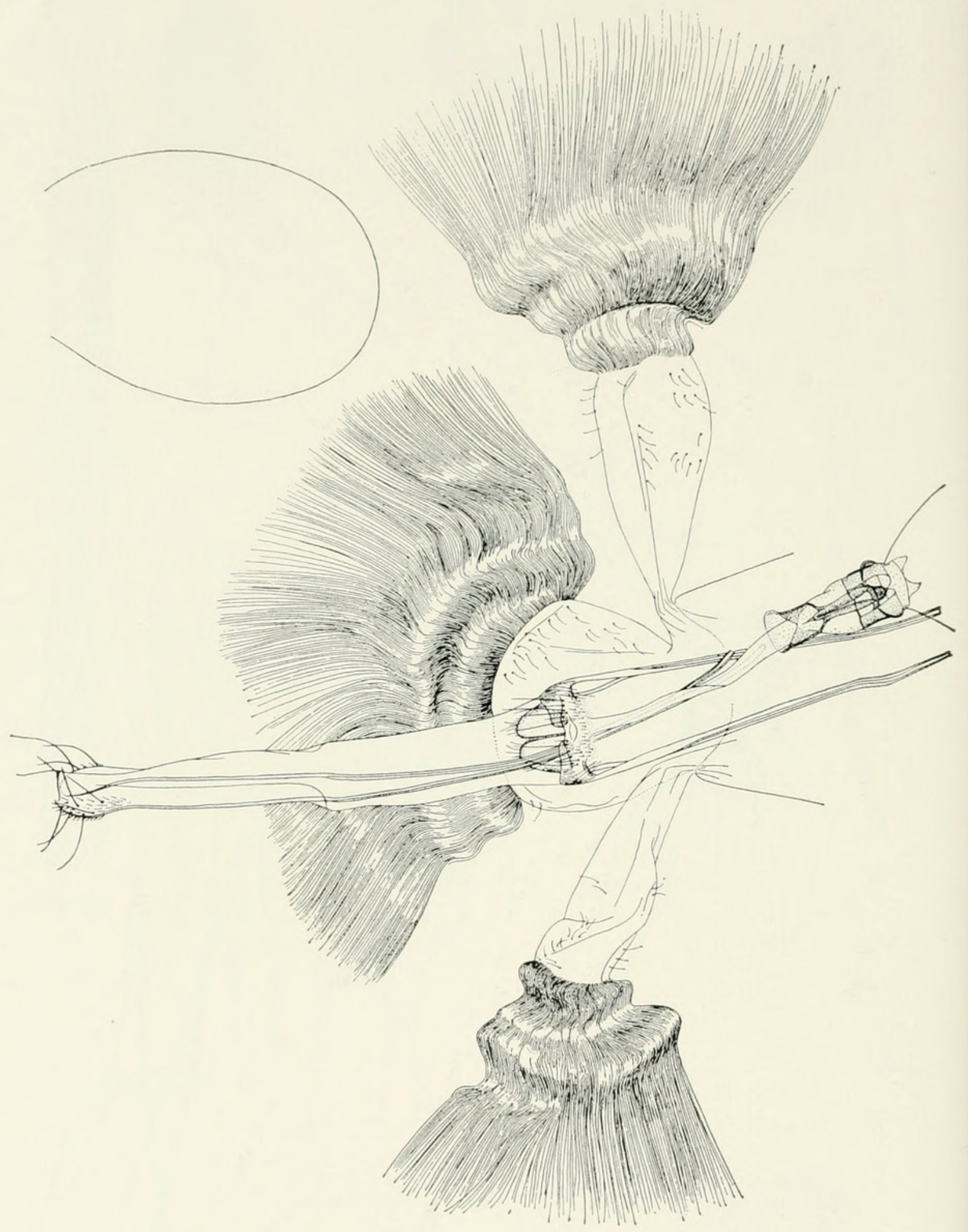

FIGURE 440.-Haplotinea subochraceella (Walsingham), $\uparrow$, slide no. 4673, abdominal pencils intact and expanded. 

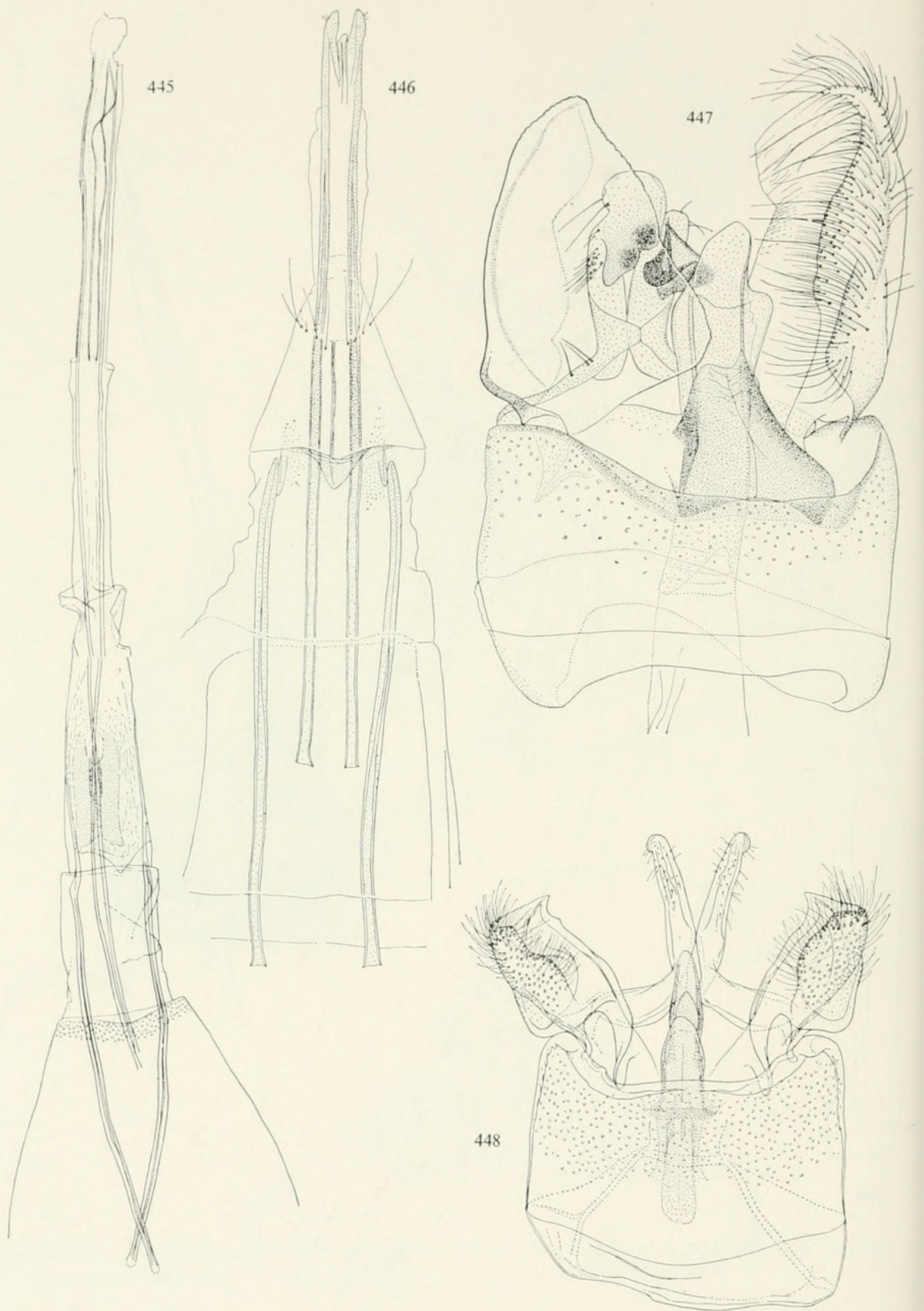

Figures 445-448.-Genitalia of Tineidae: 445, Oxytinea galactodelta, new genus, new species, \&, allotype; 446, Trachycentra cicatricosa Meyrick, $\uparrow$, holotype; 447, Haplotinea platyntis (Meyrick), $\sigma^{\top}$, lectotype; $448, H$. eurycera, new species, $\sigma^{\top}$, holotype. 


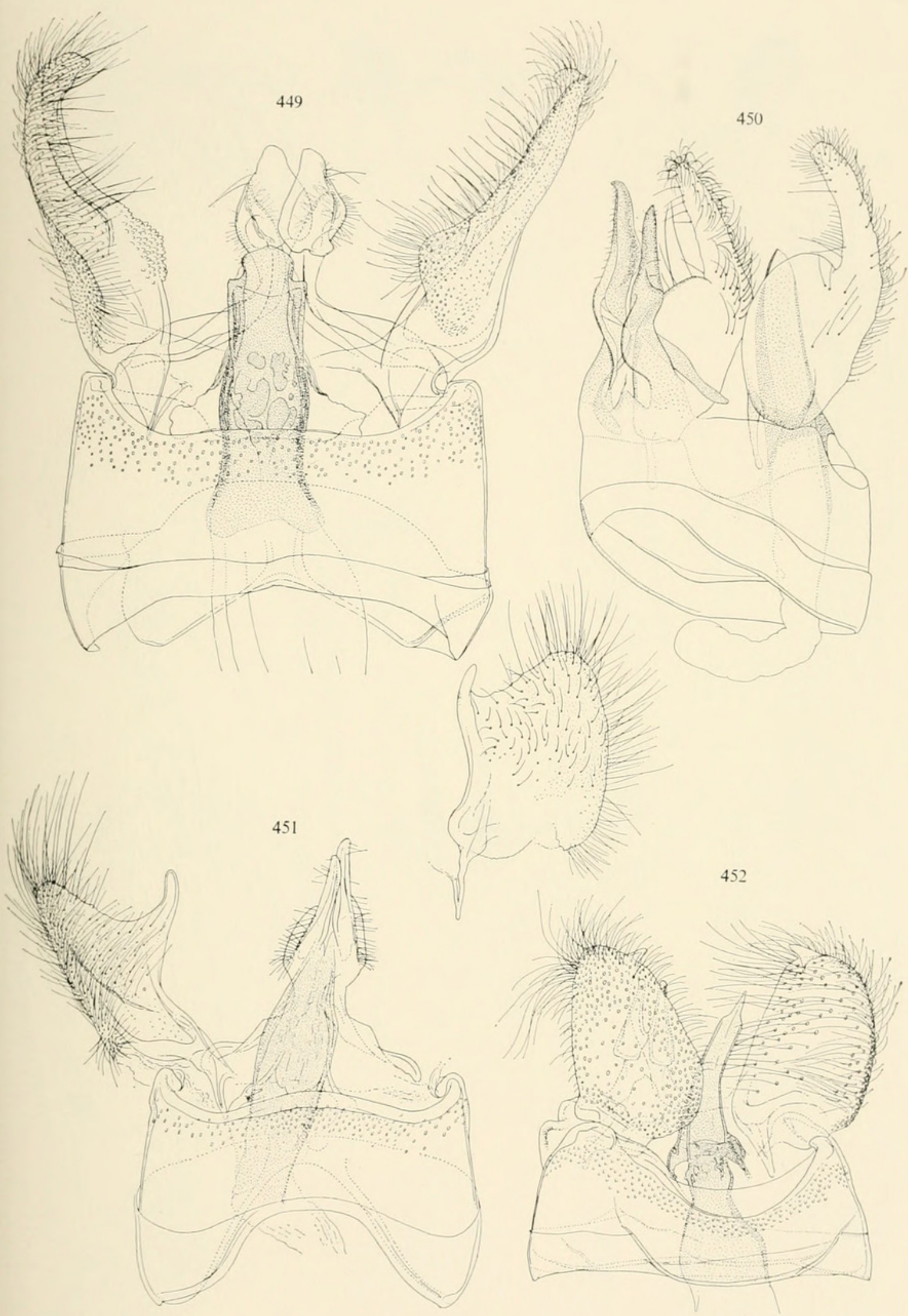

Figures 449-452.-Male genitalia of Haplotinea Diakonoff and Hinton: 449, H. subochraceella (Walsingham), slide no. 5294; 450, H. nestoria (Meyrick), slide no. 4672; $451, H$. hemilampra, new species, holotype with, above, right valva; $452, H$. cymopelta (Meyrick), slide no. 5276. 


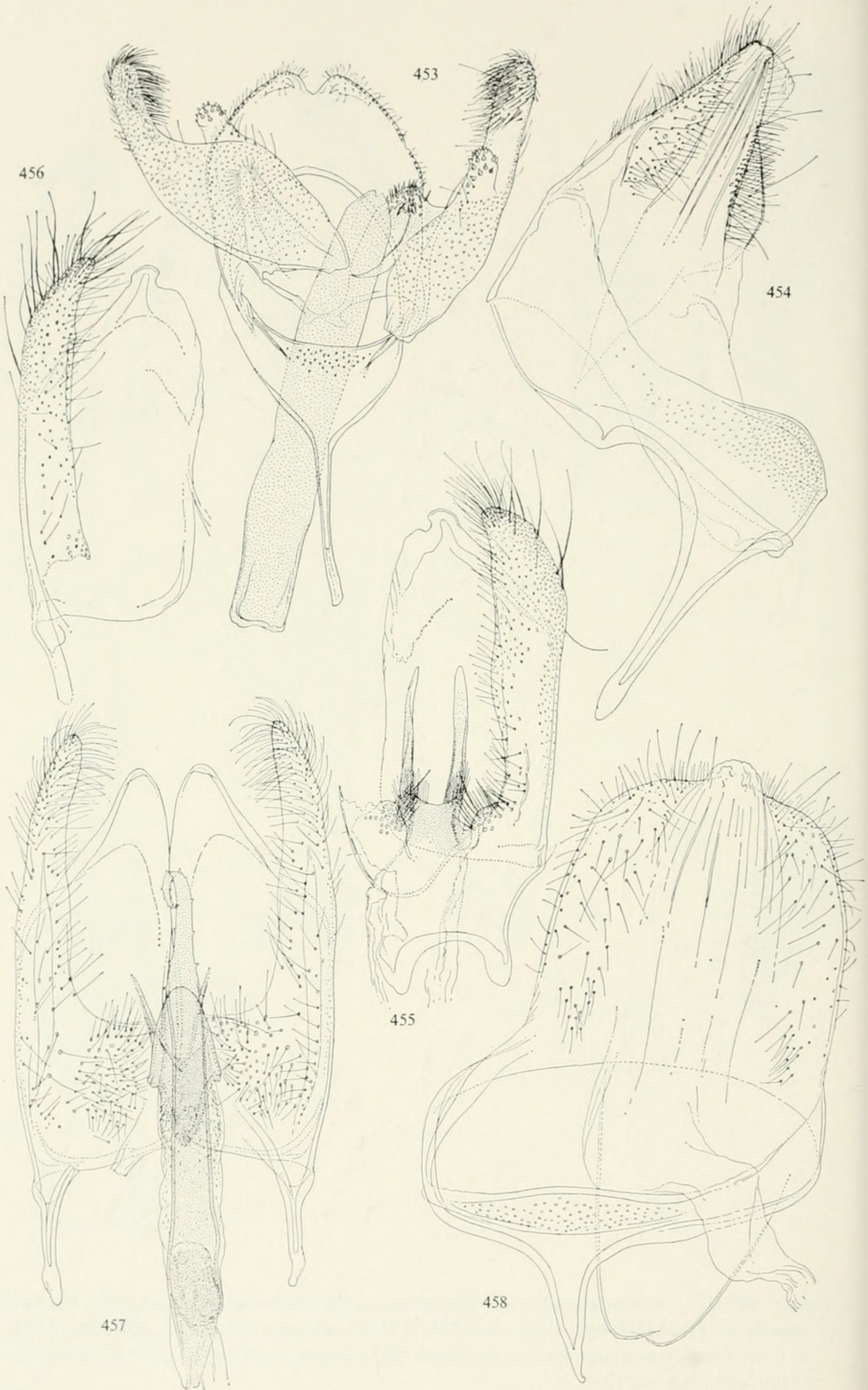

Figures 453-458.-Male genitalia of Tineidae: 453, Melasina anarmosta, new species, holotype; 454, Harmaclona cossidella Busck, slide no. 4945, IXth segment; 455, left valva, anellus; 456, right valva; 457, $H$. tephrantha (Meyrick), slide no. 5285; 458, IX segment. 


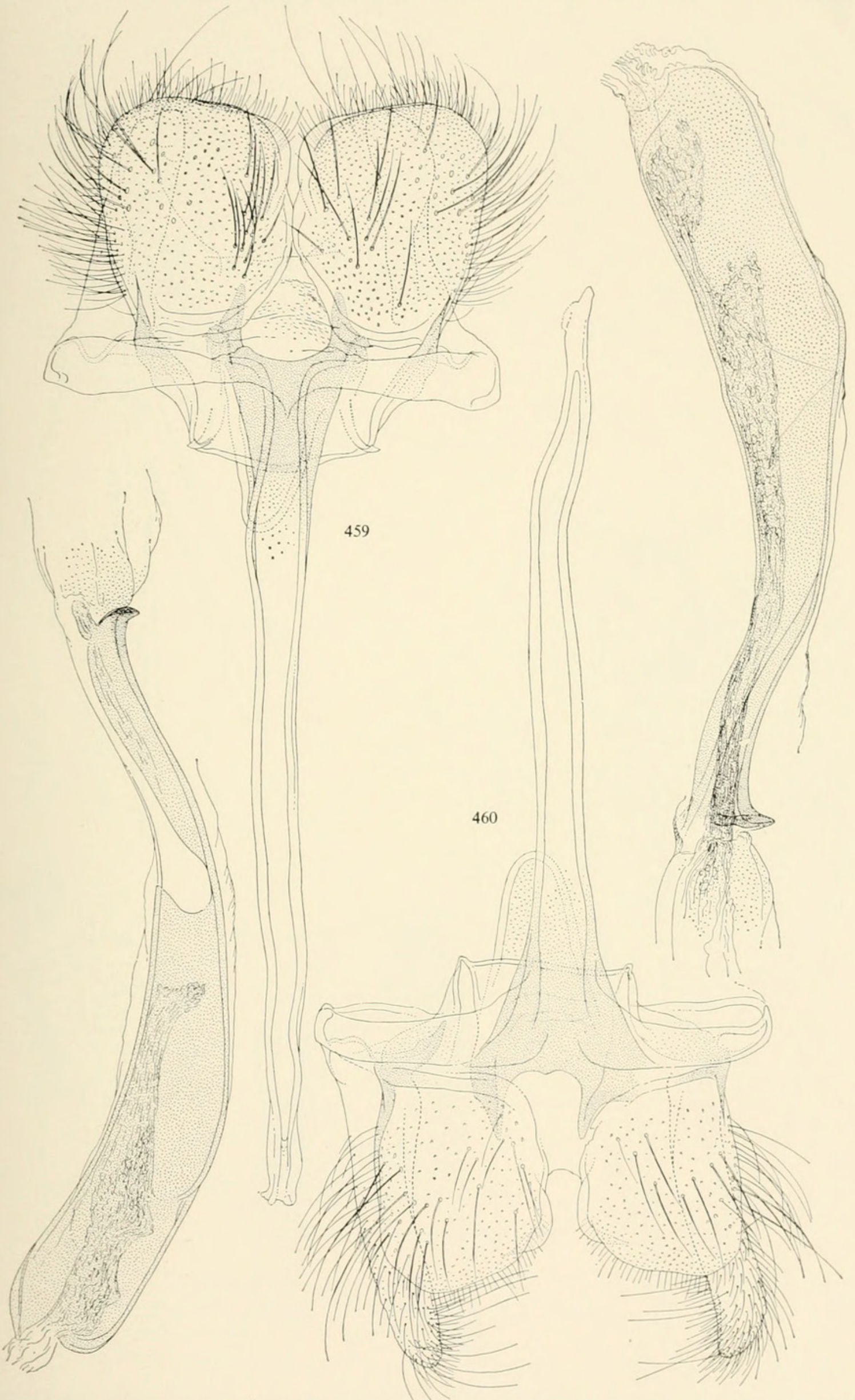

Figures 459-460.-Male genitalia of Coryptilum Zeller; 459, C. klugii Zeller, slide no. 5724 (Java), with aedeagus; $460, C$. luteum, new species, holotype, with aedeagus. 


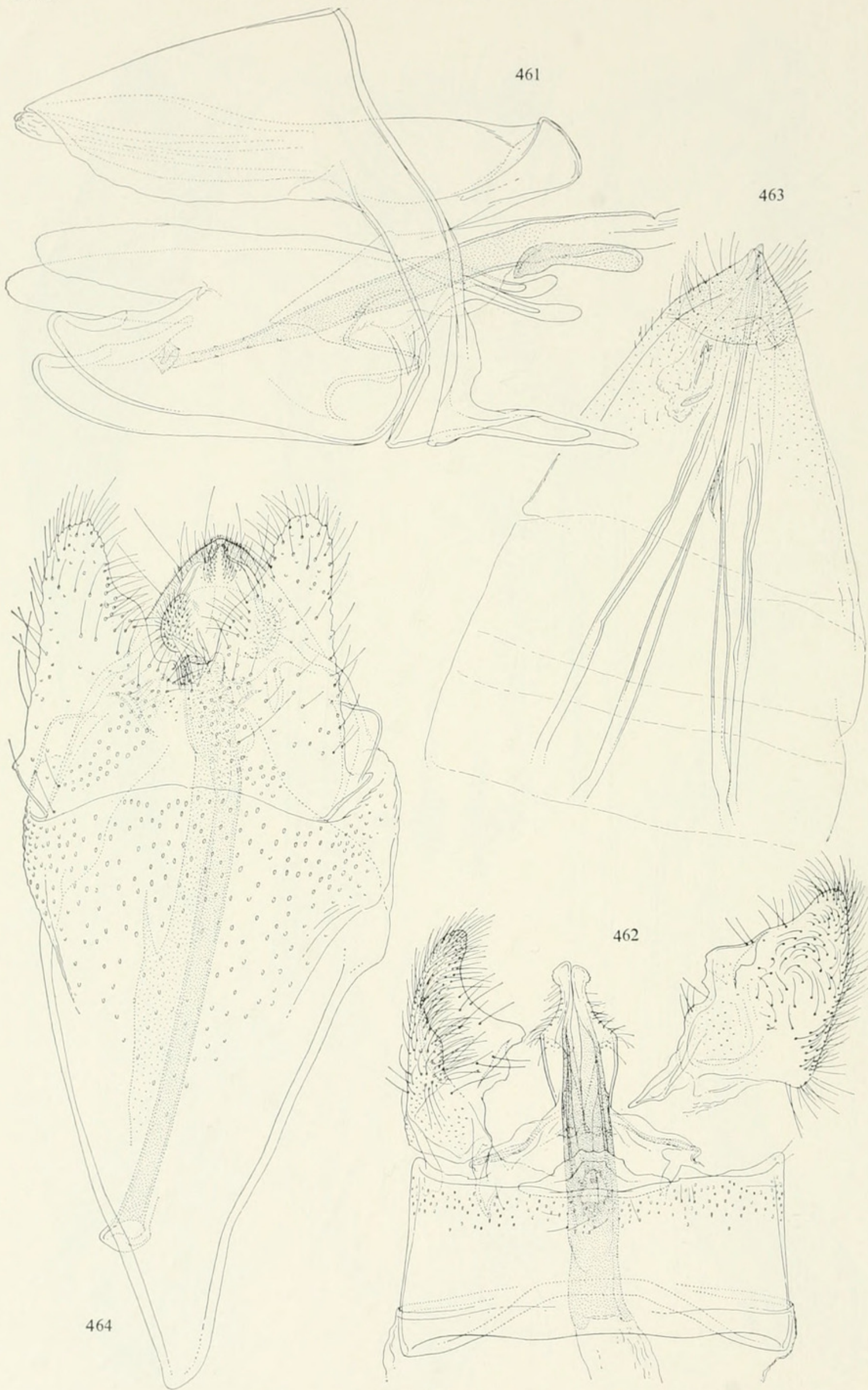

Figures 461-464.-Genitalia of Tineidae and Adelidae: 461, Harmaclona tephrantha (Meyrick), slide no. 5521; 462, Haplotinea purpurascens, new species, $\sigma^{7}$, holotype; 463 , Nemophora chalcotechna (Meyrick), o , holotype; 464, ơ, slide no. 5283. 


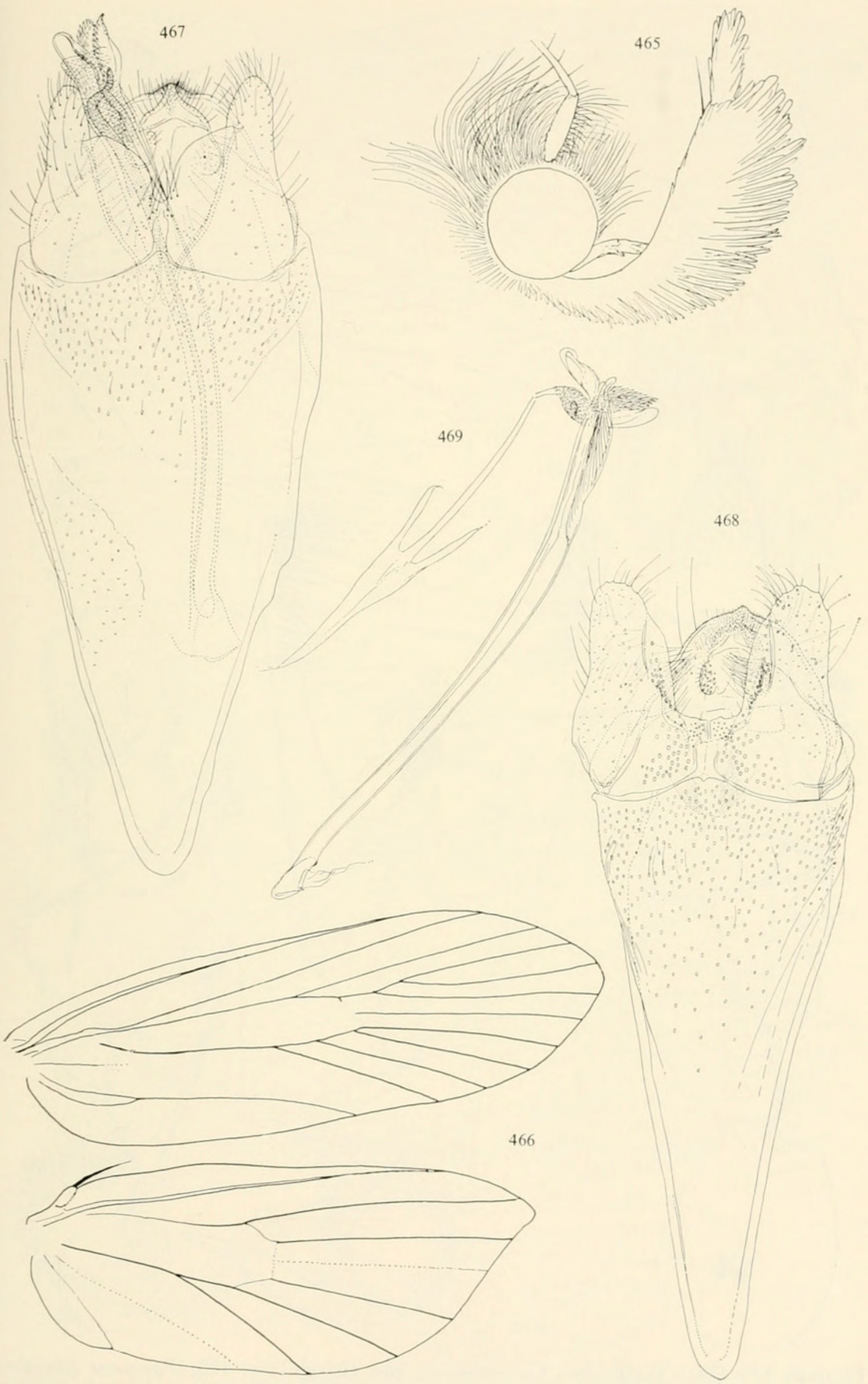

Figures 465-469.- Tineidae and Adelidae: 465, Exaxa rectilinea, new genus, new species, $\sigma^{7}$, head; 466, wing neuration; 467, Nemophora eurycitra (Meyrick), $\sigma^{7} ; 468$, N. heliochalca (Meyrick), $\sigma^{7} ; 469$, aedeagus. 


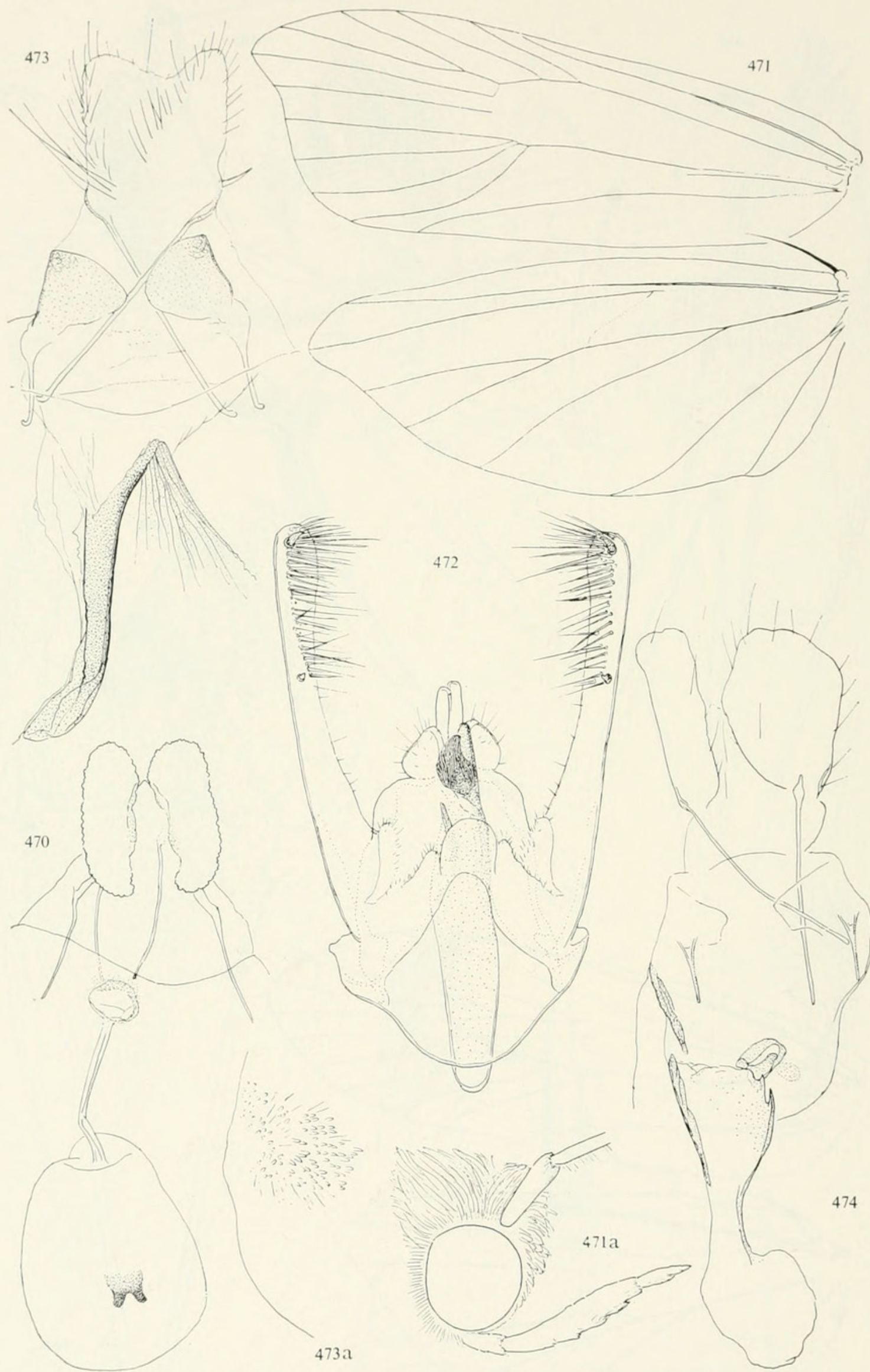

Figures 470-474.- Tortricidae, Carposinidae, and Gelechiidae: 470, Pammene leucodora Meyrick, + , slide no. 5775; 471, Campylarchis acuta, new genus, new species, $\sigma^{7}$, wing neuration; 471a, head; 472, Stegasta variana Meyrick, $\sigma^{7}$, slide no. 5776; 473, Atasthalistis ochreoviridella (Pagenstecher), + , slide no. 5787; 473a, signum; 474, Acribologa malacodes (Meyrick), $q$, slide no. 5774. 

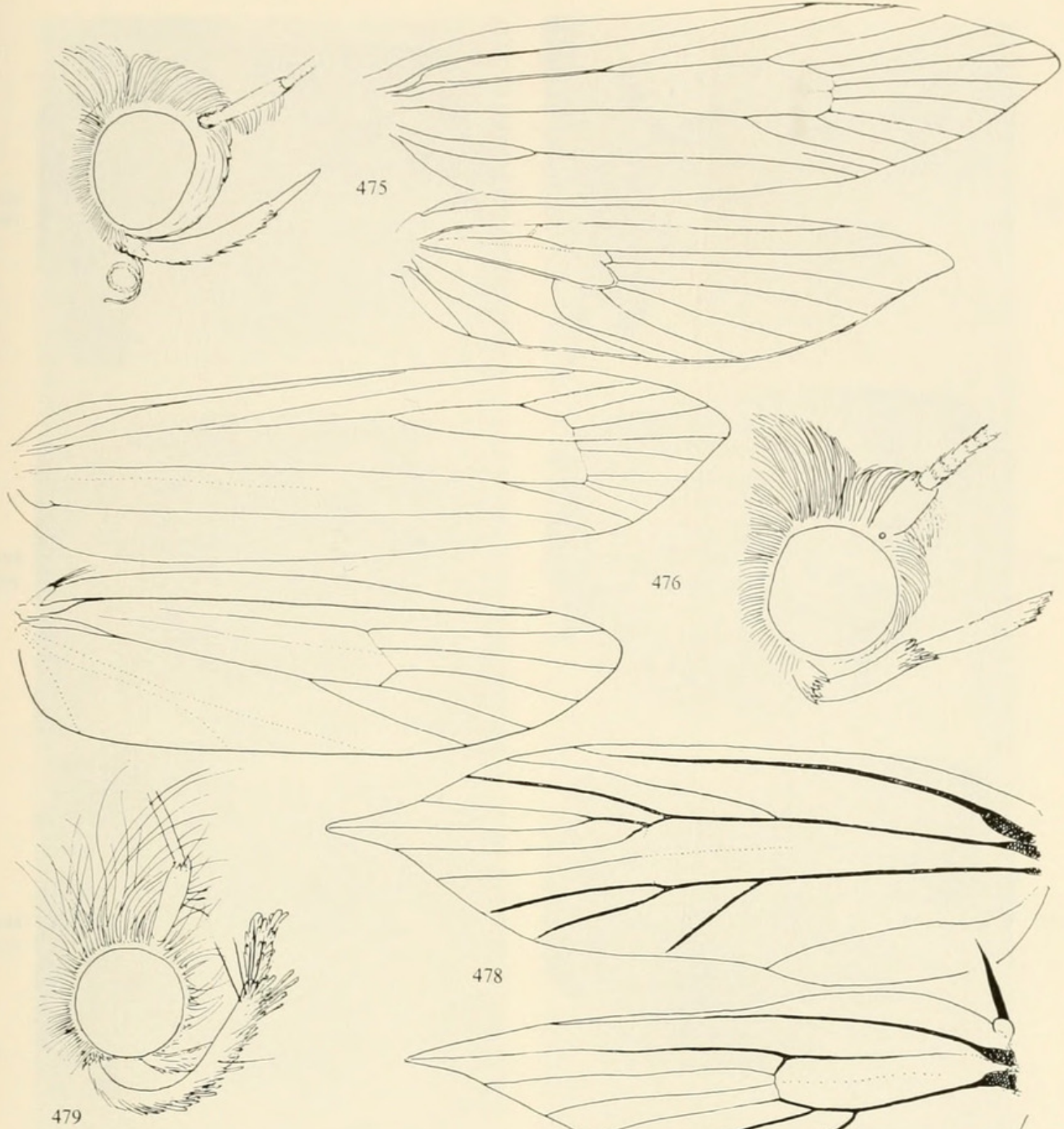

476
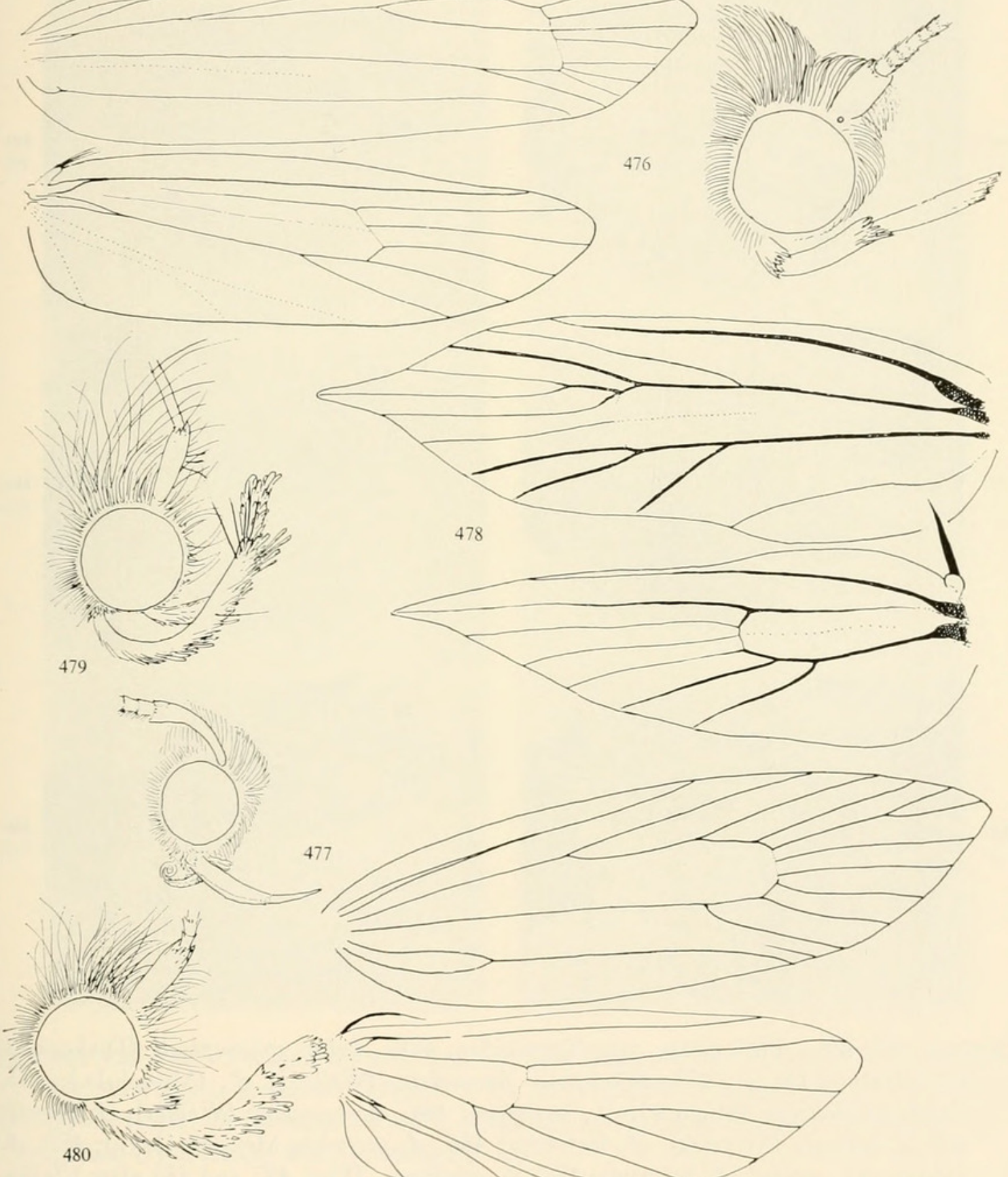

477

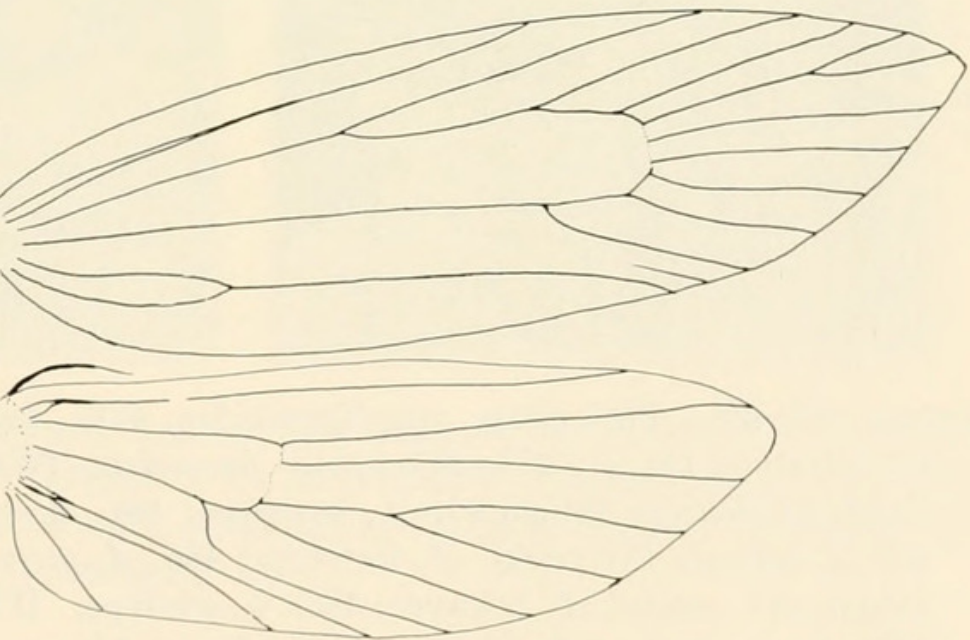

Figures 475-480.-Wing neuration and heads of Tineidae, Cosmopterygidae, and Yponomeutidae: 475, Prothorhiza cyanosticta, new genus, new species; 476, Yponomeuta interruptella (Sauber); 477, Scaeothyris pseusta, new genus, new species; 478, Oxytinea galactodelta, new genus, new species, $\sigma^{\top} ; 479$, o ; 480, $\sigma^{\top}$. 
481

483

485

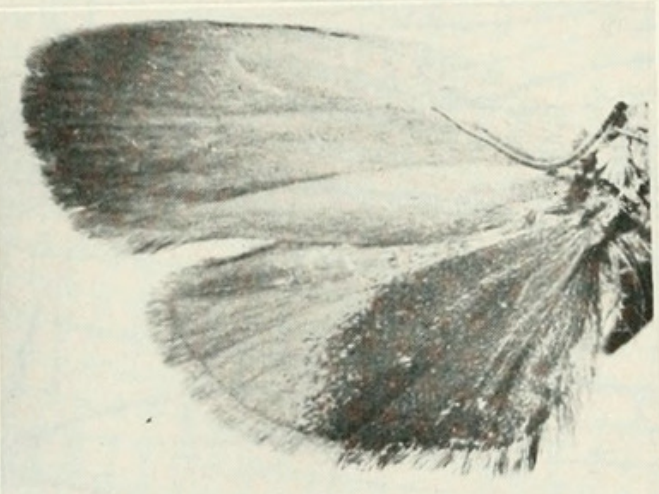

487

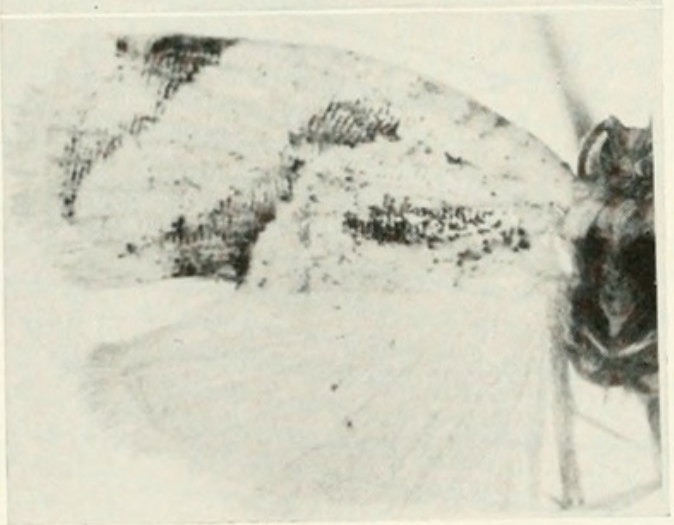

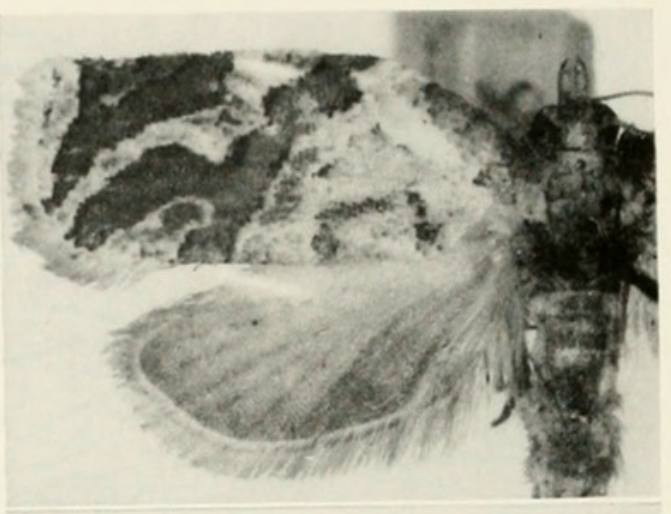

482
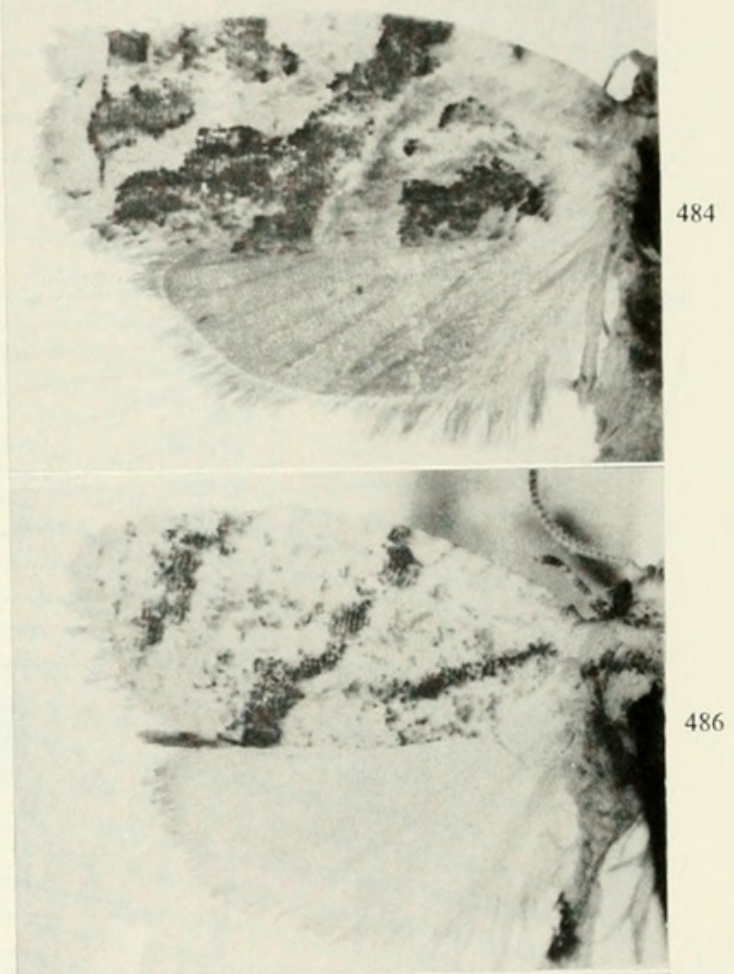

486

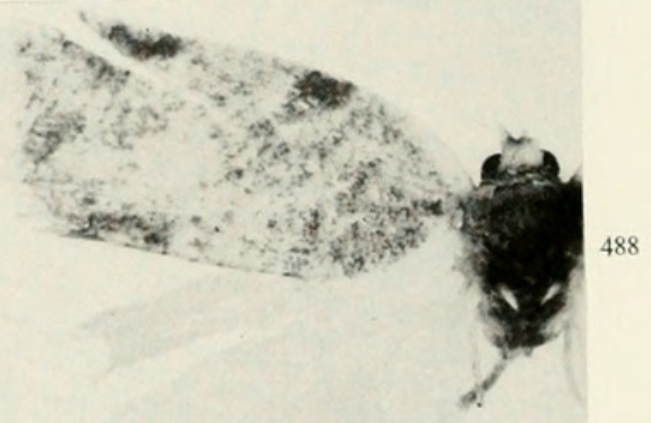

Figures 481-488.-Phaloniidae and Tortricidae: 481, Aethes sphenophora (Diakonoff), $\sigma^{7}$, paratype (Java); 482, Adoxophyes fasciculana (Walker), $\sigma^{7}$, (Misool Is.), 483, Zacorisca electrina (Meyrick), ๆ, lectotype; 484, A. privatana (Walker), જ (Java); 485 , Z. heliaula (Meyrick), $\sigma^{7}$, lectotype; 486, $A$. perstricta Meyrick (Java); 487, $A$. aurata, new species, $\sigma^{\top}$, holotype; 488, $\%$, allotype. [Figs. 483 and 485 after Clarke, 1958, by courtesy of the Trustees of the British Museum, Natural History.] 
489

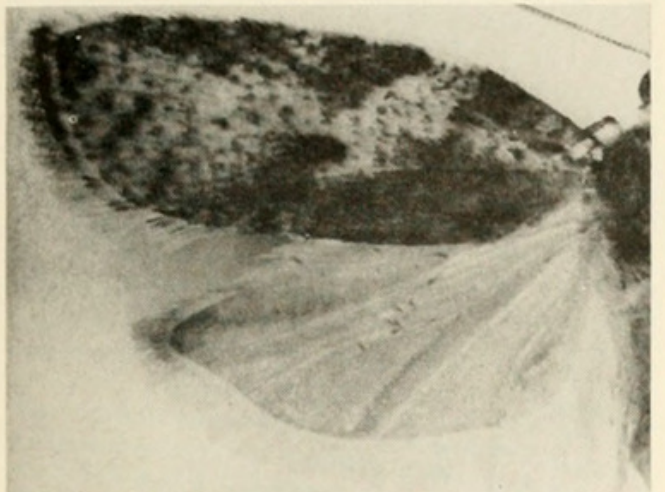

491

493

495
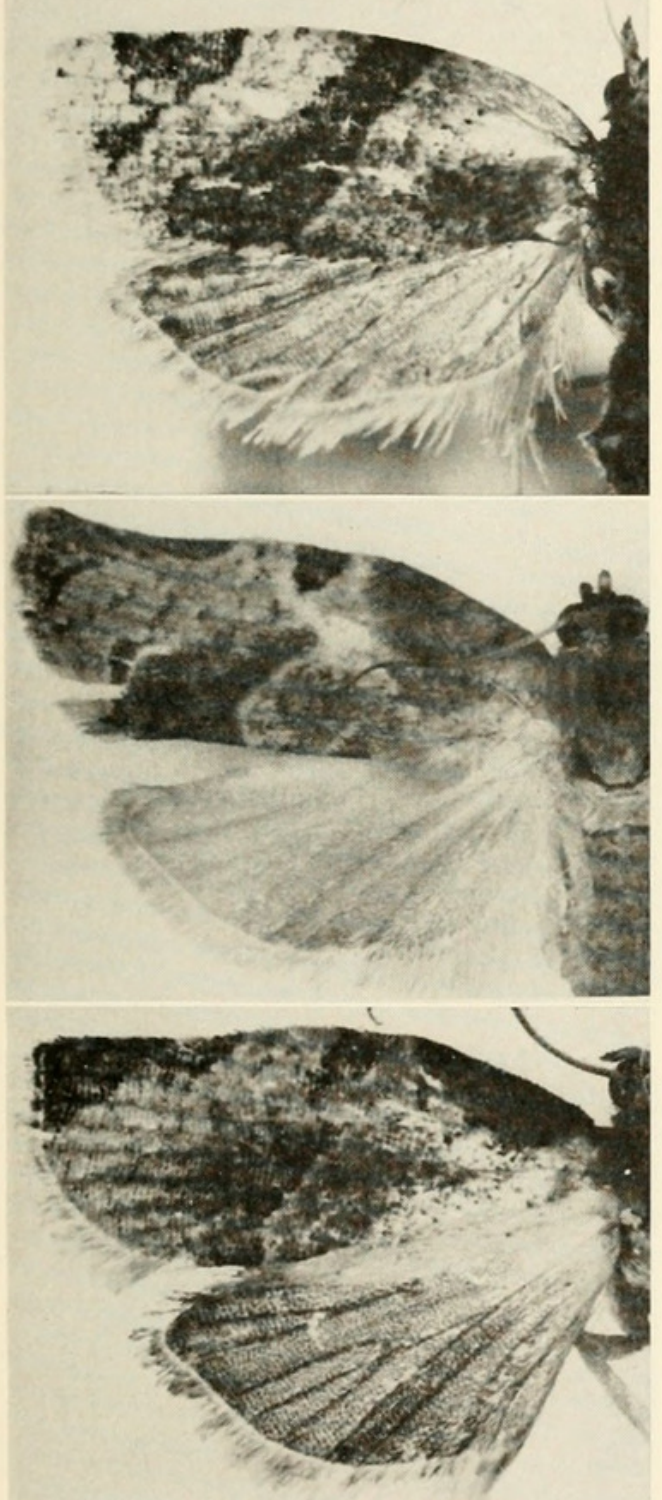

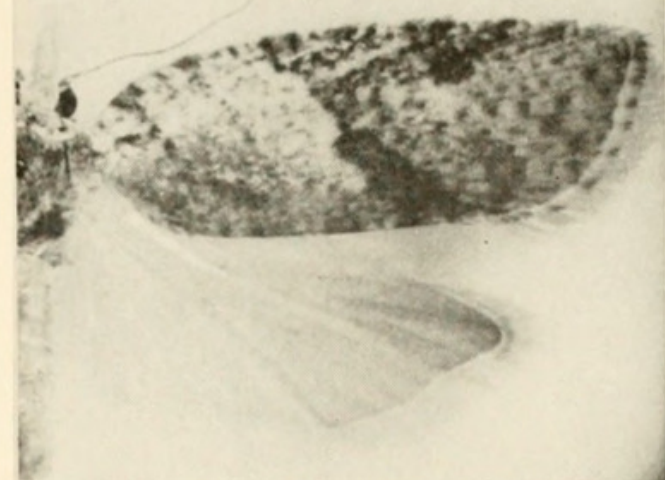

490

492

494
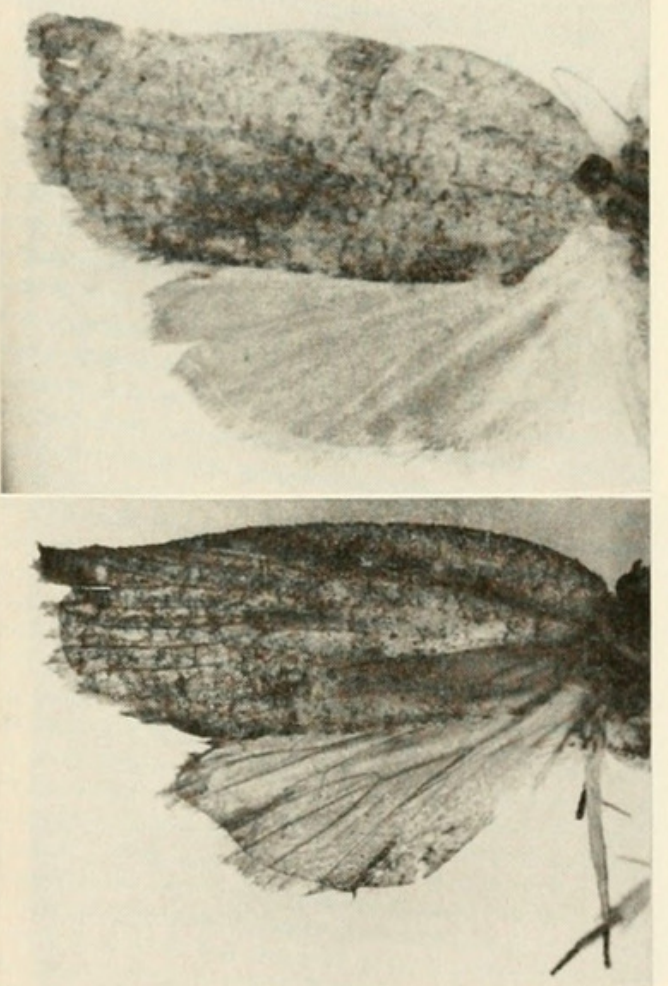

Figures 489-496.-Tortricidae: 489, Isotenes inae Diakonoff, ơ (Java); 490, ㅇ, (Java); 491, Neocalyptis nematodes (Meyrick), శా ; 492, Homona aestivana (Walker), o7 (New Guinea); 493, H. phanaea Meyrick, ơ (Solomon Is.); 494, † ; 495, H. bicornis, new species, $\sigma^{7}$, holotype; 496, $q$, allotype. 

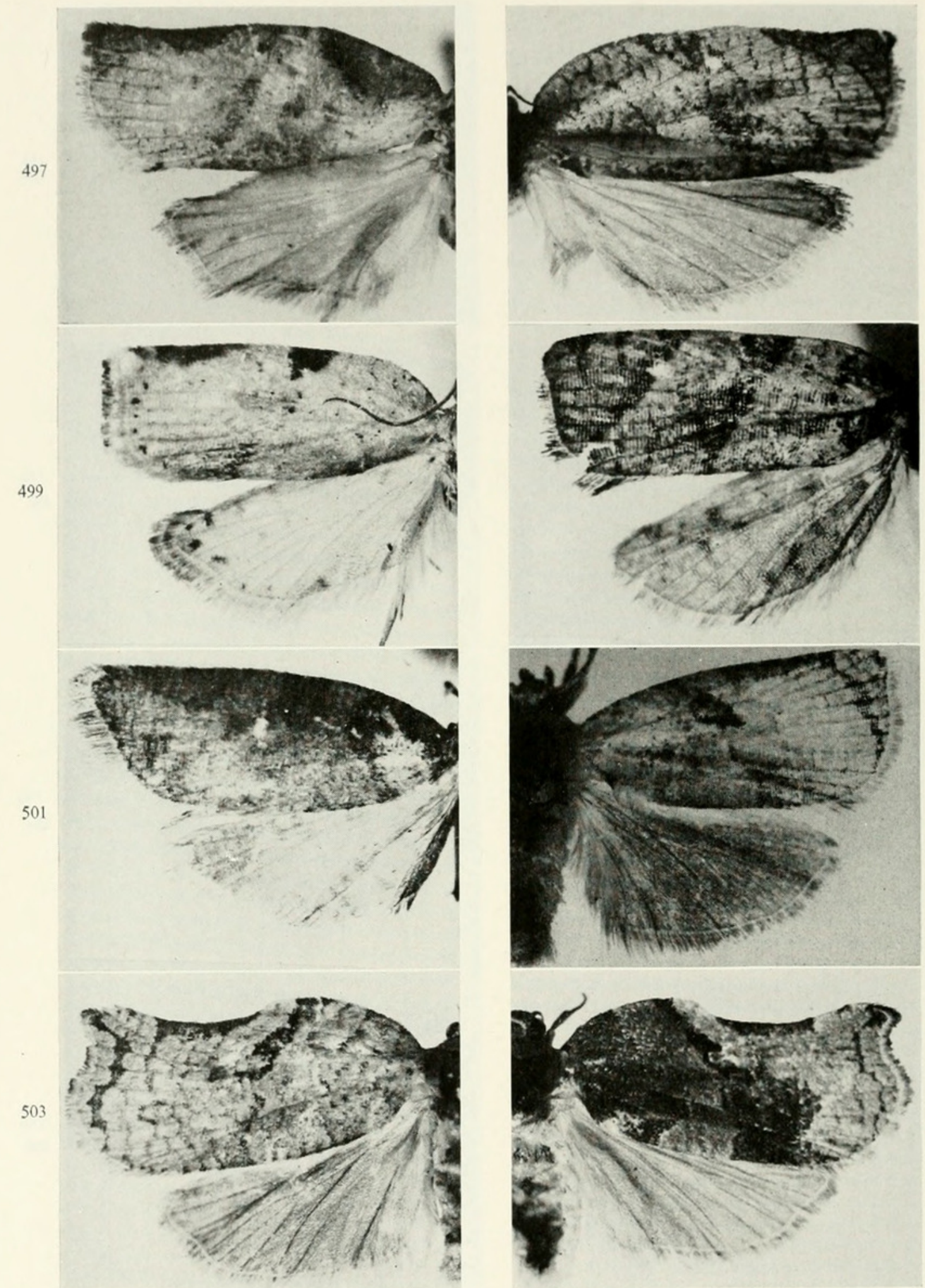

Figures 497-504.-Tortricidae: 497, Homona bakeri, new species, $\sigma^{\top}$, holotype; 498, $q$, allotype; 499, Capua retractana invalidana (Walker), ơ'; 500, Capua thelmae, new species, $\sigma^{7}$, holotype; 501, C. fabrilis Meyrick, $\sigma^{7}$, lectotype; 502, Archips salaconis (Meyrick), $\sigma^{7} ;$ 503-504, color varieties of + . [Fig. 501 after Clarke, 1958, by courtesy of the Trustees of the British Museum, Natural History.] 

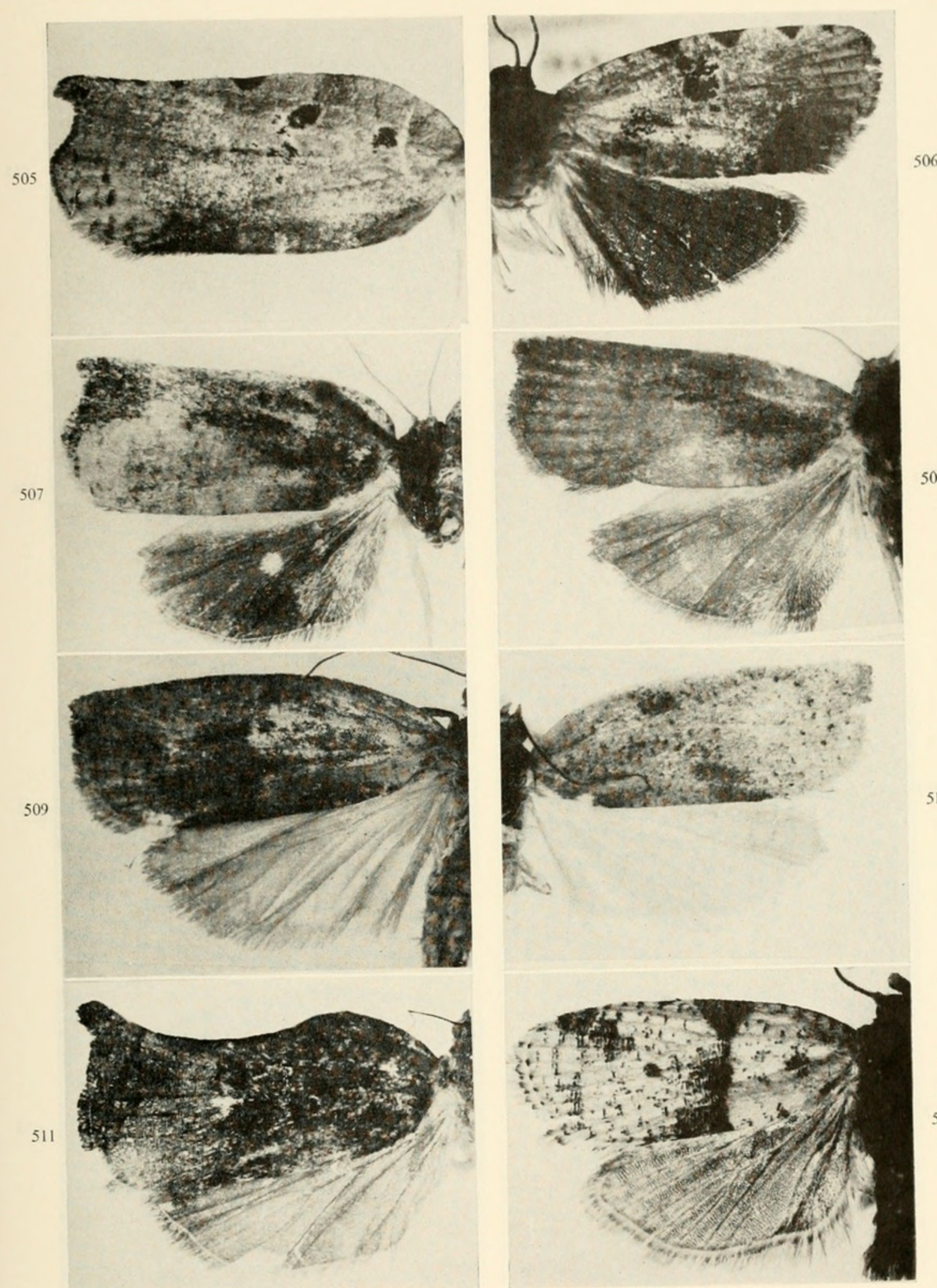

506
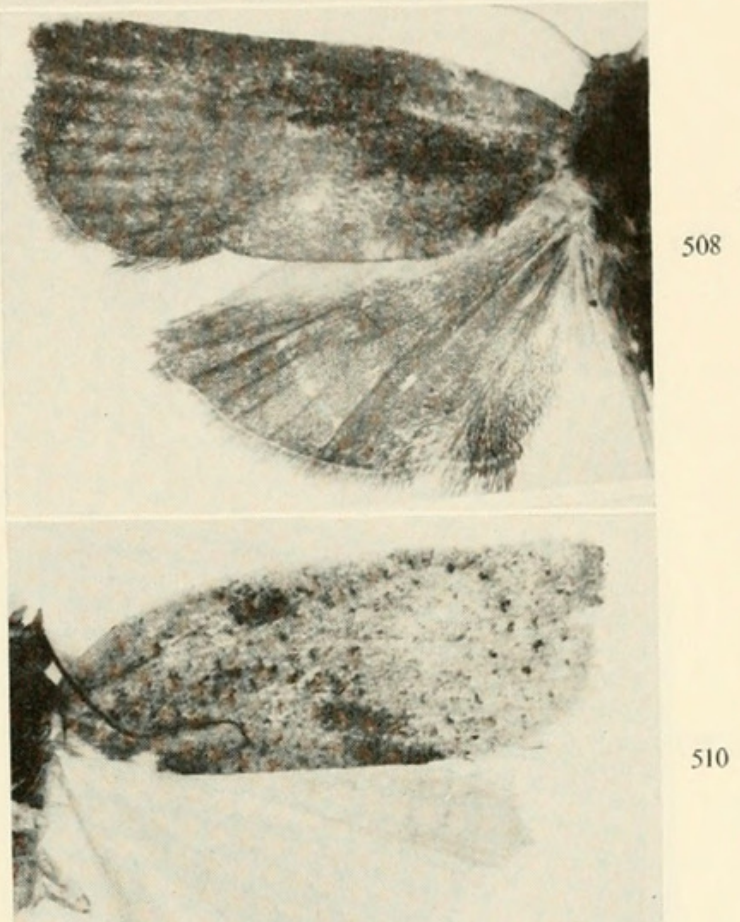

Figures 505-512.-Tortricidae: 505, Archips dicaeus, new species, + , allotype; 506, $\sigma^{7}$, holotype; 507, A. difficilis (Meyrick), $\sigma^{7} ; 508$, ๆ ; 509, Archidemis anastea, new genus, new species, $\uparrow$, allotype; 510, $\sigma^{7}$, holotype; 511, Archips aperta, new species, + , holotype; 512, Snodgrassia stenochorda (Meyrick), ơ 

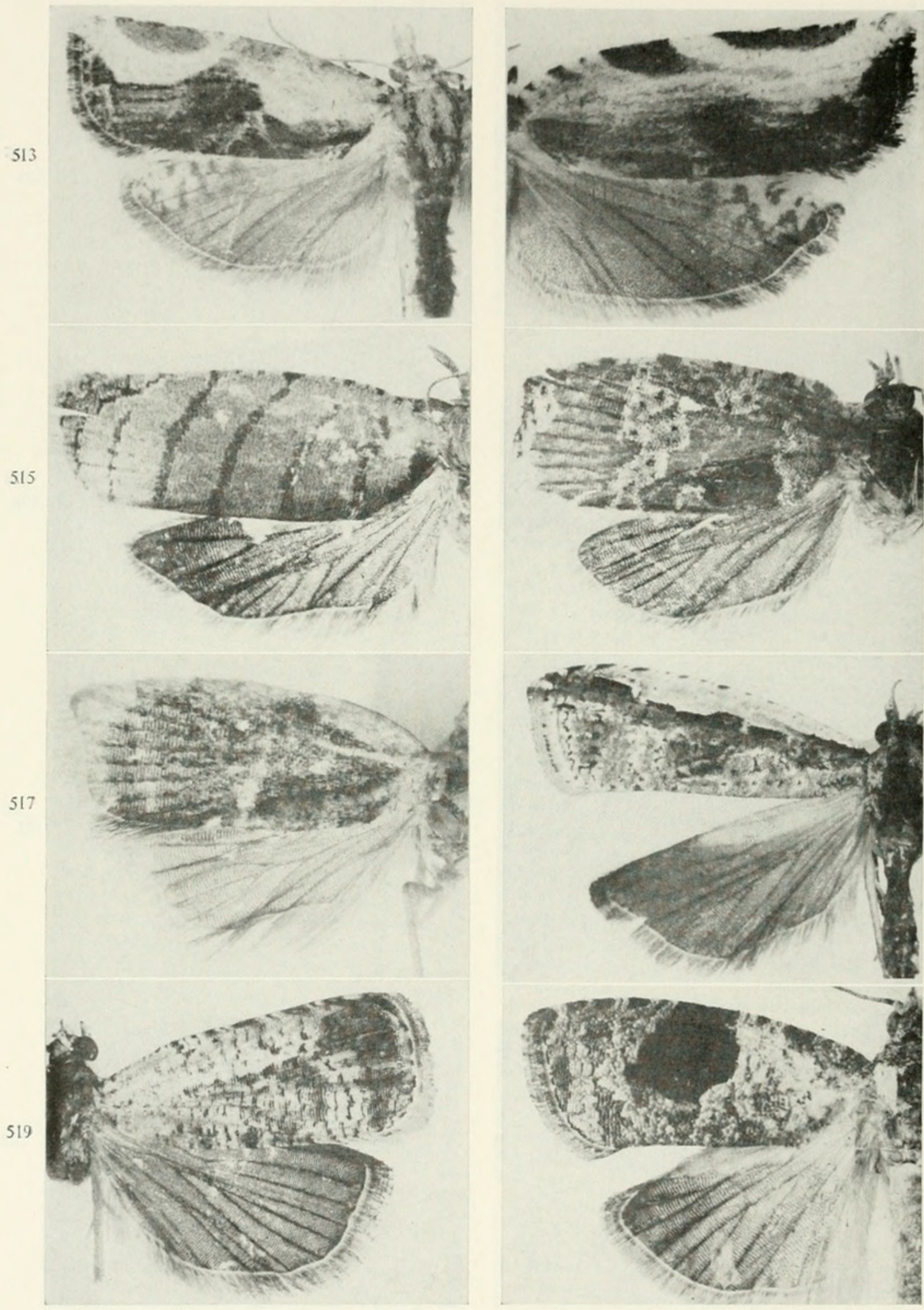

Figures 513-520.-Tortricidae: 513, Isodemis serpentinana (Walker), ơ; 514, ㅇ ; 515, Polemograptis stauroma, new species, + , holotype; 516, Ebodina simplex, new genus, new species, $\sigma^{7}$, holotype; 517, Spatalistis numismata, new species, $q$, holotype; 518 , Phricanthes flexilineana (Walker), o (Java); 519, P. biocellana (Walker), ơ; 520, Hedya (Platypeplus) mormopa (Meyrick), ơ (Java). 

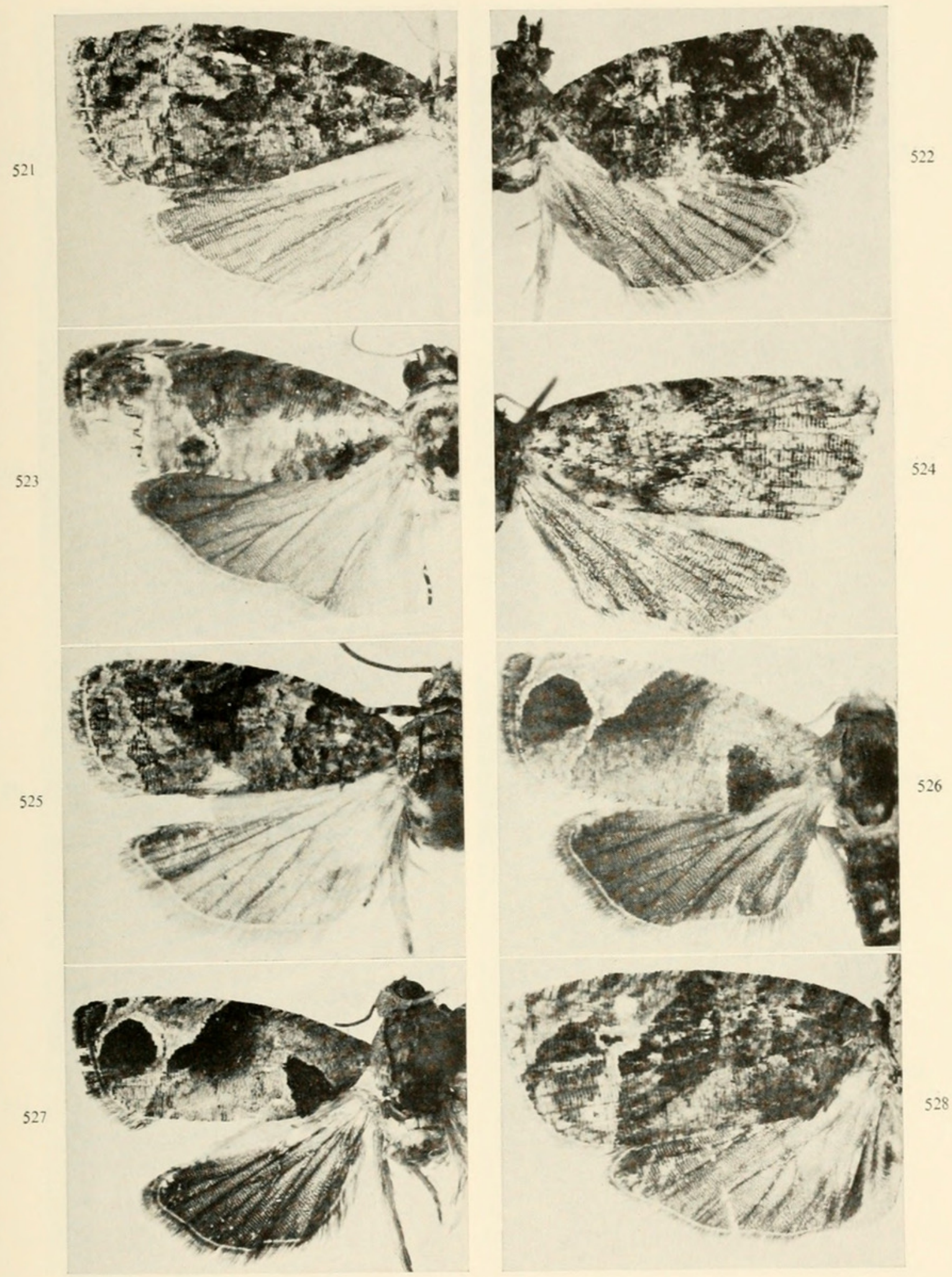

Figures 521-528.-Olethreutinae: 521, Gatesclarkeana asynthetes, new genus, new species, ᄋ , allotype; 522, $\sigma^{7}$, holotype; 523, Hedya (Platypeplus) aprobola (Meyrick), ơ (Java); 524, Hedya (H.) atrifraga, new species, $\sigma^{7}$, holotype; 525, Hedya (Cellifera) cellifera (Meyrick), ơ (Java); 526, Eudemis (E.) archimedias (Meyrick), o (Java); 527, Eudemis (E.) oxygona, new species, + , holotype; 528, Eudemis (Acanthothyspoda) chortodes, new species, $\sigma^{7}$ holotype. 

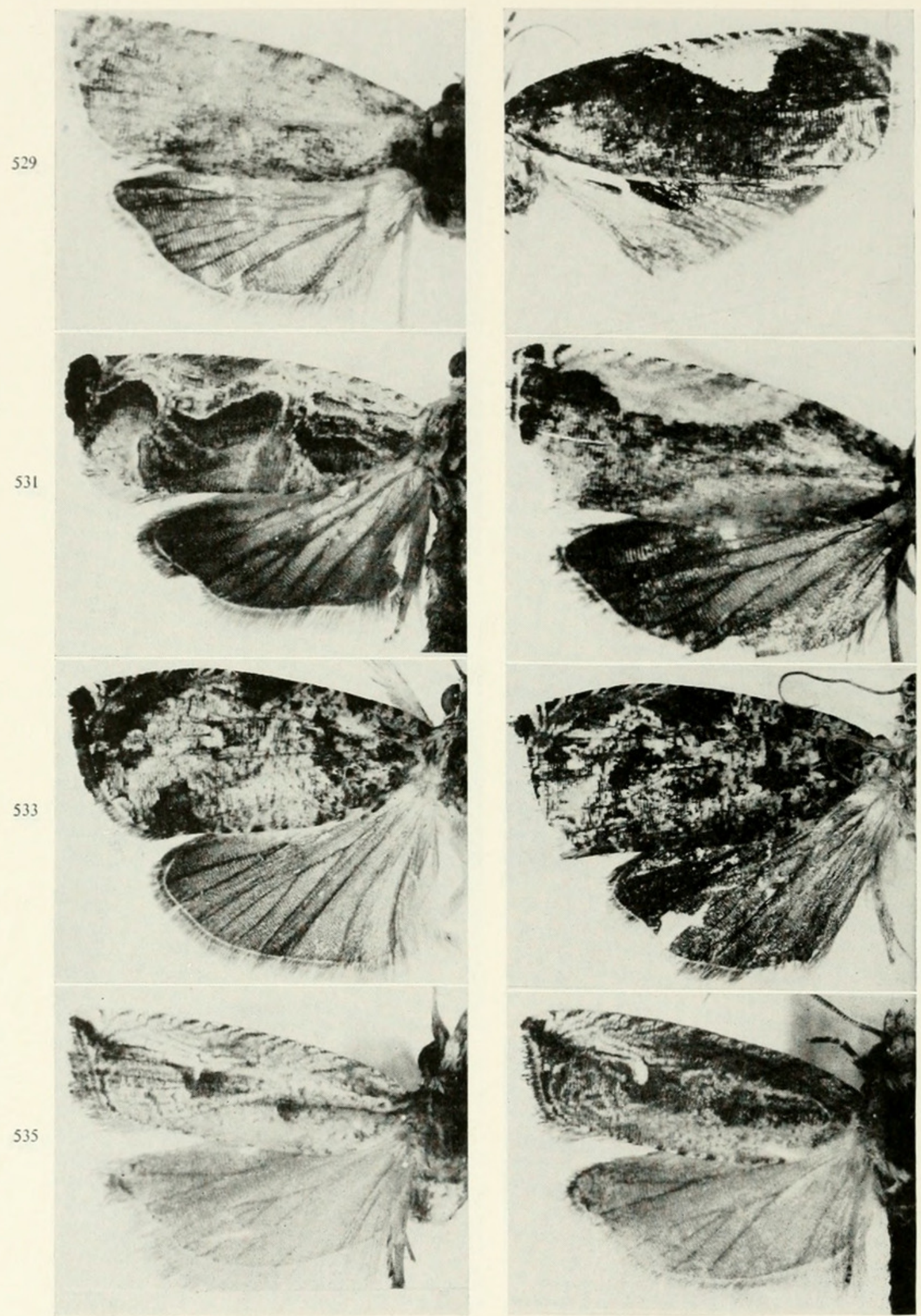

Figures 529-536.-Olethreutinae: 529, Eudemis (Acanthothyspoda) homalopa, new species, q, holotype; 530, Statherotis discana (Felder and Rogenhofer), ơ ; 531, Phaecadophora mosaica (Lower), $\sigma^{7}$ (Java); 532, Statherotis olenarcha (Meyrick), ơ', neallotype; 533, Sycacantha inodes perspicua, new subspecies, $\sigma^{7}$, holotype; 534, S. potamographa, new species, ơ , holotype; 535, Bactra (Chiloides) coronata Diakonoff, ơ (Java); 536, B. (C.) venosana (Zeller), જð (Java) 

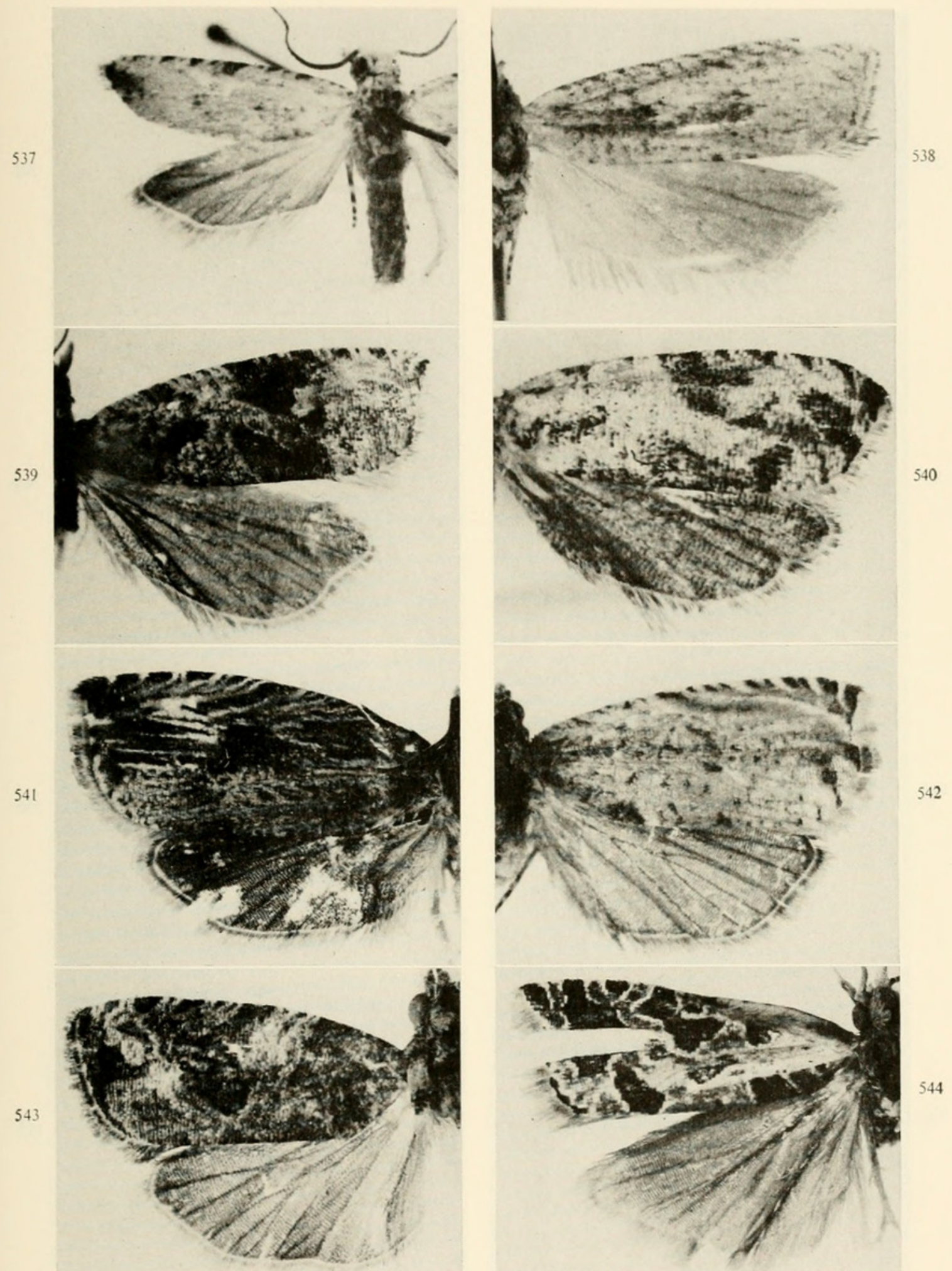

Figures 537-544.-Olethreutinae: 537, Bactra (Nannobactra) phaulopa Meyrick, ơ' 538, B. (Chiloides) orbiculi minax Diakonoff, $\sigma^{7}$, holotype; 539, Bubonoxena endaphana, new species, \&, holotype; 540, B. spirographa, new species, ơ , holotype; 541, Tetramoera schistaceana (Snellen), $\sigma^{7} ; 542$, Argyroptocha phalaenopa, new genus, new species, $\sigma^{7}$, holotype; 543, Gnathmocerodes petrifraga, new genus, new species, $\sigma^{7}$, holotype; 544 , Peridaedala dendrochlora, new species. $\sigma^{\top}$, holotype. 

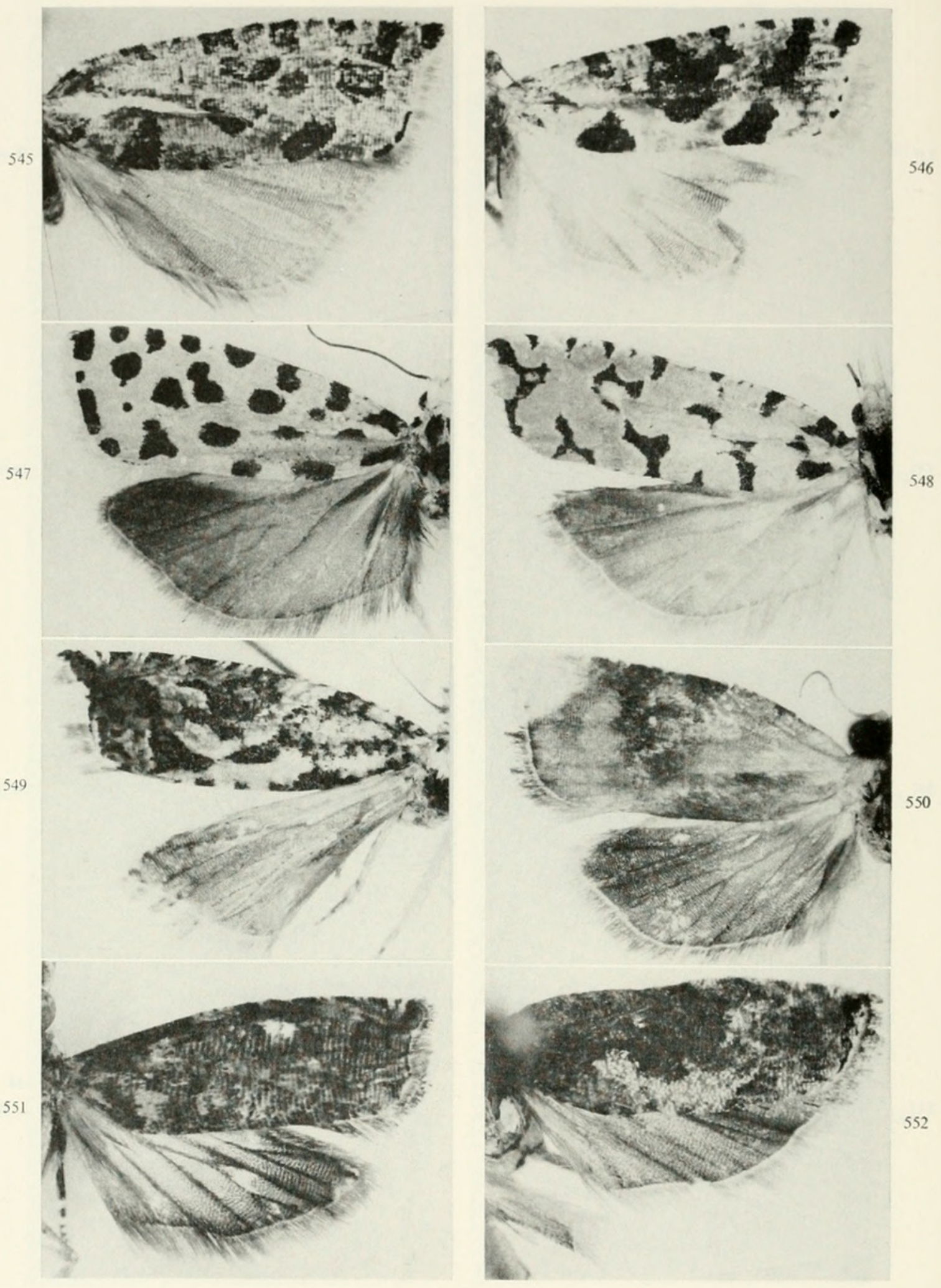

Figures 545-552.-Olethreutinae: 545, Peridaedala dendrochlora, new species, + , allotype; $546, P$. thylacophora, new species, $\sigma^{7}$, holotype; 547, $P$. melanantha, new species, $q$, holotype; 548, $P$. stenoglypha, new species, $q$, holotype; $549, P$. crocoptila, new species, + , holotype; 550, Costosa allochroma, new genus, new species, $\sigma^{7}$, holotype; 551, Eucoenogenes deltostoma, new species, ơ', holotype; 552, Strepsicrates ejectana Walker, ơ'. 

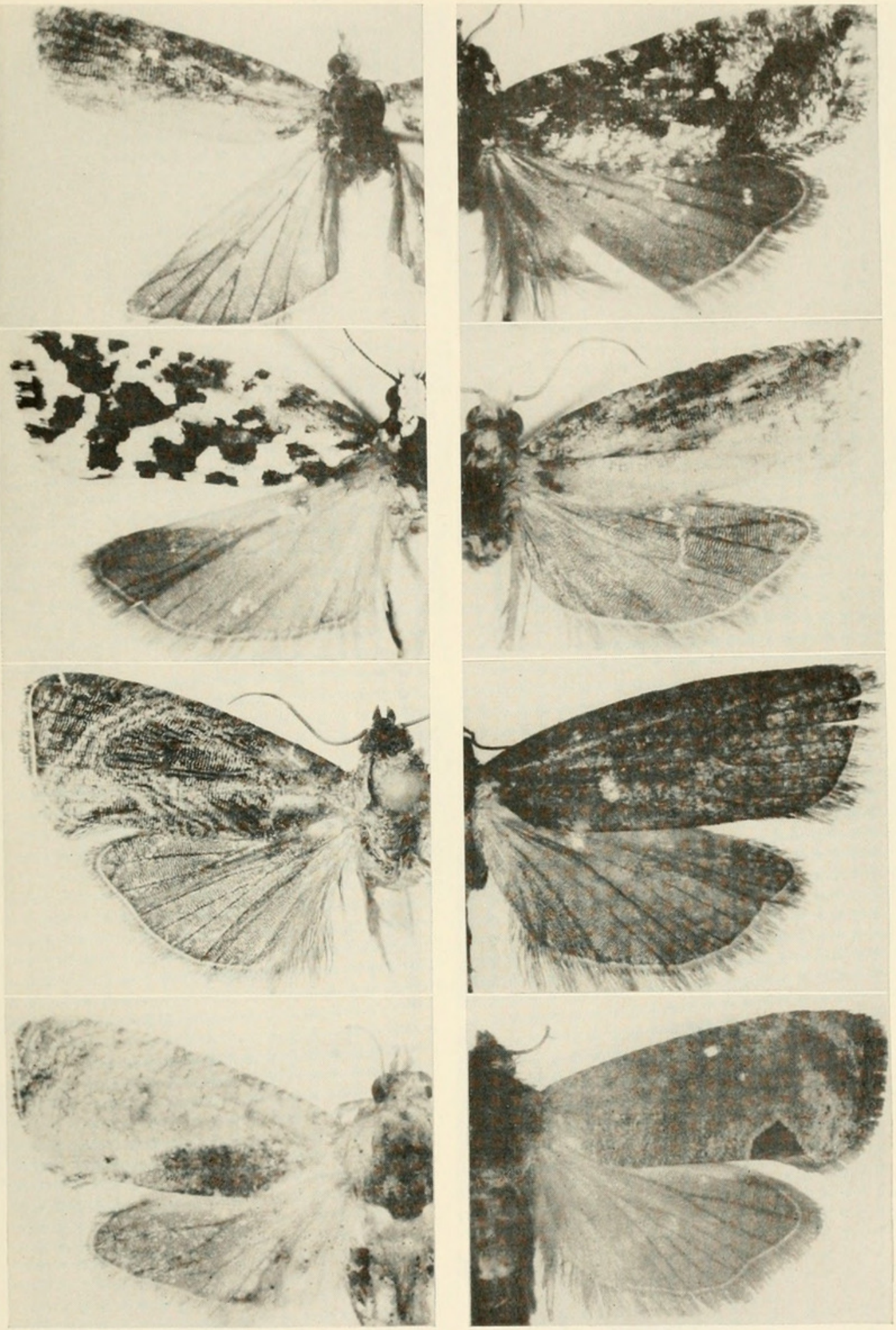

Figures 553-560.-Olethreutinae: 553, Strepsicrates inobtrusa, new species, ơ , holotype; $554, S$. discobola, new species, $\sigma^{7}$, holotype; 555, Petrova scalaris, new species, + holotype; 556, Eucosma iographa, new species, $\sigma^{7}$, holotype; 557, Cryptophlebia tetraploca (Meyrick), o'; 558, Cryptaspasma (Allobrachygonia) hesyca Diakonoff, ơ, paratype; 559, C. (C.) ombrodelta (Lower), ơ ; 560, ㅇ․ 

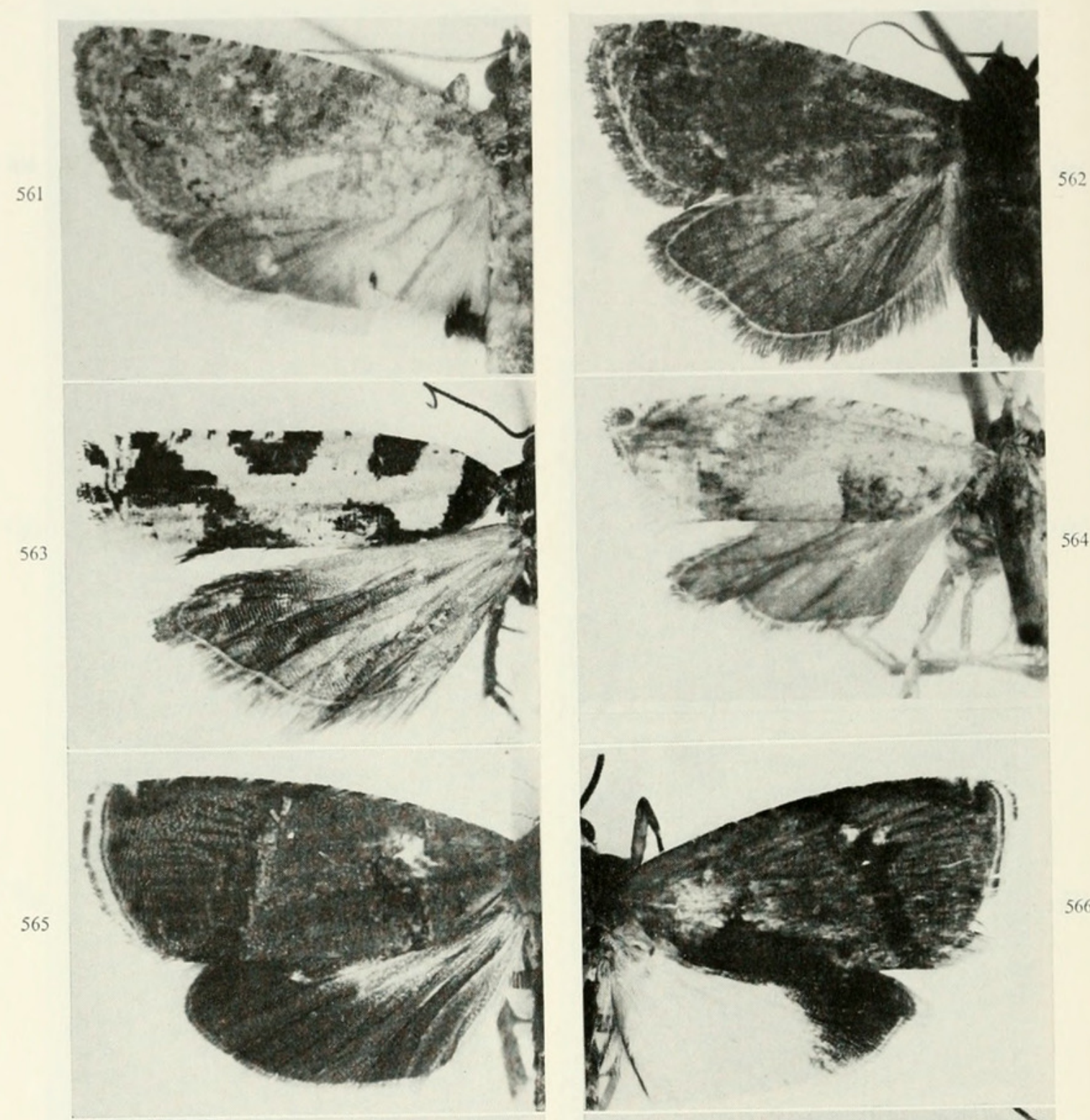

566
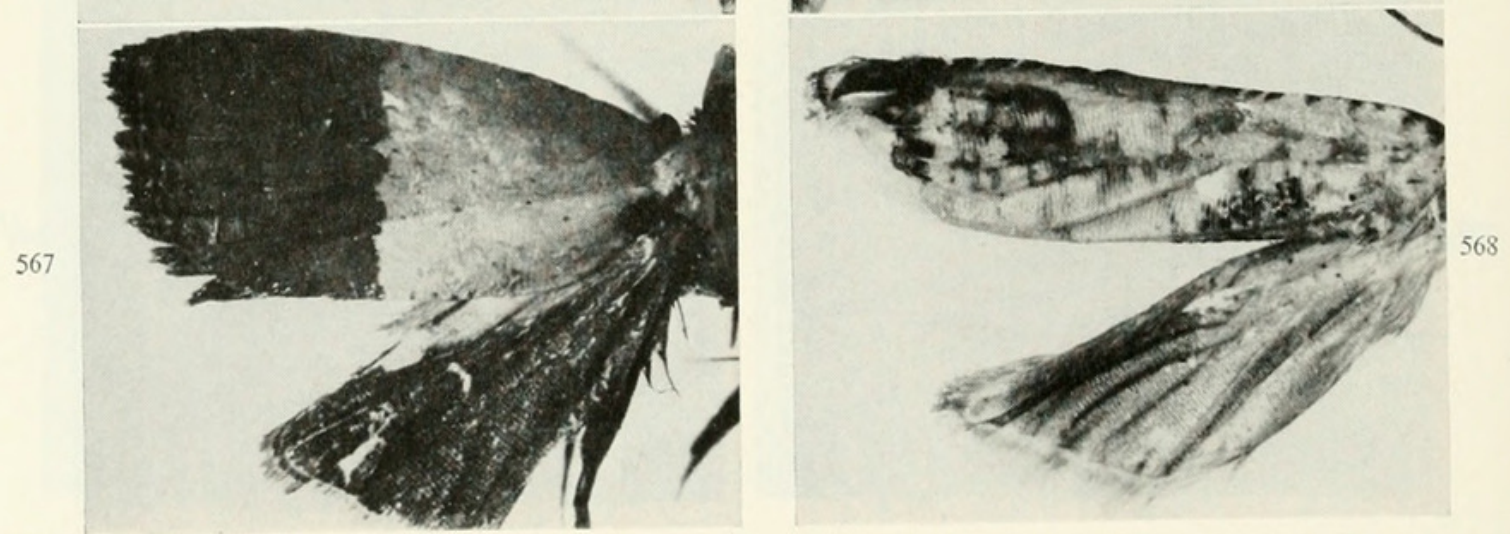

Figures 561-568.-Olethreutinae and Chlidanotinae: 561, Cryptophlebra encarpa (Meyrick), $\sigma^{7}$ (Java); 562, ๆ (Java); 563, Erinaea amphigonia, new species, + , holotype; 564, Crocidosema plebejana Zeller, q ; 565, Pammene leucodora Meyrick, ơ ; 566, ๆ ; 567, Laspeyresia gratulata Meyrick, + , holotype: 568, Caenognosis incisa Walsingham, $\sigma^{7}$. 

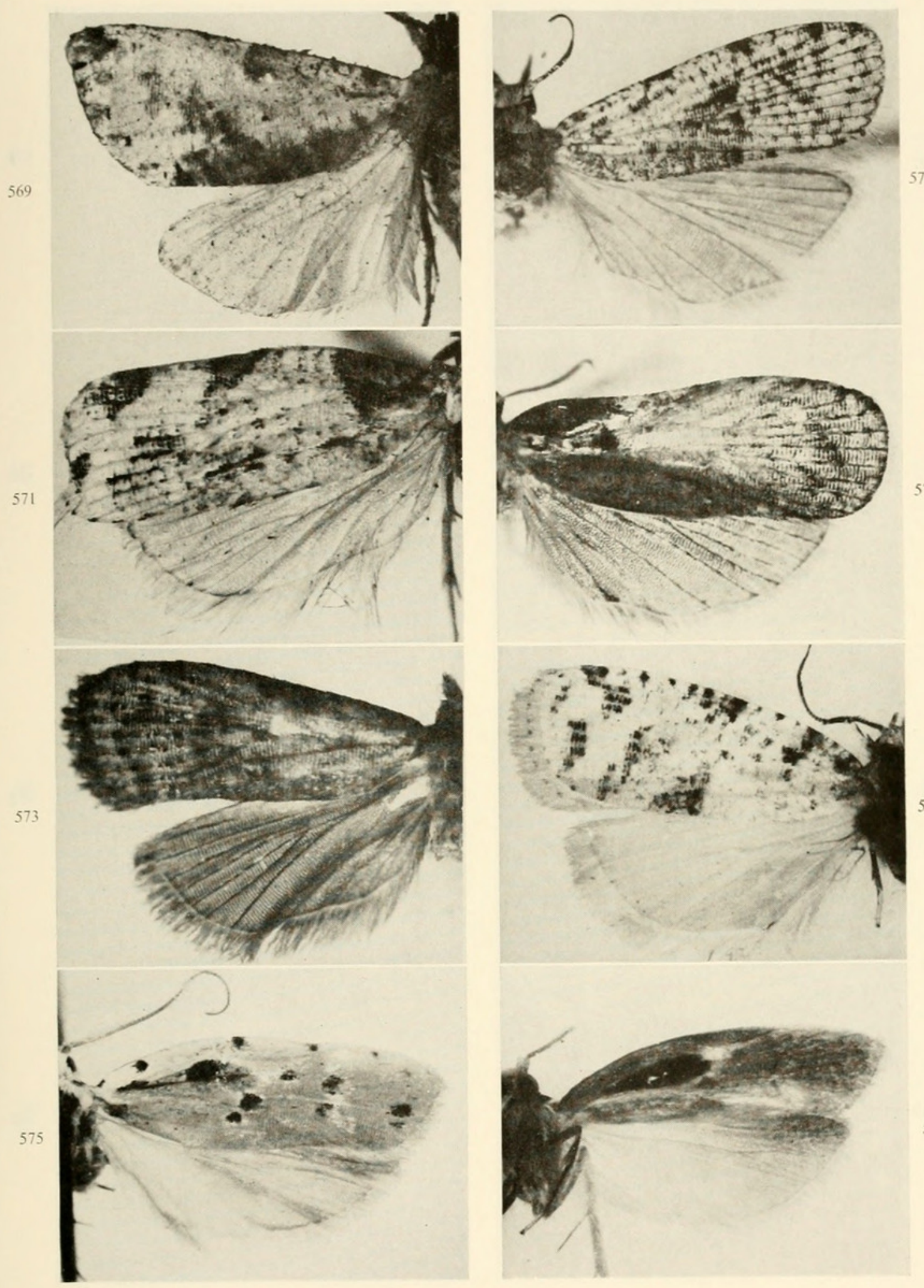

Figures 569-576.-Tortricidae, Copromorphidae, and Carposinidae: 569, Trymalitis cataracta Meyrick, $\sigma^{7} ; 570$, Copromorpha mistharnis, new species, \&, holotype; 571, Schoenotenes collarigera, new species, $q$, holotype; 572, Copromorpha smaragdarcha, new species, $\sigma^{7}$. holotype; $573, C$. dialithoma, new species, $\sigma^{7}$, holotype; 574 , Stenarchell eupista, new genus, new species, $\sigma^{7}$, holotype; 575, Heterogymna melanocrypta, new species, + , holotype; 576, underside, left pair of wings, 

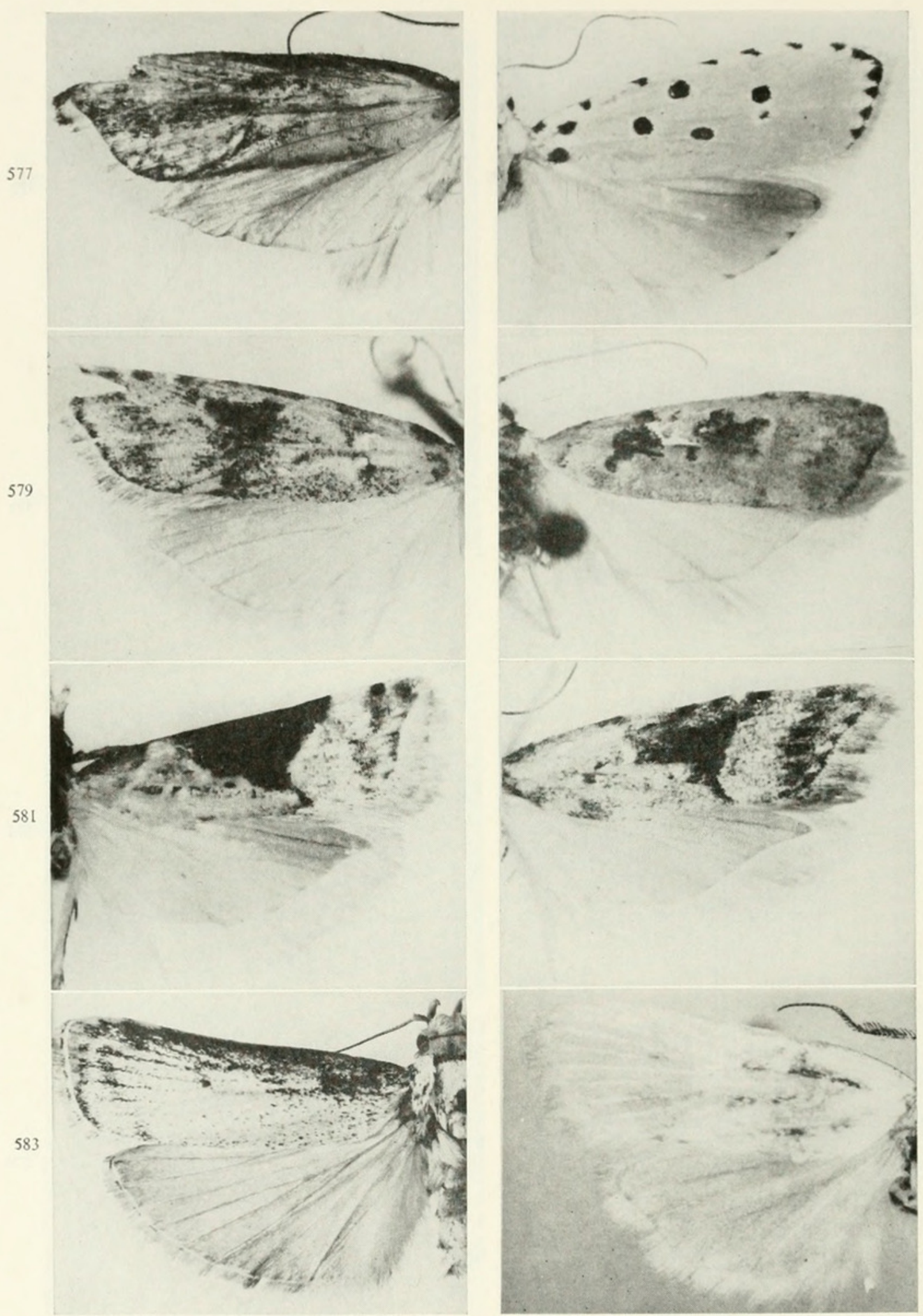

Figures 577-584.-Carposinidae and Xyloryctidae: 577, Campylarchis acuta, new genus, new species, $\sigma^{7}$, holotype; 578, Meridarchis alta, new species, + , holotype; 579, Metacosmesis illodis, new species, $\sigma^{7}$, holotype; 580, Meridarchis bifracta, new species, $\sigma^{7}$, holotype; $581, M$. oxydelta, new species, + , holotype; $582, M$. scythophyes, new species, \& , holotype; 583, Thymiatris arista, new species, $\sigma^{7}$, holotype; 584 , Amorbaea subtusvena new species, $\sigma^{7}$, holotype. 

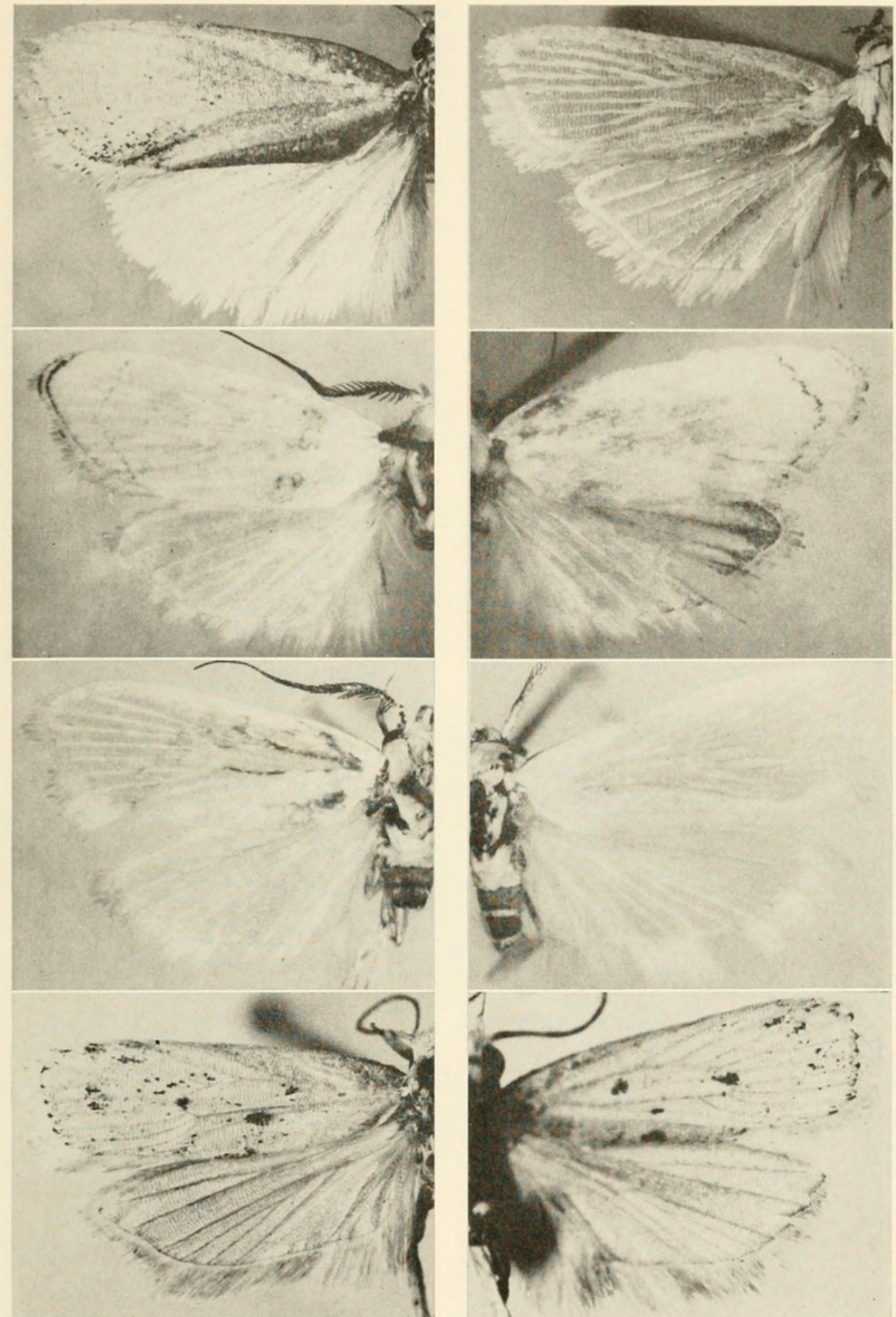

Figures 585-592.-Xyloryctidae: 585, Amorbaea subusta, new species, + , holotype; 586, Metathrinca iridostoma, new species, $\sigma^{7}$, holotype; 587, M. coenophyes, new species, $\sigma^{7}$, holotype; 588, allotype; 589, M. pernivis, new species, o', holotype; 590, M. sinumbra, new species, $\sigma^{7}$, holotype; 591, Odites perissa Meyrick, $\sigma^{7} ; 592$, O. perissa atrimersa, $\sigma^{7}$, holotype. 

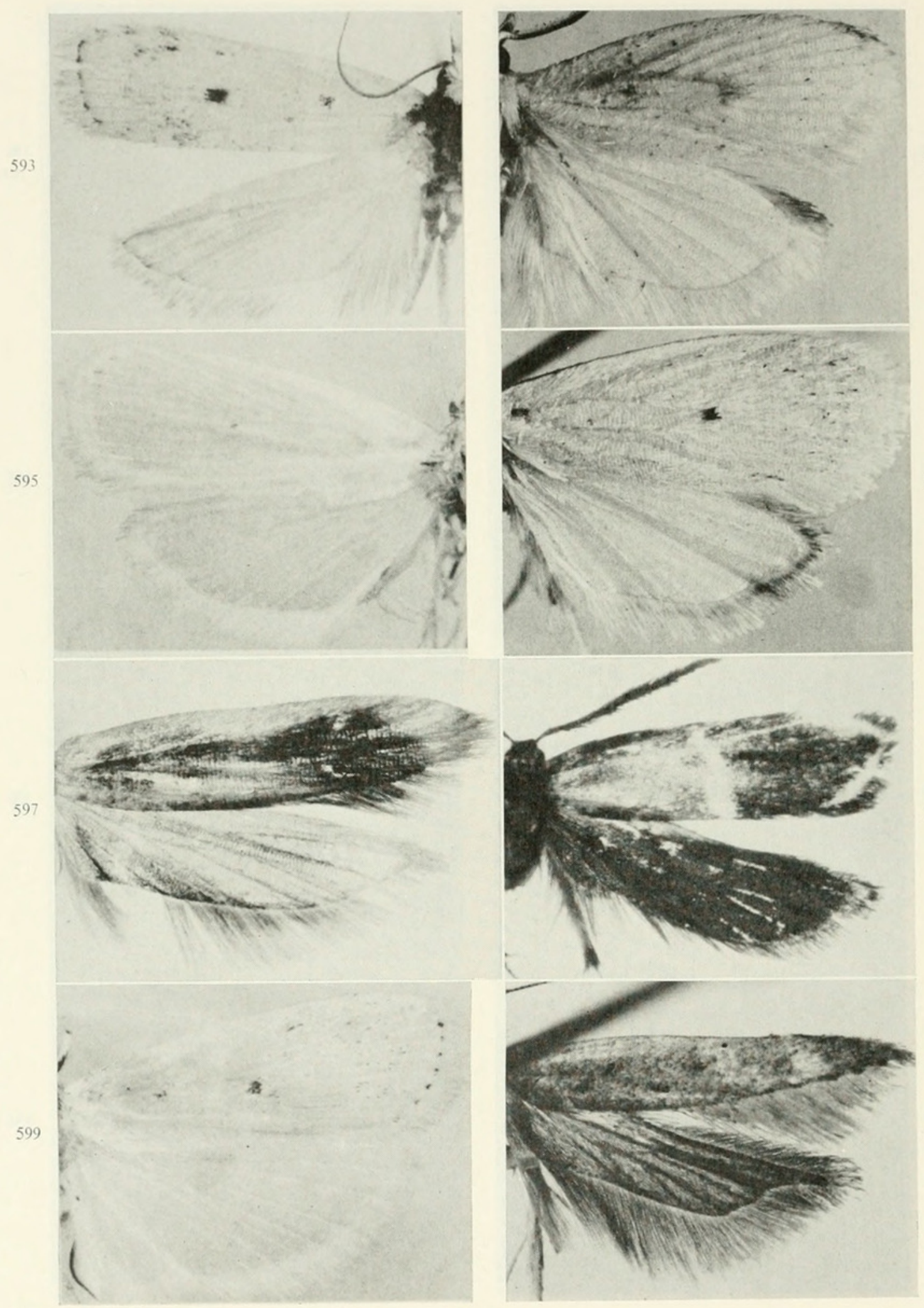

Figures 593-600.-Xyloryctidae and Timyridae: 593, Odites apicalis, new species $\sigma^{7}$, holotype; 594, O. pancyclia Meyrick, $\sigma^{7} ; 595$, O. homocirrha, new species, $\sigma^{7}$, holotype; 596, O. periscias Meyrick, $\sigma^{7} ; 597$, Canthonistis xestocephala, new species, $\sigma^{7}$, holotype; 598, Tisis auricincta, new species, + , allotype; 599, Odites brachyclista Meyrick, ơ'; 600 , Frisilia drimyla, new species, + , holotype. 
601

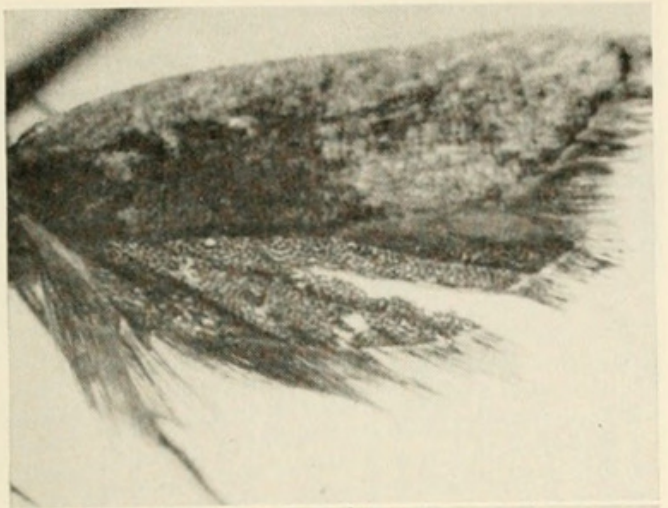

603

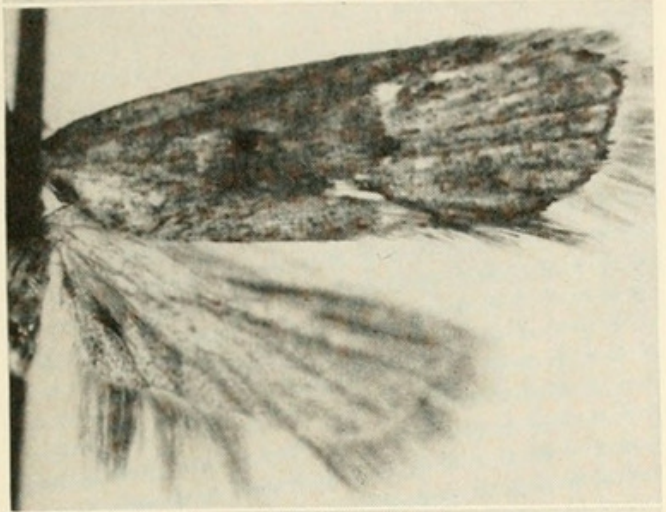

605

607
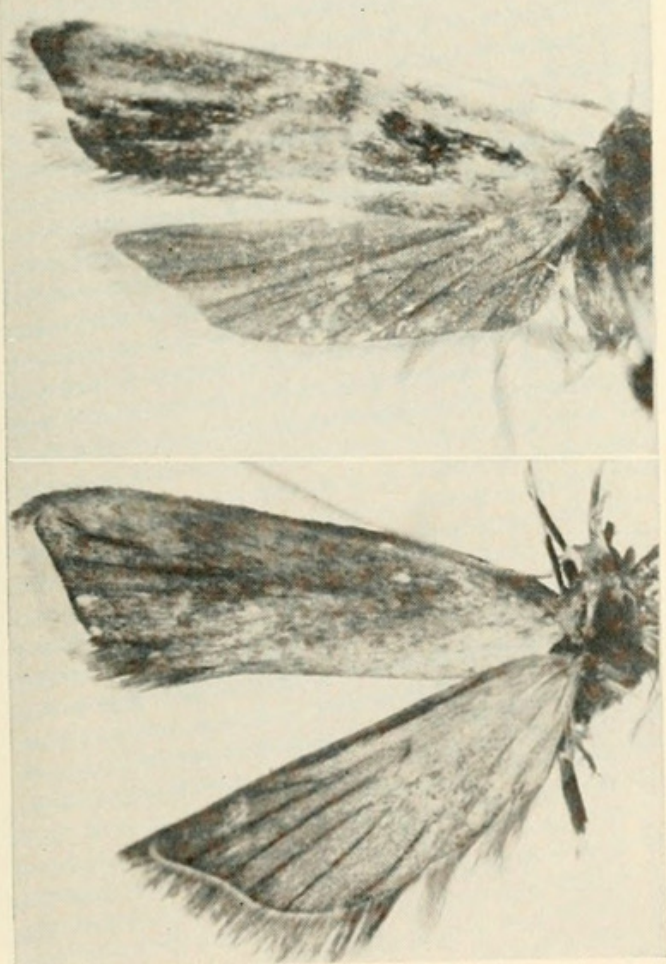

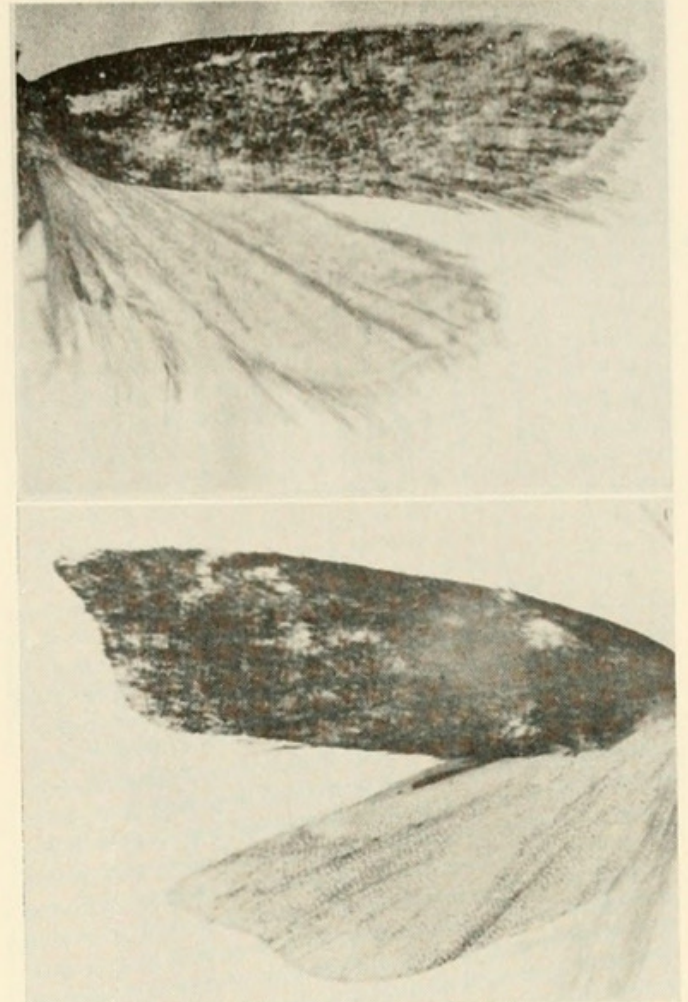

602
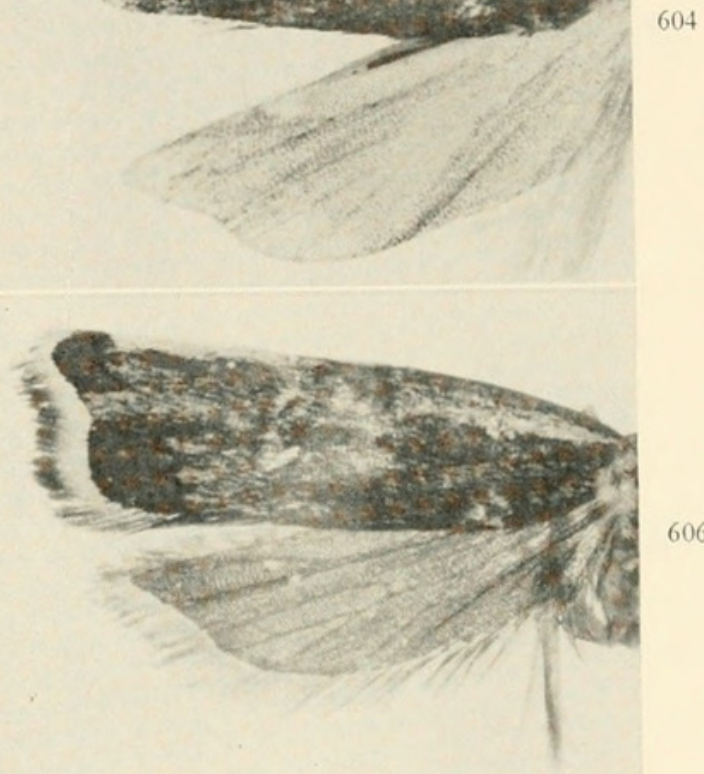

606

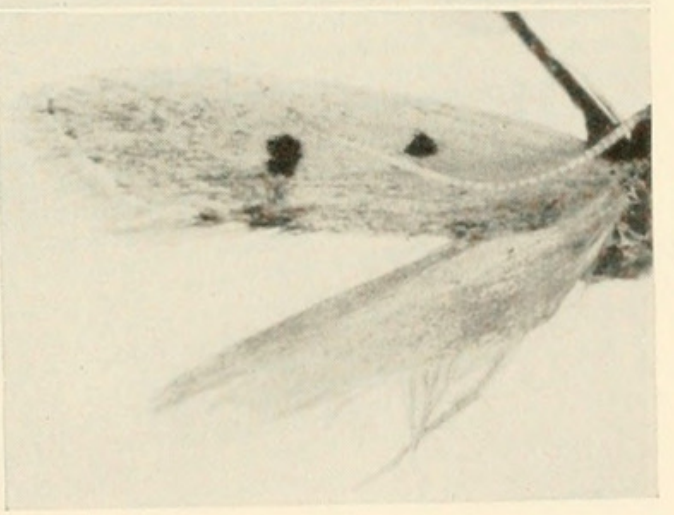

Figures 601-608.- Timyridae: 601, Homaloxestrs aganacma, new species, $q$, holotype; 602 , H. surrepta, new species, $\sigma^{7}$, holotype; 603, Lecithocera sophronopa, new species, $q$, holotype; $604, L$. activata, new species, $\sigma^{7}$, holotype; 605 , L. strenua, new species, $\sigma^{7}$, holotype; 606, L. cassiterota Meyrick, $\sigma^{7} ; 607$, L. phanerostoma, new species, $\sigma^{7}$, holotype; 608, L. megalopis Meyrick, ơ. 


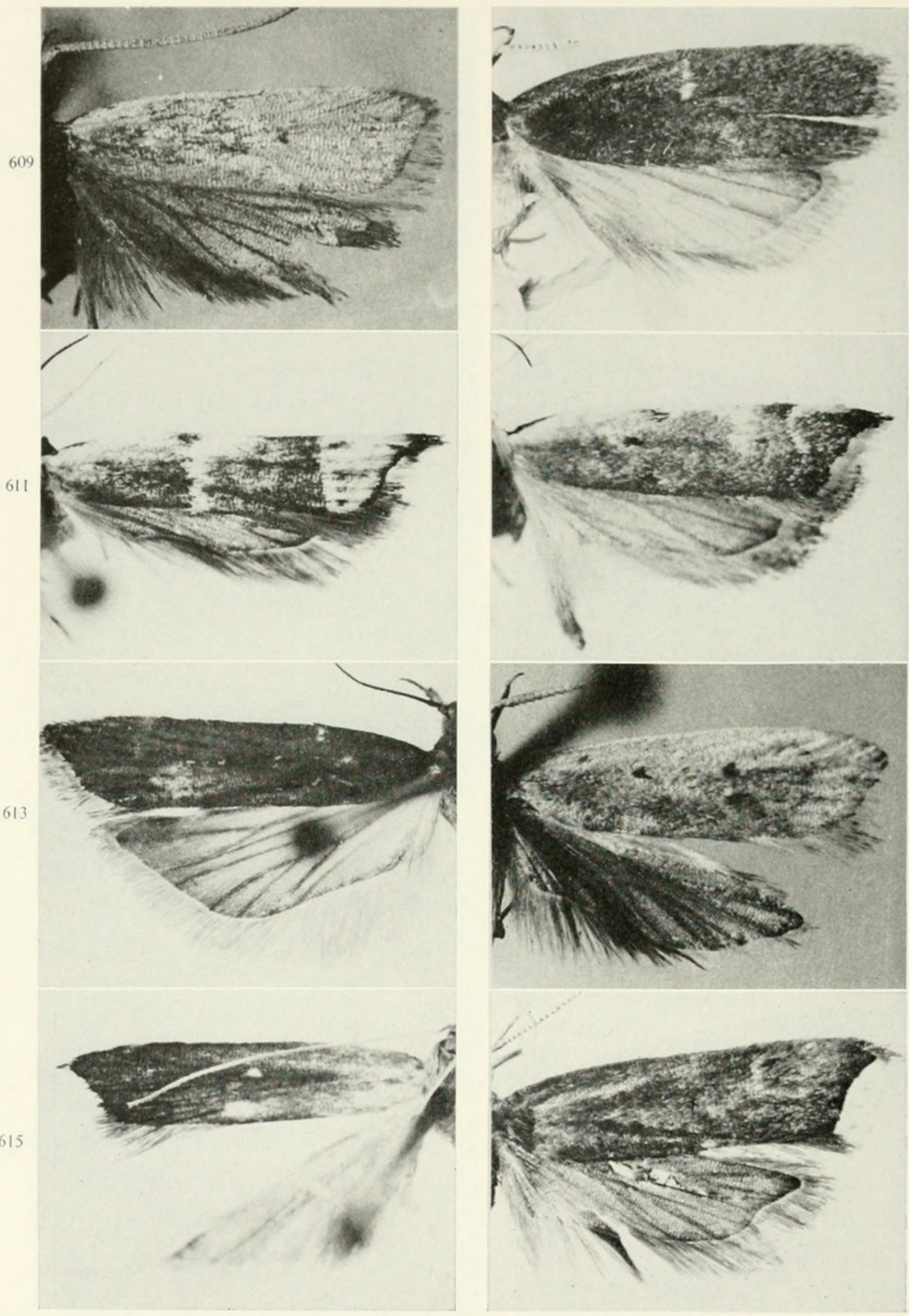

FiguRes 609-616.-Lecithocera Herrich-Schäffer: 609, Lecithocera docilis, new species, $\sigma^{7}$; 610 , L. leucomastis, new species, + , holotype; $611, L$. acribostola, new species, $q$, holotype; $612, L$. decorosa, new species, $q$, holotype; $613, L$. telosperma, new species, $q$, holotype; 614, L. goniometra Meyrick, \&, neallotype; 615, L. niphotricha, new species, ㅇ, holotype; 616, L. recurvata Meyrick, $ᄋ$. 

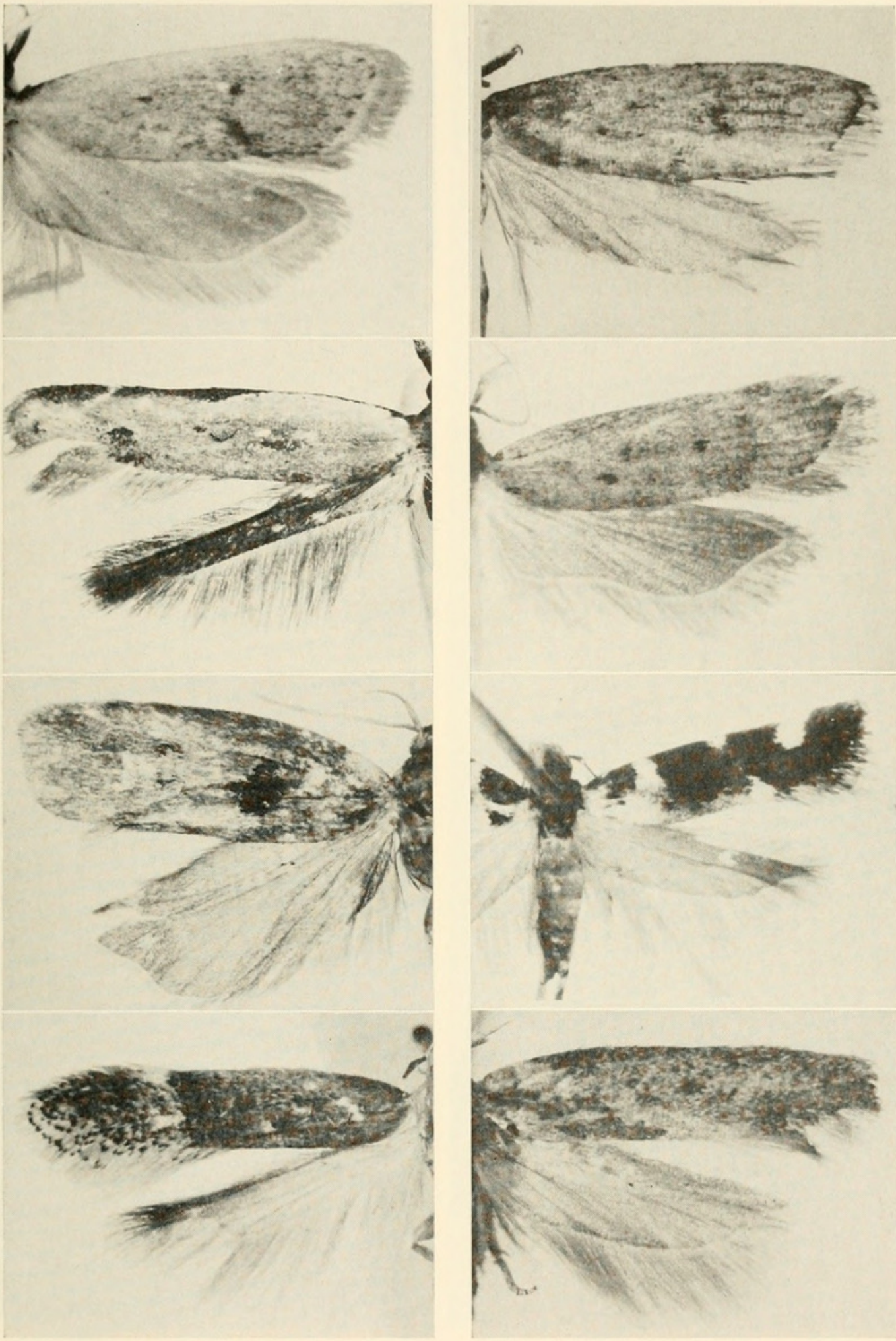

Figures 617-624.-Timyridae and Gelechiidae: 617, Lecithocera fausta Meyrick, ơ; 618, L. luteola, new species, ơ; 619, Brachyacma palpigera Walsingham, ơ (India); 620, L. improvisa, new species, q , holotype; 621, Prosodarma fibularis (Meyrick), q ; 622, Stegasta variana Meyrick. ơ (Celebes); 623, Stomopteryx subsecivella (Zeller), ơ; 624, Phthorimaea heliopa (Lower) $\sigma^{7}$. 


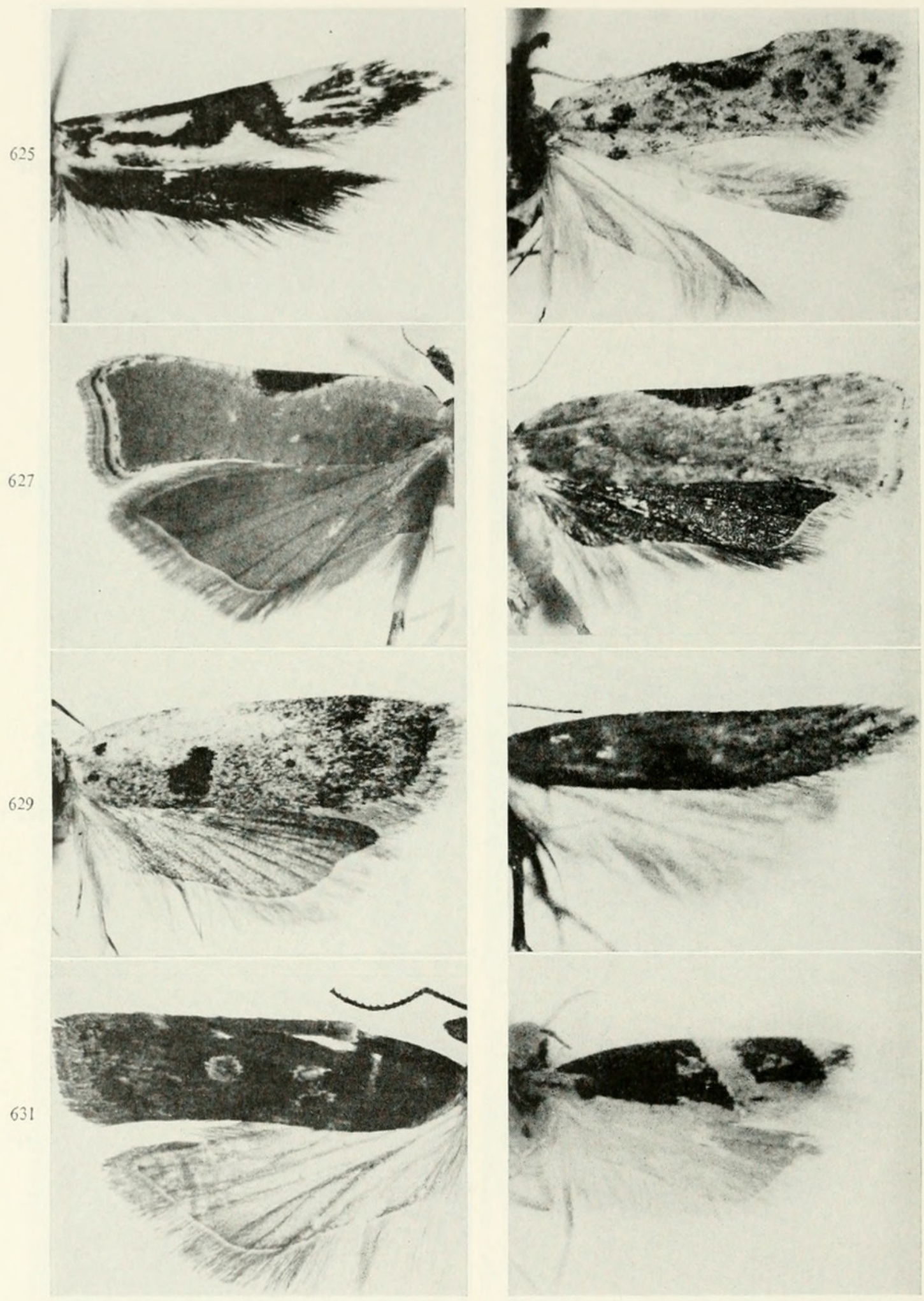

Figures 625-632.-Gelechiidae: 625, Euhomalocera heliosema, new genus, new species, ه7, holotype; 626, Hypatima heterostigma, new species, శ7, holotype; 627, Atasthalistis diacrita, new species, $\sigma^{7}$, holotype; 628, + , allotype; 629, Hypodrasia acycla, new genus, new species, $\sigma^{\top}$, holotype; 630, Acribologa malacodes (Meyrick), + ; 631, Brachmia tristella (Snellen), \& ; 632, B. heterotoma, new species, $\sigma^{\top}$, holotype. 

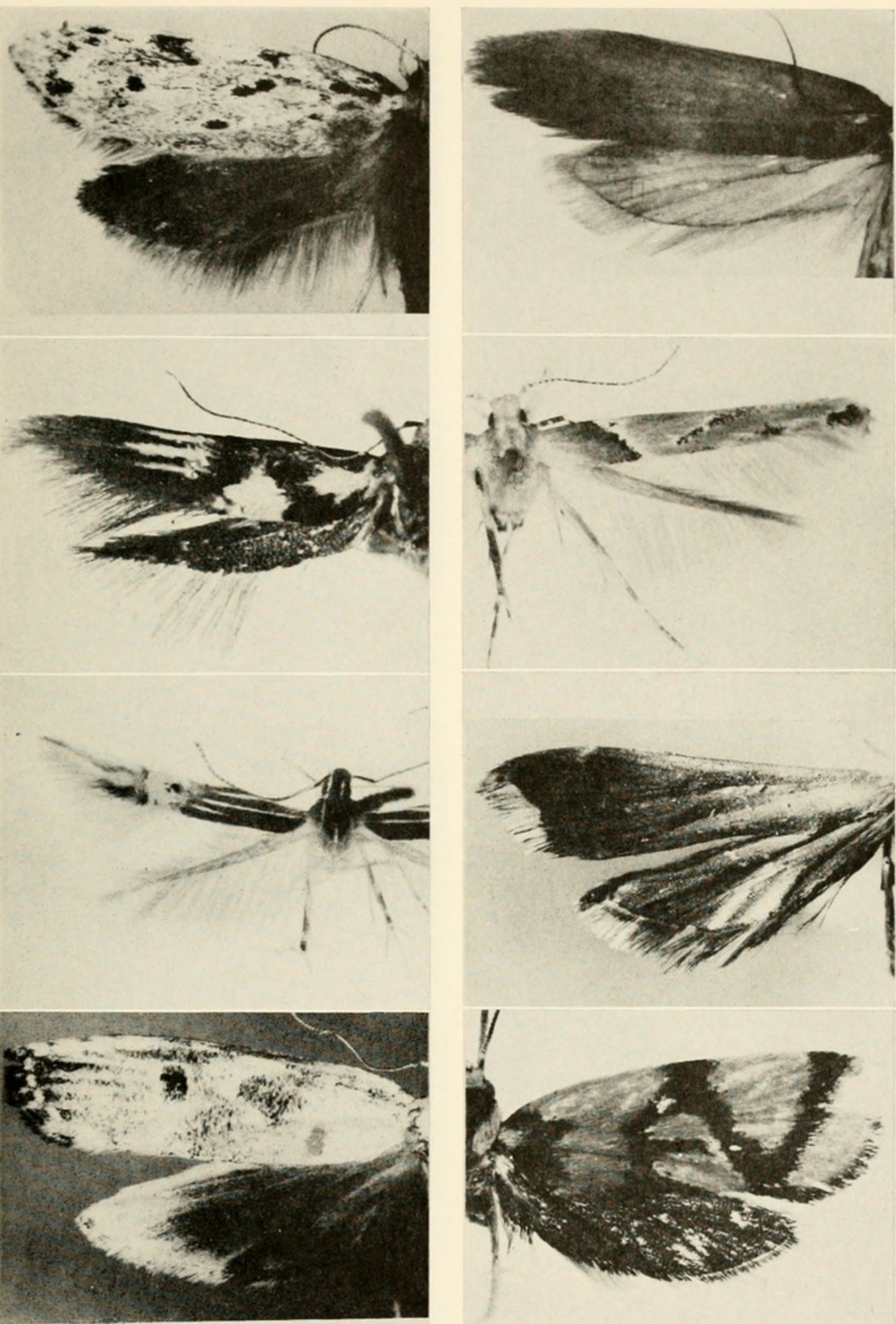

Figures 633-640.-Cosmogterygidae. Timyridae. Oecophoridae: 633, Syntomaula simulatella (Walker), \& (Java); 634, Scaeothyris pseusta, new genus, new species, or, holotype; 635, Limnaecia acontophora Meyrick, +, holotype; 636. Pyroderces simplex Walsingham, ơ; 637, Cosmopteryx dulcivora Meyrick, ơ (Java); 638, Lecithocera ochrocapna Meyrick, ๆ, holotype; 639, Epimecyntis chlorogenes Meyrick, \&; 640, Diploclasis balbidophora, new genus, new species, $\sigma^{7}$, holotype. [Fig. 638, by courtesy of the Trustees of the British Museum, Natural History.] 

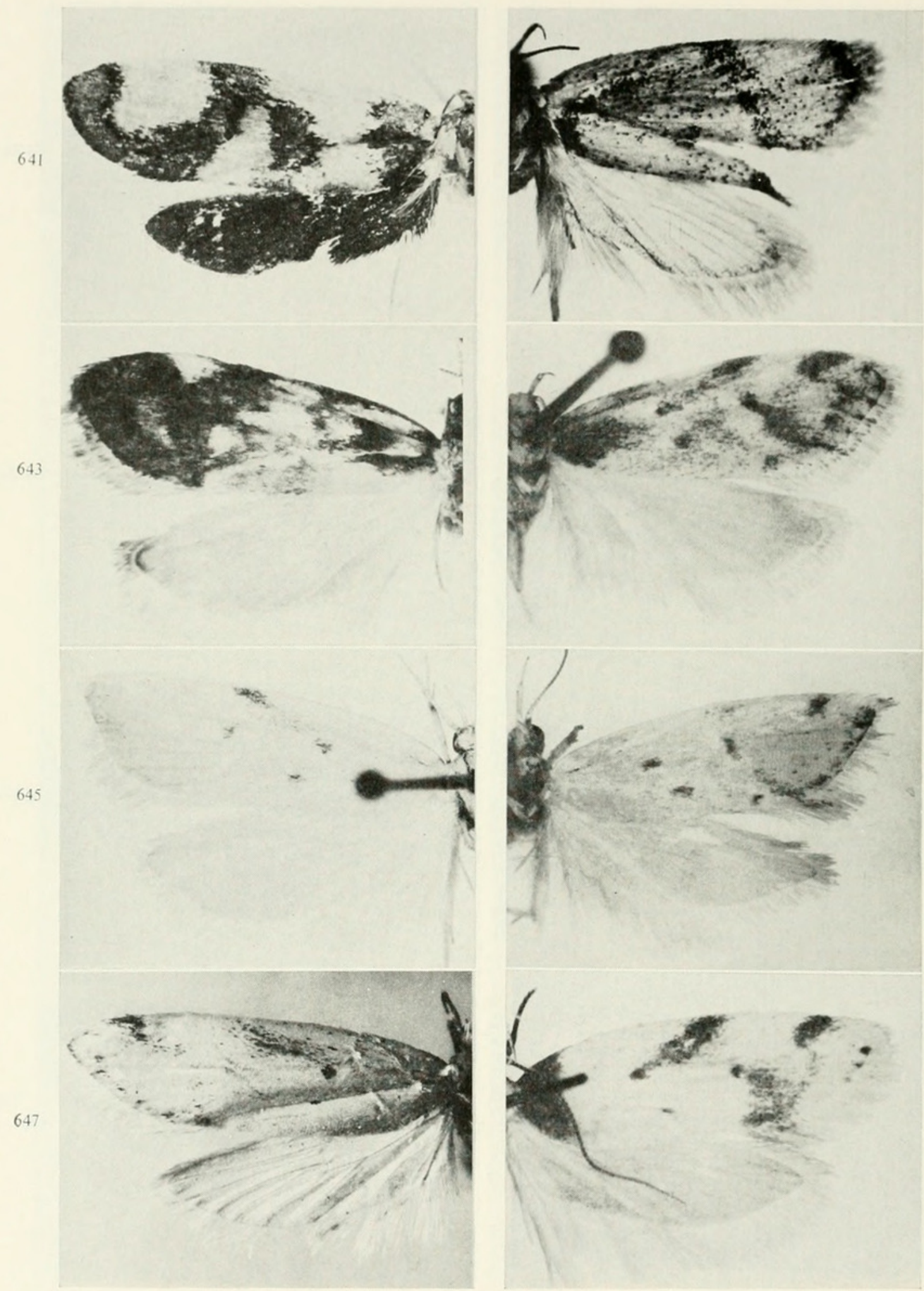

648

Figures 641-648.-Oecophoridae: 641, Astiarcha praedives, new species, $\uparrow$, holotype; 642, Tanyzancla amydrographa, new species, $q$, holotype; 643, T. pepona, new species, $\sigma^{7}$, holotype; 644, $\sigma^{7}$, allotype; 645, T. catadea, new species, $\sigma^{7}$, holotype; 646, T. cincta, new species, $\sigma^{7}$, holotype; $647, T$. lanceolata, new species, + , holotype; 648, Philobota loxographa, new species, $\sigma^{7}$, holotype. 
649

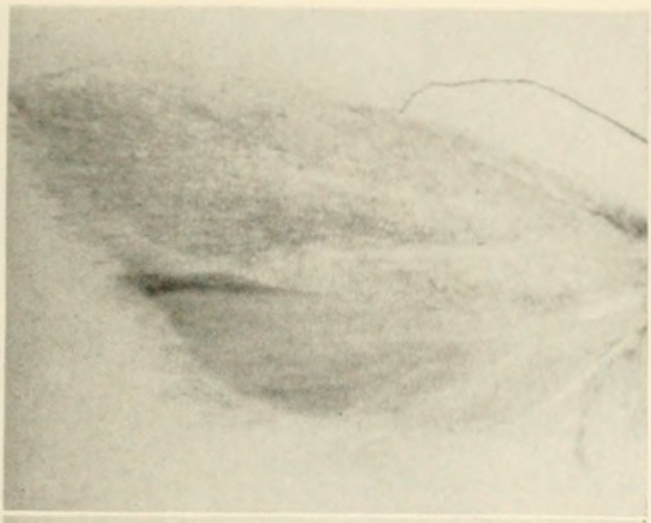

651

653

655
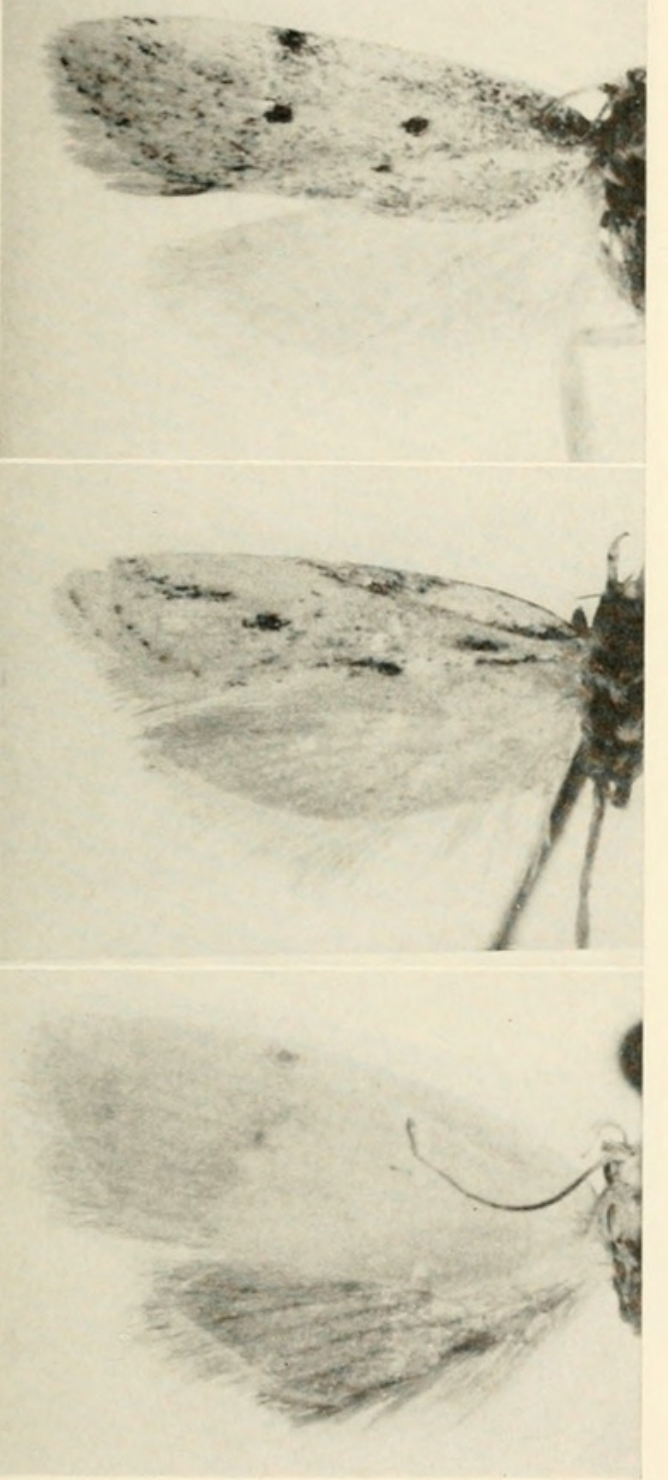

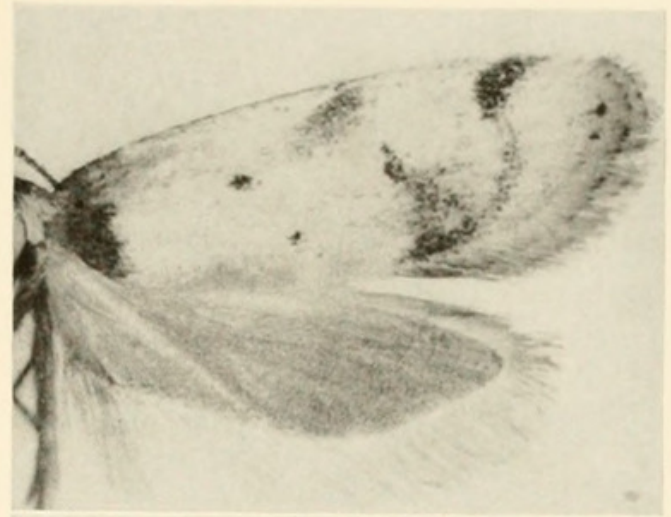

650

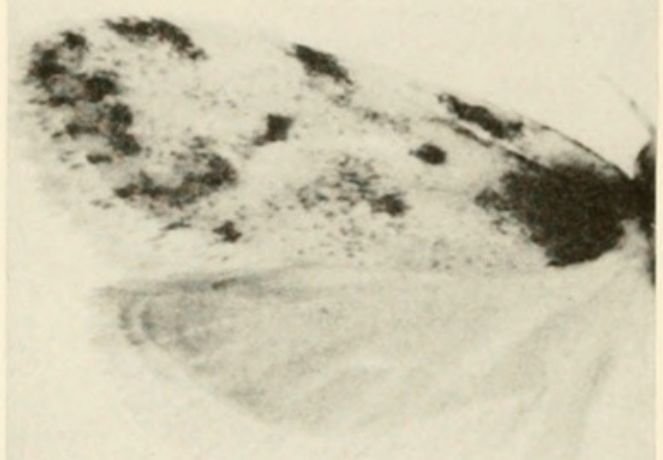

652

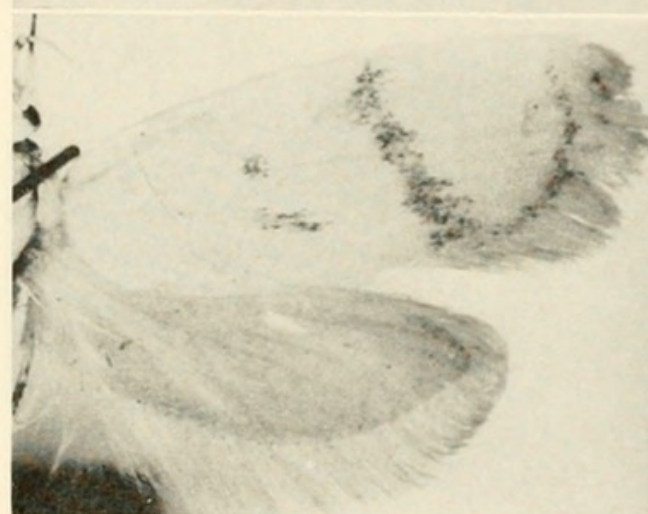

654

Figures 649-656.-Oecophoridae: 649, Chrysonoma aporopis (Meyrick), o7, neallotype; 650, Philobota loxographa, new species, + , allotype; 651 , C. eumorpha, new species, ơ, holotype; 652, C. poecilosema, new species, $\sigma^{7}$, holotype; 653 , C. fragmentaria, new species, $\sigma^{7}$, holotype; 654, C. hesitans, new species, $\sigma^{7}$, holotype; 655, C. hypocapna, new species, $\sigma^{7}$. holotype; 656, C. inermis, new species, o , holotype. 

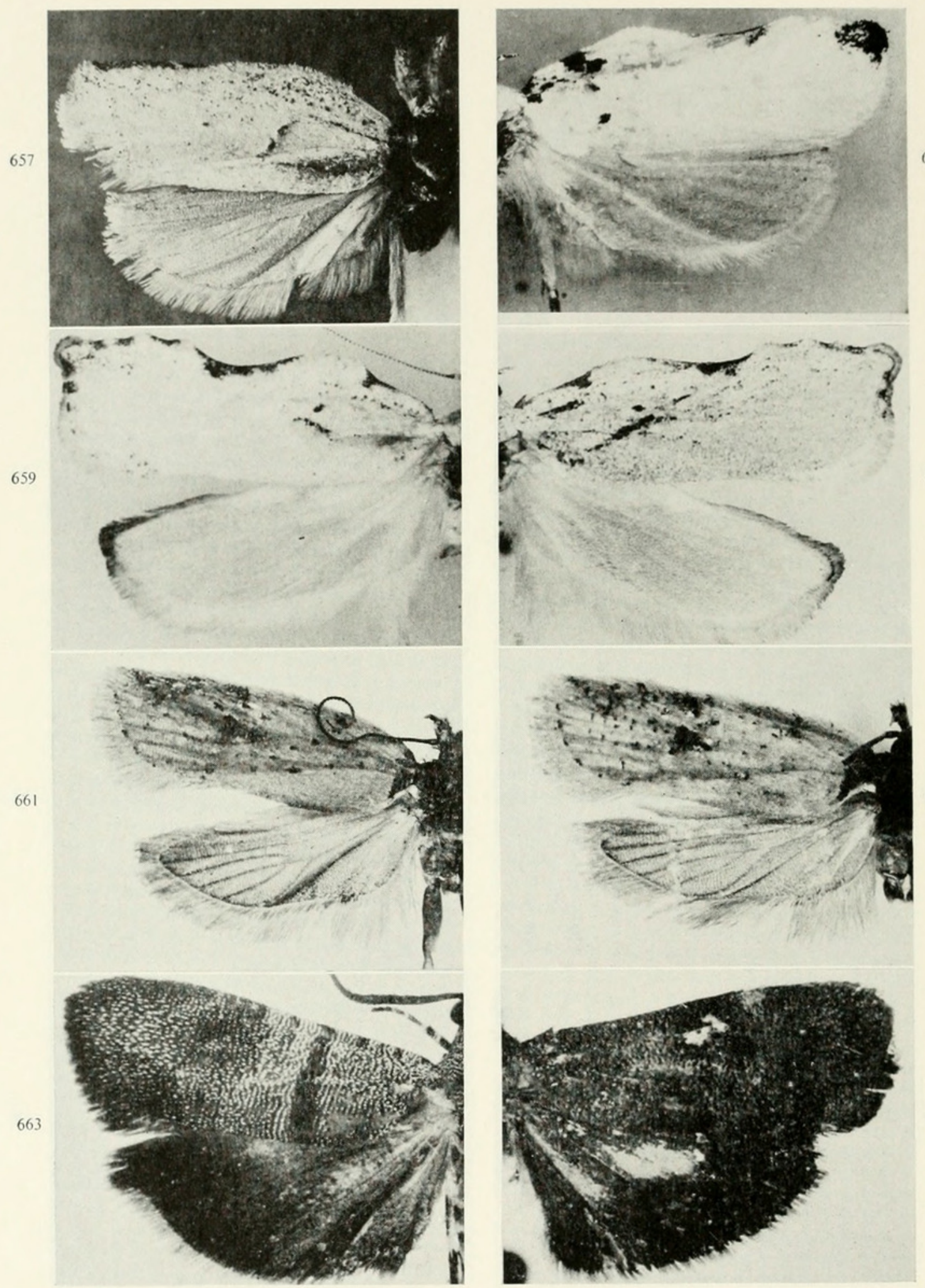

Figures 657-664.-Oecophoridae and Glyphipterygidae: 657, Tonica argessa, new species, q , holotype; 658, T. citrantha, new species, $q$, holotype; 659, T. lagaropis Meyrick, q ; 660, $\sigma^{7} ; 661$, Psorosticha neglecta, new species, $\sigma^{7}$, holotype; 662, $q$, allotype; 663, Phycodes minor Moore, $\sigma^{7} ; 664$, Sagalassa eubrachycera, new species, $\sigma^{7}$, holotype. 

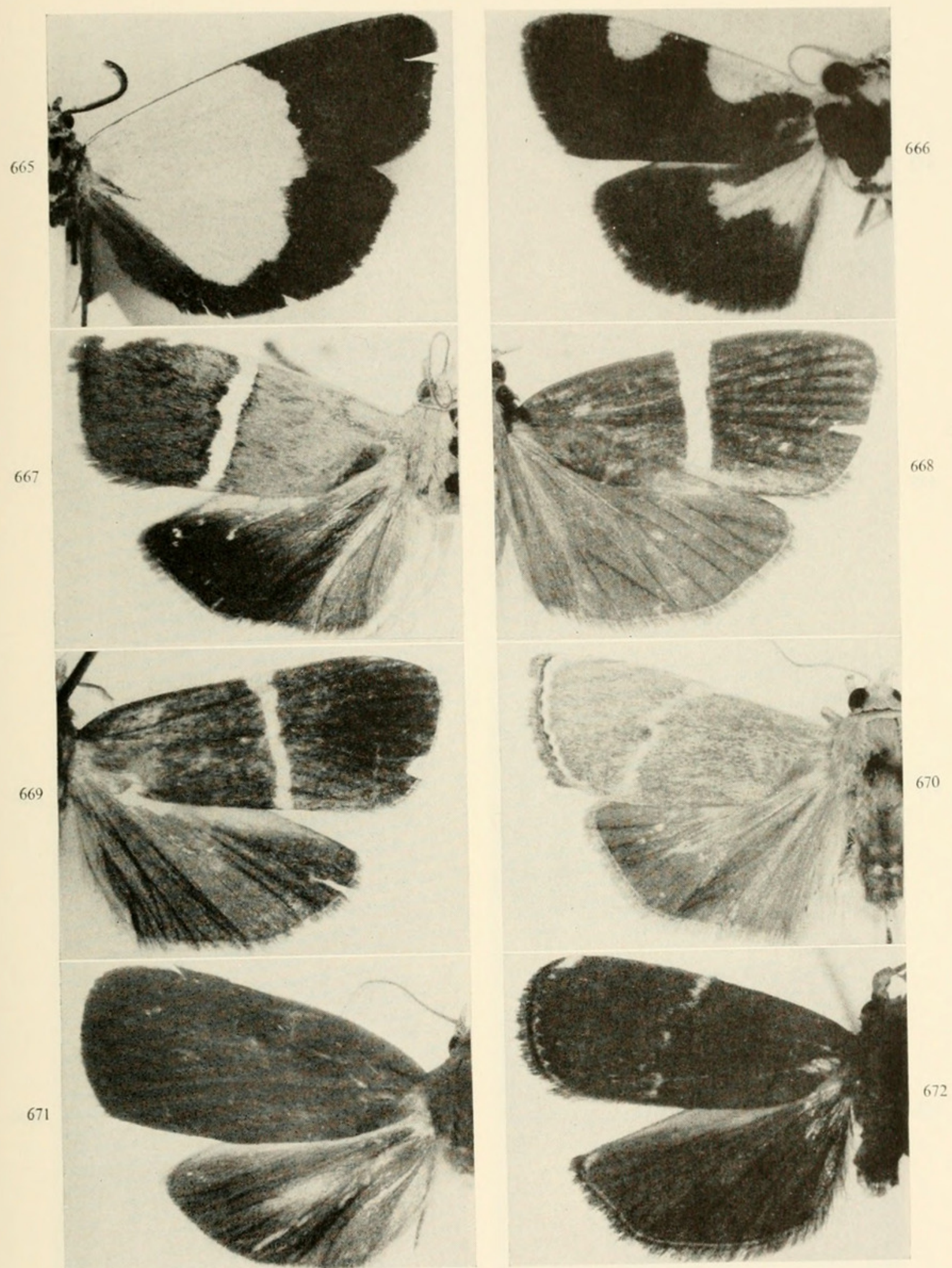

Figures 665-672.-Imma Walker: 665, Imma aurantiaca (Semper), o ; 666, I. chrysocosma, new species, $\%$, holotype; 667, I. albifasciella (Pagenstecher), + ; 668, I. macrochorda, new species, $\sigma^{7}$, holotype; 669, I. macrochorda regmophora, new subspecies, $\sigma^{7}$, holotype; 670 , I. poecilostoma, new species, $\sigma^{7}$, holotype; $671, I$. sarophora, new species, $\sigma^{7}$, holotype; $672, I$. pyragra, new species, $\sigma^{7}$, holotype. 

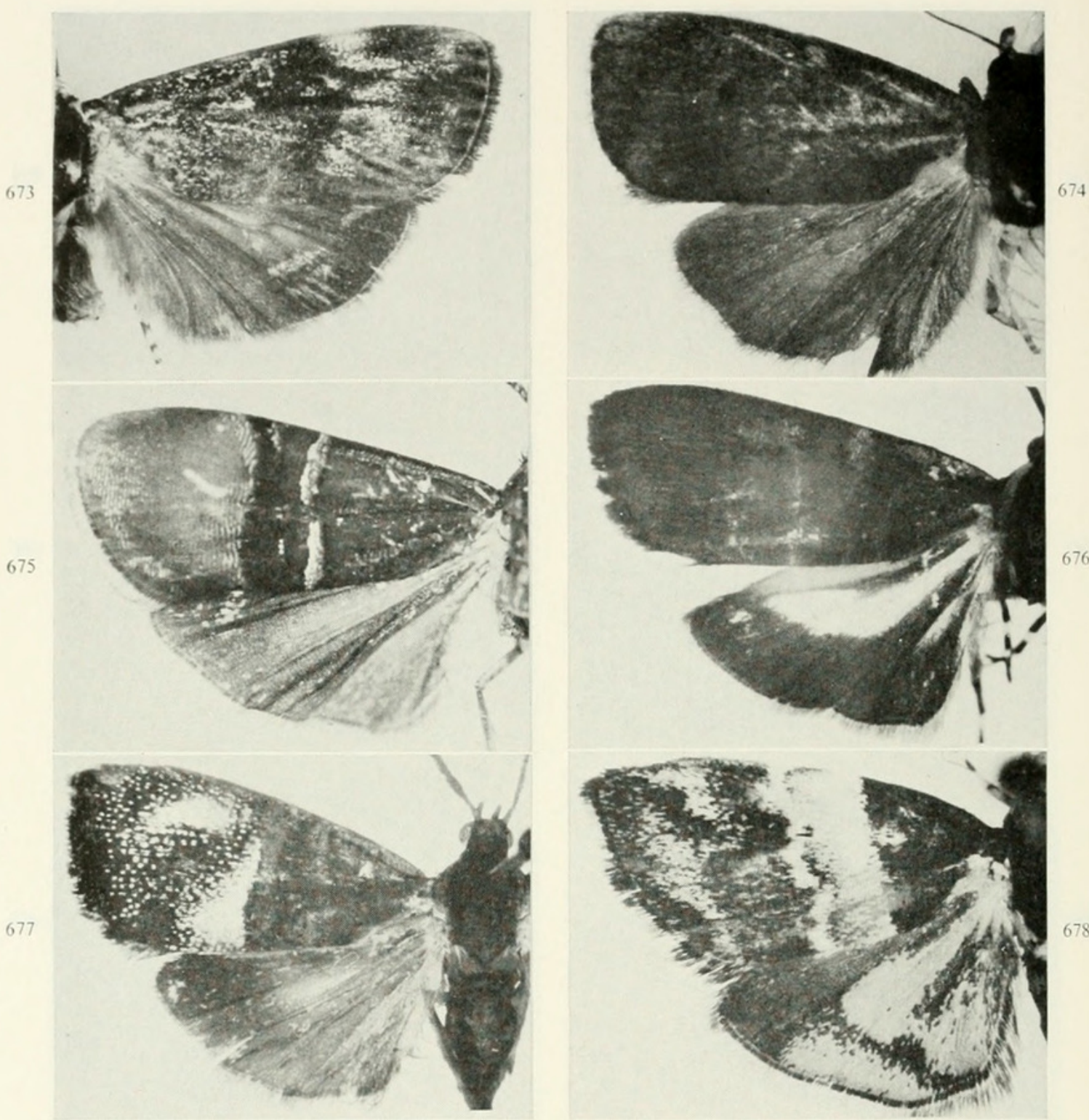

676
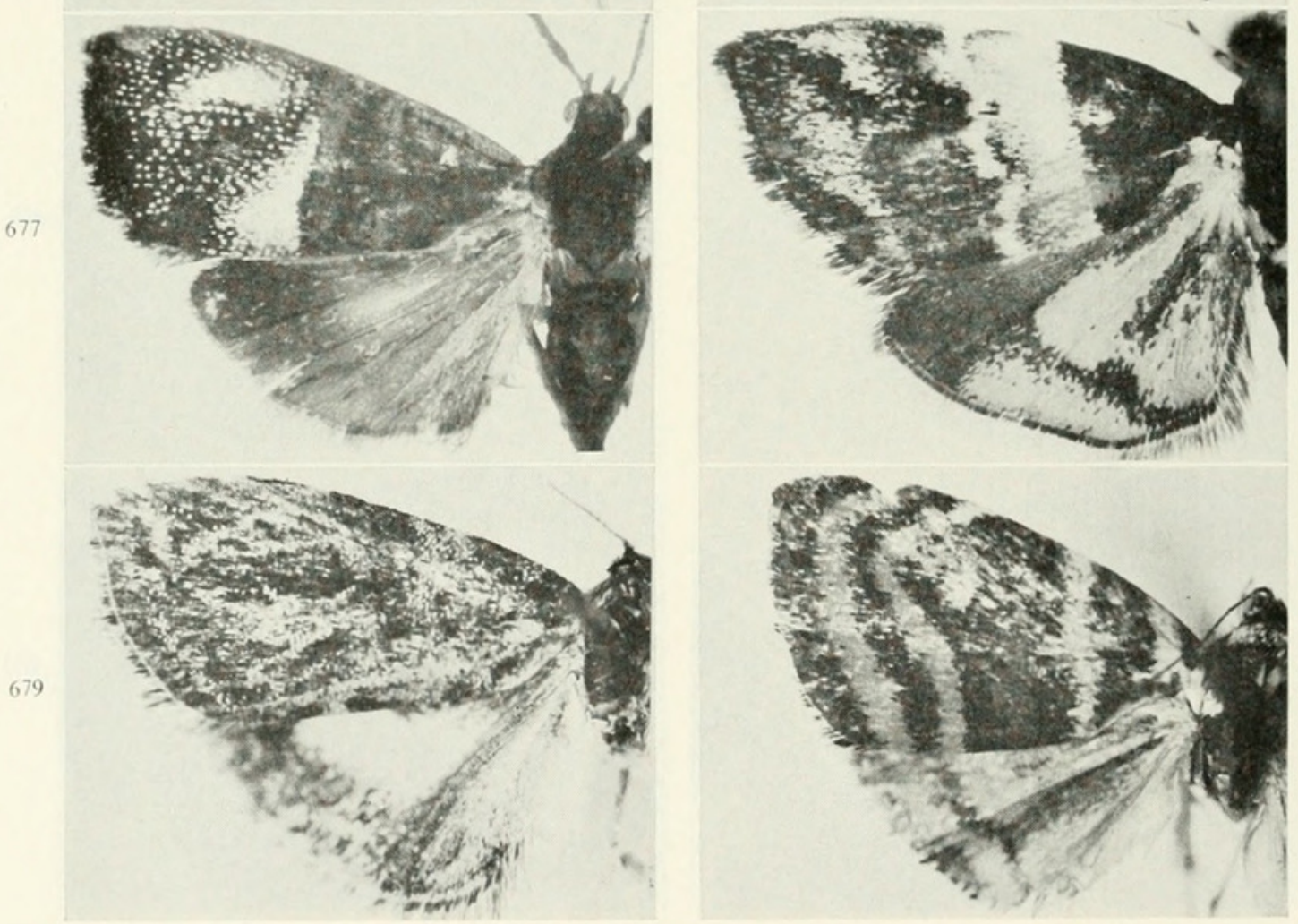

Figures 673-680.-Glyphipterygidae: 673, Imma tyrocnista Meyrick, $\sigma^{7} ; 674$, I. nephodryas Meyrick, $\sigma^{7} ; 675$, Tortyra elegans (Walsingham), $\sigma^{7} ; 676, T$. divitiosa (Walker), $\sigma^{7}$; 677, T. macrospila, new species, $q$, holotype; 678, Anthophila basalis (Felder), ơ; 679 , A. streptatma (Meyrick), ơ';680, A. angulosa, new species, \& , holotype. 

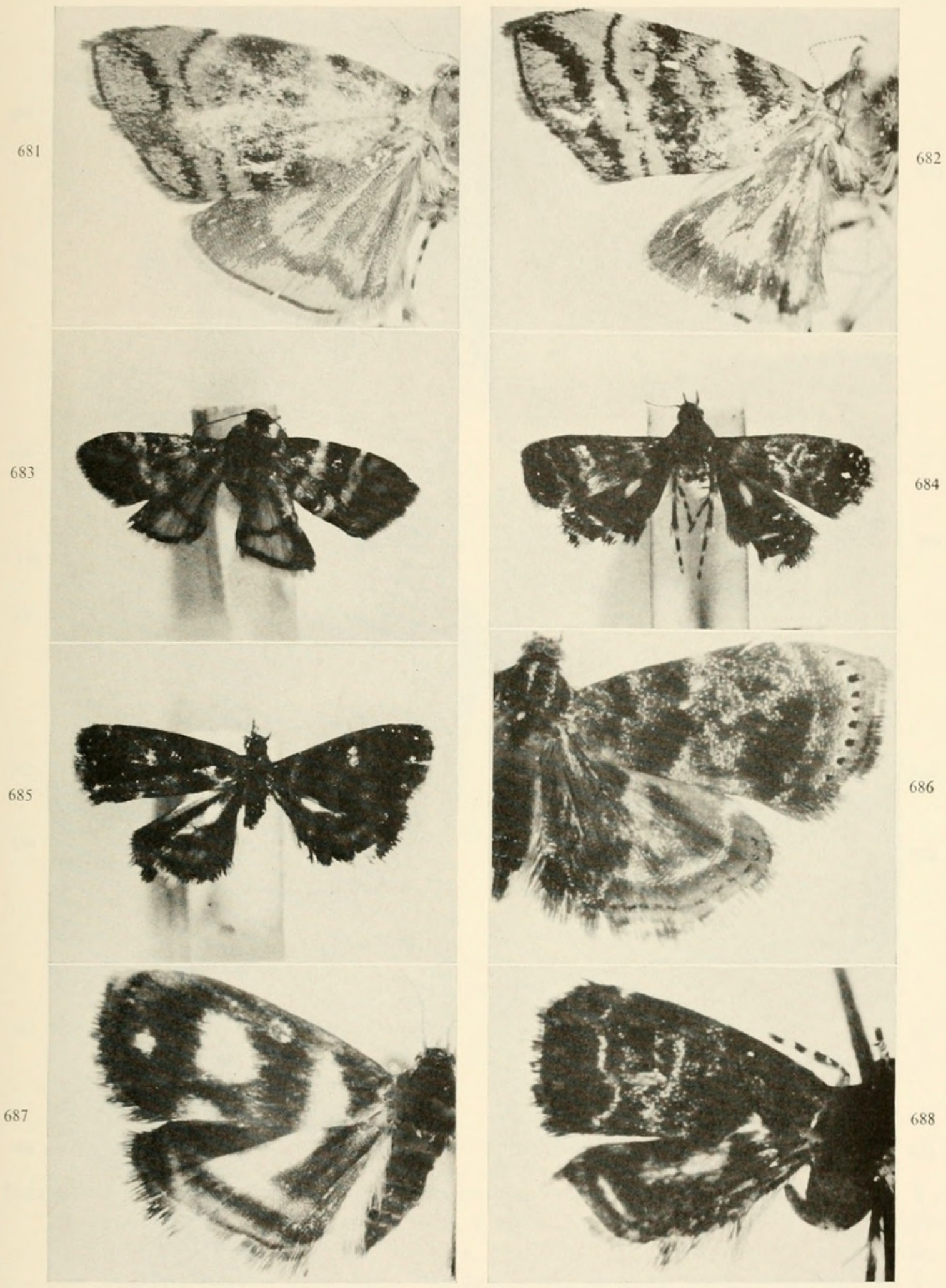

Figures 681-688.-Glyphipterygidae: 681, Anthophila amethystodes (Meyrick), \&, holotype; 682, $\sigma^{7}$, lectotype; 683, A. anthorma (Meyrick), $\%$, holotype; 684, Brenthia harmonica Meyrick, $q$, holotype; 685, B. trilampas Meyrick, + , holotype; 686, B. lithocrossa Meyrick, $\uparrow$ (Celebes); 687, B. albimaculana Snellen, $\uparrow$, holotype (Celebes); 688, Brenthia anisopa, new species, holotype, $\sigma^{7}$. [Figs. 683-685, by courtesy of the Trustees of the British Museum, Natural History.] 
689

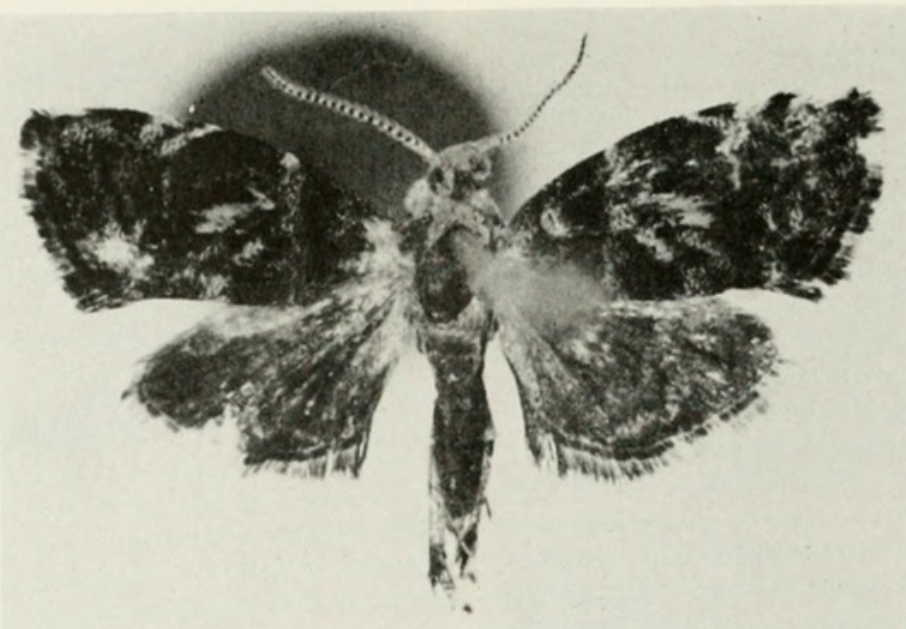

690
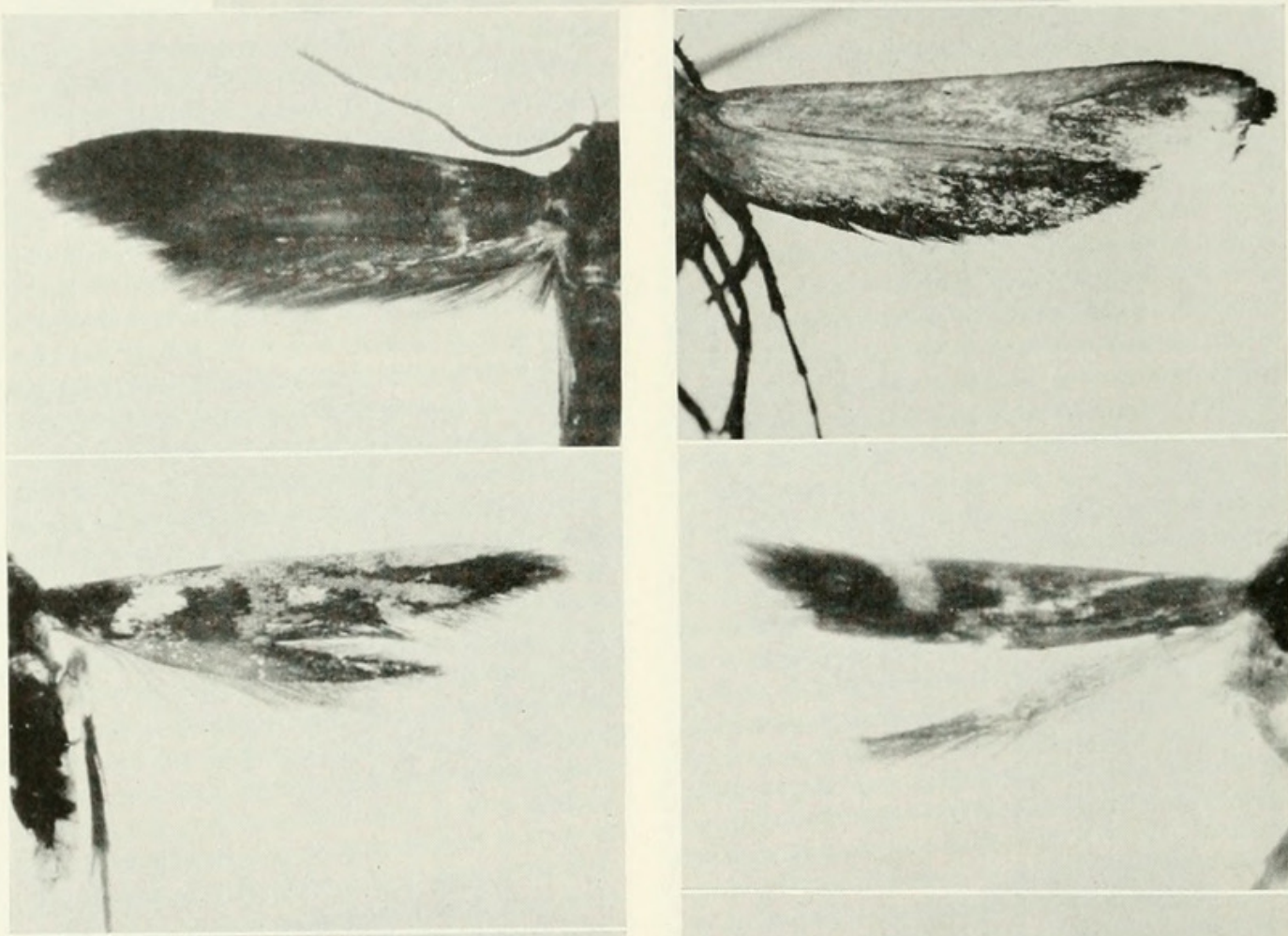

694
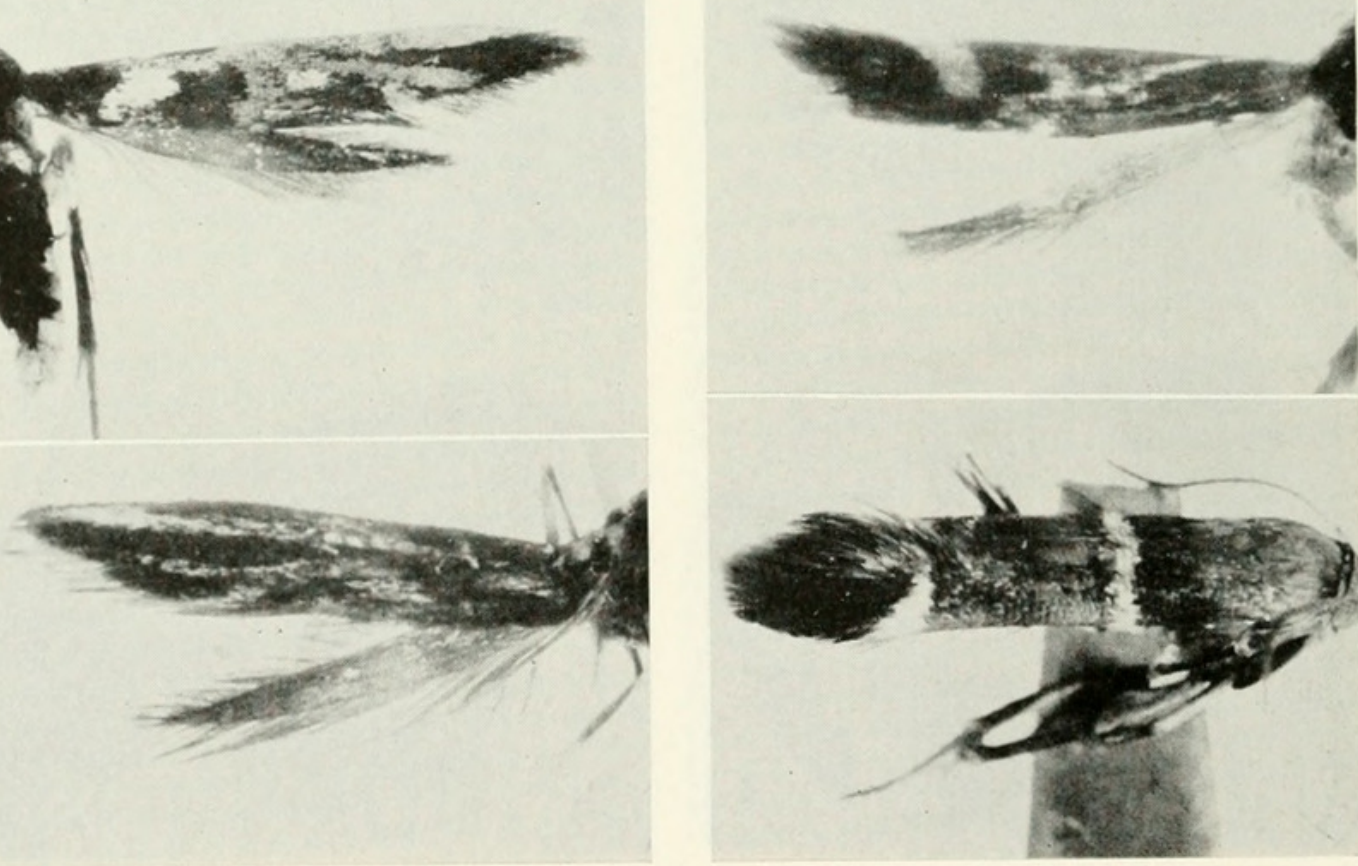

Figures 689-695.-Heliodinidae and Glyphipterygidae: 689, Choreutis sexfasciella (Sauber), + , holotype; 690, Aeoloscelis perigrapha, new species, + , holotype; 691, Thriambeutis coryphaea Meyrick, $\uparrow$, no. 5321; 692, Craterobathra ornata, new species, $\sigma^{7}$, holotype; 693, C. demarcata, new species, $\uparrow$, holotype; 694, C. argyracma, new species, ơ, holotype; 695, Xestocasis iostrota (Meyrick). [Fig. 689, by courtesy of Senckenberg Museum, Frankfurt a.M.] 
69

697

699

700

702

703

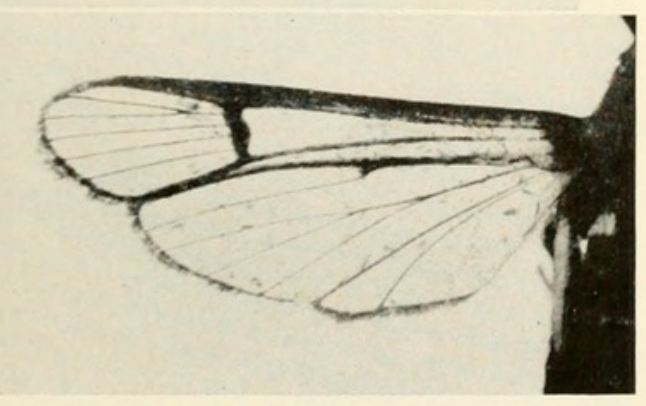

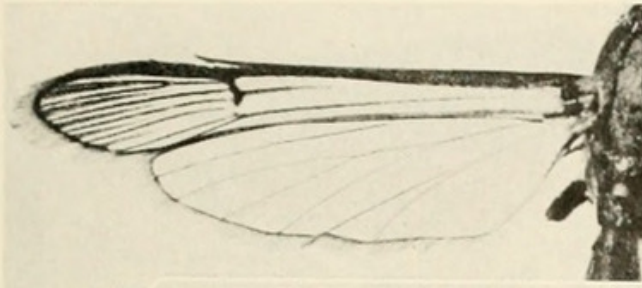

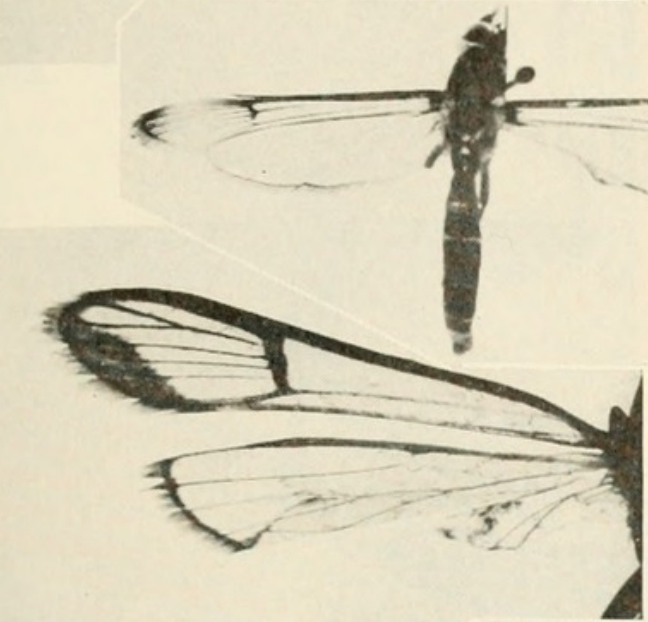

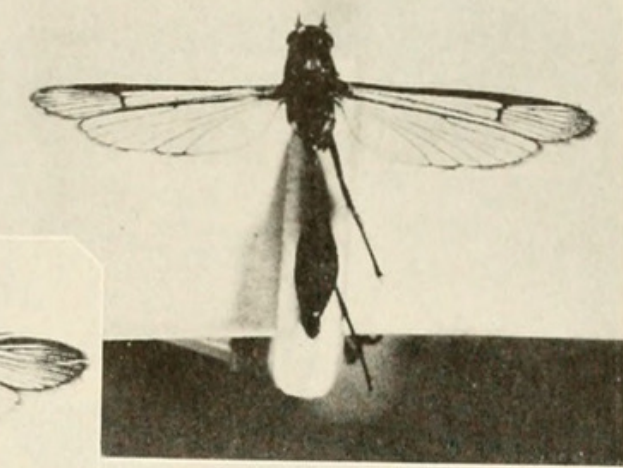

698

Figures 696-705.-Aegeriidae: 696, Sphecosesia melanostoma, new species, holotype, $q$, left pair of wings; 697, total aspect; 698, S. atarea Hampson, holotype, $q$; 699, Synanthedon cirrhozona, new species, holotype, $\sigma^{7} ; 700$, total aspect; 701, S. chrysostetha, new species, $\sigma^{\top}$, right pair of wings; 702, Lepidopodalutescens, new species, holotype, $?$, 703, left pair of wings; 704, Synanthedon sphenodes, new species, holotype, $\sigma^{7} ; 705$, right pair of wings. [Fig. 698, by courtesy of the Trustees of the British Museum, Natural History.] 

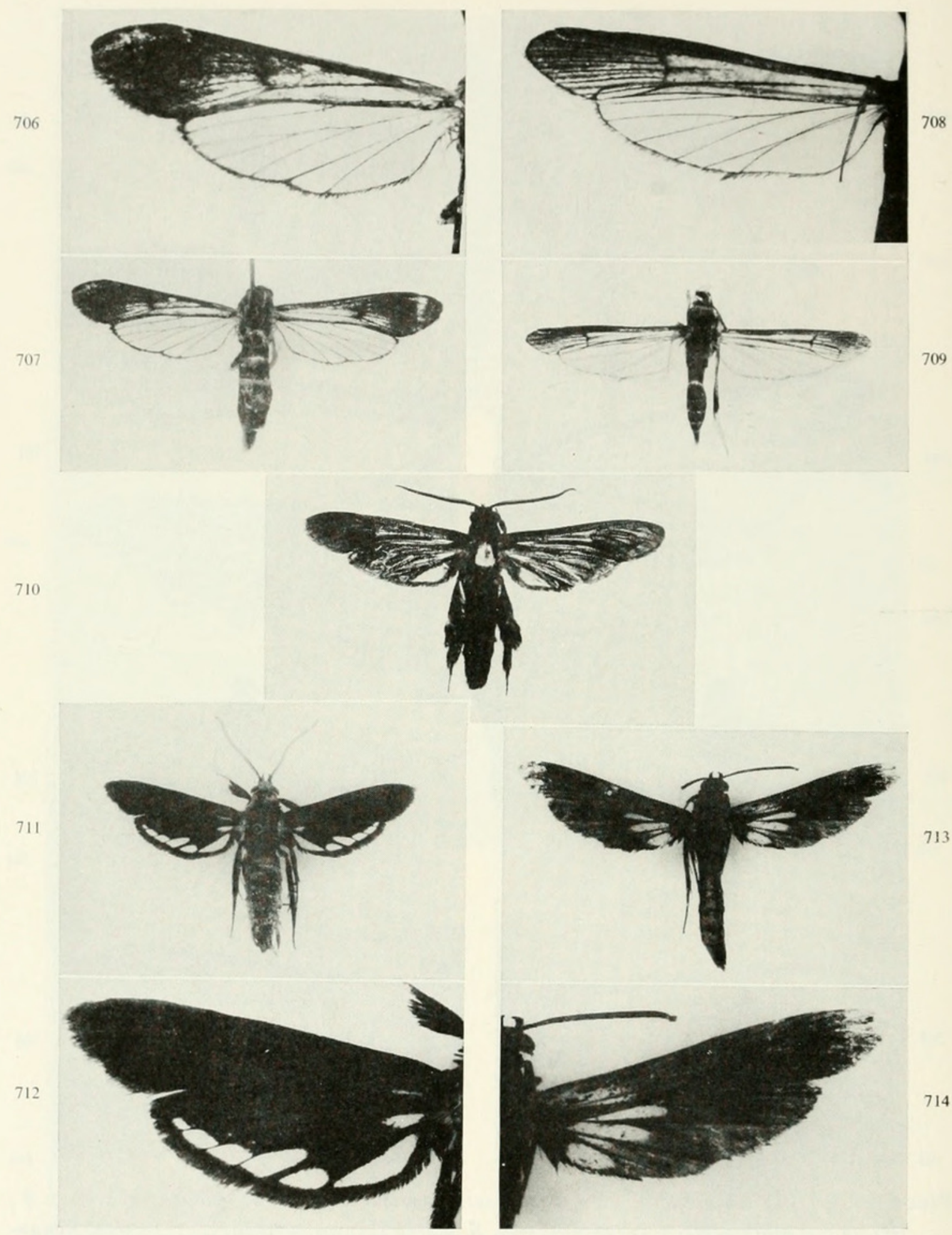

Figures 706-714.-Aegeriidae: 706, Glossosphecia pelocroca, new species, holotype, $q$, left pair of wings; 707, total aspect; 708, G. micans, new species, holotype, $\uparrow$, left pair of wings; 709, total aspect; 710, Trilochana triscoliopsis Rothschild, holotype, $q$; 711, Sura cyanolampra, new species, holotype, $q ; 712$, left pair of wings; 713, S. tetrapora, new species, holotype, $q ; 714$, right pair of wings. [Fig. 710, by courtesy of the Trustees of the British Museum, Natural History.] 
715
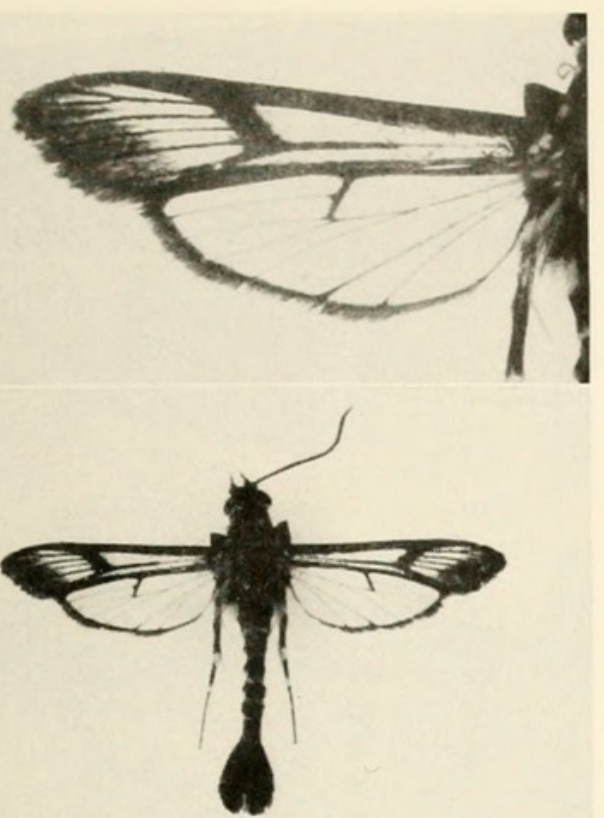

719

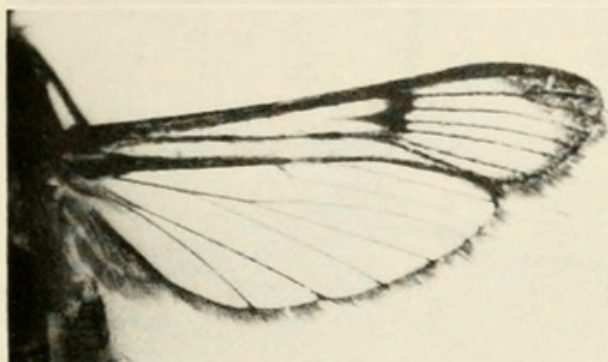

721

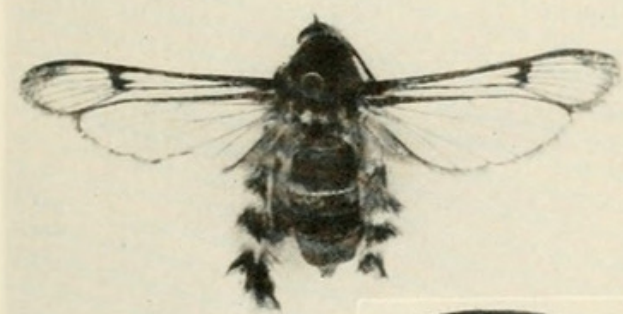

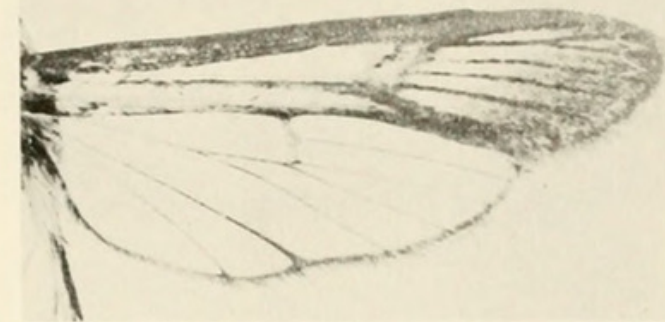

716
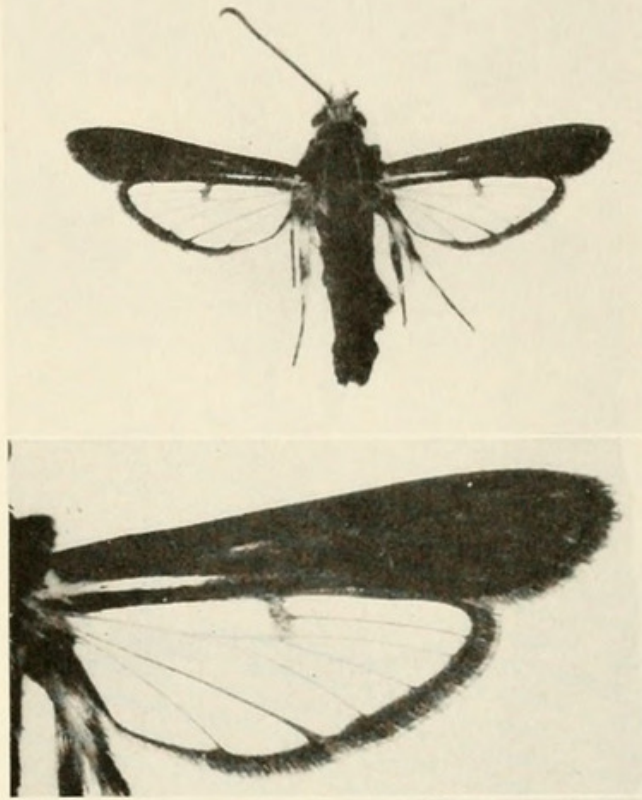

720

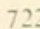

723

Figures 715-723.-Aegeriidae: 715, Paranthrene heterodesma, new species, holotype, $\sigma^{7}$, left pair of wings; 716 , allotype, $q$, right pair of wings; 717 , holotype, $\sigma^{7}$, total aspect; 718, $P$. poecilocephala, new species, holotype, $\sigma^{7} ; 719$, Melittia gigantea Moore, $q$, right pair of wings; $720, P$. poecilocephala, right pair of wings; $721 \mathrm{M}$. gigantea, total aspect; 722, Melittia siamica Walker, $q$; 723, left pair of wings. 

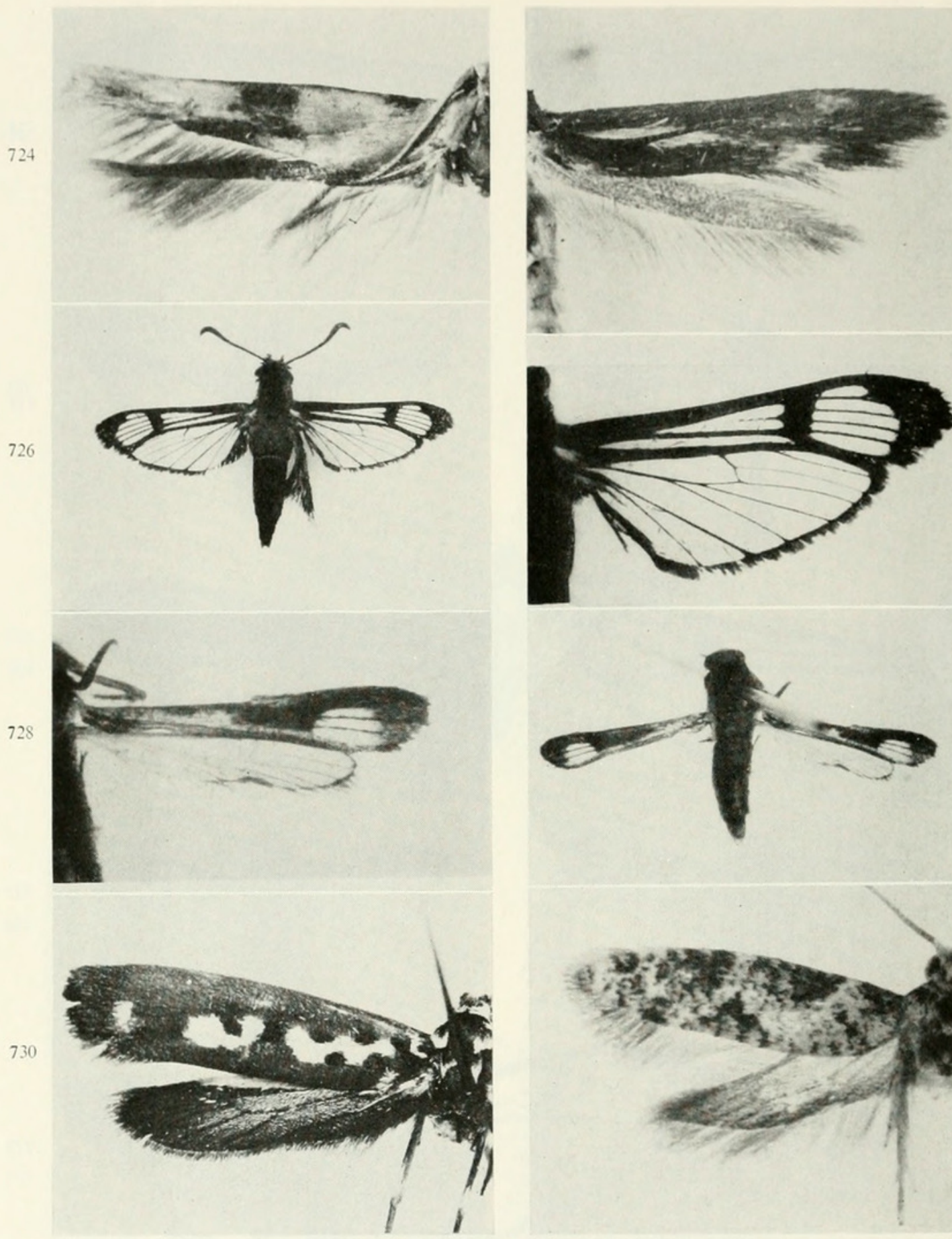

Figures 724-731.- - Heliodinidae, Aegeriidae, and Yponomeutidae: 724, Stathmopoda piacida Meyrick, $\sigma^{7}$, slide no. 5135; 725, Eretmocera percnophanes Meyrick, $\sigma^{\top}$ (Negros); 726, Melittia eurytion (Westwood), \& , 727, right pair of wings; 728, Bembecia fortis, new species, holotype, $\sigma^{7}$, right pair of wings; 729 , general aspect; 730 , Yponomeuta interruptella (Sauber), o ; 731, Prays endolemma, new species, holotype. $\sigma^{7}$. 

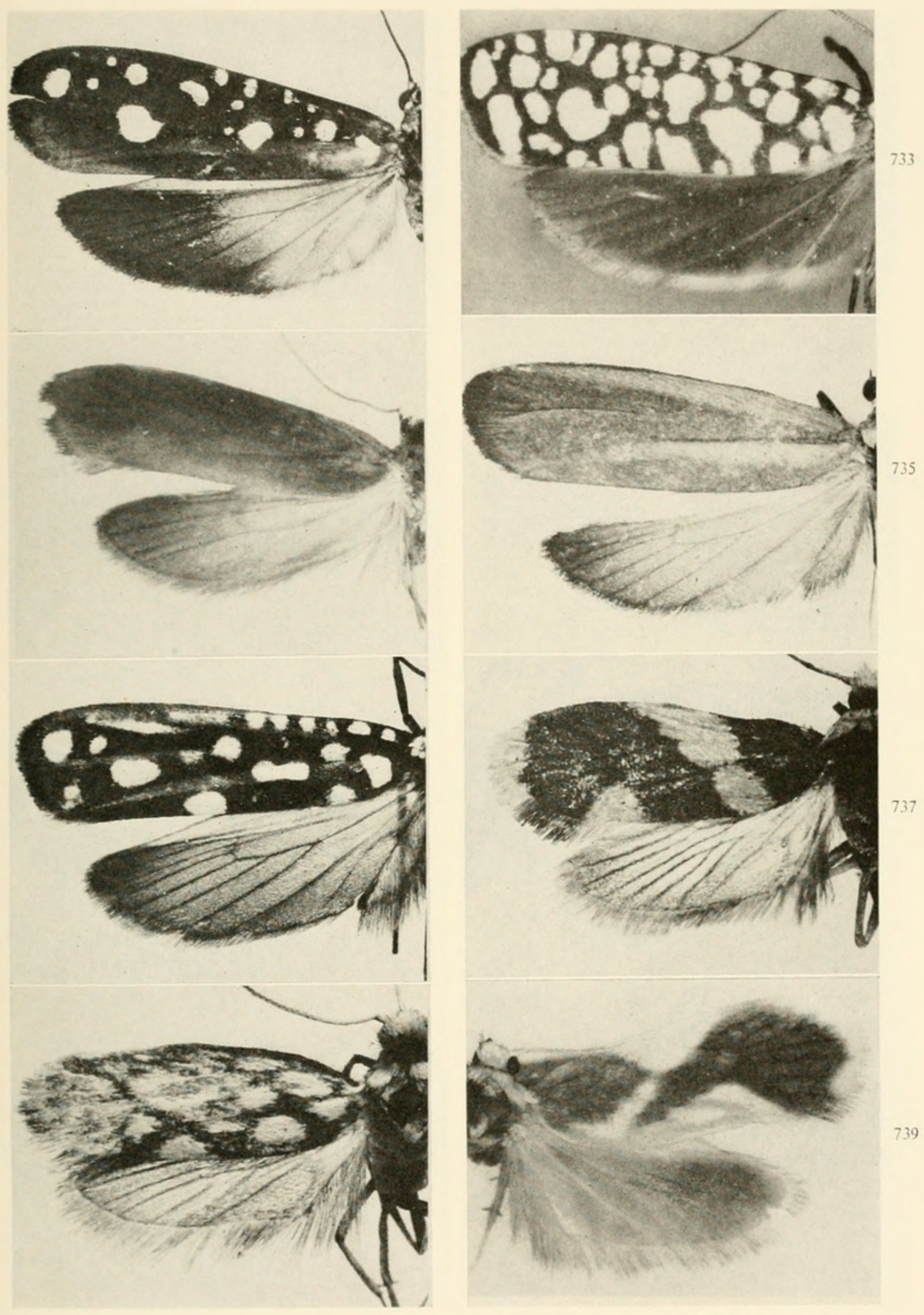

Figures 732-739.-Y ponomeutidae: 732, Atteva triplex, new species, holotype, $+, 733, A$. brucea Moore, o (Java); 734, A. holenopla, new species, holotype, $+; 735, A$. scolecias Meyrick, $\uparrow ; 736, A$. balanota Meyrick; 737, Anticrates rutilella (Pagenstecher), ơ' $738, A$. digitosa, new species, holotype, $\sigma^{7} ; 739, A$. denticulata, new species, holotype, $\sigma^{7}$. 
740
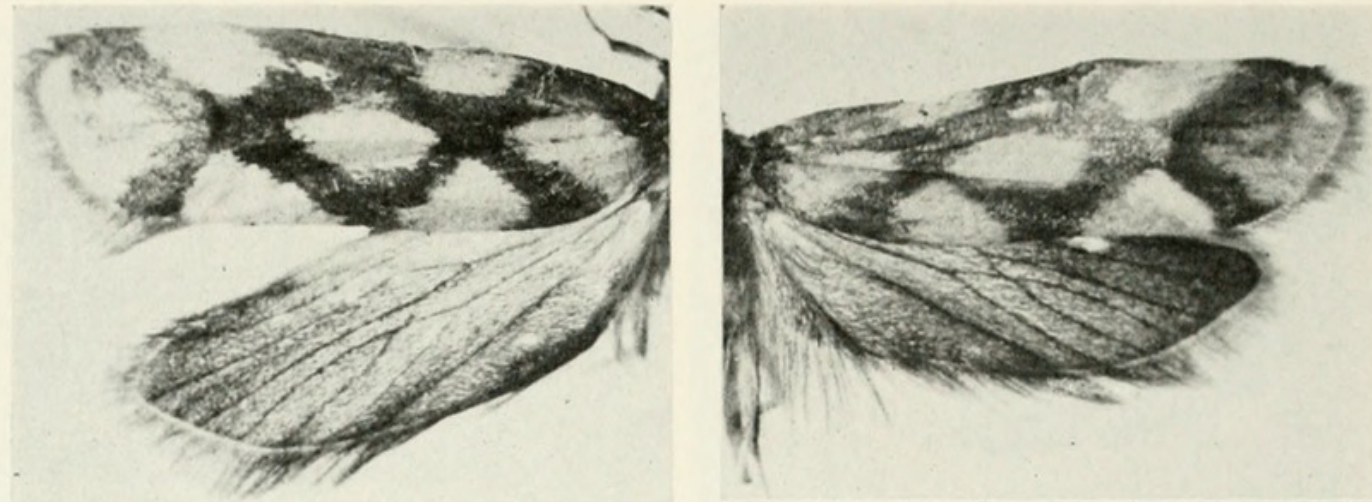

741

742

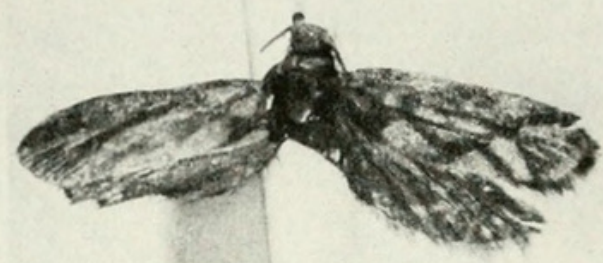

.1 लिख्य

Tats
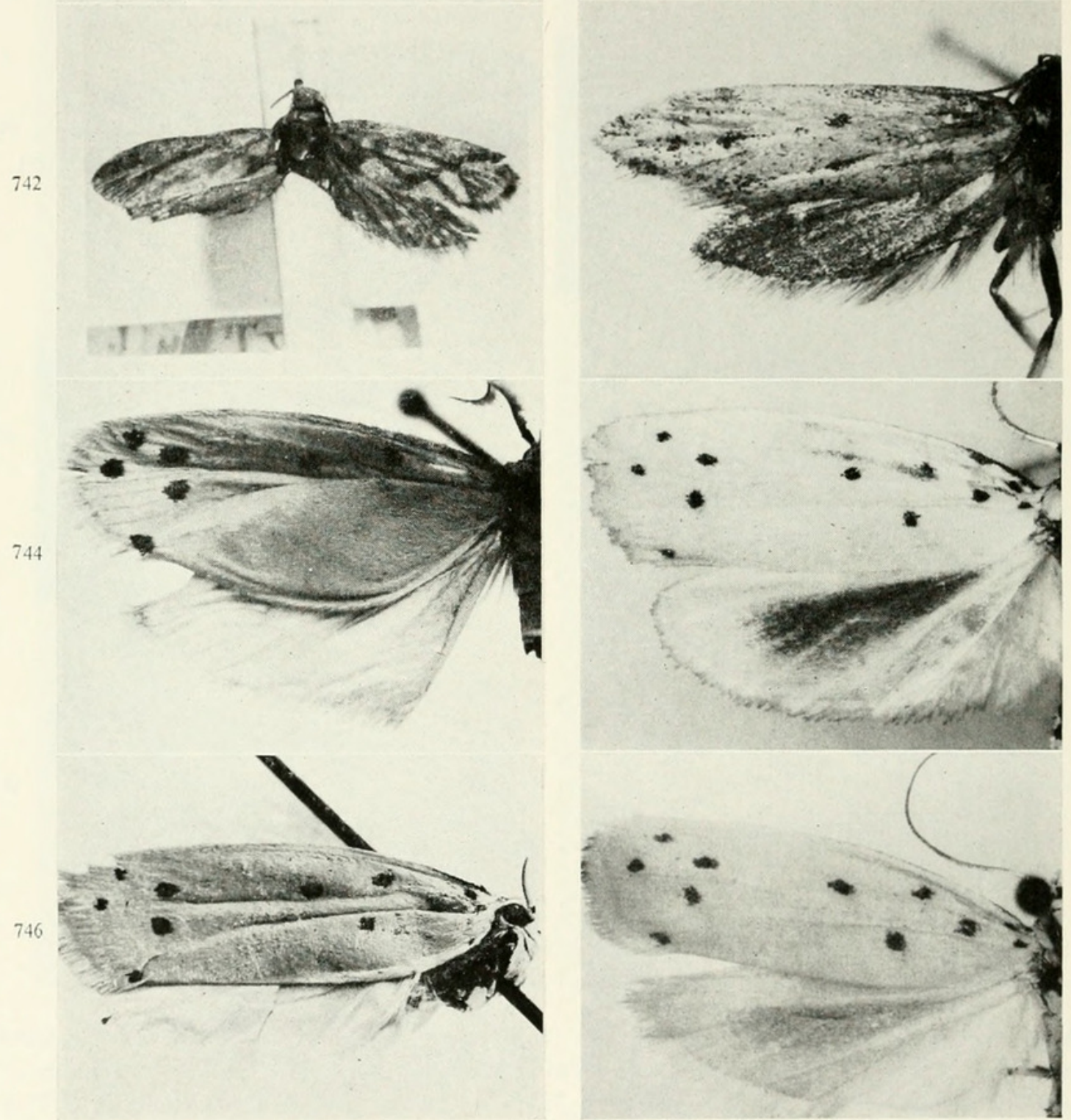

Figures 740-747.- Y Y ponomeutidae and Ethmiidae: 740, Anticrates rhodometra, new species, holotype, $\sigma^{7} ; 741$, allotype, $+; 742, A$. paratarsa Meyrick, lectotype, $q ; 743$, Protorhiza cyanosticta, new species, holotype, $+; 744$, Agrioceros platycypha Meyrick, ơ ; 745, q ; 746, A. magnificella (Sauber), o'; 747, ९. [Fig. 742, by courtesy of the Trustees of the British Museum, Natural History.] 

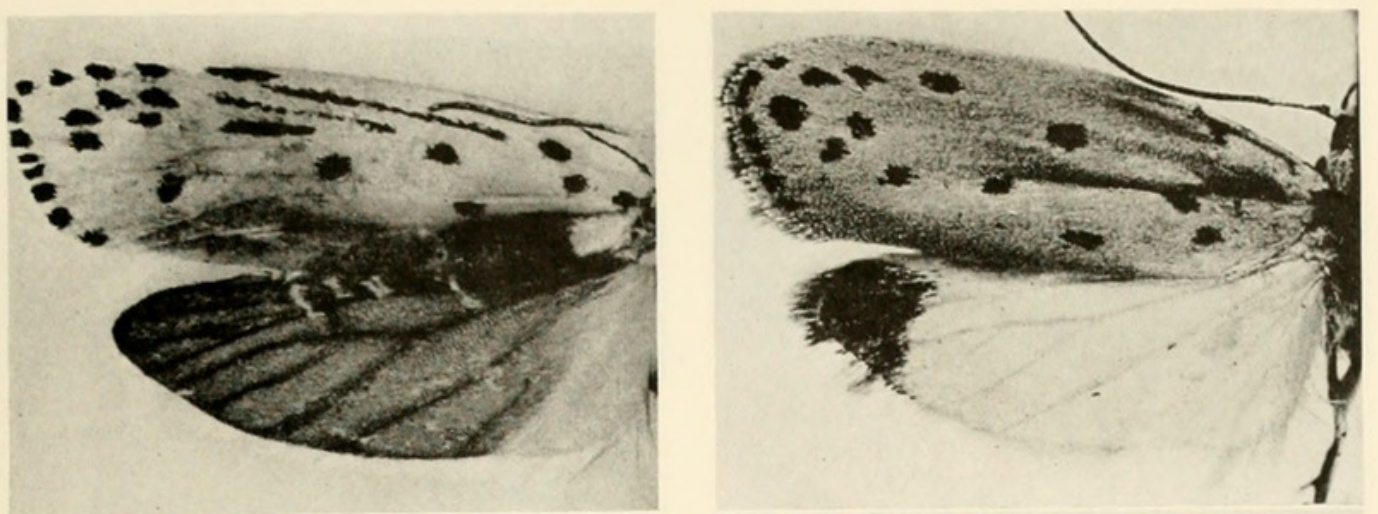

749
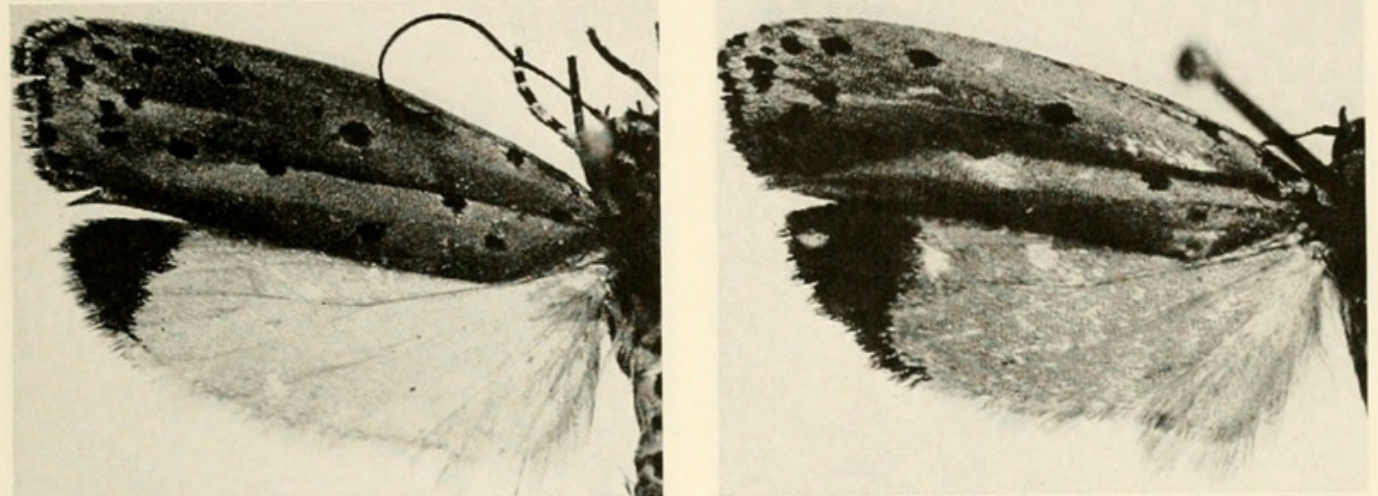

751

752
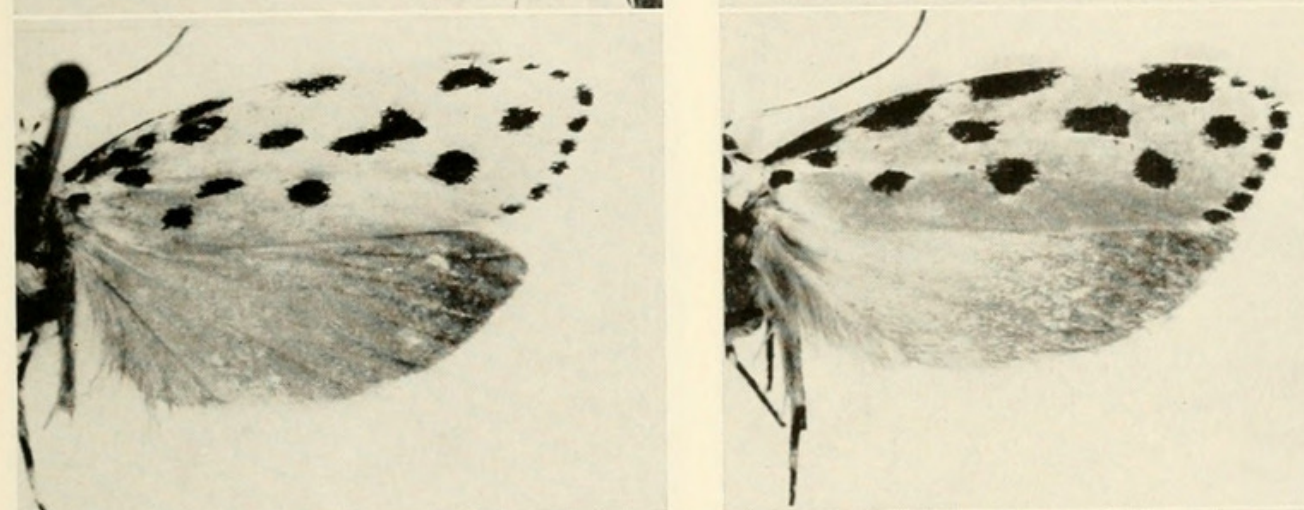

753

754
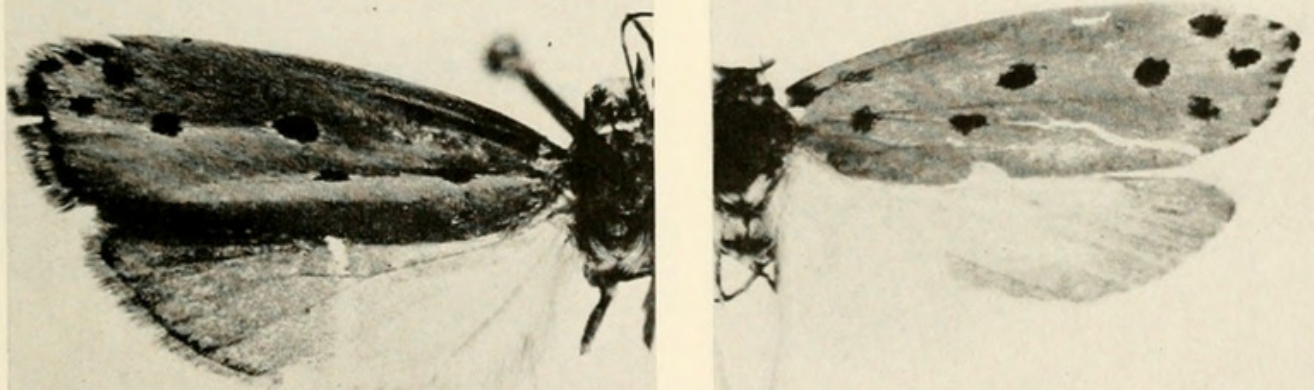

755

Figures 748-755.-Ethmia Hübner: 748, E. palawana Schultze, + ; 749, E. praeclara Meyrick, \% ; 750, E. colonella Walsingham, $q ; 751$, E. dentata, Diakonoff and Sattler, allotype, †; 752, E. c. crocosoma Meyrick, † (Formosa); 753, E. c. resignata, new subspecies, holotype, $q ; 754, E$. nobilis, new species, holotype, $+; 755$, E. reposita, new species, holotype, $\uparrow$. [Fig. 748, courtesy of the Zoological Museum, Copenhagen.] 


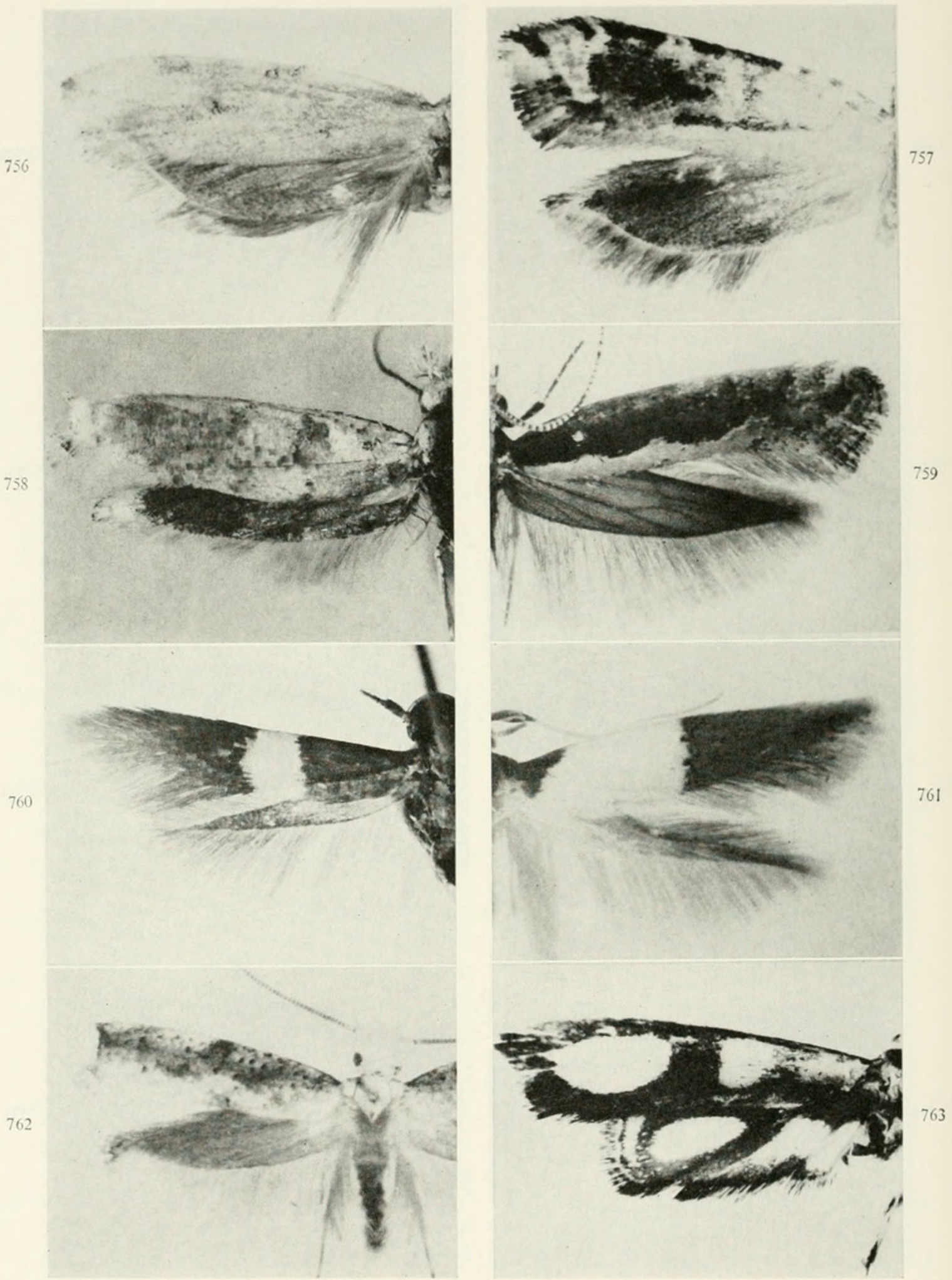

Figures 756-763.-Plutellidae and Lyonetiidae: 756, Harpeptila corethrodes, new genus, new species, holotype, $\sigma^{7} ; 757, H$. prasina, new genus, new species, holotype, $\sigma^{7}$; 758, Acrocenotes niphochrysa, new genus, new species, holotype, $\sigma^{7} ; 759$, Plutella maculipennis (Curtis), o7 (Europe); 760, Opogona flavofasciata (Stainton), \& (Celebes); 761, O. dimidiatella Zeller, ơ (Java); 762, Decadarchis minuscula (Walsingham), ơ (Java); 763, Placanthes xanthomorpha Meyrick, holotype, o'. [Fig. 763, by courtesy of the Trustees of the British Museum, Natural History.] 

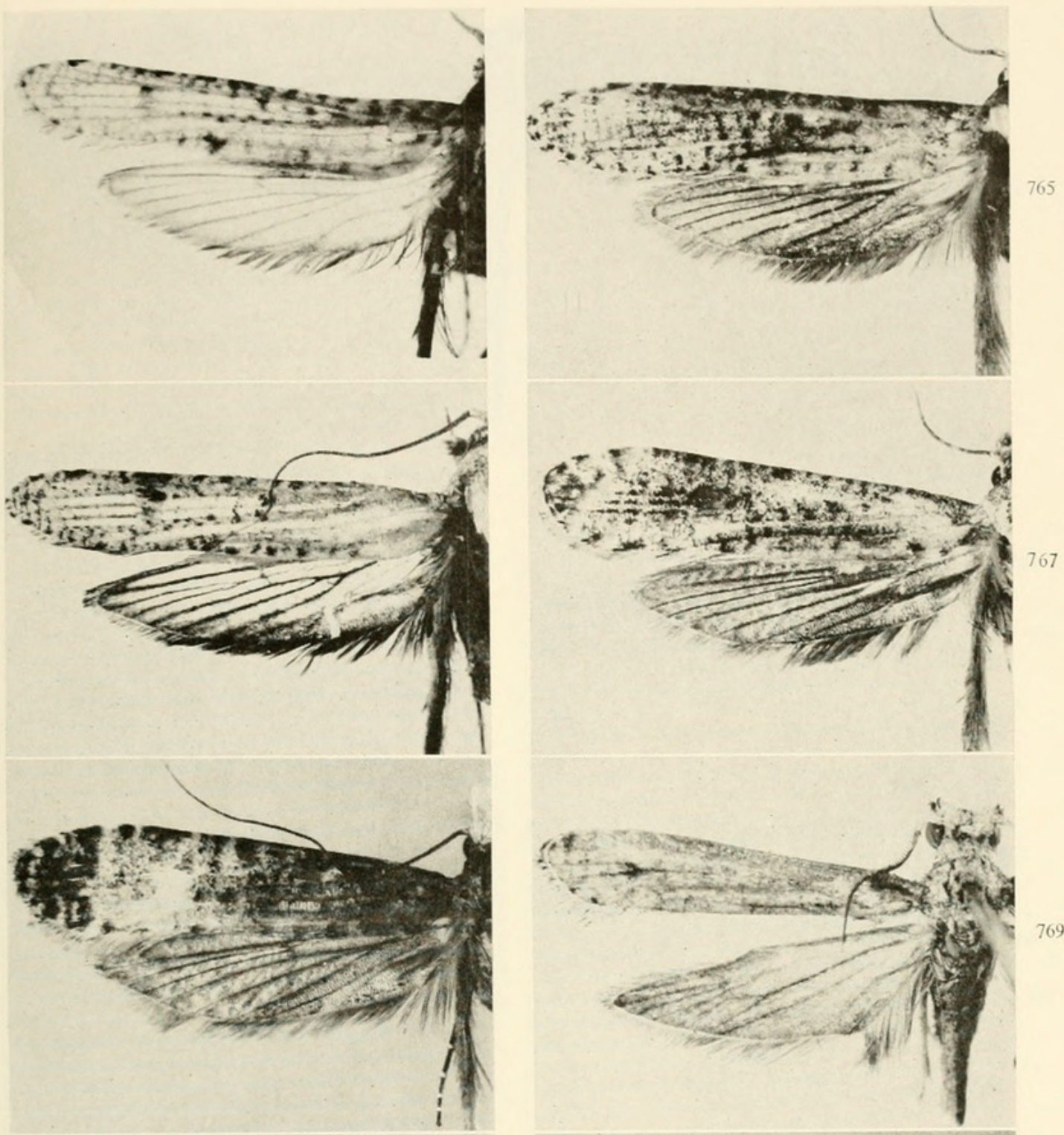

770
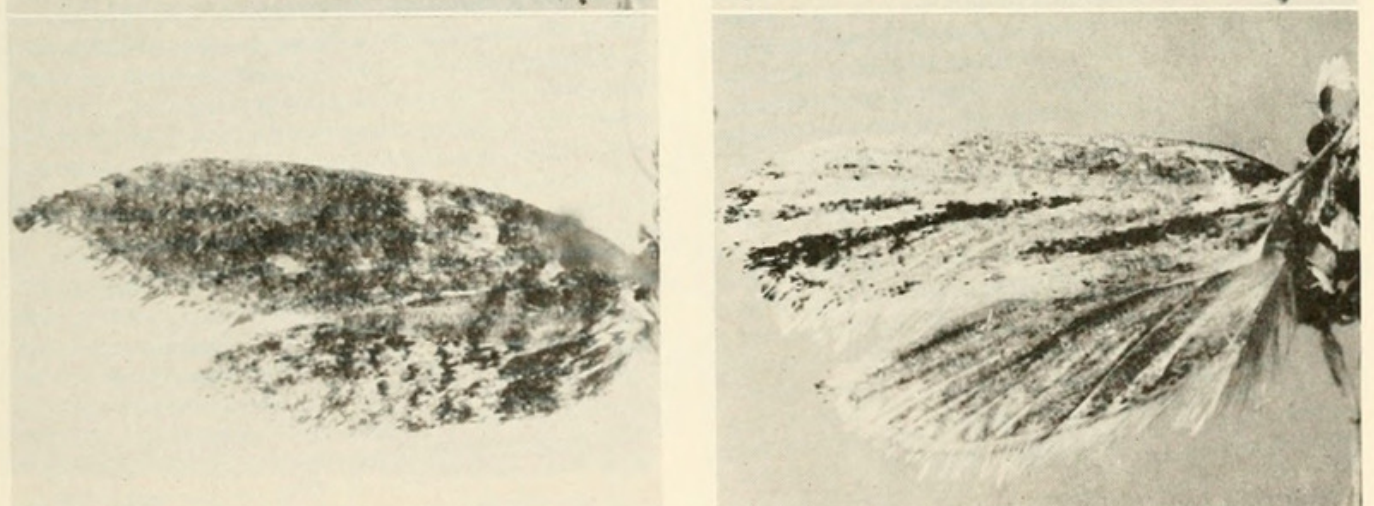

Figures 764-771.-Tineidae: 764, Gerontha captiosella Walker, $\sigma^{7} ; 765$, G. c. capna, new form, q, holotype; 766, G. monostigma, new species, holotype, + ; 767, G. diascopa, new species, q, holotype; 768, G. nivicaput, new species, holotype, $q$; 769, Harmaclona tephrantha (Meyrick), $\sigma^{7} ; 770$, Holacarta chalcatra, new species, holotype, $7 ; 771$, Exaxa rectilinea, new species, holotype, $\uparrow$. 


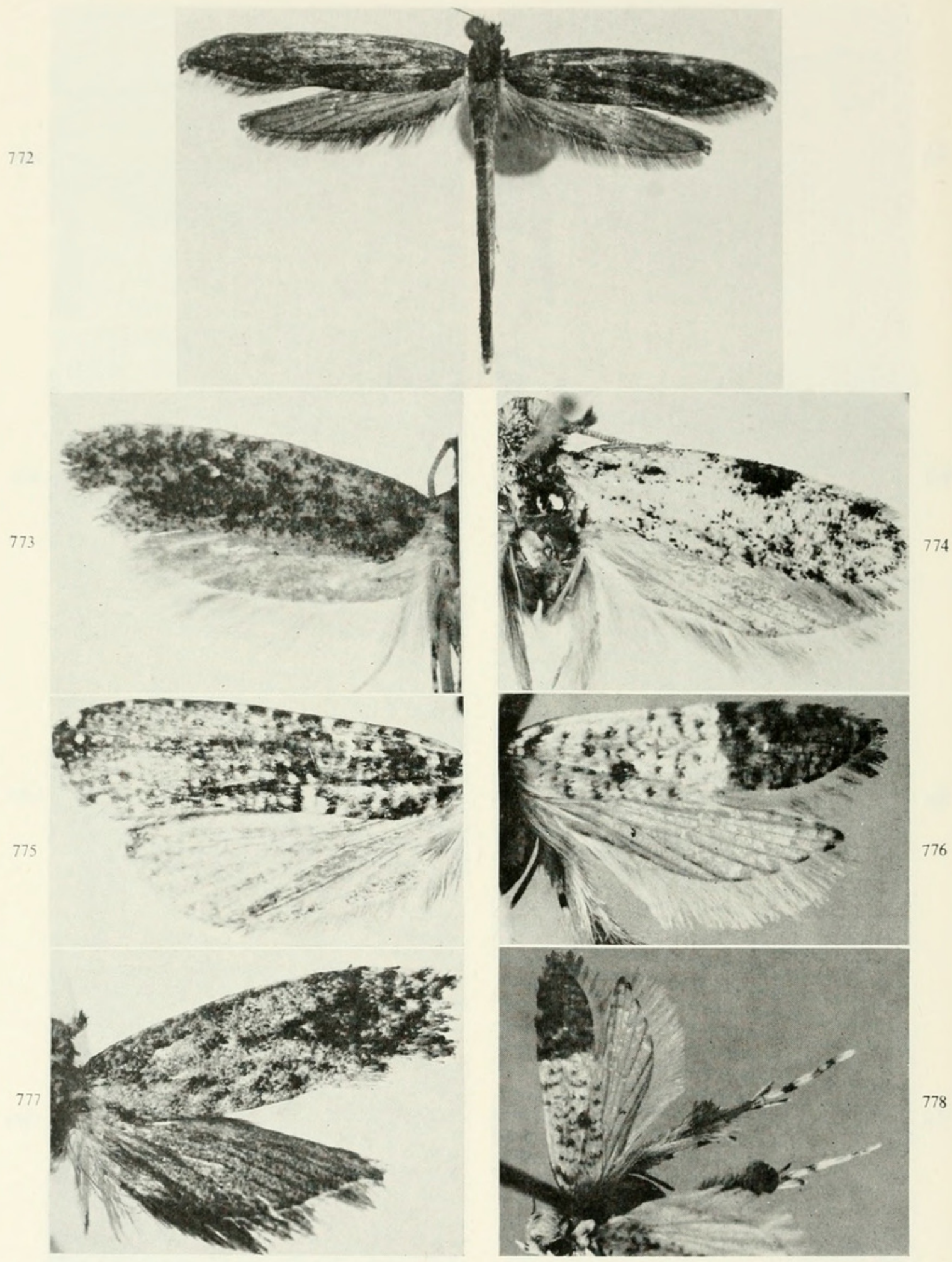

Figures 772-778.-Tineidae: 772, Ischnuridia virginella Sauber, holotype, $q$; 773, Setomorpha rutella Zeller, ơ, (Java); 774, Hapsifera albescens, new species, holotype, $\&$, 775, Tinissa torvella Walker, + ; 776, T. baliomicta Meyrick, ơ; 777, Trachycentra cicatricosa Meyrick, q, holotype; 778, Tinissa baliomicta Meyrick, total aspect of right side. [Fig. 772, by courtesy of Senckenberg Museum, Frankfurt a. M.; fig. 778, of Muséum Nationale d'Histoire Naturelle, Paris.] 

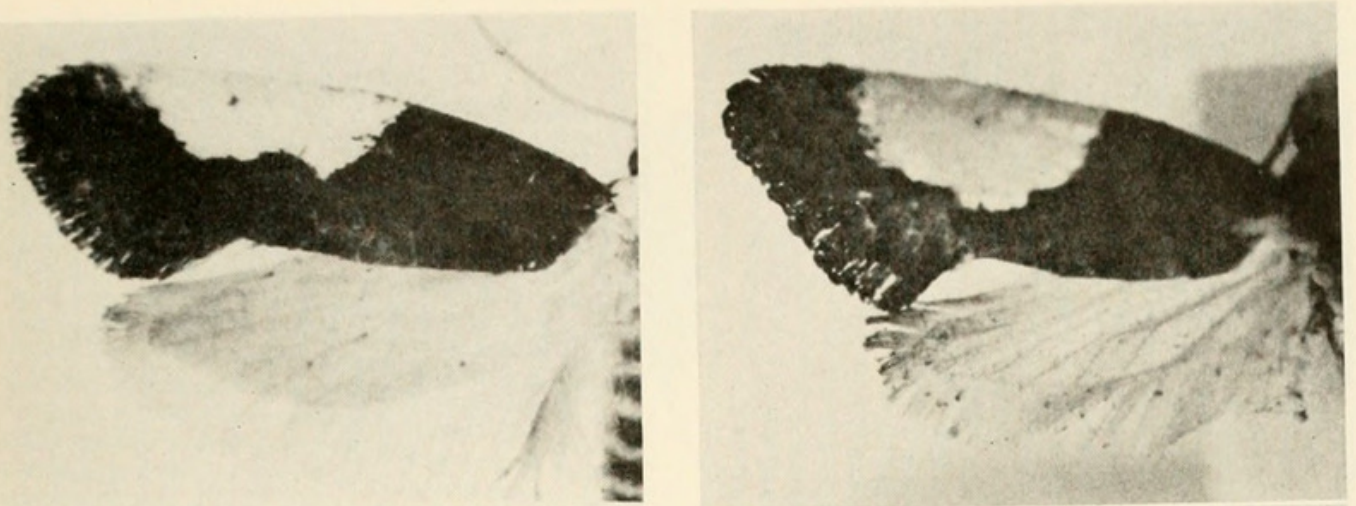

780

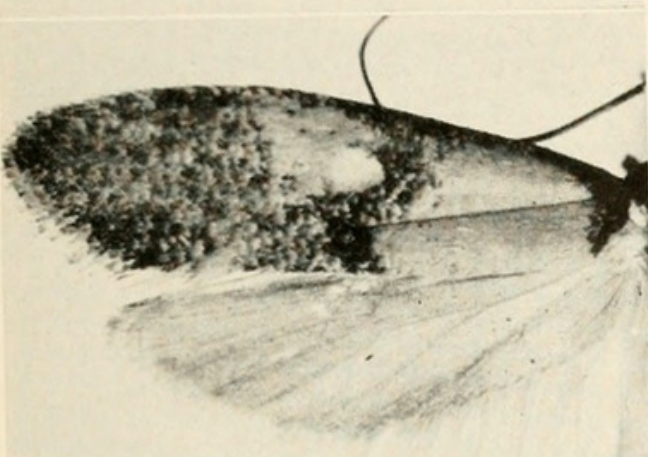

783
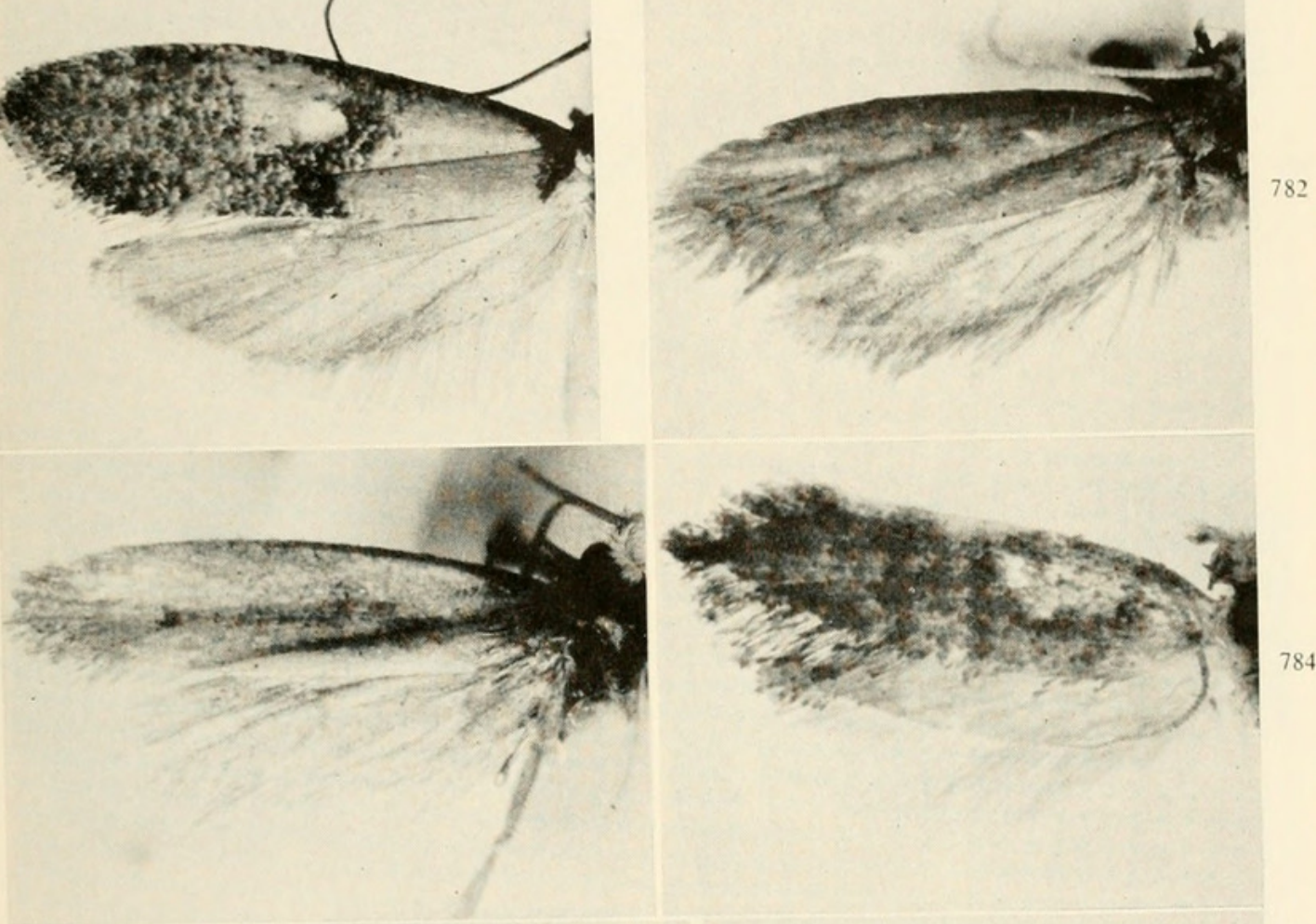

782
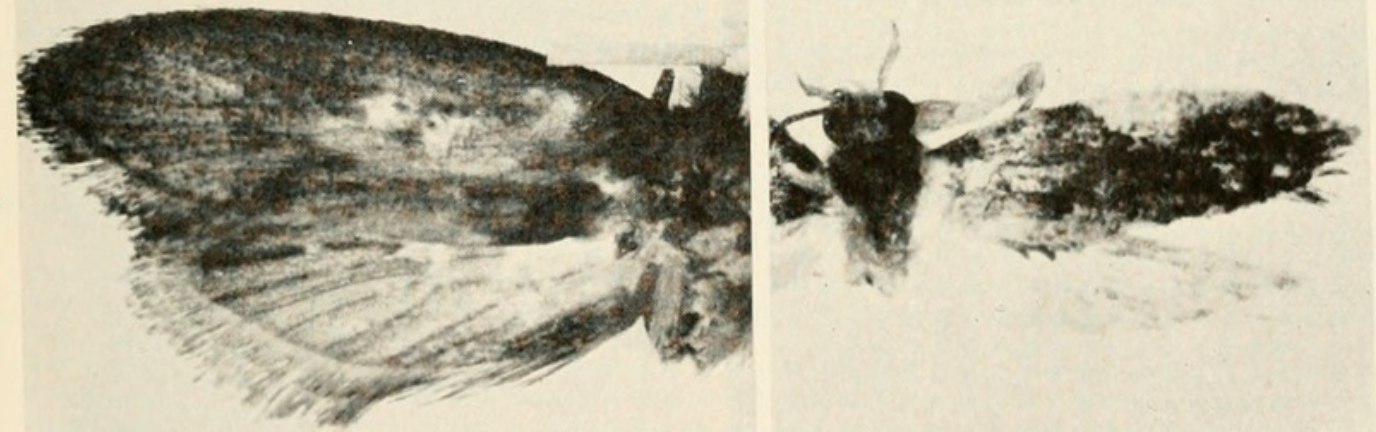

Figures 779-786. - Tineidae: 779, Monopis monachella (Hübner), $q ; 780$, M. hemicitra Meyrick, क ; 781, M. avara Meyrick, $\sigma^{7} ; 782$, Haplotinea subochraceella (Walsingham), ; 783, H, nestoria (Meyrick), lectotype, $\sigma^{7} ; 784$, Oxytinea galactodelta, new species, allotype, $+; 785$, H. eurycera, new species, holotype, $\sigma^{7} ; 786,0$. galactodelta, new species, holotype, $\sigma^{7}$. 

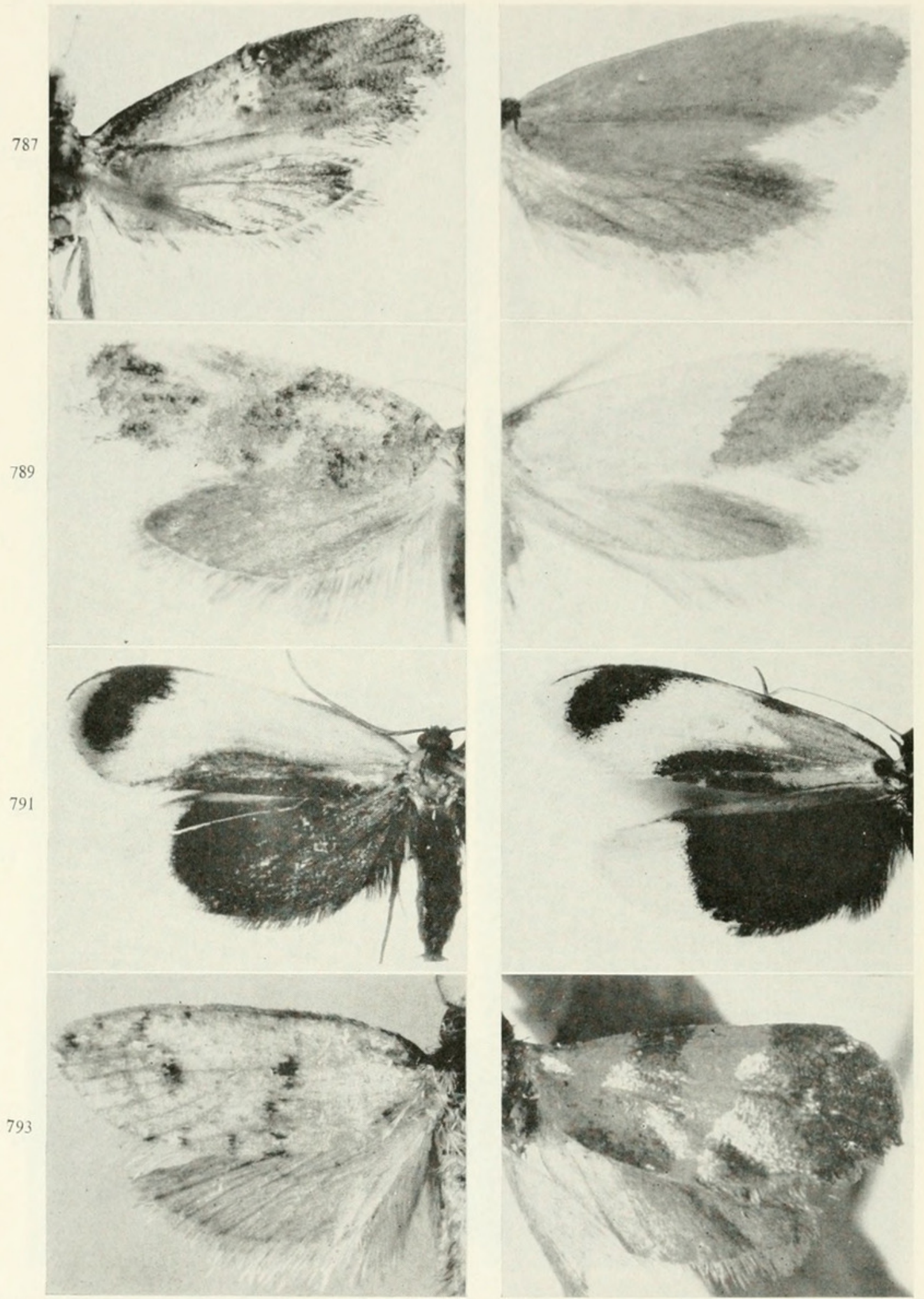

Figures 787-794.-Tineidae and Adelidae: 787, Haplotinea hemilampra, new species, holotype, ơ; 788, H. purpurascens, new species, holotype, ơ; 789, Hapsifera rugosella (Stainton), ơ ; 790, Haplotinea cymopelta (Meyrick), o ; 791, Coryptilum klugii Zeller, q ; 792, C. luteum, new species, holotype, $q ; 793$, Melasina anarmosta, new species, holotype, $\sigma^{7} ; 794$, Nemophora apollonis, new species, holotype, $\sigma^{7}$. 


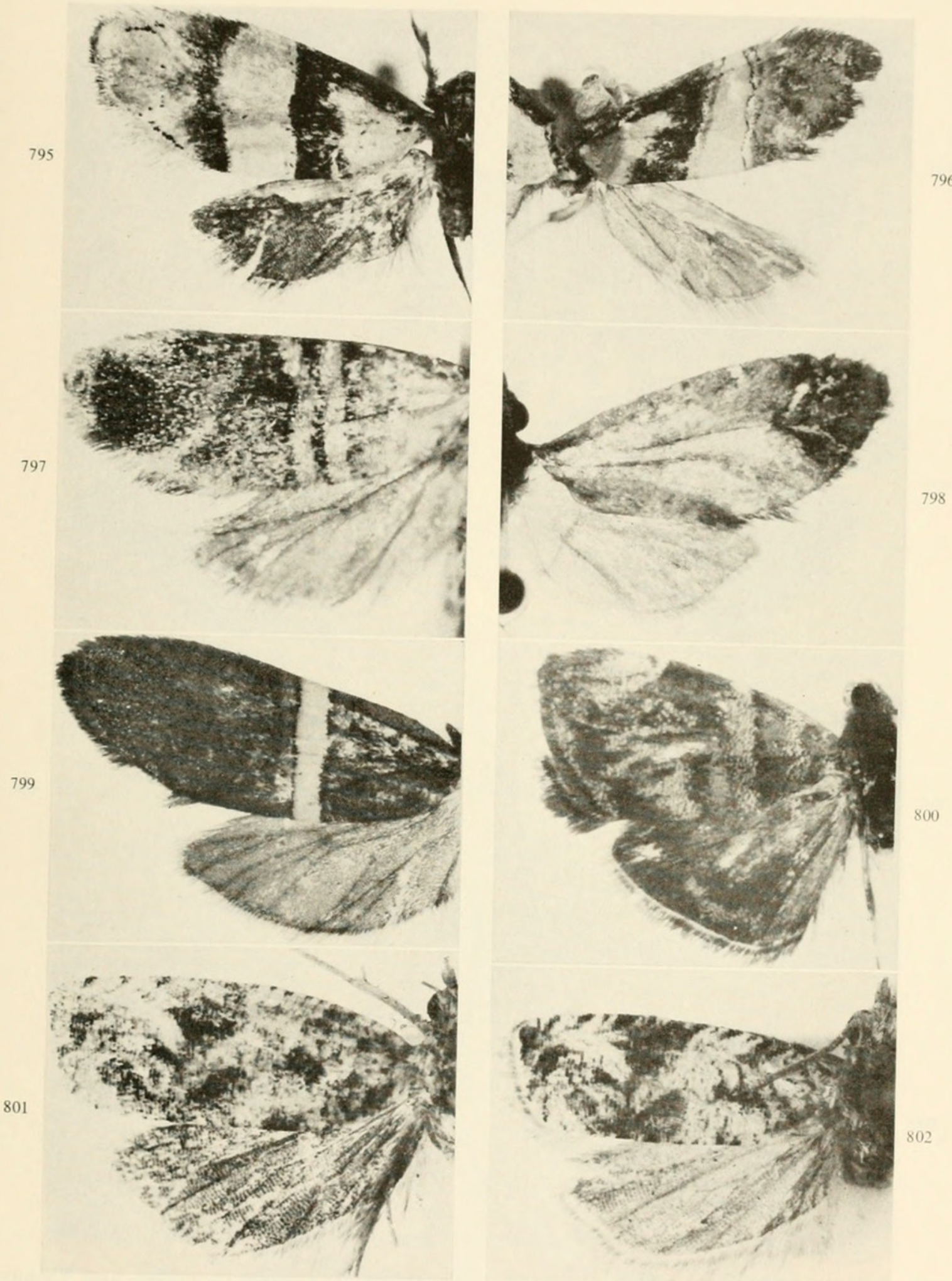

Figures 795-802.-Adelidae, Glyphipterygidae, Tortricidae: 795, Nemophora eurycitra

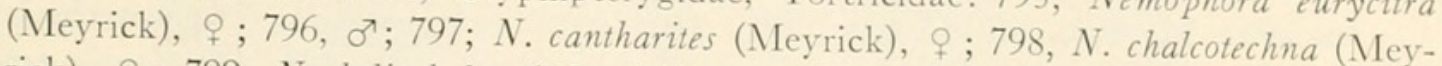
rick), $+; 799, N$. heliochalca (Meyrick), o7; 800, Anthophila orthogona (Meyrick), ơ ; 801, Bubonoxena ephippias (Meyrick), + , (India); 802, lectotype, ơ (India). 

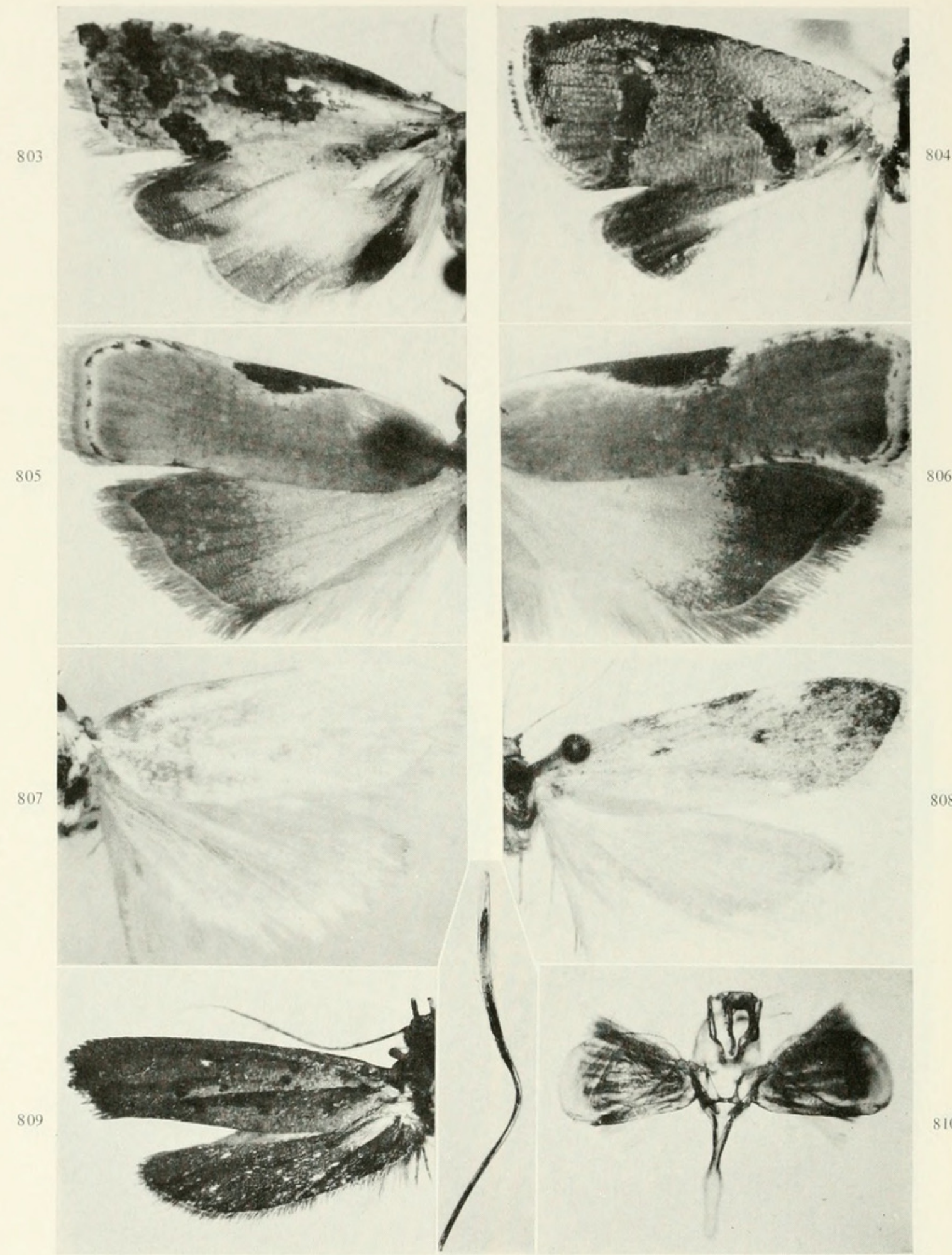

Figures 803-810. - Tortricidae, Gelechiidae, Xyloryctidae, Cosmopterygidae, and Yponomeutidae: 803, Peridaedala physoptila, new species, holotype, ơ' 804, Pammene leucodora Meyrick, $\sigma^{7}$, holotype; 805, Atasthalistis ochreoviridella (Pagenstecher), $\sigma^{7}$; 806, † ; 807, Amorbaea subtusvena, new species, allotype, f ; 808, Tanyzancla pepona, new species, paratype, $+; 809$, Yponomeuta melanaster Meyrick, lectotype, $\sigma^{7} ; 810$, genitalia, with middle, aedeagus. [Figs. 804, 809-810, by courtesy of the Trustees of the British Museum, Natural History.] 

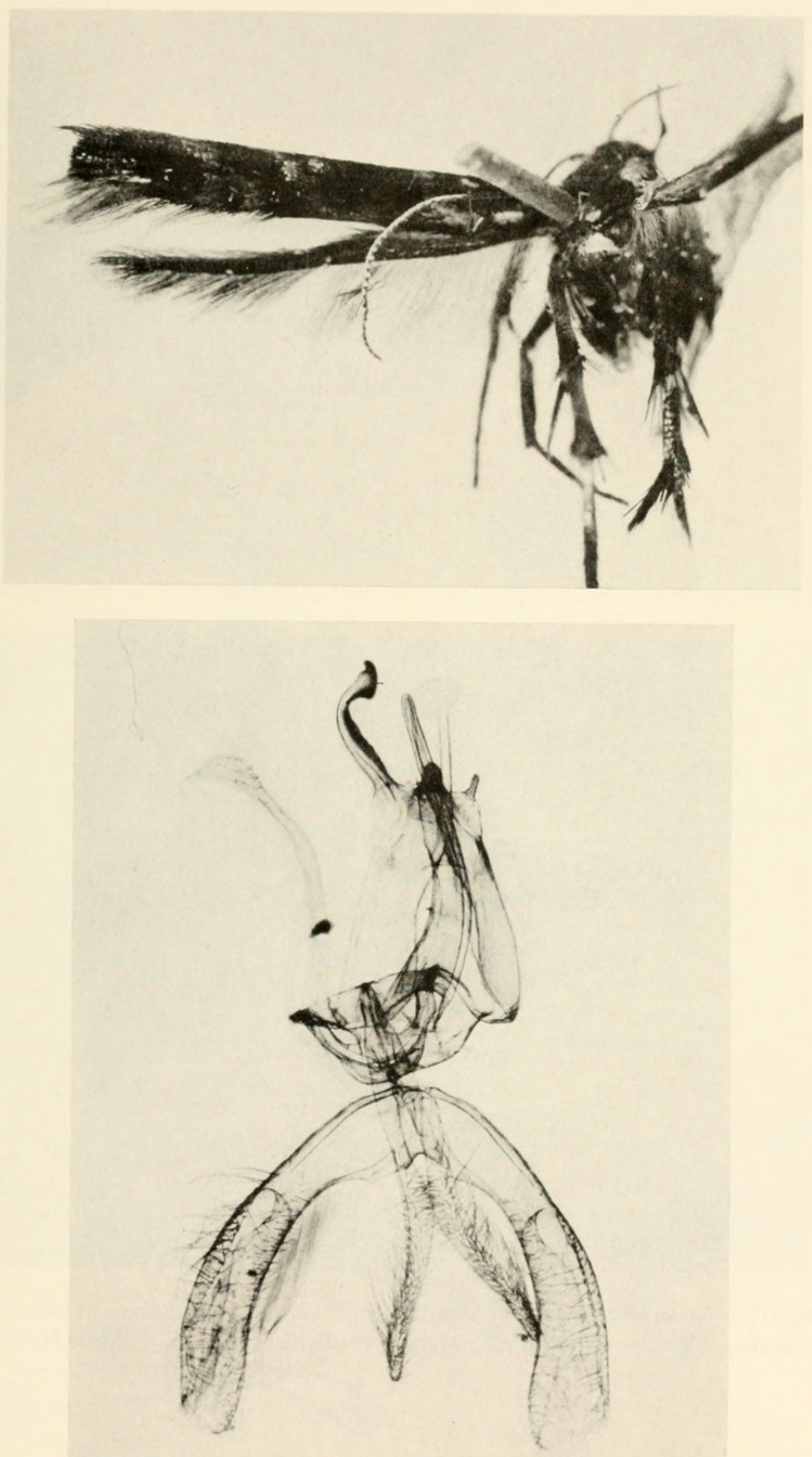

Figure 811.-Xestocasis erymnota Meyrick, $\sigma^{7}$, lectotype: top, left pair of wings; bottom, genitalia. [By courtesy of the Trustees of the British Museum, Natural History.] 

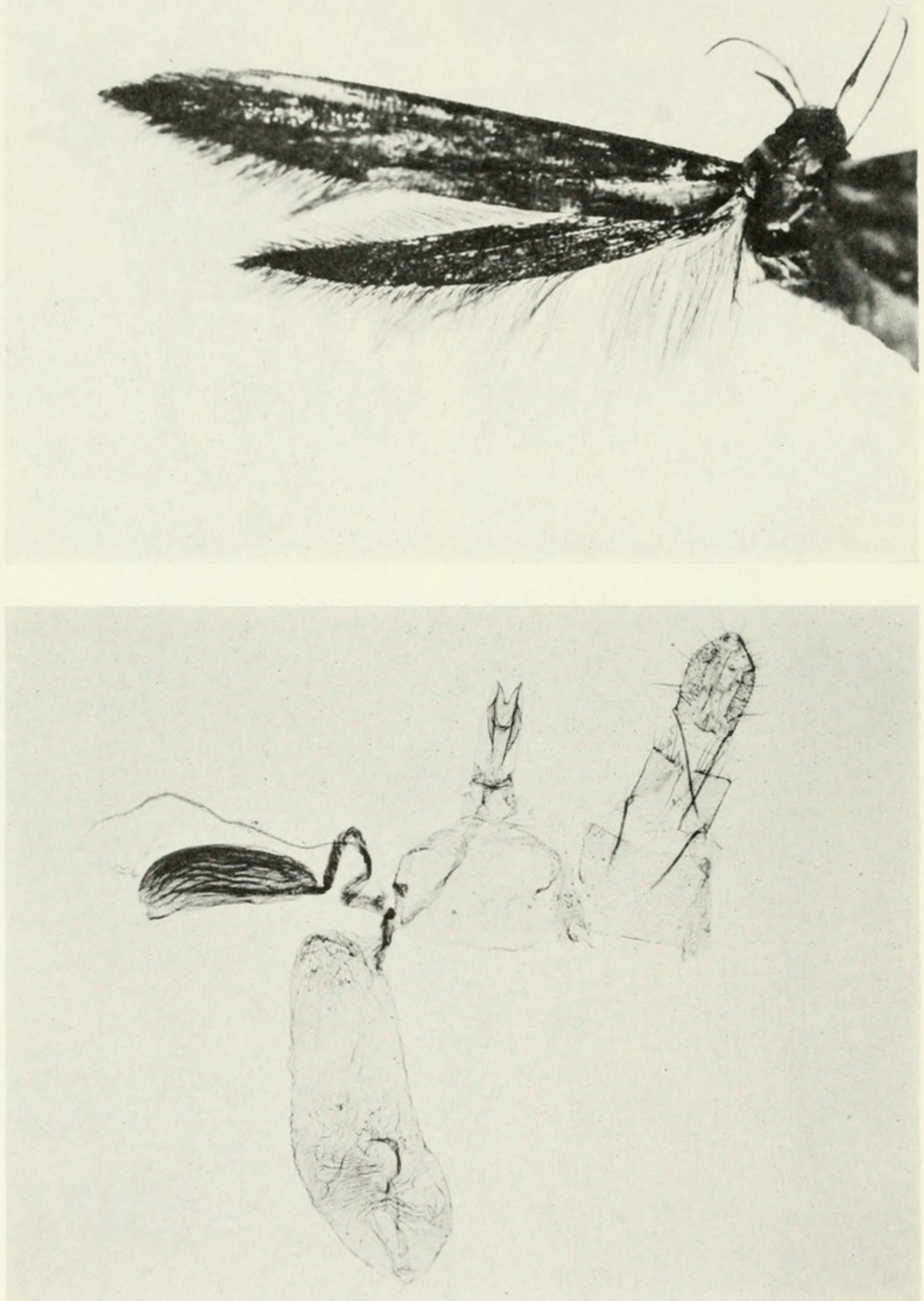

Figure 812.-Lamachaera cyanacma Meyrick, $q$, holotype: top, left pair of wings; bottom genitalia. [By courtesy of the Trustees of the British Museum, Natural History.] 


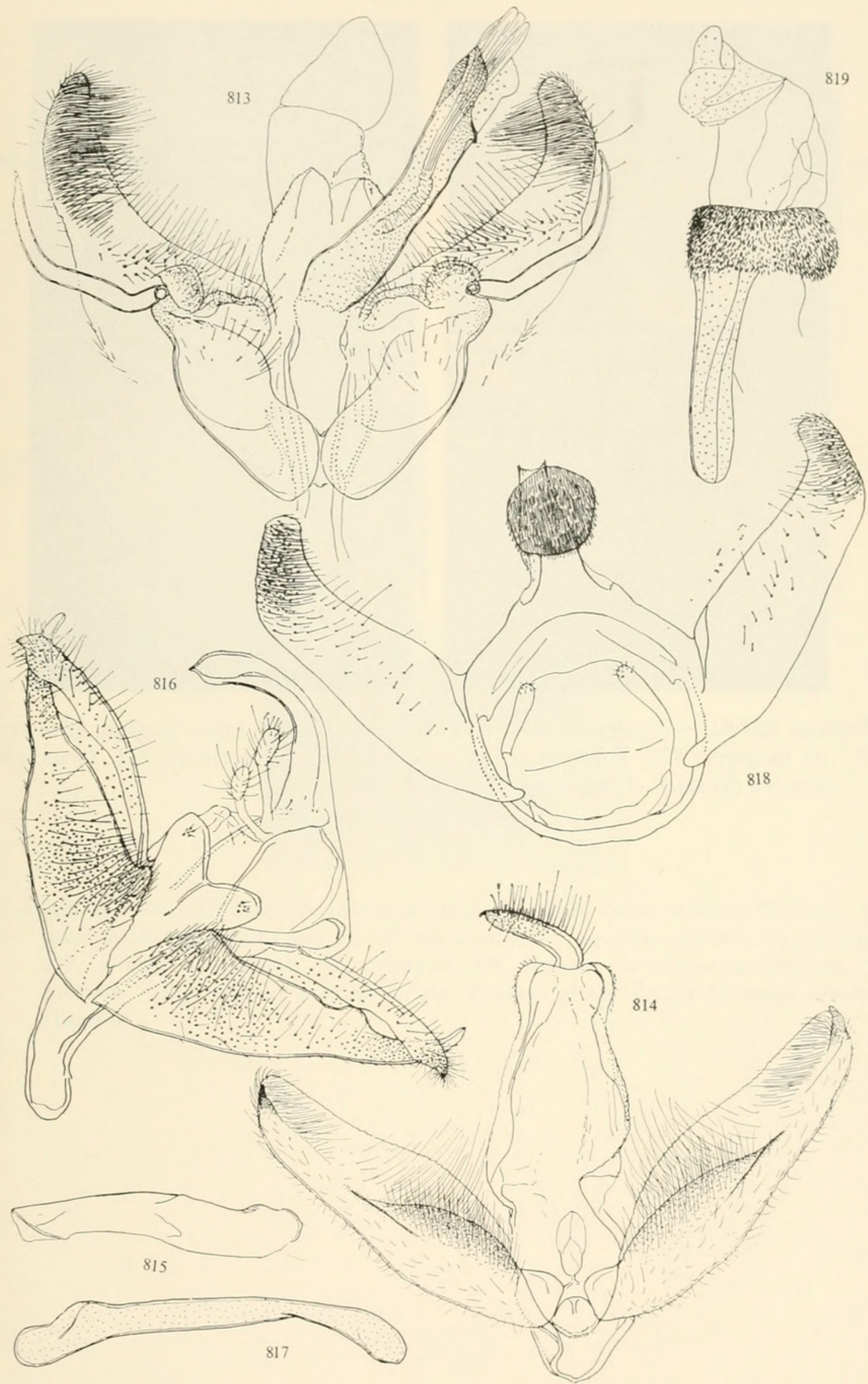

Figures 813-819.-Male genitalia of Glyphipterygidae: 813, Imma lathidora Meyrick, ơ', holotype; 814, I. arcifraga Meyrick, $\sigma^{7}$, lectotype; 815, aedeagus; 816, I. palaeodes Meyrick, $\sigma^{7}$, lectotype; 817, aedeagus; 818, Lampristica purpurata Meyrick, lectotype, $\sigma^{7} ; 819$, aedeagus. 

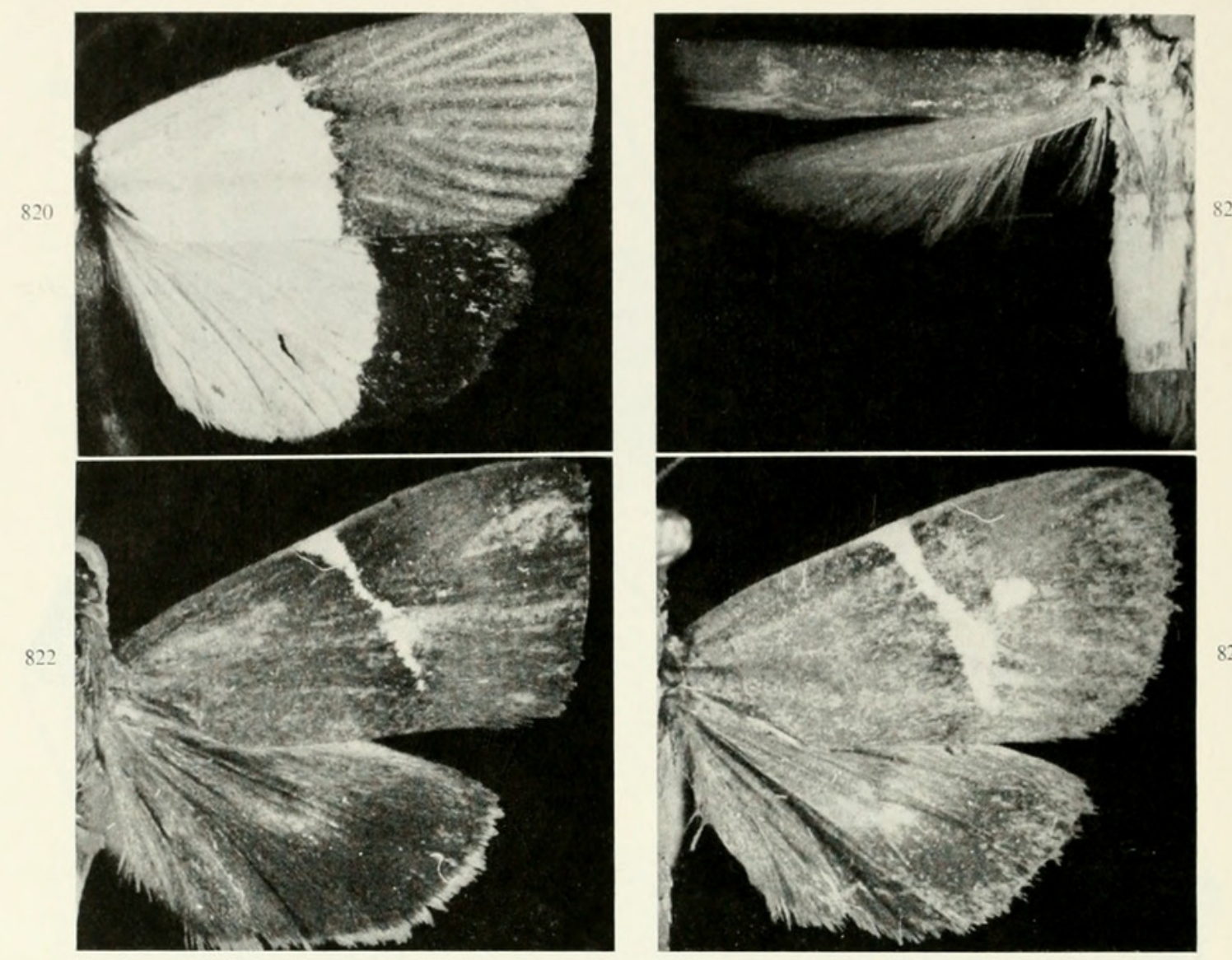

823

Figures 820-823.-Glyphipterygidae and Heliodinidae: 820, Imma basiflava (Semper), $\sigma^{7}$, lectotype; 821, Trichothyrsa bicolorella (Sauber), $\sigma^{7}$, lectotype; 822, Imma albo-

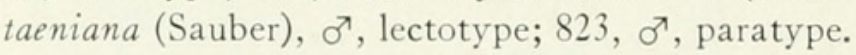




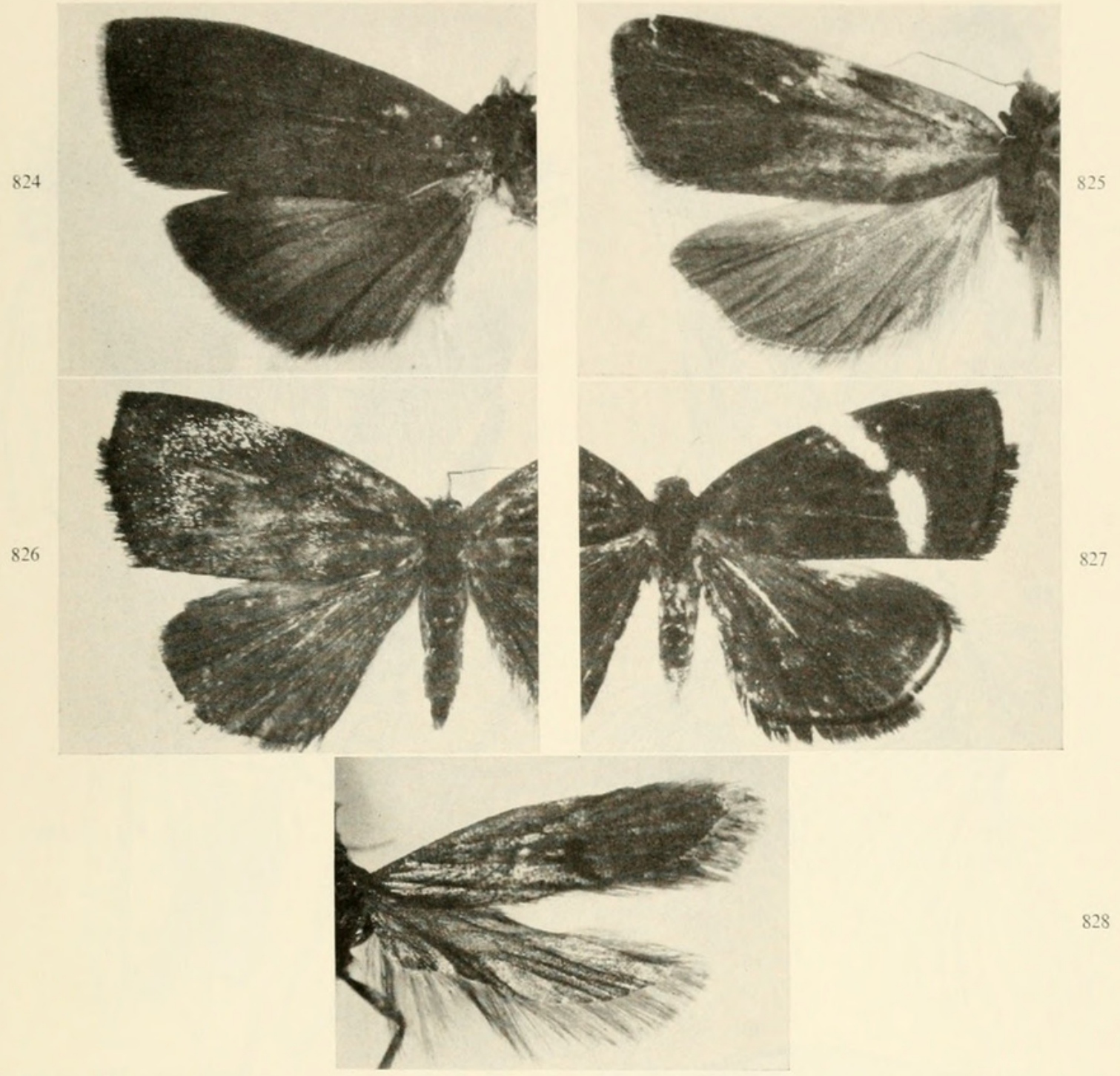

Figures 824-828.-Glyphipterygidae and Timyridae: 824, Imma lathidora Meyrick, ơ', holotype; 825, I. fungosa Meyrick, $\sigma^{7}$, holotype; 826, I. palaeodes Meyrick, + , paratype; 827, I. arcifraga Meyrick, †, paratype; 828, Homaloxestis alopecopa Meyrick, $\sigma^{7}$, holotype. [Fig. 828, by courtesy of the Trustees of the British Museum, Natural History.] 


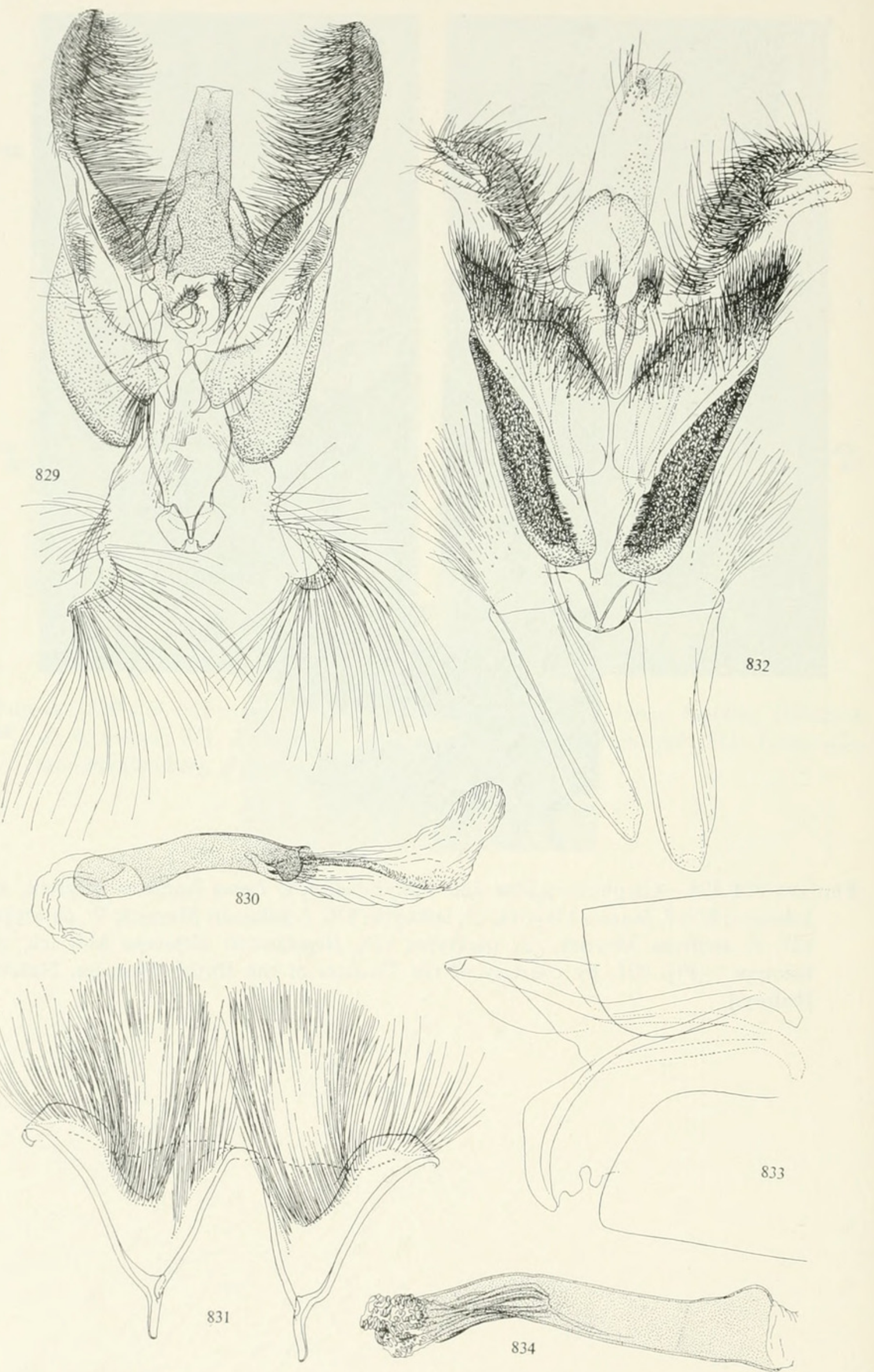

Figures 829-834.-Male genitalia of Glyphipterygidae: 829, Imma albotaeniana (Sauber), lectotype; 830, aedeagus; 831, coremata with menses; 832, I. basiflava (Semper). lectotype; 833, menses; 834, aedeagus. 

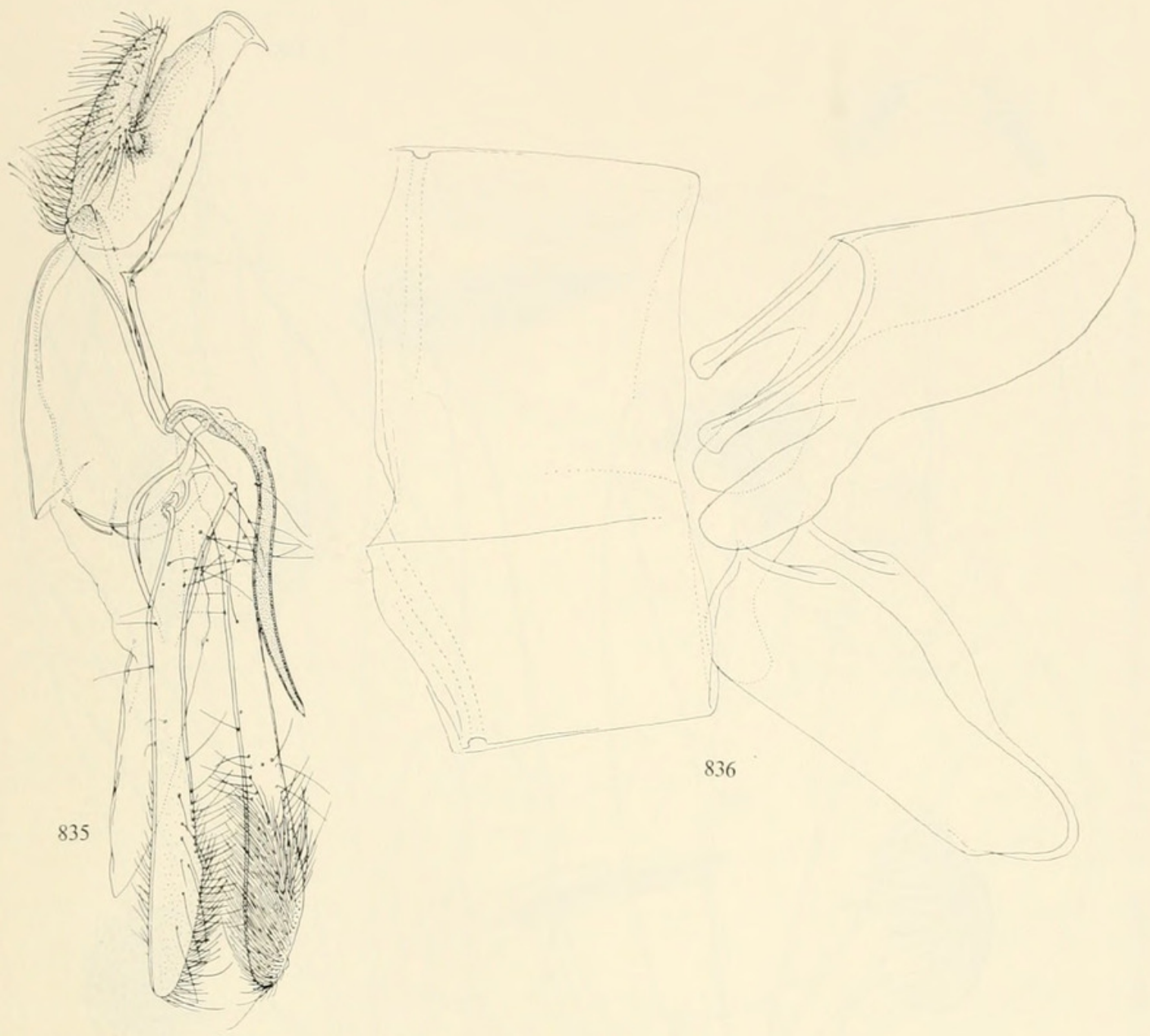

Figures 835-836.-Male genitalia of Trichothyrsa bicolorella (Sauber), lectotype: 835, sublateral aspect; 836, left, abdominal segment 7 and, right, modified segment 8 . 


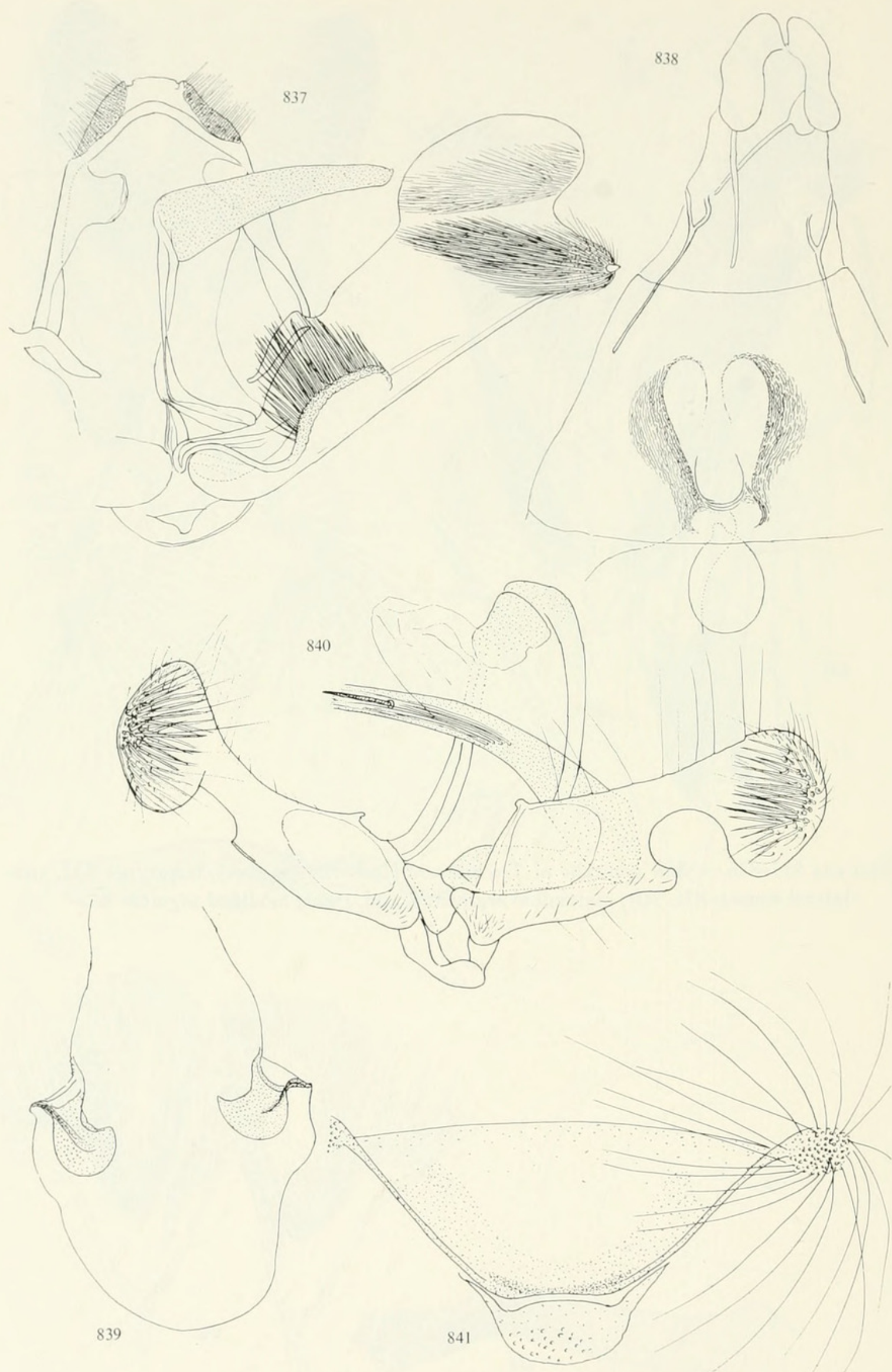

Figures 837-841.-Genitalia of Olethreutinae: 837, Loboschiza clytocarpa (Meyrick), new genus, $\sigma^{7}$, holotype; 838, Pammene ionia Wileman and Stringer, $q$, holotype, ovipositor and sterigma, with upper part of corpus bursae and the receplaculum seminis; 839, corpus bursae; $840, \sigma^{7}$, neallotype; 841 , menses and right corema (subschematically). 


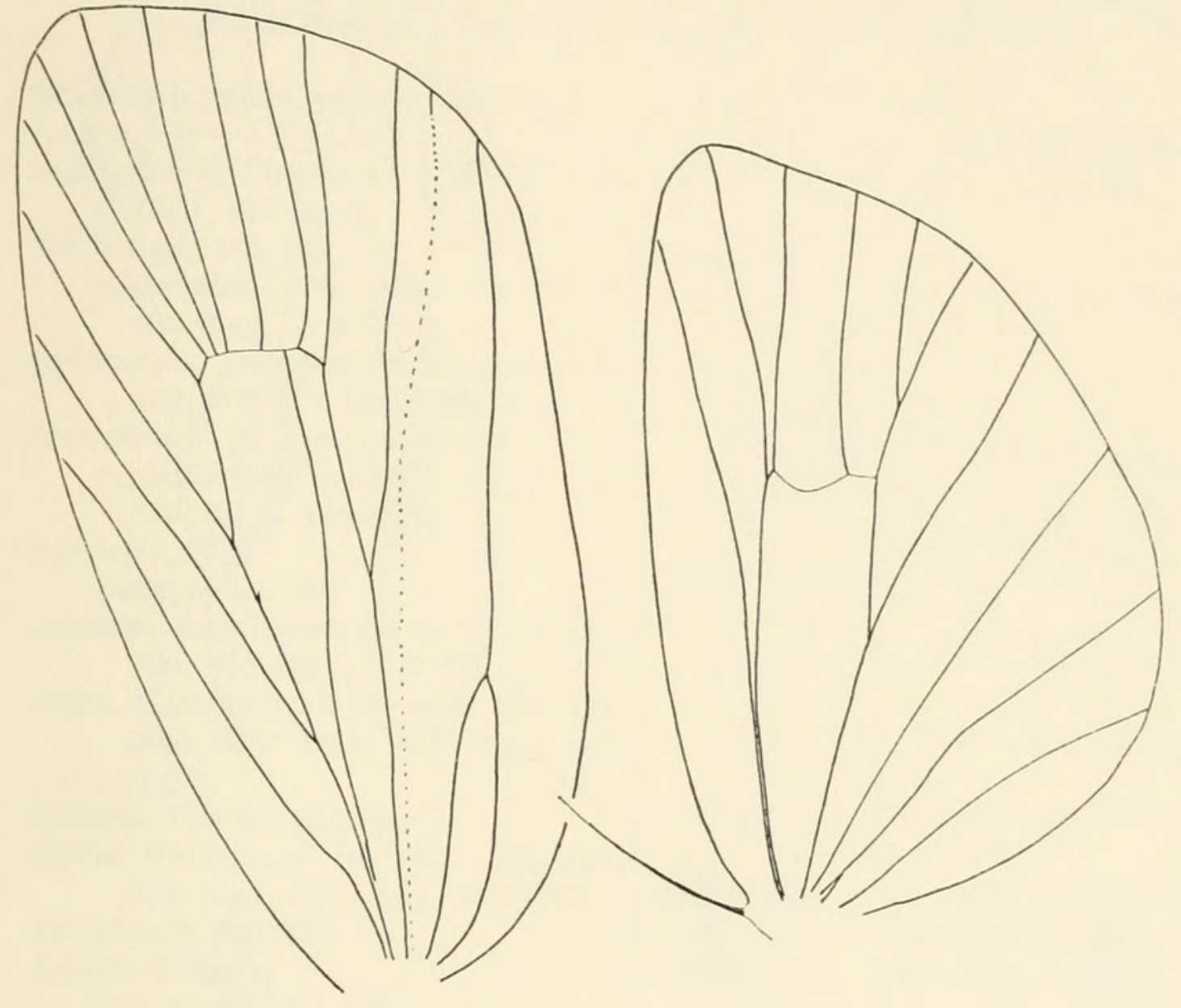

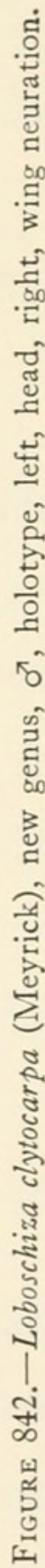




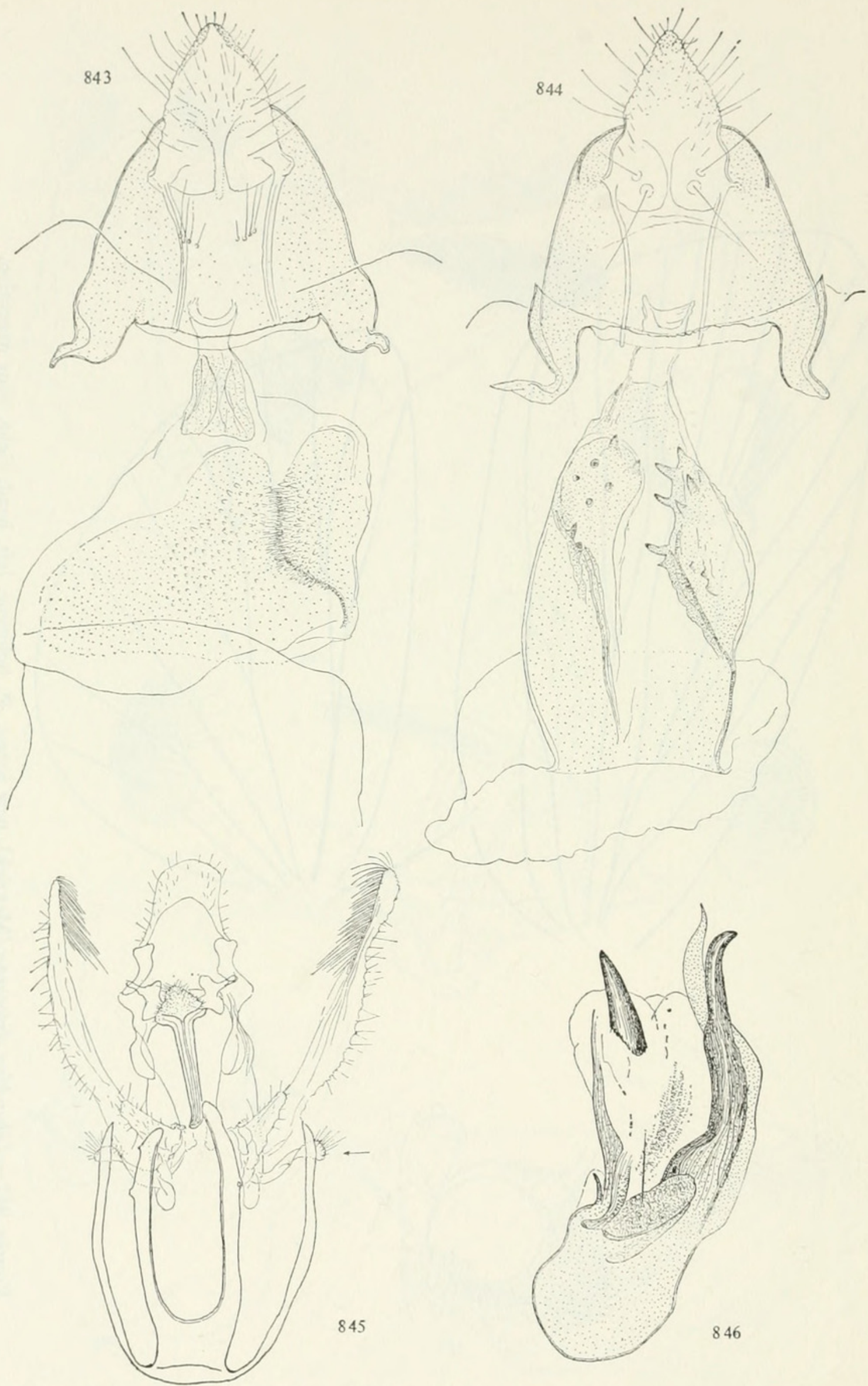

Figures 843-846.-Yponomeutidae and Gelechiidae: 843-844, female genitalia of Prays: 843, P. endocarpa Meyrick (Java); 844, P. endolemma, new species, allotype. 845, male genitalia of Atasthalistis ochreoviridella (Pagenstecher), total aspect; 846, aedeagus, to scale. 


\section{Index}

[Synonyms of genera and species and page numbers of principal accounts in italics. For index of food-plants, see page 484.]

Acanthothyspoda, subgen., 48, 51

Acleris, 8

acontophora, Limnaecia, 164, 305, 360 (fig.), 433 (fig.)

Acribologa, 148, 158

malacodes, 158, 304, 412 (fig.), 432 (fig.)

acribostola, Lecithocera (n. sp.), 132, 139, 304, 351 (fig.), 430 (fig.)

Acrocenotes (n. gen.), 259, 262

niphochrysa (n. sp.), 262, 307, 399 (fig.), 448 (fig.)

Acrolepia, 262

perlepidella, 262

activata, Lecithocera (n. sp.), 132, 133, 304, 355 (fig.), 429 (fig.)

acuta, Campylarchis (n. sp.), 100, 101, 303, 338 (fig.), 412 (fig.), 426 (fig.)

acutana, Phaecadophora, 57

acycla, Hypodrasia (n. sp.), 156, 304, 356 (fig.), 362 (fig.), 432 (fig.)

Adelidae, 5, 293, 308

Adixoa, 219, 234

tomentosa, 234, 307

Adoxophyes, 8, 10, 11 (key)

aurata (n. sp.), 11, 14, 301, 309

(fig.), 414 (fig.)

cyrtosema, 14

epizeucta, 13

euryomis, 14, 15

fasciculana, 11, 301, 414 (fig.)

heteroidana, 10

luzonica, 11

melichroa, 13

perstricta, 11, 14, 301, 313 (fig.), 414 (fig.)

privatana, 11, 14, 301, 414 (fig.)

tripselia, 13

adustipennis, 157

Aegeriidae, 5, 218, 219 (key), 306, 307 aeolochlora, Eudemis (Acanthothyspoda), 51
Aeoloscelis, 209, $21 S$

perigrapha (n. sp.), 213, 306, 375

(fig.), 440 (fig.)

Aeoloscelis, 217

aeolotechna, 57

aestivana, Homona, 16, 301, 375 (fig.), 415 (fig.)

Aethes, 7

sphaenophora, 7

sphenophora, $7,301,414$ (fig.)

aganacma, Homaloxestis (n. sp.), 129, 304,352 (fig.), 429 (fig.)

agitata, Statherotis, 55

Agrioceros, 249, 250 (key)

magnificella, 249, 250, 251, 300, 307, 393 (fig.), 446 (fig.)

platycypha, 249, 250, 307, 393 (fig.), 446 (fig.)

albescens, Hapsifera (n. sp.), 27\%, 308, 403 (fig.), 450 (fig.)

albifasciella, Imma, 190, 193, 305, 370 (fig.), 381 (fig.), 437 (fig.)

albimaculana, Brenthia, 206, 207, 306, 439 (fig.)

albitibiana, Sisona, 58, 61, 6s, 300

Grapholitha (Sisona), 300

albotaeniana, Imma, 190, 194, 305, 458 (fig.), 460 (fig.)

Tortricomorpha, 300

allochroma, Costosa (n. sp.), 81, 302, 323 (fig.), 336 (fig.), 422 (fig.)

alopecopa, Homaloxestis (n. sp.), 129, 130, 304, 459 (fig.)

alta, Meridarchis (n. sp.), 103, 104, 303, 341 (fig.), 426 (fig.)

alteana, 93

Amblothridia, 241

amethystodes, Anthophila, 202, 204, 300, 306, 381 (fig.), 439 (fig.)

Simaethis, 300

amoebea, Statherotis, 55 
Amorbaea, 113, 114, 115 (key)

hepatica, 115

subtusvena (n. sp.), 115, 303, 343 (fig.), 345 (fig.), 426 (fig.), 454 (fig.)

subusta (n. sp.), 115, 116, 303, 344 (fig.), 427 (fig.)

amphicarpa, Canthonistis, 127, 128, 300 amphigonia, Erinaea (n. sp.), 91, 303, 331 (fig.), 424 (fig.)

amydrographa, Tanyzancla (n. sp.), 171, 305, 365 (fig.), 434 (fig.)

Anacampsis, 149

anarmosta, Melasina (n. sp.), 292, 308, 408 (fig.), 452 (fig.)

anastea, Archidemis (n. sp.), 30, 301, 311 (fig.), 312 (fig.), 313 (fig.), 417 (fig.)

Analrachyntis, 165

ancistrias, Metathrinca, 116

ancosema, Statherotis, 55

andrepictura, Lepidopoda, 225

angulosa, Anthophila (n. sp.), 202, 306, 375 (fig.), 438 (fig.)

anisopa, Brenthia (n. sp.), 207, 306, 382 (fig.), 439 (fig.)

Anthophila, 188, 201 (key)

amethystodes, 202, 204, 300, 306, 381 (fig.), 439 (fig.)

angulosa (n. sp.), 202, 306, 375

(fig.), 438 (fig.)

anthorma, 202, 205, 306, 439 (fig.)

basalis, 202, 203, 306, 375 (fig.), 438 (fig.)

chionodesma, 203

inscriptana, 203, 206

irimochla, 204

macropa, 202

orthogona, 202, 205, 206, 306, 376

(fig.), 453 (fig.)

pyraustella, 204

streptatma, 201, 202, 306, 374

(fig.), 438 (fig.)

xanthogramma, 202, 204, 306

anthorma, Anthophila, 202, 205, 306, 439 (fig.)

Anticrates, 235, 243 (key)

denticulata (n. sp.), 243, 244, 307,

386 (fig.), 387 (fig.), 445 (fig.)

digitosa (n. sp.), 243, 245, 246, 307,

386 (fig.), 387 (fig.), 445 (fig.)

miltochorda, 247
Anticrates-Continued

paratarsa, 243, 247, 307, 388 (fig.), 446 (fig.)

rhodometra (n. sp.), 243, 246, 307, 385 (fig.), 386 (fig.), 388 (fig.), 446 (fig.)

rutilella, 243, 307, 387 (fig.), 445 (fig.)

tridelta, 244, 245

aperta, Archips (n. sp.), 24, 28, 301, 312 (fig.), 316 (fig.), 318 (fig.), 417 (fig.)

Aphelia, 64

apicalis, Atteva, 239, 240

Odites (n. sp.), 120, 122, 303, 342 (fig.), 428 (fig.)

apollonis, Nemophora (n. sp.), 293, 308, 452 (fig.)

aporopis, Chrysonoma, 17\%, 178, 305, 366 (fig.), 435 (fig.)

A proaerema, 150

aprobola, Hedya (Platypeplus), 46, 301, 419 (fig.)

aptatella, 149

Archidemis (n. gen.), 8, 30

anastea (n. sp.), 30, 301, 311 (fig.), 312 (fig.), 313 (fig.), 417 (fig.)

archimedias, Argyroploce, 49

Eudemis (Eudemis), 49, 419 (fig.)

Archips 8, 24 (key)

aperta (n. sp.), 24, 28, 301, 312 (fig.) 316 (fig.), 318 (fig.), 417 (fig)

dicaeus (n. sp.), 24, 26, 301, 317 (fig.), 417 (fig).

difficilis, 24, 28, 301, 311 (fig.), 417 (fig.)

encausta, 27, 28, 317 (fig.)

machlopis, 29

salaconis, 24, 301, 310 (fig.), 312

(fig.), 333 (fig.), 416 (fig.)

spilotoma, 26

xanthochroma, 24, 25

Archips, 33

Archisopha, 163

arcifraga, Imma, 298, 457 (fig.), 459 (fig.)

Sidyma, 300

argessa, Tonica (n. sp.), 183, 184, 305, 367 (fig.), 368 (fig.), 436 (fig.)

argopa, Ethmia, 256, 394 (fig.)

Argynnis, 1 
argyracma, Craterobathra (n. sp.), 210, 211, 306, 378 (fig.), 440 (fig.)

Argyroploce, 46, 47, 69, 94

Argyroptocha (n. gen.), 39, 70

phalaenopa (n. sp.), 70, 302, 330 (fig.), 421 (fig.)

arista, Thymiatris (n. sp.), 113, 303, 345 (fig.), 426 (fig.)

Articolla, 82

asperana, Phricanthes, 36

aspidias, Statherotis, 55

Astiarcha, 167, 169 (key)

aureatella, 169, 170, 363 (fig.)

praedives (n. sp.) 169, 305, 363 (fig.), 365 (fig.), 434 (fig.)

asynthetes, Gatesclarkeana (n. sp.), 42, 43, 301, 321 (fig.), 419 (fig.)

Atasthalistis, 148, 151 (key), 304

ochreoviridella, 151, 152, 304, 412 (fig.), 454 (fig.), 464 (fig.)

diacrita (n. sp.), 151, 152, 304, 359 (fig.), 360 (fig.), 432 (fig.)

viridella, 154, 359 (fig.)

aterea, Sphecosesia 219, 221, 306, 441 (fig.)

atrifraga, Hedya (Hedya) (n. sp.), 45, 301, 323 (fig.), 419 (fig.)

atropunctana, Penthina, 44

Atteria, 9

Atteva, 235, 239 (key)

apicalis, 239, 240

balanota, 239, 242, 307, 390 (fig.), 445 (fig.)

basalis, 239, 240, 307

brucea, 239, 241, 307, 445 (fig.)

fabricella, 241

holenopla (n. sp.), 239, 241, 307, 385 (fig.), 445 (fig.)

scolecias, 239, 242, 307, 390 (fig.), 445 (fig.)

triplex (n. sp.), 239, 240, 307, 385 (fig.), 445 (fig.)

aurantiaca, Imma, 190, 191, 305, 370 (fig.), 437 (fig.)

Sidyma, 300

aurata, Adoxophyes, 11, 14, 301, 309 (fig.), 414 (fig.)

aureatella, Astiarcha, 169, 170, 363 (fig.) Harpella, 300

auricincta, Tisis (n. sp.), 125, 304, 345 (fig.), 354 (fig.), 428 (fig.)

auriflora, 58 autoberylla, Eudemis (Acanthothyspoda), 51

avara, Monopis, 281, 282, 308, 401 (fig.), 403 (fig.), 451 (fig.)

Azinis, 255

Bactra, 40, 63 (key)

(Chiloides) coronata, 63, 302, 420 (fig.)

geraropa, 64

(Chiloides) orbiculi minax, 63, 65, 302, 327 (fig.), 421 (fig.)

(Nannobactra) phaulopa, 63, 65, 302, 421 (fig.)

scythropa, 64

(Chiloides) venosana, 63, 64, 302, 420 (fig.)

bakeri, Homona (n. sp.), 16, 20, 301, 313 (fig.), 316 (fig.), 416 (fig.)

balanota, Atteva, 239, 242, 307, 390 (fig.), 445 (fig.)

balbidophora, Diploclasis (n. sp.), 167, 168, 305, 363 (fig.), 364 (fig.), 433 (fig.)

baliomicta, Tinissa, 279, 308, 401 (fig.), 450 (fig.)

barbaroglypha, Metacosmesis, 102

basalis, Anthophila, 202, 203, 306, 375 (fig.), 438 (fig.)

Atteva, 239, 240, 307

basiflava, Imma, 190, 191, 192, 194, 305, 458 (fig.), 460 (fig.)

Sidyma, 300

basilisca, Cosmopteryx, 165, 166, 305

Bathraula, 161

Bathybalia, 161

Batodes, 29

Batrachedra, 165

Bembecia, 219, 234

fortis (n. sp.), 234, 307, 383 (fig.), 444 (fig.)

bicolorella, Trichothyrsa, 218, 306, 458 (fig.), 461 (fig.)

Eretmocera, 300

bicolorella, 255

bicornis, Homona (n. sp.), 16, 18, 301, 314 (fig.), 316 (fig.), 415 (fig.)

bifracta, Meridarchis (n. sp.), 103, 104, 303, 339 (fig.), 426 (fig.)

biocellana, Phricanthes, S7, 301, 318 (fig.), 319 (fig.), 418 (fig.)

Blabophanes, 282

blackburni, 93 
Brachmia, 148, 156, 158 (key) heterotoma (n. sp.), 158, 304, 359 (fig.), 432 (fig.)

tristella, 158, 304, 362 (fig.), 432 (fig.)

Brachmia, 149

Brachyacma, 148, 157

palpigera, $15 \%, 304,357$ (fig.), 431 (fig.)

brachyclista, Odites, 120, 124, 303, 343 (fig.), 428 (fig.)

Brenthia, 188, 206 (key) albimaculana, 206, 207, 306, 439 (fig.)

anisopa (n. sp.), 207, 306, 382 (fig.), 439 (fig.)

catenata, 207, 208, 306

harmonica, 206, 209, 306, 439 (fig.) lithocrossa, 206, 209, 306, 372 (fig.), 439 (fig.)

trilampas, 206, 208, 306, 439 (fig.) brucea, Atteva, 239, 241, 307, 445 (fig.) bryanthes, Copromorpha, 109

Bubonoxena (n. gen.), 40, 65, 66 (key) endaphana (n. sp.), 66, 67, 302, 322 (fig.), 421 (fig.)

ephippias, 68, 327 (fig.), 332 (fig.), 453 (fig.)

spirographa (n. sp.), 66, 302, 327

(fig.), 333 (fig.), 421 (fig.)

Cacoecia, 24, 28, 32, 33

Caenognosis, 96 incisa, 96, 303, 338 (fig.), 424 (fig.)

Callartona, 193

callichlora, Eudemis (Acanthothyspoda), 51

camarotis, Eudemis (Acanthothyspoda), 52

Campylarchis (n. gen.) 100 acuta (n. sp.), 100, 101, 303, 338

(fig.), 412 (fig.), 426 (fig.)

phaeodelta, 100

picroscopa, 100

vitiata, 101

cantharites, Nemophora, 293, 294, 308, 453 (fig.)

Canthonistis, 125, 126, 127 (key)

amphicarpa, 127, 128, 300

xestocephala (n. sp.), 127, 304, 353

(fig.), 428 (fig.)

capna, Gerontha captiosella f., 268, 269, 308, 449 (fig.) captiosella, Gerontha, 267, 268, 308, 399 (fig.), 400 (fig.), 449 (fig.)

Capua, 8, 22 (key)

fabrilis, 22, 301, 416 (fig.)

favillaceana, 23

retractana invalidana, 22, 301, 320 (fig.), 416 (fig.)

thelmae, (n. sp.), 22, 23, 301, 312 (fig.), 416 (fig.)

Сариа, 15

Carpocapsa, 37

carpophaga, 89, 90

Carposinidae, 5, 100 (key), 303

cassiterota, Lecithocera, 131, 135, 304, 350 (fig.), 354 (fig.), 429 (fig.)

catadea, Tanyzancla (n. sp.), 170, 174, 305, 368 (fig.), 434 (fig.)

cataracta, Trymalitis, 97, 303, 425 (fig.)

catenata, Brenthia, 207, 208, 306

catharota, Statherotis, 55

caustospila, Lecithocera, 144

cellifera, Hedya (Cellifera), 47, 302, 325

(fig.), 331 (fig.), 419 (fig.)

Cellifera (n. subgen.), 40, 44, 47

centrifuga, Tortyra, 201

Ceratophora tristella, 300

Ceratophora, 152, 158

Ceratophysetes, 257

Cerostoma, 277

chalcathra, Holacarta (n. sp.), 275, 308, 396 (fig.), 449 (fig.)

chalcotechna, Nemophora, 293, 294, 308, 410 (fig.), 453 (fig.)

chalybacma, Epicephala, 263, 307

Chiloides, subgen., 63

chionodesma, Anthophila, 203

Chlidanotinae, 96 (key), 303

Chlidanotini, 96 (key), 303

chlorogenes, Epimecyntis, 167, 305, 433 (fig.)

chlorosphena, Imma, 197

Choanograptis, 24

Choganhia, 47, 51

Choregia, 188

Choreutidia, 206

Choreutis, 188, 206

scintilulana, 206

sexfasciella, 206, 306, 440 (fig.)

Choreutis, 202

chorospila, Heterogymna, 108

chortodes, Eudemis (Acanthothyspoda)

(n. sp.), 52, 302, 326 (fig.), 419

(fig.) 
Chrosis ephippias, 68, 300

chrysocosma, Imma (n. sp.), 190, 192, 305,372 (fig.), 437 (fig.)

Chrysonoma, 167, 177 (key)

aporopis, $17 \%, 178,305,366$ (fig.), 435 (fig.)

corsota, 182

eumorpha (n. sp.), 177, 178, 305, 367 (fig.), 435 (fig.)

fragmentaria (n. sp.), 177, 180, 305, 366 (fig.), 435 (fig.)

hesitans (n. sp.), 177, 180, 182, 183, 305, 364 (fig.), 365 (fig.), 435 (fig.)

hypocapna (n. sp.), 177, 182, 305, 369 (fig.), 435 (fig.)

inermis (n. sp.), 177, 183, 305, 366 (fig.), 435 (fig.)

poecilosema (n. sp.), 177, 179, 305, 367 (fig.), 435 (fig.)

chrysostetha, Synanthedon (n. sp.), 221, 306, 380 (fig.), 441 (fig.)

cicatricosa, Trachycentra, 278, 308, 406 (fig.), 450 (fig.)

cincta, Tanyzancla (n. sp.), 170, 17s, 305, 364 (fig.), 434 (fig.)

cirrhozona, Synanthedon (n. sp.), 221, 222, 306, 383 (fig.), 441 (fig.)

citrantha, Tonica (n. sp.), 183, 184, 186,

clydonias, 57 305, 368 (fig.), 436 (fig.)

clytocarpa, Loboschiza, 94, 303, 462 (fig.), 463 (fig.)

codonectis, 47

Coenogenes, 82

coenophyes, Metathrinca (n. sp.), 117, 119, 303, 342 (fig.), 344 (fig.), 427 (fig.)

coffearia, Homona, 18

collarigera, Schoenotenes (n. sp.), 98, 303, 318 (fig.), 425 (fig.)

colonella, Ethmia, 253, 254, 255, 307, 394 (fig.), 395 (fig.), 447 (fig.)

contaminata, Glossosphecia, 225

Copromorpha, 108, 109 (key)

bryanthes, 109

dialithoma (n. sp.), 109, 111, 303, 342 (fig.), 425 (fig.)

efflorescens, 109

gypsota, 109, 110

lichenitis, 109

lignisquama, 110

metallitis, 109
Copromorpha-Continued

mistharnis (n. sp.), 109, 112, 303, 339 (fig.), 425 (fig.)

myrmecias, 110

narcodes, 110

nesographa, 110

phytochroa, 109

pleurophanes, 110

pyrrhoscia, 109

roepkei, 110

smaragdarcha (n. sp.), 109, 110, 303,340 (fig.), 425 (fig.)

tetrarcha, 110

thrombota, 110

Copromorphidae, 5, 108, 303

corethrodes, Harpeptila (n. sp.), 260, 262, 307, 391 (fig.), 396 (fig.), 448 (fig.)

coriacella, 165

coronata, Bactra (Chiloides), 63, 302, 420 (fig.)

corsota, Chrysonoma, 182

coryphaea, Thriambeutis, 213, 306, 376

(fig.), 440 (fig.)

Coryptilum, 266, 291 (key)

euchromella, 291

klugii, 291, 308, 409 (fig.), 452 (fig.)

luteum (n. sp.), 291, 292, 308, 409

(fig.), 452 (fig.)

woodfordi, 291

Cosmopterygidae, 5, 160, 305

Cosmopteryginae, 164 (key), 305

Cosmopteryx, 164, 165 (key)

basilisca, 165, 166, 305

dulcivora, 165, 166, 305, 360 (fig.), 433 (fig.)

pallifasciella, 166

cossidella, Harmaclona, 27\%, 398 (fig.), 408 (fig.)

Costosa (n. gen.), 40, 80

allochroma (n. sp.), 81, 302, 323 (fig.), 336 (fig.), 422 (fig.)

crastidochroa, Peridaedala, 77

Craterobathra, 209, 210 (key)

$\operatorname{argyracma}($ n. sp.), 210, 211, 306, 378 (fig.), 440 (fig.)

demarcata (n. sp.), 210, 212, 306, 379 (fig.), 440 (fig.)

ornata (n. sp.), 210, 211, 306, 377

(fig.), 440 (fig.)

tabellifera, 210

Crocanthes, 134 
Crocidosema, 40, 92

plebejana, 92, 303, 424 (fig.)

Crocidosema, 93

crocoptila, Peridaedala (n. sp.), 74, 79, 302, 335 (fig.), 422 (fig.)

crocosoma crocosoma, Ethmia, 257, 447 (fig.)

crocosoma resignata, Ethmia (n. subsp.), 253, 256, 307, 396 (fig.), 447 (fig.)

Croesopola, 152

crotalariella, 157

crypsigenes, Lecithocera, 146

Cryptaspasma, 40, 88

(Allobrachygonia) hesyca, 88, 302, 423 (fig.)

Cryptolechia, 161

Cryptophlebia, 40, 89 (key)

carpophaga, 89, 90

(Cryptophlebia) encarpa, 89, 91, 302, 334 (fig.), 424 (fig.)

illepida, 90

(Cryptophlebia) ombrodelta, 89, 90, 302, 423 (fig.)

(Cryptophlebia) tetraploca, 89, 302, 332 (fig.), 423 (fig.)

cuspidigera, Monopis, 283

cyanacma, Lamachaera, 216, 306, 456 (fig.)

cyanana, Penthina, 44

cyanolampra, Sura (n. sp.), 228, 229, 307, 380 (fig.), 442 (fig.)

cyanosticta, Protorhiza (n. sp.), 248, 307, 385 (fig.), 413 (fig.), 446 (fig.)

cyclostoma, Imma, 198

Cydia, 57, 69

cymineuta, 188

cymopelta, Haplotinea, 286, 290, 308, 407 (fig.), 452 (fig.)

Cyphophanes, 70

cyrtosema, Adoxophyes, 14

Dasyses, 277

Decadarchis, 264, 265

minuscula, 265, 308, 448 (fig.)

decorata, Statherotis, 54

decorosa, Lecithocera (n. sp.), 132, 141, 304, 355 (fig.), 430 (fig.)

delicata, 237

deltostoma, Eucoenogenes (n. sp.), 82, 302, 323 (fig.), 333 (fig.), 422 (fig.)

demarcata, Craterobathra (n. sp.), 210, 212, 306, 379 (fig.), 440 (fig.) dendrochlora, Peridaedala (n. sp.), 74 , 77, 302, 329 (fig.), 421 (fig.), 422 (fig.)

Dendroneura, 274

dentata, Ethmia, 253, 256, 307, 395 (fig.), 397 (fig.), 447 (fig.)

denticulata, Anticrates (n. sp.), 243, 244 , 307, 386 (fig.), 387 (fig.), 445 (fig.)

diacrita, Atasthalistis (n. sp.), 151, 152, 304, 359 (fig.), 360 (fig.), 432 (fig.)

dialithoma, Copromorpha (n. sp.), 109, 111, 303, 342 (fig.), 425 (fig.)

diascopa, Gerontha (n. sp.), 268, 270, 308, 400 (fig.), 449 (fig.)

dicaeus, Archips (n. sp.), 24, 26, 301, 317 (fig.), 417 (fig.)

Dichelia, 14, 22

difficilis, Archips, 24, 28, 301, 311 (fig.), 417 (fig.)

digitosa, Anticrates (n. sp.), 243, 245, 246, 307, 386 (fig.), 387 (fig.), 445 (fig.)

dimidiatella, Opogona, 264, 265, 308, 448 (fig.)

Diploclasis (n. gen.), 167, 305

balbidophora (n. sp.), 167, 168, 305, 363 (fig.), 364 (fig.), 433 (fig.)

discana, Statherotis, 55, 56, 302, 326 (fig.), 420 (fig.)

discobola, Strepsicrates (n. sp.), 84, 85, 302, 328 (fig.), 423 (fig.)

distorta, 89

divisa, Phaecadophora, 57

divitiosa, Tortyra, 200, 306, 381 (fig.), 438 (fig.)

docilis, Lecithocera (n. sp.), 132, 144, 145, 304, 349 (fig.), 430 (fig.)

Drachmobola, 35

drimyla, Frisilia (n. sp.) 128, 304, 353 (fig.), 428 (fig.)

dulcivora, Cosmopteryx, 165, 166, 305, 360 (fig.), 433 (fig.)

Eboda, 35

variabilis, 35

Ebodina (n. gen.), 8, 34 simplex, 35, 301, 319 (fig.), 418 (fig.)

Eccopsis, 46

efflorescens, Copromorpha, 109

ejectana, Strepsicrates, 83, 84, 85, 302, 325 (fig.), 422 (fig.) 
elaeodes, Acanthothyspoda, 47, 51

electrina, Zacorisca, 8, 9, 301, 414 (fig.) elegans, Tortyra, 200, 306, 438 (fig.)

Enaemia, 243

encarpa, Cryptophlebia, 89, 91, 302, 334 (fig.), 424 (fig.)

encausta, Archips, 27, 28, 317 (fig.)

endaphana, Bubonoxena (n. sp.), 66, 67, 302, 322 (fig.), 421 (fig.)

endocarpa, Prays, 238, 239, 389 (fig.), 464 (fig.)

endolemma, Prays (n. sp.), 237, 307,

Epagoge, 22 389 (fig.), 444 (fig.), 464 (fig.)

ephippias, Bubonoxena, 68, 332 (fig.), 327 (fig.), 453 (fig.)

Chrosis, 300

Epicephala, 263

chalybacma, 263, 307

epichorda, 157

Epimecyntis, 167

chlorogenes, 167, 305, 433 (fig.)

Epirrhoeca, 96, 97

epizeucta, Adoxophyes, 13

Eretmocera, 209, 214

bicolorella, 300

percnophanes, 214, 306, 376 (fig.), 377 (fig.), 379 (fig.), 444 (fig.)

Eretmocera, 218

Ereunetis, 265

Ericia, 16

Erinaea, 40, 91

amphigonia (n. sp.), 91, 303, 331 (fig.), 424 (fig.)

Erminea, 235

erotias, Gatesclarkeana, 42, 321 (fig.), 322 (fig.)

Platypeplus, 42

erymnota, Xestocasis, 215, 216, 300, 306, 455 (fig.)

escharota, Sycacantha, 59, 62

Ethmia, 249, 252, 253 (key)

argopa, 256, 394 (fig.)

bicolorella, 255

colonella, 253, 254, 255, 307, 394

(fig.), 395 (fig.), 447 (fig.)

crocosoma crocosoma, 25\%, 447 (fig.)

crocosoma resignata (n. subsp.), 253, 256, 307, 396 (fig.), 447 (fig.) dentata, 253, 256, 307, 395 (fig.), 397 (fig.), 447 (fig.)

heptasema, 259
Ethmia-Continued

hilarella, 252, 255

hilarella, 255

lapidella, 259

lineatonotella, 254

meteoris, 255

nobilis (n. sp.), 253, 258, 307, 395

(fig.), 397 (fig.), 447 (fig.)

octanoma, 258

palawana, 253, 307, 447 (fig.)

praeclara, 253, 254, 255, 256, 307,

394 (fig.), 447 (fig.)

pullata, 255, 300, 395 (fig.)

pyrausta, 252

reposita (n. sp.), 253, 25\%, 307, 397

(fig.), 447 (fig.)

Ethmiidae, 5, 249 (key), 307

eubrachycera, Sagalassa (n. sp.), 189, 305, 369 (fig.), 436 (fig.)

euchroa, 152

euchromella, 291

Eucoenogenes, 40, 82

deltostoma (n. sp.), 82, 302, 323

(fig.), 333 (fig.), 422 (fig.)

melanancalis, 82

Eucosma, 40, 88

iographa (n. sp.), $88,302,328$ (fig.), 423 (fig.)

Eucosma, 49, 84

mniochlora, 49

Eudemis, 39, 47

Eudemis (Acanthothyspoda), 48, 51, 52 (key)

aeolochlora, 51

autoberylla, 51

callichlora, 51

camarotis, 52

chortodes (n. sp.), 52, 302, 326 (fig.), 419 (fig.)

elaeodes, 51

herbifera, 51

heteraspis, 51

homalopa (n. sp.), 52, 54, 302, 336

(fig.), 420 (fig.)

margaritopa, 52

phyllochlora, 51, 52

prasinias, 52

ptilosema, 52

semiculta, 51

sphaerocopa, 52

stygiaula, 52

temenopis, 52

Eudemis 39, 47, 48 
Eudemis (Eudemis), 49 (key)

archimedias, 49, 419 (fig.)

mniochlora, 49

oxygona (n. sp.), 49, 50, 302, 322

(fig.), 335 (fig.), 419 (fig.)

pompholycias, 49

porphyrana, 49

Eudemopsis, 50

purpurissatana, 50

Euhomalocera (n. gen.), 147, 150

heliosema (n. sp.), 150, 151, 304, 358 (fig.), 432 (fig.)

eumarodes, 84

eumorpha, Chrysonoma (n. sp.), 177, 178, 305, 367 (fig.), 435 (fig.)

eupista, Stenarchella (n. sp.), 99, 303, 337 (fig.), 425 (fig.)

eurycera, Haplotinea (n. sp.), 286, 289, 308, 406 (fig.), 451 (fig.)

eurycitra, Nemophora, 293, 295, 308, 411 (fig.), 453 (fig.)

euryomis, 14, 15

eurytion, Melittia, 233, 307, 444 (fig.)

evonymella, Yponomeuta, 235

Exaxa (n. gen.), 266, 275

rectilinea (n. sp.), 276, 308, 403 (fig.), 411 (fig.), 449 (fig.)

fabricella, 241

fabrilis, Capua, 22, 301, 416 (fig.)

fasciculana, Adoxophyes, 11, 301, 414 (fig.)

fausta, Lecithocera, 132, 188, 304, 348 (fig.), 354 (fig.), 431 (fig.)

favillaceana, Capua, 23

fibularis, Onebala, 300

Prosodarma, 147, 304, 357 (fig.), 431 (fig.)

fimbriata, Phaecadophora, 56, 57

flavofasciata, Opogona, 264, 265, 308, 448 (fig.)

flexilineana, Phricanthes, 39, 301, 418 (fig.)

fortis, Bembecia (n. sp.), 234, 307, 383 (fig.), 444 (fig.)

fragmentaria, Chrysonoma (n. sp.), 177, 180, 305, 366 (fig.), 435 (fig.)

Frisilia, 125, 128, 304

drimyla (n. sp.), 128, 304, 353 (fig.), 428 (fig.)

fungosa, Imma, 298, 459 (fig.)

galactodelta, Oxytinea (n. sp.), 285, 308, 403 (fig.), 406 (fig.), 413 (fig.), 451 (fig.)
Gatesclarkeana, 40, 41, 321 (fig.), 419 (fig.)

asynthetes (n. sp.), 42, 43, 301, 321 (fig.), 419 (fig.)

erotias, 42, 321 (fig.), 322 (fig.)

Gelechia, 148, 149, 157

Gelechiidae, 5, 147 (key), 304

geraropa, 64

Gerontha, 266, 267, 268 (key)

captiosella, 267, 268, 308, 399 (fig.), 400 (fig.), 449 (fig.)

captiosella f. capna, 268, 269, 308, 449 (fig.)

diascopa (n. sp.), 268, 270, 308, 400 (fig.), 449 (fig.)

monostigma (n. sp.), 268, 269, 308, 403 (fig.), 449 (fig.)

nivicaput (n. sp.), 268, 271, 308, 401 (fig.), 449 (fig.)

gigantea, Melittia, 233, 307, 443 (fig.)

globosa, Meridarchis, 104

Glossosphecia, 219, 225 (key)

contaminata, 225

micans (n. sp.), 225, 226, 306, 380 (fig.), 442 (fig.)

pelocroca (n. sp.), 225, 306, 383 (fig.), 442 (fig.)

Glyphipterygidae, 5, 188 (key), 305, 306

Glyphipteryx, 188

Gnathmocerodes (n. gen.), 40, 71

lecithocera, 72,73

lecythophora, 72

petrifraga (n. sp.), 72, 302, 326

(fig.), 336 (fig.), 421 (fig.)

tonsoria, 72

Gnorimoschema, 148

goniometra, Lecithocera, 132, 139, 140, 304, 348 (fig.), 353 (fig.), 430

(fig.)

gossypiella, 165

Grapholitha (Sisona) albitibiana, 300 schistaceana, 300

Grapholitha, 58, 69, 93

gratulata, Laspeyresia, 94, 303, 424 (fig.)

gypsota, Copromorpha, 109, 110

Haplotinea, 267, 285, 286 (key), 290

cymopelta, 286, 290, 308, 407 (fig.), 452 (fig.)

eurycera (n. sp.), 286, 289, 308, 406 (fig.), 451 (fig.)

hemilampra (n. sp.), 286, 288, 308, 407 (fig.), 452 (fig.) 
Haplotinea-Continued

insectella, 285

misella, 285

nestoria, 290, 407 (fig.), 451 (fig.)

platyntis, 289, 406 (fig.)

purpurascens (n. sp.), 286, 287, 308, 410 (fig.), 452 (fig.)

subochraceella, 164, 286, 308, 404 (fig.), 405 (fig.), 407 (fig.), 451 (fig.)

Hapsifera, 266, 27\% (key)

albescens (n. sp)., 27\%, 308, 403 fig.), 450 (fig.)

hirsutella, 277

rugosella, 27\%, 308, 392 (fig.), 398

(fig.), 452 (fig.)

rugosellus, 277

Harmaclona, 266, 272

cossidella, 272, 398 (fig.), 408 (fig.) tephrantha, 272, 273, 308, 401

(fig.), 408 (fig.), 410 (fig.), 449 (fig.)

Harmologa, 9

harmonica, Brenthia, 206, 209, 306, 439 (fig.)

Harpella aureatella, 300

Harpella, 169

Harpeptila (n. gen.), 259, 260 (key)

corethrodes (n. sp.), 260, 262, 307,

391 (fig.), 396 (fig.), 448 (fig.)

prasina (n. sp.), 260, 261, 307, 384

(fig.), 448 (fig.)

hecataea, 207

Hedia, 44

Hedya, 40, 44

(Platypeplus) aprobola, 46, 301, 419 (fig.)

(Hedya) atrifraga (n. sp.), 45, 301, 323 (fig.), 419 (fig.)

(Cellifera) cellifera, 47, 302, 325 (fig.), 331 (fig.), 419 (fig.)

(Cellifera) codonectis, 47

(Platypeplus) mormopa, 46, 301, 418 (fig.)

(Hedya) salicella, 44

Hedya subgen., 40, 44, 45

heliaula, Zacorisca, 8, 9, 301, 414 (fig.)

Helictophanes, 70

heliochalca, Nemophora, 293, 294, 308,

411 (fig.), 453 (fig.)

Heliodinidae, 5, 209 (key), 306 heliopa, Phthorimaea, 148, 304, 356 (fig.), 357 (fig.), 358 (fig.), 431 (fig.)

heliosema, Euhomalocera (n. sp.), 150, 151, 304, 358 (fig.), 432 (fig.)

hemicitra, Monopis, 281, 308, 405 (fig.), 451 (fig.)

hemilampra, Haplotinea (n. sp.), 286, 288, 308, 407 (fig.), 452 (fig.)

hepatica, Amorbaea, 115

heptasema, Ethmia, 259

herbifera, Eudemis (Acanthothyspoda), 51

hesitans, Chrysonoma (n. sp.), 177, 180, 182, 183, 305, 364 (fig.), 365 (fig.), 435 (fig.)

hesyca, Cryptaspasma (Allobrachygonia), 88, 302, 423 (fig.)

heteraspis, Eudemis (Acanthothyspoda), 51

heterodesma, Paranthrene (n. sp.), 230, 232, 307, 379 (fig.), 382 (fig.), 443 (fig.)

Heterogymna, 100, 107, 108 chorospila, 108

melanocrypta (n. sp.), 107, 303, 337 (fig.), 425 (fig.)

heteroidana, Adoxophyes, 10

heterostigma, Hypatima (n. sp.), 154, 304, 358 (fig.), 432 (fig.)

heterotoma, Brachmia (n. sp.), 158, 304, 359 (fig.), 432 (fig.)

hierograpta, Peridaedala, 73, 75, 76

hilarella, Ethmia, 252, 255

hilarella, 255

hilarograpta, Sycacantha, 58

hirsutella, 277

Holacarta, 266, 275

chalcathra (n. sp.), 275, 308, 396 (fig.), 449 (fig.)

holenopla, Atteva (n. sp.), 239, 241, 307, 385 (fig.), 445 (fig.)

holotephras, 84

homalopa, Eudemis (Acanthothyspoda) (n. sp.), 52, 54, 302, 336 (fig.), 420 (fig.)

Homaloxestis, 125, 129 (key)

aganacma (n. sp.), 129, 304, 352 (fig.), 429 (fig.)

alopecopa (n. sp.), 129, 130, 304, 459 (fig.)

surrepta (n. sp.), 129, 180, 304, 352 (fig.), 429 (fig.) 
homocirrha, Odites (n. sp.), 120, 124, Imma-Continued 303,346 (fig.), 428 (fig.)

Homona, 8, 16 (key)

aestivana, $16,301,375$ (fig.), 415 (fig.)

bakeri (n. sp.), 16, 20, 301, 313 (fig.), 316 (fig.), 416 (fig.)

bicornis (n. sp.), 16, 18, 301, 314

(fig.), 316 (fig.), 415 (fig.)

coffearia, 18

intermedia, 20

nubiferana, 21

phanaea, 16, 17, 301, 315 (fig.), 415 (fig.)

posticana, 16

wetan, 18, 19

Homona, 28

humerosa, 233

hybristis, Phricanthes, 37, 38

Hypatima, 148, 154

heterostigma (n. sp.), 154, 304, 358 (fig.), 432 (fig.)

Hyperperissa, 8

Hyphantes, 235

hypocapna, Chrysonoma (n. sp.), 177, 182, 305, 369 (fig.), 435 (fig.)

hypochrysa, Monopis, 283

Hypodrasia (n. gen.), 133, 147, 155

acycla (n. sp.), 156, 304, 356 (fig.), 362 (fig.), 432 (fig.)

Hyponomeuta, 235

icterica, Opogona, 264, 308

illepida, 90

illodis, Metacosmesis (n. sp.), 102, 303, 339 (fig.), 426 (fig.)

Imma, 188, 190 (key), 298

albifasciella, 190, 193, 305, 370

(fig.), 381 (fig.), 437 (fig.)

albotaeniana, 190, 194, 305, 458

(fig.), 460 (fig.)

arcifraga, 298, 457 (fig.), 459 (fig.)

aurantiaca, 190, 191, 305, 370

(fig.), 437 (fig.)

basiflava, 190, 191, 192, 194, 305, 458 (fig.), 460 (fig.)

chlorosphena, 197

chrysocosma (n. sp.), 190, 192, 305,

372 (fig.), 437 (fig.)

cyclostoma, 198

fungosa, 298, 459 (fig.)

lathidora, 298, 457 (fig.), 459 (fig.)

macrochorda (n. sp.), 190, 194, 195, 305, 373 (fig.), 437 (fig.)

Imma, 9

macrochorda regmophora (n. sub-

sp.), 190, 195, 305, 437 (fig.)

mesochorda, 195

monodesma, 193

mylias, 197

nephodryas, 190, 199, 305, 373

(fig.), 438 (fig.)

otoptera, 197

palaeodes, 299, 300, 457 (fig.), 459

(fig.)

poecilostoma (n. sp.), 190, 196, 305,

371 (fig.), 437 (fig.)

purpurascens, 193

pyragra (n. sp.), 190, 198, 305, 374

(fig.), 437 (fig.)

sarophora (n. sp.), 190, 197, 305, 374 (fig.), 437 (fig.)

tyrocnista, 190, 198, 305, 371 (fig.), 376 (fig.), 438 (fig.)

improvisa, Lecithocera (n. sp.), 132, 146, 304, 354 (fig.), 431 (fig.)

inae, Isotenes, 9, 301, 415 (fig.)

incisa, Caenognosis, 96, 303, 338 (fig.), 424 (fig.)

indentatus, 84

inermis, Chrysonoma (n. sp.), 177, 183, 305, 366 (fig.), 435 (fig.)

inflata, Laspeyresia, 94, 303

inobtrusa, Strepsicrates (n. sp.), 84, 85, 302, 328 (fig.), 423 (fig.)

inodes, Sycacantha, 59, 324 (fig.)

inodes perspicua, Sycacantha (n. subsp.), 59, 61, 302, 324 (fig.), 420 (fig.)

inscriptana, Anthophila, 203, 206

insectella, Haplotinea, 285

insularis, 15

intermedia, Homona, 20

interruptella, Yponomeuta, 235, 236, 300, 307, 391 (fig.), 413 (fig.), 444 (fig.)

Teinoptila, 300

interruptellus, 235

iographa, Eucosma (n. sp.), 88, 302, 328 (fig.), 423 (fig.)

ioloncha, 157

ionia, Pammene, 94, 95, 303, 462 (fig.)

iostrota, Xestocasis, 215, 306, 378 (fig.), 440 (fig.) 
iridostoma, Metathrinca (n. sp.), 117, |Lecithocera-Continued

$118,120,303,344$ (fig.), 346

(fig.), 427 (fig.)

irimochla, Anthophila, 204

Ischnuridia, 266, 273

virginella, 273, 274, 308, 392 (fig.), 396 (fig.), 450 (fig.)

Isodemis, 8, 29

serpentinana, 29, 301, 418 (fig.)

isogramma, Argyroptocha, 70

Isotenes, 8,9

inae, 9, 301, 415 (fig.)

miserana, 9

klugii, Coryptilum, 291, 308, 409 (fig.), 452 (fig.)

lacticaput, Monopis, 283

lagaropis, Tonica, 183, 185, 305, 368 (fig.), 436 (fig.)

Lamachaera, 209, 216

cyanacma, 216, 306, 456 (fig.)

lamprodesma, Lecithocera, 136

Lamprystica purpurata, 299, 300, 457 (fig.)

lanceolata, Tanyzancla (n. sp.), 171, $175,305,365$ (fig.), 434 (fig.)

lapidella, Ethmia, 259

Laspeyresia, 41, 94 (key), 303

gratulata, 94, 303, 424 (fig.)

inflata, 94, 303

lathidora, Imma, 298, 457 (fig.), 459 (fig.)

Lathontogonus, 157

lavaterana, 93

Lecithocera, 125, 131 (key), 133, 134, 304

acribostola (n. sp.), 132, 139, 304, 351 (fig.), 430 (fig.)

activata (n. sp.), 132, 133, 304, 355

(fig.), 429 (fig.)

cassiterota, 131, 135, 304, 350

(fig.), 354 (fig.), 429 (fig.)

caustospila, 144

crypsigenes, 146

decorosa (n. sp.), 132, 141, 304, 355

(fig.), 430 (fig.)

docilis (n. sp.), 132, 144, 145, 304, 349 (fig.), 430 (fig.)

fausta, $132188,304,348$ (fig.), 354

(fig.), 431 (fig.)

goniometra, 132, 139, 140, 304, 348

(fig.), 353 (fig.), 430 (fig.)

improvisa (n. sp.), 132, 146, 304, 354

(fig.), 431 (fig.) lamprodesma, 136

leucomastis (n. sp.), 132, 145, 304, 352 (fig.), 430 (fig.)

luteola (n. sp.), 132, 145, 304, 351

(fig.), 431 (fig.)

megalopis, 132, 138, 144, 304, 429 (fig.)

niphotricha (n. sp.), 132, 142, 304, 347 (fig.), 430 (fig.)

ochrocapna, 131, 139, 304, 433 (fig.)

orbata, 144

perenobela, 144

phanerostoma (n. sp.), 131, 187, 304, 355, (fig.), 356 (fig.), 429 (fig.) protolyca, 144

recurvata, 132, 138, 142, 143, 304, 349 (fig.), 430 (fig.)

rhabdostoma, 139

sophronopa (n. sp.), 182, 304, 355

(fig.), 429 (fig.)

strenua (n. sp.), 131, 134, 304, 350

(fig.), 429 (fig.)

telosperma (n. sp.), 132, 143, 304, 351 (fig.), 430 (fig.)

lecithocera, Gnathmocerodes, 72, 73

lecythophora, 72

Lepidopoda, 219, 224

andrepictura, 225

lutescens (n. sp.), 224, 306, 380 (fig.), 441 (fig.)

leucaspis, Statherotis, 55

leucodora, Pammene, 94, 95, 303, 331

(fig.), 412 (fig.), 424 (fig.), 454

(fig.)

leucomastis, Lecithocera (n. sp.), 132, 145, 304, 352 (fig.), 430 (fig.)

lichenitis, Copromorpha, 109

ligniferana, 84

lignisquama, Copromorpha, 110

Limnaecia, 162, 164, 305

acontophora, 164, 305, 360 (fig.), 433 (fig.)

Limnoecia, 215

lineatonotella, Ethmia, 254

Lipatia, 157

Lita, 149

Lithocolletidae, 5, 263 (key), 307

Lithocolletis, 263, 264

triarcha, 264, 307

lithocrossa, Brenthia, 206, 209, 306, 372

(fig.), 439 (fig.) 
Loboschiza (n. gen.), 40, 93, 94 clytocarpa, 94, 303, 462 (fig.), 463 (fig.)

longella, 282

loxographa, Philobota, (n. sp.), 175, 305, 367 (fig.), 434 (fig.), 435 (fig.)

Lozostoma, 265

lucasseni, 188

luteola, Lecithocera (n. sp.), 132, 145, 304, 351 (fig.), 431 (fig.)

lutescens, Lepidopoda (n. sp.), 224, 306, 380 (fig.), 441 (fig.)

luteum, Coryptilum (n. sp.), 291, 292,

luzonica, 11 308, 409 (fig.), 452 (fig.)

Lyonetiidae, 5, 264 (key), 308

macarista, 97

machlopis, Archips, 29

macrochorda Imma (n. sp.), 190, 194, 195, 305, 373 (fig.), 437 (fig.)

macrochorda regmophora, Imma (n. subsp.), 190, 195, 305, 437 (fig.)

macropa, 202

macrospila, Tortyra (n. sp.), 199, 200, 306, 389 (fig.), 438 (fig.)

macroura, 39

maculipennis, Plutella, 263, 307, 448 (fig.)

magnificella, Agrioceros, 249, 250, 251, 307, 393 (fig.), 446 (fig.)

Psecadia, 300

malacodes, Acribologa, 158, 304, 412 (fig.), 432 (fig.)

margaritopa, Eudemis (Acanthothyspoda), 52

Megalodoris, 9

megalopis, Lecithocera, 132, 138, 144, 304, 429 (fig.)

melanancalis, Eucoenogenes, 82

melanantha, Peridaedala (n. sp.), 74, $7 \%$, 302, 337 (fig.), 422 (fig.)

melanaster, Yponomeuta, 235, 237, 307, 454 (fig.)

melanocrepida, Psorosticha, 187

melanocrypta, Heterogymna (n. sp.), 107, 303, 337 (fig.), 425 (fig.)

melanostoma, Sphecosesia (n. sp.), 219, 306, 382 (fig.), 441 (fig.)

Melasina, 266, 292

anarmosta (n. sp.), 292, 308, 408 (fig.), 452 (fig.)

melichroa, Adoxophyes, 13

melitacma, Thymiatris, 113, 114
Melittia, 219, 233 (key)

eurytion, 233, 307, 444 (fig.)

gigantea, 233, 307, 443 (fig.)

humerosa, 233

siamica, 233, 307, 443 (fig.)

strigipennis, 234

sumatrana, 233

Meridarchis, 100, 103 (key)

alta (n. sp.), 103, 104, 303, 341 (fig.), 426 (fig.)

bifracta (n. sp.), 103, 104, 303, 339 (fig.), 426 (fig.)

globosa, 104

oxydelta (n. sp.), 103, 105, 303, 340

(fig.), 341 (fig.), 426 (fig.)

scythophyes (n. sp.), 103, 106, 303, 340 (fig.), 426 (fig.)

Meridarchis, 100, 101, 102

mesochorda, Imma, 195

Metacosmesis, 100, 102

barbaroglypha, 102

illodis (n. sp.), 102, 303, 339 (fig.), 426 (fig.)

metallitis, Copromorpha, 109

Metathrinca, 113, 116, 117 (key)

ancistrias, 116

coenophyes (n. sp.), 117, 119, 303, 342 (fig.), 344 (fig.), 427 (fig.)

iridostoma (n. sp.), 11\%, 118, 120, 303, 344 (fig.), 346 (fig.), 427 (fig.)

pernivis (n. sp.), 117, 118, 303, 341 (fig.), 427 (fig.)

sinumbra (n. sp.), 117, 120, 303, 347 (fig.), 427 (fig.)

meteoris, 255

micans, Glossosphecia (n. sp.), 225, 226, 306, 380 (fig.), 442 (fig.)

Micrerethista, 272

microsperma, Syntomaula, 161, 163

miltochorda, Anticrates, 247

minax, Bactra (Chiloides) orbiculi, 63, 65, 302, 327 (fig.), 421 (fig.)

minor, Phycodes, 188, 305, 369 (fig.), 436 (fig.)

minuscula, Decadarchis, 265, 308, 448 (fig.)

misella, 285

miserana, 9

mistharnis, Copromorpha (n. sp.), 109, 112, 303, 339 (fig.), 425 (fig.)

mniochlora, Eucosma, 49

mochlacma, Harmaclona, 272 
modicella, 149

monachella, Monopis, 281, 282, 308, 451 (fig.)

monodesma, 193

Monopis, 266, 281 (key), 283

avara, 281, 282, 308, 401 (fig.), 403

(fig.), 451 (fig.), 453 (fig.)

cuspidigera, 283

hemicitra, 281, 308, 405 (fig.), 451

(fig.)

hypochrysa, 283

lacticaput, 283

longella, 282

monachella, 281, 282, 308, 451

(fig.)

prosarithma, 281

victa, 283

monostigma, Gerontha (n. sp.), 268, 269, 308, 403 (fig.), 449 (fig.)

mormopa, Hedya (Platypeplus), 46, 301, 418 (fig.)

mosaica, Phaecadophora, 57, 302, 420 (fig.)

mylias, Imma, 197

myrmecias, Copromorpha, 110

Nannobactra, subgen., 65

narcodes, Copromorpha, 110

Narthecoceras, 150

neglecta, Psorosticha (n. sp.), 187, 305, 370 (fig.), 436 (fig.)

nematodes, Neocalyptis, 15, 301, 309 (fig.), 310 (fig.), 415 (fig.)

nematodes insularis, Neocalyptis, 15, 309 (fig.), 310 (fig.)

Nemophora, 293 (key)

apollonis (n. sp.), 293, 308, 452 (fig.)

cantharites, 293, 294, 308, 453 (fig.)

chalcotechna, 293, 294, 308, 410

(fig.), 453 (fig.)

eurycitra, 293, 295, 308, 411 (fig.), 453 (fig.)

heliochalca, 293, 294, 308, 411

(fig.), 453 (fig.)

tristrigella, 295

Nemotois, 294, 295

Neocalyptis, 8, 15

insularis, 15

nematodes, 15, 301, 309 (fig.), 310

(fig.), 415 (fig.)

nematodes insularis, 15, 309 (fig.),

310 (fig.)

telutanda, 15 neoris, 96,97

nephodryas, Imma, 190, 199, 305, 373

(fig.), 438 (fig.)

nerteria, 149

nesographa, Copromorpha, 110

nestoria, Haplotinea, 290, 407 (fig.), 451 (fig.)

niphochrysa, Acrocenotes (n. sp.), 262, 307, 399 (fig.), 448 (fig.)

niphotricha, Lecithocera (n. sp.), 132, 142, 304, 347 (fig.), 430 (fig.)

niveosella, 161

nivicaput, Gerontha (n .sp.), 268, 271, 308, 401 (fig.), 449 (fig.)

nobilis, Ethmia (n. sp.), 253, 258, 307, 395 (fig.), 397 (fig.), 447 (fig.)

Nothris, 158

nubiferana, Homona, 21

numismata, Spatalistis (n. sp.), 36, 301, 320 (fig.), 418 (fig.)

Nygmia, 235

obscura, 93

ochracea, Phaecadophora, 57

ochreoviridella, Atasthalistis, 151, 152, 304, 412 (fig.), 454 (fig.), 464 (fig.)

ochrocapna, Lecithocera, 131, 139, 304, 433 (fig.)

octanoma, Ethmia, 258

Odites, 113, 120 (key)

apicalis (n. sp.), 120, 122, 303, 342 (fig.), 428 (fig.)

brachyclista, 120, 124, 303, 343, (fig.), 428 (fig.)

homocirrha (n. sp.), 120, 124, 303, 346 (fig.), 428 (fig.)

pancyclia, 120, 123, 303, 343 (fig.) 428 (fig.)

periscias, $120,123,124,303,346$ (fig.), 428 (fig.)

perissa (n. sp.), 120, 121, 122, 303, 346 (fig.), 347 (fig.), 427 (fig.)

perissa atrimersa, 120, 122, 303, 427 (fig.)

perissopis, 121

plocamopa, 122

Oecophoridae, 5, 166 (key), 305

olenarcha, Statherotis, 55, 56, 302, 325

(fig.), 420 (fig.)

Olethreutes, 40,58

separatana, 44

Olethreutes, 46, 47, 48, 56, 94

Olethreutinae, 89 (key), 301, 302, 303 
ombrodelta, Cryptophlebia, 89, 90, 302, 423 (fig.)

Onebala fibularis, 300

Onebala, 147

Opogona, 264 (key)

dimidiatella, 264, 265, 308, 448 (fig.) flav of asciata, 264, 265, 308, 448 (fig.)

icterica, 264, 308

optima, 97

orbata, Lecithocera, 144

orbiculi minax, Bactra (Chiloides), 63, 65, 302, 327 (fig.), 421 (fig.)

ornata, Craterobathra (n. sp.), 210, 211, 306, 377 (fig.), 440 (fig.)

Orneodes, 159 (key)

spilodesma, 159, 160, 304

toxophila, 159, 304, 382 (fig.)

Orneodidae, 5, 159, 304

orthogona, Anthophila, 202, 205, 206, 306,376 (fig.), 453 (fig.)

otoptera, Imma, 197

oxydelta, Meridarchis (n. sp.), 103, 105, 303, 340 (fig.), 341 (fig.), 426 (fig.)

oxygona, Eudemis (Eudemis) (n. sp.), $49,50,302,322$ (fig.), 335 (fig.), 419 (fig.)

Oxytinea (n. gen.), 266, 284

galactodelta (n. sp.), 285, 308, 403

(fig.), 406 (fig.), 413 (fig.), 451 (fig.)

Pachnistis, 156

Paedisca, 93

palaeodes, Imma, 299, 300, 457 (fig.), 459 (fig.)

palawana, Ethmia, 253, 307, 447 (fig.) pallifasciella, 166

palpigera, Brachyacma, 15\%, 304, 357 (fig.), 431 (fig.)

Pammene, 41, 94 (key)

ionia, 94, 95, 303, 462 (fig.)

leucodora, 94, 95, 303, 331 (fig.),

412 (fig.), 424 (fig.), 454 (fig.) rescissa, 96

pancyclia, Odites, 120, 123, 303, 343 (fig.), 428 (fig.)

Paranthrene, 219, 230 (key)

heterodesma (n. sp.), 230, 232, 307,

379 (fig.), 382 (fig.), 443 (fig.)

poecilocephala (n. sp.), 230, 232,

307, 384 (fig.), 443 (fig.)

regale, 233

Paraspistes, 157
Parastega, 155

paratarsa, Anticrates, 243, 247, 307, 388 (fig.), 446 (fig.)

pelocroca, Glossosphecia (n. sp.), 225, 306, 383 (fig.), 442 (fig).

pelograpta, Peragrarchis, 101

Penthina atropunctana, 44

cyanana, 44

Penthina, 44, 49, 93

pepona, Tanyzancla (n. sp.), 170, 172, 305, 364 (fig.), 368 (fig.), 434 (fig.), 454 (fig.)

Peragrarchis, 101

pelograpta, 101

rodea, 101

syncolleta, 102

percnobela, Lecithocera, 144

percnophanes, Eretmocera, 214, 306, 376 (fig.), 377 (fig.), 379 (fig.), 444 (fig.)

peregrinana, 93

Peridaedala, 40, 73, 74 (key)

crastidochroa, 77

crocoptila (n. sp.), 74, 79, 302, 335 (fig.), 422 (fig.)

dendrochlora (n. sp.), 74, 77, 302, 329 (fig.), 421 (fig.), 422 (fig.)

hierograpta, 73, 75, 76

melanantha (n. sp.), 74, $7 \gamma, 302$, 337 (fig.), 422 (fig.)

physoptila (n. sp.), 74, 75, 302, 335 (fig.), 454 (fig.)

stenoglypha (n. sp.), 74, 78, 302, 336 (fig.), 422 (fig.)

thylacophora (n. sp.), 74, 76,302 , 339 (fig.), 422 (fig.)

perigrapha, Aeoloscelis (n. sp.), 213, 306, 375 (fig.), 440 (fig.)

periscias, Odites, 120, 123, 124, 303, 346 (fig.), 428 (fig.)

perissa, Odites, (n. sp.) 120, 121, 122, 303, 346 (fig.), 347 (fig.), 427 (fig.)

perissa atrimersa, Odites, 120, 122, 303, 427 (fig.)

perissopis, 121

perlepidella, Acrolepia, 262

pernivis, Metathrinca (n. sp.), 117, 118, 303, 341 (fig.), 427 (fig.)

Peronea, 39

perspicua, Sycacantha inodes, 61, 302, 324 (fig.), 420 (fig.)

perstricta, Adoxophyes, 11, 14, 301, 313 (fig.), 414 (fig.) 
petrifraga, Gnathmocerodes (n. sp.), 72, 302, 326 (fig.), 336 (fig.), 421 (fig.)

Petrova 40,86

scalaris (n. sp.), 86, 302, 335 (fig.), 423 (fig.)

Phaecadophora, 40, 56

acutana, 57

aeolotechna, 57

clydonias, 57

divisa, 57

fimbriata, 56, 57

mosaica, $57,302,420$ (fig.)

ochracea, 57

Phaecasiophora, 58, 59

phaeodelta, Campylarchis, 100

Phalaena Tinea, 44

phalaenopa, Argyroptocha (n. sp.), 70,

Phalonia, 7 302, 330 (fig.), 421 (fig.)

Phaloniidae, 5, 7, 301

phanaea, Homona, 16, 17, 301, 315 (fig.), 415 (fig.)

phanerostoma, Lecithocera (n. sp.), 131, 137, 304, 355 (fig.), 356 (fig.), 429 (fig.)

phaulopa, Bactra (Nannobactra) 65, 302, 421 (fig.)

Philobota, 167, 175

loxographa (n. sp.), 175, 305, 367 (fig.), 434 (fig.), 435 (fig.)

Phoxopteris, 64

Phricanthes, 8, 36

asperana, 36

biocellana, 37, 301, 318 (fig.), 319 (fig.), 418 (fig.)

flexilineana, 39, 301, 418 (fig.)

hybristis, 37,38

macroura, 39

Phthinolophus, 84

Phthorimaea, 148, 149

heliopa, 148, 304, 356 (fig.), 357 (fig.), 358 (fig.), 431 (fig.)

Phycodes, 188

minor, 188, 305, 369 (fig.), 436 (fig.)

phyllochlora, Eudemis (Acanthothyspoda), 51, 52

physoptila, Peridaedala (n. sp.), 74, 75 , 302, 335 (fig.), 454 (fig.)

phytochroa, Copromorpha, 109

picroscopa, Campylarchis, 100

Pieris, 1

$237-168-67-32$
Placanthes, 125, 131

xanthomorpha, 131, 304, 448 (fig.)

placida, Stathmopoda, 217, 306, 377

(fig.), 444 (fig.)

platycypha, Agrioceros, 249, 250, 307, 393 (fig.), 446 (fig.)

platyntis, Haplotinea, 289, 406 (fig.)

Tinea, 300

Platypeplus, subgen., 40, 44, 46 (key)

Platypeplus, 42

plebejana, Crocidosema, 92, 303, 424 (fig.)

pleurophanes, Copromorpha, 110

plocamopa, Odites, 122

Plutella, 259, 263

maculipennis, 263, 307, 448 (fig.)

Plutellidae, 5, 259 (key), 307

poecilocephala, Paranthrene (n. sp.), 230, 232, 307, 384 (fig.), 443 (fig.)

poecilosema, Chrysonoma (n. sp.), 177, 179, 305, 367 (fig.), 435 (fig.)

poecilostoma, Imma (n. sp.), 190, 196, 305, 371 (fig.), 437 (fig.)

Pogonozada, 89

Polemograptis, 8, 33

stauroma, S3, 301, 320 (fig.), 418 (fig.)

poliophora, 86

Polychrosis, 47, 68

pompholycias, Argyroploce, 49

Eudemis (Eudemis), 49

porphyrana, Tortrix, 47, 49

posticana, 16

potamographa, Sycacantha, 59, 62, 302, 324 (fig.), 420 (fig.)

praeclara, Ethmia, 253, 254, 255, 256, 307, 394 (fig.), 447 (fig.)

praedives, Astiarcha (n. sp.), 169, 305, 363 (fig.), 365 (fig.), 434 (fig.)

prasina, Harpeptila (n. sp.), 260, 261, 307, 384 (fig.), 448 (fig.)

prasinias, Eudemis (Acanthothyspoda), 52

Prays, 235, 237

endocarpa, 238, 239, 389 (fig.), 464 (fig.)

endolemma (n. sp.), 237, 307, 389 (fig.), 444 (fig.), 464 (fig.)

privatana, Adoxophyes, 11, 14, 301, 414 (fig.)

Promalactis, 150

prosarithma, Monopis, 281

Proschistis, 55 
Prosodarma, 125, 147 fibularis, 14\%, 304, 357 (fig.), 431 (fig.)

Proteopteryx, 93

protolyca, Lecithocera, 144

Protorhiza (n. gen.), 235, 247

cyanosticta (n. sp.), 248, 307, 385 (fig.), 413 (fig.), 446 (fig.)

Protypanthes, 36

Psecadia magnificella, 300

\section{Psecadia, 252}

Pseudogalleria, 89

pseusta, Scaeothyris (n. sp.), 163, 164, 305, 392 (fig.), 413 (fig.), 433 (fig.)

Psoricoptera, 277

Psorosticha, 167, 187

melanocrepida, 187

neglecta (n. sp.), 187, 305, 370 (fig.), 436 (fig.)

zizyphi, 187, 188

ptiladelpha, 93

ptilosema, 52

Ptochoryctis, 115

Ptychoxena, 272

pulchella, Zacorisca, 8, 301

pullata, Ethmia, 255, 300, 395 (fig.)

purpurascens, Haplotinea (n. sp.), 286, 287, 308, 410 (fig.), 452 (fig.)

Imma, 193

purpurata, Lamprystica, 299, 300, 457 (fig.)

purpurissatana, Eudemopsis, 50

purpurissatana, 49

pyragra, Imma (n. sp.), 190, 198, 305, 374 (fig.), 437 (fig.)

Pyrameis, 1

pyrausta, Ethmia, 252

pyraustella, Anthophila, 204

Pyroderces, 164, 165

coriacella, 165

gossypiella, 165

simplex, 165, 305, 433 (fig.)

pyrrhoscia, Copromorpha, 109

rectilinea, Exaxa (n. sp.), 276, 308, 403 (fig.), 411 (fig.), 449 (fig.)

recurvata, Lecithocera, 132, 138, 142, 143, 304, 349 (fig.), 430 (fig.)

regale, Paranthrene, 233

relapsa, Statherotis, 55

reposita, Ethmia (n. sp.), 253, 25\%, 307, 397 (fig.), 447 (fig.)

rescissa, Pammene, 96

retractana invalidana, Capua, 22, 301, 320 (fig.), 416 (fig.)

rhabdostoma, Lecithocera, 139

rhodometra, Anticrates (n. sp.), 243, 246, 307, 385 (fig.), 386 (fig.), 388 (fig.), 446 (fig.)

rodea, Peragrarchis, 101

roepkei, Copromorpha, 110

rugosella, Hapsifera, 27\%, 308, 392 (fig.), 398 (fig.), 452 (fig.)

rugosellus, 277

rutella, Setomorpha, 284, 308, 450 (fig.)

rutilella, Anticrates, 243, 307, 387 (fig.), 445 (fig.)

Sagalassa, 188, 189

eubrachycera (n. sp.), 189, 305, 369 (fig.), 436 (fig.)

salaconis, Archips, 24, 301, 310 (fig.), 312 (fig.), 333 (fig.), 416 (fig.)

salicella, Phalaena Tinea, 44

Saphtha, 200

Saptha, 200

sarophora, Imma (n. sp.), 190, 197, 305, 374 (fig.), 437 (fig.)

saxana, 84

Scaeosophinae, 160 (key), 305

Scaeosopha, 161, 162

Scaeothyris (n. gen.), 160, 163

pseusta (n. sp.), 163, 164, 305, 392

(fig.), 413 (fig.), 433 (fig.)

scalaris, Petrova (n. sp.), 86, 302, 335 (fig.), 423 (fig.)

Scalidomia, 277

schistaceana, Grapholitha, 300

Tetramoera, 69, 302, 329 (fig.), 332

(fig.), 421 (fig.)

Schoenotenes, 97,98

collarigera (n. sp.), 98, 303, 318

(fig.), 425 (fig.)

Schoenotenini, 96, 97 (key), 303

Sciaphila, 39, 83, 84

scintilulana, Choreutis, 206

scolecias, Atteva, 239, 242, 307, 390 (fig.), 445 (fig.)

scythophyes, Meridarchis (n. sp.), 103, 106, 303, 340 (fig.), 426 (fig.)

scythropa, 64

semiculta, Eudemis (Acanthothyspoda), 51

separatana, Olethreutes, 44 
serpentinana, Isodemis, 29, 301, 418 (fig.)

servilisana, 84

Setomorpha, 266, 284

rutella, 284, 308, 450 (fig.)

sexfasciella, Choreutis, 206, 306, 440 (fig.)

siamica, Melittia, 233, 307, 443 (fig.)

Sidyma, aurautiaca, 300

basiflava, 300

Sidyma, 190, 191

Simaethis, 203, 204, 205, 206, 207

simplex, Ebodina, 35, 301, 319 (fig.), 418 (fig.)

Pyroderces, 165, 305, 433 (fig.)

simulatella, Syntomaula, 161, 163, 305, 361 (fig.), 433 (fig.)

sinumbra, Metathrinca (n. sp.), 117, 120, 303, 347 (fig.), 427 (fig.)

Sippharara, 291

Sisona, 58,63

albitibiana, 58, 61, 63, 300

smaragdarcha, Copromorpha (n. sp.), 109, 110, 303, 340 (fig.), 425 (fig.)

Snodgrassia (n. gen.), 8, 32

stenochorda, $32,33,301,314$ (fig.), 318 (fig.), 417 (fig.)

sophronopa, Lecithocera (n. sp.), 132, 304, 355 (fig.), 429 (fig.)

Spatalistis, 8, 36

numismata (n. sp.), $36,301,320$ (fig.), 418 (fig.)

sphaenophora, 7

sphaerocopa, Choganhia, 47, 51

Eudemis (Acanthothyspoda), 52

Sphecosesia, 219 (key)

aterea, 219, 221, 306, 441 (fig.)

melanostoma (n. sp.), 219, 306, 382

(fig.), 441 (fig.)

pedunculata, 219

sphenodes, Synanthedon (n. sp.), 221, $228,306,384$ (fig.), 441 (fig.)

sphenophora, Aethes, 7, 301, 414 (fig.)

Sphynx, 221

spilodesma, Orneodes, 159, 160, 304

spilonota, 84

spilotoma, Archips, 26

spirographa, Bubonoxena (n. sp.), 66, 302, 327 (fig.), 333 (fig.), 421 (fig.)

Stagmatophora, 165

Statherotis, 40, 54, 55 (key)

agitata, 55
Statherotis-Continued

amoebea, 55

ancosema, 55

aspidias, 55

catharota, 55

decorata, 54

discana, 55, 56, 302, 326 (fig.), 420

(fig.)

leucaspis, 55

olenarcha, 55, 56, 302, 325 (fig.), 420 (fig.)

relapsa, 55

Statherotis, 55

Stathmopoda, 209, 217 (key)

placida, 217, 306, 377 (fig.), 444 (fig.)

theoris, 217, 306, 378 (fig.)

stauroma, Polemograptis, 3S, 301, 320 (fig.), 418 (fig.)

Stegasta, 148

variana, 148, 304, 412 (fig.), 431 (fig.)

Stenarchella (n. gen.), 97, 99

eupista (n. sp.), 99, 303, 337 (fig.), 425 (fig.)

stenochorda, Snodgrassia, 32, 33, 301, 314 (fig.), 318 (fig.), 417 (fig.)

stenoglypha, Peridaedala (n. sp.), 74, 78, 302, 336 (fig.), 422 (fig.)

Stenoptycha, 93

Stomopteryx, 148, 149

subsecivella, 149, 304, 356 (fig.), 357 (fig.), 431 (fig.)

strenua, Lecithocera, 131, 134, 304, 350 (fig.), 429 (fig.)

Strepsiceros, 84

Strepsicrates, 40, 83, 84 (key)

discobola (n. sp.), $84,85,302,328$ (fig.), 423 (fig.)

ejectana, 83, 84, 85, 302, 325 (fig.), 422 (fig.)

inobtrusa (n. sp.), 84, 85, 302, 328 (fig.), 423 (fig.)

poliophora, 86

streptatma, Anthophila, 201, 202, 306, 374 (fig.), 438 (fig.)

stygiaula, Eudemis (Acanthothyspoda), 52

subochraceella, Haplotinea, 164, 286, 308, 404 (fig.), 405 (fig.), 407 (fig.), 451 (fig.)

subsecivella, Stomopteryx, 149, 304, 356 (fig.), 357 (fig.), 431 (fig.) 
subtusvena, Amorbaea (n. sp.), 115, 303, 343 (fig.), 345 (fig.), 426 (fig.), 454 (fig.)

subusta, Amorbaea (n. sp.), 115, 116, 303, 344 (fig.), 427 (fig.)

sumatrana, 233

Sura, 219, 228, (key)

cyanolampra (n. sp.), 228, 229, 307, 380 (fig.), 442 (fig.)

tetrapora (n. sp), 228, 307, 383 (fig.), 442 (fig.)

surrepta, Homaloxestis (n. sp), 129, 130, 304, 352 (fig.), 429 (fig.)

Sycacantha, 40, 58, 59 (key)

auriflora, 58

escharota, 59, 62

hilarograpta, 58

inodes, 59, 324 (fig.)

inodes perspicua (n. subsp.), 59, 61, 302, 324 (fig.), 420 (fig.)

potamographa (n. sp.), 59, 62, 302, 324 (fig.), 420 (fig.)

Synanthedon, 219, 221 (key)

chrysostetha (n. sp.), 221, 306, 380

(fig.), 441 (fig.)

cirrhozona (n. sp.), 221, 222, 306, 383 (fig.), 441 (fig.)

sphenodes (n. sp.), 221, 223, 306, 384 (fig.), 441 (fig.)

vespiformis, 221

syncolleta, Peragrarchis, 102

Syndemis, 30

synneurota, 93

Syntomaula, 160, 161 (key)

microsperma, 161, 163

simulatella, 161, 163, 305, 361

(fig.), 433 (fig.)

tephrota, 160, 161, 361 (fig.)

Syntozyga, 66

tabellifera, Craterobathra, 210

Tanyzancla, 167, 170 (key)

amydrographa (n. sp.), 171, 305, 365 (fig.), 434 (fig.)

catadea (n. sp.), 170, 171, 174, 305, 368 (fig.), 434 (fig.)

cincta (n. sp.), 170, 173, 305, 364 (fig.), 434 (fig.)

lanceolata (n. sp.), 171, 175, 305, 365 (fig.), 434 (fig.)

pepona (n. sp.), 170, 172, 305, 364 (fig.), 368 (fig.), 434 (fig.), 454 (fig.)
Teinoptila interruptella, 300

Teinoptila, 235

Teleia, 149

telosperma, Lecithocera (n. sp.), 132, 143, 304, 351 (fig.), 430 (fig.)

telutanda, Neocalyptis, 15

temenopis, 52

Temnolopha, 57

tephrantha, Harmaclona, 272, 273, 308, 401 (fig.), 408 (fig.), 410 (fig.), 449 (fig.)

tephrota, Syntomaula, 160, 161, 361 (fig.)

Tetramoera (n. gen.), 39, 68, 302

isogramma, 69

schistaceana, 69, 302, 329 (fig.), 332 (fig.), 421 (fig.)

tetraploca, Cryptophlebia, 89, 302, 332 (fig.), 423 (fig.)

tetrapora, Sura (n. sp.), 228, 307, 383 (fig.), 442 (fig.)

tetrarcha, Copromorpha, 110

thelmae, Capua (n. sp.), 22, 23, 301, 312 (fig.), 416 (fig.)

theoris, Stathmopoda, 217, 306, 378 (fig.)

Thiotricha, 147

Thriambeutis, 209, 213, 306

coryphaea, 213, 306, 376 (fig.), 440 (fig.)

thrombota, Copromorpha, 110

thylacophora, Peridaedala (n. sp.), 74, 76,302

Thymiatris, 113,114

$\operatorname{arista}$ (n. sp.), 113, 303, 345 (fig.), 426 (fig.)

melitacma, 113, 114

Thyrsochares, 285

Timyridae, 5, 125 (key), 304

Tinea platyntis, 300

Tinea, 282, 286, 289, 290

Tineidae, 5, 266 (key), 308

Tineola, 286

Tinissa, 267, 278 (key)

baliomicta, 279, 308, 401 (fig.), 450 (fig.)

torvella, 279, 308, 402 (fig.), 450 (fig.)

Tisis, 125

auricincta (n. sp.), 125, 304, 345

(fig.), 354 (fig.), 428 (fig.)

tomentosa, Adixoa, 234, 307 
Tonica, 167, 183 (key)

argessa (n. sp.), 183, 184, 305, 367 (fig.), 368 (fig.), 436 (fig.)

citrantha (n. sp.), 183, 184, 186, 305, 368 (fig.), 436 (fig.)

lagaropis, 183, 185, 305, 368 (fig.), 436 (fig.)

tonsoria, Gnathmocerodes, 72

Tortricidae, 5, 7, 301

Tortricinae, 7 (key), 301

Tortricomorpha albotaeniana, 300

Tortricomorpha, 193, 194

Tortrix, 11, 22, 47, 49

Tortyra, 188, 199 (key)

centrifuga, 201

divitiosa, 200, 306, 381 (fig.), 438 (fig.)

elegans, 200, 306, 438 (fig.)

macrospila (n. sp.), 199, 200, 306, 389 (fig.), 438 (fig.)

torvella, Tinissa, 279, 308, 402 (fig.), 450 (fig.)

toxophila, Orneodes, 159, 304, 382 (fig.)

Trachycentra, 266, 278

cicatricosa, 278, 308, 406 (fig.), 450 (fig.)

triarcha, Lithocolletis, 264, 307

Trichothyrsa, 209, 218

bicolorella, 218, 306, 458 (fig.), 461 (fig.)

tridelta, Anticrates, 244, 245

trilampas, Brenthia, 206, 208, 306, 439 (fig.)

Trilochana, 219, 227

triscoliopsis, 227, 306, 442 (fig.)

triplex, Atteva (n. sp.), 239, 240, 307, 385 (fig.), 445 (fig.)

tripselia, Adoxophyes, 13

triscoliopsis, Trilochana, 227, 306, 442 (fig.)

tristella, Brachmia, 158, 304, 362 (fig.), 432 (fig.)

Ceratophora, 300

tristrigella, Nemophora, 295

Trochilium, 233

truculenta, 64

Trychnostoia, 109

Trymalitis, 97 cataracta, 97, 303, 425 (fig.)
Trymalitis-Continued

macarista, 97

optima, 97

thylacophora, Peridaedala, 74, 76, 302, 339 (fig.), 422 (fig.)

tyrocnista, Imma, 190, 198, 305, 371

(fig.), 376 (fig.), 438 (fig.)

Ulodemis, 8

variabilis, Eboda, 35

variana, Stegasta, 148, 304, 412 (fig.), 431 (fig.)

venosana, Bactra (Chiloides), 63, 64, 302, 420 (fig.)

vespif ormis, Synanthedon, 221

victa, Monopis, 283

virginella, Ischnuridia, 273, 274, 308, 392 (fig.), 396 (fig.), 450 (fig.)

viridella, Atasthalistis, 154, 359 (fig.)

vitiata, Campylarchis, 101

wetan, Homona, 18, 19

woodfordi, 291

xanthochroma, 24, 25

xanthogramma, Anthophila, 202, 204, 306

xanthomorpha, Placanthes, 131, 304, 448 (fig.)

Xestocasis, 209, 210, 215 (key)

erymnota, 215, 216, 300, 306, 455 (fig.)

iostrota, 215, 306, 378 (fig.), 440 (fig.)

xestocephala, Canthonistis (n. sp.), 127, 304, 353 (fig.), 428 (fig.)

Xyloides, 100

Xyloryctidae, 5, 113 (key), 303

Xystophora, 149

Yponomeuta, 161, 235 (key)

delicata, 237

evonymella, 235

interruptella, 235, 236, 300, 307, 391 (fig.), 413 (fig.), 444 (fig.)

interruptellus, 235

melanaster, 235, 237, 307, 454 (fig.)

Yponomeutidae, 5, 235 (key), 307

Zacorisca, 7, 8 (key), 9

electrina, 8, 9, 301, 414 (fig.)

heliaula, 8, 9, 301, 414 (fig.)

pulchella, 8, 301

zizyphi, Psorosticha, 187, 188 


\section{Index of Latin names of Food-plants}

Acacia arabica, 22, 91

Acacia spp., 91

Adenanthera pavonia, 91

Aegle marmelos, 91

Anona muricata, 21

Arachis hypogaea, 150

Barleria prionitis, 22

Bauhinia purpurea, 91

Caesalpinia pulcherrima, 264

Caryota rumphiana, 284

Cassia corimbosa, 158

fistula, 91, 148

flora, 158

mimosoides, 148

occidentalis, 91

tora, 148

Chrysanthemum, 22

Citrus, 91, 188, 238

Crotalaria, 158

Cynometra edulifolia, 96

Cyperus rotundus, 64

Darwinia fasciculata, 84

Dillenia indica, 39

Elaeis guineensis, 165

Elephanthopus scaber, 22

Eriodendron frondosum, 165

Eugenia aquea, 47

jambolana, 47

malaccensis, 47

Ficus endothrix, 111

odorata, 188
Gossypium, 22, 165, 264

Indig ofera, 158

Jambora vulgaris, 47

Jasminum sp. 148

Kunzea capitata, 84

Lantana, 22

Leptospermum ericoides, 84

Mallotus, 43

Mangifera indica, 162

Nephelium, 56

litchi, 91

Nicotiana tabacum, 149, 284

Parkinsonia aculeata, 91, 158

Pinus, 1

merkusii, 10

Pithecolobium dulce, 91 scutiferum, 95

Poinciana pulcherrima, 265

Psidium guajava, 84

Psoralea corylifolia, 150

Saccharum dulce, 69, 166, 215, 286

Sesamum indicum, 150

Sesbania aculeata, 91 grandiflora, 91

Soya hispida, 150

Tamarindus indica, 91

Tephrosia, 158

Teronea elephantum, 91

Thea, 10

Vachellia farnesiana, 158

Ziziphus jujuba, 91 


\section{$2 \mathrm{BHL}$ Biodiversity Heritage Library}

Diakonoff, Alexey. 1968. "Microlepidoptera of the Philippine Islands." Bulletin 257, 1-484. https://doi.org/10.5479/si.03629236.257.1.

View This Item Online: https://www.biodiversitylibrary.org/item/33179

DOI: https://doi.org/10.5479/si.03629236.257.1

Permalink: https://www.biodiversitylibrary.org/partpdf/1954

\section{Holding Institution}

Smithsonian Libraries

\section{Sponsored by}

Smithsonian

\section{Copyright \& Reuse}

Copyright Status: NOT_IN_COPYRIGHT

This document was created from content at the Biodiversity Heritage Library, the world's largest open access digital library for biodiversity literature and archives. Visit BHL at https://www.biodiversitylibrary.org. 